\title{
Political Liberalization in Post-Communist States: A Comparative Analysis of Church-State Relations in Croatia and Slovenia
}

By Tamara Kotar, BA, MPA

\author{
A thesis submitted to \\ the Faculty of Graduate Studies and Research \\ in partial fulfillment of \\ the requirements for the degree of \\ Doctorate of Philosophy
}

Department of Political Science

Carleton University

Ottawa, Ontario

Canada

(C) Tamara Kotar 2008 


$\begin{array}{ll}\begin{array}{l}\text { Library and } \\ \text { Archives Canada }\end{array} & \begin{array}{l}\text { Bibliothèque et } \\ \text { Archives Canada }\end{array} \\ \begin{array}{l}\text { Published Heritage } \\ \text { Branch }\end{array} & \begin{array}{l}\text { Direction du } \\ \text { Patrimoine de l'édition }\end{array} \\ \begin{array}{l}\text { 395 Wellington Street } \\ \text { Ottawa ON K1A 0N4 } \\ \text { Canada }\end{array} & \begin{array}{l}\text { 395, rue Wellington } \\ \text { Ottawa ON K1A 0N4 } \\ \text { Canada }\end{array}\end{array}$

Your file Votre référence ISBN: 978-0-494-47479-2

Ourfile Notre référence

ISBN: 978-0-494-47479-2

NOTICE:

The author has granted a nonexclusive license allowing Library and Archives Canada to reproduce, publish, archive, preserve, conserve, communicate to the public by telecommunication or on the Internet, loan, distribute and sell theses worldwide, for commercial or noncommercial purposes, in microform, paper, electronic and/or any other formats.

The author retains copyright ownership and moral rights in this thesis. Neither the thesis nor substantial extracts from it may be printed or otherwise reproduced without the author's permission.
AVIS:

L'auteur a accordé une licence non exclusive permettant à la Bibliothèque et Archives Canada de reproduire, publier, archiver, sauvegarder, conserver, transmettre au public par télécommunication ou par l'Internet, prêter, distribuer et vendre des thèses partout dans le monde, à des fins commerciales ou autres, sur support microforme, papier, électronique et/ou autres formats.

L'auteur conserve la propriété du droit d'auteur et des droits moraux qui protège cette thèse. $\mathrm{Ni}$ la thèse ni des extraits substantiels de celle-ci ne doivent être imprimés ou autrement reproduits sans son autorisation.
In compliance with the Canadian Privacy Act some supporting forms may have been removed from this thesis.

While these forms may be included in the document page count, their removal does not represent any loss of content from the thesis.
Conformément à la loi canadienne sur la protection de la vie privée, quelques formulaires secondaires ont été enlevés de cette thèse.

Bien que ces formulaires aient inclus dans la pagination, il n'y aura aucun contenu manquant.

\section{Canada}




\title{
Political Liberalization in Post-Communist States: A Comparative Analysis of Church-State Relations in Croatia and Slovenia
}

\author{
By Tamara Kotar, BA, MPA
}

\author{
A thesis submitted to \\ the Faculty of Graduate Studies and Research \\ in partial fulfillment of \\ the requirements for the degree of \\ Doctorate of Philosophy
}

Department of Political Science

Carleton University

Ottawa, Ontario

Canada

(C) Tamara Kotar 2008 


\begin{abstract}
A major distinction between Croatian and Slovenian politics is the foundations upon which their respective political elites based their programmes and how these programmes developed in response to internal and external challenges. In Croatia, the foundation was based on a historical tradition of the Croatian state. This informed a political approach that was more obstructionist and that, more often than in Slovenia, was used to justify zero sum games and revolutionary change with the maximal goal of independence. Slovenia lacked a state tradition and was cognizant of the pressures exerted by great powers, particularly on its northern and western borders. The Slovenian political elite focused on ensuring Slovenian linguistic rights and cultural distinctiveness with the maximal goal of autonomy achieved through a greater reliance on positive sum games-incremental change and co-operationist politics. Neither nation was "liberal," according to liberal democratic standards, prior to the 1990s. However, there are discernable historical patterns of politics that demonstrate greater and lesser amenability to the development of political liberalism.

The relationship between church and state is but one realm of policy making that can be used to illuminate patterns of post-communist political liberalization. Church-state relations were chosen for this case study because both Croatia and Slovenia were faced with the same issues, including concordat content and creation, property restitution, public funding of the Catholic Church, and the RCC's involvement in education. In addition, the same types of government, party, and Church actors are involved.
\end{abstract}


Part I: Introduction 1

Chapter 1: Overview 1

1.1 Outline of the Work 6

Chapter 2: Theoretical Framework and Literature

Review 12

2.1 Introduction $\quad 12$

2.2 Historical Institutionalism and Institutions 13

2.2.1 Accounting for Change $\quad 17$

2.2.2 Elite and Institutions 22

2.3 Institutions Central to This Study: The State,

Political Parties and the Roman Catholic Church 25

2.3.1 The State $\quad 25$

2.3.2 Political Parties $\quad 27$

2.3.3 The Roman Catholic Church 29

2.4 Political History, Memories and

Transformations $\quad 34$

2.4.1 Political Memories $\quad 40$

2.4.2 Transformations $\quad 42$

2.5 Liberalism 44

2.5.1 Liberalism and Church-State Relations $\quad 49$

2.6 Historical Patterns $\quad 57$

2.6.1 Types of Authority and Legitimization $\quad 59$

2.6.2 Pragmatism and Ideology 60

2.6.3 Compromise, Zero Sum versus Variable Sum Games 63

2.6.4 Incrementalism and Revolutionary

Change 64

2.7 Methods 65

Part II: Political History $\quad 71$

Chapter 3: Historical Patterns of Politics 73

3.1 Geographical Circumstances and Settlement $\quad 73$

3.2 Founding Memories $\quad 76$

3.3 General Patterns $\quad 80$

3.4 Croatia and State Right $\quad 82$

3.5 Slovenia and Cultural Rights $\quad 87$

Chapter 4: Political Parties 95 
4.1 Introduction

4.2 Politics of the Modern Era: Parties and Politics

Before the First Yugoslavia

97

4.2.1 Croatian Political Parties 97

4.2.2 The Illyrian Movement 98

4.2.3 The National Party and Yugoslavism 101

4.2.4 The Croatian Party of Right 103

4.2.5 The Croatian-Serb Coalition 106

4.2.6 The Croatian Peasant Party (HSS) 108

4.3 Slovenian Political Parties 111

4.3.1 The Clericals and the Co-operatives

113

4.3.2 The Clericals: The Slovene People's Party (SLS)

4.3.3 The Liberals: The National Progressive Party

4.4 The Socialists and Communists in Slovenia, Croatia and Yugoslavia

4.5 Conclusions

123

Chapter 5: The First and Second Yugoslavia

5.1 Introduction

127

5.2 Centralization, Dictatorship, and Demise of the First Yugoslavia 1918-1941

5.2.1 The Royal Dictatorship and the End of the First Yugoslavia

5.3 Socialist Yugoslavia and Post War

Repression

5.4 Croatia and Slovenia as Republics

Within Socialist Yugoslavia

5.5 Rivalry Among the Republics and the

Federation

5.6 The 1970 s and 1980 s and the Two Springs 154

5.7 The Eve of Transformation 168

5.8 Conclusions 174

Chapter 6: Independent Croatia and Slovenia $\quad 176$

6.1 Introduction $\quad 176$

6.2 Setting up the Regime 176

6.3 Conclusions to Part II: Political History 185

Part III: Introduction to Part III

Chapter 7: Overview: The Roman Catholic Church in Croatia and Slovenia

7.2 The RCC and the Interwar Era 
7.3 The Role of the Roman Catholic Church in Politics: From the Second World War Forward

7.3.1 Slovenia

7.4 Conclusions: The RCC and Post Communism in General

Chapter 8: The Establishment of Church-State

Relations in Concordat Creation 216

8.1 Introduction 216

8.2 The Croatian Agreements 221

8.2.1 Secrecy and Swiftness 223

8.2.2 Silencing of Criticisms 224

8.2.3 Canon Law and the Separation of Church and State

8.2.4 Agreements with Other Religious Communities

8.3 The Slovenian Agreement 245

8.3.1 Debate and Consideration 247

8.3.2 Separation of Church and State 253

8.3.3 Canon Law and Slovene Law 255

8.3.4 Inequality 257

8.3.5 Future Obligations 259

8.4 Conclusions 260

Chapter 9: Church, State and Education in Croatia and Slovenia 263

9.1 Introduction $\quad 263$

9.2 Post-Communist Educational Reforms 266

9.2.1 General Educational Reform in Croatia 267

9.2.2 General Educational Reform in Slovenia 273

9.3 Religious Instruction, Croatia 279

9.3.1 Education and Religious Communities in Croatia other than the RCC 286

9.3.2 Religious Instruction in Kindergartens 292

9.4 Religious Instruction: Slovenia $\quad 297$

9.4.1 Private Schools 298

9.4.2 Concessional Schools 301

9.4.3 The Debate Regarding Religious Instruction in Public Schools 304

9.4.4 The Religion and Ethics Course $\quad 313$

9.5 Conclusions $\quad 320$ 
Chapter 10: Church and State, Finance and Property Restitution

10.1 Introduction

10.2 Republic of Croatia - Holy See Accord, Financial Support

10.2.1 Financial Agreements between Croatia and the Holy See

10.2.2 State Justification of the Agreements 334

10.2.3 Other Religious Communities and

Agreements with the Republic of Croatia

10.2.4 Republic of Croatia - Holy See Accord, Property Restitution

10.3 Financial Agreements and the Church in Slovenia

10.3.1 Concerns of RCC Favouritism

10.4 Conclusions

365

Chapter 11: Conclusions $\quad 368$

Appendices

382

Appendix A: Croat Serb Relations 382

Appendix B: Monuments and the RCC 386

Appendix C: Territorial Settlements 388

Appendix D: Post WWII Reprisal and Repression 392

Appendix E: Post-Communist Croatia and Slovenia 396

Appendix F: War in Croatia and War in Slovenia 418

Appendix G: Croatia, the RCC and The International

Criminal Tribunal for the Former Yugoslavia (ICTY) 427

Appendix H: Interviews

1. Interviews in Croatia May-June $2002 \quad 436$

2 Interviews Slovenia May-June $2002 \quad 437$

Works Consulted 


\section{Part I: Introduction \\ Chapter 1: Overview}

On June 25, 1991 Slovenia and Croatia declared independence from the Socialist Federal Republic of Yugoslavia, both with the goal of joining Western Europe as sovereign, liberal-democratic states. More than a decade later, both are sovereign, but Slovenia has emerged as the more liberal of the two states.

Slovenia's swifter political liberalization has helped it in securing European Union membership in 2004. ${ }^{1}$

Meanwhile, Croatia has lagged behind its neighbour in political liberalization. European Commission approval for EU-Croatia pre-accession negotiations occurred less than a month prior to Slovenia's May 2004 accession to the union. ${ }^{2}$ This is because previously the commitment and stability of political liberalization in Croatia was in question. The governing and legislative institutions and processes in Slovenia have, with greater stability, transparency, and vigour, acted upon the central precepts of liberalism, including individual rights and freedoms, the rule of law, tolerance, the secular promotion of prosperity, and a government limited by the rights of citizens. Almost every work that compares the former Yugoslav republics and mentions Slovenia attests to the advancement of

\footnotetext{
${ }^{1}$ Although EU membership entails many requirements, the key requirement is a secure system of liberal governance, which includes among other things regularized rules, state adherence to the rule of law, and respect for individual rights. This is not to say that all existing EU member states meet the highest of these standards, but all member states have been judged by their peers to have made significant and successful efforts to achieve them.

${ }^{2}$ Commission of the European Communities, Croatia: Opinion on the Application of Croatia for Membership of the European Union (Brussels: European Commission, 2004) 257.
} 
liberalism in Slovenia as compared to the other former Yugoslav republics.

Generally, these works take into account the last decades of Yugoslavia but focus on comparing Serbian and Croatian politics. ${ }^{3}$

This work seeks to explain the long-term and critical differences that influenced political liberalization in the post-communist era by focusing on the former Yugoslav republics that were in 1990 considered to be in the best position to establish liberal democracies. ${ }^{4}$ Differences in political liberalization will be explained through a historical institutionalist approach that focuses on the state, political parties, and the Roman Catholic Church while tracing four ideal typical patterns of modern politics (historical patterns of politics) that have characterized distinctive approaches to common areas of concern. Both states faced a common concern for greater autonomy, self-determination, and decentralization within multi-national, multi-confessional states threatened by hostile neighbours and more powerful states. In the post-communist era there were common concerns in securing territorial integrity, international recognition, and above all liberal democracy. This study of historical institutions also explicitly recognizes the use

\footnotetext{
${ }^{3}$ Some of the more prominent works include John R. Lampe, Yugoslavia as History: Twice There was a Country; Alexander N. Draganic, The First Yugoslavia: Search for a Viable Political System; Mihailo Crnobrnja, The Yugoslav Drama; Aleksa Djilas, The Contested Country: Yugoslav Unity and Communist Revolution, 1919-1953; Stevan K. Pavlowitch, Yugoslavia; Misha Glenny, The Fall of Yugoslavia: The Third Balkan War; Susan L. Woodward, Balkan Tragedy: Chaos and Dissolution After the Cold War; Sabrina Petra Ramet, Balkan Babel: The Disintegration of Yugoslavia From The Death of Tito to Ethnic War; Lenard J. Cohen, Broken Bonds: Yugoslavia's Disintegration and Balkan Politics in Transition; Viktor Meier, Yugoslavia: A History of Its Demise; Christopher Bennett, Yugoslavia's Bloody Collapse: Causes. Course and Consequences. ${ }^{4}$ They were the most economically prosperous republics and had the most experience with the West and Western ideals. For an overview of their economies in Yugoslavia see Sabrina Petra Ramet, Nationalism and Federalism in Yugoslavia 1962-1991, Bloomington: Indiana University Press, 1992.
} 
and importance of political memories that inform the politics of the present. ${ }^{5}$ Over time, institutions and memories constrain and shape accepted political activity and contribute to the establishment of new regimes, goals, and priorities.

Although there were numerous regime changes from the late $19^{\text {th }}$ century onwards, successive political actors selectively drew on procedures, norms and rules shaped by prior institutions in establishing new ones. These political institutional continuities are chronicled in this paper in four historical patterns of politics that have informed the establishment and operation of successive institutions in Croatia and Slovenia. These are: (1) rational legal or charismatic authority; (2) pragmatism or ideology; (3) positive sum or zero sum games, and (4) incrementalism or revolutionary change. Legal authority, pragmatism, positive sum games, and incrementalism are all factors that usually contribute to or are a part of liberal political systems. The aforementioned historical patterns do not always accompany one another, nor do they always contribute to liberal systems, but they have played a more prominent role in modern Slovenian political discourse. Historical patterns of politics in Croatia have to a greater extent than in Slovenia relied on charismatic authority, ideology, zero sum games, and revolutionary change. It is well established that Slovenia has had more success in political liberalization. This does not make Slovenia a better or more righteous state, it

\footnotetext{
${ }^{5}$ Kathleen Thelen and Sven Steinmo note that historical institutionalism is particularly well suited for cross-national studies and at its best can account for both continuity and change. Thelen and Steinmo, Structuring Politics: Historical Institutionalism in Comparative Analysis (Cambridge: Cambridge University Press, 1992) 14-15.
} 
simply achieved a common goal with greater success. These patterns provide a historically grounded framework to aid in accounting for differences in political liberalization in the post-communist era.

These patterns are presented here as ideal types, as general concepts abstracted from historical political activities and understandings, that have held a long-term influence and impacted short-term change. The many distinctions do not preclude some similarities, nor do they preclude counter examples, all of which will be taken note of in subsequent chapters. The distinctions are not mirror opposites, nor do they automatically exclude one another, but they do help trace overlooked and understudied causative factors through the interplay of political institutions and memory, the politics of the past and of the present.

This study takes historical patterns of politics as central explanatory factors in the attempt to interpret present day trajectories of liberalization. In both countries political parties played a key role in establishing new state systems and shaping political institutions in the midst of great changes and in the absence of the former state system. For the first time parties in both new states were able to act without great external pressures that had kept them in multinational empires and dictated the political systems within which they acted. The great majority of members of the political elite and the citizenry had endorsed a liberal democratic system, and in the absence of overwhelming external influences political actors were given wide 
scope in establishing the type of liberal democratic rule they desired through the processes and products of reform.

This dissertation seeks to distinguish between the varied paths taken by the two countries and to discern patterns of politics in order to understand political institutions through a yet unexplored comparative political history and uncompared post-communist church-state relations. As Zsolt Enyedi notes, in post-communist countries both churches and states have been forced to define and justify their position on church-state relations explicitly "in an environment where religion is a politically important factor. ${ }^{, 6}$ The examination of post-independence church-state relations, particularly in regards to concordat creation, education and finance demonstrates the pace of political liberalization in both countries. The process and content of policy-making in a contentious area such as church-state relations tests the validity of the hypothesis that historical patterns of politics continue to inform the types of liberal democratic regimes established in each country after 1991. Church-state relations were chosen to test the influence of historic institutions because these issues are central to liberalization, are historically important, have yet to be comparatively studied and to a great extent are chosen by domestic political actors. Yet while the issues that arose in both countries are similar and while church actors in both countries have sought the same goals and employed the same methods, the results are quite different.

${ }^{6}$ Zsolt Enyedi, "Conclusion: Emerging Issues in the Study of Church-State Relations," Church and State in Contemporary Europe: The Chimera of Neutrality, eds. John T. S. Madeley and Zsolt Enyedi (London: Frank Cass, 2003), 227. 
The divergent approaches taken by Slovenia and Croatia in postcommunist political liberalization did not simply emerge in the wake of the breakup of the Socialist Federal Republic of Yugoslavia (SFRY). Rather, as demonstrated by the overview of political history and examination of postcommunist relations between church and state in this dissertation, institutional legacies and political memories have influenced the divergent trajectories of Slovenian and Croatian politics. The institutional context in which the elite in both countries found itself on the eve of independence structured power relations, policy choices, and political transformations as a whole. Although 1989 signalled a period of great change, previous institutional contexts and political memory afforded some elite actors and strategies certain advantages in the processes of political liberalization. It is this elite and these strategies that continued to reap benefits during the time when rules of the game, modes of operation, and other institutions were re-established or changed.

\subsection{Outline of the Work}

This work is divided into three parts. Part I, after the introduction, explains the main concepts that inform this exploration, historical institutionalism and liberalism, and then develops the variables that model this study, the four historical patterns of politics. 
Part II, chapters 3-5, of this dissertation, provides an historical overview with a focus on general patterns that have informed political responses and actions. These chapters provide a basis for comparative political analysis, relying on the work of respected contemporary historians, but drawing out comparisons and isolating causative factors that have not been made previously. These chapters provide a crucial context and establish patterns that persist in the post-communist era. The persistence of these patterns is demonstrated in Part III, chapters 6-9, with the analysis of one area of post-communist policy making, church-state relations. Combined, the chapters in this dissertation contribute to a greater understanding of the causal complexity of political developments in both countries.

The chapters in Part II elucidate the patterns of politics that have been shaped through institutional dynamics as well as the memories currently used to explain these political developments. This section explores the history of Sloveneand Croat-inhabited lands, focusing on historical legacies and political patterns. Although the chapters focusing on history will be roughly chronological, not every event, space, institution, or symbol will be explored in depth - only the ones that have been the most prominent and politically influential. This analysis is centred on the $19^{\text {th }}$ century and the $20^{\text {th }}$ century, the era of modern politics in Croatia and Slovenia. The founding of political parties that sought to represent Croatians and Slovenians as a nation from the late 1800 s onward marks this era. 
Among the most influential domestic institutions that differentiated Croatian and Slovenian politics in multi-national states were political parties. Among the most forceful justifications used to perpetuate the power of political parties, aside from constraints of the regime, were appeals to national political history. The shape of institutions of the past and the way in which they are remembered constitute a political legacy that has created, and been utilized in establishing, post-communist political orders.

Within the late Austro-Hungarian Empire, the Kingdom of Serbs, Croats, and Slovenes, and even socialist Yugoslavia, political parties in Croatian and Slovenian lands remained key domestic/national institutions. Although these parties were very different and operated under very different regimes, there are common patterns of political activity, practices, interest, intermediation, and historical memory that informed institutional constraints that influenced successive regimes and played a role in the post-communist politics of each country. The chapters in Part II are devoted to the main political institutions, events, and resultant patterns that informed modern Croatian and Slovenian politics. They highlight the differences in response of the elite to similar events in Slovenia and Croatia.

Part III of this work outlines how memories and institutions have influenced post-communist politics in general and in one policy area in particular, church-state relations. This section describes the general post-communist political environment of both countries as well as liberalization, with a focus on post-1991 church-state 
relations. Church-state relations were chosen because they were of interest in postcommunist politics, involving actors with similar interests but dealing with them in very different ways. Each chapter in Part III will be dedicated to exploring a prominent social and political dilemma of church-state relations in Slovenia and Croatia: concordat content and creation, education, finance and property restitution. The relationship between church and state remains a contentious area of post-communist policy-making in which there is no externally mandated model for a liberal-democratic order. There is no pre-determined set of rules for church-state relations within the European Union to follow, nor is there a benchmark of churchstate relations in a consolidated liberal democratic country for Slovenia and Croatia to emulate. ${ }^{7}$ Slovenia and Croatia are not alone when it comes to re-thinking and re-establishing church-state relations. This phenomenon has been observed throughout post-communist Eastern Europe and the former Soviet Union. Postcommunist reconfiguring of church-state relations has included both re-

\footnotetext{
${ }^{7}$ The Vatican does exert influence in ECE countries with the RCC majorities, particularly if it has a concordat with them. However, the extent of Vatican influence on formal policy-making and the areas that I will explore is largely limited by the government in power. European Union members are not penalized by other states or organizations if they do not choose to enter into legal relations with the Holy See. However, depending on the state, some governments might be penalized by voters for not establishing such relations. Although concordats with the Holy See do place certain obligations on the states with which they are signed, this does not negate the fact that the states that do sign concordats are not impelled or directed by some overwhelming transformational force. Not every country with a Roman Catholic majority has signed an agreement. Relations with the Holy See are not considered paramount in liberal and democratic transitions, and thus there is no uniform set of relations with the Holy See that a state must maintain to be considered a part of the liberal and democratic world. Nor are such relations mandated for EU accession. Signing (or not signing) an agreement and thus placing part of sovereign decision-making on church-state relations in the hands of an out-of-state organization is a choice that is ultimately made by governments in question. The question is whether these decisions have been and continue to be made in accordance with liberal and democratic principles.
} 
secularization of the public realm (as in Slovenia and the Czech Republic), and re-establishment of a traditional, national church (as in Croatia and Poland). ${ }^{8}$

The third section of this dissertation provides empirical proof of the continued influence of the distinct patterns of politics in post-communist reform and the differences in degrees and speed of liberalization. This way, the chapters focusing on history and the ones focusing on post-communist church-state relations will contribute to a broader understanding of the institutions, memories and circumstances that have come to shape the liberal-democratic transition in Slovenia and Croatia. The conclusion presents thoughts on political liberalization and the historical role of institutions as related to other wider ideas discussed in the literature.

This dissertation does not simply pick elements of historical development that suit its theory, but undertakes a detailed examination of history and prominent patterns, in order gain a greater understanding of the elements informing the politics of the present. It is precisely at the moment of great political upheaval, when both new regimes and new states are being formed, that distinct strategies and choices justified by political memories and historical institutions are most clearly exemplified. At this moment, key political institutions and influential actors

\footnotetext{
${ }^{8}$ A 1994 survey found that the Church was highly trusted in Slovakia, Hungary, and Poland, and that it was least trusted in the Czech Republic and Slovenia. Richard Rose and Christian Haerpfer, "New Democracies Baramoter III: Learning from What is Happening," Studies in Public Policy 230 (1994): 18. In the 1994 Slovenian Public Opinion Survey, the Catholic Church was the fourth least trusted institution out of 14 institutions ranging from political parties, the army, parliament, and private enterprises. Niko Toš, et. Al. , "Slovensko Javno Mnenje," Center za Raziskovanje Javnega Mnenja in Množičnih Komunikacija (Ljubljana: FDV: CJMMK, 1994) 36.
} 
in both countries choose distinct strategies in order to achieve a similar goal, liberalization. 


\section{Chapter 2: Theoretical Framework and Literature Review}

\subsection{Introduction}

This study is concerned with answering the question why polities such as Slovenia and Croatia, which were in the same federation for 70 years and underwent many of the same historical events and external pressures, developed such distinct politics. What has made modern political developments in one country more compatible with the process of political liberalization? In order to answer this question, the present study explores the relationships among modern political institutions, memory, and liberalization with a focus on patterns in political history in general and post-communist policy-making in particular.

Although new, the two states have a modern history that informed their approach to post-communism and the way they dealt with the pressures of the break-up of Yugoslavia and beyond. The historical patterns of politics isolated in this study are taken as ideal types that continue to influence public policy-making in Slovenia and Croatia. These patterns, as traced through Part II and Part III of this study, will be used to explain why Slovenia engaged in swifter and more secure political liberalization in the post-communist era than Croatia.

This chapter builds the theoretical framework of the study. It discusses the main concepts that inform this dissertation, historical institutionalism, memory and liberalism. This section also explains the key variables of this study, the historical 
patterns of politics. An analysis of long-term causal patterns with a focus on the constraints and opportunities provided by political institutions is a key component of any theoretical framework endeavouring to explain post-communist transformations. Such a framework should include an understanding of what causes institutional crises and changes, responses to these changes, as well as a detailed exploration of the effects of these historical patterns and moments on the reconfiguration of political institutions. In post-communist countries, democratic transformation implicitly requires political liberalization. Both Slovenia and Croatia are liberal democracies that have experienced divergent levels and trajectories of liberalization. An important part of liberalism and liberalization is church-state relations that conform to the liberal ideals of the separation of church and state. This chapter provides a theoretical framework for the case studies of Slovenia and Croatia, which are presented in the following chapters.

\subsection{Historical Institutionalism and Institutions}

In this empirically driven analysis, it is argued that institutions as well as the constraints, opportunities, and attitudes that have developed with them, have influenced current political actors in Slovenia and Croatia. The patterns of history that influence institutional design, the actions of state actors and popular perceptions may not be readily apparent in regions as tumultuous as southern and central-eastern Europe. Through generations, however, there persist discernable 
strategies, perceptions, and ideals informing distinct institution-building drawn upon by current political actors in policy-making. Historical institutionalism (HI) combines the study of historical particularities and generalizations in an effort to explain real world puzzles. ${ }^{9}$ Historical institutionalism is problem-driven rather than theory-driven, and it is most easily distinguished by its research strategy.

Historical institutionalists are criticized for hypothesising patterns that stretch over long periods of time, making continuities seem impossible given the different political regimes involved. A related assertion is that the historical arguments put forward are often an unruly agglomeration of the most popular and accessible understandings of history available at the time. Peter Hall and Rosemary Taylor agree that historical institutionalists have not established a unique and systematic approach to the structure-agency question. ${ }^{10}$ Instead, historical institutionalism contributes to comparative political studies through developing hypotheses based on the comparative study of long-term and unique temporal processes. By taking history seriously, HI provides context for some hypotheses based primarily on macro patterns of institutional development and some hypotheses based on micro patterns, namely elite activity within those institutions. As Paul Pierson and Theda Skocpol note, "Historical institutionalists make visible

\footnotetext{
${ }^{9}$ Dietrich A. Rueschemeyer, Evelyne Huber Stephens, and John D. Stephens, Capitalist Development and Democracy (Chicago: University of Chicago Press, 1992) 12.

${ }^{10}$ Peter A. Hall and Rosemary C. R. Taylor, "The Potential of Historical Institutionalism: A Response to Hay and Wincott," Political Studies 46 (1998): 958-962.
} 
and understandable the overarching contexts and interacting processes that shape and reshape states, politics and public policy-making."11

Ellen Immergut asserts that historical institutionalists focus on "publicly expressed, organized demands," not on individual preferences. ${ }^{12}$ This study employs historical institutionalism to discern how the rules of the game are set up, why certain elite actors are powerful, and what legacies and broad ranges of ideas and conceptions of history and politics influence the creation and recreation of institutions.

Institutions that have structured high politics, including representative assemblies, constitutions, and political parties, are the focus of this study, along with the Roman Catholic Church, an institution with an important political presence in both countries. The political institutions discussed here were designed to be more than just instruments to structure political procedures; they are "patterns of communication and activity" that shape and are shaped by ideals, perceptions, norms, identities, rules, actions of the elite, and policy outcomes, "usually without intentional foresight and control." ${ }^{.13}$ Political institutions include formal and informal processes that structure power configurations and distribution, including intended and unintended consequences. These institutions shape relationships

\footnotetext{
${ }^{11}$ Paul Pieson and Theda Skocpol, "Historical Institutionalism in Contemporary Political Science," The State of the Discipline, eds. Ira Katznelsonm and Helen Milner (New York: W.W. Norton, 2002) 693-694.

${ }^{12}$ Ellen M. Immergut, "The Normative Roots of the New Institutionalisms: Historical Institutionalism," Beitrage zur Theorieentwicklung in der Politik-Und Verwaltungswissenschaft eds. Arthur Benz and Wolfgang Seibel (Baden-Baden: Nomos, 1996) 325-327.

${ }^{13}$ Theda Skocpol, "Why I am an Historical Institutionalist," Polity 28.1 (Fall 1995): 105.
} 
among people in society: between the state and its citizens, representatives and electors, civil society groups, state agencies, branches of government and their agents. Collectively held norms are key to ensuring the legitimacy and influence of given actors and institutions. ${ }^{14}$ Even in times of dramatic institutional changes, norms, conventions and routines play a role in the reproduction and reconfiguring of institutional patterns in the long-term.

Like Theda Skocpol, this study takes the position that institutions are primarily "actual patterns of communication and activity," thus contradicting Douglas C. North's position which places emphasis on legal arrangements, procedures, norms, and organizational forms. ${ }^{15}$ A historical institutionalist, Skocpol emphasises human interactions in unstable formal and informal networks, with a focus on political processes and outcomes, which are often the product of unintended consequences. The rational choice perspective of Douglas North has a primary focus on formal mechanisms that predictably structure individual choice and action. ${ }^{16}$ There are many points of agreement between historical, rational choice and sociological institutionalist approaches; primarily, they all recognize the importance of institutions. However, historical institutionalism focuses on "how institutions emerge from and are embedded in concrete temporal processes,"

\footnotetext{
${ }^{14}$ Peter J. Katzenstein, Cultural Norms and National Security: Poice and Military in Postwar Japan (Ithaca: Cornell University Press, 1996) 281.

${ }^{15}$ Douglas $C$. North, Institutions, Institutional Change and Economic Performance (New York: Cambridge University Press, 1990) 4-6.

${ }^{16}$ There have been many comparisons of rational choice and historical institutionalism, the most influential being Peter A. Hall and Rosemary C. R. Taylor, "Political Science and the Three New Institutionalisms," Political Studies 6 (1996): 944.
} 
whereas rational choice theorists regard institutions as "coordination

mechanisms that generate or sustain equilibria." ${ }^{17}$ Historical institutionalism as employed in this study is inductive, addresses broad questions, and relies on empirical research.

\subsubsection{Accounting for Change}

Institutional legacies cannot be considered separately from post-communist institutions, because legacies influence power distribution as well as shape ideals, content, substance, and scope of present day initiatives. As Skokpol and Paul Pierson note, "once established, patterns of political mobilization, the institutional "rules of the game, and even citizens' basic ways of thinking about the political world will often generate self-reinforcing dynamics. ${ }^{" 18}$ Even in societies where there have been profound changes, as in post-communist countries for example, power configurations, prominent political actors, and their "self-interests and subjective cognitive maps" remain strongly influenced by previous power relations and institutions. ${ }^{19}$

\footnotetext{
${ }^{17}$ Kathleen Thelen, "Historical Institutionalism in Comparative Politics," Annual Review of Political Science 2 (1999): 369-371. Not only does historical institutionalist analysis take into account the timing and sequencing of historical events, but it also considers the timing and sequencing of policy making after particular events. As can be inferred from this conception, rational choice theory influences historical institutionalism, positing that actors make stable choices with in certain rules and given certain resources. However, historical institutionalism as used in this paper does not offer an account of individual interests or choices of policy actors that are based on a systematic equilibrium.

${ }_{18}^{18}$ Hall and Taylor, Political Studies 46, 954.

${ }^{19}$ Herbert Kitschelt, Zdenka Mansfeldova, Radoslaw Markowski, and Gabor Toka, Post-Communist Party Systems: Competition, Representation, and Inter-Party Cooperation (New York: Cambridge University Press, 1999) 19-42.
} 
Given the political upheavals of south and central-eastern Europe, the continuities of political processes over time are often ignored in the favour of shortterm explanations, which in turn foster short-term horizons and encourage the dismissal of the region as a 'cauldron that cannot be cooled.' The focus on previously unexplored patterns contributes to a greater understanding of institutions and processes that are harnessed in transformations.

Institutions are not static, being continuously influenced and reshaped by historical contingencies. At the same time, institutions are neither created nor sustained in a social-political vacuum. While institutions shape interests and establish culturally accepted rules of behaviour, they also change through contradictions and conflicts within the institutions themselves and in the context of broader societal developments. ${ }^{20}$ The question then becomes, 'How can change be accounted for if path dependence is the explanation?' Both the punctuated equilibrium model of Stephen D. Krasner and the path contingency model of Juliet Johnson explain how dramatic institutional change is not inimical to, but rather a part of, historical institutionalist understanding. ${ }^{21}$

Krasner's punctuated equilibrium model argues that extra-institutional crises can precipitate institutional changes. In the wake of these crises, new

\footnotetext{
${ }^{20}$ Paul DiMaggio and Walter W. Powell, introduction, The New Institutionalism in Organizational Analysis, eds. Paul DiMaggio and Walter Powell (Chicago: University of Chicago Press, 1991) 7. ${ }^{21}$ Juliet Johnson, "Path Contingency in Postcommunist Transformations," Comparative Politics 31 (2001): 255. Stephen D. Krasner, "Approaches to the State: Alternative Conceptions and Historical Dynamics," Comparative Politics 16.2 (1984): 223-246.
} 
institutions are established and sustained for a long period of time. ${ }^{22}$ Although this model accounts for change, it does not confirm how institutions in crisis continue to influence successor institutions. As Kathleen Thelen and Sven Steinmo note, while the punctuated equilibrium model as elaborated by Stephen Krasner states that "institutions explain everything until they explain nothing," it does not "capture the interplay of the two variables (institutional stasis and breakdowns) over time. ${ }^{, 23}$ This dissertation seeks to take account of both stasis and crisis, but pays particular attention to explaining political continuities in a region where the focus of political research has conventionally been on crisis and breakdown. ${ }^{24}$

Thelen and Steinmo focus on "institutional dynamism," taking into account the "dynamic interaction of political strategies and institutional constraints...over time. $" 25$ Preferences, strategies, and powers of actors are defined by the institutions and redefine the institutions themselves. Institutions are dynamic, and they gradually evolve, influence, and are influenced by ideals and interests; they respond to socio-economic and political shifts both within the state in question and outside of it. Thelen and Steinmo's expressions of historical institutionalism and reasoning for change are key, but the path contingency approach crafted by Juliet Johnson directly addresses changes in post-communist polities. Johnson focuses on the

\footnotetext{
${ }^{22}$ Krasner 223-25.

${ }^{23}$ Thelen and Steinmo 15.

24 The conflict in the region itself points to the importance of control over key political institutions. As Thelen and Steinmo point out, "political actors of course are not unaware of the deep and fundamental impact of institutions, which is why battles over institutions are so hard fought." Thelen and Steinmo 9.

${ }^{25}$ Thelen and Steinmo 9.
} 
"periods of extraordinary politics, in which states experience immediate and intense political and economic uncertainty. ${ }^{, 26}$ The path contingency approach explicitly recognizes that in times of intense change there is a dynamic interaction between agency and structure; there is also a tendency to engage in passive institutional design that reinforces institutional legacies. While institutional legacies remain an important factor in such periods of turmoil, institutional change is also influenced by policy choice, state capacity, and policy sequencing. ${ }^{27}$

Historical institutionalism encourages one to focus on the dynamic interplay of institutional legacies and current actors. It provides a basis from which to compare polities that had or may have similar formal or informal institutions. It can also help explain how and why different polities respond to similar political problems or contingencies in different ways. In the following chapters, I will compare different responses of Slovenia and Croatia to similar political dilemmas. My aim is to understand what these responses can reveal about the different democratic and liberalizing trajectories of these two polities. When formulating concepts concerning current political systems, routines, and dilemmas in any given polity, it is important to keep in mind that institutional development is the creation and the change factor of institutions. This development reflects and perpetuates ideas of appropriate rules and behaviour.

\footnotetext{
${ }^{26}$ Johnson 256.

${ }^{27}$ Johnson 255 .
} 
Comprehension of historical legacies is crucial to understanding current institution building, but this does not mean that these legacies are fixed and immutable. History is not destiny, as it has so often been argued in the case of the former Yugoslavia. However, perceptions of history and actual experiences do have an important role in shaping new institutions, structures, strategies, tactics, and beliefs of the actors involved. That is why I will explore events, actors, and interpretations of Slovenian and Croatian political history.

I focus on institutional legacies which shape multiple changing strategies and preferences of actors within institutional constraints and which are based on multiple ideas and conceptions, including views of common history and identity. This enables me to examine debates surrounding proposed or actual policies, in this case issues of church-state relations. As Skocpol recognises, "politics creates policies, policies also remake politics. ${ }^{, 28}$ My focus on policy-making in churchstate relations affords me an empirical measure. This measure allows the reference of influences on actors of historic legacies in creating and recreating institutions alongside the actors' resources, strategies, choices, and policy aims. In addition, I will empirically delineate how similar issues of church-state relations are approached differently in Slovenia and Croatia and how these approaches influence

\footnotetext{
${ }^{28}$ Theda Skockpol, Protecting Soldiers and Mothers: The Political Origins of Social Policy in the United States (Cambridge: Belknap Press of Harvard University Press, 1992) 58.
} 
the trajectory of democratic and liberal development in these polities. ${ }^{29}$ As Fritz

W. Scharpf notes, policy choices should be examined with regards to institutional

conceptions and constraints. ${ }^{30} \mathrm{~A}$ focus on liberalization and one area of policy-

making enables a discussion of the explanations of political processes and conflicts

including institutional constraints and opportunities, as well as the actions of actors

and their normative and ideological perceptions, all within a historical context.

\subsubsection{Elite and Institutions}

A focus on historical institutionalism implies a reliance on the political elite as the most visible and influential actor operating within political institutions. This study, like other Historical Institutionalist works, recognizes the role of individual actors, particularly of the most prominent political actors, in conveying institutional legacies. $^{31}$

\footnotetext{
${ }^{29}$ I do not assume that continuing transformations and transitions should only be conceived as conclusive steps towards liberal democracy. Yet, transformations in the ECE are commonly viewed as processes of liberalization and democratization.

${ }^{30}$ Fritz W. Scharpf, "Institutions in Comparative Policy Research," Comparative Political Studies 33.6/7 (2000): 762-790. Schapf also notes that they should be examined in relation to normative orientations of the policy actors involved, which may vary in different polities and times. To make the same point, Scharpf uses the example of the mid-1970s move of the German Bundesbank from a Keynesian to a monetarist system. At that time, Austria, Denmark, the Netherlands, and Belgium all pegged their currencies to the German mark. They were confronted with the situation in the hard currency environment which, as Scharpf interprets, in the absence of union wage restraints would produce high unemployment. Confronted with the same dilemma, they responded in different ways. What explains these differences in policy response of this given challenge is the institutional conditions and interactions of actors. According to Scharpf, comparative case studies and policy research are concerned with trying to explain differences in policy responses to a given challenge. The case is defined by the set of interactions connecting the challenge to the response. Scharpf 783 . ${ }^{31}$ As Peter Hall and Rosemary Taylor note, "it is through the actions of individuals that institutions have an effect on political outcomes... Institutions are resistant to redesign ultimately because they structure the very choices about reform that the individual is likely to make." Peter A. Hall and Rosemary C. R. Taylor, "Political Science and the Three New Institutionalisms," Max-PlanckInstitut fur Gesellschaftsforschung (Koln:Max-Planck-Institut fur Gesellschaftsforschung, 1996).
} 
A departure from traditional elitist theory, the inclusion of political elites in Historical Institutionalist analysis focuses on the actions of individuals, including the elite, with the understanding that the approaches of individual political elites are constrained by enduring institutions.

Classical elitists Gaetano Mosca and Vilfredo Pareto reiterate that all political systems are invariably ruled by the elite, who derive power from resources valued in a given society and era. ${ }^{32}$ These resources range from economic wealth or ideological and spiritual justifications to command of a well-run organization, with Robert Michels stressing the latter. ${ }^{33}$ Joseph Shumpeter clarifies that democracy as it is known today is elitist, because it relies on the competition among and the organization of the elite. ${ }^{34}$ Liberal democracy, however, relies on a plurality of the elite to ensure that the inclusiveness of democracy does not overpower the contestation of liberalism. ${ }^{35}$

I do not hold as a normative rule that the elite should be in control of the democratizing and liberalization processes in East Central Europe (ECE). For the most part, however, they simply are. My objective is to understand democratic development and liberalization in the contentious realm of policy-making which this elite shapes while acting within the constraints of historic institutional legacies.

\footnotetext{
${ }^{32}$ Gaetano Mosca, The Ruling Class, trans. A. Livingston (Toronto: McGraw-Hill, 1939). Vilfredo Pareto, Sociological Writings, ed. S. E. Finer (Oxford: Blackwell, 1976).

${ }^{33}$ Robert Michels, Political Parties (Glencoe: Free Press of Glencoe, 1949) 16.

${ }^{34}$ Joseph Alois Shumpeter, Capitalism. Socialism and Democracy (London: Allen \& Unwin, 1976) 110.

${ }^{35}$ Robert Dahl, Polyarchy: Participation and Opposition (New Haven: Yale University Press, 1971) 78.
} 
Elite is difficult to define conclusively, as its power is based on changing and divergent resources that are valued differently in different polities. Etzioni-Halevey defines the elite as "those who wield power and influence on the basis of their active control of a disproportionate share of a society's resources. ${ }^{\prime 36}$ It is thus a matter of degree rather than a distinct dichotomy between elite and non-elite members of society.$^{37}$ In post-communist countries, the elite is usually comprised of competing, interacting, and overlapping groups, including, but not limited to:

- $\quad$ Political elite - political party leaders, members of the executive and legislative branches of government, including ministers and high level bureaucrats;

- Religious elite - the hierarchy of the church (in the case of the Roman Catholic Church bishops and the archbishop);

- Civil society - leaders of movements not tied to the state or forprofit activities;

- $\quad$ Artistic elite - particularly celebrated artists (for example literary figures or musicians);

- $\quad$ Economic elite - controlling large enterprises or operating financial institutions;

- Military elite - high-ranking army officials or leaders of paramilitary groups.

The aforementioned elites, constrained by institutions, often use a

combination of resources, symbols, ideals, norms, conventions and myths to legitimize their position or change institutions, often drawing on interpretations of historical events and patterns.

\footnotetext{
${ }^{36}$ Eva Etzioni-Halevy, The Elite Connection: Problems and Potential of Western Democracy (Cambridge: Polity Press, 1993) 29.

${ }^{37}$ Etzioni-Halevy 29.
} 
2.3 Institutions Central to This Study: The State, Political Parties and the Roman Catholic Church

This comparative case study seeks to isolate political characteristics through patterns of politics that have informed distinctive modern Croatian and Slovenian politics. In order to understand how distinctive political dynamics survived, one must understand the ruling political institutions, central political actors, and the timing and sequencing of successive changes. The following chapters will describe in detail state, party, and church institutions, the changes they have undergone, and the timing and sequencing of those changes. It remains important to understand what these institutions are and why they are central in discussions concerning political history and contemporary public policy.

\subsubsection{The State}

Croatian and Slovenian political elites have for centuries operated within multi-national states. However, it was only since the late $19^{\text {th }}$ century that political interests and power struggles in Central Eastern Europe were defined in national terms. Within multi-national states, given institutions and rules of the game were replicated in distinctive administrative regions, but often to different effect and with different results. In these multi-national states, Croatian and Slovenian elites had distinctive constituencies and strategies but similar aims in terms of wining greater autonomy for the people they claimed to represent and for their own political gain. 
Every change of political regime was accompanied by sweeping changes in state institutions, for example constitutions, territorial administration and the structures of legislative bodies as well as almost inevitable changes in political parties and relations with other societal institutions such as the Roman Catholic Church. A majority of the institutions changed, but there were key patterns of politics reproduced in political strategies, historical memories, and national ideals that lay beneath these changes and marked distinctive politics. It is often during "critical junctures" in politics that the most enduring political characteristics of political life are demonstrated, because they influence the establishment of new institutions. $^{38}$

The institutional design of the different states that occupied a position in Croatia and Slovenia in the $20^{\text {th }}$ century has had a strong influence on political issues and approaches to these issues. States are autonomous, sovereign organizations that have legitimate political power in given communities with clearly demarcated territories and populations. To become established, states must be recognized by other states, but once they are established states are not static entities and their internal dynamics can and often do change. As Max Weber understood it, the state "is a human community that claims the monopoly of the legitimate use of physical force within a given territory."39 The modern liberaldemocratic state, as established in the aftermath of the French and American

\footnotetext{
${ }^{38}$ Krasner 223.

${ }^{39}$ Max Weber, Politics as a Vocation (Minneapolis: Fortress Press, 1965$) 11$.
} 
Revolutions, is constituted to defend the rights of citizens through representative institutions both internally and in the international environment. The state does not simply provide an "arena in which social groups make demands and engage in political struggles or compromises. ${ }^{, 40}$ By virtue of the institutional configuration of the state in question, including among other things the constitutional, electoral, and legislative regimes, different types of power relations are framed and different types of interest intermediation and policy ensue. However, current state institutions are not the only ones that require examination in order to comprehend the direction of policy making; rather, a historical understanding of the issues in question, the timing and sequencing of changes, the role of civil society actors at critical points, and the role of other institutions including political parties and the church are required.

\subsubsection{Political Parties}

Political parties and their leaders are a focus of this study. Since the establishment of political parties that sought to represent Croats and Slovenes at the twilight of the Austro-Hungarian Empire, leading political parties have had the key role in negotiating and identifying national goals within very different regimes. During and after regime changes, including the establishment of the Kingdom of Serbs, Croats, and Slovenes, Socialist Yugoslavia, and independent Croatia and

\footnotetext{
${ }^{40}$ Peter B. Evans, Dietrich Rueschemeyer, and Theda Skocpol, Bringing the State Back In (New York: Cambridge University Press, 1985) 8.
} 
Slovenia, political parties played a central role in establishing new political institutions from constitutions to legislative bodies.

Political parties in Croatia and Slovenia were constrained by the established regime, but they also helped build and entrench its institutions in a way that would ideally perpetuate their advantages. In doing so, political parties and the political elite sought to shape institutions and reinterpret political history both to justify their changes and continue to mark themselves as the legitimate representatives of each respective nation. Even during the socialist era, the League of Communists of Croatia and the League of Communists of Slovenia were distinctive actors that pursued their own aims within federal Yugoslavia. In the absence of democratic representative politics, political parties in Croatia and Slovenia throughout the modern era were core institutions through which national interests were articulated and expressed; they were often the only relatively strong institutions through which interests, however bent to fit reigning ideology or regime, were expressed.

Adam Przeworski emphasises the fact that rational political actors will act to maintain and strengthen their political power through creating institutions and rules that entrench relations that are advantageous to them. ${ }^{41}$ However, what is considered advantageous is not established by virtue of pure "self interested

\footnotetext{
${ }^{41}$ Adam Przeworski, Democracy and the Market (Cambridge: Cambridge University Press, 1991) 9. What is rational is often difficult to define; even when it is defined, there may be many different rational paths and actors who either do not seek to act rationally or seek to act rationally but end up acting against their own rational self-interests. Unbounded self-interested rational maximizers are difficult to analyze without an understanding, however implicit, of the historical developments of key political institutions.
} 
behaviour," but is rather shaped by historically informed goals, strategies, and preferences as historical institutionalists emphasise. ${ }^{42}$ Political actors in Croatia and Slovenia have acted to preserve a distinct Croatian and Slovenian approach to political interest intermediation particularly when dealing with similar political pressures that both correspond to current requirements and patterns of history.

\subsubsection{The Roman Catholic Church}

No other institutional actor enjoyed the long and varied history that the RCC occupied in Central Eastern Europe (CEE). The RCC is included in this discussion because it is an institution that has long held political influence in both countries and is also central to the post-communist policy example included in this dissertation.

Administratively the RCC has always been an important institution in CEE and throughout the Christian world, particularly as a model of modern bureaucracy. Over centuries, the RCC secured its position through increasing administrative rationality while pursuing confessional expansion. By the late Middle Ages, the RCC had established a non-hereditary cadre of administrators. ${ }^{43}$ Church-trained professionals entered secular offices as well, but they mainly functioned as cadres of specialists trained to ensure institutional reproduction if not the reproduction of

\footnotetext{
${ }^{42}$ Thelen and Steinmo 9.

${ }^{43}$ Roman Cholij, "Priestly Celibacy in Patristics and in the History of the Church, Secretary of the Apostolic Exarch for Ukrainian Catholics in Great Britain," Vatican 1993, 28 Mar. 2003 $<$ http://www.vatican.va>.
} 
their biological family line. ${ }^{44}$ There are unique social, cultural, psychological, linguistic, cognitive, and political patterns that demark the RCC as a bureaucracy. ${ }^{45}$

While its mission is spiritual, the way the mission is accomplished is through a bureaucracy that has very clearly delineated rules. Members of this bureaucracy are dependent on the organization for their identity, and their actions must be justified according to written doctrine and the orders and judgements of their superiors. ${ }^{46}$ In response to the reformation the Council of Trent (1545-1563), administrative and theocratic dogma was reformed. Vatican Council I (1869-1870) and Vatican Council II (1962-1965) both signified major shifts in church teachings and organization. Vatican I's promulgation of papal infallibility and assertion that "the divine origin of the Christian religion can be proved by miracles" reaffirmed the spiritual role of the Church. ${ }^{47} \mathrm{~A}$ Church more aware and responsive to changes in the modern political environment was Vatican II, the most extensive council in centuries. The council focused on liturgical reform and had a greater ecumenical openness. ${ }^{48}$ Both councils worked to reform the church and both required a rational bureaucracy and hierarchical organization to carry out these reforms.

The RCC administration influenced the development of modern bureaucracies. Max Weber recognised the RCC as a "distinctly developed and

\footnotetext{
${ }^{44}$ Ivan Padjen, "Aristokracija i Ustavna Država: Od Plemstva i Klera Do Provodudja i Profesija," Croatian Political Science Review, 35, 1998, 98.

${ }^{45}$ Ralph P. Hummel, The Bureaucratic Experience: A Critique of Life in the Modern Organization (New York: St. Martin's Press, 1994) 4.

${ }^{46}$ Hummel 112.

${ }^{47}$ Robert C. Broderick, ed., The Catholic Encyclopaedia, Revised and Updated Edition (Nashville: Thomas Nelson Publishers, 1987) 596.

${ }^{48}$ Broderick 597.
} 
quantitatively large bureaucracy(s). ${ }^{, 49}$ The RCC pioneered the type of social organization that Weber identified as the key to any modern bureaucracy. ${ }^{50}$ As summarized by Ralph Hummel, these organizational keys included legal rational legitimacy based on fixed jurisdiction, rationalistic division of labour, expert training, clear hierarchical delegation of responsibilities, and supervision delimited by firmly established general rules that are applicable to all and recorded in written documents. ${ }^{51}$ This is not to say that the RCC operates as a completely rational organization; within the RCC there is a complex command structure that can invite irrationality and intrigue. ${ }^{52}$ The RCC promulgates social values, but it relies on bureaucratic values of stability, discipline, and reliability to ensure organizational coherence. ${ }^{53}$ The spiritual mission of the RCC is in its earthly form carried out by virtue of the rational, legal, hierarchical, rule-based organization of the Church.

As a temporal power, the RCC became caught in a struggle to defend itself against the growing power of secular civil authorities of the nation-states of the $19^{\text {th }}$ century. ${ }^{54}$ As historical institutionalists Sven Steinmo and Kathleen Thelen note, "battles over institutions are fought so hard because political actors know their

\footnotetext{
${ }^{49}$ Hans Heinrich Gerth and C. Wright Mills, Character and Social Structure: The Psychology of Social Institutions (New York: Harcourt, Brace and World, 1964) 204.

${ }^{50}$ Max Weber, Economy and Society (Berkeley: University of California Press, 1987) 956-1005.

${ }^{51}$ Hummel 88-93.

${ }^{52}$ Peter Nichols, The Politics of the Vatican and the Pope's Divisions (London: Faber \& Faber, 1981) 205 .

${ }^{53}$ Hummel 66.

${ }^{54}$ Eric O. Hanson, The Catholic Church in World Politics (Princeton: Princeton University Press, 1987) 32.
} 
significance historically and their importance. ${ }^{., 55}$ Discussions of the RCC in this dissertation, particularly in chapters 7 to 10 , focus on the temporal power struggles of the Church, state, and political parties in establishing post-communist political orders. ${ }^{56}$ The RCC has long had an important institutional presence in Croatia and Slovenia, and even during the communist era it did not give up on seeking out a role in public life.

In Europe the church had gone from sharing power with civil authorities to being subject to them along with other social groups. This was not without a struggle. Given its history, the RCC in different states is seen as a powerful institution and potential competitor for political power. Although the Vaticanendorsed Catholic-Conservative Alliance of the late $19^{\text {th }}$ century was not wholly abandoned even despite Leo XIII's Catholic social ideals, by the $20^{\text {th }}$ century the Vatican had "at least a limited rapprochement with many of the changes in European life. ${ }^{, 57}$ While the Church's distrust of authoritarian regimes grew, as did its attempts to mediate the effects of both fascism and communism on the role of the Church through the issuing of Concordats, the Church's strongest condemnation was reserved for communist movements and regimes. ${ }^{58}$ Vatican II

\footnotetext{
${ }^{55}$ Thelen and Steinmo 9.

${ }^{56}$ As committed Catholics, Michael W. Higgins and Douglas R. Letson note that the Catholic Church is "an institution like any other: human, flawed, lumbering, resistant to change, and intolerant. It is also, for believers, the mystical body of Christ and the pilgrim People of God." Michael W. Higgins and Douglas R. Letson, Power and Peril: The Catholic Church at the Crossroads (Toronto: Harper Collins Publishers Ltd., 2002) 4.

${ }^{57}$ Hanson $40-42$.

${ }^{58}$ Hanson 43. John Cornwell, Hitler's Pope: The Secret History of Pius XII (New York: Viking, 1999) 135.
} 
and the battles between reformists and conservatives to shape the Church marked an era of greater debate, creativity, reconsideration, coming to terms with, and defining Catholic thoughts on many aspects of modern life. Increased focus on the needs of the laity (particularly manifested in vernacular liturgy), inter-faith ecumenism, emphasis on Christian humanism, and internationalization of the Roman Curia were all part of Vatican II, although decisions were not implemented uniformly. ${ }^{59}$

Greatly influenced by his participation in Vatican II, Karol Józef Wojtyla (1920-2005), Cardinal-Archbishop of Krakow, was elected by his peers to succeed Pope John Paul I as Pope John Paul II on 16 October 1978. The popes who came before him are not discussed in this brief overview, though they all played a role in shaping the RCC as an institution. Pope John Paul II is mentioned because of his influence and strong focus on the cultural and spiritual heritage of Poland as a model through which to understand and enhance the role of the RCC throughout the world. ${ }^{60}$ Although there are many aspects of his pontificate that deserve indepth study, the focus on cultural and spiritual heritage of a nation as part of his policy, political strategy to promote religious freedoms, and challenge to communist regimes was influential throughout Eastern and Central Eastern Europe. The Croatian and Slovenian Churches had currents of Catholic nationalism before Pope John Paul II, but the rise of the Polish Pope and his determination to combat

\footnotetext{
${ }^{59}$ Hanson 44.

${ }^{60}$ Higgins and Letson 38.
} 
communist regimes through a focus on Catholic and cultural heritage combined with political resistance and nationalism is remarkable. By the age of modern politics the RCC had very different institutional roles in Croatia and Slovenia.

The RCC as a universal Church had the same goals in both Slovenian and Croatian lands, and it was also under the same political pressure from the ruling regimes in Yugoslavia. However, the different role that the RCC came to play in the two states is both the product of unique Croatian and Slovenian political responses to external pressures and of the memories of its role in Croatian and Slovenian cultural, political, and national development. The RCC is not monolithic; there are many different offices and actors within the RCC, even within given ecclesiastical and political boundaries. However, the universal church has common aims and structures, and in different states it has had distinctive social and political influence in both polities.

\subsection{Political History, Memories and Transformations}

Nationally bounded and defined institutions and political elites have strongly relied on political memories to reinforce collective consciousness, and as a basis for collective action. In an effort to meet contemporary political requirements, political elites tailored representations of the past, including the remote past. Croatian and Slovenian political elites of different political allegiances and through successive regimes have enlisted some similar Croatian and Slovenian 
understandings of distant collective history in order to justify their authority. In portraying a constant struggle for self-expression and freedom, easily communicated lessons were invoked to provide causal explanations and define future imperatives. Although Croats and Slovenes shared some historical experiences, pressures from great powers, and politics within federations, the two states looked back to and constructed very different national histories, just as they participated in and constructed very different polities.

While memories, particularly political memories, are invocations of the past that are intentionally or implicitly employed to justify the values, actions, and ideals of the present. Historian Pierre Nora, celebrated for his work on memory, emphasises the distinction between history and memory, while recognizing their interaction: ${ }^{61}$

Memory... accommodates only those facts that suit it. It thrives on vague, telescoping reminiscences, on hazy general impressions of specific symbolic details. It is vulnerable to transferences, screen memories, censorings, and projections of all kinds. History, being an intellectual nonreligious activity, calls for analysis and critical discourse. Memory situates remembrance in a sacred context. ${ }^{62}$

\subsubsection{Political History}

History is a complex process. The motives and intentions of historical actors and the way in which their actions and ideals are interpreted and acted upon by contemporaries is difficult to decipher. Historians struggle over questions of

\footnotetext{
${ }^{61}$ Higgins and Leston 13-14.

${ }^{62}$ Higgings and Leston 3.
} 
interpretation, perception, motivation, and lessons of the past. This work of comparative political analysis relies on the works of respected historians who have been noted for their accurate analyses of both countries' past (discussed in the brief literature review below). History is used in this dissertation to strengthen comparative analysis by critically analysing and isolating general patterns of politics that can be traced to the modern politics of both polities.

No published work has had as its main focus a comparative study of Slovenian and Croatian politics, political history, or a comparative study of their post-communist church-state relations. Conventional accounts of transformations in post-Yugoslav politics have not concentrated on a comparative exploration of Slovenia and Croatia, their differences and similarities discussed only tangentially. In discussing history, this dissertation relies most heavily on works produced between the late 1970s and today. During this time, the number of critical histories burgeoned. I particularly rely on works that approach the former Yugoslavia from the perspective of political power imbalances between the republics and of understanding the varied histories that led these present day states into and out of the South Slav federation. ${ }^{63}$ This includes Sabrina Petra Ramet's work "Nationalism and Federalism in Yugoslavia 1962-1991," which takes a

\footnotetext{
${ }^{63}$ The historical works that I most heavily rely on are Ivo Goldstein, Croatia: A History; James Gow and Cathie Carmichael, Slovenia and the Slovenes: A Small State and the New Europe; Aleksa Djilas, The Contested Country: Yugoslav Unity and Communist Revolution 1919-1953; Jože Prijevec, Jugoslavija: Nastanek, Razvoj ter Razpad Karadjordjevićeve in Titove Jugoslavije; Lenard J. Cohen, Broken Bonds: Yugoslavia's Disintegration and Balkan Politics in Transition; John R. Lampe, Yugoslavia as History: Twice There was a Country.
} 
balance of power approach. Ramet takes a critical view of the growing political influence of nationalism. ${ }^{64} \mathrm{I}$ have been careful to avoid works that are nationally biased, particularly works that present one-sided judgements on the costs or benefits of the federation for given nations.

Works from the 1970s onward were consulted for a reflective overview of the modern political history that parted with the Marxist historiography prevailing in the $1950 \mathrm{~s}$ and the $1960 \mathrm{~s}$. The focus of Marxist-informed histories, published in the west and in the east, was on the unique road to socialism pursued by Yugoslavia rather than on a nuanced reading of the histories of each constituent unit. ${ }^{65}$ Works of the late 1960 s and 1970 s contributed to a more complex reading of Yugoslav history, eroding the immutability of Yugoslavia and moving beyond class-based analysis. ${ }^{66}$

By the 1980s, works critical of the Yugoslav state, the ideal of Yugoslavia, and inter-republic relations had emerged. These histories went a long way in exposing tensions in Yugoslavia, recognizing the unique and separate histories of

\footnotetext{
${ }^{64}$ Ramet, Nationalism and Federalism 12.

${ }^{65}$ Particularly, see the introduction by Eric Fromm in Mihailo Marković, From Affluence to Praxis: Philosophy and Social Criticism (Ann Arbour: University of Michigan Press, 1974). ${ }^{66}$ Dušan Bilandžić, Povijest Socijalističke Federativni Republike Jugoslavije (Zagreb: Školska Knjiga, 1979); Paul Shoup, Communism and the Yugoslav National Question (New York: Columbia University Press, 1968); Jozo Tomašević, War and Revolution in Yugoslavia, 1941-1945: The Chetniks (Stanford: Stanford University Press, 1975); Carole Rogel, The Slovenes and Yugoslavism, 1890-1914 (New York: Columbia University Press, East European Quarterly, 1977); Mirjana Gross, Povijest Pravaške Ideologije, (Zagreb: Sveučilište u Zagrebu, Insitut za Hrvatsku Povijest, 1973). An authoritative account of religious communities in Yugoslavia is found in Stella Alexander, Church and State in Yugoslavia since 1945 (New York: Cambridge University Press, 1979).
} 
the constituent parts of Yugoslavia and the weaknesses of the state. The legitimacy of Yugoslavia as a federation and as a socialist state was increasingly questioned.

Much of this era's literature carried an increasingly nationalist agenda that scapegoated others for a litany of national "misfortunes." These works include President of Croatia (1990-1999) Franjo Tudjman's book “The Wastelands of Historical Reality" and the Memorandum of the Serbian Academy of Sciences. ${ }^{67}$ The former downplayed the atrocities committed by the WWII fascist regime in Croatia, while the latter propounded that the creation of Yugoslavia came at a great (and continuing) cost for the Serbs. Increasingly, works promoted a romantic nationalism, contributing to the erosion of Yugoslav legitimacy. The environment of growing nationalism and the questioning of the federation in which these works were produced must be remembered.

At their best, the works of the 1980s questioned the orthodoxy of previous decades and contributed to a more nuanced understanding of the formation and operation of multi-national Yugoslavia as well as the creation and destruction of states in the region. These works include Ivo Banac's "The National Question in

\footnotetext{
${ }^{67}$ Franjo Tudjman, Bespuća Povijesne Zbiljnosti: Rasprava o Povijesti I Filozofiji Zlosilja (Zagreb: Nakladni Zavod Matice Hrvatske, 1989). Miroslav Pantic, ed., "Memorandum of the Serbian Academy of Arts and Sciences, Answers to Criticisms," Presidency of the Serbian Academy of Sciences and Arts 23 Apr. 1993, 7 Aug. $2001<$ http://www.beograd.com/sanu/ images/memo.pdf $>$.
} 
Yugoslavia" and Sabrina Petra Ramet's "Nationalism and Federalism in Yugoslavia." ${ }^{68}$

In the aftermath of the wars (1991-1995) a number of books were produced with the intention of explaining the lead-up to the dissolution of Yugoslavia and the wars themselves. The majority of these works focused on the conflict between Serbs and Croats, but they also presented Slovenia and Croatia as western Yugoslav republics that sought decentralization, with Slovenia as a "success story" in terms of transition. ${ }^{69}$ While some of these works inform this study, not one of them systematically compares Slovenia and Croatia. The role of religious communities is also recognized in the works, particularly the religious-national connection between Croats and the Catholic Church, Serbs and the Serbian Orthodox Church, and Bosniaks and the Islamic community. However, there is little comparison between Catholic churches in Slovenia and Croatia. ${ }^{70}$ At the most simplistic, some works in the 1990s view Yugoslavia as cauldron of "ancient ethnic

\footnotetext{
${ }^{68}$ Ivo Banac, The National Question in Yugoslavia: Origin. History, Politics (Ithaca: Cornell University Press, 1984); Sabrina Petra Ramet, Nationalism and Federalism; Alexander N. Draganic, The First Yugoslavia: Search for a Viable Political System (Stanford: Stanford University Press, 1983);

${ }^{69}$ Misa Glenny, The Fall of Yugoslavia: The Third Balkan War (Toronto: Penguin Books, 1992); Laura Silber and Allan Little, The Death of Yugoslavia (London: Penguin Books and BBC Books, 1995). Both books provide an informed and easy to read overview of the lead-up and progress of the war. Viktor Meier, Yugoslavia, A History of its Demise, trans. Sabrina Petra Ramet (London: Routledge, 1999) provides a detailed overview of the war and is one of a few works that cover the wars with the emphasis on Slovenia's role in them.

${ }^{70}$ Sabrina Petra Ramet, Balkan Babel: The Disintegration of Yugoslavia From The Death of Tito to Ethnic War (Boulder: Westview Press, 1996). An informative account of the role of religious organizations in the wars is found in Paul Mojzes, Yugoslav Inferno: Ethnoreligious Warfare in the Balkans (New York: Continum, 1994).
} 
hatreds," a stance against which this work strongly argues. ${ }^{71}$ The most infamous of these works is "Balkan Ghosts" by Robert D. Kaplan. ${ }^{72}$ While his stance provided a ready excuse for Western non-intervention in the wars, it also precluded a nuanced discussion of the reasons behind the wars, the political histories of the states involved, and the role of political memories in the states' subsequent development.

\subsubsection{Political Memories}

The politization of memory is most forcefully represented at times of political upheaval. It is at the moment of crisis when stylized representations of the past gain particular prominence as lessons for the present and future. As Pierre Nora wrote of French history, "we can still make out the unbroken path, the permanence of an identity even now in the throes of fundamental change.,73

It is important to note that memory is fashioned out of what is remembered and what is forgotten as it shapes how certain collectives imagine themselves. Benedict Anderson, in his work Imagined Communities, implores scholars to understand nations as historical artefacts that are constantly being created and

\footnotetext{
${ }^{71}$ Robert D. Kaplan's Balkan Ghosts: A Journey Through History (New York: Vintage, 1994) informed discourse in the West that relied on an "ancient ethnic hatreds" hypothesis, although it did not directly use this phrase. This phrase is still widely used, for example in a 60 Minutes segment that aired in 2003, in which a distinguished academic and commentator Michael Ignatieff noted how the downfall of communism in Yugoslavia "unleashed ancient ethnic hatreds." Morley Safer, "Mostar: Nation Building," 60 Minutes 20 Oct. 2003, 23 June $2004<$ http://www.cbsnews.com>. ${ }^{72}$ Kaplan.

${ }^{73}$ Pierre Nora, "General Introduction: Between Memory and History," Realms of Memory, Volume I: Conflicts and Divisions, ed. Pierre Nora (New York: Columbia University Press, 1996) 23.
} 
recreated "by the style in which they are imagined." ${ }^{.74}$ Generally, memories clarify collective action in the present by virtue of the past. Institutions and memory both act to constrain political actors, but they are also changed, manipulated, and used by such actors. Historical institutionalist analysis cannot ignore memory, because paths and political patterns are not simply carried over through unchanging institutional structures or by an enduring elite. Rather, institutional paths have been replicated through different regimes and by different elites that re-establish institutions in line with distinctive patterns of politics that are often justified by recourse to national memories.

In evaluating institutional development, the influence of the following four factors should be kept in mind:

i. Legacies of pre-democratic power relations among elite political and societal actors;

ii. Sequencing, timing, and responses to events in internal or external politics and society;

iii. Broader social identities and alignments based on these legacies; iv. Popular perceptions of historic events and their interpretations.

In this case, legacies refer to the patterns of already existing political power and institutions that affect the distribution of power and shape the establishment of new institutions in the post-communist era.

Power is at the heart of historical institutionalist research problems. Primary consideration is given to how and why actors achieve their ideals, interests, strategies, and goals given institutional opportunities and constraints. In the

\footnotetext{
${ }^{74}$ Benedict Anderson, Imagined Communities. Reflections on the Origin and Spread of Nationalism (London: Verso, 1983) 4-6.
} 
political context, power remains an essentially contested concept. This paper takes "power" to mean the overt and covert ability of an actor to affect the interests and ideals of another actor. ${ }^{75}$ This acknowledges the capacity of institutions to shape these power relations. Although unidentified agents can exercise power, this study focuses on identifiable agents, namely the political elite, whose goals are taken from their public statements and actions identified within an institutional context.

\subsubsection{Transformations}

The relationship among historical institutions, memories of modern political history, their role in post-communist transformations and liberalization is one that has not been adequately explored. One of the major approaches to post-communist transformations has been that of transitology. Transitologists compare the transitions to democracy in southern Europe and Latin America to post-communist transformations. The most notable text-based debate concerning transitology took place among Valerie Bunce, Philippe C. Schmitter and Terry Lynn Karl. ${ }^{76}$ Valerie Bunce is among the most notable opponents of transitology, arguing that the differences between the cases in question are too vast to provide for meaningful

\footnotetext{
${ }^{75}$ Unlike Robert Dahl in Modern Political Analysis, 1 do not take power to mean the ability of A to make $B$ do something that $A$ intends and that $B$ would not otherwise do. At the same time, I do not prescribe to Steven Luke's interpretation that A has power over B when A makes B act contrary to B's objective interests. Such objective interests are as difficult to identify conclusively, as are the intentions of the powerful actor in Dahl's conception.

${ }^{76}$ Valerie Bunce, "Should Transitologists Be Grounded," Slavic Review 54.1 (1995): 111-127. Philippe C. Schmitter and Terry Lynn Karl, "The Conceptual Travels of Transitologists and Consolidologists: How Far to The East Should They Attempt to Go?" Slavic Review 53.1 (1994): 173-185.
} 
observations. Transitologists such as Philippe Shmiter and Terry Lynn Karl argue that there is a common process that can be seen in transitions from a dictatorship to democracy. ${ }^{77}$ While such processes might contribute to studies of transformations, theories of transitology do not provide adequate explanations of post-communist transformations, because they undervalue the complex role of political institutions, ignore historical patterns, and focus on the transition to democracy rather than on the requirements and realization of political liberalization. $^{78}$

This work posits that the past plays the key role in current political developments and that it is not overcome. The unique histories of different polities negate the known final point that is common for all. Similarly, Karen Orren and Stephen Skowronek see social change in Eastern Europe as "transformationrearrangements, reconfigurations and recombinations., ${ }^{, 79}$ Although liberal democracy is the common goal, the characteristics of liberal democracies differ widely among post-communist polities because of divergent patterns of history and political institutions.

\footnotetext{
${ }^{77}$ Other readings in transitology include Juan Linz and Alfred Stepan, Problems of Democratic Transition and Consolidation: Southern Europe, South America, and Post-Communist Europe (Baltimore: Jons Hopkins University Press, 1996); Guillermo O’Donnell, Philippe C. Schmitter, and Laurence Whitehead eds., Transitions from Authoritarian Rule: Tentative Conclusions About Uncertain Democracies (Balitimore: Johns Hopkins University Press, 1986).

${ }^{78}$ I employ the word "transformation" rather than "transition," because the idea of transformation better suits the unique and relatively stable yet ongoing changes that are not directed towards a known final point. The idea of transition implies a homogenous pattern of change, with a teleological assumption that the past has been overcome to the benefit of a known future. Richard Sakwa, Postcommunism (Philadelphia: Open University Press, 1999).

${ }^{79}$ Karen Orren and Stephen Skowronek, "Beyond the Iconography for Order: Notes for a New Institutionalism," The Dynamics of American Politics, eds. Lawrence Dodd and Calvin Jillson (Boulder: Westview Press, 1994) 311-332.
} 


\subsection{Liberalism}

The primary goal voiced by leaders and citizens in post-communist polities was ensuring liberal democracy. Contemporary democracy is generally taken to mean liberal democracy. The liberal component emphasizes the rule of law as well as equal rights and freedoms, while the democratic component stresses the political power of individual citizens. Liberal democracy in this conceptualization is a combination of the rule of law, the freedom of individuals who possess electoral and civil rights, as well as legal and political equality. The minimal requirements of democracy, as articulated by Joseph Schumpeter, are enfranchisement and the right to vote or run for office in competitive, regular elections by secret ballot. ${ }^{80}$ The basic requirements of liberalism are free speech, free press and association, and the rule of law. The rule of law denotes adherence to standard legal rules that are neither arbitrary nor contradictory, but are applicable to all citizens including ruling politicians.

It is common in post-communist states for the liberal component of liberal democracy to be ignored to the detriment of the development of equitable, stable,

\footnotetext{
${ }^{80}$ Schumpeter's minimalist definition of democracy holds that democracy is an "institutional arrangement for arriving at political decisions in which individuals acquire the power to decide by means of competitive struggle for the people's vote." Schumpeter 269. Schumpeter emphasizes that democracy is the rule by the elected elite, who ach ieve their power through free, fair, regular, competitive elections. His conception includes plurality of political parties, promotion of plurality of beliefs and actions, as well as active participation in society. This also implies freedom of belief, association, and action, all with in the limits of the law, and political powers that are divided in a system of checks and balances.
} 
and reliable rights and freedoms. ${ }^{81}$ A State's description as authoritarian or semi-authoritarian can often be attributed to its lack of liberalization rather than to its lack of implementing democratic procedures. The disappointments and dangers of democracies not informed by liberal rights, freedoms, and the rule of law have been widely documented by Fareed Zakaria. ${ }^{82}$ As Fareed Zakaria notes, liberal democracy is "a political system marked not only by free and fair elections but also by the rule of law, a separation of powers, and the protection of basic liberties of speech, assembly, religion, and property."

There is no authoritative definition of liberalism, just as there is no quintessential liberal thinker. As often noted, conceptualizations of liberalism have varied over time and with location, so no thinker should be considered outside of their historical context. Most prominent classical and modern liberal thinkers have diverging interpretations of central political issues. However, political liberalism, in all of its incarnations, includes a focus on individual rights and freedoms, the rule of law, and tolerance required to achieve various visions of the good life. ${ }^{84}$

\footnotetext{
${ }^{81}$ As Marc F. Plattner argues, liberal democracy has been simply called democracy. Marc F. Plattner, "From Liberalism to Liberal Democracy," Journal of Democracy 10.3 (1999): 131. ${ }^{82}$ Fareed Zakaria, The Future of Freedom: llliberal Democracy at Home and Abroad (New York: W.W. Norton, 2003).

${ }^{83}$ Zakaria 17.

${ }^{84}$ Liberalism relies on commonly applied standards of liberty and justice to secure the rights of individuals to security, property, and liberty as well as the individual freedoms of expression, assembly, and religion. This is based on a focus on individual reason and responsibility. Classical and modern liberals posit that individuals are self-interested and ideally would act rationally on their self-interest to the benefit of stability, peace, and prosperity. Stephen Holmes notes, classical liberals invoked Hobbes and thought of individuals as self-destructive rather than economic animals who also acted on irrational impulses in their self-interest, including "spiritual goals such as avenging a perceived slight or compelling neighbours to attend church." Stephen Holmes, Passions
} 
Political liberalism is the focus of this work. Although generally considered mutually reinforcing due to the focus on individual rights and responsibilities, political and economic liberalism do not necessarily develop simultaneously. For example, global economic forces have lead to an economic but not a political liberalization in a large and increasing number of societies in the Middle East and Asia, including China. ${ }^{85}$ Most post-communist countries have sought both political and economic liberalization, adding to the difficulty of identifying both the importance and the components of political liberalism. The long history of liberalism in western societies leads to further conflation of political and economic liberalism. However, it remains important to disaggregate economic and political liberalism, in part because disappointment with economic liberalism in post-communist states could easily lead to disenchantment with political liberalization. Liberalism in post-communist states is criticized mostly for being a "controversial economic strategy.", 86

In this study, liberalization stands for various processes in different ECE polities that have, especially since 1989 , worked towards:

Establishment of the rule of law, adhered to by the citizens and the state, in which are enshrined the principles of individual rights and freedoms consistent with equality before that law; tolerance, which contributes to freedom from arbitrary power or officially sanctioned

and Constraint: On the Theory of Liberal Democracy (Chicago: University of Chicago Press, 1995) $2-4$.

${ }^{85}$ Michel Girard, "Two Dilemmas of Liberalism: Historical Exhaustion and Internal Division in a World of Globalization, The Meaning of Liberalism - East and West, eds. Zdenek Suda and Jiri Musil (New York: Central European University Press, 2000) 147.

${ }^{86}$ Jerzy Szacki, Liberalism after Communism (New York: Central European University Press, 1995) 5. 
discrimination, based on individually or externally imposed social or group affiliation such as political party, sex, race, ethnicity, or religion.

These goals are neither static nor predetermined. There is no decided end point to the processes of liberalization, nor are there predetermined ways to liberalize all polities. In fact, it is not necessary for all of them to liberalize. Yet, in polities where citizens voice their demands for individual and group rights and freedoms, and where elected leaders present liberalization as one of their main goals, an attempt to measure liberalization and an understanding of how it has developed and what can pose threats to it remain important.

Classical liberals, including John Locke, Adam Smith, and Alexis de Tocqueville, focused on individual reason and responsibility that afforded the same rights and responsibilities to all, the rulers and the ruled. While Tocqueville shared in the ideal of industry based on self-interested individuals as the key to prosperity, he also warned against threats to individual liberty that extreme individualism could bring. ${ }^{87}$ For Tocqueville, a society where individuals focus on their own material gain, public conformity, and apathy could risk tyranny by an overbearing government. Ideally classical liberals see governments as based on a social contract and ensuring the conditions for security, peace, and prosperity. Traditional and imposed hierarchies are not considered to have special claims to authority; rather, the starting point for public life is individual rights and responsibilities that are accorded to all.

${ }^{87}$ Alexis de Tocqueville, Democracy in America, Volume I (New York: A. A. Knopf, 1949) 230. 
It is precisely because classical liberal theorists recognized that individuals live within societies and that social mores are important that they focused on individual freedom. In advancing the idea that all individuals are equally self-interested and have the same liberties, rights, and responsibilities, liberals posit that these rights and responsibilities need to be respected by all, ruler and ruled. This is the key to ensuring that the rule of law prevails.

Liberals disagree on the extent of government's power and involvement in political, social, and economic life. However, they do agree that a stable and reliable rule of law is key. Modern liberal thinkers generally emphasize positive and negative freedoms in order to facilitate self-development. In practice, modern liberalism promotes the welfare state that seeks to lessen inequalities within society with the aim to give individuals a greater equality of opportunity to reach their potential. John Rawls' egalitarian stance recognizes the role of social and economic equality in promoting individual rights and freedoms. However, he notes the supremacy of equal rights and liberties over equality of opportunity: "Each person has an equal claim to a fully adequate scheme of equal basic rights and liberties, which scheme is compatible with the same scheme for all. ${ }^{988}$

In broadening the concept of justice, Rawls reiterates the need for legal equality as well as constitutional guarantees of political and personal rights and freedoms. Universal and impartial application of the rule of law, regardless of sex, gender, race, ethnicity, culture, or religion is the key component of all liberal

${ }^{88}$ John Rawls, Political Liberalism (New York: Columbia University Press, 1993) 5. 
polities. In post-communist polities, the primary task has been the creation of constitutions and laws that are stable, impartial, and possessing the confidence of the people, particularly given the arbitrary nature of rule in the communist era. Impartial rules are difficult to establish when one group, for example a particular religious denomination, is formally privileged over another. In post-communist transformations, religious denominations have sought formal privileges based on an appeal to tradition. Entrenchment of special rights for a particular religious group may work against the establishment of a voluntary and spontaneous civil society that can empower governments to work on their behalf and to interact on a foundation of tolerance, equal rights, and liberties.

\subsubsection{Liberalism and Church-State Relations}

This study evaluates post-communist political liberalization with a focus on one particularly contested area of reform, church-state relations. Given this focus, this section discusses general concepts of political liberalism along with liberal views on church-state relations.

The RCC has always been sceptical of liberalism. The liberal focus on individual freedom rather than on divinely sanctioned rule was the key starting point for the antipathy. Liberal focus on enlightened self-interest as opposed to revelation and individual rights and reason was part of the liberal doctrine that the RCC found challenging to its power. Liberals exhorted that an individual need not "sacrifice themselves for the good of the church or the state," and that, rather, the 
liberal polity exists "as a legal and moral order necessary not only to protect them [church and state] from each other and adjudicate their conflicts but also to enable them to achieve their goals. ${ }^{.89}$ The autonomy of individuals is a threat to the traditional church hierarchy. The RCC has posited that liberalism,

proclaims man's absolute autonomy in the intellectual, moral and social order, Liberalism denies, at least practically God and supernatural religion. If carried out logically, it leads even to a theoretical denial of God, by putting deified mankind in place of God. $^{90}$

Although Locke vigorously opposed the RCC, he was a devout Christian. He and many other liberals emphasised Christian virtues of industry, prudence, and justice. Liberals do not generally deny God, but they deny the establishment of one true religion upon which state authority rests. By advocating on behalf of individual autonomy and liberty, liberals seek to enhance the ability of every person to practice his or her religion free from influences that seek to use religion to enhance temporal power. Pius IX, in the Encyclical "Quanta Cura" of the $8^{\text {th }}$ of December, 1864 , forcefully protested the liberal idea of freedom of the individual, religion, and speech. ${ }^{91}$

A century later in the Vatican II Declaration on Religious liberty, Dignitatis Humanae declared that,

\footnotetext{
${ }^{89}$ James T. Kloppenberg, The Virtues of Liberalism (New York: Oxford University Press, 1998) 56.

${ }_{90}^{90}$ Robert C. Broderick, ed., The Catholic Encyclopaedia 26 Nov. 2002

$<$ http://www.newadvent.org/cathen/09212>.

${ }^{91}$ Pope Pius IX, "Quanta Cura," Papal Encyclicals 8 Dec. 1864, 24 Mar. 2002

$<$ http://www.papalencyclicals.netPius09/p9quanta>.
} 
The human person has a right to religious freedom...the right to religious freedom has its foundation in the very dignity of the human person, as this dignity is known through the revealed word of God and by reason itself. This right of the human person to religious freedom is to be recognised in the constitutional law whereby society is governed. Thus it is to become a civil right. ${ }^{92}$

The church of Pope Pius IX was writing at a time when the church had greater influence and political power than in the 1960s. By the time of Vatican II, the world had changed, and the RCC focused on influencing good government through social and moral concerns, without the heavy hand of its predecessors. The antipathies between liberal and Catholic traditions are far more complex and nuanced than discussed here. However, the liberal emphasis on the separation of church and state continues to thwart the influence on policy-making that the RCC seeks, even when "a wall of separation between church and state" does not exist. ${ }^{93}$ The RCC enjoyed varying degrees of religious freedom in different communist countries. However, in all of them existed a strict separation of church and state. In post-communist transformations, the RCC sought to diminish the separation of church and state so as to further its temporal aims.

Establishment of political systems based on liberal precepts is central to post-communist transformations. At a minimum, individual rights and freedoms should be respected. Such freedoms and rights are precluded in systems that confer

\footnotetext{
${ }^{92}$ Pope Paul VI, "Dignitatis Humanae," Vatican 7 Dec. 1965, 24 Mar. 2002 $<$ http://www.vatican.va/archive/hist_councils/ii_vatican_council/documents $>$.

${ }^{93}$ Thomas Jefferson, "Letter to Danbury Baptist Association: To Messers. Nehmiah Dodge and Others, a Committee of Danbury Baptist Association, in the State of Connecticut, January 1, 1802," The CIRCA Grove Computer at the University of Florida 27 Nov. 2002 $<$ http://www.grove.ufl.edu>.
} 
officially sanctioned denominational privilege. It is particularly important that states engaging in comprehensive political liberalization for the first time ensure the separation of church and state.

I rely on what Alfred Stepan postulates as the key criterion for compatibility with democracy, namely the firm establishment of "twin tolerations," freedom and tolerance of the church by the state and vice versa. Stepan argues that this is achieved when given religious organizations do not have "constitutionally privileged prerogatives that allow them to mandate public policy to democratically elected governments. ${ }^{, 94} \mathrm{He}$ notes that individuals and communities with particular religious commitments must have the freedom to pursue worship privately. They must also be permitted to have their views and values publicly known. ${ }^{95}$ This paper argues that, particularly in post-communist polities, tolerance is best achieved when there is a clear separation of church and state.

Locke advocated the separation of church and state based on the idea that only separation could ensure freedom, tolerance, and best service for individuals. Without an ultimate and God-given claim to rule, individuals would be able to consent to political authority voluntarily, through a social contract. Liberalism arose out of and rested on principles inimical to the universal claims and practices based on revelation.

\footnotetext{
${ }^{94}$ Alfred Stepan, "Religion, Democracy, and the 'Twin Tolerations, "” Journal of Democracy, 37 (2001): 39 .

${ }^{95}$ Stepan, "Religion" 40.
} 
In societies where there is no clear separation of church and state, there is a risk of the "politization of religion and religionization of politics," a phenomenon that has been highlighted during post-communist transformations. ${ }^{96}$ Since the end of the cold war, the roles of church, state, religion, and politics have come to the forefront of political deliberation in many countries. This is not limited to centraleastern Europe, but has been seen in the Middle East, the U.S. and all of the former Soviet Central Asian states. Ronald Robertson defines politization of religion as a phenomenon causing a greater concern of "religious collectives with governmental issues... grounding religious doctrine and practice in secular ideology or experience...[or] claiming that religious doctrine and practice must have ideological consequences. ${ }^{, 97}$ It is often convenient for both religious and political authorities to conflate religion and politics and claim to speak for the whole nation. There is a danger that automatic appeal to collective ethnic or religious identity in transforming societies can stifle liberalization and democratization in favour of arbitrary rule that privileges certain collectives by virtue of their 'majority' or 'traditional' status.

Eastern and Central Europe is a region where recognition of individual rights is still in its infancy, by western standards. Aggressive demands for collective rights by any institution, including a religious institution, can adversely

\footnotetext{
${ }^{96}$ Paul Mojzes, "The Camouflaged Role of Religion in the War in B\&H," Religion and the War in Bosnia, ed. Paul Mojzes (Atlanta: Scholars Press, 1998) 74.

${ }^{97}$ Ronald Robertson, "Globalization Politics and Religion," The Changing Face of Religion, eds. J Beckford and Thomas Luckmann (London: Sage, 1989) 11.
} 
affect the establishment of individual rights, norms, and practices. ${ }^{98}$ In many regions of the world, religious identification is not an individual choice but rather a part of an automatically attributed collective identity closely related to nationality. In the former Yugoslavia, the vast majority of people are considered to be part of a national/religious community, regardless of their personal beliefs. This ascribed identity allows political actors to employ religion in their programs in an appeal for collective identity. As Paul Mozjes notes,

In all three major Balkan religious communities, Eastern Orthodoxy, Roman Catholicism, and Islam, the emphasis is not on the religious behaviour of the individual, but on the collective... The entire community is God's, and the individual is either more or less active in his or her awareness and contribution to the community. Religiously inactive or even alienated individuals are still, by virtue of their family or national history, group members who will potentially, given time and right circumstances, acknowledge their belonging.

John Locke and Immanuel Kant both refute standards of group membership that imply a moral obligation to remain a future member or that assume that social superiority is natural and does not require justification. ${ }^{100}$ With this in mind, exclusivist demands of any religious denomination and of the parties that professedly seek to realize them often work against the realization of individual

\footnotetext{
${ }^{98}$ As Sabrina Petra Ramet notes, in a society where collective rights overrun individual rights, people are more compelled to dismiss those who "are not included in the group's moral field" without recourse to universal reason, since tolerance is not valued. Ramet further argues that "others" are not "viewed as equal moral actors," which leads to "the implication that larger groups have "larger' or more extensive rights than smaller groups." Sabrina-Petra Ramet, Whose Democracy? Nationalism. Religion, and the Doctrine of Collective Rights in Post-1989 Eastern Europe (New York: Rowman and Littlefield Publishers, Inc., 1997) 8-11.

${ }^{99}$ Mojzes, "Camouflaged" 77-78.

${ }^{100}$ Holmes, Passions and Constraint 195.
} 
rights. Rather, they often work to entrench religious and ethnic inequalities.

Attempts to establish the primacy of a given religious institution in ways that do not promote the participation of lay people but that are instead based on the dictates of the denominational hierarchy, discourages discussion, debate, tolerance, voluntary action, and involvement. As Larry Diamond asserts, "democracy requires the manifestation of conflict and at the same time mechanisms to contain conflict and preserve social cohesion." 101 If a certain group is privileged by virtue of an immovable higher spiritual order, they are not obliged to compete for rule on the basis of the same laws and regulations as others.

Some communitarian theorists such as Michael J. Sandel, Alasdair C. MacIntyre, and Charles Taylor argue that collective rights are of utmost importance. ${ }^{102}$ Communitarian theorists generally argue that the modern individual is a creation of the community and that individual judgments are ones made in a cultural space. I do not question that individual judgments are made within the context of society and community or that community rights and freedoms are important. However, liberal democracy is difficult to uphold if individual rights and social equality are dismissed in favour of imposing the goals of an ill-defined

\footnotetext{
${ }^{101}$ Larry J Diamond and Marc F. Plattner, Developing Democracy: Towards Consolidation (Baltimore: Johns Hopkins University Press, 1999) 9.

${ }_{02}$ Alasdair C. MacIntyre, After Virtue (Notre Dame: University of Notre Dame Press, 1984); Michael J. Sandel, Liberalism and the Limits of Justice (Cambridge: Cambridge University Press, 1981); Charles Taylor, Philosophy and the Human Sciences, Philosophical Papers 2 (Cambridge, Cambridge University Press, 1985).
} 
community that claims historical precedence and a majority. As Michael

Ignatieff states,

Group rights - to language, culture, religious expression, and land - are valuable to the degree that they enhance the freedom of individuals. ${ }^{103}$

This suggests that when group rights and individual rights conflict, individual rights

should prevail. $^{104}$

Liberal societies must settle rather than avoid the question of religion.

Church-state relations amenable to liberalization cannot simply be settled by gag rules on divisive issues. ${ }^{105}$ Stephen Holmes argues that taking items off the political agenda and seeking co-operation with others perpetuates divisiveness.

Democratization in the ECE has put church-state relations, which were for so long suppressed by socialist regimes, back on the agenda. It is through the process of dealing with these divisive issues that liberal-democratic governance will develop and become established. This is why the way governments deal with these issues can provide insights into political development. In a democratic system, the demands of collective groups like the RCC must not be entirely shut out, but they

\footnotetext{
${ }^{103}$ Michael Ignatieff, The Rights Revolution (Toronto: Anansi Press, 2000) 25.

104 Ignatieff 25.

${ }^{105}$ Stephen Holmes, "Gag Rules or the Politics of Omission," Constitutionalism and Democracy, eds. Jon Elster and Rune Slagstad (Cambridge: Cambridge University Press, 1988) 32.
} 
also must not take precedence over state guarantees of individual rights and

freedoms. $^{106}$

I do not hold that the RCC tradition in general or its heritage in Slovenia

and Croatia in particular is inimical to liberal democracy, nor do I seek to answer

such a question. Rather, I will elucidate how de-secularization or re-sacredization,

liberalization, and democratization have or have not been mutually compatible with

changing church-state relations.

\subsection{Historical Patterns}

The historical patterns expounded on in this work are posited as ideal types

that, in the tradition of Max Weber, help foster conceptual clarity rather than assign

explicit laws. These patterns provide support for the hypothesis that Slovenia is

more liberal than Croatia today due to their historical institutional development.

The following are prominent aspects of historical patterns of politics that influence

liberalisation in post-communist Slovenia and Croatia:

\footnotetext{
${ }^{106}$ While the British establishment model and the corporatist/pillarized model of church-state relations in the Netherlands are compatible with liberal democracy, polities in the CEE lack experience with tolerance and individual freedoms. Without this experience, these models may have difficulty flourishing in the near future. There are differences amongst long-established democracies and CEE polities where church-state relations are debated. In CEE such issues can tear apart governing coalitions or contribute to violence. These models may eventually develop in CEE, but separation of church and state, in the immediate post-communist decades of transformations, ensures that some sort of even "symbolic preservation of an historic religious establishment" does not turn into "decisive political privilege...granted to one religion that is denied to others" or even worse used as an excuse to persecute others. Alan Geyer, "Pluralism and Religious Freedom," Conference on "Christian Faith and Human Enmity," Kecskemet, Hungary, 24 August, 1995 $<w w w . g e o r g e f o x . e d u / a c a d e m i c s>(12$ February 2001), 10. It is for this reason that church-state models other than the separationist model should not be considered in post-communist countries. The imposition and association with the state of the symbols, ideas, law, and even armed militias of any one community or group endanger individual rights and the prospects of equality. It also engenders the language and actions of collective rights that have proven violent in the CEE time and again.
} 
- Rational legal, traditional, and charismatic authority,

- $\quad$ Pragmatism and ideology;

- $\quad$ Positive sum and zero sum games; and

- Incrementalism and revolutionary change. ${ }^{107}$

Ideal types were used by Weber as a heuristic tool to interpret and compare historical and social phenomena. Ideal types do not model a total reality but rather they assist in the understanding of certain empirical phenomena and their interpretation. Understanding and hypothesis formation is facilitated by the construction of ideals that are value-neutral and abstracted from empirical realities. These ideal types accentuate central characteristics and significance of certain phenomena, behaviours, processes or institutions. Weber relied on ideal types to explain historical, social and cultural phenomena and often used dichotomies in his ideal type constructs. ${ }^{108}$

The focus here is on ideal types that clarify patterns of history and political developments by examining a plurality of similar phenomena from the viewpoint of understanding liberalization. Concrete examples of these patterns will be elaborated in the following chapters on Slovenian and Croatian history.

\footnotetext{
${ }^{107}$ Although these patterns are presented as polar opposites, in practice these differences are not always so stark. Factors such as for example, pragmatism and ideology have both influenced Croatian and Slovenian politics, but one type of political rule, approach to change, or mode of operation is usually predominant in a given polity. Nor are these ideal types static as they take into account a wide variety of social and political dynamics.

${ }^{108}$ Max Weber, The Methodology of Social Sciences (Glencoe: Free Press, 1949) 90.
} 


\subsubsection{Types of Authority and Legitimization}

As classified by Max Weber, the ideal types of legitimate domination legal, traditional, and charismatic rule - are key in accounting for divergent social and political orders. Although all regimes use a combination of sources of legitimacy, one source of legitimacy is often privileged over others. Weber's ideal types of authority are hypothetical constructs that distinguish political orders according to prevailing patterns of accepted social relationships based on:

1. Rational grounds - resting on the belief in the legality of enacted rules and the right of those elevated to authority under such rules to issue commands (legal authority).

2. Traditional grounds - resting on the established belief in the sanctity of immemorial traditions and the legitimacy of those exercising authority under them (traditional authority),

3. Charismatic grounds - resting on devotion to the exceptional sanctity, heroism or exemplary character of an individual person, and of the normative patterns or order revealed or ordained by him (charismatic authority). ${ }^{109}$

Weber maintains that charismatic leaders are necessary in all modern states, including democracies, in order to combat the routinization and domination of political life by the administrative elite. These leaders are required to provide

${ }^{109}$ Weber, Economy 215. 
directions on which policy-making is based. ${ }^{110}$ However, without the development of political and bureaucratic legal-rational authority, charismatic rule can become arbitrary. Any means can be justified to meet the ends expressed by a visionary leader. In the post-communist era, legitimacy is conferred when governments in liberalizing and democratizing polities act consistently on liberal and democratic principles, using legal and political procedures that encourage public participation, promote pluralism, and permit debate. This does not mean that only liberal democracies are legitimate, but that achievement of liberal democracy must come on the terms of legitimacy, which have been set out by the majority of the citizens and the elite in post-communist states. Free, fair, competitive elections as well the freedoms guaranteed by classical liberalism are basic expectations of regimes in these countries. ${ }^{111}$ As a number of political scientists, including Lipset $(1959,1960)$, Linz $(1988,1996)$, and Dahl (1989) note, legitimacy lasts only if "system outcomes are congruent with citizen expectations."

\subsubsection{Pragmatism and Ideology}

The difference between pragmatic and ideological actions can be initially

\footnotetext{
${ }^{110}$ Wolfgang J. Mommsen, The Age of Bureaucracy: Perspectives on the Political Sociology of Max Weber (Cambridge: Polity Press, 1989) 20-23.

"11' From 1991 until 2000 the fairness of elections in Croatia was in question as the media was almost wholly controlled or co-opted by the ruling HDZ. Stephen C. Markovich, "Democracy in Croatia: Views from the Opposition," East European Quarterly 32.1 (1998): 85. Even more disturbing was President Franjo Tudjman's refusal to appoint the opposition coalition's choice for Zagreb mayor in 1996. However, subsequently elections in Croatia have been considered free and fair.

112 Richard I. Hofferbert and Hans-Dieter Klingemann, "Remembering the Bad Old Days: Human Rights, Economic Conditions, and Democratic Performance in Transitional Regimes," European Journal of Political Research 36.4 (1999) 162.
} 
considered in the Weberian terms purposeful versus value rationality, or of rational reason versus irrational value. Purposeful rationality (Zweckrationalität) denotes a situation where an actor systematically assesses the costs and benefits of a range of means that can be used to produce a given end. ${ }^{113}$ This is also called utilitarian or instrumental rationality, and it is the sort of rationality that is central to rational choice theory. In contrast, value rationaly (Wertrationalität) denotes an individual pursuing an end without a consideration of the cost of the means or the end. When applied empirically, Weber's categories are clearly not mutually exclusive and involve various types of action, including action based on pragmatic or ideological schemes and concerns. Pragmatism denotes more than a simple assessment of the consequences of means for one end; it is also concerned with establishing a system that regularly addresses overlapping and multiple practical concerns.

Pragmatism relies on incremental decision-making focused on practical political issues and solutions. Daniel Bell, a proponent of the pragmatic approach, thinks that scientific techniques provided for the rational resolution of political problems and the "end of ideology." 114 On the other hand, Jurgen Habermas notes the need for ideology, without which, he concludes, Western states would face a

\footnotetext{
${ }^{113}$ Weber, Economy 78.

${ }^{114}$ Daniel Bell, The End of Ideology: On the Exhaustion of Political Ideas in the Fifties (Glencoe: Free Press, 1960).
} 
crisis of legitimacy. ${ }^{115}$ Without a common political consensus, on the importance of democracy for example, all political decision-making would become technical and removed from the influence of citizens. The political process is not as technical and scientific as the extreme "end of ideology" proponents hold. ${ }^{116}$ Similarly, the "scientification" of political decision-making has not advanced to the extreme suggested by Habermas, and a crisis of legitimacy has not destroyed Western states. $^{117}$

Ideology plays a role in all political endeavours and keeps citizens interested in the political process. However, so-called holistic ideologies can systematically exclude citizens, whereas pragmatic politics seeks to include them. Pragmatic politics takes into account a plurality of ideologies, but in liberaldemocracies it rests on liberal precepts of individual rights and freedoms as well as the rule of law. In contrast, a holistic ideological vision dictated by state and government leaders can leave no space for dissent or alternative options. A focus on such an ideology ignores practical issues in favour of grand pronouncements, blueprints, and ideals towards which all political decisions should be oriented.

\footnotetext{
115 Jurgen Habermas, Legitimation Crisis, trans. Thomas McCarthy (Boston: Beacon Press, 1975) 12.

${ }^{116}$ Wolfgang J. Mommsen, The Political and Social Theory of Max Weber, Collected Essays (Oxford: Polity Press, 1989) 44-45.

117 Mommsen, "Political" 44-45.
} 
2.6.3 Compromise, Zero Sum versus Variable Sum Games

Compromise is the essential part of liberal democratic rule in which representatives are expected to resolve issues through ongoing processes of conflict and compromise. As are positive sum games, a situation where all parties win something, they benefit from the game. Zero sum games are a situation where someone wins only at another's loss. ${ }^{118}$ Zero-sumism specifies an all-or-nothing approach, relying on clearly testable games where winners and losers are distinct. Variable sum games, such as the prisoner's dilemma, at least allow for potential cooperative solutions. In such games defection has a lower payoff and cooperation holds the best payoff for all involved. ${ }^{119}$ Variable-sum games have cooperation as a potential outcome as potential losses can more easily be tempered by mutual concessions.

In the Croatian case, zero sum games predominated in the political quest for autonomy, based on an ideal of Croatian state right. The lack of common interests and willingess to regularly engage in variable-sum games on the independence/autonomy issue often led Croatian political leaders into an irreconcilable stance, contributing to political impasse, violence and regime collapse.

\footnotetext{
${ }^{118}$ For more on zero-sum games see, R. Duncan Luce and Howard Riffa, Games and Decisions: Introduction and Critical Survey (New York: John Wiley \& Sons, 1957).

${ }^{119}$ For more on the prisoner's dilemma see, John Maynard Smith, Evolution and the Theory of Games (Cambridge: Cambridge University Press, 1982).
} 
Slovenian political elites in the modern era predominantly participated in variable-sum games with a cooperationist outcomes when it came to achieving greater autonomy. Within multinational empires, where independence for Slovenian lands were not considered by power holders, Slovenian elites pursued policy options that allowed for autonomy as expressed in games where different cooperative solutions could be found.

It remains difficult to measure precisely how games are played in the historical political context as circumstances, resources and institutions are all constantly shifting and changing. It is also difficult to isolate an actors motives or their own perception of maximal utility carried out in rational, goal directed behavour, with each choice they are faced with. However, strategic political interaction plays a role in political decision making and explicitly recognizing this role can contribute to the development of valid general explanations. This is true particularly in conjunction with an appreciation of historical nuance. There are very sophisticated mathematical game theoretic models that are beyond the scope of this study. Rather, the focus here is on employing basic concepts of game theory to enrich general understandings.

\subsubsection{Incrementalism and Revolutionary Change}

Incremental change can help avoid "serious lasting mistakes" and can assure a more stable and inclusive political environment in which debate and 
compromise are part of decision-making. ${ }^{120}$ Proponents of incremental decisionmaking recognize that means and ends are often confused and that decision-making is achieved in a piecemeal, disconnected manner. The pre-eminent incrementalist, Charles Lindblom, notes that disjointed incrementalism includes noncomprehensive change, successive comparisons, and non-maximizing compromise. ${ }^{121}$ In simpler terms, these are changes that are not 'all or nothing' propositions.

The maximization of values implicated in revolutionary change assumes that ends and means are distinct; neither does it recognize that ultimate values and goals are elusive. Incremental decision-making focuses on small steps in order to achieve goals with the recognition that values are not always clear-cut. ${ }^{122}$ By sufficing rather than maximizing, political actors engage in competition and debate that recognizes a plurality of options and facilitates the development of methods of compromise crucial in liberal democratic polities.

\subsection{Methods}

This study uses multiple sources of data and relies on both unobtrusive research (literature review and library based research) and field research

\footnotetext{
${ }^{120}$ Charles Lindblom discusses the importance and the reality of incremental decision-making in modern organizations as a way of ensuring gradual rather than radical public policy reform. According to Lindblom, decision-makers who rely on incremental decision-making (rather than the idealized rational comprehensive model) pragmatically engage in compromise by making decisions that recognize pluralism and the "noncomprehensive" nature of their work. They rely on "successive comparisons" to make a decision that "suffices." Charles E. Lindblom, "The Science of 'Muddling Through," Public Administration: Concepts and Cases, Sixth Edition, ed. Richard J. Stillman II (Boston: Houghton Mifflin Company, 1996) 79-88.

${ }_{121}$ Lindblom 79-88.

${ }^{122}$ Lindblom 79-88.
} 
(interviews). It uses primary sources, including government documents, international treaties, public opinion polls, and elections results as well as secondary sources including historical research and literature review of materials in English, Slovenian, and Croatian. Focused interviews with open-ended questions were conducted during the summer of 2002 . The selection of interviewees was based on preliminary research that identified which people were most informed and involved in church-state relations and on assessing the history of both countries. During the course of my field research I interviewed numerous political, administrative, church, and other social and political leaders in Slovenia and Croatia. ${ }^{123}$ The qualitatively focused unobtrusive and field research used in this study has facilitated insight into patterns and interpretations of history and liberal democratic transformations that have often been implied, but not rigorously explored, in the case of Slovenia and Croatia.

Slovenia and Croatia were selected for comparison in this study based on a similar systems" design. This research design allows for the implicit "control" of common characteristics, so that inter-systemic differences can be highlighted as explanatory variables. ${ }^{124}$ Comparisons between Slovenia and Croatia in this study are based on a qualitative exploration of national histories and processes of policy creation as well as the content of policies in relation to church-state relations.

\footnotetext{
${ }^{123}$ See Appendix H: Interviews.

${ }^{124}$ Adam Przeworski and Henry Teune, Logic of Comparative Social Inquiry (New York: John Wiley \& Sons Inc., 1970) 32-34.
} 
The similarities and differences between Slovenia and Croatia make for a compelling comparative case study, as the two polities developed differently within a similar geo-political environment and responded differently to similar events. A comparison of church-state relations is used as contemporary proof of divergent historical trajectories and current state of political liberalism because of the key role of church-state relations in liberalism and the centrality of debates regarding church-state relations in post-communist countries.

A striking feature of post-communist transformations is the unique paths of political change taken by states with similar systems, institutions, challenges and goals in the communist era. Institutional similarities and post-communist differences are perhaps most noticeable in the successor states of the former Yugoslavia. Distinctions even arose among states that were often mentioned in one breath, Croatia and Slovenia, as the most economically prosperous and most connected to western European cultural, legal, and political traditions. The political leadership of both countries and the electorates that supported them articulated a common goal of liberal-democratic governance. However, post-communist Slovenia has been more successful than Croatia in political liberalization. Differences in approach to transformations were apparent before the outbreak of war and informed the longer and more devastating war in Croatia. Distinctions in post-communist politics cannot be explained by different state systems, different ruling ideologies, or extent of external pressure, because both Slovenia and Croatia 
had for over a century shared these factors. The explanation lies in distinctions in domestic politics, types and more significantly approaches to external pressures in a multinational state, all of which are discussed in Part II of this work .

Slovenia and Croatia are in close physiographic proximity to each other; they have both been in the same states of Austria-Hungary and Yugoslavia; they share a Roman Catholic heritage, Latin script, Slavic linguistic background and are linked with many of the same European economic and cultural networks.

Differences include the fact that in the Habsburg era Slovene lands were concentrated in the Austrian part of the monarchy, whereas Croat-inhabited lands were primarily in the Hungarian part of the monarchy and were less compact and more divided than Slovene lands. Once in Yugoslavia, "Slovenes inhabited a relatively compact territory they shared with no other nation," whereas the Croats had a wider territory they shared with a minority of Serbs. ${ }^{125}$ At the same time, during the interwar period approximately $1 / 3$ of Slovene inhabited lands were in Italy and about 60,000 Slovenes were in Austria, so Slovenes did "share their territory" as well. Moreover, while both within Austria-Hungary and Yugoslavia predominant political parties sought autonomy, they did so in very different ways. Both states also declared independence on the same day, June 251991 . However, the two polities have encountered distinctive trajectories of political liberalization.

This study provides a basis on which to compare developments in these countries not only with each other, but also with other newly democratizing

\footnotetext{
${ }^{125}$ Banac, The National Question 344.
} 
polities. It contributes to the study of liberalization through an exhaustive examination of church-state relations and can shed light on the development of the rule of law, representation, pluralism and accountability. While church-state relations are not the only indicator of liberalization, they have been the subject of much public deliberation and retain a prominent place in debates concerning public policy-making in all ECE countries. A focus on church-state relations might not provide a conclusive model of liberalization, but it does offer insight into the predominant and idealized strategies of the political elite that shape and are shaped by institutional developments. At the same time, a comprehensive study of churchstate relations with regards to liberalization in Slovenia and Croatia provides an excellent and thus far under-developed opportunity to examine the interplay of historical legacies, memory and institutional development.

The approach undertaken in this study undermines the assumption that Slovenia and Croatia experienced different liberal democratic transformations because of imagined national mentalities, the recent Yugoslav wars, or the presence or absence of certain minorities. This study highlights the need to recognize the influence of historical institutions and legacies on the practices and policies putatively designed to foster liberal democracy as forwarded by members of social and political elite to legitimize their rule in newly established and transforming states. The polities in question were not born in 1989-1991, and they experienced 
reforms and revolutions that did not end in $1989-1991$ either. ${ }^{126}$ Reform is ongoing in transforming states, and it continues to shape political struggles.

${ }^{126}$ Central Eastern Europe expert and commentator Timothy Garton-Ash referred to the immediate 1989-1991 transformations in Poland, East Germany, Hungary, and Czechoslovakia as a combination of reform and revolution, "refolution." Timothy Garton-Ash, "Eastern Europe: The Year of Truth," The New York Review of Books, 37, 2 (1990): 23. 


\section{Part II: Political History}

"Central Europeans always seem to be able to find some remote historical precedent for an explanation of the present... They flash back from the present into the past - not in years or decades, but in centuries-and they flash forward with great facility from the past to the present."127

The following comparative study traces how patterns of politics have manifested themselves in the political dynamics that distinguish Croatian and Slovenian politics and that have influenced political liberalization in the postcommunist era.

The theoretical generalization of particular patterns of politics that have shaped Croatian and Slovenian political history are in the following chapters tested against historical institutions as the legacies upon which political relations have been built. The following chapters will lay out the broad patterns of politics as postulated in this thesis. These broad outlines follow the four patterns of politics presented here as ideal types and used to "explain and to test the plausibility of causal hypotheses," in this case to explain and understand the differences in political liberalization in post-communist Croatia and Slovenia. ${ }^{128}$

Modern Croatian political history and the struggle to achieve greater autonomy has been more turbulent and violent than the Slovenian struggle. Croatian political leaders demanded greater autonomy and power in the region. The Croatian focus has been on gaining autonomy and extending their reach and status

\footnotetext{
${ }^{127}$ Lonnie R. Johnson, Central Europe: Enemies, Neighbours, Friends (New York: Oxford University Press: 2001) 5.

${ }^{128}$ Skocpol, "Why I am" 104.
} 
as a regional power, while the Slovenian focus has been on gaining and maintaining autonomy. Chapter 3 discusses founding political memories that inform modern politics in Slovenian and Croatian lands, particularly demands for autonomy and how they were pursued politically. Apparent in the programs of political parties, Chapter 4, explores the distinction between Slovenian and Croatian approaches to achieving greater political autonomy in the modern era. Chapter 5 discusses how these historic approaches to political contestation in the search for autonomy in the region became part of Yugoslav politics with the establishment of the Kingdom of Serbs, Croats and Slovenes and its socialist successor the Socialist Federal Republic of Yugoslavia. How these different political patterns contributed to the disintegration of Yugoslavia is also detailed in Chapter 5. Chapter 6 provides a brief overview of how historic approaches to autonomy gave rise to distinctive independent Croatian and Slovenian states. Historically informed divergent paths of liberalization in these new states is further examined in Part III of this work through a detailed discussion of political liberalization and church-state relations. 


\section{Chapter 3: Historical Patterns of Politics}

\subsection{Geographical Circumstances and Settlement}

The appellation of Slovenes and Croats will be used to denote the ancestors of Slovenes and Croats who lived in Southeastern Europe, even though it was not until the $18^{\text {th }}$ century that the categories of nation, Slovene, and Croat were widely utilized to describe all of the peoples who shared the Slovenian or Serbo-Croatian languages and traditions. ${ }^{129}$ Slovenes are descendents of Carinthian Slavs (Karantanci), who had a short-lived state during the $7^{\text {th }}$ century. Slovenes were called Carinthian Slavs until the $13^{\text {th }}$ century, when they were classified by their region and march (province). It was in the $18^{\text {th }}$ century that with the development of linguistic standardization these Slavs came to be popularly called "Slovenes." The Croats (sometimes along with the Avars) raided and migrated to the western Balkans as far as the eastern Adriatic coast. By the $7^{\text {th }}$ century Croats had settled along the eastern Adriatic coast, because they were invited by the Byzantines to establish permanent settlements there in order to protect these lands form the Avars. The origin of the name "Croats" is disputed and little is known of the Croats' pre- $7^{\text {th }}$ century history other than the fact that they came from White Croatia, in the general area considered the homeland of Slavs in what is present day

\footnotetext{
129 "Yug" means "south" in Serbian, Croatian, and Slovenian languages. "Yugoslavism" can be translated into "Southslavism," while "Yugoslavia" means "the land of the South Slavs." Andrew C. Janos provides further information on the categorization of Western, Southern, and Eastern Slavs. Andrew C. Janos, East Central Europe in the Modern World: The Politics of the Borderlands from Pre to Post-Communism (Stanford: Stanford University Press, 2000).
} 
Belarus, Poland, and Ukraine. The Croatian state subsequently varied in size, sovereignty, and territories it included.

From the $6^{\text {th }}$ century until the $18^{\text {th }}$ century Croats and Slovenes were subclassified into many distinct vernacular and regional groups that shared linguistic and other cultural characteristics. As a result, a pronounced regionalism remains in both Slovenia and Croatia to this day, manifested by numerous dialects and varying customs. At the same time, during the middle ages lands that were considered part of historic Croatia and where Croats lived were more drastically divided between the Habsburgs (and latter by the Austrian and Hungarian halves of the monarchy), Ottomans, and Venetians. ${ }^{130}$ On the other hand, the lands in which Slovenes lived while divided into marches (provinces), was almost entirely within the Austrian part of the monarchy. ${ }^{131}$ Given these divisions, Slovene lands were in a more

\footnotetext{
${ }^{130}$ The 1102 Pacta Conventa gave the Hungarians the right to the Croatian crown. The Golden Bull of convened a Sabor (assembly). Croatian state right was secured through the Sabor and Ban (viceroy). By 1558 the Croatian and Slavonian banovinas and Sabors united with the seat of power in Zagreb. However, the Sabor remained weak. By the mid 14th century Venitian influence in the eastern Adriatic and territorial gains by the Ottomans ensured the division of Croatian lands, disrupting trade and communications, enhancing insecurity, and establishing lasting economic, cultural, and political divisions. The free cities of Dalmatia, including Rijeka, Zadar, Šibenik, Split, and the Republic of Dubrovnik, remained relatively self-governing regardless of the ruler. The Hungarians lost most of Dalmatia and Slavonia to the Ottomans as in the 16th and 17th centuries, Habsburgs would later consolidate their rule in Croatia by defeating the Ottomans at the gates of Vienna in 1683. Due to the 1699 Treaty of Karlowitz/Sremski Karlovci, Ottomans only retained Bihać and a part of Slavonia. By the Peace of Passarowitz/Pozarevac in 1718 the Hapsburgs gained Banat and the rest of Slavonia, including Srijem and parts of northern Serbia and Bosnia. Distressing for the Croat nobility was the fact that almost all of the land gained by the Habsburgs between 1699 and 1719 was accorded to the Krajina, while at the same time Dalmatia was still under Venetian control. Venice held on to some of Dalmatia until 1797, with highly decentralized rule. The Vojna Krajina was eventually united with Croatia-Slavonia in 1881.

${ }^{131}$ The majority of Slovenes lived in lands dominated by the Franks in the 9th century, incorporated into the Holy Roman Empire in the 10th century, and melded into the Habsburg monarchy by the 13th century. The counts of Celje were powerful in the Middle Ages, but their lineage died out in 1456. As the result, the Habsburgs took direct control of their lands. In the Habsburg Empire,
} 
favourable position in terms of economic development. ${ }^{132}$ However, their proximity to Austria threatened Slovenian identity and culture. ${ }^{133}$ With the main port of Trieste close by, and having long been linked to the center of the Empire through transportation networks, Slovene lands enjoyed a closer economic connection to the West. This influenced their political and social development, including the introduction of the universal franchise a decade earlier and a higher literacy rate in the late $19^{\text {th }}$ century than in Croatia. ${ }^{134}$ Croatian lands had closer economic links to the west through Hungary, with its rail lines centered in

Slovenes predominantly lived in Inner Austria, in six separate territorial-administrative units of the Austrian crown: Styria, Carinthia, Gorizia, Istria, and Carniola. Carniola was the only unit in which Slovenes formed a majority and remains the Slovenian heartland. The 1857 Austro-Hungarian census counted approximately 1.1 million Slovenes, mostly in the Cisleithan (Austrian) half of the monarchy in what was called Inner Austria. The 1867 establishment of the Dual Monarchy found 45,000 Slovenes in Hungary and 27,000 Slovenes in Italy. Carole Rogel, Independent Slovenia 9. Zwitter, O Slovenskem Narodnem Vprašanju (Ljubljana: Slovenska Matica, 1969) 159. Slovenes in Cisleithan lands were under a steady pressure to Germanize, as German was the language of administration, higher education, and commerce. Economically, the Slovene lands were not fully incorporated into the system of German feudal tenure. The topography of the region acted against the development of large-scale agriculture, while larger feudal estates typically contained substantial areas of forest. While this prevented the accumulation of large-scale agricultural wealth, it did allow for peasant co-operatives

${ }^{132}$ Slovene lands were better integrated into the Empire-wide economy as compared with Croat inhabited lands. Slovenians were in a more central location, had good links to vital trade networks, and had greater freedoms to organize and pursue industry and trade. As a consequence of this and of their greater proximity to the major urban and economic centres of the Habsburg Empire, the Slovenes reached relatively high levels of literacy and technical development and achieved early integration into the market economy. This was also facilitated by the lack of indigenous nobility, large estates, as well as numerous rural, peasant, and urban co-operative organizations that emerged in the end of the 1800s. Gow and Carmichael 20, Rogel, "The Slovenes and Cultural Yugoslavism" 66.

${ }^{133}$ Respected Yugoslav historian John R. Lampe notes that it is difficult to find resources on the economy of Slovenian and Croatian lands in the last decades of the Monarchy. John R. Lampe, "Imperial Borderlands or Capitalist Periphery? Redefining Balkan Backwardness, 1520-1914," The Origins of Backwardness in Eastern Europe: Economics \& Politics from the Middle Ages until the Early Twentieth Century, ed. Daniel Chirot (Berkely: University of California Press, 1991) 192-193; Ivan T Berend, Economic Development in East-Central Europe in the 19th and 20th Centuries (New York: Columbia University Press, 1974).

${ }^{134}$ By 1921 only " 8.8 percent of Slovenes were illiterate, as compared with 49.8 percent of Croats and 67.8 percent of Serbs." Rogel, "The Slovenes and Cultural Yugoslavism" 66. 
Budapest, including the main port of Rijeka. ${ }^{135}$ There are a number of works that touch on the economies of Slovenian and Croatian regions in Austria-Hungary. However, not one compares their regions directly. ${ }^{136}$ While the benefits and the potential drawbacks of Slovenia's proximity to the centre should be considered, this work will not discuss the hereto uncompared economies of the regions, but rather focus on their equally uncompared politics.

\subsection{Founding Memories}

Founding memories are considered here to be memories of early medieval and medieval Slavic states that organized Croats and Slovenes. These common memories have been among the most invoked by modern Croatian and Slovenian political leaders as influential and important national legacies. The founding Slovenian memory is more amenable to liberal ideals than the Croatian one, as it focuses on the symbolic electoral contract between the Karantanian Duke and the peasants over whom he ruled. On the other hand, the golden age of the Croatian state is focused on King Zvonimir and his ability to realize Croatian statehood through military might and domination recognized by the Pope.

There are a few historically prominent Slovenian political figures in the early and late medieval periods, but they did not produce a lasting dynasty and they did not rule for long. Karantanian Slavs, ancestors to modern Slovenes, in the $620 \mathrm{~s}$ created the state of Karantania, the core lands of which are in the present day

\footnotetext{
${ }^{135}$ Lampe, "Imperial Borderlands" 194.

136 Jože Šorn, Začetki Industrije na Slovenskem (Maribor: Založba Obzorja, 1984). Mirjana Gross, ed., Društveni Razvoj u Hrvatskoj od 16 do Početka 20 Stoleća (Zagreb: Globus, 1981).
} 
Austrian province of Carinthia (Kärnten, Koroška). Christianized in the middle of the $8^{\text {th }}$ century, the Slavs of Karantania came under Frankish domination in the middle of the $9^{\text {th }}$ century. In Karantania, free members of village communities who represented the serfs would symbolically elect the Duke, the feudal ruler of Karantania. The installation ceremony at the Duke's Stone at Krn Castle in Gosposvetsko polje (Saalfeld) was re-enacted in Slovenian up to the $16^{\text {th }}$ century. This included the Duke's oath to respect and defend the rights of all peoples who had symbolically transferred their sovereignty to him. In the course of the ceremony a peasant would sit on the throne and only yield it to the Duke once he committed to serving the people. The installation ceremony remains the most cited political institution of early Slovenian history. Modern commentators cite this ceremony, as described by the $16^{\text {th }}$ century scholar Jean Bodin, as an influence on Thomas Jefferson's political vision. ${ }^{137}$

The historic kingdom of Croatia most often cited as the foundation of Croatian statehood and a representation of the golden era is the kingdom under King Zvonimir. ${ }^{138}$ The legends of the Croatian nation and of King Zvonimir have been intertwined with the rise of Croatian nationalism and calls for the reestablishment of an independent Croatian state, particularly in the $19^{\text {th }}$ and $20^{\text {th }}$

\footnotetext{
${ }^{137}$ The contention here is that in part Jefferson derived his idea of the freedom of the people to choose to invest their sovereignty in elected leaders from the Karantanian case and incorporated it into the Declaration of Independence. Carole Rogel, "In the Beginning: The Slovenes From the Seventh Century to 1945," Independent Slovenia: Origins, Movements, Prospects, eds. Jill Benderly and Evan Kraft (New York: St. Martin's Press, 1994) 4.

${ }^{138}$ Ivo Goldstein, Croatia: A History (Montreal: McGill-Queen's University Press, 1999) 20.
} 
centuries. ${ }^{139}$ Considered in popular memory to be the king who most forwarded

Croatia's territorial and political interests, Zvonimir was able to unite and stabilize

Croatia and Dalmatia both culturally and politically, although strong regional

sentiments remained. ${ }^{140}$ During Zvonimir's reign coastal lands on the Eastern

Adriatic in what is now Dalmatia were annexed, trade grew, and feudalism was

initiated. These political developments were enabled by the protection afforded by

Pope Gregory VII, whose emissary had crowned Zvonimir in 1075 . Numerous

political and Roman Catholic leaders have in the centuries since the initial Holy

See recognition of the Croatian state emphasised the historic ties between the RCC

and the Croatian nation that enabled the establishment of the Croatian State and its

golden age. ${ }^{141}$ However, as legend has it, the death of Zvonimir and of the native-

led, sovereign Croatian kingdom was precipitated by Pope Gregory VII's request

for help with the crusades. Croat nobles killed King Zvonimir rather than

\footnotetext{
${ }^{139}$ For a detailed description of why the legend of King Zvonimir appeared in 19th and 20th century Croatian political discourse see Ivo Zanic, "The Curse of King Zvonimir and Political Discourse in Embattled Croatia," trans. William B. Tomljanovic, East European Politics and Societies 9.1 (1995): 90-123.

140 Trpimir Macan, Povjest Hrvatskoga Naroda (Zagreb: Skolska Knjiga, 1999) 42-43.

${ }^{141}$ Concerning his first visit to Croatia, Pope John Paul Il recunted that, "When Pope John X addressed the first King of Croatia, Tomislav (who ruled between 910 and 930) he called King Tomislav's subjects "the most special sons of the Holy Roman Church" (specialissimi filü Sanctae Romanae Ecclesiae). During Ottoman inroads in Europe, Pope Leo X honoured the Croats by calling them "the strongest shield and the outer walls of Christianity." (Scutum saldissimum et antemurale christianitatis). This title has been very important and very true in the history of faith and holiness in Croatia; its significance has also been evident in the nine hundred year history of the Church of Zagreb." "The Pope's Address to the Pilgrims Concerning his Visit to Croatia in 1994," Vatican 14 Sept. 1994, 3 Dec. $2002<$ http://www.vatican.va $>$.
} 
participate in the crusade. Legend has it that the King's dying curse was for

Croats to remain divided and under foreign rule. ${ }^{142}$

In the $19^{\text {th }}$ and $20^{\text {th }}$ centuries an idealization of King Zvonimir's rule and determination to lay to rest King Zvonimir's curse have most often been invoked by those seeking to promote specific political programs and, more recently, to reaffirm the Catholic heritage of Croats and their medieval rulers. The memory of the $\mathrm{RCC}$ as a critical support of the medieval Croatian state was touted by several political parties in modern Croatia and was made particularly popular during the 1970 s and 1980 s by the efforts of the RCC in Croatia as it sought to establish the connection between a strong Croatian nation state and a strong Croatian RCC. ${ }^{143}$ The 1970s, Great Novena, Croatian Jubilee celebrated "thirteen centuries of Christianity of the Croat people," with a focus on King Zvonimir as the leader who "solidified Croatia's place in Western civilization" with the adoption of Roman

\footnotetext{
${ }^{142}$ No document from the era survives, however, popular legend has it that the curse stated: "Oy Croats, cursed by God, let for centuries disunity harvest you. May you never have a king of your own blood, let the foreigner rule you through the centuries, may you suffer life amidst envy, let all of you live in fear of one another." Zanić, East European Politics and Societies 94.

${ }^{143}$ During the mass Christianisation of the 9 th century, both Western Latin rites and Eastern rites took place in Croatian lands, forwarded by the efforts of Byzantine, Frankish, and Italian missionaries. Surviving stone tablets note the donation of land for a Latin rite church by Duke Trpimir of Croatia in the first half of the 9th century and the recognition of Duke Branimir by the Roman pope, John VIII, in the latter half of the 9th century. These instances of Croatian leaders' connections with the Latin rite church are often cited as part of an enduring Croat-Catholic political religious tradition. In the 10 th century the early medieval kingdom of Croatia under Tomislav (9 I0928) thwarted Hungarian and Bulgarian ambitions and became a state that linked Dalmatia and Pannonia, with costal cities as power centres. In recognition of his achievements and the Croatian state Tomislav was proclaimed Croatia's king by Pope John X in 925 AD. Erection of monasteries, churches, and tombs for Croatian rulers reinforced Croatia's ties to the West through the Latin rite church.
} 
Catholicism. ${ }^{144}$ The medieval independent statehood of Croatia with its own feudal aristocracy is contrasted with the short-lived Slavic state of Karantania and the subordinate status of Slovenes, almost exclusively as peasants.

\subsection{General Patterns}

In the age of modern politics, Croatian and Slovenian political elites in multinational states were concerned with the national question. The age of modern politics is here taken to have started in the late $19^{\text {th }}$ and the early $20^{\text {th }}$ century, when political elites began to base their political power on the claim of representing nations and national interests. The major distinction between Croatian and Slovenian political parties of that era was the foundations upon which they based their programmes and how their programmes developed in response to internal and external challenges.

The starkest difference between Croatian and Slovenian memories lies in the Croatian state tradition, with its claim to a 1,000 year independent existence, versus the Slovene experience and memories of 1,000 years of political domination. In modern Croatian politics, there has been a discernable focus on establishing the greatest possible national autonomy. Revered great political and military leaders, a history of aristocratic rulers, and an independent state were invoked by modern Croatian political actors to justify their style of rule. This helped justify political

\footnotetext{
${ }^{144}$ Vjekoslav Perica, Balkan Idols: Religion and Nationalism in Yugoslav States (Toronto: Oxford University Press, 2002) 64-65.
} 
activity of charismatic leaders, zero sum games and revolutionary change that were more characteristic of Croatian than Slovenian modern politics.

In contrast, and in recognition of their weak institutional position within the Habsburg monarchy, lack of great military and political leaders, vulnerability to competing territorial claims, and lack of a strong state tradition, the modern Slovenian political elite focused on achieving incremental gains based on rational legal appeals to cultural/linguistic rights and policies for economic advancement. These different Croatian and Slovenian foci provided a basis for politics that developed differently within the same country, Yugoslavia, and in the republics' exit from it. Specific examples of this include different approaches of Croatian and Slovenian parties to the Serbia-dominated centralization of Yugoslavia, the crisis of WWII, and the disintegration of Yugoslavia. All these are addressed in the coming chapters.

The national autonomy and independence issue occupied a larger space in Croatian politics, crowding out other political discourse and increasingly limiting the opportunities for conflict and consensus based on other political issues. Once south Slavic unity was achieved in Yugoslavia based on the Serbian Karadjordjević dynasty and Serbian rather than Croatian state tradition, Croatian political disappointment and boycott led to more radical options, ultimately with a Fascist alternative. ${ }^{145}$ At this point, the state right tradition became allied with exclusivist

\footnotetext{
${ }^{145}$ Wayne S. Vucinich, "Interwar Yugoslavia," Contemporary Yugoslavia, ed. Wayne S. Vucinich (Berkeley: University of California Press, 1969) 18-58.
} 
nationalism, a mix that was detrimental to the development of incremental positive-sum politics. It demanded a Croatian state based on historic state right, established to represent all ethnic Croats.

Slovenian nationalism, which arose in the $19^{\text {th }}$ century, was based on linguistic and cultural foundations that were primarily defensive and did not threaten (ethnic and religious) others in the way that Croat nationalism did. Cognizant of the Slovenian minority status and its weak position vis-à-vis its powerful neighbours, the Slovenian national project developed a more defensive nationalism, focusing on economic and linguistic rights that did little to threaten other nations; in the long run this contributed to politics that recognized the need for positive-sum games. Security came from knowing that Slovenian identity could be preserved through culture, but insecurity resulted from the recognition that respect and tolerance of the rights and freedoms of others was required in order to preserve Slovenian culture and autonomy. ${ }^{146}$

\subsection{Croatia and State Right}

The immediate rise of the divergent South Slavic and the exclusivist Croatian-centred political options among the Croat elite in $19^{\text {th }}$ century are attributed to a national awakening in the shadow of Hungarian centralism and

\footnotetext{
${ }^{146}$ Momičilo Zečević, Na Istorijskoj Prkretnici: Slovenci u Politici Jugoslovenski Države, 1918 1929 (Belgrade: Narodna Knjiga, 1979) 131-134.
} 
nationalism. ${ }^{147}$ Napoleon's revolutionary ideas, Metternich's regime, and the Serbian uprising against the Ottoman Empire (semi-autonomous since 1815-1817) all served to inform romantic nationalism among South Slavs throughout the Empire. These factors, in combination with an increasing focus on Croat state tradition, were particularly important in Croat-inhabited lands. Based on historical precedent, Croat state right is the ideal of Croatian sovereignty.

Nobleman Pavao Ritter Vitezović's $16^{\text {th }}$ century appeal to the state right of the Croatian kingdom and its inclusion of all South Slav lands influenced $19^{\text {th }}$ century intellectuals, who forwarded Croatian nationalist and state-based claims. ${ }^{148}$ Those advocating Croat autonomy relied most heavily on the legacy of state rights, the idea that the Croatian kingdom was still independent and should be afforded autonomy. As Ivo Banac notes,

The Croats never felt safe enough with strictly national-linguistic and cultural arguments in favour of their autonomy and statehood. They clearly believed that the rusty weapon of historical and state right were most effective in the struggle against Habsburg and Hungarian centralism. ${ }^{149}$ Although in the era of modern politics Croatian politicians sought institutional arrangements that would establish Croatian autonomy based on the legal premise of Croatian state rights, those rights were greatly diminished over the centuries. ${ }^{150}$

\footnotetext{
${ }^{147}$ Srdjan Trifković, "The First Yugoslavia and Origins of Croatian Separatism," East European Quarterly 26.3 (1992): 345-349.

${ }_{148}$ Macan 167-168. Vitezović was the first to note that all South Slavs should live in a united Croatian kingdom based on the ancient Croat kingdom.

${ }^{149}$ Banac, The National Question 75.

${ }^{150}$ The revolutions of 1848-49 were an important turning point for politics throughout Europe. Calls for equal treatment of individuals and nations voiced in the revolutions politically awakened a great number of people. The Ban of Croatia-Slavonia, Josip Jelačić (1801-1859), was a supporter of the lllyrian movement and remains a revered Croat hero for his place in the $1858-59$ revolutions and his
} 
The majority of Croat politicians and political organizations advocated reform in legislative bodies. Respect for the ideal of the Sabor (assembly) and the desire for an autonomous Croatia with an indigenously controlled Sabor, however, could not compensate for disappointing parliamentary institutions and a rule of law that did not protect individuals or the Croatian collective, but rather served Budapest, Vienna, and Belgrade.

This is not to argue that there was an absence of positive-sum games in Croatian political history, but such games were not as prevalent and as consistently used as in Slovenian political history. As Historian Srdjan Trifković notes, "The Croats knew pacts, agreements, and contracts, Ausgleich and Nagodba, the very opposite of the centralist concept."151 These pacts led to almost immediate

opposition to Hungarian domination. Appointed Lieutenant Field Marshall in 1848 Jelačić fought against the Hungarian nationalism of Lajos Kossuth (1802-1894) and was loyal to the Austrian crown. He led an Austrian invasion of Hungary and intervention in Vienna to stop the revolution and the uprising. Jelačić proclaimed the abolishment of serfdom, the creation of a new Sabor, and the abolishment of relations with the Hungarian revolutionary government. When the Hungarians deposed Jelačić, Vienna, seeking appeasement, concurred. This, along with Jelačić's defiance and desire to unify Croat lands, solidified his reputation as a national hero. Seton-Watson, The Southern Slav Question and the Habsburg Monarchy. London: Constable, 1911, 32-35. Stjepan Radić himself "called for a return of the policies of ...Josip Jelačić...[and] argued that the HPSS was the only Croat party that could be considered a successor to Jelačić." Biondich 114.

${ }^{151}$ Trifković, East European Quarterly 355. The Ausgleich established a personal union of both states, with the Hapsburg king as emperor of Austria and king of Hungary. Both states had an independent parliament, constitution, and government with a customs union; they also had a common foreign policy, ministry of Joint $F$ inance (to cover the costs of joint endeavours) and joint ministries of War and Foreign Affairs. Josip Horvat, Politička Povijest Hrvatske, 2nd ed., 2 vols. (Zagreb: August Cesarec, 1990) 353. Jaroslav Šidak, Mirjana Gross, Igor Karaman, and Dragovan Šepić, Povijest Hrvatskog Naroda, 1860-1914 (Zagreb: Školska Knjiga, 1968) 40. The Nagodba solidified Croatia's subordinate position in the Hungarian half of the monarchy, especially in financial affairs, but recognizing a limited autonomy, particularly in the use of Croatian in public administration and education. Stephen Gazi, A History of Croatia (New York Philosophical Library, 1973) 165-169. Despite the terms of the Nagodba, this was a time when the Unitarist Party dominated the Sabor and re-affirmed Croatian political and financial dependence on the Hungarian 
disappointment, as the stronger powers (Hungary, Austria, and Serbia in the cases of the Nagodba, Ausgleich, and Vidovdan [St. Guy's Day] Constitution), were seen by many as taking unsanctioned and unfair advantage of Croatia. ${ }^{152}$ There thus existed a precedent for a strong current of Croat opposition to the centre, with calls for change expressed in a more oppositional manner than in Slovenia.

This is also not due to lack of use of legitimate legal, political, and cultural channels such as the Assembly (Sabor) or literature and the arts, but rather because these channels were not consistently used in a way that promoted compromise and positive- sum games. The Croatian focus on state rights as the basis for Croatian autonomy or independence is a legally based argument. ${ }^{153}$ It is an argument that could have been associated with "tolerance and democracy," and the recognition that the "Croatian people," are all who live within the borders of the state.

However, the ideals of state right in the modern era were not consistently employed in this spirit, and rather invoked exclusivist Croatian nationalism. ${ }^{154}$ State Right was often pursued as an ideological foundation for further uncompromising nationalist politics as the patron of state's right ideology, Ante Starčevič did. ${ }^{155}$ The

crown. For example, 55 percent of Croatian revenue was placed in a joint treasury controlled by the Hungarians, while Rijeka and Medjimurje were annexed to Hungary. Tanner 99.

152 John R. Lampe, Yugoslavia as History, Twice There Was a Country (New York: Cambridge University Press, 2000) 129.

${ }^{153}$ As Sabrina Petra Ramet notes, Ante Starčević offered "an alternative to language-based or religion-base or even descent-based nationalism...for him, it is statehood which defines a nation, rather than nationhood which defines a state." James R. Felak and Herbert J. Ellison, eds., Nations and Nationalisms in East-Central Europe, 1806-1948: A Fetschrift for Peter F. Sugar (Bloomington: Slavica, 2002) 144.

${ }^{154}$ Felak and Ellison 144.

${ }^{155}$ Gross, Povijest 19-20. 
memory of a Croat great state, with a heroic history, worked against ideas of compromise and supported the ideal of a powerful leader representing the nation. ${ }^{156}$ To a greater extent than in Slovenia, in this environment Croatia's political leaders and parties focused on opposition that encouraged a focus on themselves as charismatic leaders that could realize Croatian autonomy, or a historicist focus on Croatia's glorious past and the need to return to it, or both. ${ }^{157}$ The Croatian elite did not have the same space for manoeuvres as Slovenes, because they forcefully demanded greater autonomy thus engendering greater opposition. Like Slovene political elites, Croat political elites sought to ensure linguistic and economic opportunities for Croats, by demanding greater autonomy. Unlike Slovene elites, they had recourse to memories of Croatian state right and the ideal of its continuance.

Great Croatians include linguists and literary figures, but the most honoured are military and political figures who fought for the Croatian nation and for the restoration of a state. This reinforces the idea that success relies solely on realizing independent statehood, requiring a unifying leader patterned on Croat heroes of the past. For example, Franjo Tudjman, keenly aware of the importance of history, sought to be a great unifying Croat figure who embodied the best of great Croats of the past. As Sabrina Petra Ramet notes, Tudjman embraced "Virtually every

\footnotetext{
${ }^{156}$ Gross, Povijest 2-12.

${ }^{157}$ For example, Gerald Gilbert Govorchin notes the influence of the idea of "pravaštvo," the interpretation of "the past from a purely national point of view." The core of the idea was that the Croatian Nation was being denied its rightful and historic independence. Govorchin, "Pravaštvo and the Croatian National Issue," East European Quarterly 11.1 (1996): 57-59.
} 
notable figure in Croatian history from King Tomislav to the Kaiser's loyal retainer Josip Jelačić, to Tito, to Tito's Croatian rival Andrija Hebrang, to Croatian liberal Ante Starčević to the Austrian Kaiser himself, Kaiser Franz Josef." 158 The focus on Croatian state right(s) imparted a single-mindedness that focused on gaining what Croatia had lost and often worked to undermine legal rational compromise by hardening Croatian positions, promoting obstruction, and creating stronger reactions to the Croatian stance by the Hungarians, Habsburgs, and central Yugoslav authorities. ${ }^{159}$ For example, there was the very different but informed by Croatian state right anti-centrism of Stjepan Radić, the establishment of the fascist Independent State of Croatia, and the nationalist movement at the twilight of Yugoslavia, all of which inspired a stronger outside reaction to Croatian politics than to Slovenian politics. ${ }^{160}$

\subsection{Slovenia and Cultural Rights}

The Croatian case contrasts sharply with the Slovene case. Lacking a claim to historic state rights, Slovenian politics focused on manoeuvring within present political conditions to secure as many rights as possible, including linguistic and

\footnotetext{
${ }^{158}$ Sabrina Petra Ramet, Eastern Europe and the Natural Law Tradition (Seattle: The Donald W. Treadgold Papers, the Henry M. Jackson School of International Studies, University of Washington, 2001) $32 .$.

${ }^{159}$ Dušan Bilandžić, Hrvatska Moderna Povijest (Zagreb: Golden Marketing, 1999) 67-75.

${ }^{160}$ Mark Biondich, Sjepan Radić, the Croat Peasant Party and the Politics of Mass Mobilization, 1904-1928 (Toronto: University of Toronto Press, 1999) 33. Aleksa Djilas, The Contested Country: Yugoslav Unity and Communist Revolution 1919-1953 (Cambridge: Harvard University Press, 1991) 116-117. Duncan Wilson, Tito's Yugoslavia (London: Cambridge University Press, 1978) 202-202.
} 
cultural rights; this informed politics that could be described as pragmatic. ${ }^{161}$

Slovenians lacked a great state tradition and great leaders, so instead they sought reforms that focused on linguistic and economic autonomy. ${ }^{162}$ There was a focus on what Slovenian leaders could do to forward the cultural and economic rights of Slovenes, forcing leaders to focus on political strategies that fit their capacity (as representatives of a small nation) and present day political requirements. As Slovene historian Peter Vodopivec notes, "unlike Czechs, Poles, Serbs, and Croats, the Slovenes were a nation without a great history."163 Awareness of Slovenia's history precluded a current Slovenian focus on historic state right or desire for a "greater Slovenia." Rather, Slovenia has reinforced the focus on how to achieve practical political aims through compromise. Slovene elites remained more focused on positive-sum deliberations and compromise, incrementally winning concessions.

Compromise in the name of specific cultural and economic aims informed political institutions in Slovenia throughout the era of modern political activity of the late $19^{\text {th }}$ and $20^{\text {th }}$ centuries. This is not to argue that Slovenian politics of the late $19^{\text {th }}$ century was proto-liberal or that political parties consistently promoted liberal goals. Certain institutions and approaches to politics at the time promoted ideals and practice that are the crucial components of liberalism, even in the

\footnotetext{
${ }^{161}$ Peter Vodopivec, "The Historical Background to "The Slovene Question," The Case of Slovenia, ed. Niko Grafenauer (Ljubljana: Nova Revija, 1991) 4.

$\frac{162}{162}$ The Slovenes "had absolutely no state tradition. This is one reason the Croat national ideologists from Vitezović to Starčević (and even Supilo) regularly tried to incorporate the Slovenes within the tradition of Croat stat right. But if they had no state tradition, the Slovenes had a history of cultivating their own separate linguistic medium." Banac, The National Question 112.

${ }^{163}$ Vodopivec, "The Historical Background" 25.
} 
absence of a liberal system or of widespread popularity of liberal ideals. Equally important is the fact that liberal components of past political approaches have at the end of the $20^{\text {th }}$ century been invested with legitimacy as key components of Slovenian political history and enduring legacies that should be revered and carried forward. These legacies, including respect for the rule of law, incrementalism, and consensus, were the predominant modes of political interaction. They informed Slovenian politics, including the co-operative movement of the late $19^{\text {th }}$ century, the parliamentary politics of the early $20^{\text {th }}$ century, the pluralist civil society in the 1980s, and post-communist politics. There were and remain deep political and ideological divisions in Slovenian politics, but the overriding interest in the preservation of the Slovene language and the advancement of economic interests often reinforced reliance on the rule of law to implement incremental reforms to those ends. There was general recognition that positive-sum games were required in order to advance Slovenian interests, because there was little chance that the Slovenian political elite could win zero-sum games, particularly in dealing with central governments.

Preservation of a distinct language and identity was a major way in which Slovenes forwarded their interests. Both Slovenes and Croats, like all other nations, celebrate their linguistic, military, and political heritage. However, Slovenes place a greater emphasis on their linguistic heritage and literary figures than Croats, because of the comparatively smaller Slovene pantheon of celebrated military and 
political figures and the lack of a state tradition. Added to this is the fact that the Croatian language was not a distinguishing feature of "Croatness" for over a century in the same way as the Slovene language stood for "Sloveneness."164 This is because Serbo-Croatian was the single standard literary language from 1850 until the end of the 1960s; it was officially declared dead only with the outbreak of the war in $1991 .{ }^{165}$ Linguists and literary figures who contributed to the standardization and promotion of the Slovene language, particularly from the Protestant Reformation forward, continue to be greatly celebrated. ${ }^{166}$

The Reformation did make some inroads into Northern Croatia and Southeastern Slavonia in the 1520 s and 1530 s, yet it had a far greater impact in Slovenian society. It is important to note that, although the RCC was the major social and political force in Slovenian society from the $17^{\text {th }}$ until the mid $20^{\text {th }}$ century, in Slovenia, even today the Protestant Reformation is celebrated with an official holiday on 31 October because of the contribution of Protestant reformers to the Slovenian language. Lutheran preacher Primož Trubar (1508-1586) published the first Slovene language book along with more than two dozen other books. ${ }^{167}$ Preacher Jurij Dalmatin (1547-1589), also a leading figure of the Reformation, brought out the first translation of the Bible into Slovene (1584).

\footnotetext{
${ }^{164}$ Rothschild 208.

${ }^{165}$ Robert D. Greenberg, "The Politics of Dialects among Serbs, Croats and Muslims in the Former Yugoslavia," East European Politics and Societies 10.3 (1996): 393-394.

${ }^{166}$ See Janko Moder, "Slovenski Jezikoslovci," Cerkev, Kultura in Politika, 1890-1941, eds. France M. Dolinar, Joža Mahnič, and Peter Vodopivec (Ljubljana: Slovenska Matica, 1993) 227-236.

${ }^{167}$ For a list of these works and more on the Reformation see Anton Ozinger, "Kriza Cerkvenega Zivljenja in Reformacija na Slovenskim," Zgodovina Cerkve na Slovenskem, ed. Metod Benedik (Celje: Mohorjeva Duzba, 1991) 106-107.
} 
Adam Bohoric (1520-1598), who studied at the University of Wittenberg and taught Dalmatin, produced a Slovenian orthography (bohoricica) that the Reformation leaders used. ${ }^{168}$ The contributions of Bohoric, Trubar, and Dalmatin formed the foundation of the Slovenian language. ${ }^{169}$ In the modern era Slovenes have focused on their unique language as the key to their national identity. ${ }^{170}$ Because of this, in later centuries Slovenes celebrated the role of Protestant reformers in promoting the Slovene language.

It was centuries later, in the modern era, under the continued pressure of Germanization and with the awakening of national consciousness, that the Slovene elite arose. ${ }^{171}$ This elite advanced its political goals through literary, cultural, and social endeavours. The elite did not advocate war or separation of Slovene lands from Austria. Jernaj Kopitar (1780-1844), a leading Slavic linguist, was among the most influential conservatives. He further standardized Slovenian and, like Linhart,

\footnotetext{
${ }^{168}$ Ozinger 108-109.

${ }^{169}$ This is in stark contrast with the present day memory of the Reformation in present day Croatia. Istrian Protestant Stjepan Konzul and Dalmatian protestant Anton Dalmatin produced the first Croatian translation of the Bible in 1562. Despite this, in Croatia the counter-Reformation of the 1580 s and 1590 s celebrated the RRC, while the protestant experiences were almost forgotten. For more on the idelogical differences in Slovene and Croat Protestant writers see Olga Nedeljković, "The Two Divergent Ideological Concepts Underly ing the Language Concepts of Croatian and Slovene Protestant Writers," Slovene Studies: Journal of the Society for Slovene Studies 8.1 (1986): $57-73$.

${ }^{170}$ Today only one percent of the Slovenian population is Protestant (mainly Lutheran). Yet, one of the most popular Slovene politicians since independence is President Milan Kučan, who is Lutheran. ${ }^{171}$ As historian Carole Rogel notes, "As the Catholic Reformation eradicated Protestantism in these [Slovene inhabited] Austrian provinces, the printing of Slovene books ceased altogether and did not recommence until the late $17^{\text {th }}$ century...For the most part, the cultural seeds of the 16 th century lay dormant for two hundred years." Rogel, The Slovenes and Yugoslavism 6.
} 
advocated Slovene unity and autonomy within the empire. ${ }^{172}$ Liberal historian and dramatist Anton Thomaz Linhart (1756-1795) created the first comprehensive, scholarly history of the Slovenes, which for the first time outlined the common history of Slovenes as a single ethnic-linguistic group. ${ }^{173}$ Both Kopitar and Linhart are considered among the first and most prominent Austroslavs in Slovenia. Austroslavism was the movement dedicated to the autonomy and greater influence of Slavs within the Austrian Empire. Austroslavism remained the predominant political option among Slovenes until the demise of the Empire. ${ }^{174}$

The Bishop of Maribor, Anton Martin Slomsek (1800-1862), would become a leading conservative. ${ }^{175}$ A fierce defender of the Slovene language in elementary education, Slomsek did not articulate a political program. ${ }^{176} \mathrm{He}$ promoted Slovenian in rural Sunday schools and schools for young girls. After the 1848

\footnotetext{
${ }^{172}$ Kopitar (1780-1844) was an Austroslavist. He hoped that all Slavs would unite in the Austrian empire and he also hoped they would support a common Kajkavian dialect His work influenced the Serbian linguist Vuk Karadžić (1787-1864). Karadžić established the standard Serbian language through the consistent application of the principle of "pisi kao sto govoris, citaj kao sto je napisano." Karadžić was also an avid collector of folk songs and poems and promoted the idea of greater Serbia, justified by linguistic ties of south Slavs.

${ }^{173}$ The influential liberal intellectuals gathered in a circle lead by Baron Žiga Zois (1747-1819) and included; Marko Pohlin (1735-1801) who promoted standardized Slovene and poet Valentin Vodnik (1758-1819) who in 1797 established the first Slovenian newspaper Lublanske novice (the Ljubljana News). During Napoleons rule he wrote many Slovene school textbooks.

${ }^{174}$ Mitja Velikonja, "Slovenia's Yugoslav Century," Yugoslavism: Histories of a Failed 1918-1992, ed. Dejan Djokić (London: Hurst \& Company, 2003) 85. In the immediate pre-WWI years Austroslavists came to advocate Trialism, the federalization of the Empire with Austrian, Hungarian and Slavic components, where south Slavs would be united in an autonomous state within the Empire.

${ }^{175}$ The conservatives of this era sought closer chruch-state relations and were led by clerics. The liberals of this era focused on the seperatino of chruch and state and were urban intellectuals and professionals.

${ }^{176}$ Pope John Paul II beatified Bishop Anton Martin Slomsek on the 10 September 1999. Roman Catholic Church Slovenia, "Beatification and Papal Visit," 10 Sept. 1999, 5 Nov. 2002 $<$ http://www.rck.si/slomsek>.
} 
revolutions Slomsek helped establish the Slovenian publishing house Mohorjeva Družba (Society of St. Hemagoras, 1851) and moved the seat of the Lavantine diocese to Maribor (1859). However, he is most remembered for his educational activities, particularly in Styria (Stajerska). ${ }^{177}$ Meanwhile, in Ljubljana, veterinarian Janez Bleiweis (1808-1881) forwarded his Austroslav political stance through his newspaper, the Agricultural and Craftsmen's News (1843). Although not a member of a particular party, he had significant influence on the conservative camp. Bleiweis' paper also sought to foster literary activity. However, it was the liberals who came to dominate the field of Slovene literature.

Still considered by many the greatest Slovene poet, not simply of the romantic period, France Prešeren (1800-1849) was also a convinced liberal. ${ }^{178}$ Prešeren, his mentor Matija Cop (1797-1835), and the liberal group centred in the newspaper Carniolan Bee sought to promote a refined literary Slovene language for everyday use by increasingly politically aware Slovenes. Anti-German, anti-RCC, anti-Slovene regionalism, and anti-Illyrian, this group of liberals courted the growing Slovene middle class and sought to make them nationally aware. ${ }^{179}$ Humanist and French revolutionary ideals coloured his poems, which were at once cosmopolitan but focused on preserving Slovenian culture. ${ }^{180}$ As essayist Niko

\footnotetext{
${ }^{177}$ See Branko Šuštar, ed., Pedagoski Pogledi na Antona Martina Slomska: Zbornik ob Raztavi (Ljubljana: Slovenski Solski Muzej, 1999) .

${ }_{178}$ See Henry R. Cooper, France Prešeren (Boston: Twayne Publishers, 1981) 18.

179 The Illyrian movement was a Croatian cultural and political movement predicated on the idea of a unified South Slav nationality. Lampe, Yugoslavia 41.

${ }^{180}$ See France Pibernik and Franc Drolc, eds., Poems: Pesmi (Ljubljana: Mohoreva Zolozba, 1999) 9.
} 
Grafenauer notes, Prešeren's choice to develop and work with the Slovenian language helped foster Slovene cultural autonomy that

turned out to be an obstacle to any kind of social, political and cultural homogenization [with larger neighbouring nations]," compensating for the lack of a state tradition. ${ }^{181}$

While there were some Slovenian intellectuals who had sympathies with movements to establish a common Serbo-Croat language for south Slavs, such as Valentin Vodnik (1758-1819) or Stanko Vraz, who advocated assimilation into the Serbo-Croat language, these views did not win as much influence ${ }^{182}$ This is in part because Slovenes had, before Serbian and Croatian codified a unified modern Slovenian language, so were not willing to give this up to assimilate with other south Slavs. ${ }^{183}$

Slovenian intellectuals were almost always opposed to plans for cultural unification because they believed that these would inevitably lead to the disappearance of the Slovenian language and, ultimately, to the Serbo-Croatization of the Slovenians. ${ }^{184}$

\footnotetext{
${ }^{181}$ Niko Grafenauer, "Poetic Language and Nationality," The Case of Slovenia, ed. Niko Grafenauer (Ljubljana: Nova Revija, 1991) 49-50.

${ }^{182}$ James Gow and Cathie Carmichael, Slovenia and the Slovenes (Bloomington: Indiana University Press, 2000) 20.

${ }^{183}$ The person who created the modern Slovene grammar was Jernej Kopitar (1808-1809). Andrew Baruch Wachtel, Making a Nation. Breaking a Nation: Literature and Cultural Politics in Yugoslavia (Stanford: Stanford University Press, 1998) 30.

${ }^{184}$ Baruch Wachtel 86. This is in part informed by the fact that by 1830 s during this explosion of Slovenian literary activity many Slovenes were already literate.
} 


\section{Chapter 4: Political Parties}

\subsection{Introduction}

The era of modern politics in Slovenia and Croatia began with the establishment of political parties that spoke in the name of the countries' respective interests. While "institutions" can include anything from formal to informal norms, routines, or organizations, this study focuses on institutions that have organized high politics in Croatia and Slovenia, in particular political parties. ${ }^{185}$ In the era of modern politics, from the late Habsburg period, to the royal Yugoslav regime, to socialist Yugoslavia, and to independent Slovenia and Croatia, certain dominant political parties shaped the goals, ideals, and responses to similar political pressures. These pressures included domination from the central government, achieving policy goals in a multinational state, and dealing with hostile neighbours.

Both Croatian and Slovenian political parties throughout the late $19^{\text {th }}$ and $20^{\text {th }}$ centuries sought greater autonomy from the centre. They did so mostly through existing political institutions. However, they pursued greater autonomy in different ways, in part informed by their understandings of national history. Each of the successive states -- Austria-Hungary; the Kingdom of Serbs, Croats and Slovenes; and the Socialist Federal Republic of Yugoslavia (SFRY) -- set up institutions to accommodate and contain different national politics internally and to defend their

\footnotetext{
${ }^{185}$ This study does not postulate that institutions are the "only causal force in politics;" rather, it seeks "to locate institutions in a causal chain that accommodates a role for other factors." Hall and Taylor, Political Studies 6 945-957.
} 
borders from expansionist neighbours on all sides. Save in Austria-Hungary, Croatian and Slovenian political elites operated within the same nation-state institutional framework. They also shared a national constitution and legislative body under which administrative units had the same responsibilities and rights. Although the majority of Croatians and Slovenians lived in distinct administrative units in the Austro-Hungarian Empire, in both parts of the Dual Monarchy there were similar challenges in resistance to linguistic domination (Germaization or Magyarization), and there were commonalities in the desire for unification of disparate administrative regions and for greater autonomy of unified Croatian and Slovenian administrative units. In light of greater demands for autonomy and independence for Croats than Slovenes, Vienna and Budapest used the ambitions of the Croat elite in their struggle against each other. ${ }^{186}$ This chapter focuses on political parties, their institutional roles, and the memories that their leaders invoked to justify and perpetuate distinctive patterns of political activity and ideals. ${ }^{187}$

\footnotetext{
${ }^{186}$ By the time the Dual Monarchy was established in 1867 through the Austro-Hungarian Ausgleich (Compromise). Croats were divided between the Austrian half of the Empire, which included Dalmatia, lstria, and the Vojna Krajina and the Hungarian half, which included CroatiaSlavonia. In 1868 the Hungarians signed the Nagodba (agreement) with Croatia-Slavonia. Even though the autonomy given to Croatia through the Nagodba was very limited, the Hungarians violated the terms of the agreement.

${ }^{187}$ In the absence of political parties that consistently pursued a classically liberal agenda in the late 19 th to the late 20th centuries, it is important to understand how political ideals, practices, and norms developed through institutional interest intermediation and popular memories came to inform the politics of countries that after 1990 set out to establish liberal democracies.
} 
4.2 Politics of the Modern Era: Parties and Politics Before the First Yugoslavia

\subsubsection{Croatian Political Parties}

With the rise of modern political parties in the mid to late $19^{\text {th }}$ century, Croatian political parties sought to counter the influence of the Hungarians and the power of the Austrians as well as to establish Croatian independence either as its own state or in a federation with other South Slavic kingdoms.

The strongest supporters of South Slav unification were the Croat political elite and intelligentsia, particularly with the Illyrian movement. However, most became disillusioned with the idea of a unified South Slav nationality propounded by Illyrianists, particularly after the revolutions of 1848 , and would turn to alternatives. ${ }^{188}$ Although most parties, including the Illyrians, published newspapers or pamphlets, Croatian political parties did not have much influence or popular membership until the implementation of the universal franchise in parts of the monarchy dominated by Austria in 1907 and by Hungary after the First World War. ${ }^{189}$ This is in contrast to Slovene parties of the same era, which through cooperatives promoted the participation of the population that already enjoyed the universal franchise in $1907 .^{190}$

\footnotetext{
${ }^{188}$ For more on Illyrianism and Yugoslavism see Dejan Djokić, ed., Yugoslavism: Histories of a Failed Idea 1918-1992 (London: Hurst and Company, 2003) 37.

${ }^{189}$ Barbara Jelavich, History of the Balkans: Twentieth Century (New York: Cambridge University Press, 198) 356.

190 "W With universal manhood suffrage in 1907 "the Slovenian population was in a better position to exert political influence." Jelavich 356.
} 
The most influential political options from the time of the Nagodba (agreement with Hungary) of 1867 forward included either the establishment of an independent state of Croatia or uniting South Slavic lands in a federation that would be positioned outside of the Empire. Prior to the war, the Croatian Party of Rights (HSP) was the strongest proponent of independence, while the National Party (NP) and the Croato-Serb Coalition (HSK) were the strongest supporters of Yugoslavism. ${ }^{191}$

\subsubsection{The Illyrian Movement}

The Illyrian movement, led by Croat Ljudevit Gaj, became the first political movement to promote the unification of all South Slavs within and outside of the Hapsburg Empire. Illyrianism had distinct linguistic and political components that were based on the belief in common Illyrian descent and Slavic language of all South Slavs.

The Croat direction of the movement mitigated against the voluntary inclusion of other South Slav leaders whose people had already developed or were developing their own national movements. ${ }^{192}$ The Croatian basis of the movement and lack of clarity in how this movement would preserve distinctiveness of other Slavs was informed by its focus on Croatian goals of reclaimed territorial integrity

\footnotetext{
${ }^{191}$ The Social Democratic Party of Croatia-Slavonia was also established at this time (1894) and advocated for South Slav unity, but it had a very small following. Šidak, Povijest 200-201.

${ }^{192}$ Banac, The National Question 78.
} 
and consolidation of lands that were once in the Kingdom of Croatia. ${ }^{193}$ In the $19^{\text {th }}$ century nationalism based on historical territorial integrity and Slavic unity had a prominent role in Croatian politics, with the idea that "the present day territory of the Serbian and Slovenian nations" was on Croat historical territory. ${ }^{194}$

As respected historian Ivo Banac notes, "until the 1850 s, the emphasis on Slavic reciprocity kept Croat national thought from lapsing into exclusivism;" after the $1850 \mathrm{~s}$, exclusivism in Croatian politics reigned. ${ }^{195}$ As expressed by the Illyrians a primary aim was inclusion of Serbs and Muslims who lived in what was considered traditionally Croatian lands. This way, the Croatian state could be as large as possible through the allegiance of these and other ethnic groups. ${ }^{196}$ Unique among the South Slavic linguistic national movements of the $19^{\text {th }}$ century, the Croatian Illyrian movement and party sought and produced compromise based on the adoption of the štokavian literary language. ${ }^{197}$ The

\footnotetext{
${ }^{193}$ This was informed by the Croat national ideals of Pavao Ritter Vitezovič (1652-1713) who argued for a "Greater Croatia" based on the idea of common Illyrian (Croat) heritage of Slavs. Jaroslav Šidak, Studije iz Hrvatske Povijesti XIX Stolječa (Zagreb: Sveucilište u Zagrebu-Institut za Hrvatsku Povijest, 1973) 9.

194 Šidak, Studije 47.

${ }^{195}$ Banac, The National Question 74.

${ }^{196}$ The appellation Illyrian was based on the mistaken ideal that south Slavs were decedents of Illyrians, a pre-Hellenic tribe that inhabited the Eastern Adriatic and the Western Balkans. Jelavich 306.

${ }^{197}$ Mirjana Gross, Počeci Moderne Hrvatske: Neoapsolutizam u Civilnoj Hrvatskoj i Slavoniji 1850 1860 (Zagreb: Globus, 1985) 371-372. Poet-linguist Ljudevit Gaj (1809-1872) founded and led the Croat Illyrian Movement, and with it sought to create one South Slavic Illyrian language based on the Štokavian dialect. Gaj had three dialects to choose from. Each dialect was distinguished by variations in the word "what": kaj, čak, or što. Kajkavian was and is the dialect spoken mostly in Zagreb and its environs, and it shares some similarities with Slovenian. Čakavian was and is spoken in Istria and the Dalmatian Islands. Stokavian was and is spoken by the majority of Croats, especially in Dalmatia, Slavonia, Central Croatia, and Bosnia and Hercegovina. It is also the language spoken by the majority of Serbians. Gaj chose štokavian to solidify the link between the majority of South Slavs, Croats, and Serbs. Although Gaj chose štokavian, and although štokavian is
} 
Illyrian party established in 1841 , like the movement from which it grew, sought the political unity of South Slavs within the Empire based on linguistic similarities, denying national political differences and based on the desire to secure Croatian statehood.

In the waning years before 1848 the Illyrian Party gained momentary power in the Sabor and passed laws mandating the use of Croatian in specific instances. After the national revolutions of 1848-49 the Illyrian movement left the political scene and was replaced, in its pro south Slavic unification ideals, by the Yugoslav movement and National Party established in $1860 .{ }^{198}$ However, the fact that the Illyrian movement was led by ethnic Croats, and focused on their literary, political and state history privileged the Croatian contribution and made other south Slavs wary of participating in this Croat-led movement. ${ }^{199}$ Two of the most influential Croatian linguistic and cultural movements, Illyrianism and later Yugoslavism, focused on the commonality of distinct Croatian, Serbian and Slovenian languages and cultures but denied the existence of Serb or Slovene "political people" since neither was "an organic group that could express any[thing] but Croatian statehood. ${ }^{, 200}$ Both retained a predominantly upper strata ethnic Croat leadership and following that focused on Croatian cultural heritage as well as on politics

what the majority of Croats speak, all three dialects continue to exist in Croatia. Jelavich 306-307. Within the štokavian dialect there are three variations based on pronunciation of $i$, e and ije, namely ikavian, ekavian, and ijekavian, respectively. Today Štokavian-Ikavian is considered to be the standard Croatian and Stokavian-Ekavian is considered to be the standard Serbian.

${ }^{198}$ For a chart on the development of political parties in Croatia-Slavonia see Horvat 353.

${ }^{199}$ Gross, Počeci 383.

${ }^{200}$ Banac, The National Question 91. 
focused on Croatian state tradition. ${ }^{201}$

\subsubsection{The National Party and Yugoslavism}

Illyrianism discredited by the Slavic rather than Illyrian ancestry, the strong absolutism of the $1850 \mathrm{~s}-1860 \mathrm{~s}$ and its narrow appeal limited to Croatia-Slavonia was superseded by Yugoslavism. The Ilyrian party had already been renamed the National Party by 1843 because of a Budapset ban on the word Illyrian; by the 1860 s the party was reinvigorated and had taken a new direction. ${ }^{202}$ As the guiding philosophy of the National Party, Yugoslavism initially sought to unite South Slavs both inside and outside of Austria-Hungary in an independent and federal South Slavic state. Yugoslavists were anti-Habsburg and anti-Hungarian, and therefore they sought to establish a new state of South Slavs, one based on Croatian state right. ${ }^{203}$ This Yugoslav ideal was fragmentary and fickle, changing with events and leaders, popular when relations with Serbians were widely interpreted as supporting Croatian interests and vilified when relations worsened. ${ }^{204}$ Bishop Josip Juraj Strossmayer, leader of the National Party (NP) from 1860 to 1873 , sought to foster

\footnotetext{
${ }^{201}$ Banac, The National Question 79.

${ }^{202}$ The National Party faced competition from the pro-Hungarian, Croatian Hungarian Party (established in 1841 and popularly called the Magyarones). Members of the National Party and the Magyarones violently clashed prior to the 1845 elections in fighting that claimed 22 lives. Goldstein 66.

${ }^{203}$ Rohrbacher, "Bishop J. J. Strossmayer's Yugoslavism in the Light of the Eastern Crisis of 1875 1878," East European Quarterly 15.3 (2001): 343-345.

${ }^{204}$ For example, when Croatians felt most threatened by Hungarian hegemony, the Illyrian and Yugoslavist movements were the most popular among the intellectuals. However, when fears of Serbian hegemony were prominent in the era just prior to the breakout of WWI and after the creation of the first royalist Yugoslavia, anti-Serb and anti-Yugoslav options rose in popularity. For example, the Party of State Right and the Croatian Peasant Party were created at this time.
} 
a sense of cultural, spiritual, and ultimately national unity among all South

Slavs. To this end he funded numerous South Slav cultural initiatives, was a great patron of the arts, and created the Yugoslav Academy of Science and Art (1868). ${ }^{205}$

Yugoslavists, most notably through the wealthy Bishop of Djakovo, Strossmayer, donated funds for the cultural development of Croatian and other South Slavic nations, re-affirming their recognition of Slovene and Serb distinctive cultural traditions. However, Yugoslavists based their political aims of South Slavic unity exclusively on Croat state right, not any Serb or Slovene political foundations, re-affirming that any South Slavic state will automatically be designed to forward Croatian political aims. As historian Mirjana Gross notes, Franjo Rački (1828-1894) argued that the

Croat people [have] a legal and ensuring right to ownership of the whole space from Bojana [which forms the present day border between Montenegro and Albania] to the Drina [which runs along much of the border between Bosnia and Hercegovina and Serbia] and the Danube. ${ }^{206}$

The push for South Slav unity was primarily the product of Croat intellectuals rather than Serb or Slovene intellectuals. However, Croat intellectuals advanced South Slavic unity with the plan that Croatia and Zagreb would be the power centres of any South Slav state and that the state would primarily be the

\footnotetext{
${ }^{205}$ Franjo Šanjek, Krscanstvo na Hrvatskom Prostoru: Pregled Religiozne Povijesti Hrvata (Zagreb: Krscanska Sadasnjost, 1996) 414-421. The Yugoslav Academy of Science and Art was the first institution to bear the name Yugoslav. However, its name was changed to the Croatian Academy in $1941-45$, and it has borne that name since 1991.

${ }^{206}$ Gross, Povijest 44-45.
} 
vehicle for the centuries-long desire to re-assert Croatian state right and independence.

Strossmayer's strong Yugoslavism and sympathy for Serbian politics turned into antipathy in the 1870 s and 1880s. This was because of resentment of Serbs after the Vojna Krajina joined Civil Croatia and because of Serb machinations in the Bosnia crisis. ${ }^{207}$ Strossmayer condemned leading Serb politicians for their exclusivist nationalism and pursuit of establishing a Greater Serbia. ${ }^{208}$ The same events that prompted Strossmayer's reconsideration of Yugoslavism also promoted the ascendancy of the nationalist Croatian Party of [state's] Rights (Hrvatska stranka prava, HSP)

\subsubsection{The Croatian Party of Right}

Established in 1861 by Ante Starčević (1823-1896) and Eugen Kvaternik (1825-1871), the HSP held that "both history and theology sanctioned Croatian independence. ${ }^{209}$ The HSP advocated a completely sovereign Croatian state encompassing most of the South Slav inhabited lands, where the peoples who did not consider themselves Croatian would be Croatianized. They based this claim on the idea of state right held by the Croat people due to their $6^{\text {th }}$ century settlement,

\footnotetext{
${ }^{207}$ Rohrbacher 368-369.

${ }^{208}$ Govorchin 60 . Greater Serbia is an idea that came to the fore in the mid to late 1800 s and that was attributed to Ilija Garašanin (1812-1874) Minister of the Interior for Serbia and his Načertanije (1844). It advocated a Serbia-centred South Slavic state analogous to Tsar Dušan's medieval Empire. Lampe, Yugoslavia 52-54. It was followed and mimicked by others throughout the ages, who argued that certain Western Balkan lands should, by virtue of historical or ethnic composition, be part of the Serbian state. At its core was the idea of unification of all Serbs and alleged Serbian lands (including much of the Western Balkans).

${ }^{209}$ Govorchin 59.
} 
their $11^{\text {th }}$ century kingdom and the mission to restore the independent state.

This gave them the historic right to dominate all South Slavic lands politically, as Serbs and Slovenes were simply Croats. ${ }^{210}$ It is not that Croats lost their independence, rather, the Hungarians and the Habsburgs did not uphold their obligations in recognizing that independence and therefore Starčević demanded that Austria "restore Croatian [national and] territorial integrity." leaders of the party were committed to complete Croat independence, they never directly mentioned dethronement of the Habsburgs, as this "amounted to treason against the dynasty. ${ }^{, 212}$

However, Kvaternik decided to take his own treasonous action. A small, short, and ill-fated rebellion lead by Kvaternik resulted in the party being banned, though it later re-emerged in the 1880 s as a more moderate force, that still retained its core principles of state right. ${ }^{213}$ The revived Party of State Right under Starčević recognized the distinctness of Slovenes, Serbs, and Serbo-Croat speaking Muslims. However, after Starčević's death, Josip Frank (1844-1911) led an increasingly unpopular HSP that was virulently anti-Serb.

Frank and his followers, the Frankists (Frankovci), advocated the establishment of an autonomous Croatia within the Austro-Hungarian Empire in

${ }^{210}$ Gross, Povijest 73-74.

${ }^{211}$ Govorchin 58.

${ }^{212}$ Banac, The National Question 88.

${ }^{213}$ Days after a resounding victory in the Sabor elections of 1871 , the second in command of the Party of State Right, Eugen Kvaternik without Starčević's knowledge lead a rebellion in the Vojna Krajina village of Rakovica. The rebellion, initiated to protest the $1868 \mathrm{Nagodba}$, had less than 500 participants and lasted only a few days. Once Austro-Hungarian authorities crushed the uprising, the party was banned and lead an underground existence until the1880s. Goldstein 83-84. 
order to counter Serb power in Southeastern Europe. The Frankists, like Antun Starčevic, counted Slovenia, Bosnia, and Hercegovina as Croat lands. ${ }^{214}$ In 1895 the Frankists broke from the Party of Right and established the Pure Party of Right based on xenophobic anti-Serb Croat nationalism centred on religious and ethnic identity. ${ }^{215}$ Although Frank spoke of Croatian independence, he co-operated with Vienna and sought a trialist solution. ${ }^{216}$ The party maintained that all Slovenes, Serbs, and Serbo-Croat Speaking Muslims were in fact ethnic Croats, reserving particular hatred for the mostly orthodox Serbs in whose own nationalism they saw a great enemy to the Greater Croatian ideal. In 1908 Mile Starčević, Ante Starcevic's brother, created a faction that broke from the Frankists but disbanded by 1918 because they sought the establishment of a south-Slavic state.

Generally rightists (pravaši), followed Ante Starčević in viewing South Slavs as Croats. Ante Starčević characterized Slovenes as benign irrelevant "Highland Croats," Serbs as Orthodox traitors and an "unclean race," and SerboCroat speaking Muslims as Croats who had gone astray. ${ }^{217}$ At the same time Ante Starčević, although non-practising himself, advocated the identification of Croats with Catholicism and invoked the idea of defending religion and homeland through exclusionary nationalism based on the strength of "Bog i Hrvati" (God and the

${ }^{214}$ Gross, Počeci 373.

${ }^{215}$ Robert W. Seton-Watson, The Southern Slav Question 109-110.

${ }^{216}$ Robert A. Kann, A History of the Habsburg Empire, 1526-1918 (Berkeley: University of California Press, 1974) 447. In the immediate pre-WWI years, Austroslavists came to advocate Trialism, the federalization of the Empire with Austrian, Hungarian, and Slavic components, where South Slavs would be united in an autonomous state within the Empire.

${ }^{217}$ Bilandžić, Hrvatska 31. Ante Starčević, Misli i Pogledi, ed. Blaž Jurišić (Zagreb: Matica Hrvatska, 1971) 112. 
Croats). ${ }^{218}$ Although the HSP did not have a strong presence in the Sabor, Ante Starčević maintained a strong presence in Croatian politics. As historian Gerald Gilbert Govorchin notes, Ante Starčević "became a legend in his own time, largely because he seemed to fulfill the need for a messianic personality who reflected Croatia's national objectives and national spirit.,219

Strossmayer and Starčević and their ideas and slogans have survived for generations in political discourse and were appropriated by later leaders, most often erroneously, as posthumous partisans of their cause. For example, Ante Pavelić, Croatia's WWII fascist leader, would openly proclaim his indebtedness to Starčević, looked to the RCC to support his political cause, and saw Bosnian Muslims as the most pure Croats, the "flower of the Croatian nation." 220 Starčević, like Tudjman would do more than a century later, called himself the "father of the nation." Tito, on the other hand, emphasised the struggle between Croats and the Austro-Hungarian monarchy as one of class. Nonetheless, he saw something commendable in Strossmayer's Yugoslavism and its focus on the unity of Slavs. ${ }^{221}$

\subsubsection{The Croatian-Serb Coalition}

Although it was a moderate force that engaged in compromise and played a key role in Croatian politics from 1906 until 1918, "even in Croatia the Croatian-

\footnotetext{
${ }^{218}$ Saeton-Watson 53.

${ }^{219}$ Govorchin 60 .

${ }^{220}$ Tanner 106.

221 Tanner 106.
} 
Serbian Coalition (HSK) did not represent the majority of the country. ${ }^{.222}$

Parties such as the National Party, the Party of Right, the Party of Pure Right (a breakaway and more extreme faction of the Party of Right), and the Croatian Peasant Party (then called the Croatian People's Peasant Party) sought a "more radical solution to the South Slav problem" and "disapproved of the compromises made" by coalition politicians. ${ }^{223}$ The HSK contained radical and moderate factions and co-operated with the government only some of the time. ${ }^{224}$

By the time of the Austrian annexation of Bosnia and Hercegovina in 1908, the Croatian-Serbian Coalition had a majority in the Sabor which it increased from 1906 but lost in $1910 .{ }^{225}$ By 1910, absolute rule set in, embodied in the rule of Ban Pavao Rauch (Ban, 1908-1910) and his successors and oscillated between times of greater or lesser freedom. ${ }^{226}$ By 1915 Frano Supilo and Ante Trumbić, Croat founders and leaders of the HSK, formed the Yugoslav Committee which was composed of South Slav, predominantly Croat, intellectuals from the Habsburg Empire exiled to Paris. The Yugoslav Committee (Jugoslavenski Odbor, 19151918), helped negotiate the post-First World War South Slav state. However, Supilo would resign from the Committee in 1916 in a dispute over the Treaty of

\footnotetext{
${ }^{222}$ Barbara Jelavich and Charles Jelavich, The Establishment of the Balkan National States, 1804 1920 (Seattle: University of Washington Press, 1993) 260. Tihomir Cipek, "The Croats and Yugoslavism," Yugoslavism: Histories of a Failed Idea 1918-1992, ed. Dejan Djokić (London: Hurst \& Company, 2003) 73.

${ }^{223}$ The Party of Right was a Coalition member until 1910. Even when it was a coalition member it maintained a radical stance. Jelavich 71 .

${ }^{224}$ Jelavich 70-71.

${ }^{225}$ See Appendix A: Croat Serb Relations.

${ }^{226}$ Kann 447-448.
} 
London, in which the Entente promised Italy certain South Slavic inhabited lands in exchange for joining the war. ${ }^{227}$ Once Yugoslavia was formed in 1918, the Croato-Serb Coalition disappeared. ${ }^{228}$ Although some Croat elites were the main proponents of South-Slav and Yugoslav unity, when that unity was realized after the First World War the Croat elite became the main opponents of the unified centralized Yugoslavia. ${ }^{229}$ The most influential and obstructionist of all Croatian elite groups, the HSS sought autonomy at least and independence at most. ${ }^{230}$

\subsubsection{The Croatian Peasant Party (HSS) ${ }^{231}$}

The Croatian Peasant Party (hereafter referred to as the HSS) was established in 1904 and was headed by brothers Stjepan (1871-1928) and Antun (1868-1919) Radić. The HSS was committed to encouraging political participation of Croatian peasants and representing them in what the HSS hoped could be an independent democratic republic. ${ }^{232}$ It was only until the inter-war years that a

\footnotetext{
${ }^{227}$ In the 1915 secret Treaty of London the allies had promised northern Adriatic as well as some Slovene and Croat inhabited lands to the Italians. The 1920 Treaty of Rapallo extended the northern Adriatic lands that Italy received, because of the penetration of Italian forces into Slovenian territory. Supilo disputed the relinquishment of Croatian lands mandated to Italy in the secret Treaty of London and feared that the Yugoslav federation would be unequal. Gazi 246-251.

${ }^{228}$ In 1927 there was a brief Peasant-Democratic Opposition Coalition, composed of parties which primarily represented Croatian Serbs and Croatians, but it was eliminated by the 1929 dictatorship. ${ }^{229}$ Dragan ic 89.

${ }^{230}$ Macan 306-309.

${ }^{231}$ For ease of reading, this chapter will refer to the Croatian Peasant Party and ignore a number of name changes. The party was established as the Croatian People's Peasant Party HPSS (Hrvatska Pucka seljacka stranka) and held that name from 1904 until 1920. From 1920 until 1925 the party was called the Croatian Republican Peasant party HRSS (Hrvatska repoublicanska seljacka stranka) and from 1925 until 1941 the party was known as the Croatian Peasant Party HSS (Hrvatska seljacka stranka) 1925-1941.

${ }^{232}$ Hugh Seton-Watson, Eastern Europe Between the Wars, 1918-1941 (Cambridge: Cambridge University Press, 1946) 46.
} 
party, the HSS would attempt to represent the majority of Croat men by first organizing at the grassroots level. However, similarly grand goals of Croatian autonomy and independence led the HSS to not co-operate with others and focus on its leading light, Stjepan Radić.

Stjepan Radić subscribed to liberal values, because he was a student of Thomas G. Masaryk in Prague (1895), but he also appealed to conservative and Christian values, while maintaining his strong anti-clericalism and less pronounced anti-Semitism. ${ }^{233}$ Radić condemned the RCC hierarchy as simply a "gentlemen's club," an elite that sought to keep the peasants down. He even opened meetings and rallies with "Praise be to Jesus and Mary, down with the priests!" Despite anticlericalism, the Radićes and the HSS were strongly Christian. Historian Mark Biondich argues that the Christian morality of the Radićs, including their "exaggerated belief in the supposedly deeply religious nature of the peasantry,"

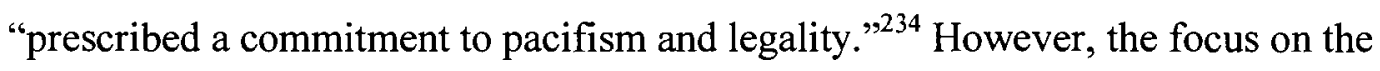
spiritualism of the peasantry and the leadership of the party worked to obfuscate a focus on legality. Radić and the HSS combined the historic state's right ideology with a call to South Slavic unity in order to justify a Croatian homeland that

\footnotetext{
${ }^{233}$ Horvat 238. Biondich 53. T. G. Masaryk was a Czech democrat who focused on social justice and was the first president of the inter-war Czechoslovak republic.

${ }^{234}$ Biondich, Stjepan Radic, the Croat Peasant Party 80.
} 
encompassed all South Slav lands and peoples. ${ }^{235}$ Above all, the HSS was a party centred on the personal leadership of Stjepan Radić. ${ }^{236}$

The HSS was first and foremost committed to mobilizing the peasant community and initially establishing an autonomous peasant state. To this end, Radić called on liberal, Christian, and socialist ideals and principals that informed his agrarian stance. For example, Radić's HSS started out by establishing cooperatives, libraries, and other local community-based organizations to mobilize peasants for a class war. He called for strengthening of the rule of law and rights, but for the collective peasant community, not for individuals. The radicalizing and mobilizing experiences of war, the extension of the universl male franchise in 1918, and the 1920 constituent assembly elections ensured that the HSS remained the most popular Croatian party in the inter-war period. This was despite the fact that until 1925 Radić and the HSS boycotted the government in protest of Serbiandominated centralism. The HSS "received the third largest popular vote in the November 1920 elections" and it could have played a "decisive role in the deliberations of the Assembly." 237

\footnotetext{
${ }^{235}$ In the 1890s Radić was committed to combating the historicist focus of Starčević and the Great Croatia ideals, rather focusing on South Slavic unity (narodno jedinstvo). Biondich 49 . However, "Radić would eventually return to the principle of state right as a powerful legitimizing weapon in the national cause." Biondich 52.

${ }^{236}$ Jelavich 149.

${ }^{237}$ Steven L. Burg, Conflict and Cohesion in Socialist Yugoslavia: Political Decision Making Since 1966 (Princeton: Princeton University Press) 16.
} 


\subsection{Slovenian Political Parties}

In contrast to Croatian political parties of the era, Slovenian parties did not demand a high degree of autonomy based on historic right. Therefore, they did not engender the opposition from central authorities with which Croat parties had to contend. The goals of the Slovenian elite were not as strong, its disappointments and defeats were not as devastating, and reaction to them was not as strong. The focus on autonomy for further linguistic, economic, and cultural development was in recognition of a lack of historic rights to a given territory and was more amenable to incremental gains and co-operation. Within Austria-Hungary and later in Yugoslavia Slovenian political elites sought pragmatic compromise in forwarding "national emancipation endeavours."238

During the rise of modern political parties in the mid to late $19^{\text {th }}$ century, Slovene intellectuals grasped the importance of liberal ideals for a small nation without an independent state tradition; they would later focus on this again. ${ }^{239}$ Slovene elites concentrated on linguistic rights and economic advancement as a way to promote Slovenian interests in the end of the $19^{\text {th }}$ century. "The central

\footnotetext{
${ }^{238}$ Rogel, The Slovenes and Yugoslavism 5-10.

${ }^{239}$ Even in the heyday of Romantic nationalism, including the 1848 revolutions, by far the most popular Slovenian political option among the small circle of politically active Slovenes did not call for outright independence or a South Slav political union, but rather for linguistic, cultural, and political autonomy with in the Austro-Hungarian Empire. The United Slovenia (Združena Slovenija) program of 1848 written up by the elite "was the only one of the political programs of the Habsburg nations [at the time] to appeal exclusively to natural law," and focus on human rights, "sovereignty of the people,... freedom of the press and political tolerance." Peter Vodopivec, "Slovene Intellectuals' Response to Political and Social Modernization in the Nineteenth and at the Beginning of the Twentieth Centuries," Slovene Studies 23.1 (2001): 5.
} 
topics of Slovene politics of the second half of the nineteenth century were: the Slovene language, its use in schools and in public, Slovene literature, culture and its institutions, and the danger of Germanization." ${ }^{240}$ In order to secure these rights, Slovene elites sought incremental reforms through compromise. ${ }^{241}$

Although Slovene national consciousness had formed in a united opposition to Germanic domination, there were conservative (the Clericals) and liberal (National Progressive Party, young Slovenes) camps that had already emerged on the eve of the nineteenth century. Significantly, the most influential Slovene party, the Clericals, understood the importance of including peasants in political and economic activities and immediately set out to do so through establishing cooperatives. On the other hand, the second most influential party, the Liberals, focused on promoting Slovene language and culture as ways of promoting autonomy. This is because at the time their literary activities made the Liberals preeminent among Slovene intellectuals. ${ }^{242}$ The general Liberal versus

Clerical/conservative currents in Slovenian politics that had emerged by the mid $19^{\text {th }}$ century had by the late $19^{\text {th }}$ century consolidated into political parties. ${ }^{243}$

\footnotetext{
${ }^{240}$ Vodopivec, "Slovene Intellectuals" 8.

241 "Of the South Slavs the Slovenes remained most loyal to the monarchy," they worked within it stressing "national autonomy in cultural affairs." Jelavich and Jelavich 258.

${ }^{242}$ The Liberals were not liberal as the word is understood today or in this dissertation'.

${ }^{243}$ The 1861 establishment of a constitutional monarchy and the bi-cameral Reichsrat ensured that the political elite began to engage in parliamentary politics, where representation gradually increased and where conflict and consensus were required. This led to the rise in influence of Slovenian political parties. The groups of intellectuals and clergy that had up to this point influenced politics were able to exert even greater political influence through parties and a parliament that ensured their need to be responsive to the widening electorate in the decades following 1861 . However, political parties at the time responded to the desire for economic and cultural needs and
} 
The Slovene political elite in Vienna pursued its national programs "legally, temperately, and with patience. $" 244$ During the $19^{\text {th }}$ and $20^{\text {th }}$ centuries, the predominant Slovenian party, regardless of political ideology or orientation, compromised with and participated in the central government, whether in AustriaHungary or Yugoslavia. This often afforded Slovenia concessions enabling the development of Slovenian cultural and political institutions. ${ }^{245}$

\subsubsection{The Clericals and the Co-operatives}

The Slovene Clericals, established in 1892 and re-named the Slovene People's Party (SLS) in 1905, had by the 1890s become the strongest political party among Slovenes. Their dominance of the Slovene political scene lasted until the Second World War. However, the Clericals experienced splits within their party. The Clericals supported co-operatives in order to help realize the autonomy for Slovenes and in the process strengthen their party. ${ }^{246}$ While they were focused

freedoms, while still remaining within the framework of collective needs. Slovene political elite participated in the government, and this brought important experience in conflict and compromise. ${ }_{244}^{24}$ Rogel, The Slovenes and Yugoslavism 63-64.

${ }^{245}$ Janez Cvirn, "Evropska Razsežnost Celjskega Gimnazijskega Vprašanja," Slovenci v Evropi (o Nekaterih Vidikih Slovenske Povezanosti s Sosedi in Evropo), ed. Peter Vodopivec (Ljubljana: Historia 5 Znanstvena Zbirka Oddelka za Zgodovino Filozofske Fakultete Univerze v Ljubljani, 2002) 35-42; Rogel The Slovenes and Yugoslavism 27. The development of Slovene identity, culture, and language was gradually restricted in Italy. Pamela Ballinger, History in Exile: Memory and Idenity at the Borders of the Balkans (Princeton: Princeton University Press, 2003) 136-136. The Slovenes in Austrian Carinthia also found their language rights restricted. Andreas Moritsch, "German Nationalism and the Slovenes in Austria between the Two World Wars," Slovene Studies: Journal of the Society for Slovene Studies 8.1 (1986): 15-21. This is in contrast with the development of Slovene language, culture, and administrative autonomy in Yugoslavia. These institutions included the separate Slovenian administrative unit that afforded the development of admin istration and education in the Slovene language.

${ }^{246}$ Vinenc Rajšp, "Prispevek Katoliške Duhovščine k Promociji Slovenskega Jezika in Slovenske Narodnosti," Slovenija 1848-1998: Iskanje Lastne Poti, eds. Stane Granda and Barbara Šatej 
on national not liberalizing endeavours, the Clericals' desire to provide

parliamentary representation for peasants and their focus on pragmatic economic and cultural concerns remained central. A significant manifestation of this was the co-operative movement of the pre-WWI era. ${ }^{247}$ The dominant Clericals (the Slovene People's Party, SLS) through co-operatives promoted political and economic participation that reinforced institutionalized routines, procedures, and norms focused on the rule of law and compromise. Through these co-operative peasants actively organized themselves to promote their economic, cultural, and political goals. ${ }^{248}$ These co-operatives included credit and non-credit co-operatives for producers and consumers, reading rooms, sports clubs, co-operative banks, as well as agricultural and craftsmen societies. ${ }^{249}$ The first co-operatives in Slovene lands were established in the 1850 s by liberals and then by socialists, but it was not until the $1870 \mathrm{~s}-1890 \mathrm{~s}$ that co-operatives became widespread, established by Clericals and encouraged by Pope Leo XIII's encyclical Rerum novarum (1891). ${ }^{250}$

(Ljbuljana: Zveza Zgotovinskih Društev Slovenije, 1998) 218-219. The Liberals, the other predominant Slovenian political option prior to WWI, also established co-operatives, but lacked the dense network that the SLS had built up.

${ }^{247}$ Toussaint Hočevar, The Structure of the Slovene Economy 1848-1963 (New York: Studia Slovenica, 1965) 23-75.

248 "Transcending Austria's provincial boundaries, the co-operatives served to foster a Slovene national consciousness - one whose purpose was to make Slovenes economically strong and thereby politically independent from Austrian-German domination." Leopoldina Plut-Pregelj and Carole Rogel, Historical Dictionary of Slovenia, Euripean Historical Dictionaries, No. 13 (Lanham: The Scarecrow Press, Inc., 1996) 68.

249 "In 1910, according to Austrian statistics, there were 902 Slovene co-operatives; the 783 that reported data to the census commission that year listed 195,268 members. (The total Slovene population in 1910 was $1,359,032$.)" Plut-Pregeli and Rogel 68 .

${ }^{250}$ Vinko Potočnik, "Krek in Socialna Misel pri Slovenskih Katoličanih," Cerkev, Kultura in Politika, 1890-1941, eds. France M. Dolinar, Joža Mahnič, and Peter Vodopivec (Ljubljana: Slovenska Matica, 1993) 79-83. 
National awakening and political organization was fostered not simply by a handful of intellectuals, teachers, and priests, but also through the prolific network of grassroots organizations that promoted public activity among peasants and were an important part of the support for the Clerical party. ${ }^{251}$

The Slovene political elite may have placed grater focus on the peasant majority than the Croat political elite because universal male suffrage was introduced in Slovene lands almost a decade prior to WWI, while in Croat lands it appeared only after WWI. Above all, the SLS and other Slovenian political parties took the opportunity to organize peasants through co-operatives in a move that helped support their political opinions and Slovene autonomy within AustriaHungary. This tradition was carried on in the first Yugoslavia, where autonomy was reinforced without engendering the obstructionism of Croatian political parties.

\subsubsection{The Clericals: The Slovene People's Party (SLS)}

By the late 1890s the Clericals (SLS) articulated a distinct program and increasingly utilized their dense, grassroots networks to organize politically. ${ }^{253}$ The

\footnotetext{
${ }^{251}$ Rajšp 218.

${ }^{252}$ Whereas the Radical and the Croatian Peasant leaders expended themselves after 1918 in exclusively political struggles, the clerical chiefs of the Slovene Populists [the SLS, the Clericals] consistently, albeit paternalistically, attentive to the economic and cultural as well as political aspirations and needs of their village and small-town constituencies. Through their comprehensive co-operative movement, the Populists [the Clericals, SLS] supplied Slovenia with a resource sadly lacking in the rest of interwar Yugoslavia: ample and cheap agricultural credit. Through their systematic program of Catholic popular education, they nurtured a relatively homogenous and advanced Christian-Social culture. Rothschild 212.

${ }^{253}$ Rajšsp 217-222.
} 
SLS advocated greater unity of Slovenes in Austria, but was divided as a party by 1908. Ivan Šušteršič (1863-1925), who advocated the unification of Catholic South Slavs within the Empire, was strongly monarchist and against "political Serbs" heading the conservative faction. ${ }^{254}$ A strong conservative influence was also exerted by Anton Mahnič (1850-1920), who did much to organize political Catholicism among Slovenes. ${ }^{255}$ Bishop of Ljubljana, Anton Bonaventura Jeglič (1850-1937), was also a conservative. However, he supported Krek and his cooperatives. $^{256}$

Janez Evangelist Krek remained the most prominent leader and headed the dominant Christian socialist faction. He was not an exclusivist Catholic. However, the party favoured all-South Slav unification within the Empire. ${ }^{257}$ To help justify this third Slavic unit and preceding the collapse of the empire, the Clericals allied with the Croat Party of Right and recognized Croatian historic state rights. ${ }^{258}$ In the 1912 Declaration of Ljubljana, the Slovenes conceded that Slovenes and Croats were one people and even proposed giving up the Slovene language if a South Slavic unit would be established as a third part of the monarchy. ${ }^{259}$ This act was

\footnotetext{
${ }^{254}$ Banac, The National Question 113-1 15. Sustersic's slogan was "For Religion, Home, and Emperor."

${ }^{255}$ Janko Pleterski, "Katoliška ali Socialna, Narodna ali Ljudska Stranka? (Koncepcije Katoliške Ljudske Demokracije 1980-1918)," Cerkev. Kultura in Politika, 1890-1941, eds. France M. Dolinar, Joža Mahnič, and Peter Vodopivec (Ljubljana: Slovenska Matica, 1993) 21-22.

256 "Jeglič was great because of his visionaryness." Franc M. Dolinar, "Katoliška Cerkev na Slovenskem med Politiko in Versko Prakso," Slovenci v XX Stoleju: Simpozij (Ljubljana: Slovenska Matica, 2001) 100-105.

${ }^{257}$ Rogel, "Eve of World War I" 410-411.

${ }^{258}$ Rogel, "Eve of World War I" 410-411.

${ }^{259}$ Gross, Povijest 398-399.
} 
one of desperation, forced by the rift with Slovene clericals and German conservatives. ${ }^{260}$ This declaration did not change the past of SLS's support of autonomy based on Slovene distinctiveness and its reinforcement through cooperatives and cultural endeavours. ${ }^{261}$ The two other major political options of the day, the Liberals and the Social Democrats, "refused to consider bargaining away the Slovenian language. ${ }^{262}$ In a few years, after the demise of the Empire, the search for a trialist solution was dead. Rather, the SLS and other Slovenian parties refocused on the search for Slovene autonomy within the newly created Kingdom of Serbs, Croats and Slovenes. The SLS focused on ensuring Slovene interests through winning autonomy based on the distinctiveness of Slovene language and culture. ${ }^{263}$

Krek's successor, Anton Korošec (1872-1940), adopted Krek's democratic socialist vision and Trialism. He presented Krek's May Declaration (1917), which called for the unification and autonomy of all South Slavs in the Empire. ${ }^{264}$ Although the parliament rejected the declaration, it sparked grassroots interest and anti-war agitation.

At the end of WWI, when it was clear Austria-Hungary would disintegrate, Korošec promoted an independent South Slav federation. ${ }^{265}$ Although the post-war

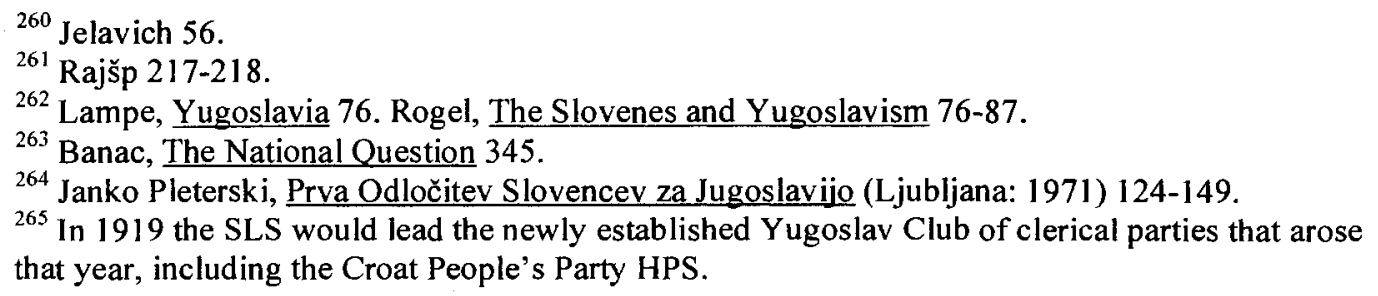


South Slav kingdom of Serbs, Croats, and Slovenes (kingdom of SHS) would not be a federation, Korošec lead the SLS, the most influential inter-war Slovene political party. ${ }^{266}$ The inter-war SLS took advantage of its place in Yugoslavia, cooperating with and joining the government, but also taking a stand on Slovene autonomy. Disappointed with the 1921 constitution, Korošec still engaged in compromise with Belgrade. ${ }^{267}$ Having joined the government in 1918-1921 and again in 1924, in 1928 Korošec became Prime Minister, the only non-Serb prime minister in interwar Yugoslavia. Still in the government in the 1930s, by 1933 Korošec had come to strongly advocate for Slovene autonomy and through the Slovene Declaration to call for greater autonomy of a united Slovenia that included Slovenes from Italy, Austria, Hungary, and Yugoslavia. ${ }^{268}$ However, in 1935 the Clericals boycotted the elections only to become part of the government later that year, as Korošec was to be the interior minister from 1935 to 1938. During this time, Korošec's autonomy demands were again put in the background, with cooperation in the foreground. In seeking greater autonomy, the SLS took a very different stance from the dominant Croatian party, the Croatian Peasant Party (HSS). While the HSS battled against centralization directly and was clearly an

\footnotetext{
${ }^{266}$ WWI and the kingdom of SHS will be discussed following the sections on Slovenian and Croatian political parties, which were formed prior to the war and some of which played a role in the kingdom of SHS.

${ }^{267}$ Darko Friš, "SLS in Slovensko Nacionalno Vprašanje med Sprejetjem Vidovdanske Ustave in Blejskim Protokolom," Slovenija 1848-1998: Iskanje Lastne Poti, eds. Stane Granda and Barbara Šatej (Ljbuljana: Zveza Zgotovinskih Društev Slovenije, 1998) 180.

${ }^{268}$ Branko Petranović and Momčilo Zečević, eds. Jugoslavija 1918/1988: Tematska Zbirka Dokumenata (Beograd: Izdavačkat Radna Organizacija "RAD," 1988) 339. Janko Prunk, Slovenski Narodni Vzpon (Ljubljana: Državna Založba Slovenije, 1992) 258-262.
} 
opposition party, the SLS sought to further Slovene autonomy wherever

possible, particularly through ensuring that there remained a distinctive Slovenian

political unit in the kingdom in which the Slovene language was preserved and advanced. ${ }^{269}$

In the 1930s, in the face of economic and parliamentary crisis accompanied by growing political polarization throughout Europe, the seemingly unshakable Catholic political block, which had for so long dominated Slovenian politics, began to fragment further. ${ }^{270}$ In exchange for co-operation, mediation, and legitimization of the central government, the SLS elicited concessions for Slovenes in political, cultural and economic affairs. ${ }^{271}$ They did not receive the amount of autonomy that the Croats did just prior to the death of the kingdom with the 1939 Cvetkovic Maček Agreement, simply referred to as the sporazum (agreement). The Croat autonomy proved disastrous, as extremist elements quickly took over the Croat Banovina.

After 1935 the Clericals were among the strongest advocates for greater autonomy for the banovinas (provinces), re-organized in 1931. Korošec also became the leader of the Drava Banovina (which encompassed Slovenian lands). Korošec even helped negotiate the sporazum, hoping for similar concessions for the

\footnotetext{
${ }^{269}$ Andrej Rahten, Slovenska Ljudska Stranka v Beograjski Skupscini (Ljubljana: Založba ZRC, 2002) 63-82.

${ }^{270}$ Egon Pelikan, Akomodacija Ideologije Političnega Katoličizma na Slovenskem (Maribor: Založba Obzorja, 1997) 45.

${ }^{271}$ That there was a separate Slovene political administrative unit, where Slovene was officially spoken, Slovene schools and even a university were established, speaks to the concessions made to the Slovenes in Yugoslavia, concessions which were not made, for example in neighbouring Italy which had $1 / 3$ of the Slovene population.
} 
Drava Banovina, which did not take place and which resulted in deeper divisions between leftist and rightist political forces in Slovenia. Resolution was not to come in the framework of the Kingdom of SHS, because shortly after the sporazum the rest of Europe and Yugoslavia plunged into war. Plagued with internal rivalries, controversies, and compromises that accompanied all political endeavours, the SLS dominated Slovenian political life until the eve of the Second World War.

\subsubsection{The Liberals: The National Progressive Party}

The main competitor for the SLS were the Liberals, the National Progressive Party (NNS) established in 1891 and renamed the Yugoslav Democratic Party in 1918.

Until WWII, the Clericals dominated Slovenian politics as a whole, while the liberals had a strong presence in Ljubljana, since they appealed to urban, middle class constituents, intellectuals, and Slovene nationalists. ${ }^{272}$ To varying degrees and at different times, the liberals focused on Slovene nationalism, anti-clericalism, anti-Germanism, social-conservativism, "free-thinking," pan-Slavism, and proYugoslavism. Given their often-unstable positions, lack of focus on peasants, and their anti-Clericalism, the liberals failed to attract much support from Slovenes. Liberals Ivan Hribar and Ivan Tavčar were mayors of Ljubljana from 1896-1910

\footnotetext{
272 "The Slovene Liberals, in practice, were following Karl von Vogelsang [founder of the Austrian Christian Social Movement of the late 1800s] (and not [John Stewart] Mill)." Vodopivec, "Slovene Intellectuals" 7.
} 
and 1911-1921, respectively. ${ }^{273}$ In that capacity, both promoted the development of a middle class through standardizing banking institutions, business contacts, and transportation links, along with some of the ideals of the "freethinkers" who preceded them in the party. ${ }^{274}$ The liberals faded in stature in the last decade of Habsburg rule, because they did not formulate a timely or popular approach to a United Slovenia. ${ }^{275}$ The party was discredited because it supported unitarism and because of the 1921 centralizing constitution. By the 1930s, due to its entry into the government and due to Europe-wide economic and radicalizing pressures, the party fragmented and lost what little popularity it had among Slovenes.

\subsection{The Socialists and Communists in Slovenia, Croatia and Yugoslavia}

Another political party that gained ground in Slovenia and, by the time of the Kingdom of SHS, competed with the Clericals and Liberals was the Socialists. The Slovenian Yugoslav Social Democratic Party established in 1896 was under the strong influence of the Austrian Social Democratic Party. Therefore, most sought a solution to the "South Slav national problem" in an Austria that would expand to unify all Yugoslavs and incorporate other Balkan states. ${ }^{276}$ Etbin Kristan (1867-1953) led the majority that sought a Yugoslav solution within the Empire,

\footnotetext{
${ }^{273}$ Rogel, The Slovenes and Yugoslavism 41.

${ }_{274}^{274}$ Rogel, The Slovenes and Yugoslavism 41-42.

${ }^{275}$ Renamed the Yugoslav Democratic Party in 1918, the party steadily lost influence among intellectuals, who began to organize outside of it. For more on the Liberals in the first Yugoslavia see Jurij Perovšek, Liberalizem in Vprašanje Slovenstva: Nacionalna Politička Liberalnega Tabora v Letih 1918-1929 (Ljubljana: Modrijan, 1996).

${ }^{276}$ Rogel, "Eve of World War I" 415-416.
} 
but a few dissenters, most notably writer Ivan Cankar (1876-1918), called for a Yugoslav federation carved out of Austria. Although a Yugoslavist, Cankar underlined the importance of national and cultural autonomy. ${ }^{277}$ Recognized as Slovenia's prominent modern writer, socialist Ivan Cankar argued for a Yugoslavia that would preserve linguistic and cultural distinctions among Yugoslavs. For him, some kind of Yugoslav question in the cultural or overall linguistic sense does not exist...at all. Maybe it once existed, but it was solved when the Yugoslav tribes separated into four peoples with four completely clear and independent cultural lives. ${ }^{278}$

The socialists had little influence until the1920s, when they joined the Communist Party of Yugoslavia (CPY). Initially, they advocated an Austrian federation. The party in Slovenia and the Communist Party in Croatia eventually followed the same line, as they were both part of the Communist Party of Yugoslavia.

The communists first favoured unitarism and then federalism in the kingdom of SHS, but they did not have much influence in the kingdom. They did well in the Constituent Assembly elections of 1920, garnering the third most number of seats in the country. However, by August 1921 the party was outlawed. ${ }^{279}$ The party was forced to lead a marginal underground existence, which prepared its members to fight the fascist occupiers by the 1940 s. $^{280}$ Through the 1920 s and 1930s the party worked through internal fractionalization to clarify its

\footnotetext{
${ }^{277}$ Peter Vodopivec, "The Slovenes and Yugoslavia," East European Politics and Society 6.3 (1992): 220-242.

${ }^{278}$ Ivan Cankar in Baruch Wachtel 86.

${ }^{279}$ The Communist Party was putatively outlawed because of assassination attempts on Prince Alexander and the Minister of Home Affairs. Stevan K. Pavlowitch, Yugoslavia (New York: Prager Publishers, 1971) 61-64.

${ }^{280}$ Lešnik 16, 18.
} 
approach in Yugoslavia. By the mid-1930s the Comintern adopted a Popular Front policy that was employed in Yugoslavia, where the party established alliances with other anti-fascist groups. At the same time, the party affirmed its commitment to promoting national equality and self-determination of nationalities, but only within a Yugoslav federation.

The communists sought to harness the disaffection of nationalities, but recognized that Germany could more easily dominate small rather than large states. This clarification of policy came just as the political crisis, depression, and high unemployment rate among an increasingly educated youth in the 1930s led many to radical politics, from communist to proto-fascist. ${ }^{281}$ With its commitment to Yugoslav integrity, recognition of national autonomy, multi-ethnic leadership, and country-wide underground organizational network, the CPY was transformed form a marginal urban movement to the leading institution that provided the partisan resistance with its goals and strategy. The party gained political prominence once it organized the partisan defence of Yugoslavia, particularly after the Nazi invasion of USSR in June 1941 and after the Allies gave them support in 1943. Communist Yugoslavia, established after the Second World War, and the roles of the Slovenian and Croatian Communist Parties will be discussed in the following chapters.

\subsection{Conclusions}

\footnotetext{
${ }^{281}$ Ervin Dolenc, "“The Generation at a Closed Door": Slovenian Intellectual Issues between the Two World Wars," Slovene Studies 23.1 (2001): 15-16.
} 
"The resilient notion of Croatia's rights (pravice) was an inseparable ingredient in its political culture. ${ }^{282}$ The ideal of states' rights served as an "integrating myth" that inspired a more heroic reading of Croatian history and greater demands for independence than ones existing in Slovenia, where political battles were waged primarily about linguistic, cultural, and economic rights. Unlike in Croatia, in Slovenia linguistic standardization resulted in a clearly demarked Slovenian national identity, so this issue was not part of party politics in the way that Illyrianism and Yugoslavism were in Croatia. At the same time, instead of claiming territories based on the sovereignty of a Slovenian state, which in Croatia was central, Slovenes looked to concessions based on requirements of cultural and economic rights. This did not provoke resistance from other national groups, as was the case with Croats and Serbs.

The most influential parties in Croatia in the late $19^{\text {th }}$ century were the Illyrians and the Yugoslavists, who sought a South Slavic unity based on Croat state tradition and cultural and linguistic unity of South Slavs. The Party of State Right sought greater independence and autonomy for Croatia based exclusively on state right. The most influential Croatian party during the interwar period was the Peasant Party, which also relied on Croat state right along with Croat peasants' rights. ${ }^{283}$ To a greater extent than Slovene parties of the period the Peasant Party fought against centralization and for autonomy or independence. The Peasant Party

\footnotetext{
${ }^{282}$ Trifković 346.

${ }^{283}$ Biondich, Stjepan Radic, the Croat Peasant Party 114.
} 
did not allow for compromise and incremental non-zero sum politics used by

Slovenes. Its focus on an independent state tradition was far different from

Slovenia's focus, and it provided the basis for political parties that demanded more for Croatia from the centre.

The stance of the Croatian parties can be contrasted with that of Slovenian parties in the late $19^{\text {th }}$ century. The most influential Slovenian party of the era was the Clerical Party, which focused on strengthening Slovene autonomy through establishing economic co-operatives. Other influential Slovenian parties, the Liberals and the Social Democrats, focused on promoting autonomy through Slovenian language and culture. During the interwar period, the Clericals engaged in greater co-operation and compromise with the center, coming up with accommodating politics based on the recognition required to ensure Slovene autonomy. Through history, Slovenian political elite recognized that as a small nation without a strong military, aristocracy, state tradition, or political presence, Slovenia could not afford to pursue revolutionary change and would have to negotiate to reach its aims.

In 1918, Slovene and Croat leaders, constrained by geo-political requirements and the dissolution of Austria-Hungary, resolved to enter into the Kingdom of Serbs, Croats and Slovenes, later renamed Yugoslavia. ${ }^{284}$ They expressed similar concerns about centralization, but dealt with them in different

\footnotetext{
${ }^{284}$ Yugoslavia is the appellation used here to denote the country that existed from 1918-1991, unless otherwise noted. The country had various names and incarnations during this period, which will be discussed in the following historically themed chapters.
} 
ways. ${ }^{285}$ However, different characteristic approaches were taken and concrete circumstances existed, so that even if the general sequencing of events and the overall state structure was the same, political parties pursued their goals in a different manner and using distinct resources. Predictably, their experiences, outcomes, and memories were different. It was only with the demise of Socialist Yugoslavia, however, that these differences informed the establishment of independent states, each with a distinct path of political liberalization.

${ }^{285}$ Lampe, Yugoslavia 130-200. 


\section{Chapter 5: The First and Second Yugoslavia}

\subsection{Introduction}

The kingdom of Serbs, Croats and Slovenes (kingdom of SHS) was established on 1 December $1918 .^{286}$ With the formation of Yugoslavia, the focus on Croatian state right expressed itself in the maximal goal of independence. In pursuing this goal, the Croat political elite employed obstructionist politics. ${ }^{287}$ Within both the first, royal, and the second, socialist, Yugoslavia, the Slovenian political elite focused on linguistic and identity rights, with the maximal goal of autonomy through a strategy that was "more co-operationist than [that of] their Croatian counterparts., 288

Having settled on unification under a Serbian monarch, the political elite in each of the constituent parts of the new kingdom of Serbs, Croats, and Slovenes still harboured different visions of what unification would mean. ${ }^{289}$ The nationality issue and the desire to retain autonomy remained the primary concern for Slovene

\footnotetext{
${ }^{286} \mathrm{lt}$ is important to note that Slovenia was under immense pressure form Italy and Austrian land claims and military advances. Whereas Croatia was under pressure from Italian land claims. Stjepan Radić strongly opposed unification. It is also important to note that Sjepan Radić was the only delegate of the National Council of Slovenes, Croats and Serbs to "object to the actions that" resulted in the creation of the state of Kingdom of Serbs, Croats and Slovenes. Jelavich 149. ${ }^{287}$ Baruch Wachtel 77.

${ }^{288}$ Baruch Wachtel 77.

${ }^{289}$ The integration of these diverse territories, peoples, economies, cultures, and politics was to be a challenge that ultimately could not be overcome. Pieces of the dead multinational Ottoman and Habsburg Empires found their way into what would eventually become the last large multinational state in the Balkans, Yugoslavia. As historian Jože Pirjevec notes, most Slovenes had lived under Austria, most Croats under Hungary, Bosnia and Hercegovina under Austria-Hungary, both Serbia and Montenegro were independent kingdoms, while Kosovo-Metohija and Vradar Macedonia were only joined with Serbia after the Balkan wars of 1912-19I3. Jože Pirjevec, Jugoslavija: Nastanek. Razvoj ter Razpad Karadjordjevićeve in Titove Jugoslavije (Koper: Založba Lipa, 1995) 12.
} 
and Croat political elites. ${ }^{290}$ The most essential conflict that would plague the new kingdom, and later socialist Yugoslavia, was the conflict between centralists and decentralists, the former represented by Serbian politicians and the latter by Slovenian and Croatian ones. ${ }^{291}$

The obstructionism of the Croatian political elite during the interwar period, and the WWII fascist Croatian state that invoked state right arguments of the past, ensured that after the war there existed an even greater fear and stronger reaction to anything seemingly invoking historical patterns of Croatian obstructionism, nationalism, and calls for greater autonomy on the part of the Yugoslav government. The interwar co-operationist politics of the Slovenian political elite, the lack of a fascist state, and a recognition of how "Slovene" interests were forwarded in the past critically informed center-Slovene relations within Yugoslavia. Slovenes were afforded greater scope to forward what were considered "Slovene" interests, as they did not have the same type of history attached to their autonomy efforts. This history, from the inception to the demise of Yugoslavia informed the divergent exits of Croatia and Slovenia from the federation in 1991.

\footnotetext{
${ }^{290}$ Of the 12 million citizens of this country 8 million had the same literary language, SerboCroatian, which Serbs and Montenegrins wrote in Cyrillic, Croats in Latin...[there were] 750,000 Bosniaks...600,000 Macedonians, 500,000 Germans and almost as many Hungarians and Albanians, more than 200,000 Romanians, 150,000 Turks, 115,000 Czechs and Slovaks, as well as Ukrainians, Polish, Italians, Jews and Roma... [there was also great religious diversity with] approximately 5 million Orthodox, 4.7 million Catholics, 400,000 Uniates, 1.3 million Muslims, 229,000 Protestants and 36,000 Jews. Jože Pirjevec 12 . To put it in other terms, roughly $43 \%$ of the population were Serbs and Montenegrins, $23 \%$ Croats, $8.5 \%$ Slovenes, $5 \%$ Macedonians, $6 \%$ Bosniaks, $14.5 \%$ non Southern Slavs (including Albanian and Turkish Muslims, Germans, Magyars, Romanian Christians and Jews). Rothschild 202-303.

${ }^{291}$ Dimitrije Djordjević, "The Yugoslav Phenomena," The Columbia History of Eastern Europe in the Twentieth Century, ed. Joseph Held (New York: Columbia University Press, 1992) 314-323.
} 
5.2 Centralization, Dictatorship, and Demise of the First Yugoslavia 1918-1941

The Kingdom of SHS (Kingdom of Serbs, Croats and Slovenes) was established in 1918 and on St. Vitus Day (June 28) 1921 Serb centralization was imposed with a constitution that frustrated both Slovene and Croat desires for a decentralized federation. Politicians in Belgrade had never before worked in a multinational parliament. It was the predominant Slovenian political party, the Clericals, that had the most experience in a multinational parliament and acted on its requirement for co-operation. While it was the predominant Croatian political party, the HSS, that engaged in obstructionism. Neither Slovenes nor Croats sought subordinate positions, like the ones they once held.

The Slovenian People's Party (the Clericals) held the most influential role in the national political scene. However, the SLS waged a fierce struggle with the liberals within Slovenia. As remembered today the pragmatic politics of the SLS focused on autonomy within the kingdom of SHS. This often entailed co-operation with and concessions to the central government. ${ }^{292}$ As historian Joseph Rothschild notes,

The Slovenes...had learned the arts of bargaining and manoeuvring coalitions in the politically and ethnically intricate setting of the prewar Vienna Reichsrat, and, being generally literate and pragmatic, had become highly skilled in local government and general administration... [educated Slovenes were bilingual and many found positions in ] the central ministerial bureaucracies of Belgrade. The hard-bargaining Slovenes, in short, were administratively overprivileged in interwar Yugoslavia. ${ }^{293}$

\footnotetext{
${ }^{292}$ Pirjevec, Jugoslavija 46-49.

${ }^{293}$ Rothschild 208.
} 
Slovenes were "administratively overprivileged," or in other words had more influence than their Croatian counterparts, in large part due to their cooperation. This co-operation stemmed from the pragmatic recognition that the Yugoslav state was needed in order to ensure Slovenian autonomy. By adopting this approach, Slovenia became a lynchpin keeping Yugoslavia together by lending legitimacy to the state, promoting compromise, and working within it. ${ }^{294}$ The Slovene elite recognized that Yugoslavia was the only state in which they could maintain and strengthen their autonomy given the territorial settlements of the WWI era. ${ }^{295}$

The loss of one third of Slovene lands to Italy following WWI was resented but accepted in Slovenia and did not inspire radical politics. ${ }^{296}$ Rather, the loss of territories and fear of centralization reinforced the focus on Slovenian identity through linguistic preservation and the need to ensure that identity within

\footnotetext{
${ }^{294}$ Historian John Lampe quotes an unnamed Belgrade historian, "Yugoslavia began and ended with Slovenia." Lampe goes on to note that "Monsignor Anton Korošec, argued that "even a bad Yugoslavia is better than no Yugoslavia." Lampe, Yugoslavia 3.

${ }^{295}$ As leader of the SLS Korošec said to a member of the Croatian Peasant Party: "The territory of Croatia and Slavonia was recognized under the Austro-Hungarian Monarchy as a political nation, and succeeded in preserving its autonomy to a considerable extent. The Croats, therefore, have lost so much in the new state that their unyielding opposition to it is most understandable. But you should understand us, too. We lost nothing - on the contrary, we have achieved noteworthy gains under the new order. Under Austria-Hungary, we Slovenes did not have our own high schools and a Slovenian uiniversity seemed a utopian dream. The Croats had their own schools from first grade through university; Croatian was the official language on Croatian territories. In the Slovenian provinces, German had been imposed. In the new State, the Slovenes received all they had previously lacked, high schools and a university to boot. As long as my party is represented in the government, Belgrade will allow us to administer Slovenia according to our own wishes. Although I realize that this centralizing system cannot maintain itself very long, I consider it wise to profit form the circumstances as they exist and to obtain a few favours in the bargain." Jelavich 153, as quoted in Vlatko Maček, In the Struggle for Freedom (University Park: Pennsylvania State University Press, 1957) 93-94.

${ }^{296}$ For more on territorial losses see Appendix C: Territorial Settlements.
} 
Yugoslavia. ${ }^{297}$ Like Croats, Slovenes resented centralization and sought greater autonomy, but like they had in Austria-Hungary they sought to achieve this through positive sum games and bargaining. ${ }^{298}$

Slovenes had, by virtue of geography and unique language, achieved a certain distance from Serbian domination. Despite these circumstances the Slovene language, and therefore autonomy, was threatened by leading Serbian political elite, who opposed the development of autonomous Slovenian institutions. ${ }^{299}$ Already by February 1921 Slovene intellectuals issued the Autonomous Statement (Avtonomistična izjava), calling for Slovenian cultural and economic autonomy as an important "step toward forming a civil society." ${ }^{300}$ This statement was signed by many Slovene professionals and adopted by most political parties in Slovenia. They achieved this through their continued use of co-operatives, promotion of Catholic education, influence in the central government, and increasing administrative autonomy at home.

\footnotetext{
${ }^{297}$ Movements focusing on human rights as the only way to ensure the rights of the Slovene minorities in Italy and Austria gained popularity in the 1920s and 1930s. Egon Pelikan, Tajno Delovanje Primorske Duhovščine pod Fašizmom (Ljubljana: Korenine, Nova Revija, 2002) 413444.

298 Bojan Balkovec, Prva Slovenska Vlada 1918-1921 (Ljubljana: Znanstveno in Publicistično Središče, 1992) 31-32.

${ }^{299}$ For the tension between co-operation and ensuring autonomy see Miroslav Slana-Miros, Oživitev Dr. Antona Korošca: Oče Domovine na Tehtnici (Maribor: Založba za Alternativno Teorijo, 1991) 58 .

${ }^{300}$ Dolenc 17-18.
} 
Resentment over Serbian domination did not take on the same dimensions it did in Croatia. ${ }^{301}$ In Croatia the aim was to reassert Croatian state right and the fact that south Slavic federation had been achieved on the basis of Serbian state tradition was difficult to reconcile with the continued focus on Croatian autonomy based on Croatian state right. Croats struggled against the central government for autonomy with greater vigour. This can in part be attributed to patterns of politics under Hungary and the perpetual distrust of central and political authorities, Hungarian or Serb. As Joseph Rothschild notes, relegated to permanent underrepresenation and subjected to cultural magyarization, Croatia had spawned a political tradition and political elite that placed a high value on defensive obstructionism in the parliament and administration, while acceptance of the responsibilities of power and of office had come to evoke suspicions of cooptation and incipient betrayal. ${ }^{302}$

The Croat-Serb competition for political dominance in the Kingdom focused leaders from both sides on political power. Croatian politicians became the champions of radical opposition to centralization. The issues of centralization and decentralization came to dominate Yugoslav politics during the inter-war period. Accordingly, Stjepan Radić became the centre of opposition to centralization, a charismatic leader of a populist HSS, who took a different course than the

\footnotetext{
${ }^{301}$ As Sabrina Petra Ramet notes, "Although the Slovenian Clerical Populist party under Anton Korošec co-operated closely with the Serbs, the Slvoenes overwhelmingly recoiled from the Serbian-dominated centralist apparatus." Ramet, Nationalism and Federalism 7. Historian Barbara Jelavich notes that "Slovenian interests continued to be represented primarily by the Peoples party...conservative, clerical, and highly opportunistic, it was able to win the solid backing of the Slovenian electorate." Jelavich 149.

${ }^{302}$ Rothschild 208.
} 
Slovenian SLS. The HSS initially advocated an independent agrarian state and later at least a confederation of the kingdom of SHS. ${ }^{303}$ Radić essentially dictated policy,

the local leadership was expected simply to carry out the decisions of the central leadership...Radić's personal popularity was strong enough that he never lost the support of the countryside. ${ }^{304}$

Although it was the dominating force in Croatian inter-war politics, the HSS boycotted the Constituent Assembly (Skupština) from 1921 until $1925 .^{305}$ This boycott continued despite the fact that the HSS received the third largest number of votes of any political party in the 1920 Constituent Assembly elections and the second highest number of votes of any party in the 1923 and 1925 national elections. ${ }^{306}$ During this time Radić was imprisoned twice, in part because the boycott and HSS policy focused on upholding Croatian state right. ${ }^{307}$ Initially, Radić demanded an independent Croatian state, and between 1920 and 1924 Radić and the HSS demanded a confederation established by an independent Croatia. In June of 1924 Radić joined the Presidium of the Peasant International based in Moscow. For this and other agitations Radić and prominent members of the party were arrested. However, with favourable election results in the

\footnotetext{
${ }^{303}$ Even more than Ante Radić, Stjepan Radić "neglected economic issues for political... [and] revelled in the newspaper polemics of the new mass politics." Lampe, Yugoslavia 80. ${ }^{304}$ Biondich, 227.

305 "As early February 1919...Radić supported Croatian secession." Ramet, Nationalism and Federalism 7.

${ }^{306}$ The HSS received 14.3 percent of the votes and 50 seats in the 1920 Constituent Assembly elections and 21.8 percent of the votes and 70 seats in the 1923 Constituent Assembly elections. Biondich 172-188.

${ }^{307}$ Horvat 255-280.
} 
Constituent Assembly elections of 1925 and the lack of international support for an independent Croatia or confederation, Radić recognized unification, the Karadjordjević Dynasty, and the St. Vitus day constitution. ${ }^{308}$ "The tactics of extreme opposition, despite grave sacrifice, did not bring success." So that Radić changed tactics. ${ }^{309}$ However, even within the government the HSS had been "in opposition in sprit the whole time. ${ }^{310} \mathrm{He}$ stopped the boycott of the Constituent Assembly in exchange for greater administrative autonomy for Croatian districts. This was certainly a compromise on Radić's part, but his gesture did not reach the level of compromise that the SLS had employed over the years to meet Slovenian concerns.

Radić and the HSS in part joined a government coalition in 1925 out of recognition of the threatened rise of radical right-wing elements in Croatia and power of fascist Italy that surpassed Radić's misgivings about co-operation with Serbian politicians. ${ }^{311}$ For six months in 1925-26 Radić even held the post of education minister. Radic and the HSS went back to the opposition in 1926. The

\footnotetext{
${ }^{308}$ The HSS results for the Skupština election of February 8, 1925 was 22.3 percent of the vote (the second highest in the country) and 67 seats. Rothschild 224-225.

${ }^{309}$ Horvat 296.

${ }^{310}$ Biondich 221. From a speech by Stjepan Radić, "Tri Skupštine HSS u Zagrebu," Dom 22 Dec. 1926: 6 .

${ }^{311}$ By the mid 1920s it was clear that no foreign power that held influence in the region and that did not desire some Croatian territory would fully support the Croatian independence/ autonomy cause. The Italians supported a separate Croatia, and in that bid supported extremists and terrorists, but this was because they sought a weak Croatia from which they could take land that they felt was unfairly denied them in the 1920 Treaty of Rapallo. Trifković 360-363.
} 
ensuing years were filled with tension and on 20 June 1928 Radić was shot by Puniša Račić a Montenegrin Serb deputy in the parliamentary chambers. ${ }^{312}$

\subsubsection{The Royal Dictatorship and the End of the First Yugoslavia}

In the aftermath of the parliament shootings King Aleksander

Karadjordjević (1888-1934, king from 1921) established the Royal Dictatorship on

6 January 1929. The constitution was suspended as were political parties and numerous social groups, and the king became the sole source of political authority. ${ }^{313}$ The country was renamed Yugoslavia, and its territorial units were reconfigured into banovinas (provinces) according to river systems, in an attempt to quell separatist sentiment focusing on historical borders and grievances. Also, this reconfiguration allowed for a Serbian majority in six of the nine banovinas.

Slovenia was changed into Drava Banovina, while Croatian lands were almost entirely within the Savska Banovina and the Primorska Banovina. As the dictatorship came under international criticism, Aleksander issued a new constitution in September 1931. While it provided for an elected legislature, balloting was not secret and the king retained veto control of the legislation. ${ }^{314}$ Slovenian liberals joined the government in 1931 and the Clericals by 1935, but neither garnered the concessions they had hoped for. The radicalizing effect of

\footnotetext{
${ }^{312}$ Other delegates of the HSS, Djuro Basariček and Pavele Radić, were also killed, and Ivan Pernar and Ivan Grandja were wounded. Trifković 231.

${ }^{313}$ Pirjevec, Jugoslavija 57-75.

${ }^{314}$ Aleksander was still the commander of the armed forces and the supreme source of authority. He also continued to outlaw parties that he saw as dangerous. Rothschild 241-242.
} 
unreliable parliamentary politics and economic depression facilitated the reconfiguring of politics in Slovenia, Croatia, and Yugoslavia. The focus on political allegiances and conflict in Slovenia shifted from liberal and political Catholic to anti-fascist and anti-communist. ${ }^{315}$

The Croatian push for more autonomy continued to be strong, and some political actors became radicalized. ${ }^{316}$ The radical group that came to establish modern Croatia's first independent state was the Ustaša headed by Ante Pavelić.

Ante Pavelić fled Croatia after the dictatorship and established the Ustaša movement dedicated to using force in re-establishing an independent Croatia within what he defined as its historic borders.

The Ustaša and the HSS were very distinct organizations that practiced distinct methods the former violence the later pacifism, however, they had the same goal, an independent Croatia. Historian James J. Sadkovich suggests that the differences in ideology between the HSS and Ustaša were "relatively minor," and that in light of their common goal they should be viewed "as factions of a single coalition. ${ }^{.317}$ The HSS under Vlatko Maček (1879-1964), who replaced Stjepan Radić in 1928, had a hand in establishing the Ustaše, closely co-operated with it from July 1928 until June 1930, and co-ordinated HSS and Ustaše activities within

\footnotetext{
${ }^{315}$ Dolenc 23-24.

${ }^{316}$ Many Central and Eastern European countries became economically dependent on a radicalizing Germany that was willing to buy their agricultural produce. Some political actors in ECE sought to copy that success and promoted radicalization of politics as the path to success. See Traian Stojanovic, Balkan Worlds: The First and Last Europe (Armonk: M.E. Sharpe, 1994).

${ }^{317}$ Sadkovich goes on to argue that the HSS tacitly approved of the Ustaša which enabled the Ustaša to operate. James J Sadkovich, "Terrorisim in Croatia, 1929-1934," East European Quarterly 22 (1988): 58-61.
} 
but not outside of Yugoslavia. ${ }^{318}$ While the HSS did not collaborate with the Ustaša, once they had established the Independent State of Croatia the leaders of the HSS including Maček endorsed the state. ${ }^{319}$

Forced into exile and for a while based in Italy, the Ustaša and the Internal Macedonian Revolutionary Organization (IMRO) assassinated King Aleksander in Marseilles in 1934, leaving Prince Pavle (1893-1976) as regent until Aleksander's son Prince Petar II (1923-1970) came of age. ${ }^{320}$ In a further attempt to quell Croatian calls for more autonomy, the regent renewed arrangements for a concordat with the Holy See in 1937. Although the Concordat had been in various stages of negotiation since 1922, by 1937 it failed. ${ }^{321}$ By 1939 the Croat question had not subsided, and Maček was able to negotiate with a weak government for greater autonomy for Croatia. On August 20, 1939 Yugoslav Prime Minister Dragisa Cvetković (1893-1963 Prime Minister from 1939-1941) singed the Sporazum (agreement) with Vlatko Maček, which established a reconfigured semiautonomous Banovina of Croatia. ${ }^{322}$ The Banovina of Croatia included all of what was the Savska and Primorska Banovinas as well as the district of Dubrovnik

\footnotetext{
${ }^{318}$ Ramet, Nationalism and Federalism 7.

${ }^{319}$ Ramet, Nationalism and Federalism 8.

${ }^{320}$ Cohen, Broken Bonds 17. Mussolini's rise to power in Italy between 1922 and 1926 added another dimension to Central European instability. Mussolini sought domination of the Adriatic Sea at the expense of Yugoslavia. Yugoslavia's disgruntled neighbours became allies of Mussolini, while the nascent fascist-Ustaša movement was in part supported by him. Tomašević, War 31-40.

${ }^{321}$ This reinforced the religious-ethnic divide between Serbian Orthodox and Catholic. Pavlowitch 95-96.

${ }^{322}$ According to the terms of the agreement Maček became deputy prime minister, and the Croatian Sabor was granted exclusive governing powers in all areas except for defence, foreign affairs, internal security, trade, transport, and communications (post) which remained in the jurisdiction of the federal government. Lampe, Yugoslavia 195.
} 
(which was in Zetska Banovina). The threat of radicalization forced the Yugoslav government to grant wide autonomy to the Banovina of Croatia (that the agreement established) and hope that the more moderate Croat political elite such as Vlatko Maček could gain greater clout and crowd out the radicals. However, things would not work this way, as Europe was on the eve of war, and Yugoslavia was on the brink of its first dissolution. The weak position of the central government and the already deep concessions ensured that Croatian radicals were not satiated. Even the moderates were demanding more autonomy, while the Serbs resented any autonomy, ensuring that this arrangement would not last.

\subsubsection{World War II and Yugoslavia}

In 1939 Hitler invaded Poland, igniting the WWII conflict. Already

surrounded by pro-Axis governments in 1941 with the exception of Greece, Regent Prince Pavle and his government reluctantly signed the Tripartite Pact on 25 March $1941 .^{323}$ Two days later a military coup lead by General Dušan Simović ousted

Prince Petar and solicited widespread public support for renouncing the pact. ${ }^{324}$ The new Yugoslav government, recognizing their predicament, agreed to sign the Tripartite Pact, but it was too late. ${ }^{325}$ The attempted appeasement did not work and Luftwaffe bombs announced the invasion of Yugoslavia on 6 April 1941. By 10

\footnotetext{
${ }^{323}$ Signed on 27 September 1940, the Tripartite Pact was an agreement on mutual co-operation and defence between Germany, Italy, and Japan. Hungary, Romania, and Bulgaria all subsequently joined the axis powers by signing the Tripartite Pact. Yugoslavia refused to join the Axis powers and was rewarded with the Nazi German invasion.

${ }^{324}$ The coup was greeted with slogans that characterized Serbian resistance. These included "Bolje rat nego pakt" (better war than the pact), "Bolje grob nego rob" (better the grave than a slave).

${ }^{325}$ Djilas 136.
} 
April the Ustaša proclaimed the creation of the Axis-backed Independent State of Croatia (Nezavisna Država Hrvatska, NDH, 1941-1945), and on 17 April the Yugoslav government fled.

The Second World War is a complex period in Yugoslavia's history, which will not be covered here in depth, as this has been done by numerous other works. ${ }^{326}$ However, it is important to note the differences between Slovenian and Croatian wartime experiences. In Croatia, the Ustaša regime was an indigenous fascist regime that proclaimed its realization of Croatian state right through the establishment of an independent state. This was far more extreme than the small bands of indigenous fascist collaborators that came to operate in Slovenia at the time. In Slovenia, there was no quisling or indigenous fascist regime. This can in part be attributed to the lack of zero sum games and ideological focus on state right that helped radicalize politics in Croatia. Great goals and obstructionist politics characterized Croatian politics in the era preceding the war and lent Croatia to greater radicalization.

What should be kept in mind is the important distinction between the role of fascism in Croatia and Slovenia during the Second World War. Namely, those who chose to collaborate in Croatia supported an indigenous fascist regime. This regime

\footnotetext{
${ }^{326}$ All works that deal with 20th century Yugoslavia and Tito touch on the war to varying degrees. For more on WWII in Yugoslavia specifically see Jozo Tomašević, The Chetniks: War and Revolution in Yugoslavia, 1941-1945 (Stanford: Stanford University Press, 1975); Jozo Tomašević, War and Revolution in Yugoslavia, 1941-1945, Occupation and Collaboration (Stanford: Stanford University Press, 2001). For personal accounts see Fredrick William Deakin, The Embattled Mountain (London: Oxford University Press, 1971); Milovan Djilas, Wartime (New York: Harcourt, Brace, Jovanovic, 1977).
} 
took as its central mission the defence of the Croatian nation in a well-

articulated doctrine that relied on invoking memories of Croatian independence and on the ideals of state right. ${ }^{327}$ In contrast, in Slovenia there were coalitions of indigenous political and military forces that primarily sought to fight communists and so sided with the occupying fascist forces. The largest groups of Slovene collaborationists, the Home Guard (Domobranci, established in 1943), supported the Yugoslav government in exile until forced by their German suppliers to declare allegiance to the Nazi Germans in $1944 .{ }^{328}$ The absence of state right dogma and lack of memory of an independent Slovenia ensured that radical options were unable to harness such national historicist arguments in Slovenia.

Similar to Italian fascism but guided by the ideal of the Croatian state, Ustaša's ideology focused on establishing a sovereign Croatia of Croats, idealized as noble peasants dedicated to their nation state and the Catholic faith. ${ }^{329}$ The Ustaša focused on nationalism, a "glorious past" and "glorified future", but unlike Italian or German fascism Croatian fascism was stable and not dynamic ultimately focused on "the creation of a nationally homogenous Croat State." ${ }^{330}$ The methods

\footnotetext{
${ }^{327}$ Djilas 103-107.

328 "Though they probably acted under duress and with reservations, the fact that the Home Guards took this oath made them suspect in the eyes of Western Allies." Tomašević, War 124-125. For a general work on the Slovenian Domobrance see Boris Mlakar, O Položaju Slovenskega Domobranstva 1943-1945 (Ljubljana: IZDG, 1980).

${ }^{329}$ Djilas 103-127.

${ }^{330}$ Trifković 367.
} 
used to achieve this Croatian "Promised Land" were brutal. ${ }^{331}$ The Ustaše members claimed to be the heirs of Ante Starčević, and they used his slogan, "God and Croats," emphasising a connection between the RCC and the medieval Croatian kingdom. ${ }^{332}$ With the establishment of the fascist Ustaše regime in 1941, Ustaše leader Ante Pavelić issued a legal decree regarding the "Crown of Zvonimir as the bearer of Croatian sovereignty." 333 This decree "resurrected the old Croatian kingdom, and has spiritually and politically connected" the events of WWII with Croatian history. ${ }^{334}$ In an attempt to make a direct link to the medieval kingdom of Tomislav (910-928) that Pavelić idealized the Italian Duke of Spoleto, who would never set foot in Croatia, was crowned Croatian King Tomislav II. ${ }^{335}$

The question of Croatian popular support for the Ustaša is muddled and complex. The Ustaša were a group of exiles who had not established roots in Croatia prior to their installation. The Ustaša, while clearly a Croatian fascist group, mostly trained in exile and did not have a strong presence in Croatia prior to 1939. ${ }^{336}$ This forced it to rely on Italian and German benefactors. The vast majority of Croats supported the Croat Peasant Party, not the Usatše movement. However, Ustaše's domestic co-operation with the Croatian Peasant (HSS) party (between

\footnotetext{
331 "The marked similarities between the NDH and the Third Reich included the conviction that terrorism and genocide were necessary for the preservation of the state. In fact terrorism and genocide were extremely damaging to both states." Djilas 123 .

332 Jill Irvine, The Croat Question: Partisan Politics in the Formation fo the Yugoslav Socialist State (Boulder: Westview Press, 1993) 96. Djilas 117.

${ }^{333}$ Zanic 101 .

${ }^{334}$ Zanic 101.

${ }^{335}$ Jelavich 264.

${ }^{336}$ Tomašević, War 336-342.
} 
1928 and 1934) and the HSS endorsement of the Ustaše-led Independent State of Croatia in 1941 further complicates the question of popular domestic support for the Ustaše. ${ }^{337}$ The Ustaše's proclamation of an independent Croatia was initially greeted enthusiastically, as it was seen as the realization of the goal of Croatian statehood, but what is disputed is how many people were strong supporters and remained dedicated to the regime through its brutal and murderous rule. ${ }^{338}$ Many Croats were dismayed by the immediate parceling out of Croatian territory and were especially horrified by the brutal persecution of Serbs and other minorities. The number of supporters, those who accepted, and those who fought the Ustaše during the Second World War is hotly disputed to this day. ${ }^{339}$ Political rivals use memories, symbols, and images from that past sometimes to implicate their competitors and sometimes to support their cause. Indeed, after the collapse of communism Ustaše-specific symbols became commonplace at rallies and demonstrations supporting right-wing parties, while communist symbols and symbols of the former Yugoslavia were not displayed in the same way, as the regime was so recently discredited. ${ }^{340}$

\footnotetext{
${ }^{337}$ Ramet, Nationalism and Federalism 7.

${ }^{338}$ It is speculated that many Croats were undoubtedly sympathetic to Pavelic's demands for an independent Croatian State, as he invoked the dogma of Croat state right. Irvine 100.

${ }^{339}$ For example, John Lampe states that "Total support for the Ustaša remained "Iess than 10 percent of politically active Croats." Lampe, Yugoslavia 208. Whereas, Sabrina Petra Ramet argues that HSS endorsement of the Independent State of Croatia resulted in the "support of a good 50 percent of CPP (Croatian Peasant Party, HSS) members (the HSS was the dominant political party in Croatia at the time)." Ramet, Nationalism and Federalism 10.

${ }^{340}$ Željka Godeč, "Monument in Slunj: Provocation or Manipulation?" Nacional 15 June 2000, 15 Apr. $2003<$ http://www.nacional.hr>.
} 
There was a strong partisan resistance in Croatia. Indeed, in post-1991 Croatia, 22 June, 1941 became a national holiday. That day was considered to be the date of the establishment of the "first partisan unit" in all of Yugoslavia, a unit that was composed mostly of Croats. ${ }^{341}$ However, there was no national front similar to one that existed in Slovenia. In the midst of the Slovenian RCC's anticommunism there was a sizable Christian socialist movement which participated in the Partisan resistance. ${ }^{342}$ In Croatia the RCC and the Catholic heritage of Croats were positioned in even starker opposition to the socialists and communists. After the war the Yugoslav government saw a greater threat in the Croatian RCC as a bearer of Croat nationalism than it did the Slovenian $\mathrm{RCC} .{ }^{343}$ The government attempted to root out Croatian nationalism and sideline the RCC, but the RCC became even more strongly associated with the Croatian nation as the only institution that could defend the Croatian nation.

Although the Ustaše glorified the memory of a Catholic (and western) Croatia, in an attempt to win the support of the approximately 700,000 Muslims in $\mathrm{BiH}$ the Ustaše proclaimed them the "flower of the Croatian nation." ${ }^{344}$ Pavelić,

\footnotetext{
${ }^{341} 22$ June 1941 was celebrated as a "counter-anniversary" during the communist era, because the authorities had chosen a different day, 27 July, to commemorate Croatia's partisan resistance. This way the celebrations of Serbia's and Montenegro's uprisings came first. Drago Roksandic, "Shifting References: Celebrations of Uprisings in Croatia, 1945-1991," East European Politics and Societies 9.2 (1995): 259.

${ }^{342}$ Kocbek 47.

${ }^{343}$ This is in large part due to the conflict between Tito and Stepinac and the sizable membership in Slovenian priests associations. See the sections on the Slovenian and Croatian Roman Catholic Churches. Alexander, Church 112.

${ }^{344}$ Goldstein 135 .
} 
like Starčević (of the Croatian Party of State's Rights), portrayed Bosnian

Muslims as the most ethnically pure Croats, a tribe of the Croatian nation. ${ }^{345}$

The memory of Bosnia as a core Croat territory and Bosnian Muslims as "pure Croats" was considered a way for Croatia to easily absorb Bosnian territory. ${ }^{346}$ These ideals exempted Bosnian Muslims from the Ustaša commitment to eliminating non (Catholic)-Croats (namely Jews, Roma, Serbians and communist sympathizers) from Croatian territory. ${ }^{347}$ To aid in this endeavour, Serbs and Jews were forced to wear armbands, their organizations and schools were banned, and the regime established the Croatian Orthodox church in $1942 .^{348}$

The Croatian Orthodox church was established so that Serbs could with greater ease profess their allegiance to the regime and Catholic faith, but the church did not attract many supporters and was sidelined by more vicious measures. The unwritten, but widely cited, Ustaša policy towards Serbs was to kill one third, expel one third, and convert one third. ${ }^{349}$ The Ustaša sought to erase the SerbianOrthodox population of approximately 1.9 million and the Jewish population of

\footnotetext{
345 Tomašević, War 489-494.

${ }^{346}$ Although it did not consistently pursue a hard line on the issue even the Croatian Peasant Party argued that "on the basis of state rights and people's rights, all of Bosnia and Herzegovina belonged to Croatia." Tomašević, War 488.

347 Tanner 489-494.

348 Alexander, Church 22-25.

${ }^{349}$ Goldstein 137 . Stella Alexander notes that this phrase was iterated by the Ustaše Minister of Education, Mile Budak at Gospić on June 22, 1941. Alexander, Church 22.
} 
18,000 from the 6.5 million inhabitants of the $\mathrm{NDH} .{ }^{350}$ The majority of those killed by the Ustaša were murdered in the concentration camp Jasenovac. ${ }^{351}$

During WWII Yugoslavia was divided politically, militarily, and territorially. Political options were increasingly confined to rigidly defined right and left forces, and the main military protagonists were most often affiliated with one of these political groups. The armed factions included the Partisans, the Nazis, the pro-monarchist Serbian Chetniks, the fascist Ustaša, the fascist collaborators Croatian Domobranci (Home Guards), the Slovenian Bela Garda (White Guard, including the Village Guard and the Legion of Death) later renamed the Domobranci (Home Guard after 1943), and Slovenian Chetniks (Plava Guarda, Blue Guard). Serbs, Croats, Slovenes, Macedonians, Albanians, and other Yugoslavs fought among themselves and with each other. In the end, it was Yugoslavs, not the Nazis or the Italian fascists, who killed most of the estimated 1.1 million Yugoslav people during the war. ${ }^{352}$ In addition, many Roma were massacred, and approximately 60,000 Yugoslav Jews were killed. ${ }^{353}$

\footnotetext{
${ }^{350}$ Jelavich 263.

${ }^{351}$ Death toll estimates of the victims of the Ustaša range from the low number propounded by Franjo Tudjman, who only cites deaths at Jasenovac $(60,000)$ to the high number propounded by some Serb scholars (1 million). Djilas 126. Djilas notes that an objective and comprehensive study by Serbian scholar Bogoljub Kočović estimates that there were approximately 334,000 Serbian Ustaše victims in Croatia and BiH. Bogoljub Kočović, Žrtve drugog svetskog rata u Jugoslaviji (Veritas Foundation Press, London, 1985) 23.

${ }^{352}$ Dimitrije Djordjević notes that the figure of 1.1 million Yugoslav war dead is probably more accurate than the 1.7 million claimed during SFRY. Regardless, most Yugoslavs died "at the hands of their countrymen. Djordjević, "The Yugoslav Phenomena" 324.

353 “"78 percent of all Yugoslav Jews were killed in the Second World War." Tanner 152.
} 
Territorial divisions were as complicated as the military ones. In Serbia, Nazis installed a quisling government headed by General Milan Nedić, but still allowed neighbours to annex parts of Serbia. ${ }^{354}$ Slovenia was mainly divided between the Nazis who annexed Štajerska, Gorenjska, northern Dolenjska, and Mežiška dolina to the Reich and the Italians who took most of Notranjska, Dolenjska, and Ljubljana. The Hungarians only annexed Prekmurje. ${ }^{355}$ Even the NDH (Independent State of Croatia) was broken apart by its fascist sponsors. Baranja and Medjumure (parts of Slavonia) were annexed to Hungary. Parts of Dalmatia, including some islands and the Bay of Kotor, were annexed to Italy. The rest of $\mathrm{BiH}$ was annexed to Croatia. Ante Pavelić, the Poglavnik (leader) of the $\mathrm{NDH}$, even allowed his patrons, the Italian fascists and the German Nazis, to retain two distinct spheres of influence inside of the nominally independent state. ${ }^{356}$

The nationalist inspired brutality, including mass murder that characterized the NDH, was not imposed. As many accounts note, the Nazis disapproved of the "chaotic conditions created by the massacres and the maladministration." 357 Regardless, Pavelić's benefactors militarily propped up his weak state. Once Italy capitulated in 1943 the territories either annexed or influenced by Italians in were

\footnotetext{
${ }^{354}$ Today, Baranja, Srjem, and Slavonia are in Croatia, whereas parts of Banat, Backa, and Eastern Srjem are in Vojvodina.

${ }^{355}$ See Helga H. Harriman, "Slovenia as an Outpost of the Third Reich," East European Quarterly 5.2 (1971) 222-231.

356 Jelavich 263-264.

${ }^{357}$ Jelavich 265.
} 
left for the Germans to defend. The Germans generally had a stronger presence in the north of Yugoslavia than in the south.

Although Slovenes and Croats were well represented in the Partisans given their proportion in the population, due to the Ustaša terror in Croatia and Bosnia and Hercegovina, most Partisans in Croatia and the rest of Yugoslavia were ethnic Serbs. ${ }^{358}$ Initially, many Serbs joined the Chetniks, led by General Draža Mihailović (1893-1946). However, as it became clear that the Chetniks were not the most capable force against the occupiers, Serbs and many Croats began to join the communist Partisans lead by Tito. ${ }^{359}$ In December 1943, at the Theran Conference, the Allies decided to throw their support behind Tito and the Partisans. ${ }^{360}$ This, combined with the capitulation of the Italians in September 1943 and the partisan support by leaders of the Croat Peasant Party, added strength to the partisan cause. Many Croatian army personnel defected to the Partisans. ${ }^{361}$ How Josip Broz Tito (1892-1980) came to lead the Partisans and then a multinational Yugoslavia for 35 years is an epic story that will not be detailed here. ${ }^{362}$ Although

\footnotetext{
${ }^{358}$ SFRY, Savezni Zavod za Statistiku, "Borci, Vojni Invalidi i Porodice Palih Boraća," Statistički Biliten, 1174, April 1977.

${ }^{359}$ Mihailović lead the monarchist Chetniks, taking their name from the Serb guerrilla forces who had fought against the Ottomans. Mihailović increasingly questioned whether the Allies would send any substantial support. At the same time he began to view the Partisans as his main enemy and continued to fear that the Germans would wipe out his supporters by their policy of killing Serb civilians in retribution for any Chetnik actions (as in the Kragujevac massacre). All of this led Mihailović to collaborate with the German and Italian occupiers. See Tomašević, Chetniks 143-148. ${ }^{360}$ See Fitzroy Maclean's recollections of his mission as a British intelligence officer and liaison for Tito and the British. Fitzroy Maclean, Eastern Approaches (London: J Cape, 1950) 308-553.

${ }^{361}$ Tomašević, War 428-438.

${ }^{362}$ Tito himself warrants much discussion. However, the focus of this work is on another subject. The following are among the most notable English language biographies of Tito. Vladimr Dedijer, Tito Speaks: His Self Portrait and Struggles with Stalin (London: Weidenfeld and Nicholson, 1953);
} 
it is important to note that Tito initiated the National Liberation Struggle (NOB) in July 1941 and created the Partisans, a multinational communist force to fight against the fascist occupiers of Yugoslavia. Through his wartime activity and with the establishment of Socialist Yugoslavia Tito sought to bring the various nations of Yugoslavia together under the banner of communism, with slogans extolling "brotherhood and unity."

In November 1942 the Anti-Fascist Council of National Liberation of Yugoslavia (Antifašističko veće narodnog oslobodjenja Jugoslavije, AVNOJ) "proclaimed itself the supreme political body of the NOB [National Liberation Struggle]," and announced its intention of a federal democratic Yugoslavia. ${ }^{363}$ At the second AVNOJ meeting in November 1943 at Jajce, the AVNOJ was established as the leading body of the revolutionary parliament of Yugoslavia. Tito was proclaimed Marshal of Yugoslavia at Jajce and in 1944 the leader of the Provisional Government of Democratic Yugoslavia. The AVNOJ resolved that at the end of the war Yugoslavia would be a federal democratic country comprised of six republics and two autonomous provinces. ${ }^{364}$ On November $29^{\text {th }}, 1945$, the Socialist Federal Republic of Yugoslavia was established.

Milovan Djilas, Tito the Story From Inside, trans. Vasilije Kojić and Richard Hayes (New York: Harcourt, Brace, Jovanovic, 1980); Jasper Ridley, Tito: A Biography (London: Constable, 1994); Richard West, Tito and the Rise and Fall of Yugoslavia (London: Sinclair-Stevenson, 1994). Also see, Nora Beloff, Tito's Flawed Legacy: Yugoslavia and the West, 1939-1984 (London: V. Gollancz, 1985).

${ }^{363}$ Plut-Pregelj and Rogel 18.

${ }^{364}$ Shoup 72. Infamous far-right politician and Governor of the Austrian province of Carinthia (1989-1991 and again in 1999 till his death in 2008) Jorg Haider has always rallied against the Slovene minority in Carinthia and Slovene inclusion in the EU. In the autumn of 2000 Haider 


\subsection{Socialist Yugoslavia and Post War Repression}

Tito ruled over Socialist Yugoslavia for three and half a decades and was able to hold the fractious union together despite political rifts. Among Tito's main tools were his extraordinary charisma that drew popular support from Yugoslavs and his ability to keep his political opponents on the defensive by constantly changing political rules, including constitutions. Socialist Yugoslavia's first constitution was written in 1946, modeled on Stalin's 1936 constitution. It seemed to ensure that the Yugoslav federation would closely emulate the Soviet model. ${ }^{365}$ His style, politics, and negative perception of Stalin put him at odds with the communist world and got him expelled from the Cominform on St. Vitus Day (June 28) $1948 .^{366}$ Faced with political dissent after his expulsion from the Cominform, Tito purged the party of Stalin sympathisers, accusing them of being "Cominformists." Tito also sought to beat Stalin at his own game by creating the most orthodox and, by presumption, the most successful communist regime

\footnotetext{
demanded the repeal of AVNOJ, which mandated the expropriation of property of nationals from occupying Axis powers. However, not all such nationals have been denied property restitution, as approximately 1,000 Austrians have already (by the start of 2003) benefited from restitution in Slovenia. Against Slovenian accession to the EU, Haider argued that the AVNOJ issues should further lim it Slovenia's prospects of joining. Slovene politicians (mostly of the left) argued that much was sacrificed in WWII and that history cannot be changed. However, after Constitutional Court review AVNOJ was re-affirmed as foundational for Slovenia. Interestingly, Haider contentiously inherited a 15 million dollar estate in Barental that his uncle acquired from ItalianJewish owners fleeing Nazi persecution. Controversy and Joerg Haider," BBC News 29 Feb. 2000, 5 Dec. $2001<$ http://www.news.bbc.co.uk./hi/english/world/europe/464260>.

${ }^{365}$ Not only was the constitution similar, there was also a strong reliance on coercion. See Appendix D: Post WWIl Reprisal and Repression.

${ }^{366}$ Petranović and Zečević 926-930. Also See Ivo Banac, With Stalin against Tito: Cominformist Splits in Yugoslav Communism (Ithaca: Cornell University Press, 1988).
} 
through concentrating on building heavy industry and ensuring collectivization.

Collectivization of agriculture, nationalization of industry, centralization of the

economy, and social activities ensued, but they were not fully achieved. By 1953

Tito abandoned the Stalinist model, leading to greater agricultural and economic success in the $1960 \mathrm{~s} .{ }^{367}$ In response, Tito's chief ideologue, Slovene Edvard

Kardelj, mobilized support for a unique Yugoslav path of socialism, informed by the myth of a uniform partisan war of liberation and the system of worker's selfmanagement. ${ }^{368}$

\subsection{Croatia and Slovenia as Republics Within Socialist Yugoslavia}

After the first repressive years, the attempt to entrench Stalinist type rule, and its abandonment in the 1950s, Tito's Yugoslavia went through a host of

${ }^{367}$ Mellisa K. Bokovoy, Peasants and Communists: Politics and Ideology in the Yugoslav Countryside, 1941-1953 (Pittsburg: University of Pittsburgh Press, 1998) 26-31.

${ }^{368}$ Beside the Communist Party, Workers' Self Management (WSM) was the central economic, political, and social institution of communist Yugoslavia. It was on the basis of WSM that Yugoslavia pursued its unique path. According to the chief party ideologue Slovenian Edvard Kardelj, Yugoslav "democratic socialism" would advance through reform based on "the leading role of the working class" through decentralization and increasing workers' social, economic, and political control. At its most basic, WSM entailed employee rather than state or private control of the economy and social property. WSM was based on the theory that workers would contribute to the political, social, and economic decisions directly affecting them. Ideally, WSM would achieve economic, social, political, and therefore national equality for all workers, at which point the state would wither away. Workers' Councils were established in 1950 in all state enterprises and were reaffirmed in the 1953 constitution as bodies through which ownership of the means of production was accorded to the workers. Workers' Councils were the dejure managerial body in a given enterprise, issuing decisions on investment, production, and wages. However, managers, bureaucrats, and the League of Communists of Yugoslavia (LCY) were in charge de facto. The 1953 constitution instituted local management of education, health, and cultural organizations along with the representation of workers in the second chamber of the Federal Parliament, the Council of Producers. In order to keep up with the widening and deepening of WSM, Yugoslavia developed four different constitutions between 1946 and 1974. It also used three different electoral systems, namely single candidate, multiple candidate, and indirect delegate, based on territorial, population, and economic representation, respectively. Encouraging constant change and adopting revisions were ways in which the party sought to ensure that the Yugoslav brand of socialism was innovative, unique, true to Marxist formulations in empowering workers. However, WSM was confusing, both in theory and practice. 
political experiments in the 1960 s and 1970 s. ${ }^{369}$ The political response to these experiments was different in different republics. In Slovenia and Croatia these differences reinforced patterns that had long characterized politics in both states. As demonstrated in socialist Slovenia and Croatia, communist parties allowed for indigenous political patterns of politics to continue influencing interest intermediation, albeit to a far more subtle extent than in the years prior to and after the communist regime. While the political elite in both Slovenia and Croatia sought greater decentralization, the Croatian party leadership and civil society challenged the central authorities quicker, with greater focus on nationalism, and to worse effect for political liberalization. The Slovenian Communist Party (LCY) leadership refrained from direct challenges until the late 1980s when issues of liberalization through expansion of economic, linguistic, and political rights became the focus of political mobilization. ${ }^{370}$ The key feature of Yugoslav

\footnotetext{
${ }^{369}$ Numerous works deal with institutional development and economics of socialist Yugoslavia during the 1960s and 1970s. Among the most respected English language works are Sabrina Petra Ramet, Nationalism and Federalism in Yugoslavia 1962-1991 (Bloomington: Indiana University Press, 1992); Fred Singleton and Bernard Carter, The Economy of Yugoslavia (New York: St. Martin's Press); Paul Shoup, Communism and the Yugoslav National Question (New York: Columbia University Press, 1968); Dennison Rusinow, The Yugoslav Experiment 1948-1974 (London: C. Hurst \& Company, 1977); April Carter, Democratic Reform in Yugoslavia: The Changing Role of the Party (Princeton: Princeton University Press, 1982); Steven L. Burg, Conflict and Cohesion in Socialist Yugoslavia, Political Decision Making Since 1966 (Princeton: Princeton University Press, 1983); Lenard J. Cohen, The Socialist Pyramid: Elites and Power in Yugoslavia (Oakville: Mosaic Press, 1989).

${ }^{370}$ Political scientist, Valerie Bunce argues the Croatian nationalist challenge of the $1970 \mathrm{~s}$ engendered a divisive and zero-sum political environment where liberals were marginalized and nationalists seen as the only alternative to the communist regime. This is in contrast to the Slovenian case where "the majority and the minorities were free to coalesce around the issues of republican sovereignty and liberal democracy.... liberal agenda combined with a nationalist agenda." However, Bunce does not explore why nationalist mobilization occurred earlier in Croatia than in Slovenia. Valerie Bunce, "Rethinking Recent Democratization: Lessons from the Postcommunist Experience," World Politics 55 (January 2003), 177-178.
} 
socialism from the 1960s onward was that political power, along with economic power, was increasingly devolved to the republics. ${ }^{371}$

In the 1960s both the Croatian and Slovenian Communist Party elite began to seek greater decentralization based on economic "liberalizing," as they were the most economically prosperous republics. ${ }^{372}$ However, by the late 1960s "the Croatian party leadership escalated its demands and sought far-reaching reforms that went beyond the desires of its coalition partners," which included Slovenia. ${ }^{373}$ As in previous eras, the Croatian political elite had a stronger oppositional stance to the center than the Slovenian political elite, which in turn engendered a stronger crackdown on Croatian political activity, further frustrating the development of incremental change. ${ }^{374}$ As will be discussed later in this chapter, the move from liberalizing to more radical demands based increasingly on a national appeal informed the "Croatian Spring," and ended with the "Croatian silence." In contrast, Slovene incremental moves for greater autonomy began with economic demands and ended with the "Slovene Spring".

\footnotetext{
${ }^{371}$ Political scientist Sabrina Petra Ramet, in her work Nationalism and Federalism in Yugoslavia 1962-1991, posited that Yugoslavia of that era could be understood by studying domestic relations through an international balance of power lens given the autonomy and power of the federal units. Ramet, Nationalism and Federalism 9-16.

${ }^{372}$ In the early 1960s, both Slovenian and Croatian political elites "transformed economic issuesdecentralizaiton of economic decision making, dismantling of central planning, and curtailment of aid to unprofitable enterprises in the south- into political issues- opposition to Serbian hegemony and support of "liberalization." Ramet, Nationalism and Federalism 17.

${ }^{373}$ The coalition partners at that time included the party's of Macedonia, Bosnia and Hercegovina, Kosovo, Vojvodina and Slovenia. Ramet, Nationalism and Federalism 18.

${ }^{374}$ Ramet, Nationalism and Federalism 19.
} 
5.5 Rivalry Among the Republics and the Federation

Slovenia and Croatia did not take the same course of action, nor did they

have the same policy goals and activities. This is despite the fact that they were the most economically prosperous republics and both sought greater economic decentralization. Differences in approach between the two are best exemplified by the controversies that inspired the most political debate. ${ }^{375}$ These controversies included the Dictionary Debate concerning the Serbo-Croatian dictionary, the Slovenian Road Affair, and the Croatian Spring and Slovenian Spring. ${ }^{376}$ During the 1960s, the 1963 constitution, political demise of Aleksander Ranković and the Slovenian road affair cleared the way for future decentralization demands. ${ }^{377}$ However, in the midst of the struggle for liberalizing reforms, the Croatian leadership took an increasingly radical stance, focusing on Croatian

\footnotetext{
${ }^{375}$ Further empowering would-be reformers, in 1966 Tito forced the resignation of Aleksander Ranković, Yugoslav Vice President, Minister of the Interior, and Chief of the Secret Police. A staunch centralist and a conservative, Ranković was removed due to his crackdown on Kosovars, his opposition to economic and decentralizing reforms, and for allegedly spying on Tito.

${ }^{376}$ Produced in 1967, the first two volumes of the standard Serbo-Croatian dictionary privileged Serbian pronunciation that was added to the litany of accusations of economic, political, and cultural exploitation and domination by Belgrade that would explode in 1970. Greenberg 393-415. In 1969 the Slovenian Party leadership protested the distribution of World Bank loans for highway construction. The controversy was over distribution of funds, further market and political liberalization that the Slovene leadership sought as a way to improve the economic position of Slovenes. Burg 88-89 In an unprecedented move, the Slovenian Executive Council and the Secretariat of the Central Committee of the League of Communists of Slovenia openly called for the reversal of the decision. Repe, "Liberalizem" 77I-774.

${ }^{376}$ In the aftermath of the resignation travel restrictions were lifted, the activities of the secret police were scaled back, and artistic, press, and political freedoms were increased. Rankovic's removal was a collective victory for decentralists, liberalisers, and nationalists, but their ideas and the fierceness of economic and other debates in the highest state bodies were increasingly along republican lines, as was the issue of Serbo-Croatian linguistic equality in 1967.

${ }^{377}$ The 1963 constitution added four chambers to the Federal Assembly and endowed all of the chambers with greater policy-making powers. However, the federal government lost power to devolution of economic decision-making to the republics.
} 
nationalism. This nationalistic position alienated Slovenian and Macedonian supporters and drew opposition from Serbia, Montenegro, and Kosovo. In light of political changes of the era, the stage was set for the rise of Croatian nationalism and its suppression in the 1970 s.

\subsection{The 1970s and 1980s and the Two Springs}

The Croatian Spring, which in this discussion includes the political activities of the Croatian party leadership and civil society between 1969 and 1972, is here presented in contrast with the Slovenian Spring, which in this discussion includes both the activities and actions of the Slovenian party leadership and civil society between 1986 and 1990 . The two springs occurred in very different political environments. The Croatian spring took place while Tito was alive and still able to control Yugoslavia, while the Slovenian spring occurred when Tito was dead, Yugoslavia in disarray, and communist regimes in the region weakening. This serves to re-emphasise pragmatism as a component of political timing. Croatian party leaders pushed an increasingly radical agenda at an inopportune time, while the Slovenian party elite worked on the margins, addressing specific economic and political concerns without mounting the same challenge as the Croats. It was only in the late 1980s, when it became clear that Slobodan Milošević would not allow for compromise in continuing economic and political liberalization demanded by 
an increasingly active civil society, that the Slovenian party elite began to discuss options that would challenge the federation. While the discussion of the two springs are at times confined to mass civil society movements that occurred in Croatia in 1970-1972 and in Slovenia in 1988-1991, here the springs are also used to denote the reformist communist party leaderships in each republic, whose political activities inspired and influenced the mass movements that spilled onto the streets.

The Croatian and Slovenian springs were the two most important movements to involve political elites and civil societies in the decades prior to the collapse of communism. These two movements were seminal in establishing the environment of post-communist politics in Slovenia and Croatia. How and why the two movements occurred, when they occured, and their effects on each republic demonstrate how Slovenian and Croatian elites adhered to different political approaches sanctioned by history, within socialist Yugoslavia. While the two elites sought economic and political decentralization, the focus in Croatia became national and radicalized, whereas in Slovenia the approach was more pragmatic, incremental, and eventually allowed for reforms that were more amenable to political liberalization in the post-communist era.

The mass movement in Croatia reached its height in 1971, elicited strong repression from central authorities. ${ }^{378}$ In Croatia, incremental reform was stymied,

\footnotetext{
${ }^{378}$ The Croatian Spring and the Croatian National Movement (or as it is alternatively called Maspok, Masovni pokret [Mass movement]) were inspired by the reformist leadership of the
} 
setting the stage for the type of politics that would inform the state during the

post-communist era. In the late $1980 \mathrm{~s}$, when the control of the League of

Communists of Croatia loosened along with the power of the federal government, a monolithic nationalist opposition arose that would again opt for revolutionary change that excluded all labelled as "others." ${ }^{379}$ This can be contrasted with the gradual development of a pluralistic civil society in the 1980 s Slovenia that precipitated incremental change. Different civil society groups and leaders negotiated on common points of interest and opted for a focus on positive sum change. They focused on rational legal reforms in a more liberal democratic system within the existing federation. The League of Communists of Slovenia (LCS) and did not take repressive action against these movements, gradually came to negotiate

\footnotetext{
Croatian League of Communists (LCH), who in 1969 focused on democratic and nationally informed reforms for greater Croatian independence in Socialist Yugoslavia. Support for the leadership's efforts spontaneously swept across Croatia from 1969-1972. In response to Maspok and even more so to the failure of Croatian party leaders to combat or contradict it, Tito initiated decentralizing reforms, but Croatian demands continued to grow. At the same time the LCH's efforts and Maspok were increasingly overshadowed and overtaken by appeals to nationalism, zero sum games, and revolutionary change. Goldstein 179-180. In response to the radical demands of the Croats, Tito sought compromise with the Croats, but they were playing a zero sum game and exacting autonomy on increasingly demanding terms. Tito began by extensively purging the Croatian party leadership in December 1971. In the following year, he proceeded to purge thousands of the Croatian party members. Jelavich 396-397.

${ }^{379}$ The Maspok was portrayed and remembered as ethnically homogenous, a Croatian movement for autonomy based on Croatian rights. The movement was not as plural as the movements in Slovenia in the $1980 \mathrm{~s}$, and so it was both seen as more threatening and easier to combat than the pluralized civil society movements that arose in the mid to late 1980 s in Slovenia. The Croatian Spring was fuelled by feelings of economic exploitation that were compounded by perceptions of political, economic, and linguistic discrimination and under-representation of Croats both with in the federation (for example, in Vojvodina, Bosnia, and Hercegovina) and in Croatia. It was often said that the Serbs in Croatia were only 12 percent of the population but that they dominated in the ranks of the League of Communists of Croatia (approximately 40 percent) and the police force (approximately 70 percent) as well as the general public service. Bennett 63 .
} 
with them, and slowly moved towards greater Slovenian independence in the federation.

The Croatian Spring was met with severe repression by Tito. This effectively destroyed the Croatian communist reform movement, ousted liberals in the party, and drove nationalists underground. The Catholic Church in Croatia filled the organizational vacuum to become the strongest Croat institution forwarding national ideas. Although there were purges throughout Yugoslavia (including in Slovenia) in 1972, the Croat Communist Party and republican leadership had the least autonomy, as it was constantly monitored for "nationalist deviations," making it hard-lined and paralysed. Even after Tito's death Croat communists did not dare initiate the types of reforms that enabled incremental liberalization in Slovenia in the 1980s.

Despite the crackdown of 1971-72, the provisions of the 1974 constitution were decentralizing and liberalizing, while still maintaining a one-party state. This was done in order to prevent a resurgence of reformers as well as decentralizing and liberalizing demands that could again spin out of the control of the party. However, the constitution established a system where devolution of agenda setting and decision making to republics increased the autonomy and the power of republican leaders. In what was considered an almost con-federal arrangement, republican leaders increasingly and openly lobbied in the interest of their respective 
republics to the detriment of the federal state. ${ }^{380}$

At the time of its implementation in February 1974 the Yugoslav

constitution was the longest and arguably the most confusing in the world. It re-

affirmed the right to self-determination and expanded WSM in part through the

delegate system of indirect elections. This system basically functioned so that

republican politics would predominate and republican interests would have primacy

at the federal level. This provided the institutional pathway through which the

politicians of all republics would assert their republic-based desires, clash, and

precipitate the demise of SFRY. ${ }^{381}$

Owing their positions to Tito and cognizant of the expectation that they

remain loyal to the LCY and federal Yugoslavia, and steering clear of anything that smacked of "liberalization," "nationalism," or insubordination, the leaders of the

League of Communists of Croatia remained among the most conservative in Yugoslavia. ${ }^{382}$ They were unwilling to take any chances with actions outside of those directly prescribed by the LCY. They were wary of change and remained

\footnotetext{
${ }^{380}$ As Ramet notes, the inter-republican committees established at the federal level to promote debate and co-operation worked in the late 1960 s to promote co-operation and resolution of common issues until they were downgraded in 1973. At this point, their members, selected so as to parlay instructions form the provincial authorities to the federal level, diminished the spirit of compromise. Ramet, Nationalism and Federalism 67-75.

${ }^{381}$ Both autonomous provinces in Serbia were recognized as constituent parts of Yugoslavia. This gave them an autonomous position in relation to the Serbian government in federal bodies, although they were supposed to be subordinated to Serbia. This inspired resentment amongst some Serbs, who would in the 1980 s openly voice the sentiment that "Serbs win in war but lose in peace." The reasoning was that Serbs suffered the most casualties in WWI and WWII and were on the wining side only to spill their blood for a Yugoslavia in which they were discriminated against. In this Yugoslavia, they claimed, Serbs were not all in one republic, and Serbia itself was territorially divided, where Hungarian and Albanian minorities enjoy more rights.

${ }^{382}$ The most prominent conservatives were Vladimir Bakarić, Jakov Blažević, Dušan Dragosavac, Stipe Šuvar, and Milka Planinc.
} 
highly sensitive to any "movements" outside of the party. Although liberal reformers had lost the battle in all of the republics, liberalization continued in a piecemeal manner. Although the ruling communists in Slovenia, under the leadership of Franc Popit, were also conservative, by the mid-1980s people in Slovenia more than in any other republic began to take indipendent action, while a new liberalizing leadership arose ${ }^{383}$ In Croatia, two decades of rule based on an orthodox interpretation of Yugoslav Socialism followed. ${ }^{384}$

The LCH did not allow for open civil society and simply drove the nationalist movement underground, from where it re-emerged at the end of the 1980s. Although it was the Slovenian League of Communists (LCS) that had in the late 1960 s been at the forefront of negotiating economic liberalization and political decentralization in the federation, the LCS had not appealed to nationalism nor engaged in anti-centralism in the same way as in the Croatian case.

Prior to discussing politics in the 1970s, it is important to note that in the aftermath of the crackdown on the Croatian spring the Roman Catholic Church was the only well-organized, non-communist Croatian institution to avoid substantial repression. The church was one of the only places where Croats came to celebrate their nation, heritage, and later anti-communism collectively and relatively openly, without being persecuted or sanctioned. This carried through the role that the RCC

\footnotetext{
${ }^{383}$ Both Serbian and Slovenian politicians took advantage of this opening. In Serbia there was a rise in exclusivist nationalism while in Slovenia there was a rise in political pluralism and demands for liberalization.

384 "The Croatian communists were "more rigid than the Communists who rules Serbia till 1987 and more so, especially, than those in Slovenia." Goldstein 179-180.
} 
had acquired after the Second World War. However, in the absence of an equal number of other societal actors or new social movements as in Slovenia, in Croatia the increasing activism of the RCC was not undertaken in an environment of equally increasing pluralism. The lack of pluralism would prove to be a great challenge in post-communist Croatia, where the RCC and the HDZ (Franjo Tudjman's Croatian Democratic Union) were portrayed as the two most representative organizations for all "patriotic" Croats. In the 1990s, the RCC benefited from its status as a nationalistically-minded, anti-communist Croat organization claiming the membership of most Croats. The RCC managed to parlay its status into political influence, disregarding those who did not share its interests.

The 1980s were a time of political renewal in Yugoslavia, as the WWII old guard died off and became replaced by a younger group of politicians less influenced by the fight against fascism. The deaths of Tito in 1980 and of Kardelj and thousands of other WWII partisan heroes during the 1980s diminished the ranks of those committed to communist Yugoslavia's "brotherhood and unity." The founding myth of the united partisan struggle against a common enemy had eroded and exposed mutual suspicion and inter-republican rivalries. With the curtailment of federal influence, republics and provinces came to consolidate their national, cultural, economic, political, and social distinctions and interests. In the midst of political and economic crises, opposing positions were staked out and in some cases collective enemies were defined and scapegoated. 
By the late 1980s, inflation, wage freezes, plant closings, and strikes were on the rise. ${ }^{385}$ Its economy deteriorating, Yugoslavia was increasingly drawing on international loans in an environment where it was increasingly difficult to repay them because of poor investment, spending on consumption, and decreases of remittances from gastarbeiter (guest workers), which were slowing down due to a global recession. ${ }^{386}$ In what would be the last ditch attempt to prop up the economy, in 1989 the newly appointed Prime Minister, Ante Marković, implemented shock therapy. He introduced an anti-inflation program (as inflation had reached 2,000 percent per annum) restricting the money supply, devaluing the dinar, destroying contractual socialism, creating freer markets, and privatizing social property. ${ }^{387}$ The program was initially successful in reducing inflation, but it failed because of continued overvaluation of the dinar, lack of implementation by some leaders, and overspending. An unsound political-economic system, botched attempts to fix the situation, and the deteriorating economy continued to fuel political dissatisfaction among the republics.

The frustration with the economic situation, and by the mid to late $1980 \mathrm{~s}$ the increasing inability of Slovene party leaders to achieve even incremental reforms in the federation due to the opposition of Slobodan Milošević, led the

\footnotetext{
${ }^{385}$ Susan Woodward, Socialist Unemployment: The Political Economy of Yugoslavia 1945-1990 (Princeton: Princeton University Press, 1995): 352-366.

${ }^{386}$ Susan Woodward, Balkan Tragedy: Chaos and Dissolution After the Cold War (Washington: The Brookings Institution, 1995) 47-81. Lampe, Yugoslavia 326-331. Harold Lydall, Yugoslav Socialism: Theory and Practice (Oxford: Clarendon Press, 1984) 82-88. Harold Lydall, Yugoslavia in Crisis (Oxford: Clarendon Press, 1989) Tables 10.1, 10.2, and 10.3.

${ }^{387}$ Warren Zimmerman, Origins of a Catastrophe: Yugoslavia and Its Destroyers-America's Last Ambassador Tells What Happened and Why (New York: Random House, 1996) 48-50.
} 
Slovenian party leadership to increasingly pursue political liberalization within the republic as a way to secure a power base. The Slovene party leadership was initially tolerant and later encouraging of cultural and then political pluralization. This was in contrast to the political and civil society situation in Croatia, which worked predominantly against political liberalization.

The Croat republican leadership monitored for signs of nationalist "deviation" so forcefully that it was unable to reform and nationalist sentiments were driven underground. ${ }^{388}$ In Croatia new secret ballot voting procedures for the party leadership were introduced in 1986 . This enabled younger leaders to replace some of the older members who were appointed post 1971, however "one could not call the new leadership team in Zagreb reform-oriented." ${ }^{389}$ By contrast, starting in 1986 the new Slovenian leadership was "reform-oriented," and fought for increased regional autonomy and a Yugoslavia where market principles and liberal rights and freedoms would be fostered. Serbian leadership promoted Serb-dominated centralization, sought to enhance the role of the JNA and LCY, and ultimately promoted exclusivist nationalism to enforce a Yugoslavia built on Serbian terms. The same issues that provided ammunition for political battles in the 1970s, particularly when it came to the subjects of economy and nationalism, fuelled intrarepublican feuds and caused a crisis in the $1980 \mathrm{~s}$.

\footnotetext{
${ }^{388}$ Tim Judah, The Serbs: History, Myth \& the Destruction of Yugoslavia (New Haven: Yale University Press, 2000) 149.

${ }^{389}$ As Meier notes, the Zagreb leadership was led by pragmatic Ante Marković however he focused on economic issues and had a propensity to "leave political decision-making to others." Meier 36.
} 
The 1980s marked an era of non-party pluralism in Slovenia, as various groups, from religious to political, worked together in search of reforms. ${ }^{390}$ The influential League of Communists of Slovenia came under the leadership of Milan Kučan, who had since his inauguration in 1986 allowed for pluralism outside of the sphere of the party. This in turn encouraged gradual society-wide changes and innovation through on-the-ground bargaining of emerging and diverse interest, identity, and cultural groups. By the late 1980s these groups would inform political pluralization. These multiple and diverse groups came to form an unofficial opposition that was united in the struggle to promote human rights, rule of law, and democracy. ${ }^{391}$

While the Slovenian Spring officially occurred in 1988, with protest and reforms, it was informed by the growth of civil society in the mid to late $1980 \mathrm{~s}$. It was an act of protest against the trial of Slovenian journalists and a junior JNA officer for betraying military secrets that set in motion what was officially considered the "Slovene Spring" that spurred on Slovenia-wide calls for

\footnotetext{
${ }^{390}$ For more on civil society in Slovenia during the 1980 s see: Igor Bavčar ed., Punk Pod Slovenci. (Ljubljana: Knjižnica Revolucionarne Teorije, 1984); Niko Grafenauer ed., The Case of Slovenia (Ljubljana: Nova Revija, 1991); Jill Benderly and Evan Kraft, eds. Independent Slovenia: Origins, Movements, Prospects (New York: St. Martin's Press, 1994); James Gow and Cathie Carmichael, Slovenia and the Slovenes (Bloomington: Indiana State Press, 2000); Leopoldina Plut-Pregelj, A leš Gabrič, and Božo Repe eds., The Repluralizaiton of Slovenia in the 1980s: New Revelations from Archival Records (Seattle: The Donald W. Treadgold Papers, the Henry M. Jackson School of International Studies, University of Washington, 2001).

${ }^{391} \mathrm{~A}$ prevalent argument in transitology is that countries that have had an experience with liberal democracy will fare better in subsequent transitions to liberal democratic rule. Slovenia, despite the lack of a liberal-democratic experiment, has developed a relatively stable liberal democratic regime. This can be attributed to patterns of politics within illiberal regimes, including the fostering of cooperative and civil societies, which have punctuated modern Slovenian political development. For more on transitology see Schmitter and Karl 173-185 and Bunce, "Should" 965-987.
} 
autonomy. ${ }^{392}$ In response to the trial, Slovenes from diverse backgrounds mobilized a large-scale peaceful protest. ${ }^{393}$ However, it was clear that the Spring was already set in motion by the mid 1980 s with the pluralization of the public sphere. Slovenian civil society organizations, or "alternative movements," included literary, arts, cultural, educational, feminist, environmental, peace, as well as lesbian and gay rights groups. These promoted a varied youth alternative subculture that included punk rock bands, which were among the first to agitate for autonomous social space. ${ }^{394}$

The autonomous, alternative, and other groups and activities in Slovenia that took aim at the policies, programs, and ideals of the authorities grew more and more diverse. In Croatia, the RCC and the Zagreb Archdiocese weekly publication Glas koncila acted as some of the few outlets for criticism of the regime, particularly with regards to social issues. ${ }^{395}$ As historian Aleš Gabrič notes, there was "no similar wave of criticism in Croatia" as in Slovenia because of "the activities of Stipe Šuvar, who at that time was Croatia's leading cultural ideologist, and who adopted the role of defender of the 'orthodox' line of thinking in cultural

\footnotetext{
${ }^{392}$ The journalists areested worked for the ZSMS magazine Mladina (Youth). Independent since 1982, Mladina publicized the activities of alternative groups, exposed political scandals, and challenged the political order like no other periodical in Yugoslavia. While Mladina consistently and brashly challenged the federal authorities, another literary and cultural Slovenian magazine established in 1982, Nova Revija (New Review), also promoted civil society and encouraged debate. In 1987 Nova Revija published Issue 57, "Contributions to a Slovenian National Program." Niko Grafenauer, ed., The Case of Slovenia (Ljubljana: Nova Revija, 1991).

${ }^{393}$ On June 22, 1988 at least 40,000 people demonstrated against the trial. Ramet, Balkan Babel 24.

${ }^{394}$ Tomaž Mastnak, "From the New Social Movements to Political Parties," Yugoslavia in Turmoil: After Self-Management, eds. James Simmie and Jože Dekleva (New York: Pinter Publishers, 1991) 47.

${ }^{395}$ Ramet, Balkan Babel 189.
} 
creativity. ${ }^{, 396}$ In Slovenia, the media became more diversified and critical. As

Sandra Basic Hrvatin notes, the Slovenian media was the first to promote

democratization and pluralism, and its articles were the most critical. ${ }^{397}$ And Aleš

Gabrič notes,

The rest of Yugoslavia judged that Slovenia was very much in the lead as far as liberalization was concerned. Even writers from other Yugoslav republics often pointed out at the time that periodicals in Slovenia were the most open media in Yugoslavia. ${ }^{398}$

By the end of 1988 the League of Communists of Slovenia openly and strongly supported political pluralism, and by September 1989 it had instituted constitutional amendments to that effect. ${ }^{399}$ Among the most important amendments was the right to secede without the consent of other republics, the rights to private ownership, the freedom to establish other political parties, and the formal end to the leading role of the LCS. ${ }^{400}$ By December of 1989 the Slovene Communist Party legalized alternative parties and called for the first multiparty elections in Yugoslavia, which were held in April 1990. By April/May of 1990 Croatia had also undertaken free, democratic, multiparty elections. However,

\footnotetext{
${ }^{396}$ Gabrič, "Cultural" 25.

${ }^{397}$ Basic Hrvatin, "The Role of the Media" 269.

${ }^{398}$ Gabrič, "Cultural" 26. "During 1988 Mladina was selling out a 50,000 print-run each week...at the same time research revealed that each edition was read by seven people, which meant that every edition of the magazine was reaching at least 350,000 people out of a total population of around 2 million." Gow and Carmichael 95. "Nova revija" became the platform for a group of anti-Leninist cadres who were inspired by the Polish Solidarity movement, as well as other developments in postKavčič politics in Slovenia itself." Gow and Carmichael 94.

${ }^{399}$ Tine Hribar, "Od ločitev za Samostojnost," Mladina 29 Dec. 1989: 6.

${ }^{400}$ Republic of Slovenia, "Ustava Republike Slovenije," Uradni List 33/1991.
} 
Croatia did so under different circumstances, lacking the pluralism that had developed in Slovenia. ${ }^{401}$

It is important to note that Serb and Slovene political leaders propounded opposite reforms in Yugoslavia. ${ }^{\mathbf{4 0 2}}$ The Serbs pursued a centralist, hard-line, and increasingly nationalist approach, while the Slovenes saw their interests better served by liberalization and pluralism. Realizing the threat posed by a Serbdominated federation, the Croat leadership had only come to support the Slovene position firmly by 1989-1990. Due to earlier polarization, libreralizing reformers were largely absent from the ranks of communist and nationalists in Croatia, ensuring that liberalization would be more difficult. ${ }^{403}$ By 1989 it was clear that the federation would not be able to survive as it had in the past and that change was inevitable.

\footnotetext{
${ }^{401}$ As political scientist Lenard J. Cohen notes, the leadership of the League of Communists of Croatia "admitted that it had been slow in recognizing" what they saw as "the historic exhaustion of the single party system. Lenard J. Cohen, Broken Bonds: Yugoslavia's Disintegration and Balkan Politics in Transition (Boulder: Westview Press, 1995) 83.

${ }_{402}$ Incremental reforms and compromise were impossible, given the increasingly unwavering stance of the Serbian elite that came to be led by Slobodan Milošević. Judah, Serbs 156-167. Controlling the votes of Kosovo, Vojvodina, and Montenegro, Milošević blocked liberalizing reforms. Silber and Little 73. Direct conflict only broke out between Serb and Slovene political elites in 1989, when Slovene leaders protested the imposition of martial law in Kosovo, fearful of loosing their own autonomy. Slovenian authorities stood up to defend Kosovars and at the same time reinforced their autonomy through constitutional changes. The September 1989 amendments to the Slovene constitution, which allowed for unilateral secession, and prevented the imposition of a state of emergency from outside of Slovenia, further aggravated already tense relations with the Serbian leadership. Božo Repe, Slovenci v Odsemdesetih Letih (Ljubjana: Zveza Zgodovinkih Društev Slovenije, 2001) 47-57. In response, Milošević attempted to organize a rally in Ljubljana and the Serbian Communist Party and Socialist Alliance of Working People issued a boycott of Slovenianmade goods.

${ }^{403}$ Valerie Bunce, "Rethinking Recent Democratization: Lessons from the Postcommunist Experience," 170, 177-178.
} 
With the December 1989 election of Ivica Račan as President, reformers came to firmly control the League of Communists of Croatia. The new Croat leaders relied on the Slovenian political elite to defend "their common interests and shared viewpoints," particularly on decentralization and economic liberalization. ${ }^{404}$ This was because the Croatian leadership knew that Milošević's ultra-nationalism could incite Serbs in Croatia. This factor alone, however, was not enough to overcome the internal opposition and radicalism engendered by the crackdown in the 1970s, which would express itself in a strong nationalist movement that took control of Croatian politics prior to the break-up of Yugoslavia.

The Slovene leadership, in the lead of liberalizing demands, recognized that it could not fight Milošević's centralization and nationalism through the party or official federal channels, but that it had to rely on local civil society that had grown in strength throughout the 1980s. The extensive changes in Slovenia and the hastily initiated reforms in Croatia, in place by 1989 , frustrated Milošević, who was at the time consolidated his control over Kosovo, Vojvodina, and Montenegro. At the Fourteenth Extraordinary Congress of the League of Communists of Yugoslavia (LCY) (January 1990) Milošević successfully blocked all Slovene and Croat initiatives at decentralizing and liberalizing change. In response to Milošević's moves and to the sound of applause from the remaining delegations, on the $23^{\text {rd }}$ of January the Slovene delegation, soon after followed by the Croat delegation,

\footnotetext{
${ }^{404}$ Meier 37.
} 
walked out of what would be the last meeting of the LCY. ${ }^{405}$ Despite this,

Slovenian, Croatian, Macedonian, and Bosnian communist parties proposed plans

for a con-federal Yugoslavia. ${ }^{406}$ Their proposals were ignored and derided by

Milošević, whose control over the votes of Serbia, Montenegro, Kosovo, and

Vojvodina precluded any compromise.

\subsection{The Eve of Transformation}

In April 1990 Slovenia held the first free multiparty democratic parliamentary and presidential elections in SFRY, followed by Croatia in April-

May 1990. Slovenia had developed a diverse civil society, and so there were more competitive organized political parties in Slovenia than in Croatia. The political climate and style of party politics reflected the fact that prior to the collapse of the communist regime in Slovenia individuals had the opportunity to participate actively in a variety of associations and evinced a diversity of ideals, goals, interests, and identities.

The practice of pluralism allowed for political participation that engaged a populous cognizant of the rights of others and able to negotiate a multi-party

\footnotetext{
405 "Each Slovene proposal - from human rights to Yugoslavia's role in Europe--failed to get even half the total of 1,612 votes needed to be adopted. Rounds of applause greeted each defeat. The Slovenes were humiliated. It became clear to them that the Serbian and Montenegrin delegation had been instructed to vote down any Slovene proposal." Silber and Little 79-80.

${ }^{406}$ Even in November 1990 Slovenian Foreign Minister Dimitrij Rupel confirmed Slovenia's focus on confederation as the most desirable option. Ramet, Balkan Babel 225. Slovenian and Croatian leaders, along with $\mathrm{BiH}$ and Macedonian leaders, proposed confederalization. The last attempt of the latter two was the Gligorov and Izetbegović's "four plus two" plan, which Milošević rejected. This plan, presented in June, proposed a federation between all four republics except for Slovenia and Croatia, which would have a confederal arrangement with the four republics.
} 
system based on conflict and consensus. ${ }^{407}$ In Slovenia the initial post-

communist consensus with the DEMOS coalition was based on forward looking

goals that required further liberalization, while in Croatia Tudjman's imposed

consensus, "reconciliation" based on radical Croat nationalism, hindered

liberalization. ${ }^{408}$ The primary political goals in Slovenia were the achievement of a

liberal-democratic state that would allow for economic prosperity and political

stability, enabling Slovenia to join the EU. After the first years of consensual

politics in Slovenia, right-left political divisions prevailed, but did not challenge

liberalization nor endanger the goals of EU accession.

\footnotetext{
${ }^{407}$ There is one issue that brings into question the equal application of the rule of law in Slovenia, it involves a group of people that are collectively known as the izbrisani (the erased). One has to keep in mind that the erased are people who are not systematically discriminated against on the basis of religion, sex, sexual orientation or beliefs, but rather by citizenship status. The erased are a group of approximately 18,300 citizens of Yugoslav republics other than Slovenia, who in the aftermath of Slovenia's declaration independence, failed to apply for Slovene citizenship or permanent residence; as required by a 1991 administrative decree. Approximately 180,000 people of the approximately 2000,000 affected by this decree applied for and received citizenship and permanent residency. The remaining 18,3000 failed to do so by the February $26^{\text {th }} 1992$ deadline. These who failed to meet the deadline lost the legal rights afforded to Slovene citizens and permanent residents and were thus administratively "erased." A 1999 law allowed for the erased, who maintained a permanent residence in Slovenia. to regain residency status. However, not much action was taken until 2003 when the Constitutional Court ruled that all erased, regardless of place of residency, should be afforded the rights they had lost in 1992. A law to this effect passed in early 2004, but was only applicable to those who resided in Slovenia, which amounted to approximately 4,300 people who were able to regain their legal rights in Slovenia. Within a few months a referendum, challenging the substance of the 2003 Court ruling and subsequent law, passed and the 2004 law on the erased was annulled. As of May 2004 the issue highlights a marked case of exclusion and violation of human rights in Slovenia. For a comprehensive ovierview of the issue of the erased see Jasminka Dedić, Vlasta Jalušič and Jelka Zorn, "The Erased : Organized Innocence and the Politics of Exclusion," (Ljubljana; Peace Institute, Institute for Contemporary Social and Political Studies, 2003). For more on the erased see Annual Reports of the Office of the Human Rights Ombudsman, Republic of Slovenia, available <http://www.varuh-rs.si/index.php?id=6\&L=6> The Ombudsman has been a tireless advocate for the rights of the erased.

408 "The April 1990 election in Slovenia was a showcase for the entire country. One of the first campaign developments was the consolidation of the wide variety of different political groups founded in Slovenia during the emergent pluralist phase of 1988 and 1989." Cohen, Broken Bonds 89.
} 
The April 1990 elections in Slovenia, after the collapse of the Communist Party but before the collapse of Yugoslavia, were based on proportional represenation for the legislature and direct election for the president. The DEMOS coalition won 55 percent of the votes and 127 out of 240 seats in the Assembly. ${ }^{409}$ The DEMOS (Democratic Opposition of Slovenia) coalition was established in 1989 and came to form a majority centre-right coalition government. ${ }^{410}$ The victory of the center right in the legislature was balanced by the victory of Milan Kučan as president. ${ }^{411}$ Milan Kučan, the unofficial leader of the reformed communists, won the presidency with 44.3 percent of the vote. ${ }^{412}$ During the next several years, all parties worked together in the establishment of autonomous and later independent Slovenia.

Slovenia held a referendum on independence on December 23, 1990, after it became increasingly clear that Milošević would not allow for confederalization. In the referendum, 93.2 percent of the electorate voted, and 88.2 percent approved Slovenian independence to be declared after a six-month period. ${ }^{413}$ Authorities in Croatia hastily prepared their own referendum, which the Serbian population boycotted, but which still resulted in a vote for independence. In the campaign

\footnotetext{
${ }^{409}$ Sabrina Petra Ramet, "Democratization in Slovenia-the Second Stage," Politics, Power and the Struggle for Democracy in South-East Europe, eds. Karen Dawisha and Bruce Parrott (New York: Cambridge University Press, 1997) 196-197.

${ }^{410}$ The DEMOS coalition only officially lasted until the 30 December 1991.

${ }^{411}$ Cohen 93.

${ }^{412}$ Ramet, "Democratization" 196-197.

${ }^{413}$ Republic of Slovenia, "Independence Day and 10th Anniversary of the Plebiscite, June 2001" Public Relations and Media Office 4 Nov. $2002<h t t p: / / w w w . u v i . s i / e n g / s l o v e n i a / b a c k r o u n d-$ information/plebiscite>.
} 
leading up to the referendum, slogans such as "a Croatia for Croatians only" were prevalent. ${ }^{414}$ Out of the 85 percent of the voting population that showed up for the May 19, 1991 referendum, 94 percent voted for Croatian independence. ${ }^{415}$

In Croatia, the renamed League of Communists-the Party of Democratic Change (SKH-SDP, later named SDP) moved quickly, holding free multiparty elections in April/May of 1990, based on a first-past the post system with the president elected by the national assembly. By the end of that year all six republics of the SFRY had held free, multiparty democratic elections. In Croatia's free multiparty elections of April/May 1990, the reformed Communists (SKH-SDP) and the liberal Centrists secured 57 percent of the vote. However, with 42 percent of the popular vote, the Croatian Democratic Alliance (HDZ) won the elections, and its leader Franjo Tudjman became president. ${ }^{416}$

The HDZ was established in February 1989. However, due to the majority electoral system, the HDZ gained 205 of the 356 seats in the legislature and 54 seats in the 80-seat Socio-Political chamber and Tudjman became President. ${ }^{417}$ The sense of urgency and the victory of the HDZ led Tudjman to discount and exclude the need to negotiate with other political options or representatives of Croatia's

\footnotetext{
${ }^{414}$ Lampe, Yugoslavia 360.

${ }^{415}$ Council of Europe, “Report Submitted by Croatia, 1999," Human Rights 10 Jan. 2001 $<$ http://www.humanrights.coe.int/ Minorities/statereports/1999/croatia $>$.

${ }^{416}$ Lampe, Yugoslavia 360.

${ }^{417}$ Lenard J. Cohen, "Embattled Democracy: Postcommunist Croatia in Transition," The Consolidation of Democracy in East-Central Europe (New York: Cambridge University Press, 1997) 80-115.
} 
600,000 Serbs. ${ }^{418}$ Rather, the HDZ ruled as if it were the only party and the only legitimate representative of the Croat nation. The HDZ government regarded all issues as either good or bad for the Croat nation. From this perspective, numerous decisions were taken that undermined the position of Serbs in Croatia. For example, upon gaining power Tudjman led a purge of Serb state employees and decreed that signs that combined Latin and Cyrillic be replace with Latin ones. ${ }^{419}$ Tudjman was not experienced in nor was willing to share power or promote accommodation; he ran a patrimonial semi-authoritarian regime. ${ }^{420}$

However, this does not mean that because of the presence of the 12 percent Serbian minority and Milošević's tactics Croatian politics was destined to be semiauthoritarian. ${ }^{421}$ The long-standing desire to re-establish an independent Croatian state, the appeal of a strong leader, the lack of a civil society, combined with the suppression of pluralism during the 1970s and 1980s prompted the acceptance of radical nationalism, the illiberal tactics of the HDZ, and implicit support for those tactics. As historian Ivo Goldstein notes on the HDZ, under communism these people could not have learned how to run a state on democratic lines, or obtained any practice in it. They ruled in the way that their former Party had taught them: as a one-party system. The principles of separation of powers into legislature, executure and judiciary

\footnotetext{
${ }^{418}$ The main Croatian-Serb party was the Serbian Democratic Party (SDS) established in February 1990. Tudjman did not explore the possibility of negotiations with the SDS early on, when the SDS may have been amenable to such talks. As the 1990 elections drew nearer, SDS became "increasingly vocal and more nationalistic." Cohen, "Embattled Democracy" 80.

${ }^{419}$ Glenny 13-14.

${ }^{420}$ Kitschelt 39-41.

${ }^{421}$ Council of Europe, "Croatia: Demographic and Ethnic Structure of Population, 1999," Human Rights $10 \mathrm{Jan} .2001<$ http://www.humanrights.coe.int/minorities/1999/croatia $>$.
} 
was completely neglected...Franjo Tudjman's authoritarian behaviour and style of governing contributed greatly to the general climate. ${ }^{422}$

Politicians and the population were not practiced in political compromise, but rather were accustomed to opposition and mobilization. This made it easy for the HDZ to present its program as one of national reconciliation, based simply on Croat nationalism that focuses on state right and the need to unite against common enemies, communists and Serbs in Croatia. ${ }^{423}$ As political scientist Lenard J. Cohen notes, Tudjman ran a "high profile nationalist campaign," which rested on including Croats and Muslims in Bosnia-Hercegovina as a "new affirmation of Croatian sovereignty," and on Croatian nationalism that alienated the Serbian minority. ${ }^{424}$ The prominence of Tudjman and his nationalist crusade in Croatia were heightened by the xenophobic anti-Croat propaganda of Milošević. ${ }^{425}$ Milošević's nationalist rhetoric, combined with Tudjman's authoritarian style and nationalist rhetoric, made many Serbs in Croatia suspicious of the intentions of Tudjman's regime and incited some Serbs in Croatia to take armed action. Tudjman's historicist focus on nationally exclusive Croat state right alienated the Serb population in Croatia. Tudjman himself discounted the crimes of the fascist Second World War Independent State of Croatia (NDH) at a time when memorials

\footnotetext{
${ }^{422}$ Council of Europe, "Croatia: Demographic and Ethnic Structure of Population, 1999," Human Rights 10 Jan. $2001<$ http://www.humanrights.coe.int/minorities/1999/croatia>.

${ }^{423}$ Tudjman often lamented that Serbs occupies a disproportionate number of official government posts. Cohen, Broken Bonds 97-99.

${ }^{424}$ Cohen, Broken Bonds $97-99$.

${ }^{425}$ For more on Milošević and his rise to power see Lenard J. Cohen, Serpent in the Bosom: The Rise and Fall of Slobodan Milošević (Boulder: Westview Press, 2000).
} 
to NDH leaders were raised and memorials of their Partisan opponents

demolished. Tudjman

engaged in the selective rehabilitation of the NDH [WWII era Independent State of Croatia], in order to assert a continuity between that state structure and the new Croatia established in $1990 .^{426}$

At an early campaign speech Tudjman argued that the NDH "stood for the historic aspirations of the Croatian people for an independent state. ${ }^{4427}$ Tudjman illustrated his disregard for any identities or sympathies other than a "patriotic" Croat, a move which contributed to this authoritarian hold on the political agenda and which notably excluded an increasingly restive Serb population. The Croat leadership placed more emphasis on nationalism than on pluralism and liberal reforms than the Slovenian leadership, which became clear once both countries had undertaken free multi-party elections.

\subsection{Conclusions}

Under Tito, Yugoslavia began a political experiment in an effort to make the fractious, ethnically diverse federation work. During these years Tito constantly changed constitutions, decentralized, re-centralized, liberalised, and cracked down on perceived opponents. These experiments allowed the republics to attain progressively more political power and influence within the federation.

\footnotetext{
${ }^{426}$ Sabrina Petra Ramet, "Afterward: the Murky Legacy of Franjo Tudjman," Nationalism, Culture and Religion in Croatia Since 1990, ed. Vjeran Pavlakovic (Seattle: The Henry Jackson School of International Studies, University of Washington, 2001) 72.

${ }^{427}$ Lampe, Yugoslavia 361.
} 
Yugoslavia entered the 1980s a federation divided, its architects dead, its economy deteriorating, and its sustaining values and ideologies questioned and attacked by its constituent parts. Along with the re-awakening of cultural identities came the economic and political crises of the 1970s and 1980s, driving deeper wedges between the republics and re-affirming their different political trajectories. Croatia and Slovenia had different reactions and approaches to the continuing economic and political crises of the 1980s. In Slovenia, economic crises and disaffection led to the development, toleration, and ultimately official support of a vibrant and diverse civil society keen on political liberalization. When liberalizing reformist communists took the helm in 1985-86 they had a certain degree of freedom from the severe scrutiny of federal authorities and Slovene leaders also enjoyed support inside of the republic to engage in liberalizing reforms in Slovenia. Croatia suffered from a lack of such liberalizing reformers. This is because radical politics in previous eras, particularly during WWII and the 1970s, precluded political pluralization.

By 1990 the Slovene political elite had already begun setting up an exit strategy from Yugoslavia focusing on autonomy. Tudjman did not have a coherent exit strategy; rather, he based independence on re-affirming Croatian state right, the historic legacy of a Croat state whose link to Western Europe was in part facilitated through the Catholic Church. 


\section{Chapter 6: Independent Croatia and Slovenia}

\subsection{Introduction}

On June 25, 1991 Croatia and Slovenia emerged from the same federation. Both Croatian and Slovenian elite established institutions justified by the practices of the past and projections of their future in Europe. Through the invocation of memories, political leaders attempted to justify newly won independence on a continent where the historical foundations for states were routinely traced back centuries. The differences between post-communist Croatia and Slovenia did not develop by chance or through recent circumstance. ${ }^{428}$

\subsection{Setting up the Regime}

An important distinction between the two states, which greatly influenced politics in the 1990 s, was the way in which the ruling parties negotiated political change in the year prior to the outbreak of war. The Croatian leadership under Tudjman, a full year prior to independence and war, exacerbated tensions with the Serb minority through a focus on state right which was exclusively focused on the Croatian nation and its centuries-old mission of re-establishing an independent state. $^{429}$ The war in Croatia certainly had an effect on political liberalization, but

\footnotetext{
${ }^{428}$ See Appendix E: Post-Communist Croatia and Slovenia

${ }^{429}$ Tudjman incorporated an appeal "a revival and return" to the NDH with the idea of "all Croats in one state." Damir Pilić, "Intervu, Don Ivan Grubišić, Svećenik i Sociolog," Feral Tribune 9 June 2001: 6 .
} 
what is important to remember is that the war was not inevitable. ${ }^{430}$ The stance of the Tudjman government from its election in 1990, a year before the war in Croatia broke out, relied on fostering exclusionary nationalism, particularly through its appeal to the Croat past. In a survey undertaken during the 1990 elections, when asked what things were important to the nation, 62.3 percent of respondents stated that history was very important and 65.6 percent stated that culture was very important, while only 55.6 percent stated that the economy was very important. ${ }^{431}$

In Croatia's political scene, political parties of the 1980 s had not grown together in an environment where pluralism was enabled, as in Slovenia. They lacked a public forum for conflict and co-operation. Once in power, Tudjman continued to restrict the space for public debate, and while other political parties existed, they found it difficult to challenge the Croatian memory strategy employed by Tudjman. This strategy portrayed "patriotic" Croats as ethnically Croat, denominationally Catholic, anti-communist, and dedicated to Croat state right. ${ }^{432}$ Once Tudjman came to power, it was difficult to shift the focus of political

\footnotetext{
${ }^{430}$ See Appendix F: War in Croatia and War in Slovenia. For more on the aftermath of the war and "heroes of the homeland war" in Croatia see Appendix G: The International Criminal Tribunal for the Former Yugoslavia (ICTY).

${ }^{431} 2,608$ people were questioned on the eve of the election. Goran Čular and Nebojša Blanduša, "Prilozi," Hrvatska Politika 1990-2000, ed. Mirjana Kaapović (Zagreb: Biblioteka Politička Misao, $2001) 254$.

${ }_{432}$ Sandra Prlenda, "Odnos Izmedju Nacije i Religije u Hrvatskim Nacionalnim Ideologijama," Religija. Društvo i Politika. Kontroverzna Tumačenja i Približavanja, ed. Thomas Brember (Bonn: Wissenschaftliche Arbeitsgruppe fur Weltkirchliche Aufgaben der Deutschen Bischofskonferenz, October 2002) 131-141.
} 
discourse from the grand needs and desires of the Croatian nation to the prosaic issues of day-to-day policymaking. ${ }^{433}$

In Slovenia, prior to independence the focus was on achieving economic and political liberalization. ${ }^{434}$ This was a future-oriented focus rather than one that sought to right past injustices to the nation or regain lost glory. During the socialist era the Slovenian Communist Party allowed for pluralism and later for the formation of autonomous parties not guided by a single long-standing doctrine such as state right fused with nationalism. ${ }^{435}$

Rather, a larger number of parties shared similar goals, but remained strongly politically differentiated. In Slovenia the reading of history and requirements for a "patriotic" Slovenian nation were not as uniformly portrayed by the leaders of the country, because prior to independence there was a space for plural political options. ${ }^{436}$ This extended into the post-communist era, when there remained a clear division of left and right parties informing conflict and consensus.

\footnotetext{
${ }^{433}$ For almost a decade the Croatian system under Tudjman was semi-parliamentary, a constitutional parliamentary democracy that was up until Tudjman's death semi-authoritarian, centred on the president. See Gordana Uzelak, "Franjo Tudjman's Nationalist Ideology," East European Quarterly 31.4 (1998) 449-472.

${ }^{434}$ Jože Mencinger, "The Costs and Benefits of Secession," Making a New Nation: The Formation of Slovenia, ed. Danica Fink-Hafner and John R. Robbins (Brookfield: Dartmouth Publishing Company, 1997) 205-211.

${ }^{435}$ Erica Harris notes that politics in Slovenia, influenced and affected by experiences during the communist era, encouraged the development of nationalism that complimented rather than hindered Slovenia's post-communist political liberalizing developments. Erica Harris, Nationalism and Democratization: Politics of Slovakia and Slovenia (Burlington: Ashgate, 2002) 61.

${ }^{436}$ It must be remembered that even before independence or the "homeland war" (1991-1995) Croatian political discourse was dominated by constant invocations of former independence and the unity of the Catholic faith and Croat nationality. In Slovenia's case, on the other hand, nationalism was harnessed in the almost unanimous goal of establishing a liberal democratic government, the goal that was not burdened with visions of a reincarnated or vindicated national history.
} 
The Slovenian memory strategy also sought justification in the past, but in this recognized a history of a small nation that relied on manoeuvring within greater powers. ${ }^{437}$ Its focus was on discrete policy issues. Thus, the Slovenian focus on closer ties with the European Economic Community, which due to the mandate of the European Commission focused on the economy, gradually developed into a focus on cultural, political, and human rights issues. ${ }^{438}$

Prior to the outbreak of war, the Croatian Consitution, adopted in December 1990, reaffirmed an exlusivist stance based on historic state right. In most states, the creation of the constitution offers a space for and requires intense reflection of the population and the elite. The process focuses on the values, practices, conventions, and norms that lead up to the current situation and should continue to support the new framework of the state in question. In the case of Croatia, the constitution was hastily drawn up in the months after the HDZ victories in 1990 and can be considered a standard liberal democratic constitution, save for the opening section entitled "Historical Foundations." As the preamble states,

The millenary identity of the Croatia nation and the continuity of its statehood, confirmed by the course of its entire historical experience within different forms of states and by the preservation and growth of the idea of a national state, founded on the historical right of the Croatian nation to full sovereignty... the Croatian nation by its freely expressed will at the first democratic elections (1990) reaffirmed its millenary statehood. ${ }^{439}$

\footnotetext{
${ }^{437}$ Vodopivec, "The Historical Background" 25-30.

${ }^{438}$ Jelko Kacin, Personal Interview, 23 March, 2004, Chateau Laurier, Conference: The Changing Face of Europe Opportunities for Canada..

${ }^{439}$ Republic of Croatia. "The Constitution of the Republic of Croatia." Official Gazette 1998. 17 Jan. $2001<\mathrm{http}: / \mathrm{www}$.usud.hr/html/the_consitution_of the_republic $>$. Despite the fact that the NDH was not mentioned in the constitution it was clear in Tudjman's public statements that he viewed the $\mathrm{NDH}$ as legitimate expression of the age old tradition and striving for Croatian
} 
This section of the constitution reflects the interpretation of history that Tudjman encouraged which focused on national unity as the ultimate aim of politics and the measure of good governance.

Both Slovenian and Croatian constitutions "seek legitimization in the presumption of national sovereignty." ${ }^{440}$ However, as Sabrina Petra Ramet notes, the Croatian constitution establishes a "national state" as such, while the Slovenian constitution "pays obeisance, in passing, to the national principle" in order to justify disassociation by declaring itself a "'democratic' rather than a 'national' state. $\$ 441$

The "Historical Foundations" section of the Croatian constitution distinguishes between the Croatian nation and other citizens, implicitly placing Croats in an exalted position and guaranteeing them rights that "others" may or may not enjoy. This combined with Tudjman's many quips regarding the historical place of Serbs in the Croatian State did much to destabalize the situation, prior to open hostilities.

As Tudjman once famously noted in reference to Serbs and Croats in Croatia, "all people are equal in Croatia but it must be clear who is the host and statehood. The constitution recognized AVNOJ instead of the NDH as carrying on the Croatian state tradition, however in HDZ circles and Tudjman himself notes that this distinction is not so clear and often states that this was "not only a quisling organization and a fascist crime but was also and expression of the Croatian nation's historic desire for an independent homeland." Tanner 223. ${ }^{440}$ Sabrina Petra Ramet, Eastern Europe and the Natural Law Tradition (Seattle: The Donald W. Treadgold Papers, the Henry M. Jackson School of International Studies, University of Washington, 2001) 36 .

${ }^{441}$ Ramet, Eastern Europe 36-37. 
who is the guest. ${ }^{, 442}$ These distinctions were encoded in the laws. As sociologist Srđan Vrcan notes,

Tudjman almost never used the term Serbian people, Serbian national community in Croatia, or Serbian national group but preferred to speak of them as a Serbian populous, underlining symbolically the crucial distinction between Croats as being a nation and Serbs as being a populous (Hrvatski narod i Srpsko pucanstvo) which meant denying them their collective subjectivity. ${ }^{443}$

This constitutional clause, combined with Tudjman's nationalist view of history, the prominent role of the RCC in politics, the resuscitation of certain Croatian symbols, the open firing of Serbians from state jobs including the police force, and Milošević's propaganda struck fear into Serbs in Croatia. Milošević's propaganda urged Croatian Serbs to equate any assertion of Croatian independence with the fascist Ustaše Independent State of Croatia (NDH). ${ }^{444}$ At the HDZ party congress on February $24^{\text {th }}, 1990$ Tudjman himself stated,

Our opponents see nothing in our program but the claim for the restoration of the independent Croatian Ustaše state. These people fail to see that the state was not the creation of fascist criminals; it also stood for the historic aspirations of the Croatian people for an independent state. They knew that Hitler planned to build a new European Order. ${ }^{445}$

In this atmosphere, the prominent display of the sahovnica (the chequered crest of Croatia) which was also used in the NDH and renaming the currency the

\footnotetext{
${ }^{442}$ Goldstein 210.

${ }^{443}$ Srdjan Vrcan, "Elections in Croatia: A Symptomatic Case or an Anomaly?" Center for Democratic Transition 2000, 13 Nov. $2002<$ http://www.cedet.org.yu>.

${ }^{444}$ Bilandžić, Hrvatska 771.

${ }^{445}$ Silber and Little 86.
} 
kuna (its medieval name, but also the one used during the NDH) were seen as offensive. ${ }^{446}$ This was augmented by new tolerance for expressions of nostalgia for the NDH in song, symbol, and word. Some streets and schools were renamed to honour leading NDH figures. ${ }^{447}$ The State assembly was renamed the Croatian State Assembly (Hrvatski Drzavni Sabor), as it was named in the NDH. Added to this was Tudjman's anti-Semitic book "The Wastelands of Historical Reality" published in 1988, which sought to discount as myth the extent of Ustaša mass killings of Serbs, Jews, and Roma as well as the role of ethnic Croats in perpetuating them. ${ }^{448}$

Tudjman saw his view of history as one that could reconcile Croats with their past by imagining the solidarity of all Croats in their desire for an independent homeland and by minimizing the crimes committed in its name during WWII. ${ }^{449}$ As part of his agenda, in 1996 Tudjman proposed reburying NDH soldiers alongside the victims of fascism at the site of the Croatian WWII concentration camp

\footnotetext{
${ }^{446}$ Goldstein 215.

${ }^{447}$ Ivica Dikic, "Victims of Our-Ism," Feral Tribune 17 May 1999, 3 Feb. 2002 $<$ http://www.feral.hr>.

${ }^{448}$ Tudjman calculated that at most 40,000 people died in the most infamous Croatian concentration camp, drastically underestimating the number of victims of the Ustasa as a whole. He even argues that most of the victims died at the hands of the Jews. Michael Shafir, "Deflective Negationism of the Holocaust in Postcommunist East-Central Europe (Part 4), Deflecting the Guilt to the Jews," Rad io Free Europe/Radio Liberty, East European Perspectives 30 Oct. 2002, 11 Nov. 2002 $<$ http://www.rferl.org/eepreport/2002/10/22-301002>. Tudjman's book, The Wastelands of Historical Reality, the English translation of which is called The Horrors of War: Historical Reality and Philosophy, excludes some of the most controversial statements and anti-Semitic passages. Franjo Tudjman, Bespuca Povijesne Zbilinosti: Rasprava o Povijesti i Filozofiji Zlosilja (Zagreb: Nakladni Zavod Matice Hrvatske, 1989). Franjo Tudjman, The Horrors of War: Historical Reality and Philosophy (New York: M. Evans and Company, 1996).

449 "Tudjman himself encouraged the writing of a new national historiography that portrayed the Ustašas as patriots," this included textbooks that minimized Ustaša crimes while highlighting crimes of Chetniks and communists. Perica, Balkan Idols 188-189.
} 
Jasenovac. $^{450}$

The distinctive foci of political elites as informed by memories in Slovenia and Croatia were all the more clear on Independence Day, June 25, 1991. The lyrics of the national anthems that greeted independence were a testament to the distinct nature of the two states. The lyrics of the Slovenian national anthem were written by France Prešeren (1800-1849), Slovenia's most revered poet. ${ }^{451}$ The seventh stanza from Prešeren's 1844 poem The Toast (Zdravljica, published in 1849) ${ }^{452}$ continues to resonate with Slovenes so much that it was chosen as the lyric for the Slovenian national anthem in 1990:

God's blessing on all nations,/Who long and work for that bright day,/When o'er earth's habitations, No war, no strife shall hold its sway;/Who long to see,/That all men free,/No more shall foes, but neighbours be. ${ }^{453}$

By contrast, the 1991 Croatian national anthem is more exclusively nationalist. The anthem derives its lyrics from Antun Mihanović's 1835 poem Our Beautiful Homeland (Lijepa nasa domovino). Written in the same era as Prešeren's poem, Mihanović's poem and the excerpt used for the post 1991 national anthem illuminate the focus on heroic figures and the state. This poem and its themes have been so popular in Croatia that it was adopted for the national anthem during the

\footnotetext{
${ }^{450}$ Marinko Čulić, "Bones in the Mixer," Feral Tribune 29 Apr. 1996, 5 Feb. 2002 $<\mathrm{http}: /$ www.feral.hr>. Due to this article both the author of this article and the editor of Feral Tribune were charged with libel against the President (articles 71 and 72 of the Croatian Criminal Code) a charge that in the Tudjman era could result in 6 months to 1 year in prison. Both were later acquitted.

${ }^{451}$ Cooper 15.

${ }^{452}$ Pibernik and Drolc 6.

${ }^{453}$ Republic of Slovenia, "Law on the Coat-of-Arms, Flag and the National Anthem of Republic of Slovenia," Official Gazette Republic of Slovenia 67/94 (1990): 2.
} 
WWII fascist Independent State of Croatia as well as the current Croatian state

established in 1991:

Beautiful is our homeland,/O so fearless,/O so gracious./Our Fathers' ancient glory,/May God bless you, live forever!/You are our only glory,/You are our only treasure,/Yes, we love your plains and valleys,/Yes we love your hills and mountains./Sava, Drava, keep on flowing,/Danube, do not lose your vigour,/

Deep blue sea go tell the whole world,/That a Croat loves his homeland./When his fields are kissed by sunshine,/When his oaks are whipped by wild winds,/When his dear ones go to heaven,/Still his heart beats for Croatia! ${ }^{454}$

Two days after these anthems announced the establishment of two new states, Slovenia plunged into a ten-day war, to be followed by the outbreak of war in Croatia later that summer which lasted until $1995 .{ }^{455}$ The duration and intensity of the wars is a factor that distinguished Croatian and Slovenian politics. However, the wars' characteristics were largely influenced by the unique approaches to postcommunist politics in both states prior to their outbreak. In particular, Croatian political actions and rhetoric prior to the war, which focused on grand aspirations and state right, played a critical role in precipitating the war.

\footnotetext{
${ }^{454}$ Republic of Croatia, "Law on the Coat-of-Arms, the Flag, and the National Anthem of the Republic of Croatia, and on the Flag and Sash of the President of the Republic of Croatia" Official Gazette 34/92 (1990): 1.

${ }^{455}$ There are many books that deal with the wars in the former Yugoslavia, including Misa Glenny, The Fall of Yugoslavia: The Third Balkan War (Toronto: Penguin Books, 1992); James Gow, Legitimacy and the Military: The Yugoslav Crisis (New York: St. Martin's Press, 1992); Janez Janša, The Making of the Slovenian State 1988-1992: The Collapse of Yugoslavia (Ljubljana: Mladinska Knjiga, 1994); Laura Silber and Allan Little, The Death of Yugoslavia (London: Penguin Books and BBC Books, 1995); James Gow Triumph of the Lack of Will, International Diplomacy and the Yugoslav War (New York: Columbia University Press, 1997).
} 
In Slovenia the focus on pragmatic policies rather than on a past or state tradition aimed to ensure a smooth transition and influenced how the country dealt with the war.

When federal authorities decided to take power away from Republican Secretariats of republican based Territorial Defence forces (TO) and to bring these forces under the direct control of the JNA, Slovenia had already prepared a blueprint for autonomous action that would prove to be successful.

Croatia and $\mathrm{BiH}$ (Bosnia and Hercegovina) had not prepared for war. As Victor Maier reports, Slovene military officials met with former Croatian defence minister Martin Špegelj, but Tudjman refused to agree to any joint plans. ${ }^{456}$ Furthermore, Špegelj

President Kučan relayed that in the crucial days before the declarations of Slovenian and Croatian independence, in joint meetings with the Croatian leadership it was clear that Tudjman had not made any substantial plans for independence and simply opted for a "declarative act." $" 457$

\subsection{Conclusions to Part II: Political History}

Despite having declared independence from the same federation on the same day, distinctive patterns of political history distinguished Slovenian and Croatian politics through their inclusion in Austria-Hungary, the Kingdom of

\footnotetext{
${ }^{456}$ Ramet, Yugoslavia 176.

${ }^{457}$ Ramet, Yugoslavia 176.
} 
Serbs, Croats and Slovenes, the Socialist Federal Republic of Yugoslavia (SFRY) and in their independence. Yugoslavia and the republics that emerged from it came into popular worldwide consciousness with the wars of 1991-1995. However, the history of Slovenia and Croatia extends beyond the wars of the early 1990s and must be taken into account when discussing post-communist, political liberalization. Part II of this dissertation aimed to bring a comparative look at history to the discussion of post-communist polities in an attempt to gain insight on contemporary political developments.

As Central European states that were in the same state for just over 70 years, there were many political and institutional similarities between Slovenia and Croatia. While in Austria-Hungary, Croatia dealt with pressures from Hungary and Italy and a Serbian minority within Croatia. Slovenia dealt with pressures from Italy and Austria and later the incorporation of many Slovenians as a minority in those two countries. During both the first and second Yugoslavia Croatian and Slovenian political elites sought greater autonomy and decentralization. In dealing with these pressures during the modern era, political elites in both countries kept to certain patterns described by the ideal types in this thesis. These patterns persisted from the late $19^{\text {th }}$ century to the present day.

Political elites and parties in Croatian and Slovenian administrative regions of Austria-Hungary that later became part of Yugoslavia shared an interest in 
decentralization but went about achieving this goal in very different ways. ${ }^{458}$

Political parties were the main institutions through which external pressures were negotiated and through which specific interests were channeled in multinational states. Generally, since the end of the $19^{\text {th }}$ century, Croatian political parties and elites openly fought for greater independence and power within each of the multinational federations they belonged to. This was informed by the fact that Croatia had a state tradition through the Croatian Kingdom until the demise of Austria-Hungary. That historical memory, promulgated by successive political actors, cited this idealized kingdom as the justification for greater independence and power. While this stance rested on a legal claim to an independent state and did include political options that sought compromise, the power of this kingdom was exaggerated and its memory was often invoked by charismatic leaders seeking to realize their political goals without recourse to bargaining or compromise within multinational federations.

A focus on re-establishing an independent Croatian state informed political strategies that had a greater reliance on zero sum games and favoured revolutionary change. In this way, charismatic authority was favoured over rational legal

\footnotetext{
${ }^{458}$ As noted in numerous sources including Herbert Kitschelt et. al., who examine communist political and bureaucratic legacies and post-communist party competition in order to explain differences, specifically in Bulgarian, Czech, Hungarian, and Polish democracies. While the authors undertake an exemplary study in post-communist democracies and discuss differences during the communist era, they fail to undertake a detailed examination of pre-communist politics. Herbert Kitschelt, Zdenka Mansfeldova, Radoslaw Markowski and Gábor Tóka, Post-Communist Party Systems: Competition, Representation, and Inter-Party Competition, (New York: Cambridge University Press, 1999).
} 
authority, a return to an idealized past was entrenched, and the search for a national saviour was emphasized. In contrast, the focus of successive Slovenian political parties in different regimes was to achieve as many legally entrenched concessions that would preserve and forward cultural and economic goals. Political parties in Slovenia were cognizant of the lack of a "heroic" past, an enduring traditional kingdom or great military achievements. They chose instead to focus on compromise. This focus was based on memories and institutional patterns that relied on positive sum engagement with stronger powers that resulted in the incremental forwarding of political, economic, and linguistic autonomy for Slovenians. In both instances these are underlying patterns of political history that informed interest intermediation and bargaining throughout successive regimes. These patterns of politics re-occur in different Croatian and Slovenian regimes with different political parties and actors. Examples of the patterns that were brought forth in Part II of this work will be explored more in depth in Part III of this dissertation, which is dedicated to comparative analysis of one area of policy making in both post-communist states. 


\section{Part III: Introduction to Part III}

Part II was dedicated to demonstrating how distinctive patterns of politics have carried through Croatian and Slovenian modern politics up to the postcommunist era. Part III forms the main subject mater of this thesis, demonstrating how there historical patterns influenced political liberalization as illustrated in changing church-state relations. The first chapter of this section, Chapter 7 , will provide a brief overview of the Roman Catholic Chruch in Croatia and Slovenia. Chapter 8, concerns concordat creation, Chapter 9, focuses on educational reform, Chapter 10, discusses finance and property restitution and Chapter 11 provides conclusions for the study.

The institutions, choices, and memories of the past facilitated the types of choices that political parties and party elites made in the post-communist era when establishing new governing institutions. More than ever before, in post-communist Croatia and Slovenia political parties and the elite have been afforded the chance to establish the type of state they desired. While there remained international constraints and the constraint of the common goal of establishing a liberal democratic state, political parties and the elite had considerable autonomy in establishing post-communist political institutions. Political parties in postcommunist polities had a key role in managing the distribution of power with other institutional actors, including the Roman Catholic Church. 
In order to ground the generalized patterns of politics traced in Part II, which explain in general post-communist liberalization, Part III focuses on one realm of policy-making common to both polities and provides an example of how these general patterns and ideal types of modern politics informed policy outcomes in the post-communist era. Relations between church and state did not provide the focus for the historical institutionalist analysis in Part II; rather, the focus was on historical political constellations and transformations of state and party. Croatian and Slovenian politics are explained in this paper through contrasting ideal types of politics emerging from distinctive historical experiences and reactions to political challenges within the same multinational empires. The ideal types presented here center on rational legal and charismatic authority, pragmatism and ideology, positive sum and zero sum games, as well as incrementalism and revolutionary change. Part III takes these generalizations to another level, demonstrating that ideal historical types of political patterns continue to play a part in post-communist policy processes and outcomes.

This study holds that the distinct trajectories of liberalization of Slovenia and Croatia can best be explained by tracing the complicated but recognizable patterns in the development, entrenchment, and operation of political institutions informing political actors in Slovenia and Croatia and helping them negotiate complex political issues facing the two countries today. Some of the most controversial and complex issues that have faced both polities have involved 
church-state relations, including the negotiation of concordats, educational, legal, social and financial arrangements that meet the desires of the Roman Catholic Church and the requirements for a liberal polity. 


\section{Chapter 7: Overview: The Roman Catholic Church in Croatia and}

\section{Slovenia}

\subsection{Overview}

The Roman Catholic Church has for centuries been an important spiritual, social, and political institution in Croatian and Slovenian lands. The political influence of the RCC waxed and waned in different eras and areas. Christianisation of the Croats and Slovenes took place during the $8^{\text {th }}$ century, while the establishment of the RCC took place between the $9^{\text {th }}$ and $11^{\text {th }}$ centuries. By the $16^{\text {th }}$ century the Reformation had a far greater effect on Slovenian society than in Croatian society, although the counter-Reformation was undertaken in a similar way, which asserted the social, cultural, educational, economic, and political influence of the RCC in the Habsburg realm. Habsburg $18^{\text {th }}$ century enlightened reforms strengthened the role of the state at the cost of the RCC. The short-lived rule of Napoleon in the Illyrian provinces, the reintegration of these lands into the Habsburg fold, and the threats from French revolutionary ideals and nationalism in the mid- $19^{\text {th }}$ century ensured that church-state ties strengthened.

In the $19^{\text {th }}$ century the RCC continued to have great influence on educational and cultural life, as the RCC was a common institution in the multinational and weakening Habsburg Empire. However, each of these changes over the centuries combined with particular local circumstances to ensure distinct responses and roles of the RCC in Croatian and Slovenian political life. The 
monuments, bureaucracy, and political involvement of the Roman Catholic

Church have through the centuries left their mark on Croatia and Slovenia. Similar

to the case of France, in the two states the religion of the majority, the RCC, has

"maintained a steady institutional as well as monumental visibility." ${ }^{, 459}$ An

important distinction between the RCC in Croatia and Slovenia is the role the RCC

was remembered as having in representing the nation and the establishment of the

state.

Memories of centuries of papal support for Croatian kings were combined

with the post-WWII popularity of the Croatian RCC as a Croatian institution that

carried forward national history, culture and a semblance of independence in

communist Yugoslavia. ${ }^{460}$ It was more difficult for the Slovenian RCC to invoke

analogous memories to their cause as in Slovenian lands there was not an

indigenous state for the RCC to prove it supported. ${ }^{461}$ The RCC in Slovenia relied

on its influence through a political party (the SLS) that in the interwar era engaged

${ }^{459}$ Claude Langlois, "Catholics and Seculars," Realms of Memory, Volume I: Conflicts and Divisions, ed. Pierre Nora (New York: Columbia University Press, 1996) 113. See Appendix B: Monuments and the RCC

${ }^{460}$ For more on Papal recognition of the Croatian kingdom see Šanjek 56-53.

${ }^{461}$ A strong Slovenian memory is of the Protestant Reformation. The influence of the Reformation in Slovenia and the political battles of the Counter Reformation made it difficult to present the Slovenian RCC in memory as an institution that had consistently defended the Slovene nation. An opinion exists that the Protestant Reformation was "revived" in Slovenian lands by the late 19th century, just as socialists began to compete with the RCC, and that Slovenes were again introduced to an ideology alternative to that of the RCC. Igor Lukšič, "Political Culture in Slovenia," in Plasser and Priberski 96. The fact that the RCC chose to support occupiers and fascists in the 20th century ensured that while it remained socially important and vital it was no longer the political force it once was. By the late 20th century, the contributions of the RCC were recognized, but the contributions of Protestant reformers were particularly celebrated, as they had laid the foundation for the use and standardization of the Slovenian language. 
in political compromise with the central government. ${ }^{462}$ The RCC in Croatia was not afforded that role due to opposition from the most popular Croatian party (the HSS) during the interwar period, so it was reserved a space in political life where it could become the standard bearer for the Croatian nation. ${ }^{463}$

During and after the WWII, the SLS, along with the Roman Catholic Church, played a diminished role in Slovenian public political life, the exact opposite of what happened with the RCC in Croatia. This marks an important shift in Croatian and Slovenian political life. From the Second World War onwards, the RCC in Croatia would exert much political pressure outside of the political arena, particularly through the invocation of the memories of Holy See support for Croatian sovereigns in centuries past (reaffirming Croatia's state right) and of the strong connection between ethnic national identity and Catholicism. In building a post-communist state, political leaders turned to the RCC as a uniquely national institution for organizational support, and the RCC took that opportunity to influence public policy.

\footnotetext{
${ }^{462}$ This role in everyday politics, however, was not exalted; it was just a part of everyday life. Therefore, it was relatively easy for Slovenes to discredit the RCC for its temporal endeavours and alignments in the Second World War. After all, it was seen as having both spiritual and temporal roles, the latter of which was not idealized or mythologized.

${ }^{463}$ Even though Radic "clung to Christian principles he remained an opponent of Catholic clericalism." Biondich 49.
} 
7.2 The RCC and the Interwar Era

\subsubsection{Slovenia}

The RCC, through its connections with the SLS, had a strong role in the start of modern Slovene political life through its support of co-operatives and in cooperationist politics in interwar Yugoslavia. Within the SLS itself there was a strong conservative and democratic-socialist split. ${ }^{464}$ The democratic-socialist wing was the most influential as it established Slovenian run co-operatives, banks, and unions that engaged a large number of Slovenes in economic and political life.

Although many in the Slovenian People's Party (clericals) sought to retain its Christian socialist foundations, the publication of the Papal Encyclical Quadragesimo Anno in 1931 forced political Catholics in Slovenia and in other parts of Europe to choose sides, left or right (many unnoted Catholics remained in the centre). ${ }^{465}$ The 1931 Papal Encyclical denounced socialism. ${ }^{466}$ Its publication prompted a left-right split within the SLS that grew throughout the 1930s. As the inter-war years progressed, the RCC, a conservative force, moved decidedly to the right, in line with Quadragesimo Anno. In 1930 Bishop Gregorij Rožman (18831959) replaced Bishop Anton Bonaventura Jeglič, who retired as Bishop of

\footnotetext{
${ }^{464}$ Prunk, Slovenski 221.

${ }^{465}$ Egon Pelikan, "Slovenski Politični Katoličizem v Tridesetih Letih v Luci Evropskih Izkusenj," Slovenci v Evropi (O Nekaterih Vidikih Slovenske Povezanosti s Sosedi in Evropo), ed. Peter Vodopivec (Ljubljana: Historia 5 Znanstvena Zbirka Oddelka za Zgodovino Filozofske Fakultete Univerze v Ljubljani, 2002) 115-122.

${ }^{466}$ Quadragesimo Anno was written 40 years after Rerum Novarum as a continuation of polemics on the "social question" in modern life. It warned that the workers had to look to the church exclusively, not to Liberalism or socialism (or any combination of the three) in their attempts to deal with the injustices of modern life. Pope Pius XI, "Quadragesimo Anno: On Reconstruction of the Social Order," Vatican 15 May 1931, 25 Nov. $2001<$ http://www.vatican.va>.
} 
Ljubljana. Unlike Jegalič, Rožman was a staunch conservative, who saw no redeeming factors in Christian socialism. Rožman strongly supported the rightist shift among the Clericals.

In 1937 Pope Pius XI issued the Papal Encyclical Divini Redemptoris, which warned against the modern evils of "Bolshevistic and atheistic communism. ${ }^{, 467}$ These and other encyclicals, along with the onset of WWII and the strong rightist leanings of Bishop Rožman, forced politically active Catholics in Slovenia to choose between the conservative, rightist option or Christian Socialism. ${ }^{468}$ As the Clericals moved steadily to the right (along with most of the Catholic church hierarchy), poet Edvard Kocbek (1904-1981) became the leading Christian socialist. ${ }^{469}$ Many chose the Christian socialist option led by Edvard Kocbek and followed him in joining the Liberation Front (OF) in $1941 .^{470}$ Bishop of Ljubljana Gregorij Rožman, on the other hand, supported the occupiers and adopted a hard line against communists and Partisans. He was very involved in

\footnotetext{
${ }^{467}$ Other encyclicals by Pope Pius X1 that attacked socialism and communism included Miserentissimus Redemptor (1928) Caritate Christi (1932) Acerba Animi (1932) and Dilectissima Nobis (1933). Pope Pius IX, "Encyclicals," Vatican 23 Nov. 2002 <http://www.vatican.va>. ${ }^{468}$ Pelikan, "Slovenski" 120-128.

${ }^{469}$ Janez Juhant, "Versko in Cerkveno Življenje v Dobi Dozorevanja Slovenskega Naroda: IdejnoPolitični Tokovi in Socialna Dejavnost," ed. Metod Benedik, Zgodovina Cerkve na Slovenskem (Celje: Mohorjeva družba, 1991) 216-220.

${ }^{470}$ Edvard Kocbek, Dnevnik 1945 (Ljubljana: Cankarjeva Založba, 1991). Edvard Kocbek was forced to resign his official posts in 1952 because of his criticism of the monism of the Communist Party.
} 
politics, helping to choose candidates for administrative positions and issuing memoranda "giving detailed advice on how to fight the Partisans."

As historian Stella Alexander notes, Rožman was "far less reserved in his public attitude [towards the Italian and later German occupiers] than Archbishop Stepinac." ${ }^{472}$ Bishop Rožman was above all an anti-communist. He co-operated with the occupiers in the Ljubljana Province, first the Italians and then the Germans who replaced them in 1943. Rožman's support provided the collaborationist Home Guard with a great source of legitimacy. ${ }^{473}$ By the end of the war, the leftist Catholics had been co-opted into the Liberation Front, the rightist Catholics had been discredited, and the RCC had been brutally suppressed until 1953.

\subsubsection{Croatia}

During the interwar period the Croatian Peasant Party and its leader, Stjepan Radić, took a different course from Slovene clericals. Radić advocated an anti-clerical spirituality that distanced the RCC from everyday politics and thus helped reserve a place for it in the national public life. Zagreb's Archbishop Stepinac and the RCC took up that space, particularly after the Second World War, with his post-war opposition to the communist regime. ${ }^{474}$

${ }^{471}$ For excerpts of Rožman's September 12, 1942 memorandum to General Robotti, commander of the XIth Army Corps see see Tomašević, War 519-520.

${ }^{472}$ Alexander, Church 42.

${ }^{473}$ Gregor Tomc, "Slovensko Domobranstvo: Od Kontrarevolucije do Kolaboracije," Rdeče in Črno: Slovensko Partizanstvo in Domobranstvo, eds. Doroteja Lešnik and Gregor Tome (Ljubljana: Znanstveno in Publicistično Središče, 1995) 150.

${ }^{474}$ It was with the death of Radić, the weakening of his party, and rise of the fascist regime that the RCC under the leadership of Archbishop Stepinac was able to secure a greater role in Croatian 
In 1937 the RCC in Croatia decided to "fortify the tradition and

continuity of nationhood and church-nation symbiosis... [and through this] develop a Croatian equivalent to the Kosovo myth." ${ }^{475}$ This would be done through a grand jubilee, which was announced in 1939 as the "Great Novena-Thirteen Centuries of Christianity in the Croat People" and began in 1941, only to be stopped by the war. ${ }^{476}$ Belgrade attempted to placate Slovenes and Croats through the 1922-1939 concordat negotiations with the Holy See. Although the concordat was signed in July 1935 , it was never ratified. ${ }^{477}$ The view of the RCC as a key Croat institution was aided by the HSS's incorporation of symbols of Croatian history, including Zvonimir:

Zvonimir became more a symbol of the religious identity of the Croats in the face of the practically official state religion of Orthodoxy (within Yugoslavia), and was remembered for his fostering of the Catholic Church in Croatia. ${ }^{478}$

This sentiment was furthered during WWII with the Croat Fascist regime, whereby "the Catholic Church supplied the new regime with crucial components of statehood, such as a founding myth, patriotic ritual, and state bureaucracy., $\$ 479$ However, it must be remembered that during the same era the Slovenian RCC did

public life. Stepinac maintained a very public role during the war and was able to present himself as a unifying figure for Croats.

${ }^{475}$ Perica, Balkan Idols 20.

${ }^{476}$ Perica, Balkan Idols 21 .

${ }^{477}$ Lampe, Yugoslavia 179.

${ }^{478}$ Zanic 99-100.

${ }^{479}$ Perica, Balkan Idols 19. 
not gain the same prominence despite the pre-eminence of the Orthodox Church and WWII factions. ${ }^{480}$

In Croatia the Ustaša regime of the fascist Independent State of Croatia sought to co-opt the RCC as an important national organization, one that could be invoked to justify the distinct Catholic heritage of the Croatian state and could provide a base for organization. ${ }^{481}$ The RCC was viewed as central to Croatia's unique historical mission to defend western Catholicism and Croatian state right. The Ustaša relied on the RCC for legitimising its regime. To carry out the forced conversions that were part of the Ustaša plan, mostly through rebaptism, the Ustaša relied on some in the RCC hierarchy. The Archbishop of Sarajevo, Ivan Šrić (1871-1960), and numerous Franciscan priests from Hercegovina embraced the Ustaša cause as their own. ${ }^{482}$ However there were those in the RCC that supported the Partisans, including “Archbishop Kuzma Jedretić, Franciscans Bosiljko Ljevar and Viktor Sakić, and the pastor of Saint Mark's Church in Zagreb, Msgr. Svetozar Rittig." ${ }^{483}$ The Archbishop of Mostar, Alojzije Mišić, roundly condemned the

\footnotetext{
480 "After the trying experiences under the Kingdom of Yugoslavia in which Croats had failed to achieve the autonomy they had sought, the Croatian Catholic hierarchy initially welcomed the establishment of a separate Croatian state." Pedro Ramet, "The Catholic Church in Yugoslavia 1945-1989," Catholicism and Politics in Communist Societies, ed. Pedro Ramet (Durham: Duke University Press, 1990) 183.

481 "According to the myth, the NDH was the outgrowth of the thirteen centuries-old tradition ...Tens of thousands of members of Catholic lay organizations served the NDH. The new state recruited a large number of its officials form the Catholic lay movement and from graduates of Catholic seminaries and gymnasia. Most of Catholic clergy outside Italian-occupied zones were Ustaša supporters." Ramet 183.

The Franciscans were seen as some of the most vehement Ustaše supporters.

${ }^{482}$ Tomašević, War 368-372.

${ }^{483}$ Ramet, "Catholic Church"1 82.
} 
murderous violence of the Ustaša. ${ }^{484}$ Mišić and Archbishop Stepinac also recognized that "the Ustaše were driving people into the Partisans, and doing great harm to the church. ${ }^{485}$ However, the majority in the RCC took a wavering stance exemplified by the highest and most controversial Catholic authority in Yugoslavia, Archbishop of Zagreb, Alojzije Cardinal Stepinac (1898-1960, Archbishop from 1934).

Stepinac would become a Croatian hero after the war. ${ }^{486}$ Stepinac supported the idea of an independent Catholic Croatia, but did not advocate mass killing in the name of it. At first, Stepinac openly and with enthusiasm welcomed the fascist $\mathrm{NDH}$ (Independent State of Croatia) ${ }^{487} \mathrm{He}$ also promoted mass conversions, but "only when they were voluntary"; the overwhelming majority, of course, were not. Throughout the war though he remained strongly anti-communist, in line with the Papal Encyclicals issued by Pope Leo XIII and Pope Pius XI ${ }^{488}$ When Stepinac became more aware of the actions of the NDH he sent private criticisms and indictments to others in the RCC, including the Vatican, as well as to the Ustaša leaders. ${ }^{489}$ However, Stepinac knew the Ustaša killed hundreds of thousands, and the only resistance he organized was critical sermons, particularly towards the end

\footnotetext{
${ }^{484}$ Alexander, Church 32.

${ }^{485}$ Alexander, Church 23.

${ }^{486}$ Stella Alexander's book The Triple Myth: The Life of Archbishop Alojzije Stepinac remains a seminal detailed explanation of conflicting accounts and the conflicted self of Stepinac. Stella Alexander, The Triple Myth: The Life of Archbishop Alojzije Stepinac (New York: East European Monographs, Columbia University Press, 1987).

${ }^{487}$ Pavlowitch 113.

${ }^{488}$ Pavlowitch 98.

${ }^{489}$ Šanjek 463- 469. Alexander, Triple Myth 90-91.
} 
of the war, and the saving of a relatively small number of Jews and Serbs from persecution. ${ }^{490}$ However, he did not break relations with the Ustaša regime, in part because they were "members of his flock," and because he could not have helped save the people otherwise. ${ }^{491}$

Even after the communists won power Stepinac remained in Croatia to serve his flock. This move solidified the position of the RCC as the central institution that represented ethnic Croats after the Second World War. Stepinac and the RCC became symbols for national resistance, a repository for Croatian national aspirations. The RCC in Croatia became an institution increasingly associated with protecting the nation, particularly in the face of the communist regime.

7.3 The Role of the Roman Catholic Church in Politics: From the Second World War Forward

At the close of the war, the property of all church denominations throughout Yugoslavia was confiscated; hundreds of priests were killed, imprisoned, and harassed; church activities of all kinds were suppressed. ${ }^{492}$ The era of severe

\footnotetext{
${ }^{490}$ Alexander, Triple Myth 97-99. There are no agreed upon figures as to how many people the Archbishop helped save from Ustaša terror. In May 1942 he openly protested the actions of the regime and by 1943 his sermons became more openly against the regime.

${ }^{491}$ Alexander, Triple Myth 3, 93.

${ }^{492}$ For figures on post-war repression of those in the church see Sabrina Petra Ramet, Cross and Commisar: The Politics of Religion in Eastern Europe and the USSR (Bloomington: Indiana University Press, 1987) 29-31. Also see Tamara Griesser-Pečar, "Procesi Proti Duhovnikom in Redovništvu po Maju 1945," Temna Stan Meseca: Kratka Zgodovina Totalitarizma v Sloveniji 1945-1990, ed. Drago Jančar (Ljubljana: Nova Revija) 113-126. For more on the RCC in socialist Yugoslavia see Zdenko Roter, Katoliska Cerkev v Jugoslaviji 1945-1973 (Ljubljana: Cankarjeva Založba, 1976) and Ivan Grubišić, Religija i Sloboda: Religijska Situacija u Hrvatskoj. 1945-1990
} 
repression persisted until $1953 .{ }^{493}$ While all religious denominations were persecuted in the immediate post-war era, the RCC in Croatia was singled out for particular retribution because of its organizational capacity, the influence of the Holy See, its promotion of Croatian autonomy and nationalism, its instances of clergy collaboration with the fascists, and the popularity of Archbishop of Zagreb, Alojzije Stepinac. The RCC in Slovenia did not have such a prominent position and Christian socialism was already a popular option for Slovenian clerics prior to the Second World War. Shortly after the war this created a channel of communication between the RCC and the authorities. ${ }^{494}$ Stepinac's stature as the most illustrious figure of the Croatian RCC pantheon in large part resulted from his unwillingness to compromise with Tito or to be co-opted by the communist regime; his denial of the fact that Croats should be collectively punished or that their nationalism should be squashed because of NDH; and his perceived international reputation, bolstered by his cardinalship. ${ }^{495}$ This was in stark contrast to his counterpart in Slovenia, the Bishop of Ljubljana, Gregorij Rožman.

(Split: Piblioteka "Znanost I Durstvo," 1993); Sabrina Petra Ramet, Balkan Babel: The Disintegration of Yugoslavia from the Death of Tito to Ethnic War (Boulder: Westview Press, 1995); andVjekoslav Perica, Balkan Idols: Religion and Nationalism in Yugoslav States (Toronto: Oxford University Press, 2002).

${ }^{493}$ Sabrina Petra Ramet notes five different phases of communist-church interaction in Yugoslavia: the first phase between 1945-53 of extreme repression; the second phase 1953-64 of all parties seek ing a modus vivendi; the third phase 1964-1970 of greater toleration; and the fourth phase 1970-1989of several major issues re-igniting tensions. Ramet, Balkan Babel 145-148.

${ }^{494}$ Alexander, Church 124.

${ }^{495}$ Tito attempted to convince the Croatian Catholic hierarchy, including Stepinac, that they should create their own Croatian Catholic church, at arm's length from the Vatican, so that Tito could hold greater control over it Ivan Grubišić, "Katoličizam i Postkomunizam u Hrvatskoj," Crkva i Država u Društvima u Tranziciji, ed. Ivan Grubišič (Split: Knjižnica Dijalog, 1997) 158. 


\subsubsection{Slovenia}

During the Second World War, the Bishop of Ljubljana, Gregorij Rožman, collaborated with the Italian occupiers and supported Slovenian anti-communist forces. He fled the country when the war ended, so he did not become a figurehead like Stepinac. Rožman's activities discredited the RCC as a representative of the nation. ${ }^{496}$

Widespread indigenous Christian socialism in Slovenia enabled greater cooperation between the church, which was not seen as greatly compromising itself, and the state, which felt it did not need to crack down on what was perceived to be a great opponent. By contrast, many Croats resented being included in a federation where they were held in suspicion given their previous attempts at autonomy and their persistant desire for a degree of autonomy. As Jožo Tomašević notes,

A large majority of Slovenes and Slovene priests supported the Yugoslav federal state, considering it the best solution form the point of view of Slovene national interests, whereas in Croatia much of the population and many Catholic priests favoured an independent Croatian State. ${ }^{497}$

Marriage, education, and hospitals were secularized, but there continued to exist training institutes for clergy and faculties of theology. Yugoslav authorities set up priests' associations as "a sort of clerical trade union" to co-opt lower clergy through, for example, health, social, and taxation benefits. ${ }^{498}$ There were a number

\footnotetext{
${ }^{496}$ Bishop Rožman was tried in absentia and sentenced to 18 years in prison. He spent most of his remaining years in parishes in the Cleveland, Ohio area. Meier 56.

${ }^{497}$ Tomašević War 522.

${ }^{498}$ Alexander, Church 124.
} 
of different priests' associations for Catholic priests which varied according to "local and historical circumstances." ${ }^{.499}$ The most influential associations for Catholic priests were Dobri Pastir, which operated among Franciscans primarily in Bosnia and Herzegovina, and the Ciril-Metodsko Društvo [CMD], which operated among priests in Slovenia. Priests' associations split the RCC between the RCC hierarchy and priests, particularly in Bosnia and Hercegovnia, due to the influence of Dobri Pastir, because bishops forbade priests' associations in $1953 .{ }^{500}$ However, the CMD was not as controversial, because it "sprang out of the Christian Socialist movement and had genuine roots among the clergy [in Slovenia]. ${ }^{, 501}$ The CMD was recognized as not being a tool of the government, because many of its priests were Christian socialists who sought to be objective. ${ }^{502}$

As relations between the Church and state became less hostile and the liberalizing openings of the 1960s allowed for greater church freedoms, the RCC in Slovenia kept a low profile. After the Croatian national movement of 1967-1972, leaders of the Slovenian RCC were used to mediate. ${ }^{503}$ By the 1980 s the RCC in Slovenia had gained comfortable relations with the state so much so that it was the

\footnotetext{
${ }^{499}$ Alexander, Church 124.

${ }^{500}$ Alexander, Church 131.

${ }_{501}^{5}$ Alexander, Church 126.

${ }^{502}$ Alexander, Church 131. The name of CMD was chosen after the war, because it was the name of the pre-war priests' association in Slovenia and 1stria that was founded at the end of the 19th century "to oppose the Germanisation and Italianisation of these areas." Alexander, Church 129. The CMD counted 60 percent of Slovenian priests as members in 1952. Alexander, Church 126.

${ }^{503}$ Perica, Baikan Idols 56-63.
} 
first republic in which a church hierarch was allowed to transmit a Christmas greeting over the radio. ${ }^{504}$

By the late 1980s the RCC was one of many actors that participated in the pluralization of the political scene in Slovenia. With a right wing coalition winning the first free elections, but ousted in a vote of non-confidence two years later, grand coalitions have predominated Slovenian politics. The "Catholic Bloc," center right and right wing parties, either traced or paid respect to the role of the RCC in Slovenian political history. However, the role of the RCC in state tradition and nation building was not as mythologized as in Croatian memory, while the postcommunist, post-Yugoslav Slovenian political scene was more plural.

Even though the Catholic Bloc parties sought to strengthen the role of the RCC in political life, they had to do so through bargaining, which resulted in incremental changes that reinforced the rational legal basis for political liberalization. Unlike in Croatia, in Slovenia the RCC was not afforded an a priori privileged public role due to the ideology of one leading party. Rather, the Catholic Bloc parties had to convince the electorate that concessions to the RCC would benefit all of society and reinforce the goals of political transformation. The institutional support of the RCC was not perceived to be valuable in Slovenia as it was in Croatia, because there was a greater plurality of actors in Slovenia and

\footnotetext{
${ }^{504}$ Pedro Ramet notes that "not surprisingly, it is in Slovenia-where both Strossmayer and Stepinac are largely irrelevant-that church-state relations have acquired a somewhat friendlier tone." Ramet, "Catholic Church" 204.
} 
because the memories associated with the RCC also had a number of different and equally strong connotations.

\subsubsection{Croatia}

In Croatia after WWII the communist authorities were unwilling to seek immediate normalization of the relationship with the RCC because Stepinac became a powerful symbol and because they did not want to be seen as cooperating with those whom they accused of collaborating with indigenous fascist authorities. ${ }^{505}$ There was a fear that normalization would only legitimize communist opposition in Croatia rather than placate it. The previous regimes attempted to placate Croat opposition, while autonomist aims only led to greater calls for autonomy and, combined with the exigencies of war, the fascist NDH. Many Croats still sought autonomy and saw the RCC as an institution that had long supported Croat distinctiveness.

Show trials peaked in the late 1940s, with one of the most infamous of postwar Yugoslavia being the trial of Archbishop Stepinac. ${ }^{506}$ While experts have subsequently debated Stepinac's culpability, the communist authorities sentenced him to 16 years of prison for co-operation with the Ustaša. ${ }^{507}$ Stepinac was remanded to house arrest after 1951 in his home town of Krašić. When in 1952 the Vatican began procedures to make Stepinac a Cardinal, Tito severed diplomatic ties

\footnotetext{
${ }^{505}$ Aleksa Benigar, Alojzije Stepinac, Hrvatski Kardinal (Rome: Ziral, 1974) 490-545.

${ }^{506}$ Lampe, Yugoslavia 229.

${ }^{507}$ Shoup 106.
} 
with Vatican. However, by 1953 repressive measures were curtailed and some clergy members were amnestied. In that same year the separation of church and state was enshrined in the constitution, as was freedom of belief and worship in the Law on the Status of Religious Communities. ${ }^{508}$ The gradual improvement of church-state relations in the 1950s and 1960s was reflected in Tito's decision to permit Cardinal Stepinac, who had died in 1961, to be buried in the Zagreb cathedral with the full honours due to an archbishop. ${ }^{509}$ After the Second Vatican Council (1962-65), in 1966 the Holy See and SFRY signed a protocol recognizing each other's jurisdictions and established a "modus vivendi." 510 Tito also allowed for more religious publications and authorized the creation of the first full and modern translation of the bible into Serbo-Croatian in 1968. By 1971, the SFRY and the Holy See had re-established full diplomatic relations. ${ }^{511}$ During this era the churches gained greater freedoms, issued periodicals and broadened social programmes, this at the same time as the Croatian spring.

During the détente (1967-1971), the validity of Tito's charges against Stepinac were more openly questioned. And it was during this period that Catholic

\footnotetext{
${ }^{508}$ Ramet, Balkan Babel 146.

${ }^{509}$ Initially, his tomb was marked with a simple plaque carved by Ivan Meštrović (1883-1962) to which was added, behind the altar, a large open coffin-like structure with a replica of Stepinac inside.

${ }^{510}$ This protocol allowed for the RCC to maintain ties with the Vatican and ensure "free conduct of religious affairs and rites," while committing to respect the laws of Yugoslavia and ensuring that religious and church functions do not have a "political character." Ramet, "Catholic Church" $192-$ 193.

${ }^{511}$ Alexander, Church 289.
} 
clergy “in Rijeka, Split, Zadar and Zagreb responded enthusiastically to the Croatian liberal-nationalist groundswell of 1967-1971.."512

The role of the RCC in Croatia came to the forefront of Croatian popular and political consciousness during the 1970s and 1980s, in large part because of the efforts of Archbishop Franjo Kuharić (1919-2002), who in June 1970 was appointed Archbishop of Zagreb (until 1996) and in February 1983 Cardinal. ${ }^{513}$ This was done in the name of human rights, namely freedom of religious and national expression. The RCC also sought to broaden its spheres of activity, for example in education and social work among youth. Kuharić and the RCC hierarchy did not openly involve the church in the Croatian Spring, but they did foster the idea of a centuries-long synthesis between the nation and Catholicism that preserved the Croat nation. This was the same idea upon which Tudjman would later come to rely. In 1970 Archbishop Kuharić held the first annual public commemorations of Stepinac in an "unofficial Croatian national holiday - Cardinal Stepinac's Day." ${ }^{514}$ After the Croatian national movement was suppressed in 1972, "the Church became the only driving force of Croatian ethnic nationalism," so much so that even secular nationalist leaders became practicing Catholics. ${ }^{515}$

\footnotetext{
${ }^{512}$ Ramet, "Catholic Church" 193.

${ }^{513}$ Appointed in 1970, Šeper's successor, Archbishop Cardinal Franjo Kuharix (1919-2002) was more of an activist "Kuharić is devoted to the memory of Stepinac and makes an occasion of the special mass celebrated each year on February 10th, the anniversary of his death." Alexander, Triple Myth 73

${ }^{514}$ Perica, "Catholic Church" 59-60.

${ }^{515}$ Perica, Balkan Idols 63.
} 
In 1980 the Croat RCC began the procedures required to beatify

Stepinac. ${ }^{516}$ Another unifying figure was the Virgin Mary, and in 1971 a series of jubilees with Marian elements was inaugurated to establish "The Virgin Mary, Queen of Croats" as "the major religious and national symbol of Catholic Croatia." 517 The SFRY was committed to religious freedom, so the Croatian RCC began to call for greater religious freedoms publicly, while fusing church and nation. $^{518}$

The connection among the historic Croatian kingdom, its leaders, and the $\mathrm{RCC}$ became a focus due to the activities of the Croatian RCC, including the gatherings at Marjija Bistrica and Solin in 1972, the 1975 resumption of the Great Novena (which had begun in 1941), the celebration of "Thirteen Centuries of Christianity in the Croat People," the 1977 commemoration of the first papal visit to Slavic lands 800 years earlier, the 1978 anniversary of the basilica at Biskupija built by King Zvonimir 900 years before, and the 1979 commemoration of the choice of Prince Branimir, 1100 years earlier, that maintained a connection with the

\footnotetext{
516 The Pope visited Croatia in 1994 and again in 1998 to beatify Stepinac. Beatification is the last step in the process of canonization. HINA, "Biography of Cardinal Alojzije Stepinac," Papa 30 Sept. 1998, 18 Nov. $2002<$ http://www.papa.hr/mvijesti/10>. During the fist decade following the collapse of communism the Pope recognized and beatified a number of Catholic religious figures in post-communist countries.

${ }_{517}$ Perica, "Catholic Church" 50.

518 The signing of the Helsinki Accords in 1975 only added credence to the RCC's actions. The Helsinki Accords (1975) were the final Act of the Conference on Security and Cooperation in Europe (CSCE) which was renamed the Organization for Security and Cooperation in Europe (OSCE) in 1995. All European countries except Albania ratified the agreement. This set a precedent for communist counties, whose citizens began to demand that the rights outlined in the Accords be implemented. The second series of meetings to deal with policy issues of the OSCE was held in Belgrade in 1977-1978.
} 
Church of Rome. ${ }^{519}$ While the RCC was suppressed for years, it built up support through collective action outside of formal politics. ${ }^{520}$ Vjekoslav Perica notes that, between 1975 and 1984, with the celebration of the Great Novena, the jubilee of "Thirteen Centuries of Christianity among the Croat People," the RCC in Croatia publicly celebrated its revisionist history:

The new history symbolically as well as explicitly announced urbi et orbi that the small Croat nation had survived for thirteen centuries, above all thanks to the Catholic Church which together with native ethnic princes in the seventh century C.E. brought the Croats into the "sphere of Western civilization." 521

The jubilee culminated with the Croatian National Eucharistic Congress and Marian congress held at Marija Bistrica, the most prominent pilgrimage shrine in Croatia. With this celebration and the activities surrounding it the RCC cemented the idea that the RCC and the Croatian nation developed through mutual cooperation and support for thirteen centuries, the implication being that the RCC would continue to work for the strengthening of the Croatian nation. ${ }^{522}$

Marija Bistrica, the national shrine dedicated to "the Virgin Mary, Queen of the Croats" hosted Pope John Paul II when he beatified Cardinal Alozije Steipinac

\footnotetext{
${ }^{519}$ Perica, "Catholic Church" 63-67.

${ }^{520}$ By 1981, under Kuharićs' direction, the "Bishop's conference was now in open dispute with the authorities. At their spring meeting the bishops issued a statement denying that they had any political pretensions or wanted social privileges...but they pointed out that the religious freedoms guaranteed by the authorities were often restricted... and they defended the "spontaneous paying of respect," which took place constantly at Stepinac's grave. Alexander, Triple Myth 215. Support for Step inac and the RCC would become closely tied to political mobilization in the 1980s and the 1990 s, when commemorations and beatification of Stepinac took place.

${ }^{521}$ Perica, "Catholic Church" 55.

${ }^{522}$ Perica, Balkan Idols 63-68.
} 
on October $3,1998{ }^{523}$ The shrine continues to be the site of pilgrimages ranging from Assumption pilgrimages to pilgrimages held for different Croatian towns, and even the annual pilgrimage of the Army and Police held on the first Sunday of every October. Beyond pilgrimages, the 1980s saw an increase in church activity, particularly in towns and cities, as well as an increase in the number of church-related ceremonies and rites such as marriages, baptisms, and confirmations. At the same time statistics showed a decline in religiosity among Slovenes and Croats during the 1970 s and mid-1980s. ${ }^{524}$

The communist authorities were not pleased with the greater public role of the RCC during the 1980s. For example, they tried to exploit rifts in the RCC hierarchy, most notably regarding Medjugorje. ${ }^{525}$

When nationalist activity and calls for Croat autonomy again became pronounced in the 1970s and the RCC began to engage in nationalist activity, however, it was independent of the main political forces in the Croatian National

\footnotetext{
${ }^{523}$ A crowd of over 400,000 gathered for the beatification. "Pope Beatifies Controversial Croatian Cardinal," CNN 3 Oct. 1998, 8 Nov. 2002 $<$ http://www.cnn.com/world/europe/9810/03/pope.croatia>.

${ }^{524}$ Ramet, Balkan Babel 153. In the late 1980s and 1990s in Croatia people publicly identified themselves as Catholics and engaged in Catholic ceremonies, but with varying degrees of "identification and meaning." Marijan Valković, "Vera i Moral u Hrvatskoj, Djelomično Izvješće, Opći Uvod," Bogoslovska Smotra 22.4 (1998): 461-467

${ }^{525}$ For more information on the controversy over Medjugore see Mart Bax, Medjugorje: Religion, Politics, and Violence in Rural Bosnia (Amsterdam: VU University Press, 1995). Medjugorje has became one of the most famous Marian pilgrimage sites in the world since the 1981 apparitions of the Virgin Mary in this predominantly Croat inhabited area of Hercegovina (in BiH). On June 24, 1981 six children in Medjugorje reported a vision of the Blessed Virgin Mary (Gospa or the Queen of Peace). The children first reported this vision to the local Franciscan priest, and the Franciscans have ever since interpreted Mary's words as favourable to their continued control of parishes in the region. Neither the communist authorities nor the Mostar Diocese were pleased with this. Medjugorje was opened as a pilgrimage site in 1984.
} 
Movement that was crushed in 1972. This enabled the Croatian RCC to avoid the crackdown that befell these nationalist forces and through the 1980s solidify its role as an institution that could forward Croatian nationalist interests outside of official politics. This attracted the attention of anti-communist forces, particularly of Tudjman, with whom many in the RCC would co-operate. The support from Croatian communities abroad, where "Catholic missions became the foci of social, cultural and religious life" was crucial for the RCC in Croatia, where there were even parishes known as "Deutschemark parishes," where donations from migrants were high. ${ }^{526}$ These donations helped the Croatian RCC to organize outside of the auspices of the state.

In post-communist Croatia the RCC was afforded a place in the political marketplace that it had not enjoyed in the modern era, in large part due to the recognition of Franjo Tudjman, the legitimacy the RCC had enjoyed, and the benefits of ecclesiastical support. Even after Tudjman died the RCC remained an important political institutional actor, winning a privileged role in public life without having to negotiate with others.

\subsection{Conclusions: The RCC and Post Communism in General}

In Slovenia and Croatia, RCC leaders justify their political involvement and demands by appeals to the memories of the traditional or majority religion. Both

${ }^{526} \mathrm{Bax} 41$. 
are considered Catholic countries, and in both countries the RCC acts as if it were, by virtue of institutional tradition and memory, the unquestioned religious option. While in Croatia this held true in the 1990s, with the percentage of Croats and percentage of Catholics increasing between the 1991 census and the 2001 census, in Slovenia the percentage of Catholics has decreased even more dramatically than the population of Slovenes. This points to increasing secularization of Slovenian society that may be have been spurred on by the material claims of the church and its desire to undermine church-state separation through RCC involvement in political matters. As statistician Niko Toš notes, 'Legalization' of the Catholic Church, which as a result enhanced its political and economic influence, did not increase its social prestige. On the contrary, the process seems to have stimulated a new wave of secularization in Slovenia. ${ }^{527}$

At the end of the socialist era the RCC sought the same goals in both Slovenia and Croatia but it was far less successful in realizing its goals in Slovenia than in Croatia. The RCC is a more powerful political institution in Croatia because of popular historical memory, its role in power struggles and war, and the exigencies of party politics in the post-communist era. In memory the RCC is portrayed as an institution that helped preserve a distinct Croatian nation in a region where civilizational, religious and national borders collide. The church in Slovenia,

${ }^{527}$ Niko Toš, Vinko Potocnik, Sergej Flere, Marjan Smrke, Samo Uhan, and Sreco Dragoš, Podobe o Cerkvi in Religiji (na Slovenskem v 90-ih) (Ljubljana: Fakulteta za Duzbene Vede, Centre za Razikovanje Javnega Mnenja in Množičnih Komunikacij, 1999) 229. Based on Slovenian Public Opinion Survey (1969-1999) as well as Slovenian data sets form World Values Survey (1992 and 1995 ) and Religion ISSP module (1991 and 1998) renowned statistician Dr. Niko Toš notes waves of secularization in the $1960 \mathrm{~s}$ and $1970 \mathrm{~s}$, a wave of de-secularization in $1980 \mathrm{~s}$, and a wave of resecularization in the 1990s. 
as in other European nations is invested with a degree of national symbolic significance, as the church of the majority of the population. However, the experience with a clerical party in the early $20^{\text {th }}$ century and the plurality of civil society in the late 1980 s all worked to ensure that the RCC failed to turn symbolic into political influence in the post-communist era.

The influence of the RCC in Croatia did not prompte secularization as it did in Slovenia, although the political, economic, and social influences of the RCC far exceed those in Slovenia. The acceptance of RCC influence on public affairs and its influence in post-communist Croatia speaks to enduring patterns of political history. While there has not been an ancient or modern history of direct and overwhelming RCC political power in Croatia, the influence of the RCC in postcommunist Croatia can be attributed to historical patterns of politics which, to a greater extent than in Slovenia, have relied on ideological claims based on zero sum games and revolutionary change characterized by unreliable enforcement of laws and reliance on traditional and charismatic authority. Franjo Tudjman, "the father of the Croatian nation," and his party, the ruling Croatian Democratic Union (HDZ), focused on Croatia's Catholic and Western heritage as part of a glorious past that would facilitate a decisive move from Yugoslavia and the Balkans to Europe. ${ }^{528}$ This rhetorical and historicist focus on the Catholic Church as key to

\footnotetext{
${ }^{528}$ A preferred Tudjman title was "The Father of the Croatian Nation," oft repeated at major events and in patriotic news. "Dr. Franjo Tudjman-Historian and Statesman," HRT 13 Dec. 1999 $<$ http://www.hrt.org $>$.
} 
Croatia's glorious past and its European future ensured the RCC a position of influence in political affairs. 


\section{Chapter 8: The Establishment of Church-State Relations in}

\section{Concordat Creation}

\subsection{Introduction}

As newly independent states, Slovenia and Croatia both initiated official relations with the Holy See during the 1990s in an effort to gain international recognition. However, subsequent negotiations for concordats and the content of the concordats differed. A concordat is a treaty between a given state and the Holy See that establishes the state's legal responsibilities to the RCC. Concordats are not required from the state's point of view to ensure legal relations with the $\mathrm{RCC}$, as internal legislation regarding church-state relations is able to establish that. ${ }^{529}$ However, the RCC views concordats as a way to ensure international treaty obligations to the Holy See, obligations that can go further in entrenching RCC prerogatives than domestic legislation alone.

The different concordats in Croatia and Slovenia are indicative of widely divergent approaches to policy-making and governance in Slovenia and Croatia,

\footnotetext{
529 "Concordats are the classic form of harmonization of ecclesiastic and civil law; they are international agreements that the Apostolic See concludes with other states." Borut Košir, "Legal Concept of the Chruch Property," State and Chruch: Selected Historical and Legal Issues, International Conference June 21-22,2001, eds. A lenka Šelih and Janko Pleterski (Ljubljana: Slovenska Akademija Znanosti in Umetnosti, 2002) 575. Dr. Marko Kerševan, sociologist of religion notes that there have namely been three types of concordats; Conciliatory Concordats reached at the end of conflict or strained relations (for example, the concordat of Worms 1122 or the concordat with napoleon after the French revolution reached in 1801); Defensive Concordats as a way to reach international agreements in order to avoid hardship for the RCC, and; Friendly Concordats, which "express mutual inclinations of the state and RCC (for example, the concordat with Austria in 1933). Marko Kerševan, "Sporazumi s Svetim Sedežem in Družbeni Položaj Rimskokatoliške Cerkve (RCK) v Republiki Sloveniji," Carnijev Zbornik (1931-1996): Zbornik Mednarodnih Družboslovnih in Humanističnih Razprav, ed. Alojz Cindrič (Ljublijana: Filozofska Fakulteta v Ljubljani Oddelek za Sociologijo, 1999) 14.
} 
indicating a swifter entrenchment of political liberalism in the former. In both countries the RCC sought to establish broad-ranging legally entrenched state responsibilities as quickly as possible.

In Croatia the RCC was unquestionably established as a symbol of the Croat nation and an institution that had supported Croat independence. ${ }^{530}$ The effect was an absence of debate regarding the concordats based on an ideological commitment to the RCC as a pillar of the nation. ${ }^{531}$ Tudjman's ruling party had even "adopted the social teachings of the Roman Catholic Church as official party doctrine." ${ }^{532}$ Croatia signed four agreements with the Holy See, whereas Slovenia only signed one. ${ }^{533}$

Croatian support for the RCC was presented politically in zero sum terms; in other words, one either supported the demanded privileges of the RCC or was labelled unpatriotic. ${ }^{534}$ The concordats were part of the revolutionary rather than incremental changes that affected Croatian society, because they were simply

\footnotetext{
${ }^{530}$ Prlenda 131-141. "After the collapse of communism the Catholic Church in Croatia again [as it had in ancient times and in WW1I] became a kingmaker...the Church helped the coming-to-power of the nationalistic historian Franjo Tudjman." Perica, Balkan Idols 187.

${ }^{331} \mathrm{ln}$ an official visit to Australia in 1995 Tudjman explained that independent Croatia was established through the "Croatian statehood idea [state right] and the Croatian Church." Alen Anic, "Polemics on the Role of the Catholic Church in Croatia, Aim Press 3 Apr. 1996: . The important place of the RCC in Croatian nationhood, is exemplified by its characterization as "Church in the Croat People," an institution that has time and again been part of Croatian independence. "The Pope's Address to the Pilgrims Concerning his Visit to Croatia in 1994," Vatican 14 Sept. 1994, 3 Dec. $2002<$ http://www.vatican.va>.

${ }_{532}$ Perica, Balkan Idols 190.

533 "Agreement" and "concordat" are used interchangeably here, because concordats are composed of agreements and these agreements have become defacto a concordat.

${ }^{534}$ The Croatian attempt at an omnipotent state has accompanied an "overly politicized Christianity." Ivan Padjen, "The State's Authority in Religious Rights," Croatian Political Science Review 38 (2002): 5.
} 
presented to the public upon their signing. ${ }^{535}$ This is in contrast to Slovenia,

where debate concerning the only concordat signed was fierce and wide ranging. ${ }^{536}$

The debate included those with an ideological conception of the RCC as a national

symbol, along with those who saw the issue in terms of the legal requirement of

church-state separation. ${ }^{537}$ The consideration of this issue led to a more incremental

change, with the Slovenian state signing a concordat regarding legal relations

alone. The concordats in Croatia are particularly important, as they entrenched

RCC privileges in education and public finances and complicated church-state separation.

Throughout the early 1990 s the Croatian government secretly and hastily negotiated four agreements with the Holy See. ${ }^{538}$ These agreements were made in a zero sum manner, with the state negotiating agreements that were only presented to the public once they were signed, with little to no opportunity for open debate to influence changes. ${ }^{539}$ These agreements were sigend on the basis of an official ideology that saw the RCC as a critical supporter of the Croat state both in the

\footnotetext{
${ }^{535}$ The timing of the ratification agreements was also felicitous, the agreements were ratified in November 1998, just days before the Papal beatification of Cardinal Stepinac in Croatia. ${ }^{536}$ Matija Grah, "Marko Kerševan, v Strahu je Tudi Država," Delo 27 Nov.1999 15.

${ }^{537}$ Dejan Pušenak, "Dva Pogleda na Vatikanski Sporazum, A: Še Več Nejasnosti, B: Nič Novega, Delo 7 Dec. 2001: 9. Anton Stress, "Naš Komentar, Sporazum: Da Ali Ne," Družina 12 Dec. 1999: 3.

${ }^{538}$ The Holy See is subject to international law, while the Vatican is not. In most discussions the appellations Holy See and the Vatican are used interchangeably and the agreements are commonly called the Vatican agreements.

${ }^{539}$ Feral Tribune, editorial, 2 Sept. 2000: 781.
} 
present era and in the past. ${ }^{540}$ The Croatian Holy See agreements were widely criticized for violating the constitutionally stipulated separation of church and state as well as the equality of individuals and religious communities. ${ }^{541}$ Some even view them as endangering the sovereignty of the Croatian state. ${ }^{542}$

Given the European Union requirements for religious equality, the government of Croatia in light of the agreements with the Holy See had little choice but to undermine the separation of church and state even further in the name of equality and to sign similar agreements with other religious communities, including the Serbian Orthodox Church, the Islamic community, and a number of Protestant churches in Croatia, a process started only in December 2002. ${ }^{543}$

While similar criticisms have been levelled at the agreement in Slovenia, the circumstances of its creation and its contents reflect a greater application of open debate, incrementalism, and a focus on pragmatic policy requirements consistent with principles of secular equality and church-state separation. In Slovenia, at various times negotiations have been held in-camera, but key discussions have been made public throughout the process. Civil society actors

\footnotetext{
540 "The Pope's Address to the Pilgrims Concerning his Visit to Croatia in 1994," Vatican 14 Sept. 1994, 3 Dec. $2002<$ http://www.vatican.va>.

${ }^{541}$ Nikola Orčolić, "Razgovor s Ivanom Padjenom," Kana 31 July 1999: 5.

${ }^{542}$ Zoran Daskalović, "Vatikanska Zavjera," Feral Tribune 10 Feb. 1997: 3.

${ }^{543}$ Republic of Croatia, "Ugovor Između Vlade Republicke Hrvatske i Islamske Zajednice u Hratskoj o Pitanjima od Zajedničkog Interesa," Narodne Novine 176/03 <http://www.nn.hr>.
} 
have also been diverse and strong enough to force public debate at times when the government was not necessarily forthcoming. ${ }^{544}$

Pervasive open public debate has affected the process so much that the government of Slovenia only signed one Agreement on Legal Questions with the Holy See in December 2001, ratified by the National Assembly in January $2004 .^{545}$ Even when the agreement was initialled after vigorous debate, the concern of maintaining separation of church and state meant that there was extensive involvement of the Constitutional Court in reviewing the agreement. In contrast, Croatia in 1996 signed and by February 1997 ratified three agreements with the Holy See: the Accord of Juridical Questions, the Accord on Co-operation in the Educational and Cultural Field, and the Accord on Religious Assistance to the Catholic Members of the Armed Forces and of the Police. ${ }^{546}$

In 1998 the fourth agreement between Croatia and the Holy See, the Accord on Economic Questions, was ratified. This chapter will discuss the creation and content of the concordats, with a focus on the Slovenian proposed agreement on legal issues and the Croatian Accord on judicial questions. The focus here is on the general legal foundation of RCC-state relations, since the subsequent chapters

\footnotetext{
${ }^{544}$ Dejan Pušenjak, "Hvala Bogu za Krivica," Delo 18 Nov. 1999: 18.

${ }^{545}$ Republika Slovenija, Ministarstvo za Zunanje Zadeve, "Sporazum med Republiko Slovenijo in Svetim Sedežem o Pravnih Vprašanjih," EVA (2002): 1811-2004.

${ }^{546}$ All of the agreements between the Holy See and Croatia were officially printed in the following volume that was released in 2001 and is used as the main source in this paper: Nedjelko Pintarić, Ugovori Izmedju Svete Stolice i Republike Hrvatske, eds. Nikola Eterović and Josip Bozanić (Zagreb: Glas Koncila, 2001). Separately the agreements were also published in the official gazette: Narodne Novine 02/97, Dodatak Medjunaroni Ugovori 03/97; Narodne Novine 02/97; Narodne Novine 03/97; Narodne Novine 18/98 <http://www.nn.hr>.
} 
regarding education and finance include discussions of educational and

financial issues that the concordats set out.

\subsection{The Croatian Agreements}

To secure a mutually beneficial relationship between the state and the RCC, Tudjman's regime made haste to enshrine domestic RCC privileges in agreements with the Vatican that covered social, political, and economic life. In the modern era, Croatia enforced the Austrian Concordat of 1855, which secured the rights and freedoms of the RCC and guaranteed that all Catholic youth would be educated "in conformity with the doctrine of the Catholic religion." ${ }^{547}$ This Concordat de facto remained the main reference point for church-state relations until WWII. ${ }^{548}$

In the 1930s and until its final defeat in the National Assembly, the Kingdom of Serbs, Croats, and Slovenes attempted to negotiate a concordat with the Holy See. ${ }^{549}$ The Yugoslav government signed the concordat, but was unable to get the parliament to ratify it due to opposition of the Serbian Orthodox Church. ${ }^{550}$ Although the Yugoslav government signed a Protocol with the Holy See in 1966, it

${ }^{547}$ Ivan Padjen, "Church and State in Croatia," Law and Religion in Post Communist Europe, eds. Silvio Ferrari and Elizabeth Sewell (Trier: European Consortium of Church and State Research, 2003) 2.

${ }^{548}$ Padjen, "Church and State" 3.

${ }^{549}$ Šanjek 448-449. Karl Bonutti, "The Unratified Concordat between the Kingdom of Yugoslavia and the Holy See of 1935," State and Chruch: Selected Historical and Legal Issues, International Conference June 21-22,2001, eds. Alenka Šelih and Janko Pleterski (Ljubljana: Slovenska Akademija Znanosti in Umetnosti, 2002) 461-477.

${ }^{550}$ In opposition to the concordat, the prominent bishop of Žića, Nikolaj Velimirović, in 1937 proclaimed that "Serbian national consciousness is awakened because it resists the attack form all internationalists and those who build bridges for the pope of Rome and his Church- the oldest international, the oldest fascism, the oldest dictatorship in Europe." Perica, Balkan Idols 19. From Nikolaj Velimirović, "Konkordatska Borba 1937 Godine," Vladika Nikolaj: Izabrana Dela, Kniiga XII, eds. Ljubomir Ranković, Radovan Bigović, and Mitar Milovanović (Valjevo: Glas Crkve, 1997) 310 . 
did not move to establish a concordat. ${ }^{551}$ It was with independence that the issue of the concordat arose again.

Croatia's agreements with the Holy See were ratified by 1997 and 1998 and were so comprehensive that the Holy See considers them a benchmark for future concordats. ${ }^{552}$ Despite unease among a small minority of parliamentarians concerning the implications of the ratification of the agreements for Croatian society, $75 \%$ of the House of Representatives in Croatia voted to ratify the agreements. ${ }^{553}$ By that time, Catholicism had de facto become the state religion and had become so closely related to Croatian identity and the HDZ that actions deemed against the RCC were simultaneously interpreted as unpatriotic. ${ }^{554}$ As a U.S. State Department report noted in 1999 ,

While there is no official state religion, the dividing line between the Roman Catholic Church and the State was often blurred, and the ruling party throughout the period covered by this report attempted to identify itself closely with the Catholic Church. ${ }^{555}$

The very act of creating concordats, which afforded the RCC rights that other religious communities did not enjoy, violated Article 41 of the Croatian

\footnotetext{
${ }^{551}$ Marija Čipić Rehar, Priprava, Sprejem in Pomen Protokola Med SFRJ in Svetim Sedežem (Ljubljana: Institute za Novejso Zgodovino, Prispevki za Novejso Zgodovino, 2002) 7.

${ }^{552}$ Daskalović 3.

${ }^{553}$ For a detailed account of the process of ratification see Gojko Marinković, "Assembly Votes Contrary to the Constitution," Aim Press 28 Feb. 1997, 7 Apr. $2001<$ http://www.aimpress.org>. ${ }^{554}$ Gojko Marinković, "Assembly Votes Contrary to the Constitution," Aim Press 28 Feb. 1997, 7 Apr. $2001<$ http://www.aimpress.org>.

${ }_{555}$ The report went on to note that "religion and ethnicity are so closely intertwined in the country that it is difficult to distinguish between ethnic discrimination and religious discrimination against Serbs, who are Orthodox Christian and against Bosniak Muslims." United States of America, "Report on Religious Freedom: Croatia," Department of State 9 Sept. 1999, 18 Dec. 2002 $<$ http://www.state.gov>.
} 
Constitution, which provides for equality of all religious communities before the law and their separation from the state. ${ }^{556}$ The preamble of the agreements even stated that Catholicism is the religion of the majority of Croats, and that the RCC does not just have a historical role, but a vital role in current social matters as well. $^{557}$

\subsubsection{Secrecy and Swiftness}

By all accounts, the agreements between the HS and RH were products of strong political will as well as quick negotiation and ratification. ${ }^{558}$ Secrecy and disregard for open debate crucial to liberal parliamentary politics facilitated this speed. ${ }^{559}$ Negotiations were seamless, with Tudjman's HDZ directing the process, and the small circle of secret negotiators robbing potential critics of material with which to question the deliberations. Only a small circle of church, state, and HDZ insiders were informed of the negotiations leading to the first batch of three agreements. Fewer still were aware of the terms of these agreements, and an even smaller group was involved in drawing them up. ${ }^{560}$

Only when it came to the ratification of the first three agreements were the majority of Sabor members informed of the negotiations and the content of the

\footnotetext{
${ }^{556}$ Padjen, "Church and State" 4.

${ }^{557}$ Pintarić 35

558 Toni Gabrić, "Bog i Hrvati D. D.” Feral Tribune 2 Nov. 1998: 20-23.

${ }^{559}$ Concordats generally take a much longer time to negotiate. The concordat with Italy in 1984 was considered relatively speedy with only 18 years of negotiation. Alternatively, for example, the 1978 Spanish concordat took decades, even though it was a revision of the 1953 concordat. Dejan Pusenjak, "V Sensi Vatikanskega Sporazuma," Delo 12 Dec. 2001: 19.

${ }^{560}$ Davor Gjenero, personal interview, 18 June 2002.
} 
agreements, at which point they were requested to ratify them immediately.

Ivan Milas, a leader of the right-wing faction of the HDZ, criticized the secretive proceedings of the first three agreements with the Holy See, stating: "The contract is not a (sacred) cow, so that it would be forbidden to talk about it." ${ }^{" 561}$ There was little open public dissent upon the presentation of ratified agreements, as most saw them as a fait acompli. Four years after the ratification of the fourth agreement some voices publicaly questioned the agreement, coinciding with the September 2001 release of the book entitled State Agreements between the Holy See and Croatia, which contained the text of all agreements. ${ }^{562}$ In December 2001 the Croatian government backed away from its promise to rein in the obligations set by the Tudjman regime for state financial support of the $\mathrm{RCC}$ because of pressure from the RCC, which compounded the silencing of criticisms.

\subsubsection{Silencing of Criticisms}

Secular opponents contended that these agreements disadvantaged the RH relative to the RCC and weakened state sovereignty while exclusively benefiting the Vatican. Debate in Croatia was not as focused or as effective as in Slovenia for a number of reasons. Firstly, the agreements were presented as a zero sum game, without space for public debate. Secondly, there are far more points of contention

\footnotetext{
${ }^{561}$ Gojko Marinković, "Assembly Votes Contrary to the Constitution." Aim Press 28 Feb. 1997, 7 Apr. $2001<\mathrm{http}: / / \mathrm{www}$.aimpress.org>.

${ }^{562}$ Mladen Pleše, "The State Firmly Committed Itself to Unconditionally Fulfilling All the Controversial Issues in the Controversial Contracts between Croatia and the Vatican," Nacional 12 Dec. 2001, 19 Sept. $2002<$ http://www.nacional.hr>.
} 
in HS-RH agreements, so opposition was not as focused as in Slovenia. Thirdly, critics of the agreements were often dismissed as anti-church and/or anti-Croat. These are damaging insults in Croatia. For example, in a pre-Christmas press conference Archbishop Bozanic chastised those who argued that the agreements could privilege canon law over state law by stating that the "mentality is that from [the] Socialist Revolution, communists, in Soviet Union endeavour to realize one new legal system... where the central committee has all things right."

Račan's 2000 government was elected on a platform of rolling back the privilege not only of the RCC but the army and the police as well. Yet, this mandate was difficult to fulfil and was not fulfilled in the realm of church-state relations. Račan's government was more interested in protecting itself from attacks by Catholic bishops than responding to the discontent of citizens, who were increasingly voicing criticism of the agreements after 2001. The Račan government was pressured from the right wing and the RCC, which at every turn opposed the fledgling new government. In October 2001 the European Union ambassadors urged the Vatican to "put pressure on the Catholic Church in Croatia to moderate its opposition to the centre-left government. ${ }^{9564}$ However, an even stronger antigovernment message was sent in November 2001 by the Croatian Bishop's Conference (HBK) in the "Message from the Croatian bishops on the current social

\footnotetext{
${ }^{563}$ Ivanka Toma and Darko Pavičić, "Sukob Bozanić-Zunec: Je Li Ugovor Vatikana i Hratske Neustavan," Jutarnji List 5 Jan. 2002: 27.

${ }^{564}$ Dragutin Hedl, "Clerics Attack Government," Balkan Crisis Report, Institute for War and Peace Reporting 2 Nov. 2001, 2 Feb $2002<$ http:/www.balkanpeace.org/rs/archivenov01>.
} 
situation in Croatia." $" 565$ This made it difficult for the post-Tudjman government to address sensitive issues such as the concordats, lest they be accused of being anti-Croat or neo-communist.

Some secular critics of the agreements in Croatia expressed a fear that Canon Law, by virtue of the agreement on legal issues, could be privileged. Defenders of the agreements in Croatia responded in the same way as their Slovenian counterparts: the agreement merely reiterated the rights, responsibilities, freedoms, and guarantees that the Croatian constitution already afforded to all religious groups. ${ }^{566}$ Jure Radić, head of the government delegation, signatory of the accords, and former vice prime minister, stated that "the majority of laws in Croatia are on the line of the Gospel," and therefore the agreements do not alter the status $q u o .^{567}$ If this were the case, then why would such an extensive concordat composed of four agreements be necessary?

Even more than in Slovenia, an examination of the clauses of the Accord on Juridical Relations, reveals that this agreement, even in the absence of the three other agreements, grants the RCC certain rights and responsibilities that could infringe on state authority and privilege the RCC in comparison to all other social groups.

\footnotetext{
565 "Message from the Croatian Bishops on the Current Social Situation in Croatia," Croatian Bishop's Conference 7 Nov. 2001, 18 Sept. $2002<$ http://www.hbk.hr>.

566 Jure Radić, personal interview, June 2002.

${ }^{567}$ Gabrič, 21.
} 
There was some criticism of the agreement from within the HDZ and the RCC in Croatia. Vice Vukojevic of the HDZ resented the sudden presentation of the agreements on the eve of the elections. ${ }^{568}$ However, the strongly proagreement faction of the HDZ, informally headed by Dr. Jure Radić, the lead government negotiator of the agreements, easily overshadowed Vukojevic. ${ }^{569}$ There were also divisions within the RCC among clergy, nuns, monks, and lay theologians. Some argued that the agreements were driven exclusively by the few bishops in the Croatian Bishops' Conference led by Josip Bozanić, Archbishop of Zagreb and the president of the Croatian Bishops' Conference. An outspoken critic of church involvement in politics, Fra. Bono Zvonimir Sagi decried lack of debate and prevalence of secrecy within the church with regards to these agreements. ${ }^{570}$

Lower level church officials were simply not consulted, and consequently their concerns were not addressed in the agreements. Another complaint was that church involvement in high politics would only damage the reputation and prestige of the RCC, as well as endanger the sovereignty and independence it desired. ${ }^{571}$ One of the Croatian RCC's mottos is "Slobodna Crkva u slobodnoj državi"(Free Church in a Free State); in this case the motto is used not to recognize the power of secular authorities, but rather to infer that the church and state should have equal,

\footnotetext{
${ }^{568}$ Darko Pavičič, "Ključni Dogovori Hrvatski i Vatikana," Panorama 24 May 1995: 21.

${ }^{569}$ Daskalović 3.

${ }^{570}$ Bono Zvonimir Šagi, "Crkva u Postkomunizmu," Vijenac 86 (1997): 151-179.

${ }^{571}$ Ivan Grubišić, "Zagubljeno Kršćanstvo," Čovjek Nadasve 2 (Split: Knjižnica Dijalog, 2001) 91 93.
} 
parallel powers. ${ }^{572}$ The RCC hierarchy in Croatia argues that all four

agreements with the HS and RH are essential to ensuring this freedom. ${ }^{573}$

Many provisions of the agreement are contentious. However, critique can

be grouped into concerns over how the agreements were reached and their content, namely breaching church-state separation and enhancing religious inequality.

Clauses debated most often included the primacy of cannon law, the separation of church and state, the financial obligations of the state, and religious instruction in public schools.

\subsubsection{Canon Law and the Separation of Church and State}

Article one of the RH-HS accord notes the sovereignty and independence of the HS and RH. However, as in the Slovenian agreement, critics wondered whose sovereignty and independence would prevail in the case of conflict. ${ }^{574}$ Archbishop of Sisak and Papal nuncio of Ukraine, monsignor Nikola Eterović, in the commentary that supplemented the Croatian Bishops' Conference (HBK)/Glas

\footnotetext{
${ }^{572}$ Ivan Ugrin, "I Veliki Petak-Neradni Dan!?" Slobodna Dalmacija 7 Dec. 1996: 3.

573 Živko Kustić, "Dva Ugovora u Jednome," Glas Koncila (25 October, 1998): 5.

${ }^{574}$ Article 2, which recognizes the legal character of the RCC, is also similar to Article 2 in the Slovenian agreement as are the critiques of it, namely why the RCC should be afforded this status. The RCC defends this status by referring to canon law, in particular canon 113: "The Catholic Church and the Apostolic See have the status of a moral person by divine disposition;" 114: "Aggregates of persons or of things which are directed to a purpose befitting the Church's mission, which transcends the purpose of the individuals, are constituted juridical persons" the purposes include "works of piety, of the apostolate or of charity, whether spiritual or temporal;" 116: "Public juridical persons are aggregates of persons or of things which are established by the competent ecclesiastical authority so that, within the limits allotted to them in the name of the Church and in accordance with the provisions of law, they might fulfil the specific task entrusted to them for the public good. Other juridical persons are private." Catholic Church, Code of Canon Law: A Text and Commentary (New York: Paulist Press, 1985). The question remains, however, of why canon law should have bearing on the legal order of the Republic of Croatia or Slovenia.
} 
Koncila publication of the agreements in 2001, defended the recognition of the sovereignty and independence of the Catholic Church and $\mathrm{RH}$ because of the essentially different foundations of both institutions. He noted that the state was based on the will of the people, especially in democratic societies, whereas the Church was based on the teachings of Jesus Christ and the salvation of souls. ${ }^{575}$ This line of argument leads to the conclusion that since both institutions work to forward the common good, they should each be granted independence and sovereignty to reach it. Archbishop Eterović notes that both church and state in Croatia have corresponding priorities in "total human development," particularly in spiritual and material dimensions. ${ }^{9576}$ However, critics worry that these two "independent and sovereign" bodies have conflicting definitions of the common good. ${ }^{577}$ Is the RCC afforded the same rights as the sovereign and independent state of Croatia? Or, in order to ensure harmony, would the state be beholden to the same code of canon law that governs the Church?

Critics argue that the equal footing of canon law and state law, as the agreement prescribes, could endanger Croatian state sovereignty and play a role in obstructing legislative and regulatory prerogatives of the Croatian state, particularly with regards to the $\mathrm{RCC} .{ }^{578}$ For example, Article 1 of the accord reiterates the

\footnotetext{
${ }_{575}^{575}$ Pintarić 147.

${ }^{576}$ Pintarić 147.

577 Darko Pavičić, "Crkva Kao Država," Obzor 15 Feb. 1997: 14. See Esad Ćimić, "Graniće Pravne Regulative-Graniće (Ne)Slobode," Crkva i Država u Društvima u Tranziciji, ed. Ivan Grubšić (Split: Nkjižnica Dijalog, 1997) 223-226.

${ }^{578}$ As legal expert Ivan Padjen notes, "Since art. 134 of the Constitution states that 'international agreements concluded and ratified in accordance with the Constitution and made public, and which
} 
independence and sovereignty of RH and HS, where the HS will respect the laws of RH but will act in accordance to the laws of the Holy See. ${ }^{579}$ The former Supreme Court Judge and later member of Parliament, Vladimir Primorac, argued that these agreements already impinge on Croatian sovereignty through acknowledging the jurisdiction of church courts and by creating a "superficial immunity" of the Church in Croatian courts. ${ }^{580}$

Some of the most controversial legal concessions are included in Articles 7 and $8 .^{581}$ For example, Article 8 of the RH-HS accord states that competent Church authorities must be informed prior to investigation of clerics for possible criminal acts and reiterates that "confession of secrets is in all situations inviolable." ${ }^{" 82}$ This gives the RCC hierarchy privileges that are not afforded other religious groups. Moreover, this begs the question of why the RCC hierarchy and the executive powers of the RCC would have the right to be first informed of possible investigation of those to whom they delegate power. Would this mean that the hierarchy could be informed of such investigations before the person under investigation? Would this also allow the RCC authorities to intervene against such

are in force, shall be part of the domestic legal order of the Republic of Croatia and shall have legal force superior to law,' the treaties with the Holy See are superior even to Croatian organic laws, which are adopted by a qualified majority of votes in the Croatian Parliament." Padjen, "Church and State" 4-5. However, he does go on to note that the agreements, although still unconstitutional by virtue of their call for negotiation rather than third party mediation, make the treaties more "similar to memoranda of understanding or gentlemen's agreements." Padjen, "Church and State" 5. ${ }^{579}$ Padjen, "Church and State" 148.

${ }^{580}$ Gojko Marinković, "Assembly Votes Contrary to the Constitution," Aim Press 28 Feb. 1997, 7 Apr. $2001<$ http://www.aimpress.org>.

${ }^{581}$ According to Canon Law 265, a cleric "must be incardinated in a particular church, or in a personal Prelature, or in an institute of consecrated life or a society which has this faculty: accordingly, acephalous or 'wandering' clergy are in no way to be allowed." Catholic Church. 582 Pintaric 95. 
an investigation or even obstruct it? These questions are not answered by the text or by the HBK.

The second paragraph of Article 8 stipulates: "Confession of secrets is in all situations inviolable." ${ }^{583}$ This is in harmony with canon law 982 , which states: "The sacramental seal is inviolable. Accordingly, it is absolutely wrong for a confessor in any way to betray the penitent, for any reason whatsoever, whether by word or in any other fashion. ${ }^{.584}$ The $\mathrm{RH}$ is thus obliged to abide by this article of canon law, even in matters where criminal proceedings would be hindered. This clause affords the RCC a special type of immunity. ${ }^{585}$

Provisions in Article 11 raised concerns that the RCC could operate beyond the bounds of state legislation. The article stipulates that diocesan bishops have the exclusive rights to decide where and how Church objects should be built. ${ }^{586}$ While it is noted that decisions should be made in consultation with competent $\mathrm{RH}$ bodies, the RCC has much political clout as well as state money backing up their building projects. This left many municipalities powerless to challenge the RCC. This political clout can be seen in the difficulties that other religious organizations have in obtaining building permits. ${ }^{57}$

\footnotetext{
${ }^{583}$ Pintarić 96.

${ }^{584}$ Eterović notes that concordats with Spain, Germany, Italy, Austria, Portugal, and Gabon contain similar clauses. Pintarić 167.

${ }_{585}$ Article 7 also notes that competent authorities of the state are only allowed to be and/or pursue activities in church spaces without the prior notification of competent RCC authorities in the case of extreme emergencies. Pintarić 65.

${ }^{586}$ Pintarić 66.

${ }^{587}$ Muslim Community has been trying to build since 1982. A location permit was first issued in 1991 , but local opposition to the mosque and bureaucratic and financial obstacles combined over the
} 
Some wait for years for permits to conduct celebrations in public, while the RCC has no similar delays. As Journalist Zoran Daskalovic notes, the RCC is able to "be manifest in the public spaces" (in terms of public celebrations and construction) without special permits or even permission, while other groups must seek out special permission and are often left without it. ${ }^{588}$ Beyond this, the RCC has been able to fund many of their projects through state finance. ${ }^{589}$ State financing of the RCC will be further discussed in Chapter ten, Finance and Property Restitution. ${ }^{590}$ However, it should be noted that Article 17 of the Accord on Juridical Questions specifies that the Republic of Croatia is obliged to provide monetary help for Church establishments, which are engaged in work that contributes to the "general good [of] society." 591 This leaves much for interpretation and provides the RCC with rights that are not afforded to other religious groups. The preamble of the first agreement recognizes the historical and current role of the RCC in Croatia, much like the preamble to the Slovenian agreement, but it goes further by stating that the "majority [of] citizens [of the]

years to delay the project. Although the location must again be approved and construction permits issued, officials within the Muslim community expect construction to begin in early 2004 . United States of America, "International Religious Freedom Report, 2003, Croatia," Department of State, Bureau of Democracy, Human Rights and Labour 18 Dec. 2003, 19 Dec. 2003 $<$ http://www.state.gov>. Released by the Bureau of Democracy, Human Rights and Labor, December 18, 2003. Robert Bajruši, "Skandal Oko Gradnje Islamskog Centra u Rijeci," Nacional 16 Oct. 2001, 19 Sept. $2002<$ http://www.nacional.hr>.

${ }^{588}$ Daskalović 3.

${ }^{589}$ Mirjana Grce, “Hrvatska Izmedju Europskih Modela," Novi List 20 Sept. 1998: 18.

${ }^{590}$ See Nikola Eterović, "Ugovor Izmedju Svete Stolice i Republike Hrvatske o Gospodarskim Pitanjima," Crkva u Svijetu (1999): 178-94.

${ }^{591}$ Paragraph one and two of Article 17 also stipulate that the Catholic Church may freely organize establishments for charity work and social care. The Church works according to its own statutes that "have the same rights and privileges that state establishments established [for the] same purposes." Other religious groups lack the benefit of such regulations. Pintarić 52. 
Republic [of] Croatia belong to [the] Catholic Church. ${ }^{, 592}$ It is not just the inclusions in the agreements that are disputed, but the precedents that these agreements set. Article 18 of the Accord on Juridical Questions states that all unresolved issues should be resolved diplomatically by both parties. ${ }^{593}$ Many of the articles can have multiple interpretations, some of which could privilege the RCC in Croatia and in the process widen the gap between the rights and responsibilities given to the RCC and those afforded other religious communities or social institutions.

To counter criticisms, the RCC continuously points to examples of other states that have concluded agreements. ${ }^{594}$ Officials usually isolate clauses from other concluded concordats similar to the Croatian agreements, to prove the validity of the Croatian concordat. ${ }^{595}$ They argue that other states would not have agreed to the concordats if the RCC were gaining any power at the expense of the civil society. ${ }^{596}$ For example, Eterović points to the concordats with Italy and Gabon, which state that the church and state are sovereign. ${ }^{597} \mathrm{He}$ states that there have been no impacts on those two states. This argument is disingenuous, since the power of a Concordat is derived from all of its clauses. Also, the implementation and interpretation of clauses differs according to political will and circumstances.

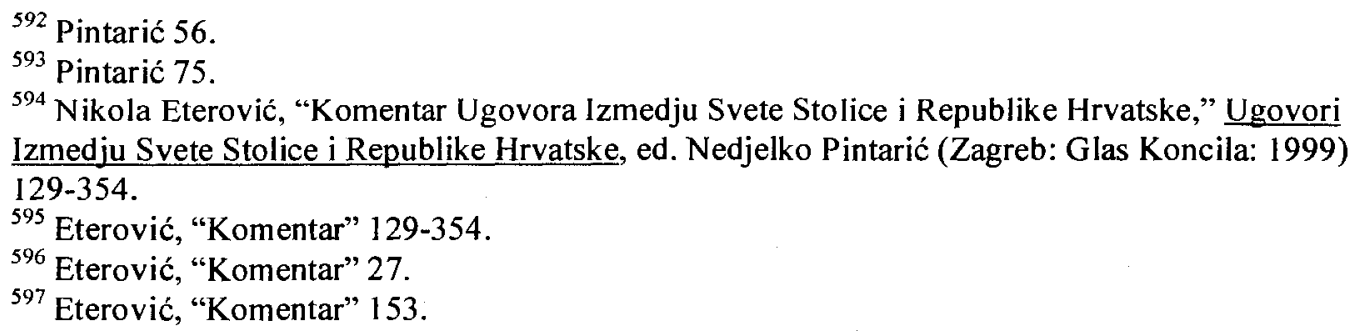


As Padjen notes, it does not matter that other countries might have similar provisions; what matters is that this agreement is against the Croatian constitution. ${ }^{598}$ In particular, Article 41 of the constitution calls for the separation of church and state as well as the equality of all religious communities.

The Tudjman regime relied on the RCC as an organization for political support. In turn, the RCC in Croatia benefited from this arrangement in many areas, particularly in education and finance, as is further discussed in Chapters nine and ten of this paper. The Accord on Juridical Questions and the others that accompanied it in 1996 solidified the position and, some argue, further opened the Croatian state to the political influence of a de facto state church, as witnessed by the funding and legal concessions granted by the accords.

Critics who warned against canon law overriding Croatian law argue that the agreement only makes specific reference to two articles of the Croatian constitution (Articles 40 and 41), while noting the need for compliance with the Second Vatican Council and the whole body of canon law. Article 40 of the Croatian Constitution stipulates: "Freedom of conscience and religion and freedom to manifest religion and other convictions shall be guaranteed." ${ }^{599}$ Article 41, the second article mentioned in the accord, is controversial in itself, because it can be interpreted as contradicting itself. It states: "All religious communities shall be

\footnotetext{
${ }^{598}$ Gojko Marinković, “Assembly Votes Contrary to the Constitution," Aim Press 28 Feb. 1997, 7 Apr. $2001<$ http://www.aimpress.org>.

${ }^{599}$ Republic of Croatia, "Constitution of the Republic of Croatia," Official Gazette 56 (135/97, $113 / 2000,124 / 2000,28 / 2001$ ). Padjen, "Church and State" 4.
} 
equal before the law and shall be separated from the State. ${ }^{.600}$ It further obliges the state to "protect and assist" all religious communities in the activities that they are free to perform, including performance of religious services as well as the establishment and management of educational, social, and charitable institutions. ${ }^{601}$ The type and scope of assistance is not stipulated in the Constitution. However, from independence until December 2002, the RCC was the exclusive beneficiary of state economic assistance, and since 2002 it has still received the most economic assistance of any religious group in Croatia, as it was only in 2002 that any state financial assistance was promised to other religious groups. ${ }^{602}$

\subsubsection{Agreements with Other Religious Communities}

The Croatian government had a comprehensive list of agreements and obligations with the RCC by 1998, while it lacked even a basic law for the recognition and registration of all other religious communities until July $2002 .{ }^{603}$ Up until that point the Croatian Law on the Legal Position of Religious Communities of 1978 "was nominally still in force." ${ }^{.604}$ While the socialist era law

\footnotetext{
${ }^{600}$ Republic of Croatia, "Constitution of the Republic of Croatia," Official Gazette 56 (135/97, 113/2000, 124/2000, 28/2001).

${ }^{601}$ Republic of Croatia, "Constitution of the Republic of Croatia," Official Gazette 56 (135/97, 113/2000, 124/2000, 28/2001).

${ }^{602}$ Sin iša Pucić, "Ugovor Hrvatske Republic of Croatia, "Constitution of the Republic of Croatia," Official Gazette 56 (135/97, 113/2000, 124/2000, 28/2001). Sinaša Pucić, "Ugovor Hrvatske Vlade s Predstavnicima Islamske Zajednice i Srpske Pravoslavne Crkve," Novi List 21 Dec. 2002.

${ }^{603}$ Republic of Croatia, "Zakon o Pravnom Polažaju Vjerskih Zajednica," Narodne Novine 83/02 <http://www.nn.hr>.

${ }^{604}$ Padjen, "Church and State" 3. Republic of Croatia, "Zakon o Pravnom Polažaju Vjerskih Zajednica," Narodne Novine 83/02 <http://www.nn.hr>, amended by Article 138, "Zakon o Novanim Kaznama," Norodne Novine 83.02 (1993).
} 
recognized the juridical personality of religious communities, guaranteed the freedom to establish religious communities, and provided legal protection of religious communities, it did not "establish criteria for either founding or identifying a religious community. ${ }^{, 605}$ The 2002 Law on the Legal Position of Religious Communities established the registration procedures for all religious communities. ${ }^{606}$

The RCC was the only religious community to have an agreement with the state until 2002. This blatant inequality informed the stumbling blocks for Croatian accession to the European Union, and the government sought to address this. ${ }^{607}$ However, in the name of equality the government further undermined the separation of church and state by initiating a process of similar agreements with other religious communities. As the Serbian Orthodox Metropolitan of ZagrebLjubljana and Italy, Jovan Pavlović, noted this decision was made to enhance Croatia's chances at gaining entry into the European Union. ${ }^{608}$ This choice was made because it would have been difficult for the government to renege on the generous agreements with the Holy See, for fear of an RCC backlash. The

${ }^{605}$ Ibid. 5.

${ }^{606}$ Republic of Croatia, "Zakon o Pravnom Polažaju Vjerskih Zajednica," Narodne Novine 83/02 $<$ http://www.nn.hr>.

${ }^{607}$ As did Pope John Paul II when he met with representative of the Jewish, lslamic, Serbian Orthodox and Protestant communities "and called for ethnic reconciliation and peacefully coexistence... [encouraging] the Croatian government to meet the conditions for full European integration." Nicole Lindstrom, "European Integration and Ethnic Reconciliation in Croatia and Serbia," Niarchos Roundtable on Overcoming Religious Nationalism in the Balkans (City: Woodrow Wilson International Center for Scholars, 2003). Both the government and the Pope called on the RCC in Croatia to support improved relations with other religious communities as well as cooperation with the International Criminal Tribunal for the Former Yugoslavia.

608 "Račan Potpisao Ugovore sa SPC-om i Islamskom Zajednicom u Hrvatskoj," HINA 20 Dec. 2003, 7 Jan. $2003<$ http://www.hina.hr>. 
government had already sustained criticism from the $\mathrm{RCC}$, including that by

lower clergy. The lower clergy feared life after HDZ and under former communists, who might not respect the role of the RCC. ${ }^{609}$

In September 2000 the Bishop's Conference issued a statement that criticized the government for not honouring Croatian war veterans for defending the homeland. ${ }^{610}$ An even stronger anti-government message was sent in November 2001 by the Croatian Bishop's Conference (HBK) in the "Message on the Current Social Situation [in Croatia]." 611 Indeed, between 2000 and 2002 the RCC issued numerous letters, sermons, and speeches delivered by all levels against the Račan regime, its supposed anti-patriotism, and its betrayal of Croat-Catholic values and interests. $^{612}$

The Račan government did not dispute the RCC agreements, but the Deputy Prime Minister and Chair of the Croatian Government Commission on Relations with Religious Communities noted that the RCC had a privileged position and that

\footnotetext{
${ }^{609}$ Editorial Comment, Slobodna Dalmacija 3 Mar. 2000, 8 Apr. 2003 $<$ http://www.slobodnadalmacija.hr $>$.

610 "Hrvatski Biskupi Izražavanju Zabrinutost za Obstanak Države," Slobodna Dalmacija 23 Sept. 2000,9 Jan. $2001<$ http://www.slobodnadalmacija.hr>.

${ }^{532}$ Dragutin Hedl, "Clerics Attack Government," Balkan Crisis Report, Institute for War and Peace Reporting 2 Nov. 2001, 2 Feb $2002<$ http://www.balkanpeace.org/rs/archivenov01 >. The HBK Message was formally created to commemorate the 110th anniversary of Pope Leo the XIII's 1891 encyclical Rerum novarum, and it reiterated Pope Leo the XIII's themes of social justice in its calls for regular pay, higher employment, and increased rights and funds for pregnant women, the sick, elderly, and the poor. Borisav Jelinić, "Catholic Social Policy and the 'Sins of Structure," Nacional 15 Nov. 2001,2 Oct. $2002<$ http://www.nacional.hr>. However, it added concerns for preservation of the legacy of the Homeland War and, in the current difficult political environment, "has only further increased the tensions in the already troubled relations between the Catholic Church and the governing coalition, and has aroused yet another strong shake up among the governing five parties. Mladen Pleše, "Open War: Bozanić and Račan," Nacional 15 Nov. 2001, 19 Dec. 2002

$<$ http://www.nacional.hr>.

${ }^{612}$ Perica, Balkan Idols 196-197.
} 
something would have to be done to address this. ${ }^{613}$ At no point, however, was the government challenging the RCC agreements. The government merely suggested that actions needed to be taken to provide for greater equality among religious communities. ${ }^{614}$

Once it was clear that the Račan government would not challenge the RCC, Church criticism became muted. Few politicians in Croatia have been willing to counter the RCC, with most seeking to court its support. "Račan did not indicate that he intended to question the Tudjman cult and the Church's privileged status in society. ${ }^{, 615}$ Therefore, the only way to ensure equality between religious communities was to entrench government support further, to get even more involved in religious affairs, and to increase religious community involvement in public affairs and institutions.

In 2002 the Račan government finally signed less elaborate and less generous agreements with the Islamic community and the Serbian Orthodox Church and in 2003 with a number of Protestant and Orthodox churches. ${ }^{616}$ Agreements have been signed with the Reformed, Evangelical, Pentecostal Churches, Christian Adventist Church, Baptist Churches, Church of God, Church of Christ, and the Reformed Movement of Seventh-Day Adventists (July 2003). In October 2003, the Macedonian and Bulgarian Orthodox Churches signed

\footnotetext{
${ }^{613}$ Knevic, D. Goran Granić interview, "Katoliče Cervka Privligenieara ugovorm s Vatikonom," Jutarnji List 7 Oct. 2000: 6.

${ }^{614} \mathrm{Ibid}$.

${ }^{615}$ Perica, Balkan Idols 196.

${ }^{616}$ Republic of Croatia," Narodne Novine 196/03 <http://www.nn.hr>.
} 
agreements. ${ }^{617}$ Although agreements were signed with smaller denominations in 2003 , these agreements generally amount only to legal recognition and ability to work in public institutions such as hospitals and prisons. ${ }^{618}$ All of the agreements were part of a series of moves that the Croatian government undertook to improve its image regarding religious and minority rights and to meet the requirements of EU integration. ${ }^{619}$

The signing of the agreements with the RCC was not done with much foresight, as the agreements locked the government into a special legal and financial relationship with one religious community ${ }^{620}$ Once the inequality of religious communities became a stumbling block in the quest for EU membership, the government was forced to reach similar agreements with other religious communities. This precedent of the agreement with the Holy See has ensured that the division of church and state in Croatia will be further eroded. As Bishop Endre Langh of the Reformed Church noted, there was no need for agreements with religious communities, but since

the previous government brought in the Catholic Church by the back door with their agreement, the state has to maintain - at least formally - that it is secular. That's why it decided to introduce agreements with other communities. $^{621}$

\footnotetext{
${ }^{617}$ Republic of Croatia, "Ugovor Između Vlade Republicke Hrvatske i Islamske Zajednice U Hratskoj o Pitanjima od Zajedničkog Interesa," Narodne Novine 176/03<http://www.nn.hr>. ${ }^{618}$ Republic of Croatia, "Ugovor Između Vlade Republicke Hrvatske i Islamske Zajednice U Hratskoj o Pitanjima od Zajedničkog Interesa," Narodne Novine 176/03 <http://www.nn.hr>. ${ }^{619}$ Pucić. Namely, to meet the Copenhagen Criteria. European Union "Copenhagen Criteria" Europa $<$ http://www.eruopa.eu>.

${ }^{620}$ Toma and Pavičić 27.

${ }^{621}$ Branko Bjelajac, "Free Churches Unhappy over Government Agreements," Forum 1 May 2003, 22 July $2003<$ http://www.hrwf.net>.
} 
The first step towards achieving agreements with communities/institutions other than the Catholic Church was a basic law and regularized processes through which to recognize the legal status of religious communities. The 2002 Law on the Legal Status of Religious Communities outlined the legal position of recognized religious communities in Croatia. ${ }^{622}$ The January 2003 Regulation on Forms and Maintaining Records of Religious Communities in Croatia outlined the registration requirements for religious communities that sought to be covered by the Law on the Legal Status of Religious Communities. ${ }^{623}$ For example, the religious community in question had to have existed as a recognized association for more than five years and had to have more than 500 members. ${ }^{624}$ However, registration and recognition under the law on the Legal Status of Religious Communities did not automatically confer the same benefits that the Catholic Church had in Croatia. Rather, the Law on the Legal Status of Religious Communities specified that the benefits provided by the state for various religious denominations, for example grants for their work or pensions for their clerics, had to be worked out through discrete agreements between the government and the religious community in question. ${ }^{625}$ However, since each community had to negotiate a separate deal with the Republic of Croatia,

\footnotetext{
${ }^{622}$ Republic of Croatia, "Zakon o Pravnom Polažaju Vjerskih Zajednica," Narodne Novine 83/02 <http://www.nn.hr>.

${ }^{623}$ Republic of Croatia, "Ispravak Pravilnika o Obrascima i Nacinu Vođenja Evidencije Vjerskih Zajednica u Republici Hrvatskoj," Narodne Novine 12/03 <http://www.nn.hr>.

${ }^{624}$ Republic of Croatia, "Zakon o Pravnom Polažaju Vjerskih Zajednica," Narodne Novine 83/02 <http://www.nn.hr>.

${ }^{625}$ Republic of Croatia, "Zakon o Pravnom Polažaju Vjerskih Zajednica," Narodne Novine 83/02 <http://www.nn.hr>.
} 
equality was also in question because there was no standard agreement. The concessions won by a given religious community might not be won by another.

Each agreement, of the ones signed in December 2003 included divergent provisions, with the RCC maintaining the most extensive agreement with the most concessions. Most religious communities were enthusiastic about the agreements, despite the fact that they are not standardized. As Drautin Matak, president of the Adventist's Adriatic Union Conference, noted:

We appreciate the opportunity to have our needs regulated, to help us function in a more proper way...we're smart enough to see we can't have the same status as the Holy See. ${ }^{.626}$

The separate agreements between the Republic of Croatia and the Islamic Community (Islamska Zajednica, IZ) and the Serbian Orthodox Church (Srpska Pravoslavna Crkva, SPC) were the most extensive post-2002 agreements, however they were not as extensive as the agreements with the Holy See. One difference between these agreements and the one with the Holy See is that these agreements do not deal with property restitution. However, these agreements provided salaries and pensions for clerics, paid for religious instruction in public schools, legally recognized marriages preformed in these churches, and made provisions for access to the state media. ${ }^{627}$ However, the RCC continues to enjoy approximately 10 hours of state media coverage per month for their events, while other communities

\footnotetext{
${ }^{626}$ Branko Bjelajac, "Free Churches Unhappy over Government Agreements," Forum 1 May 2003, 22 July $2003<$ http://www.hrwf.net>.

${ }^{627}$ Republic of Croatia, "Ugovor Između Vlade Republicke Hrvatske i Islamske Zajednice U Hratskoj o Pitanjima od Zajedničkog Interesa," Narodne Novine 176/03 <http://www.nn.hr.
} 
receive 10 minutes or less per month. ${ }^{628}$ The agreements also ensure that the state will provide funds for cultural and other social endeavours of the churches that contribute to the social good and that are in line with existing laws. ${ }^{629}$ The Serbian Orthodox Church, Islamic Community, and certain Protestant Churches can now all perform marriage ceremonies as civic ceremonies. ${ }^{630} \mathrm{~A}$ very important aspect of the agreements is that the IZ and SPC have the right to undertake religious education in elementary schools, middle schools, and kindergarten establishments. $^{631}$

The agreements with the Serbian Orthodox Church and Islamic Community stipulate that the state will "guarantee material conditions for religious work" in state educational, correctional and health institutions. ${ }^{, 632}$ To this end, the state has committed to fund the Serbian Orthodox Church and Islamic community. Articles 22 and 23 of both agreements stipulate that in exchange for working towards the "greater good," the two religious communities will, from the state budget, be provided with two average salaries for each parish and community. ${ }^{633}$ A parish or

\footnotetext{
${ }^{628}$ United States of America, “International Religious Freedom Report, 2003, Croatia," Department of State, Bureau of Democracy, Human Rights and Labour 18 Dec. 2003, 19 Dec. 2003 $<$ http://www.state.gov>.

${ }^{629}$ Republic of Croatia, "Ugovor Između Vlade Republicke Hrvatske i Islamske Zajednice U Hratskoj o Pitanjima od Zajedničkog Interesa," Narodne Novine 176/03 <http://www.nn.hr>.

${ }^{630}$ Narodne Novine 176/03.

${ }^{631}$ Narodne Novine 176/03.

${ }^{632}$ Narodne Novine 176/03.

${ }^{633}$ Narodne Novine 176/03.
} 
community is stipulated as consisting of more than 1500 members in urban areas and more than 500 members in rural areas. ${ }^{634}$

The agreements with the Serbian Orthodox Church and the Islamic community also call for publicly funded religious instruction in public kindergartens, elementary and secondary schools if there are over seven students whose parents or guardians give written consent. ${ }^{635}$ Children over 15 years of age are allowed to provide their own written consent. The extent to which these measures have been implemented with regards to the Islamic community and the Serbian Orthodox Church is yet to be seen. However, concerns with the role of the church in educational institutions and state funding of clerics in terms of the new agreements were all contentious issues that had not yet been dealt with in vigorous political debate in terms of the agreements between the Holy See and the Republic of Croatia. ${ }^{636}$ Through the agreements, select government-sanctioned religious communities have been granted access to the public educational system through which they can easily influence youth.

Although the government led by President Stipe Mesić and Prime Minister Ivica Račan sought to dislodge the networks of political intrigue and systemic inequalities that built up during the years of $\mathrm{HDZ}$ rule, the church-state relationship

\footnotetext{
${ }^{634}$ Narodne Novine $176 / 03$.

${ }_{635}^{63}$ Narodne Novine $176 / 03$

${ }^{636}$ Although there were very public criticisms of the agreements, leading politicians did not seriously consider arguments against the RCC agreements. Gabrić 23 .
} 
proved difficult to modify. As Historian Vjeran Pavlaković notes, it was Don.

Ivan Grubišić's impression that

the HDZ has destroyed Croatia's chances for recovery and democratization in post communism... [and] no government will find it easy to get rid of the church-state symbiosis as one of the forms of the new authoritarianism. ${ }^{637}$

On the one hand, the government has found it impossible to renege on this series of international agreements, but on the other hand it has been called upon by the EU to provide the same kinds of privileges to all other religious communities in

Croatia. It took until 2002 for the government to create the most basic law on religious communities that addresses the legal situation of religious communities other than the RCC.

The accord on juridical relations, like the three other agreements with the Holy See, promoted the inequality of religious groups prohibited by the Croatian Constitution and violated the separation of church and state prescribed by Article 41 (1). ${ }^{638}$ The sovereignty and independence of the RCC noted in Article 1 of the Accord on Juridical Relations, along with the "legal character" of the RCC noted in Article 2 particularly, ignore the aforementioned provisions of the Croatian constitution. ${ }^{639}$ The international agreements with the Holy See, by virtue of their ratification by the parliament, have been brought into the Croatian legal order even

\footnotetext{
${ }^{637}$ Verjan Pavlaković, introduction, Nationalism, Culture and Religion in Croatia since 1990, ed. Vjeran Pavlaković (Seattle: The Donald W. Treadgold Papers, the Henry M. Jackson School of International Studies, University of Washington, 2001) 9 .

${ }^{638}$ Republic of Croatia, "Constitution of the Republic of Croatia," Official Gazette 56 (135/97, 113/2000, 124/2000, 28/2001) Article 41.1.

${ }^{639}$ Toma and Pavičić 27.
} 
though they are unconstitutional. ${ }^{640}$ This, combined with the unwillingness and inability re-examine the RH-Holy See agreements and the drive for greater religious equality, ensured that the constitutional requirements of religious equality and separation of church and state are not met.

\subsection{The Slovenian Agreement}

Agreements with the RCC were not rushed in Slovenia as they were in Croatia, in part because the popular and political desire for RCC support was absent and because RCC's political involvement was not as pervasive and exclusive as in Croatia. ${ }^{641}$ The Slovenian concordat process began in secret but was brought into the public domain for intense debate and consideration. ${ }^{642}$ The same broad critiques of the Agreement on Legal Questions with the Holy See plagued the agreement from the initiation of negotiations through to the 1999, 2000, and the final 2001 version that was ratified by the National Assembly on January $28^{\text {th }}$, $2004{ }^{643}$ The Agreement was only ratified after it received approval through the Constitutional Court, a process that began in January 2002 and ended in early January 2004. Proceeding incrementally, the Court took measures to ensure that the agreement did not violate the constitutional sovereignty of Slovenia and the

\footnotetext{
${ }^{640}$ Toma and Pavičić 27.

${ }^{641}$ Grce, "Hrvatska" 10.

${ }^{642}$ Meta Roglič and Sonja H. Vogrič, "Vatikanski Sporazum, Njega Križi in Težave," Dnevnik 15 December 2001. Pušenjak 9. Mavtež Krivic, "Razlike Med Novemberskim in Januarskim Tekstom," paper from personal collection, (2000) 4.

${ }^{643}$ Republic of Slovenia, "Zakon o Ratifikaciji Sporazuma med Republiko Slovenijo in Svetim Sedežem o Pravnih Vprašanjih," Uradni List 12 Feb. 2004, 17 Oct. 2004 <http://www.uradnilist.si>.
} 
constitutional stipulation of separation of church and state, particularly since there were serious public disputes regarding these matters. ${ }^{644}$

Some of the main points of debate concerned the violation of the constitutional stipulation for separation of church and state, the subordination of Slovenian law to canon law, the equality of religious communities in Slovenia, the need for an agreement, and possible future obligations of the Slovenian state to the RCC. ${ }^{645}$ While these remained the most prominent concerns regarding the agreement, scrutiny ranged from questioning why this agreement was necessary to critical deconstructions of each sentence, from the preamble to the final sentence of the agreement. ${ }^{646}$ Significantly, these criticisms were taken seriously ${ }^{647}$ The Agreement on Legal Questions with the Holy See provides little more than the legal recognition to the church. There is little obligation on the part of the Slovene state to extend privileges to the RCC that are not afforded to other religious communities or that challenge church-state separation. ${ }^{648}$

Most of the debate surrounding the treaty focused on possible readings of the text. ${ }^{649}$ However, the facts that such a debate existed and that such care was

\footnotetext{
${ }^{644}$ Mavtež Krivic, personal interview, June 2002. Republic of Slovenia. "Constitution of the Republic of Slovenia," Uradini List 33/91-I (1991).

${ }^{645}$ Mavtež Krivic, personal interview, June, 2002.

${ }^{646}$ Srečo Dragoš, personal interview, May 2002.

${ }^{647}$ Grce, "Hrvatska"' 18.

${ }^{648}$ Republic of Slovenia, "Zakon o Ratifikaciji Sporazuma med Republiko Slovenijo in Svetim Sedežem o Pravnih Vprašanjih," Uradni List 12 Feb. 2004, 17 Oct. 2004 <http://www.uradnilist.si>.

${ }^{649}$ Ranka Ivelja, "Sporazum Je Lahko za Zagled," Dnevnik 16 Nov. 1999, 20 Dec. 2000

$<$ http://www.dnevnik.si>.
} 
taken in negotiating an agreement that respected equality and the rule of law speak to the influence of liberal norms and practices in Slovenia.

\subsubsection{Debate and Consideration}

Slovenia's first post-communist government, a one-bloc coalition led by Lojze Peterle, much like Tudjman's government, sought the favour of the RCC, identified itself with the interests of the Church, and promoted Catholic values and norms. ${ }^{650}$ However, from 1992-2004, the Slovene Government has been dominated by coalitions led by the centre-left Liberal Democratic Party (LDS).

The LDS governments have focused on economic and political liberalization, which includes separation of church and state. ${ }^{651}$ However, recognizing the interests of some, including right-wing coalition members, in establishing a concordat, the governing LDS initiated negotiations with the Holy See in $1996{ }^{652}$ The negotiations for the concordat proceeded slowly, were limited to a few specific issues, and were without the numerous concessions to the Holy See that Croatia offered.

To placate right-wing coalition members, the centre-left coalition in Slovenia had initiated secret negotiations with the Vatican to develop an accord on

${ }^{650}$ Rudolf M. Rizman, "Radikalna Desnica na Slovenskem,” Teorija in Praksa 2 (1998) 249-270.

${ }^{651}$ Jernej Pikalo, "Vrnitev (Ali Samo Vztrajanje) Levice na Slovenskem," Demoktratični Prehod I, eds. Danica Fink Hafner and Miro Haček (Ljubljana: Fakulteta za Družbene Vede, Knjižna ZbirkaProfesija, 2000) 204-209.

${ }_{652}$ Spomenka Hribar, "Stoletno Vprašanje-Duverenost Duha," Mladina 6 Dec. 1999: 12. 
the legal position of the RCC in Slovenia. ${ }^{653}$ In Slovenia, the intent was to accept only the text in secret initially, and then to introduce it for public debate and consideration by the constitutional court. However, the text was leaked to the media by a former constitutional court judge before a draft text was settled upon. ${ }^{654}$ In February 1999, Justice Minister Tomaž Marušič and Bishop Dr. Anton Stres, representatives of the government, and representatives of the church negotiation team, announced the completion of a draft agreement. ${ }^{65}$ On 11 November 1999 the Accord on the Legal Position of the Roman Catholic Church in the Republic of Slovenia was signed and became the basis for final negotiations on the Agreement Between the Republic of Slovenia and the Holy See on Legal Issues. ${ }^{656}$ Days later the text was leaked and intense public debate ensued ${ }^{657}$ After fielding unexpected criticisms, the text was re-negotiated. In early 2000 the

\footnotetext{
${ }^{653}$ Hibar 12.

${ }^{654}$ Janez Pogorlec, personal interview, May 2002.

${ }^{655}$ Grah, "Marko Kerševan" 15.

${ }^{656}$ Republic of Slovenia, Sporazuma med RS in Svetim Sedežem o Pravnih Vprašanjih (Ljubljana: Republic of Slovenia, 1999). This proposed agreement between the HS and RS on legal questions must be differentiated form the 1999 Accord between the Government Commission RS for the Resolution of Open Questions with the Roman Catholic Church and the Commission of the Slovenian Bishop's Conference to Settle Relations with the State. Republic of Slovenia, Soglasje: Komisije Vlade Republike Slovenije za Rešitev Odprtih Vprasanj Rimskokatoliske Cerkve in Komisije Slovenske Škofovske Konference za Ureditev Odnosov z Drzavo (Ljubljana: Republic of Slovenia, 1999). This agreement is similar to the 2000 Agreement on the Legal position of the Evangelical Church in RS. Republic of Slovenia, Sporazum o Pravnem Polozaju Evangelicanske Cerkve v Republiki Sloveniji (Ljubljana: Republic of Slovenia, 2000). The Evangelical Church, lead by Ernis Geza, in Slovenia denotes the Lutheran church, as it is the Protestant church with the most adherents in Slovenia, 19,000 members.

${ }^{657}$ Mavtež Krivic, personal interview, 2002.
} 
government slightly revised the text. ${ }^{658}$ This time, however, the text was

subject to vigorous parliamentary debate before the signing. ${ }^{659}$

While in the midst of the debate, the government signed the new text and sent it to the Constitutional Court of the Republic of Slovenia to ensure the constitutionality of the agreement and to clear the path for ratification. The process was interrupted by the April 2000 vote of no confidence for the LDS-led coalition (pushed through by 55 of the 90 members of parliament). The struggle to create an agreement with the Holy See did not save Drnovšek's coalition, which was brought down by the withdrawal of the right-wing Slovene People's Party. This led to a right-wing government, headed by Dr. Andrej Bajuk. The so-called "parties of the Slovenian spring" (named this way because they emerged during the Slovene Spring in the late 1980s and early 1990s) which formed this government included Dr. Bajuk's New Slovenia (Nsi, established August 2000), the newly merged Slovene Peoples Party and Slovene Christian Democrats (SLS+SKD, merged April 2000), and the Social Democratic Party (SDS renamed the Slovenian Democratic Party in 2003).

In the midst of this political change, negotiations concerning the agreement were put aside until October 2000. The rationale for the delay was that Bajuk's

\footnotetext{
${ }^{658}$ Vesna Vukovic, "Vatikanski Sporazum," Dnevnik 10 Mar. 2000, 8 Jan 2001 $<$ http://www.dnevnik.si>.

${ }^{659}$ The largest difference between the 1999 and 2000 versions was that Articles 4 and 10 of the 1999 version were erased. Article 10 stated that the RCC had the right to "establish and administer schools of all types and levels," and that the "state will support these institutions in the same conditions, as it supports other similar kinds of private institutions." Krivic, "Razlike" 11.
} 
government would have a stronger mandate for negotiating the agreement if they won the elections scheduled for later that year. ${ }^{660}$ In an effort to ensure a positive election result, Bajuk's government did not wish to provoke the heightened public opposition that would predictably result from flaunting close ties with the RCC. However, Dr. Bajuk's government was soundly defeated in the October 2000 elections by the LDS, which won 34 seats in the National Assembly out of the 88 seats up for contestation. ${ }^{661}$ Dr. Janez Drnovšek was again elected Prime Minister.

Dr. Bajuk and his colleagues in the Spring Parties were unable to realize pro-church initiatives, including the swift conclusion of the Slovenian-Vatican agreement. However, the vote of no confidence and the brief right-wing government gave an incentive to Dr. Drnovšek's government to renew negotiations with the Holy See in December $2000 .^{662}$ In April 2001 coalition disputes over the Slovenian-Vatican agreement became the source of another potential coalition break-up. The United List of Social Democrats (ZLSD), which opposed the draft

\footnotetext{
${ }^{660}$ Roglič and Vogrič 14. Agreements with the Holy See take longer than six months to negotiate. Bajuk's government did make steps towards closer relations with the Holy See by signing the agreement on Religious Services for Military Personnel. The same year a similar ageement was signed with the Evangelical church in Slovenia. Changes in the Law on Defence, less than two years later, provided military personnel with the right to Catholic, Orthodox, Protestant, or Muslim religious services were incorporated. United States of America, "Report on Religious Freedom: Slovenia," Department of State 7 Oct. 2002, 18 Dec. $2002<$ http://www.state.gov>. The LDS victory is commonly perceived as in part a reaction to the massive human resources changes, namely the replacement of cadres that Bajuk's government initiated in the public service including media, state-owned enterprises, and other government-administrated endeavours.

${ }^{661}$ There are 90 seats in the National Assembly, but two seats are reserved for representatives of the Hungarian and Italian minorities.

${ }^{662}$ Roglič and Vogrič 14.
} 
agreement, lobbied for a national referendum on the agreement and threatened to leave the coalition, although its efforts were ineffective. ${ }^{663}$

The ZLSD and the Slovenian National Party (SNS) remained vocal opponents to the agreement and accused the LDS of ignoring the interests of the majority of Slovenians, enabling the establishment of a state religion, and endangering the sovereignty of Slovenia. ${ }^{664}$ On December 14, 2001 the Agreement on Legal Questions Between the Republic of Slovenia (RS) and the Holy See (HS) was signed. ${ }^{665}$ By the end of the next week, the parliament had accepted the text of the proposed agreement, without the support of the government coalition members of the United List of Social Democrats (ZSLD). ${ }^{666}$

On January 24, 2002 the government sent the initialled Republic of Slovenia-Holy See Agreement on Legal Issues to Slovenia's constitutional court, to ensure that the agreement was constitutionally sound. The agreement's detractors

${ }^{663}$ Ranka Ivelja, "Koalicija se je Lotila Vatikanskega Oreha," Denvnik 18 Jan. 2001, 7 Feb 2001 $<$ http://www.dnevnik.si>.

${ }^{664}$ Prior to the confirmation of the text of the agreement the SNS announced that it will be against the adoption, because the words "represents treason [of] Slovenian national and state interests." "Kaj Vsebuje Vatikanski Sporazum?" STA (Slovenian Press Agency) 10 Dec. 2001, 9 Feb 2002 $<$ http://www.sta.si $>$.

${ }^{665}$ The government delegation included Andrej Grasselli, Undersecretary for the Foreign Ministry; Peter Toš, from the Foreign Ministry; Nina Čož, Director of the Government Office for Religious Communities; Janez Pogorelec, Spokesperson for the Government Office for Legislation; and Peter Kastelic, State Undersecretary for the Foreign Ministry. The Vatican delegation included Edmund Farhat, Apostolic Nuncio in Ljubljana; Franc Kramberger, Maribor Bishop; Dr. Anton Stres, Dean of the Theological Faculty; and Dr. Borut Košir, professor of Theology. Dimitrij Rupel, Slovenian Foreign Minister and Archbishop Jean Louis Tauran, Secretary for the Holy See's relations with states signed the agreement. People who would be expected to be involved in these negations including the Minister of Education Dr. Pavel Zgaga or the Leader of the Government Commission for the Solution of Open Questions with the Roman Catholic Church Tomaž Marušič were not. Ranka Ivelja, "Sporazum Je Lahko za Zagled," Dnevnik 16 Nov. 1999, 20 Dec. 2000 $<$ http://www.dnevnik.si>.

${ }^{666}$ Meta Roglic, "Od Dosežka do Skrpucala," Dnevnik 7 Dec. 2001, 26 Feb. 2002 $<$ http://www.dnevnik.si >. 
argued that the document violated the separation of church and state, fostered inequality of religious groups and individuals, and subordinated Slovene law to canon law. However, the government's attempt to ensure the constitution was respected provoked a new round of already familiar criticisms and some new protests to the proposed agreement. ${ }^{667}$ Even the government's request to the constitutional court to review the text was criticized for being too broad, and the constitutional court appealed to the government to send a more detailed request, one that pointed to the issues that the government wished to have resolved. ${ }^{668}$ In January 2004 the Constitutional Court of Slovenia ruled that the agreement did not violate the Constitution, particularly the separation of church and state, as long as the RCC continued to respect Slovenian legislation. ${ }^{669}$ For example, the RCC was required to continue to operate within Slovenian laws even if it did not accept the legislation, such as in the realm of religious education in public schools. By January 28 the National Assembly of Slovenia ratified the Agreement on Legal Questions between the Republic of Slovenia and the Holy See with a 44 to 12 vote. $^{670}$ The text of the ratified agreement was the same as the agreement signed in 2001 and by most accounts did not change RCC-state relations. However, criticisms regarding the text continue to address general

\footnotetext{
${ }^{667}$ Meta Roglic, "Vlada je Storila," Dnevnik 26 Jan. 2002, 26 Feb $2002<$ http://www.dnevnik.si>. ${ }^{668}$ Meta Roglic, "Vlada je Storila."

${ }^{669}$ Ranka Ivelja, "DZ Danes o Ratificakciji Vatikansega Sporozum," Dnevnik 28 Jan. 2004, 18 Mar. $2004<$ http://www.dnevnik.si>.

${ }^{670}$ Republic of Slovenia, "Zakon o Ratifikaciji Sporazuma med Republiko Slovenijo in Svetim Sedežem o Pravnih Vprašanjih," Uradni List 12 Feb. 2004, 17 Oct. 2004 <http://www.uradnilist.si>.
} 
concerns regarding the separation of church and state. The RCC also continues to criticize the agreement as not going far enough and reiterates that key issues with the $\mathrm{RCC}$ in Slovenia have not been resolved. ${ }^{671}$ Even with the ratified agreement, it is important to note the key issues debated during the years of negotiations, because these debates influenced the final agreement. The final agreement in Slovenia was more cognizant of liberal requirements than the agreements in Croatia, since important foci as discussed in the sections below included separation of church and state, the role of Slovene and canon law, and concerns about inequality.

\subsubsection{Separation of Church and State}

The President of the Slovenian group the Society for Constitutional Law, Dr. Ivan Kristan, argued in 1999 that beyond specific constitutional dilemmas this agreement would represent a particular disregard for standards of equality. ${ }^{672}$ Furthermore, he asserted that "any agreement that endangers the separation of the church and state should not even be considered. ${ }^{.673}$ This objection was magnified by the fact that the agreement would be an international agreement that empowers a foreign sovereign state and its laws. Days after the government accepted the text of the Agreement on Legal Issues, on 11 November 1999, Matevž Krivic, the former Slovenian Constitutional Court Judge and one of the most vocal critics of the

${ }^{67 t}$ STA, "Slovene Parliament Ratifies Vatican Aagreement," Delo 28 Jan. 2004: 6. STA, interview with Foreign Minister Dimitrij Rupel, Radio Television Slovenia 7 Jan. 2004.

${ }^{672}$ Ivan Kristan, "Readers Letter," Dnevnik 9 Mar. 2000, 30 Jan. $2001<$ http://www.dnevnik.si>.

${ }^{673}$ Ivan Kristan, "Readers Letter." 
agreement, gave voice to concerns that became politically influential. ${ }^{674}$

According to Krivic and most other people who have openly expressed their

disaffection with the agreement, the agreement is simply not needed and by its very existence infringes on the constitutional separation of church and state. ${ }^{675}$ As Ranka Ivelja reported, "current parliamentarians and ministers agree that "in quiet" this [the agreement] has opened the door to the church taking over what are state responsibilities. ${ }^{, 676}$

Article 14 of the agreement stipulates that the "Republic of Slovenia and the Holy See will further endeavour [to] resolve all open questions, that are not subject of this agreement. ${ }^{9677}$ This puts the RCC in a special bargaining position vis-à-vis RS legislation or proposed legislation that no other religious or other community in Slovenia holds. The RCC has since independence in 1991 expressed interest in influencing issues as diverse as health care and education, and through this agreement it could obtain that influence. A major issue that most critics recognize is that this proposed HS and RS agreement opens the door to further political and policy influence of the RCC, particularly in the realms of education, culture, and

\footnotetext{
${ }^{674}$ The agreement was still secret at that time, but Dr. Krivic received a copy and almost immediately made his concerns public. See Matevz Krivic, "Pravno Mnenje o Besedilu Sporazuma med RS in Svetim Sedežem o Pravnih Vprašanjih Odobrenem na Seji Vlade Dne 11, 1999," Dnevnik 13 December 1999: 4 and Matevz Krivic "Spodnje Pirnice," Dnevnik 1999: 16. ${ }^{675}$ Pušenak 9.

${ }^{676}$ Ranka Ivelja, "Sporazum Je Lahko za Zagled," Dnevnik 16 Nov. 1999, 20 Dec. 2000 $<$ http://www.dnevnik.si>.

${ }^{677}$ Republika Slovenija 1811-2004.
} 
institutions such as hospitals and the military ${ }^{678}$ Ivan Kristan maintains that the RCC does possess the right to propose legislative changes. Instead, it should only be able to do so "according to normal internal democratic process as equal subjects of civil society," with the same rights and responsibilities as other religious or nonreligious groups. ${ }^{679}$

\subsubsection{Canon Law and Slovene Law}

One of the most pervasive critiques of the agreement concerns potential subordination of Slovenian state law to canon law in certain matters. In analyzing the 1999 text, Krivic argued that some articles in the agreement put into question whether Slovenian law would be supreme over canon law in certain disputes. ${ }^{680}$ Subsequently, the agreement was changed to include a clause which states that actions must be in harmony with the legal order of the RS. However, the recognition of canon law as applicable even alongside Slovene law still leaves some critics concerned. The agreement could be interpreted as allowing the elevation of canon law to an equal status with Slovenian law, as each is described as independent in Article 2 of the agreement. This leaves open the question of which would prevail in circumstances where they might differ. Krivic questions the equality of the status afforded to the Slovenian legal order and the legal order of the

\footnotetext{
${ }^{678}$ Article 12 stipulates that the Catholic Church reserves the right to carry out pastoral care in "hospitals, old age homes, prisons and other institutions," in which it is difficult for individuals to move freely." Republic of Slovenia, "Sporazuma med RS."

${ }_{6879}^{67 v a n ~ K r i s t a n, ~ " R e a d e r s ~ L e t t e r, " ~ D n e v n i k ~} 9$ Mar. 2000, 30 Jan. $2001<$ http://www.dnevnik.si>. ${ }^{680}$ Krivic, "Pravno" 5.
} 
Holy See, as the text of the agreement only mentions the need to be cognizant in two Articles (Articles 7 and 14) of the constitution, while it mentions the need of the agreement to be in harmony with all of the resolutions of the Second Vatican Council and all of articles of canon law. ${ }^{681}$ Krivic points to the possibility of overlooking important aspects of the Slovenian legal order. Some argue that the ultimate primacy of Slovenian state authority should be explicitly stated somewhere in the agreement, not simply implied by requiring church actions to respect the Slovenian legal order. ${ }^{682}$

Furthermore, some fear that the recognition of the jurisdiction of canon law and the empowerment of the Holy See could endanger Slovene sovereignty by allowing the possibility of the primacy of canon law. For example, in Article 4 the Church is afforded "exclusive authority for reestablishment, change and abolition of Church structures," along with the stipulation that no diocese [of the] Catholic Church in [the] Republic of Slovenia will contain territory, which is outside of the borders of the Republic of Slovenia, and no part of the territory [of the] Republic of Slovenia will belong to territories, whose seat is outside of the Republic of Slovenia. ${ }^{683}$

Dr. Dragoš has concerns that this clause is not related to religious activity. He also wondered whether the RS would be obliged to ask permission of the RCC

\footnotetext{
${ }^{681}$ Article 7 of the constitution states: "The state and religious communities shall be separate. Religious communities shall enjoy equal rights; they shall pursue their activities freely." Republic of Slovenia, "Constitution of the Republic of Slovenia," Uradini List 33/91-I (1991).

${ }_{682}$ Krivic, "Pravno" 5. Also see the government's response to Krivic: Tone Dolčič, "Pravno Mnenje G. Krivica v Zvezi s Sporazumom med Rpubliko Slovenijo in Svetim Sedežem o Pravnih Vprašanjih," Vlada Republike Slovenije, Služba za Zakonodajo 21.9 (1999).

${ }^{683}$ Republic of Slovenia, "Zakon o Ratifikaciji Sporazuma med Republiko Slovenijo in Svetim Sedežem o Pravnih Vprašanjih," Uradni List 12 Feb. 2004, 17 Oct. $2004<$ http://www.uradnilist.si>.
} 
to incorporate new land acquired from neighbouring countries outside of current Slovenian dioceses. ${ }^{684}$ Like other critics, Dr. Dragoš speculates that the ambiguities of the agreement are in the RCC's interest because they promote the influence of the RCC and canon law in domestic affairs. ${ }^{685}$

\subsubsection{Inequality}

Concern over inequality of religious organizations in Slovenia centres around the fact that the RCC would be the only church with an international treaty. The agreement between the RS and HS would be the most extensive agreement between the Republic of Slovenia and any religious denomination, as it includes specific financial responsibilities of RS to the RCC. For example, Article 11 denotes that state, local, and Church authorities will "co-operate in preserving and maintaining cultural monuments and other cultural goods and archives, which are in Church ownership. ${ }^{.686}$ However, neither the state's exact financial responsibilities for maintenance nor the specific monuments that the church controls are clearly defined.

Srečo Dragoš, an expert in Slovenian church-state relations notes that the monuments could include "the most remote chapels and parish gathering places," including the small roadside chapels that are scattered throughout Slovenia. ${ }^{687}$ This unclear obligation is often defended through equally vague arguments of important

\footnotetext{
${ }^{684}$ Roglič and Vogrič 14.

${ }^{685}$ Roglič and Vogrič 14.

${ }^{686}$ Republic of Slovenia, "Sporazuma med RS" 2.

${ }^{687}$ Meta Roglic and Sonja H. Vogric 14
} 
historical connections between Slovenians and the RCC that can be enhanced by the agreement between the RS and the HS. The preamble of the agreement puts the RCC in a special vaunted category as both a "historic" and "useful" institution for the Slovene people. ${ }^{688}$ It states that there is "centuries [old] historical connection between [the] Slovenian people [folk] and Catholic Church. ${ }^{1689}$ Why such recognition is required and why it would necessitate recognition of the "legal character [personage] of the Catholic Church," is baffling to some critics, including sociologist Dr. Srečo Dragoš. The clear identification of the RCC as a foundational, historically important institution contributes to accusations of inequality, as it implies that the RCC should receive privileges other groups do not have. The reference to the centuries-old connection between the Slovenes and the RCC only adds cultural bias to the inequality of religious groups that would be enshrined in this agreement.

Some question whether the agreement is even required, since the RCC itself maintains that the agreement does not go beyond existing rights and responsibilities, including the rights to religious freedom, as already enshrined in Slovene legislation. ${ }^{690}$ Even legal experts, such as former constitutional court judge Dr. Tone Jerovšek and professor Lovro Šturm, argue that the agreement does not privilege since it merely reiterates elements of the constitution and the European

\footnotetext{
${ }^{688}$ Republic of Slovenia, "Sporazuma med RS" 3.

${ }^{689}$ Republic of Slovenia, "Sporazuma med RS" 3.

${ }^{690}$ Pušenak 9.
} 
Convention on Human Rights. ${ }^{691}$ If the agreement does not change existing legal relations and if there are already guarantees of basic freedoms for all religious communities and individuals in the constitution, an international agreement that simply reiterates them is redundant.

\subsubsection{Future Obligations}

Srečo Dragoš notes that agreements are usually concluded with the intent of enshrining a commonly acceptable solution to a contested question. However, in the instance of these agreements the international agreement precedes concrete questions and thus leaves open the interpretation of obligations of the Slovenian state. In an interview for the Austrian daily newspaper Die Presse, Slovenian Archbishop Dr. Rode argued that what the Slovenian RCC really desires is not simply formal legal recognition but "a whole agreement... For us it goes for [the] role [of the] Church in school, in [the] military and [other] public institutions... If the government is not ready to come to an agreement in the mentioned points, then there certainly will not be an agreement. We have time. ${ }^{, 692}$ Rode did not get all of what he desired in the 2001 text, but Article 14 of the text, which obliges the Republic of Slovenia and Holy See to resolve any future open questions, could provide the means for Dr. Rode to achieve the influence he desires eventually. For

\footnotetext{
${ }^{691}$ Lovro Šturm, “Brez Fig v Žepu," Dnevnik 15 Dec. 2001, 6 Jan. $2002<$ http://www.dnevnik.si>. Foreign minister Rupel noted that the government consulted with legal experts, including those who supported the agreement, including Tone Jerovšek, Franci Grad, and Lovro Šturm, "Vatikanski Sporazum," Dnevnik 10 Mar. 2000, 8 Jan. $2001<$ http://www.dnevnik.si>.

${ }^{692}$ Ranka Ivelja, "Sporazum Je Lahko za Zagled," Dnevnik 16 Nov. 1999, 20 Dec. 2000 $<$ http://www.dnevnik.si>.
} 
example, the RCC could compel consideration of prayer in schools, mandatory yearly funding for the RCC from the state budget, or even changing the seventh article of the constitution that stipulates separation of church and state. Dr Rode has already stated that he hopes to see the agreement "change the interpretation of the seventh article of the Slovene constitution. ${ }^{, 693}$

\subsection{Conclusions}

Slovenia has not gone as far, and its agreement is not as far-reaching, as the agreements in Croatia. In both cases, the agreements have been criticized for their potential threat to state legal and legislative regulations. These threats include possible endangerment of the constitutional principles of separation of church and state and potential subversion of state law to accommodate canon laws that govern the Roman Catholic Church. These challenges to liberal democracy are not simply a question of special legal prerogatives, but prerogatives that threaten state neutrality and plurality through inequality of religious communities and individuals.

Denominations other than the RCC have consistently been faced with systemic discrimination, particularly in Croatia. The four agreements, however, transform these systemic inequalities into internal legal obligations as part of

${ }^{693}$ Ranka Ivelja, "Pa Če Koza Crkne?" Dnevnik 14 Dec. 1999, 30 Jan. 2001 $<$ http://www.dnevnik.ca>. Rode has on numerous occasions spouted fiery rhetoric on the desires of the RCC. Another example of this was when he declared that "this school is not our school," that the $R C C$ will never agree with the school system, and "when we have a different $D Z$...the results [would be] in the palm of our hand." Tomaž Mastnak, "Ni Nas Šola," Dnevnik 29 Mar. 2000, 29 Jan. $2001<$ http://www.dnevnik.si>. 
formal international treaties. While religious communities other than the RCC in Croatia do not have as many concessions when it comes to media time, funds, or the return of expropriated property, for example, most recognize these governmentsponsored moves as contributing to greater respect for religious differences and freedoms. Despite many improvements, however, widespread discrimination remains, particularly against ethnic Serbs, not only within communities but also within state institutions. This is especially true when it comes to the justice system with regards to returning Serbian pre-war homes. The extent to which the agreements with other religious communities will improve the equality of these groups is yet to be seen.

What is certain, however, is that all of the agreements have further eroded the separation of church and state. In this respect the Slovenian case better represents liberal norms, both in the ratification and content of the agreement with the Holy See. The process in Slovenia was gradual, involving much debate and revision. The text was changed to address criticisms. However, since the RCC is one of the only religious groups, in either country, that can be a party in international treaty-making, inequality is part of any agreement with the RCC. The result of this is that both in Slovenia and in Croatia the equality of religious groups has been compromised, but to a far greater extent in Croatia than in Slovenia. In an attempt to remedy the situation, the government of Croatia further distanced itself from liberal principles and the separation of church and state prescribed in its own 
constitution through agreements with other religious communities. This still presents a challenge to the equality of religious organizations.

In Slovenia the equality of religious groups has also been challenged, but through a contravention of legislation and poor implementation in isolated cases rather than through treaties and laws established to govern church-state relations. At the forefront of the debate and concerns that influence the legislation of churchstate relations in Slovenia was the concern for the constitutionally stipulated separation of church and state, the primacy of Slovene law, and the equality of religious groups. The same considerations were not there in the Croatian case. 


\section{Chapter 9: Church, State and Education in Croatia and Slovenia}

\subsection{Introduction}

Educational reforms were among the highest government priorities in both independent Croatia and Slovenia. Both countries sought to reform similar systems, but the approach each state took and the changes that were made greatly differed. This chapter compares the debates and decisions on the introduction of religious instruction in public schools in Croatia and Slovenia. Its a contentious issue that both countries were forced to deal with after the collapse of the socialist system. In both countries the RCC remained the most powerful religious institution. The majority of self-identified believers in both countries are Roman Catholic. The RCC has also been invested with historical, symbolic and political importance, as Catholicism is often portrayed and perceived as a constituent part of national identity. However, in Croatia the RCC had a stronger influence in religious instruction in public schools than in Slovenia. The policy process and decisions in relation to religious instruction described in this chapter offer an analysis of educational reform in general with a focus on one aspect of reform, religious instruction in public schools.

The course of educational reform and religious instruction is emblematic of post-communist reforms in both countries. The debate and reform regarding religious instruction in Slovenia was closer to liberal democratic ideals and practices than in Croatia. The process of incremental, pragmatic, positive sum 
reform as practiced by the Slovenian political elite helped realize the liberal prescription of the separation of church and state. On the other hand, the secretive, zero sum and ad hoc reform of religious instruction in Croatia was pushed through by a leader who had little regard for the fine points of liberal reform. Political parties and the ruling political elite occupied an influential institutional position during the initial years of post-communist transformation. The policy decisions of these elites were part of creating a new state apparatus. At the same time, Tudjman's emphasis on historical memory placed the RCC at the center of national preservation and identity in the quest for independence. These circumstances set the stage for educational reforms that would neglect church-state separation in favour of the RCC as both historically important and powerful institution in the Croatian political scene.

In Slovenia, there was a greater focus on meeting the requirements of liberal democratic reform without the same historic and overwhelming focus on state right. In the case of religious instruction in public schools, the reform was longer, more open, wide-ranging, and legally delineated than in Croatia. In the Slovenian reform, the requirements of the law were the primary consideration. The approach adopted in Slovenia was one of incremental reform following extensive consultation and bargaining with experts and stakeholders as well as open public discussion that resulted in a clearly delineated eight-year process of well-defined reform that focused on pragmatic requirements rather than on national re- 
affirmation. Each state's approach to educational reform reflected its degree of commitment to liberal reform. The issue of the Roman Catholic Church's (RCC) involvement in the educational system highlights the different approaches to reform, because in both states the RCC sought to influence educational reform.

The considerable differences in approach to school reform in Slovenia and Croatia are highlighted by the fact that both countries were facing similar challenges in reforming their school systems, as established during the socialist era. Both endeavoured to move away from a focus on vocational-centered education and opted to promote "lifelong learning." ${ }^{694}$ They each had set priorities of adopting a nine-year elementary school program that does not stream children into select programs as early as the previous system, as well as a system that allows choice of optional subjects from the elementary to university level.

The RCC in Croatia achieved much more success in influencing educational reform than the RCC in Slovenia, to the detriment of church-state separation and the rights and opportunities of other religious and non-religious communities and individuals. This influence was justified by the memories of the RCC as the key national institution, one that could help entrench Croatian independence. Educational reform in Croatia defacto allowed the RCC to become part of the

\footnotetext{
${ }^{694}$ The centralized core curriculum reforms were more successful in Croatia, largely because of the lack of those willing to challenge the centre in the Croatian League of Communists.
} 
education system with near-mandatory religious education controlled and taught by RCC clergy and other employees in public schools. ${ }^{695}$

In Slovenia, where confessional activity is banned from public schools, debate over church and state in the education system was long, wide-ranging, open, and fierce. It was undertaken in consideration of the planned overhaul of the entire educational system. In Croatia, Roman Catholic religious instruction (RI) was introduced in public schools immediately, with little consultation with educators, parents, or students. The introduction of RI was affirmed years later by a concordat on religious education that was developed in secret negotiations between the Holy See (HS) and the Republic of Croatia (RC). ${ }^{696}$ Both Croatian and Slovenian approaches to educational reform can be illustrated through the process and policies regarding the introduction of religious instruction in public schools. However, prior to discussing religious instruction itself some general background on educational reform will be introduced.

\subsection{Post-Communist Educational Reforms}

Both countries recognized that after the dissolution of SFRY they had to make significant changes in the education system, but it was only in Slovenia that

\footnotetext{
${ }^{695}$ Republic of Croatia, "Ugovor Izmedju Svete Stolice i Republike Hrvatske o Suradnji na Području Odgoja i Kulture," Narodne Novine 02/97 <http://www.nn.hr>.

${ }^{696}$ Since the concessions to the RCC could not be rolled back, and the EU demanded the guarantee of religious and ethnic equality, $\mathrm{RH}$ has further endangered separation of church and state through agreements with other religious communities. Although there have been agreements with other religious communities, only the agreements with the Serbian Orthodox Church and the Islamic Community have provisions that allow their representatives to teach religious instruction in public pre-schools, elementary schools and secondary schools. These agreements followed more than ten years after the RCC entered public schoolsRepublic of Croatia, Narodne Novine 196/03 <http://www.nn.hr>.
} 
in the 1990s comprehensive, positive sum, and systematic curriculum change was based on such aims as inculcating individual responsibility, plurality, and tolerance. In the Croatia of the early 1990 s, the process of reform took on a pattern reminiscent of the introduction of Marxism, as instant experts ensured instant curriculum changes based on ideological rather than academic requirements. There was a drive to remove all positive references to Marxism, WSM, and the SFRY as quickly as possible, without balanced consideration of what would replace them. In Croatia the HDZ was unquestionably the leading party and its core mandate was to consolidate the new Croatian nation. In Slovenia grand coalitions have dominated the political scene and had a common mandate in establishing Slovenia as a country that could enter the European Union as a consolidated liberal democratic state. The differences in power structure, approach and mandate are reflected in the way that the issue of religious instruction in public schools was handled in both countries.

\subsubsection{General Educational Reform in Croatia}

More than a decade after independence, the educational system as a whole has yet to be comprehensively reformed, although many Croatian experts argue that it should be.

During the early 1990s the Croatian state devoted a significant amount of energy to fighting a war with Serbia rather than focusing on other domestic 
reforms ${ }^{697}$ Although laws on preschool, elementary, secondary, and postsecondary schools were ratified in the initial post-communist years, there was little debate, consultation, or implementation practices that would ensure that the changes made were implemented in an equal, fair, and systematic way ${ }^{698}$ However, even seven years after the end of war in Croatia, the need for comprehensive curricular reform has been recognized but not yet realized. ${ }^{699}$ Rather than evaluate and change the system as a whole, the HDZ authorized ad hoc changes and amendments to parts of the education system. The lack of debate and consultation on comprehensive reforms led to a focus on Croatian national identity and patriotism, as textbook content analysis has demonstrated.

For example, textbook revision was one the most immediate means by which the new regime reformed education after 1991. Pedagogical expert, Dr. Ladislav Bognar, in the conclusions of his content analysis of Croatian textbooks from 1991-1995 reported that 16\% of the overall content of all Croatian textbooks

\footnotetext{
${ }^{697} 340$ schools were destroyed in war-affected areas of Croatia. "Committee on Economic, Social and Cultural Rights Concludes Review of Initial Report of Croatia," United Nations: Committee on Economic, Social and Cultural Rights 20 Nov. 2001, 6 Nov. 2002 $<\mathrm{http}: / / \mathrm{www}$.unhchr.ch/hurricane/huricane.nsf/0/ 96415CF30899493DC1256B0S005C8B1 >. Of these schools, only a fraction re-opened, because of the extremely low rate of return of refugees who have children and the low birth rate. Where the schools have reopened, many are extremely segregated on a Croat/Serb division.

${ }^{698}$ Republic of Croatia, "Zakon o Srednem Školstvu," Narodne Novine 19/92, 27/93, 50/95

$<$ http://www.nn.hr>. Republic of Croatia, "Zakon o Osnovnom Školstvu," Narodne Novine 59/90, 27/93 <http://www.nn.hr>; Republic of Croatia, "Zakon o Brizi Odjeci Predškolske Dobi," Narodne Novine 27/93<http://www.nn.hr>.

${ }^{699}$ The Racan government recognized the need to reconsider education reforms, at all levels, given the low percentage of the population that successfully graduates from higher educational institutions. Marijan Šunji, "Higher Education in Croatia: Unfinished Reform," International Higher Education 26.4 (2002): 26.
} 
dealt with the "national question." ${ }^{, 700}$ That $16 \%$ included issues of national identity and relations with other nationalities, which emphasised conflict and nonpeaceful resolution of those conflicts. A conclusion reached by the study was that "most references to religion" in general textbooks at the elementary school level focused on national themes and spoke "of religion [Roman Catholicism] as a form of patriotism." ${ }^{, 701} \mathrm{~A}$ further conclusion was that there existed a pervasive focus on collective identity and a history curriculum that emphasised Catholic Europeans as defenders of Christian and European civilization. ${ }^{702}$

While information in textbooks changed, curriculum design and evaluation have not been standardized. The focus on learning by rote remained the preferred method of instruction. Facts and information were hastily altered, with textbooks and teaching plans emphasizing the Croatian nation, culture, and traditions. Reform was so random and unaccounted for that even in 2002 pedagogues, educational experts, parents, and students were still asking key questions such as what is included in the curriculum, who is involved in designing it, and what is the role of curriculum in the quality assurance system. ${ }^{703}$ Numerous reform initiatives, White Papers, and discussion groups have looked at education reform and put forward

\footnotetext{
${ }^{700}$ Ladislav Bognar, "Problems and Perspectives in the Development of Schooling in Croatia," Education and Media in South East Europe: Country Reports, eds. Ulf Brunnbauer, Hannes Grandits, Siegfried Gruber, Karl Kaser, Robert Pichler, and Chistian Promitzer (Graz: Centre for the Study of Balkan Societies and Cultures at the Department for Southeast European History, University of Graz, 2000) 2.

${ }^{701}$ Bognar 4.

${ }^{702}$ Bognar 4.

${ }^{703}$ Pasi Sahlberg, "Changing Croatian Education System as a part of Stabilization and Association Processes: Final Conclusions," South East European Educational Cooperation Network 24-25 May 2002, 4 Sept. $2002<$ http://www.see-educoonet/education_in?pdf/conclusions-cro-engl-t05>.
} 
proposals for comprehensive changes, but these initiatives are peripheral, often contradictory, and the government has yet to act on their suggestions in a comprehensive manner. ${ }^{704}$

In the communist era, students were taught to be passive learners and programs focused on justifying the reigning ideology of the regime. Many experts argue that the Croatian education system continues to follow that tradition. ${ }^{705}$ The lack of reliable, politically neutral regulations on the input side, such as clear learning objectives and plans, is coupled with a lack of evaluation and standards set for outputs. This has led to confusion on the part of students as to what they are required to learn; teachers have trouble determining their responsibilities and realize that they have little input into what they are teaching. There are "no policy implementation measures for quality assurance in education," or national (or even district) standards for implementation of the curriculum and evaluation of students. ${ }^{706}$ Ideologically driven reform in Croatia, in the absence of incremental and open debate, resulted in a renewed focus on learning by rote.

In most formerly communist countries the ideal learning experience consisted of teachers telling students exactly what should be known and students repeating that information. Critical independent thinking and exercise of individual

\footnotetext{
${ }^{704}$ Krek, White Paper 32.

${ }^{705}$ Sergij Gabršček and Neli Dimc, eds. Strategies of Educational Reform in South East Europe Countries: Proceedings of the Seminar Beld Slovenia June 8-10 2000 (Ljubljana: Open Society Institute, 2000) 93-97.

${ }^{706}$ Vedrana Spajić-Vrkaš, "Education Policy in Education for Democratic Citizenship and the Management of Diversity in South East Europe: Stocktaking Research Project, Country Report: Croatia," South East European Educational Cooperation Network Sept. 2001, 7 Nov. 2002

$<$ http://www.see-educoop.net
} 
choice were actively discouraged. The Croatian system "inherited many elements of the Yugoslav approach," including a focus on the repetition of facts. ${ }^{707}$ A relatively small circle of people is involved in curriculum approval in Croatia as compared to the more consultative process of curriculum approval introduced in Slovenia. Školska Knjiga, the largest publisher of school textbooks in Croatia, selects authors who write and submit books to the Ministry of Education and Sport for approval. Once internally approved, the Ministry employs three experts to review the work and suggest changes prior to release. Textbooks created in this manner should be responsive to new educational needs, employ a diversity of viewpoints, and promote pluralism. However, these goals are often not met, as noted in Dr. Bognar's extensive study. Other religions are either not mentioned or "mentioned in a neutral or negative way." ${ }^{708}$ Even if/when Školska Knjiga produces a textbook that endeavours to introduce a variety of worldviews, acknowledge the plurality of religions and religious practices, and promote critical thinking among young children, the question remains as to how such a textbook is integrated into the classroom. Other questions include, do teachers promote some of the more tolerant and pluralist ideas presented in a minority of books and organize their classes accordingly? Do teachers themselves think critically about how they use the materials? Are these materials consistently available to teachers?

\footnotetext{
707 "Country Report: Croatia 2000," South East European Educational Cooperation Network 11 Oct. $2002<\mathrm{http}: / /$ www.see-educoo.net/education_in/pdf/strat-21>.

${ }^{708}$ Bognar 5.
} 
In the absence of comprehensive reforms and a detailed reordering of the system it is difficult to answer these central questions.

Central government authorities control what is introduced into the education system, but this responsibility is shared by the Ministry of Education and Sport and the Ministry of Science and Technology. However, these agents do not have regular channels of contact with each other, making it difficult to coordinate their activities. As noted in the 2001 "White Paper on Croatian Education: Strategy for the Development of the Republic of Croatia, Croatia in the $21^{\text {st }}$ Century, uncoordinated reform and division of responsibilities has lead to "uncontrolled unorganized implementation...[which] has lead to a decrease in educational standards and to large regional disparities. If decentralization is to be sustainable it is necessary that the process of decentralization proceeds in a coordinated way. ${ }^{709}$

The White Paper on Croatian Education is one of many well-reasoned proposals on educational reform that do not mesh with one another. These disparate efforts have made it possible for the government to implement whatever is in its best interest rather than in the best interest of constituents at a given moment in time. ${ }^{710}$ This selective reform frustrates the setting of any long-term goals. ${ }^{711}$

\footnotetext{
${ }^{709}$ Nikola Pastuovic, Naima Balić, Branislava Baranović, Ante Bezen, and Vinko Barić. White Paper on Croatian Education: Strategy for the Development of the Republic of Croatia, Croatia in the 21st Century (Zagreb: Office for the Strategy of the Development of the Republic of Croatia, 2001) 105 .

${ }^{710}$ At times, these papers encourage dialogue on reform. Other times, a given suggestion is simply implemented without public discussion.

${ }^{711}$ As Bognar notes, even where there is a genuine attempt to promote comprehensive reform, as in the Ministry of Education and Sport 2000 in itiative of "points of departure," some points contradict what was published in the new Education Law of July 2001.Bognar 17. The 2000 Basis for Restructuring of the Education System of the Republic of Croatia and the 2001 White Paper on Croatian Education, suggest different solutions and are not even comprehensive in themselves.
} 
The lack of comprehensive reforms allows for arbitrary changes in the curriculum. This random approach facilitated the introduction of RI into schools without much debate and only in hopes that the introduction of religious classes would further distance the new Croatian nation from its communist past and propel it into the "civilizational space" of Western Europe. The RCC, without discussion or input from other stakeholders, was given free rein in introducing, implementing, and overseeing RI in all schools in Croatia.

\subsubsection{General Educational Reform in Slovenia}

From the 1980s onward Slovenian politicians and educational experts pursued a process of education reform that was more amenable to the requirements of a liberal democratic state. The parties within the weak and short lived one bloc coalition and the much longer serving grand coalition governments were unable to single-handedly push through ad hoc reforms. Rather, reforms were carefully considered in terms of constitutionality and of the students' best interest. The input of pedagogues was extensive, and reforms were implemented systematically.

Ultimately the course that precluded the introduction of clergy as Religious Instruction instructors in Slovenian schools was Religion and Ethics, an optional course that focused on a balanced representation of different worldviews and religious traditions. Catholicism was one of several religions taught in the course. Church experts in committees and consultations were involved in establishing this course, but there was little church influence. The course was created in the same 
way as all courses created for Slovenian elementary and high schools. The

process included a comprehensive program of consultation with teachers, experts, and the public.

The process of educational reform in 1970s-1980s SFRY was similar in form to the 1990 reforms in Slovenia. Both started with a gathering of experts, who then drew up a plan that the government implemented over the course of several years. The major differences were that in the 1990s in Slovenia:

- Debate was open, those consulted were drawn from disparate fields and standpoints, and all opinions were heeded;

- All street-level educators and many other stakeholders were given the opportunity to contribute to the creation of substantive changes throughout the process; and

- Changes were far more comprehensive encompassing all levels of the education system; and "Principles of democracy, autonomy and equal opportunity ... [which are]...based on human rights and the notion of the rule of law" were the foundation of all of these changes. ${ }^{712}$

Intense reforms commenced in 1989, when the Council of Education in the Ministry of Education and Sport (MES) officially started to dismantle the system of vocational schools. They were completely replaced with grammar schools by the 1990 school year. ${ }^{713}$ A group of experts was gathered and consulted with, but this was only the beginning of the reforms. In 1991, the MES put together a group of experts that would create a plan for complete educational reforms. The first draft of the plan was the 1993 White Paper on Education and Learning in the Republic of

${ }^{712}$ Krek, White Paper 33.

713 "The Council of Education was and still is a supreme decision-making body" in the educational sphere in Slovenia. Krek, White Paper 36. 
Slovenia ("Belo knjigo" o vzgoji in izobraževanju v Republiki Sloveniji). The final draft of the paper was published in January 1995 and was the basis for the 1996 legislation that set out the goals and methods of compressive changes to the school system in Slovenia.

Several laws that govern most aspects of education in Slovenia, adopted on 19 March 1996, enacted not only the general guidelines of the White Paper on Education of 1995 but also its specific structural recommendations. ${ }^{714}$ This legislation included the Organization and Financing Act, the Preschool Institutions Act, the Primary School Education Act, the High School Education Act, the Vocational and Professional Act, and the Adult Education Act. By far the most prominent and contested changes that directly influenced curricular reform were enshrined in the Organization and Financing Act (OFA) and Primary Education Act (PEA). ${ }^{715}$

The Law on Primary Schools laid out a program of reform that included nine-year (instead of eight-year) elementary schools, as well as comprehensive curriculum changes. The law maintained a prohibition of confessional activity in schools. Once the Primary Education Act and other educational acts were adopted,

\footnotetext{
${ }^{714}$ Republic of Slovenia, "Zakon o Gimnazijah," Uradnia List 12/96, 1996. Republic of Slovenia "Zakon o Organizaciji in Financiranju Vzgoje in Izobraževanje," Uradni List1 2/96, 1996. Republic of Slovenia, "Zakon o Osnovni Šoli," Uradni List 12/96, 1996 and 33/97, 1997. Republic of Slovenia, "Zakon o Poklicnem in Strokovnem Izobraževanju," Uradni List 12/96, 1996. Republic of Slovenija, "Zakon o vrticih," Uradni List 12/96, 1996. The general guidelines include exhortations on the promotion of education in conformity with the General Declaration of Human Rights (December 19, 1948); promotion of democratic citizenship, parliamentary democracy, and endorsement of pluralism of ideas and cultures. Republic of Slovenia, "Zakon o Organizaciji in Financiranju Vzgoje in lzobraževanje," Uradni List12/96, 1996.

${ }^{715}$ Republic of Slovenia, "Zakon o Organizaciji in Financiranju Vzgoje in Izobraževanje," Article 72.
} 
the formal process of curriculum change began. This process included a systematic change of content as well as the creation of new subjects and optional subjects.

The creation and content of these subjects were the most controversial aspects of the reforms. The optional, non-denominational subject of Religion and Ethics and the compulsory subject of Civic Education and Ethics were the focus of the majority of controversy, with the RCC as the government's main critic. The RCC attacked this legislation, declaring that human and constitutional rights have been violated by the prohibition of confessional activity in public schools. ${ }^{716}$ The church recognized that it had lost its ability to spread its message to a "large young audience." 717

As the White Paper on Education predicted, the "actual preparation of the program of this subject [Religion and Ethics] and the compulsory subject on [Civic Education and] Ethics will be one of the most interesting episodes in the reworking of school curricula." ${ }^{, 718}$ The prediction was accurate and can be best understood by an overview of the mechanics of curricular reform and the creation and implementation of the actual subject Religion and Ethics that was a result of this process.

The curricular reform process from this point forward can be divided into the following five levels and phases:

\footnotetext{
${ }^{716}$ Janez Gril, "Za Šolo po Evropskih Merah," Družina 5 Oct. 1997: 3.

${ }_{717}$ Krek, White Paper 19-20.

${ }^{718}$ Krek, White Paper 20.
} 
1. The Ministry of Education and Sport set up the National Curriculum Council (Nacionalni kurikularni svet) (NCC), a body of 27 governmentappointed experts, who set out guidelines and goals for curriculum change. While not changing the curriculum themselves, these experts held the power to approve, reject, or send proposed curricula of certain courses back to the following four groups for revisions. The work of the NCC was completed by 1999 , when the first changed curricula and nine-year schools were implemented.

2. Five Field Curricular Commissions (FCCs), one for each level of schooling, were set up to oversee and appoint members for Subject and Program Curricular Commissions (SPCCs). ${ }^{719}$

3. There were 69 SPCCs with a total of 500 experts and teachers from numerous educational fields, whose task it was to create specific syllabi for courses throughout the educational system.

4. A crucial part of these commissions were the teachers' circles. These groups were made up of all the teachers in Slovenia and organized by subject area. Each of the 69 SPCCs created at least 3 draft syllabi for a given course, which were then sent to $20 \%$ of teachers circles in a given subject area. After consultation and revision, the SPCCs created one draft syllabus and sent it to all Slovene teachers through their teachers' circles. Between $70 \%$ and $80 \%$ of these teachers made comments that were then incorporated into the final version of the syllabus, which was in the hands of the FCCs between May and June of 1998. The FCCs then passed on these syllabi to the NCC, which sent them on to the Council of Experts for either General Education, Vocational and Technical Education, or Adult Education.

5. These Experts' Councils had the final say on the adoption of curricula. Unlike the NCC, FCCs, SPCCs, and teachers' circles, they remained in existence after 1999. Experts' Councils are bodies of experts that are appointed by the national government to advise in the approval of educational materials such as textbooks and curricula change, as in creating educational legislation. ${ }^{720}$

\footnotetext{
719 The five FCCs were preschool, elementary school, secondary school, technical and vocational education, and adult education. There were 80 members of FCCs. Approximately $40 \%$ of FCC commission members were teachers from the above mentioned levels of education.

${ }^{720}$ Ministry of Education, Science and Sport Republic of Slovenia, Organization, Administration and Financing of the Slovenian Education (Ljubljana: Republic of Slovenia, 2000) 5-17.
} 
The approach to educational reform, approved by the governing political parties in the 1990 s, was one of systematic changes made after stakeholders and experts were consulted, public debate was held, and considerations of equality and separation of church and state were made paramount. This process resulted in an eight-year comprehensive reform package that included the drawing up of a definitive White Paper, a five-year phase of curricular reform (including curricular councils), and the passing of comprehensive laws. During the years of reform, the potential introduction of Religious Instruction in public schools was given serious consideration, as were all other courses. However, there was a disproportionate amount of debate spent on the issue of Religious Instruction in public schools in comparison with other subjects because of the sensitive nature of the issue. The debate and nature of reforms regarding religious instruction in Slovenia exemplified the pragmatic, positive sum and incremental change that characterized, comprehensive, open and well defined liberal educational reform, even when dealing with an issue as sensitive as religious instruction in public schools. This was in stark contrast to the introduction of religious education in Croatian schools, which was driven by Tudjman's party interested in securing the $\mathrm{RCC}$ as an institutional supporter and carrier of national identity. 
9.3 Religious Instruction, Croatia

The lack of clear rules, random nature of reforms, and overall instability of the processes enabled a system where the RCC secured a strong influence on the educational system. The intention of Croatian educational reform was to inculcate a Croatian identity in students based on the linkage of religion, language, and culture. In Croatian schools, across disciplines there continues to be a promotion of "Croat civilizational identity" or "Croatness." This is nowhere more evident than in the justification for the immediate introduction of Catholic religious instruction in Croatian public schools. The hasty introduction of religious instruction in Croatian public schools provides an example of the educational reform that Tudjman and his HDZ pushed through to strengthen the party's connection to a politically and historically powerful institution, the RCC. Reforms reiterated the homogeneity of the Croatian nation, its great leaders, and its history. ${ }^{721}$ It is only with the potential to join the EU that instruction on other religions has been allowed in schools. However, consistent implementation of these classes is yet to be seen, while in the meantime there remains a focus on a Catholic Croat European identity. In Croatia, due to rapid reforms that privileged the ideology of "Croatianess" and institutional power of the HDZ and RCC, the Church was already in schools as of $1991 .^{722}$ Without consultation and through revolutionary change, the RCC was invited into schools, by Tudjman's party, to teach Religious

\footnotetext{
${ }^{721}$ Ladislav Bognar in his content analysis of Croatian textbooks of the 1990 s reiterates this.

${ }^{722}$ Darkko Pavičić, "Knjige za Osobnu Duhovnost," Vjesnik 21 Jan. 1993: 26.
} 
Instruction (RI) courses. As of 2000 , approximately $80 \%$ of students under the age of 16 were taking Catholic religious instruction courses in Croatia. Although, as of 2002, other denominations de jure have the right to provide religious instruction for public school credit, in reality there are many obstacles to these courses. As of 2002 the ability for other religious communities to provide religious instruction in schools has been enshrined in law, but it is too early as of 2004 to evaluate implementation of these laws. Prior to 2002 education in minority religions was severely restricted.

The debate regarding religion in public schools prior to 2002 did not question the presence of just one denomination, but rather centred on the duration and range of religious instruction. The RCC, however, continues to have greater influence in public schools, because Catholicism is still presented as a form of national identification and patriotism. There are also pictures of the Pope in schools, and RCC officials are often invited into schools to address students. Even in a matter that has little to do with the RCC, such as the introduction of Yoga training for teachers, the RCC opposition persuaded the government to drop its plans.

After independence, RI was immediately introduced into Croatian public schools. RI classes in elementary and secondary schools began in the 1991/1992 school year, without any public debate or consultation with regional and local school officials, teachers, and parents. With the sanction of the governing party and 
the bureaucrats that owed their positions to that party, RI was organized and taught mostly by Roman Catholic clergy. As Dr. Baričević confirmed, in 1992 there were 1,500 teachers of RI, of which approximately $50 \%$ were pastors, 350 nuns, and 400 religious laypersons. ${ }^{723}$ Jewish groups noted that basic information provided to students about Judaism in RI courses was inaccurate, and their offers to improve the material went unheeded as of $2003 / 2004 .^{724}$

In order to solidify the relationship between Croatia and the RCC, Tudjman's government had engaged in closed negotiations with the Holy See. By 1996 the Republic of Croatia and the Holy See signed a bilateral agreement on education that came into effect in $1997 .{ }^{725}$ The agreement was negotiated in secret and guaranteed the RCC control over RI in public education. This formally entrenched what had been the practice in RI since1991. The wide-ranging agreement gave the RCC veto power over what would be taught and ensured that the RCC had a clear position of authority in the setting of curriculum content. It

\footnotetext{
${ }^{723}$ Pavičić, "Knjige" 26. Dr. Josip Baričević is the High Expert in the Catechism office of the Croatian Bishops' Conference in Education. He is also the principal of the Catehetskog Institua Katoličkoga bogoslovnog fakulteta Sveučilišta u Zagreb (Catechism Institute of the Catholic Theological Faculty at the University of Zagreb. He is the author and co-author of a number of religious instruction and other pedagogic textbooks.

${ }^{724}$ United States of America, "Report on Religious Freedom: Croatia," Department of State 26 Oct. 2001, 18 Dec. $2002<\mathrm{http}: / /$ www.state.gov>. Although other religious communities are able to substitute their catechism for Roman Catholic catechism taught in schools, there are few students who choose to participate. The reasons for this will be discussed later on in this paper.

${ }^{725}$ Republic of Croatia, "Ugovor Izmedju Svete Stolice i Republike Hrvatske o Suradnji na Području Odgoja i Kulture," Narodne Novine 02/97 <http://wivw.nn.hr>. All of the agreements between the Holy See and Croatia were officially printed in the following volume that was only released in 2001. Pintarić 296.
} 
also provided the pretext for further RCC involvement in public education, namely at the kindergarten level.

To begin with, Article 14 of the agreement ensures that any issues that arise in the realm of religious education must be "unanimously" resolved between the Holy See and Republic of Croatia. ${ }^{726}$ It stipulates that RI textbooks are to be treated equally with textbooks for mandatory subjects and must be approved by the Croatian Bishops' Conference (HBK), with final approval by the Ministry of Education and Sport (Article 4). Article 5 specifies that competent church and state authorities should together determine who will teach the course. ${ }^{727}$ Article 6 states that only theologians and catechists will be allowed to teach RI in public schools. Article 1 stipulates that $\mathrm{RI}$ is optional, but as Section 4 of that article argues, teaching of Catholic religious education in public schools runs on the same conditions as other compulsory courses, especially with regards to the situation of religious education inside scheduled hours. ${ }^{728}$

The agreement covers the duration of classes, the funding arrangements, and ultimately makes RI an educational core subject mandated by an agreement with the Holy See. Although officially optional, RI is often treated as a required subject, one that demonstrates parents' and children's "Croatianness." Zlatko Šešelj of the left of centre Social Democratic Party of Croatia (SDP) claims that many in Croatia are aware of the fact that "even those parents who have no religious

\footnotetext{
${ }^{726}$ Republic of Croatia, "Ugovor Izmedju Svete Stolice i Republike Hrvatske o Suradnji na Području Odgoja i Kulture," Narodne Novine 02/97 <http://www.nn.hr>.

${ }^{727}$ Narodne Novine $02 / 97$

${ }^{728}$ Narodne Novine $02 / 97$
} 
inclinations have been sending their children to catechism, for fear that they

will be left out."729 This, he argues, works against creating "good citizens or good churchgoers," because enrolment in RI aims at simply fitting in and does not encourage learning the value of compromise. 730

An equally vociferous opponent of RI in public schools is Don Ivan Grubišić, an influential Dominican and sociologist in Split, Dalmatia, a region noted for its concentration of Catholics who are often the strongest supporters of closer church-state relations. Grubišić, a prolific writer on the subject, believes that closer church-state relations, financially or in education, are a disservice to the RCC and citizens as whole. Rather than fostering Catholic beliefs, RI in schools and the social stigma associated with not attending RI classes resemble indoctrination rather than voluntary learning. ${ }^{731}$ Grubišić bemoans the fact that students are not taught in the parish setting by clerics who "know Christianity as a style of life and not like a doctrine. ${ }^{, 732}$ Echoing criticisms of the Croatian school system as a whole, Grubišić notes that "religion in public schools is about

\footnotetext{
${ }^{729}$ Neven Šantić, "Slučaj Šešelj," Novi List 9 Apr. 2003, 16 Sept. $2003<$ http://www.novilist.hr>. ${ }^{730}$ Darko Pavičić, "Vecernjakova Anketa: O Religijskom Odgoju u Škoki," Vecer 14 Nov. 1998: 25.

${ }^{731}$ This resembles an argument that Arthur Miller once made in a Yugoslav publication. As Slobodanka Nedović recollects: "On the topic of religious instruction in American schools, Miller explained his attitude as follows: "If you want children to hate church, religion and even God himself, then this is the best way to do it - make religious instruction obligatory and give grades for it... Official ideologists in Yugoslavia never got the message." Slobodanka Nedović, "The New Patterns of State Control: The State and Civic Education in Yugoslavia," Religion in Eastern Europe 17 (1997): 4.

${ }^{732}$ Renata Ivanović, "Don Ivan Grubišić: Vjeronauku Nije Mjesto u Školi i Vrticu," Arena 12 Nov. 1998: 31 .
} 
knowledge and not about behaviour." ${ }^{733}$ In other words, it is about information and not comprehensive understanding. Catholicism is increasingly seen as a symbolic reinforcement of the Croatian national identity rather than a way of life or a way of understanding the world and engaging in a dialogue with others. ${ }^{734}$

Grubišić argues that catechism in public schools has already damaged church attendance, estimating that in the early 1990s in the Split diocese 21,000 youths attended RI in schools, but only 7,000 regularly attend Sunday mass. ${ }^{735}$ The number of those attending mass has been falling ever since. This is a serious accusation, since an estimated 370,000 Croatian elementary and secondary students take RCC-administered RI. ${ }^{736}$ Over " $80 \%$ of all primary school students and $77 \%$ of all secondary school students" attend RCC "organized religion classes in schools." 737

Krešimir Dujmović expresses concern when he argues that most students see RI as a joke and an easy course, where high marks are the reward to those who repeat what the instructor, most often a priest, says in what amounts to "forced catechism. ${ }^{, 738}$ On the other hand, some polls show that the majority of Croats agree

\footnotetext{
${ }^{733}$ Ivanović 32.

${ }^{734}$ Ivan Grubišić, "Vjeronauk Smo Kompromitirali - Pretvorili u Predmet,” Čovjek Nadasve 2 (Split: Knjižnica Dijalog, 2001) 257-265.

${ }_{735}$ Ivanović 30.

${ }^{736}$ Bratonja Martinović, “Okrecemo Leda Europskim Dosezima,” Novi List 27 Oct. 1998: 9.

${ }^{737}$ Ivan Grubišić, "Vjeronauk Smo Kompromitirali - Pretvorili u Predmet," 256. Marijan Valković, Gordan Črpić, and Ivan Rimac, "Vjera i Moral u Hrvatskoj," Bogoslovska Smotra 68.4 (I998): 483 511 .

738 "Talking about the immorality of living together before marriage in between biology and math classes just plays out as a parody." Krešimir Dujmović, "Izgon Boga is Školskog Imenik," Vjestnik
} 
with such education being offered at public schools. ${ }^{739}$ Even if the majority of Croatian citizens agree with the basic framework and concept of RCC, taught RI in public schools, this does not mean that it is compatible with liberal precepts. Before the sudden introduction of RI, separation of church and state was not considered, nor were the rights of minority denominations taken into account.

Principles of plurality, diversity, and tolerance central to all liberal democracies were ignored in favour of strongly equating Croatian nationality to a Catholic identity in an exclusivist manner. This was undertaken as a move that the $\mathrm{HDZ}$ and the RCC viewed would strengthen their standing as defenders of the Croatian nation. In an article entitled "Religious Instruction for Yugo-nostalgics," Bishop Srakic argues that instruction of religions other than Roman Catholicism would confuse children of mixed marriages, who would not know their nationality or religion. ${ }^{740}$ Controversial, ultra-conservative Don Ante Baković, representing those on the religious extreme, stated that when discussing mandatory RI in schools,

"it is not like we, the majority, should ask them, minorities, for an opinion. Other religious denominations if they can would introduce their religious education. And if they can't, well God is one!",741

15 March 2001: 17. Lack of respect for teachers might be among the reasons for the 1998 beating of a Catholic RI teacher by his students in Senj.

${ }_{739}$ Pavičić, "Vecernjakova Anketa" 25 . However, these polls usually indicate a slim majority in favour of RI in public schools. For the most part, too few respondents participate for the polls for them to be reliable.

${ }^{740}$ Dragutin Hedl, "Focus, Pocus," Feral Tribune 19 May 2001: 22. Yugo-nostalgic is a derogatory label denoting those who either defend or long for the days of the Socialist Federal Republic of Yugoslavia.

${ }_{741}$ Gall, citing from an interview in Globus of 14 January 1994. Gall notes that this comment is by a man who earlier in the same article proclaims that he respects the religious orientation of others. 
Zlatko Šešelj, cognizant of such arguments, states: "Human rights have no majority and no minority... such ideas are deeply opposed to the very ideas of freedom. ${ }^{, 742}$ It is specious simply to argue that the majority, however large, should be the justification for RCC's control of RI in public schools. This reflects and deepens a disregard for others, so much so that the others in question have been too afraid to challenge the privileged position of the RCC in RI publicly.

\subsubsection{Education and Religious Communities in Croatia other than the RCC}

Croatian children of a denomination other than Roman Catholic have the right to religious instruction from their own communities as a substitute for $\mathrm{RI}$ in public schools, but that right has been frustrated by a number of factors. ${ }^{743}$ It was only in late 2002 that the governing coalition that had replaced HDZ rule began to establish relations with other religious denominations and officially recognized their rights to religious instruction in public schools. ${ }^{744}$ This came two years after Tudjman died and the HDZ was replaced as the party in power. However, the leading party of the new government, the Social Democratic Party (SDS), which had campaigned on a platform of a return to Europe and a return to rule of law, was constrained by a weak coalition and the continued influence of the HDZ.

\footnotetext{
${ }^{742}$ Darko Pavičić, "Rezultat Vjeronaučne Utakmice," Vecernji List 21 Mar. 2000: 3.

${ }^{743}$ As reported by numerous sources including the United States of America, Department of State, Report on Religious Freedom: Croatia, 2001 and 2002 January 232003 . <http://www.state.gov>. ${ }^{744}$ Republic of Croatia, Narodne Novine 196/03 <http://www.nn.hr>.
} 
Any move taken by the new coalition government that seemed to diminish the power or position of the RCC in Croatian society was harshly criticized by numerous HDZ and RCC leaders as unpatriotic, anti-Croat, and weakening the Croatian state and nation. ${ }^{745}$ This is why the new governing coalition and the SDS were cautious in pursuing changes that would enable greater equality of religious institutions. On the other hand, the leaders of the SDS, Prime Minister Ivica Račan and President Stipe Mešić, along with numerous others, recognized the importance of joining the European Union (EU). Increasingly, the goal of EU membership was recognized as central by the $\mathrm{HDZ}$, which returned to power in late 2003, led by the HDZ moderate Ivo Sander. ${ }^{746}$ However, to achieve this goal both the SDS and the HDZ recognized that Croatia would have to meet criteria proving that dejure and defacto all religious institutions are treated equally, while at the same time not disturbing the primary role of the RCC. This is why starting in December 2002 there has been a flood of agreements legalizing relations with a host of religious institutions. However, the extent and implementation of provisions of these acts is yet to be seen, because the SDS and now the HDZ are engaging in a difficult balancing act, attempting to fulfil the requirements of EU inclusion while reassuring the RCC and the citizens that they are not neglecting the sacrifices of the past and the requirements of the future to secure an independent state for the

\footnotetext{
745 "Hrvatski Biskupi Izražavanju Zabrinutost za Obstanak Države," Slobodna Dalmacija 23 Sept. 2000, 9 Jan. $2001<$ http://www.slobodnadalmacija.hr>.

${ }^{746}$ Dražen Ciglenečki, "Uvest Cemo Hrvatsku u Nato 2006, a u Europsku Uniju 2007 Godine," Novi List 25 Nov. 2003, 8 Dec. $2003<$ http://www.noviflist.hr>.
} 
Croatian nation. No political party in Croatia wishes to be seen as disturbing, diminishing, or disrespecting the RCC and the political gains it garnered during the 1990s, lest the RCC criticize the party in government as anti-Catholic or unpatriotic.

Prior to the 2002 and 2003 agreements with other religious communities that legislated state support for religious instruction in public schools, other communities were allowed to provide religious instruction, but this right was not acted upon by many as it was not promoted. All religious communities can propose their program to the Ministry of Education and Sport and can proceed from there. Where classes in catechism other than Roman Catholic did exist, they were not funded by the state until 2003. The December 2002 agreements between the Republic of Croatia, the Islamic Community, and the Serbian Orthodox Church in Croatia recognized the right of these denominations to provide religious education in public kindergartens, elementary schools, and middle schools. The agreements stipulated that seven children were required for religious instruction classes to be undertaken in schools. If there were not enough students to allow for Orthodox or Islamic classes in public schools, the children could attend religious instruction in their community instead. ${ }^{747}$ Although these government efforts have aided in fighting discrimination, the school system is still highly prejudicial. Students of

\footnotetext{
${ }^{747}$ The U.S. State Department reported in December 2003 that "an estimated 4,500 primary and secondary school children in 37 schools attend Orthodox religion classes, the majority of which are in Eastern Slavonia, Rijeka and Gorski Kotar." United States of America, "International Religious Freedom Report, 2003, Croatia," Department of State, Bureau of Democracy, Human Rights and Labour 18 Dec. 2003, 19 Dec. $2003<$ http://www.state.gov>.
} 
religious communities other than the RCC continue to face the social stigma of not attending RI in school and the problem of gathering enough students to participate in the alternative courses.

The ability to opt out of in-school administered RI was at least until 2003 rather specious, as students sometimes experienced difficulties in opting out and finding alternatives. The Educational Council at the Ministry of Education and Sport noted as early as 1991 that "all elementary and middle schools in Croatia are obliged by the wishes of parents and students to secure space and time for holding of religious education for organizations of religious groups. ${ }^{, 748}$ However, many minority religious groups were afraid to express such demands for fear of discrimination or retribution. ${ }^{749}$

Some parents whose religious confession is not Catholic or who do not profess a religious confession fear the social isolation of their children if their children do not take RCC-taught RI classes. Journalist Vlado Miheljak provides an example of this when he recounts a conversation with a friend from Metkovica in Dalmatia who wishes to remain anonymous. Miheljak asked if his friend was a believer, to which his friend answered that he was not. Nonetheless, he sent his children to RI because of the social stigma attached to youths who do not attend, particularly in rural districts. ${ }^{750}$ The friend went on to note that there is a division

\footnotetext{
${ }^{748}$ Republic of Croatia, "Education and Training Laws," Narodne Novine Mar. 1996, 11 Jan 2004 $<$ http://www.vlada.hr>.

${ }^{749}$ Ivana Kalogjera-Brkić, "S Molitvenikom u Školu," Vecernji List 8 June 1991: 8.

${ }^{750}$ Vlado Miheljak "Religija z Etikami," Mladina 24 Nov. 1995: 8-9.
} 
between those who attend RI and "others," who are mostly labelled "serbochetniks and communists. ${ }^{, 751}$ Many Serbs in Croatia attempt, if not to hide, than at least to obscure their Serbian roots. For example, some Serbian children attend RCC-administered RI. In another example, although many Serbs left Croatia during and immediately after the war, the number of those remaining is estimated to be higher than the officially regognized $4 \%{ }^{752}$ It is speculated that some Serbs failed to identify themselves as Serbs in the 2001 census, for fear of retribution or isolation.

Although the Serbian minority far outnumbers the Italian minority in Croatia, the latter enjoyed far more state funding and recognition of educational institutions than the former. As of 2000 there were approximately 4,000 students in Serbian primary schools and 2,000 in Serbian secondary schools. ${ }^{753}$ At the same time, there were approximately 2,200 students in Italian primary schools and approximately 800 in Italian secondary schools. This is despite the fact that the Serbian minority remains the largest minority in Croatia. For the Serbian minority, the schools that teach Serbian or are classified as Serbian schools are seldom fully

\footnotetext{
${ }^{751}$ Miheljak, 9. The exception to this acceptance of RCC RI classes as a way to prove a child blends in can be found in Eastern Slavonia. This is because the war was so fierce and divisions so deep there, that there was no attempt on the government's behalf to integrate schools. Nor was there an effort on the behalf of the Serbian minority to be integrated. 4,000 children from some 35 schools attend orthodox RI, which count towards school credits. In th is region being labelled a "serbochetnik" is already commonplace for Serbs. Serb, Croat and Romani communities in some areas remain segraagated in social, political, and economic life. "World Report: Croatia, 2003," Human Rights Watch 9 Mar. $2004<$ http://www.hrw.org>. There is little question of the promotion of pluralism, open co-operation, and consensus.

${ }^{752}$ Republic of Croatia, Croatian Bureau of Statistics, Census $2001<\mathrm{http}: / /$ www.dzs.hr/Eng/Census/ census2001>, 2001.

${ }^{753}$ Report on Religious Freedom, Croatia 2001." Department of State 26 Oct. 2001. January 23 $2003<$ http://www.state.gov>.
} 
funded or recognized by the state. This is in particular because a number of Serbian schools are in the Slavonia, Danube valley region of Croatia, where the schools are set up, organized, and funded by local Serbs as well as Serbs from Serbia. ${ }^{754}$ In regions where Austrians, Germans, Czechs, and Hungarians live, there are optional school courses in German, Czech, and Hungarian. The use of the Cyrillic Serbian script is limited to Serbian schools, however. ${ }^{755}$ The 2000 Law on Education in Languages and Scripts of National Minorities provided mechanisms through which languages other than Croatian and scripts other than Latin could be used for all levels of education. ${ }^{756}$ However, as Milorad Pupovac, the leader of the Serbian National Council (Srpsko Narodno Vijeće, SNV), stated in 2001, "the laws and rules which regulate the status of minorities in Croatia are much better than their implementation. ${ }^{, 757}$ Instead of pushing for changes in the whole public school system, some Serbian communities where there are no Serbian schools nearby have organized their own Serbian language and culture classes that take place during school breaks and involve smuggling in reading materials. As historian Vjeran Pavlaković notes,

\footnotetext{
${ }^{754}$ There are a number of schools, school activities, sections, and extracurricular learning experiences for youth that are funded and operated by international agencies, institutions, and organizations, particularly in Eastern Slavonija and Baranja. The goal of these programs is often to facilitate ethnic reconciliation and tolerance as well as to instil values and techniques of peaceful conflict resolution. An example is the Center for Creative Work (Centar za kreativni rad) with their "Schools of Tolerance," or the Center for Culture of Peace and Non-violence. ${ }_{756}^{755}$ Bognar 11.

${ }^{756}$ The law on scripts was enshrined in the Consitutional Law on the Rights of National Minorities put into effect in December 2002. Republic of Croatia, "Consitutional Law on the Rights of National Minorities," Narodne Novine 155/02 <http://www.nn.hr>.

${ }^{757}$ Vjeran Pavlaković, "Minorities in Croatia since Independence," Nationalism, Culture and Religion in Croatia since 1990, ed. Vjeran Pavlaković (Seattle: The Donald W. Treadgold Papers, the Henry M. Jackson School of International Studies, University of Washington, 2001) 17.
} 
There is no legal mechanism for importing books from Serbia and Montenegro; so these have to be smuggled across the border...this has resulted in Serbs isolating themselves in a "cultural ghetto."

Even officially recognized private schools in Croatia, especially Serbian ones, are in a precarious position, since it often takes years for these institutions to be officially recognized by the state. Even when they are recognized, their funding formulas vary.

\subsubsection{Religious Instruction in Kindergartens}

Kindergarten is not compulsory in Croatia. ${ }^{759}$ Approximately $35 \%$ of preschool aged children attend kindergartens. Administration over kindergartens is divided into 21 regional units, and within these units kindergartens can be run and financed by local administrative units such as districts and towns as well as "religious communities, trade companies, citizens associations, cultural," sports, or health institutions. This provides for a wide variation in funding, program content, time allocation, and availability. In 1995/96, 97\% of parents of preschool students paid for a part of their child's education. One fourth of them paid more than $50 \%$ of the cost, and the remainder paid even more than that, up to the full amount of the program cost.

The Agreement Concerning Catholic Religious Education in Public Schools and Religious Upbringing in Public Preschool Establishments signed between the Holy See and the Republic of Croatia in 1997 solidified the privileged position of

\footnotetext{
${ }^{758}$ Pavlaković, "Minorities" 25.

${ }^{759}$ However, one year of preschool education is compulsory and is paid for by the state.
} 
the RCC in public education at the elementary and high school levels and gave precedent for further RCC involvement in religious instruction in public preschools. Since 2001 this issue has generated heated debates. ${ }^{760}$ That year the $\mathrm{RCC}$ began a concerted campaign to have religious instruction in preschools as per the 1997 agreement. ${ }^{761}$ This put pressure on the SDS-led governing coalition that had recognized the need to limit the political influence of the RCC but at the same time knew that it could not roll back the agreements. Even though parts of the agreements had not yet been implemented, the government could not afford to turn its back on RCC demands, particularly when the RCC had already secured a voice in the public school system.

Article 3, Section 2 of the agreement states that Catholic religious instruction should be included in preschools "in the framework of total upbringing / education according to Catholic religious upbringing [of] preschool children."762 Similar to the provisions for elementary and secondary schools, the agreement stipulates that the Croatian Bishop's Council (HBK) should create teaching plans and programs for religious education including considerable powers over choice of candidates and texts for such instruction at the kindergarten level. Such instruction

\footnotetext{
${ }^{760}$ Republic of Croatia, "Ugovor Izmedju Svete Stolice i Republike Hrvatske o Suradnji na Području Odgoja i Kulture," Narodne Novine 02/97 <http://www.nn.hr. Pintarić 135.

${ }^{761}$ In 2001 the Croatian Bishop's Conference (HBK) released the "Program [for] Catholic religious upbringing [for] children of kindergarten age." See Hrvatske Biskupske Konferencije, Nacionalni Katehetski Ured, Katehetski Glasnik 4.1 (2002): 165-229.

${ }^{762}$ Republic of Croatia, "Ugovor Izmedju Svete Stolice i Republike Hrvatske o Suradnji na Području Odgoja i Kulture," Narodne Novine 02/97 <http://www.nn.hr. Pintarić 136.
} 
began to be implemented in public kindergartens shortly after the RCC pushed the issue in 2001.

While there are some parliamentary supporters for such comprehensive religious instruction at the kindergarten level, there are many detractors as well. ${ }^{763}$ Anna-Maria Gruenfelder voices that, the most basic criticism of RI in kindergartens has been that RI would place far too large of an intellectual burden on children, requiring preschoolers to learn material and contemplate concepts that are beyond their abilities. ${ }^{764}$ Similarly, some argue that kindergartens exist to facilitate basic social contacts, not to indoctrinate. There is also the question of boundaries of the RCC. Since there is no division of subjects in kindergartens, unlike elementary and high schools, there is a question regarding the amount of RCC involvement in curriculum development and delivery. If Catholic values are infused in kindergarten "education and upbringing," as the agreement stipulates, it might be difficult to limit RCC involvement once it is sanctioned. Compared to the introduction of RI in elementary and high schools, there has been far more open debate about the possible introduction of RI in kindergartens. Many people are challenging the content of the education agreement with the Holy See, and they are doing it though this newly opened debate on RI in kindergartens.

Although debate surrounding the issue was promising, on 11 December 2001 the Croatian government announced that it would introduce Religious

\footnotetext{
${ }^{763}$ Borisav Jelinić, "Catholic Social Policy and the 'Sins of Structure," Nacional 15 Nov. 2001, 2 Oct. $2002<$ http://www.nacional.hr>.

${ }^{764}$ Anna-Maria Gurenfelder, personal interview, June 2002.
} 
Instruction into public preschools. ${ }^{765}$ In the midst of what seemed like promising debate about reform, instead of engaging opponents and seeking compromise, the government had already begun training preschool teachers weeks prior to the announcement. ${ }^{766}$ In part the government pursued this initiative to assuage the harsh criticism they had received from Croatian Bishops in the previous year, and in part the government sought to secure RCC support.

Eventually the weak SDS coalition allowed for Catholic instruction in public preschools. Given that this could not be reversed, and that EU inclusion demanded equality, by December 2002 Islamic and Serbian religious instruction in public preschools was legally sanctioned. The December 2002 agreements between the Republic of Croatia, the Islamic Community (Islamska Zajednica, IZ), and the Serbian Orthodox Church (Srpska Pravoslavna Crkva, SPC) solidified the place of religious instruction in kindergartens. These agreements guaranteed that religious education would be provided for children of parents or guardians that ask for religious education in public preschools. ${ }^{767}$ Subsequent agreements with other religious communities did not yield an agreement on religious education in public schools, so inequality remains. Regardless of the concessions offered to the

\footnotetext{
${ }^{765}$ Mladen Pleše, "The State Firmly Committed Itself to Unconditionally Fulfilling All the Controversial Issues in the Controversial Contracts between Croatia and the Vatican," Nacional 12 Dec. 2001, 19 Sept. $2002<$ http://www.nacional.hr>.

${ }^{766}$ Mladen Pleše, "The State Firmly Committed Itself to Unconditionally Fulfilling All the Controversial lssues in the Controversial Contracts between Croatia and the Vatican," Nacional 12 Dec. 2001, 19 Sept. $2002<$ http://www.nacional.hr>.

${ }^{767}$ Republic of Croatia," Narodne Novine 196/03 <http://www.nn.hr>.
} 
Orthodox Church and Islamic community, the RCC still retains the greatest influence in Croatia.

Another example of strong RCC influence in the education system is the RCC objection and subsequent government cancellation of planned yoga classes for schoolteachers in 2003. Although the classes were intended to allow stress relief for teachers and relaxation in the classroom, the RCC protested that yoga classes would introduce "Hinduist religious practices dressed up as exercises into Croatian schools. ${ }^{, 768}$ The Croatian Bishop's Council further protested that,

It is unacceptable to introduce to the public education system elements that ${ }_{769}$ against the generally accepted values and cultural traditions of Europe.

The RCC feared that Hindu values ostensibly associated with yoga would find their way into classrooms and threaten "European values and traditions," which the RCC sees as their domain and justification for their position in schools.

The price of Religious Instruction in public schools was a series of costly payoffs for a state where sustained unemployment and a growing budget deficit were causing serious problems. All taxpayers contribute to schooling, including Catholic Religious Instruction, and now religious instruction for the Orthodox Church and Islamic community. The quest for both RCC support and entry to the EU has meant that church-state separation has been further eroded by agreements

\footnotetext{
768 "Croatia Education Ministry Cancels Yoga," Times of India 17 July 2003, 20 July 2003 $<\mathrm{http}: / /$ www.timesofindia.indiatimes.com>.

769 "Croatia Drops Plan for Yoga in Schools after Church Objects," Agence France-Presse 17 July 2003, 20 July $2003<$ http://www.clarinet.com>.
} 
that allow other religious communities to engage in publicly funded pre-school religious education.

\subsection{Religious Instruction: Slovenia}

Even before the process of comprehensive educational reform was completed, there were many debates regarding the role of the RCC in schools and other public spheres. The debate regarding $\mathrm{RI}$ and church involvement in public schools was not only a flashpoint for school reform, but for church-state relations in general. Unlike in Croatia, political parties and political elites did not face a pressure, or have the option, to unquestionably empower the present day RCC due to a historical memory of its role in nation building. Debates regarding RI, therefore, proceeded on the basis of what would ensure a liberal-democratic Slovenia where equal rights of individuals would be protected. Two generally different visions of how this could be achieved arose in Slovenia. Reminiscent of the pre-communist Clerical-Liberal divide in Slovenian political life, two clear political blocs emerged in post-communist Slovenia, those on the right that supported RCC involvement in political and public affairs, including in the school system, and those on the left that sought the separation of church and state. Unwilling and unable to push through arbitrary legislation, both groups of parties recognized the need for well reasoned, public and comprehensive reforms on all issues regarding the educational system. This approach was intensified when it came to sensitive issues such as church-state relations. 
Conflict and compromise between these camps was realized through incremental reforms that left Slovenia with an overhauled school system, one that left students with the option of learning about world religious traditions while keeping the church out of the public school system. The RCC and its supporters from parties of the right continue to contest this resolution. However, even when there was a right wing coalition in power in 1990-1992, and again for seven months in 2000 , these parties recognized that they could not afford to push through all of the legislation they desired, mindful of the expectation of debate and incremental change.

\subsubsection{Private Schools}

Prior to discussing the debate regarding religious instruction in public schools in Slovenia, which was by far the most contentious issue regarding the $\mathrm{RCC}$ and education, it is important to note the role of private and concessionary schools. These schools play a larger role in Slovenia than in Croatia because RI is not part of the Slovenian school curriculum, as is the case in Croatia. Therefore, in Slovenia private and concessionary schools provide a space for RCC's involvement in the school setting.

Of the four Catholic high schools in Slovenia, three are concessionary schools. They have the same program as public high schools and are $100 \%$ state 
funded. ${ }^{770}$ In 2001 the Ministry of Education provided more than 650 million tolars to finance these four schools. ${ }^{771}$ The 1991 Organization and Financing of Education Act allowed for government funding of concessionary and private schools. Both of the two private Catholic secondary schools in Slovenia were granted concessions, and their diplomas recognized by the state. By 1995 there were 11 concessional schools in Slovenia. ${ }^{772}$ The majority of concessional Catholic schools are kindergartens.

The scarcity of Catholic schools points to a lack of interest among citizens, in order to set up these schools, potential founders must provide proof of a minimum number of potential students determined by type of school and district. State guidelines for the establishment of private schools also include regulation of teacher qualifications, approval of the educational program (including timetable and course content), and a guarantee that the minimum number of students and classes needed to function will exist for a certain number of years. ${ }^{773}$ This last requirement is extremely important but quite difficult to fulfill. However, the RCC continues to blame lack of private schools on the lack of state financing, even though the state is committed, by Article 57 of the OFA, to provide $85 \%$ of all of

\footnotetext{
${ }^{770}$ Srednja Verska Šola v Vipavi and Salezijanska v Zelimljah are two of the concessionary Catholic high schools. Both operated during the communist regime as private church secondary schools and conferred diplomas that were not publicly recognized in SFRY. The third concessional Catholic high school is Škofijska Škofijska Klasicna Gimnazija v Šentvidu near Ljubljana. It was established in 1992. Škofijska gimnazija Antona Martina Slomška in Maribor, the only private Catholic high school in Slovenia, is funded $85 \%$ by the state and as such it has its own program, which is ratified by a special state commission.

${ }^{771}$ Aloz Pluško, "Od Konkordata do Sporazuma," TV Slovenia 126 Jan. 2002,.

${ }^{772}$ Krek, White Paper 235.

${ }^{773}$ Janez Krek, "Private Schools" 3-7.
} 
the financial needs of private schools, including materials and salaries. ${ }^{774}$

Religious communities are permitted to establish private educational institutions and schools at all levels. As a rule, the state co-finances the activities of private schools at between $85 \%$ and $100 \%$ of expenses in a comparable public institute, provided that the institutions complies with the law and follows approved programs. ${ }^{775}$ Even with this funding, or more particularly because of the conditions of this funding, the church has felt left out of the country's education system and feels that increased involvement in public education is a way to recruit young people. Some, particularly in Slovenian RCC circles, argue that the reasons why there are not more private Catholic schools are:

- The state only provides money for teachers' salaries equivalent to the salaries of teachers in public schools;

- Parents must pay tuition and educational taxes; and

- Some physical buildings that could house private Catholic schools have not yet been returned to the church.

It is on the basis of such arguments that Dr. Ivan S̆tuhec of the Theological Faculty at the University of Ljubljana launched an exaggerated attack on the state. He argued that the Slovenian state had not disavowed the methods of ideologically driven education that characterized pedagogy during the communist regime, because it continues to restrict freedoms of religious expression in public and

\footnotetext{
${ }^{774}$ Republic of Slovenia, "Zakon o Organizaciji in Financiranju Vzgoje in Izobraževanje," Article 57.

${ }^{775}$ Republic of Slovenia, "The State and Religious Communities in the Republic of Slovenia," Office for Religious Communities, 7 Oct. $2002<\mathrm{http}$ //www.gov.si/uvs/ang/aindex>.
} 
concessional schools. ${ }^{776}$ The sentiment that there is a nostalgia for the communist era and irrational fear of the church among state authorities continues to hold influence in the Slovenian RCC. ${ }^{777}$ This belies the desire of the RCC to introduce Catholic religious instruction in public and concessional schools.

\subsubsection{Concessional Schools}

Concessional schools are privately founded but fully funded by the state; they are bound by all state regulations for the level of schooling they provide (kindergarten, elementary, high school, technical school, or university). ${ }^{778}$ Concessional schools are legally bound to base their programs on the practises of public schools at a comparable level, if such comparisons are applicable. ${ }^{779}$ The majority of concessional schools are ones that offer secondary or post secondary

\footnotetext{
${ }^{776}$ Ivan Štuhec, "Svoboda Veroizpovedi in Šolska Zakonodaja," Zvon 14 Jan. 1998: 63.

${ }^{777}$ Ksenja Hočevar, "Dediščina Komunizma Všolstvu, Družina 14 Nov. 1999: 22-30. Ivan Puc, interview with Bishop of Maribor Anton Stres, "Intervju," Mag 1 Mar. 2002: 45-47.

${ }^{778}$ Dr. Zdenko Kodelja, personal interview, May 2002.

${ }^{779}$ The Organization and Financing Act (OFA) set the guidelines for funding public and private educational institutions. Public and concessional schools receive $100 \%$ of their funding from the state from the date of the adoption of the act forward, whereas private schools that once received $100 \%$ of their financing from the state now receive $85 \%$ of such funding effective three years after the adoption of the OFA. Republic of Slovenia, "Zakon o Organizaciji in Financiranju Vzgoje in Izobraževanje." The major reason for the distinction between "private schools" and "private schools with a concession" lies in the fact that the latter lack the essential features of private education, because their position equals that of public schools." Janez Krek, "Private Schools and Preschool Institutions: The Conceptual Background and the Legislation," Private Education, Structure. Comparison of Different Educational Systems and Legislative Solutions in the Republic of Slovenia, ed. Janez Krek (Ljubljana: The Ministry of Education and Sport, 1996) 5. The rationale behind this generous funding formula for private and concessionary schools is that parents and students should be afforded as great an opportunity as possible to choose the type of education that they want. The controversy, however, is that some argue the OFA itself limits that choice by prohibiting state funding of public and concessional educational institutions which during school hours or on school premises teach catechism or perform religious rituals. At the same time, the OFA ensures that state funding will continue to flow to private schools that are allowed to promote and engage in confessional activity. Confessional activities include faith or confessional instruction, Republic of Slovenia, "Zakon o Organizaciji in Financiranju Vzgoje in Izobraževanje," Article 72.
} 
training in specific fields such as cooking or special technology schools that have no equivalent state programs. These schools can also include kindergartens. For example, Waldorf kindergartens are required to assure authorities that their programs are the same level as those of state schools, with few exceptions. The situation is paradoxical, in that concessionary schools were founded to provide diversity in the education system, but are bound to carry out similar programs to public schools.

There is some speculation that concessionary Catholic schools, both at the high school and kindergarten levels, perform confessional activity during the school day and on their premises, in violation of Article 72 of the Funding Act. It was on the basis of this act and its prohibition of confessional activity that in 2001 a group of 50 parents of school aged children in a concessional Catholic school brought a case to the constitutional court. These parents charged that Article 72 and its prohibition of catechism and religious ritual in concessional schools discriminated against religion and contravened Article 41 of the constitution and Article 9 of the European Convention on Human Rights and Fundamental Freedoms (ECHRFF). ${ }^{780}$ Through this action the parents sought to enable the introduction of denominational activity in concessional schools. Article 41 of the constitution declares:

${ }^{780}$ Jana Taškar, “V Javnih Izobraževalnih Programih Verouka Ne Bo,” Mladina 11 Dec. 2001: 2. 
parents have the right to provide their children with a religious and moral upbringing in accordance with their beliefs. ${ }^{781}$

\section{Article 9 of the European Convention on Human Rights stipulates that}

everyone has the right to freedom of thought conscience and religion; this includes the freedom to...manifest his religion or belief in worship, teaching, practice and observance. ${ }^{782}$

In its ruling, the constitutional court directed the parents' attention to sections of the same articles that emphasised the need to respect the rights of others. ${ }^{783}$ Article 41 notes that these rights must be consistent with "free conscience and religious and other beliefs and convictions" of others, and Article 9 of the ECHRFF stipulates that

freedom to manifest one's religion or beliefs shall be subject only to such limitations as are prescribed by law and are necessary in a democratic society...or for the protection of the rights and freedoms of others. ${ }^{784}$

Freedom of religion, however, does not simply mean the right to profession

of one's religion, but also "rights of accepting religion and the right to not

\footnotetext{
781 "Religious and other beliefs may be freely professed in private and public life. No one shall be obliged to declare his religious or other beliefs. Parents have the right to provide their children with a religious and moral upbringing in accordance with their beliefs. The religious and moral guidance given to children must be appropriate to their age and maturity, and be consistent with their free conscience and religious and other beliefs or convictions." Republic of Slovenia, "Constitution of the Republic of Slovenia," Official Gazette 1991, 3 Jan. 2001 <http://www.us-rs.si>.

${ }^{782}$ Article 9 - Freedom of Though Conscience and Religion: 1.) Everyone has the right to freedom of thought, conscience and religion; this right includes freedom to change his religion or belief and freedom, either alone or in community with others and in public or private, to manifest his religion or belief, in worship, teaching practice and observance; 2.) Freedom to manifest one's religion or beliefs shall be subject only to such limitations as are prescribed by law and are necessary in a democratic society in the interests of public safety, for the protection of public order, health or morals, or for the protection of the rights and freedoms of others. "European Convention on Human Rights and Fundamental Freedoms," Council of Europe 3 Sept. 1950, 17 Apr. 2000 $<$ http://www.conventions.coe.int $>$.

${ }^{783}$ Taškar 2.

784 "European Convention on Human Rights and Fundamental Freedoms," Council of Europe 3 Sept. 1950, 17 Apr. $2000<$ http://www.conventions.coe.int $>$.
} 
accepting a religion. ${ }^{, 785}$ In this spirit, the decision handed down in this case emphasised that Slovenia should be a "state with laws [that] ensure measures, that are necessary to protect [a] negative view of religious freedom and with this also realize [the] order of neutrality. ${ }^{, 786}$ The 2001 constitutional court decision in this case upheld Article 72 of the OFA, finding that concessionary (private) schools and kindergartens could not allow confessional activity in their programs. ${ }^{787}$ Receiving concessions and/or funding from the state puts these schools under state jurisdiction. Accordingly, they have no choice but to abide by state laws. The court stressed the primacy of Article 7 of the constitution, which stipulates the separation of church and state. The church declared that this law and the law on Primary School was discriminatory, because both prevent the possibility of RCC catechism instruction in Slovene public and concessional schools and because both contribute to the lack of religious freedom. ${ }^{788}$

\subsubsection{The Debate Regarding Religious Instruction in Public Schools}

The debate surrounding religion in public schools took a disproportionate amount of time relative to numerous other economic and social reforms and the actual number of students who have so far taken the course. RI in public schools

\footnotetext{
${ }^{785}$ Jasna Snežič, "Verouka ali Confeionalnega Verskega Pouk v Javni Šoli (Se) Ni,"Vecer 10 Dec. 2001: 5 .

${ }^{786}$ Franc Testen, “Case Number: U-I-68/98, E-66/01," Ustavno Sodisce Republike Slovenije" 19 July 2002.

${ }^{787}$ Taškar 2.

${ }^{788}$ Bogoir Štefanič, interview with Bishop of Maribor Anton Stres, "Šole Kot Simboli Države: Ob Rob Razpravi o Konfesionalnosti Všolskem Prostoru," Družina 10.6 2002: 23. Snežič 11.
} 
was a particularly sensitive potential part of school curriculum that was tackled in the same way as other subjects in the reform process as outlined in the White Paper. However, the political pressures that surrounded the issue of RI ensured its place at the center of public debate, which highlighted the entire educational reform process and addressed issues at the core of the constitutional requirement for separation of church and state. As Svetlik and Brle-Lakota note, at times the parliamentary debates about the work of the various committees for curricular reform, namely regarding the subjects of religion and ethics, "shook the government coalition," but the Ministry of Education and Sport "respected the autonomy of the curricular bodies. ${ }^{, 789}$ Members of the right of center ("spring parties") would often reiterate the RCC's stance that there were not enough religious experts or those with a "positive attitudes towards religion" in various curricular commissions. ${ }^{790}$ The liberal and left-of-spectrum parties countered that there were church representatives, religious experts, and individual Christians in every commission on every level of the school reform process.

The Slovenian parliament was forced to extend its $37^{\text {th }}$ sitting in 1996 because of the debates, including the secularism of the Law on Primary Schools. The parliament adopted the law in February 1996, but as journalist Jože Poglazen

\footnotetext{
${ }^{789}$ Ivan Svetlik and Andreja Brle-Lakota, "Plenary Session Paper Curricular Reform the case of Slovenia: Strategies of Educational Reform in South East Europe Countries, Proceedings of the Seminar Beld Slovenia 8-I 0 June 2000," South East European Educational Cooperation Network 8 Jan. $2001<$ http://www.see-educoop.net>.

${ }^{790}$ Snežič 11 .
} 
noted, there were "members that still fought with the clergy in public.", The subject of Religion and Ethics was the major point of contention in parliamentary debates of the time. The right of centre Slovenian People's Party demanded control over the appointment of the Minister of Education and Sport as part of a package to ensure its membership in a coalition with Drnovšek's Liberal Democratic Party. ${ }^{792}$ This did not happen, and Marjan Podobnik, president of the SLS, denounced schools as "red" and stipulated "that religious teaching and influence should be increased. ${ }^{, 793}$

In the meantime, Marjan Podobnik became vice-prime minister. However, in 1998, when the Minister of Education Dr. Slavko Gaber extended the NCC (National Curriculum Commission) mandate, Marjan Podobnik threatened the coalition itself, arguing that Gaber's decision was a "violation of the coalition agreement" because his party was not consulted beforehand. ${ }^{794}$ Podobnik threatened to withdraw his party from the coalition, because he had hoped to appoint supporters of his and the RCC's stance to the NCC. He built on widespread RCC claims that religiously inclined people and those with a positive viewpoint on

\footnotetext{
${ }^{791}$ Jože Poglazen, “O Religijah Vesrtvih in Etici," Dnevnik 14 Feb. 1996: 17.

792 Dejan Pusenjak, "Šola Naj ne Vzgaja v Veri ali Neveri," Delo 20 Aug. 1994: 19-20.

${ }^{793}$ Zoran Odić, "Conflict over School Reform," Aim Press 23 Dec. 1997, 4 Nov. 2001 $<$ http://www.aimpress.org>.

${ }^{794}$ Zoran Odić, "Conflict over School Reform," Aim Press 23 Dec. 1997, 4 Nov. 2001 <http://www.aimpress.org>.
} 
religious education in public schools have been systematically excluded and their concerns for Catholic values in the whole curricular reform process dismissed. $^{795}$

The RCC and parties such as the SLS argued that religious people had been excluded from the process of curricular reform. ${ }^{796}$ The left of centre parties, including the United List of Social Democrats (ZLSD) and Slovenian National Party (SNS), concluded that there had been too much church influence throughout the process of reform, while there should be none at all. ${ }^{797}$ The SNS argued that it refused to be part of a political system that shepherds Slovenes back to the $18^{\text {th }}$ century, where state and RCC powers are intertwined and controlled from above. ${ }^{798}$ The ZSLD, on the other hand, strongly lobbied for a referendum on the introduction of the subject of Religion and Ethics, arguing that it is a subject that could be used for indoctrination and that other subjects such as languages would be more useful to Slovene youth. ${ }^{799}$ Attempting to facilitate a compromise, the LDS Minister of Education and Sport at the time, Dr. Slavko Gaber, made it clear that

\footnotetext{
${ }^{795}$ Stanko Gerjolj, "Modes of Religious Educaiton in Slovenia," Religion and Nationalism, eds. Miklos Tomka and John Coleman (London: Concilium, 1995/1996) 84. Alenka Šverc, "Šola Med Laičnostjo in Laicizmom, Družina 29 Nov. 1998: 9. In April 2000 Podobnik's SLS left the governing coalition, joined with the Christian Democratic party, and in a coalition with the Social Democratic party issued a vote of no confidence against Prime Minister Drnovšek. In June 2000 a right-wing government was installed, with Dr. Andrej Bajuk as the prime minister. The elections of October 2000 resulted in a victory for Drnovšek and his Liberal Democratic Party. In October 2000 elections the LDS won $36.3 \%$ of the popular vote and 34 seats in parliament. Currently the governing coalition consists of the LDS, ZLSD, SLS+SKD, and DeSUS. "Elections for Deputies to the National Assembly," Republic of Slovenia 15 Oct. 2000, 27 Mar. $2002<$ http://www.gov.si>. 796 Šverc 9.

${ }^{797}$ Miran Potrč, personal interview, June 2002.

${ }^{798}$ Zmago Jelinčic, personal interview, June 2002.

${ }^{799}$ Miran Potrč, "Zahteva za Razpis Referenuma,"Poslanska Skupina Ždružene Liste 15 Feb. 1996: 14 .
} 
Religion and Ethics would be one of at least six optional subjects available at any elementary school. ${ }^{800}$ Unfortunately, the RCC and its supporters were not pleased with the content and methods of the subject Religion and Ethics and the state's commitment to "neutrality." ${ }^{, 801}$ On the other hand, opponents of the church were sceptical that the school system would remain neutral.

The RCC has been successful in realizing their demands in the education sphere in Croatia, but it largely failed to achieve the same goals as in Slovenia. Accordingly, in Slovenia the RCC hierarchy is often incredulous that the state is as involved in the education enterprise as it claims to be. As the RCC expressed in its September 1998 pastoral letter read from the pulpit of all Slovene churches, "schooling is too serious a matter, that it would be admissible for anyone to usurp it," and the role of the RCC in education must be defended ${ }^{802}$ However, a 1999 poll indicated that Slovenes have the most confidence and trust in the education system in relation to all Slovenian institutions and the least confidence in the RCC. ${ }^{803}$

Bishop Stres relates a stance common in the Slovene RCC, namely that the state should allow the church to guide the education system regardless of the regime in power at the time. The Slovenian RCC hierarchy seeks to deny the state

\footnotetext{
${ }^{800}$ Slavko Gaber, personal interview, May, 2002.

${ }^{801}$ Jože Mlakar, "Kaj pa Pravice Kristjanov: Šolsko Vprašanje Znotraj Razmerja med Državo in Cerkvijo," Družina 16 Jan. 2000: 9. Drago Ocvirk, "Uniformirana ali Pluralna Šola: Šola za Svobodo, Resnico in Človečnost," Družina 2 Oct. 1994: 11.

${ }^{802}$ Slovenian Bishops' Conference, Pastisko Pismo ob Začetko Šolskega Leta, 1998/1999, 13 Sept. 1998, <ww.rck.si/plenary-zbor.rode>.

${ }^{803}$ Dr. Slavko Gaber, Minister of Education Republic of Slovenia, personal interview, 2002.
} 
one of its central functions, the creation and implementation of a nation-wide universal public education system. The church hierarchy in Slovenia also argues that since the country is undergoing a period of turmoil and change, there needs to be clear moral guidelines set out to direct the activities of all educational establishments. At the most, the RCC argues that it should possess greater authority to provide moral guidance in educational endeavours. At the very least, the 2002 Slovene Catholic Church Synod concluded that catechism as taught in parishes should be recognized as a public school subject. ${ }^{804}$ The issue of confessional RI prompted the most discussion in the latest Slovene Catholic Church Synod, and as Archbishop of Slovenia France Rode noted, the RCC demands not only that the $\mathrm{RCC}$ control RI in public schools, but that the state reimburse the RCC for this and any similar "burden." 805

On 4 March 1997, Pope John Paul II appointed Dr. Franc Rode as the new Archbishop of Ljubljana. Rode wasted no time in making his cause clear. In his first appearance on national television, Rode told the country that the most important issue for him was education and the introduction of non-compulsory religious education in public schools managed by the RCC. ${ }^{806}$ Dr. Rode determined

\footnotetext{
${ }^{804}$ As noted in the latest synod, "school is the most important" and time-consuming endeavour of youth and the church should have a place in it. Slovenian Bishops' Conference, Izberi Zivljenje: Sklepni Document Plenarnega Zbor Cerkve na Slovenskem (Ljubljana: Družina, 2002) 146. Accordingly, Resolution 387 of the synod demands that "parish religious instruction as an undisputed subject as one among the mandatory optional subjects [and as] a constituent part of the educational-upbringing process." Slovenian Bishops' Conference, lzberi 150.

${ }^{805}$ Ranka Ivelja, "Cerkev in Šola," Dnevnik 6 Nov. 2000: 3.

${ }^{806}$ Ranka Ivelja, "Šolstvo in Novi Nadškof: Poraz Klera, ne Demokracije," Dnevnik 12 Apr. 1997: 15.
} 
that RCC influence in education is the key part of ensuring RCC influence on the political and social life of Slovenians. At a lecture in Maribor in March 2000, he argued that "when they made these schools they ignored us, like we did not exist. $" 807$

Dr. Rode's campaign has placed him in the media spotlight. In the magazine Didacta he argued that the school system should be changed to reflect the fact that $80 \%$ of students and half of public school teachers are religious. ${ }^{808}$ Rode cited the 1991 census, in which $71.36 \%$ of Slovenes identified themselves as Catholic, but the 2002 Slovenian census recorded that only $57.8 \%$ of the population identified themselves as Catholic. However, the census data does not measure religiosity, for example, as the census question did not ask whether the person considered themselves a devout Catholic or not. Furthermore, there is no data available that measures the religiosity of public school teachers. The Secretary for Middle School at the Ministry of Education, Alojz Pluska, responded to Dr. Rode's statements, arguing that

the Archbishop... is dirtying the reputation of our educational system... I also think that Archbishop Rode's attitude towards the school system, is indicative of extreme politicization on the part of the Catholic Church. ${ }^{809}$

Rode later argued that immediate change was necessary in schools and said that the church would never accept the current situation. ${ }^{810}$ One of the main

\footnotetext{
807 “"Commentary," Dnevnik 18 Mar. 2000, 20 Jan. 2001 <http://www.dnevnik.si>.

808 "Commentary," Dneynik

809 "Commentary," Dnevnik
} 
justifications for opposition to the reformed school system in Slovenia, particularly the prohibition of confessional activity in public schools, is that the RCC was not consulted. As Archbishop Rode noted on several occasions and again in the September 1998 pastoral letter that encouraged parents not to enrol their children in Religion and Ethics, the RCC had not had enough participation in the subject for him to support it. ${ }^{811}$ However, an examination of the process of reform shows that there were RCC representatives present and active in shaping that reform. At the highest level was the Mixed Commission (KMK, Krovno mesano komisijo) established on 4 March 1993 and made up of representatives of the RCC and the Slovenian government. Its function was to resolve issues including education, for which there was a subcommittee ${ }^{812}$ No other religious groups were accorded such a privilege, but nonetheless when RCC leaders determined that not all issues would be resolved in their favour they withdrew. ${ }^{813}$

RCC members of the subcommittee on education demanded that RI should be denominational, available for two hours each week in kindergarten, elementary and high schools, and serve as an alternative to Civic Education and Ethics courses,

\footnotetext{
${ }^{810}$ Tomaž Mastnak, "On the Orders of the Devil," Dnevnik 25 Mar. 2000, 15 Apr. 2000 $<$ http://www.dnevnik.si.>.

811 Slovenian Bishops' Conference, Pastisko Pismo ob Začetko Šolskega Leta. 1998/1999, 13 Sept. $1998,<w w . r c k . s i / p l e n a r y-z b o r . r o d e>$.

${ }^{812}$ The KMK in its first session created five sub-commissions dealing with the following topics: Legal, Finance, Economic, and Social, Pastoral, Cultural, and Education and Upbringing. In the latter subcommittee the experts included on the government side,Slavko Gaber, Mladen Dollar, Marko Kerševan, Zdenko Kodelja, Gabi Cacinovic-Vogrincic and Tine Hribar. On the Church side the experts included Stanko Gerjolj, Drago Ocvirk, Vinko Potočnik, France Skrabel, and Renato Podbersic.

${ }^{813}$ As Bishop Stress noted, the RCC resigned because they were not able to work out "death points" and the debate was going nowhere. Dejan Pusenjak, "Šola" 19-20.
} 
which are at the moment mandatory. ${ }^{814}$ Beyond that, teachers should be clergy or theology faculty graduates and should be approved by the RCC. ${ }^{815}$ The government, focused on comprehensive change, argued that information on religion should be non-denominational and dispersed among various subject areas such as history, philosophy, ethics, and geography. On 16 June 1994, the church side of the KMK agreed to the creation of the subject of Religion and Ethics. Beyond that, there were many lay Catholics who participated in the process of school reform, without necessarily condoning or promoting the position of the RCC hierarchy. ${ }^{816}$

Of the 11 members of the curricular commission for the subject of Religion and Ethics, 3 were Catholic theologians ( 2 from the Theological Faculty in the University of Ljubljana and 1 from the Theological Faculty at the University of Maribor -- Stanko Gerjol, Drago Ocvirk, and Alenka Šverc, respectively). ${ }^{817}$

However, even though the church hierarchy agreed to the compromise, they continued

\footnotetext{
${ }^{814}$ The RCC hierarchy regularly criticized the mandatory subject of Civic Education and Ethics, because as Štuhec notes the title itself connotes some sort of possible overlap with the subject Religion and Ethics. An example of this position was enunciated on 31 January 1995, when the Commission for Justice and Peace (of the Slovenian Bishops' Conference) presented arguments for educational change in the State Council (Državni svet). Calling on members of the Commission State Council for Non-economic activities (Komisijo državnega sveta za negospodarske dejavnosti) the Commission for Justice and Peace argued that the compulsory course "ethics and society (or civic education and ethics as it was to be later known) would mean automatic marginalization of any religious instruction classes." Representatives of the Church that day also argued that prohibiting confessional activity in public schools is anti-constitutional, undermining Articles 14 and 4 of the Act. Štuhec 64 .

${ }^{815}$ Štuhec 70.

${ }^{816}$ The Church, in its most basic sense, is a community of believers, so it should register with the RCC hierarchy that lay Catholics are an important part of their Church, and such Catholics have inevitably had a large part in curricular reform.

${ }^{817}$ Marko Kerševan, et al. , Ucni Načrt za Izbirni Predmet: Verstva in Etika (Ljubljana: Ministry of Education Republic of Slovenia, 1998) 9.
} 
to campaign publicly against the subject. ${ }^{818}$ The RCC hierarchy made the point that since the subject Religion and Ethics was not controlled by the RCC, they were absolved from having to support the compromise. ${ }^{819}$ The actions of the RCC in this instance revealed that they it was not fully prepared to engage in the process of debate and compromise. Despite its opposition, the subject of Religion and Ethics was ready to be implemented by 1999 .

\subsubsection{The Religion and Ethics Course}

This creation of the Religion and Ethics Course extended from 1996 to $1999 .{ }^{820}$ Students in the last three years of compulsory elementary education must take three mandatory optional subjects. ${ }^{821}$ These subjects are labelled mandatory optional subjects because, once a subject is chosen, the student must take it for the rest of the year. The choice of one optional subject in one year does not oblige the student to take that subject in the following years. For example, if a child chooses Religion and Ethics in Grade 7, s/he is not obliged to take it in Grade 8 or 9. Even so, the teaching plans for all three years ensure that students build on knowledge from the previous year, ensuring progression and review rather than repetition. A

\footnotetext{
${ }^{818}$ Gerjolj 82-87.

${ }^{819}$ Sloven ian Bishops' Conference, Pastisko Pismo ob Začetko Šolskega Leta, 1998/1999, 13 Sept. 1998, <ww.rck.si/plenary-zbor.rode>. Mlakar 9.

${ }^{820}$ In 1999 there were approximately 40 optional subjects available, with approved curricula. By 2002 there were 72 such subjects available. Not all of the optional subjects available have been taught in Slovenian elementary schools. However, they have teaching plans that have been approved by the process detailed in the above section. Krek, White Paper 263, 279.

${ }^{821}$ The introduction of optional subjects at any educational level is a large step in itself. The Higher Education Act, adopted by the National Assembly on 7 December 1993, provided that a credit system would be gradually introduced into university education. Prior to that university students were not afforded one optional course.
} 
student must choose at least one optional subject from each of the two divisions into which the optional subjects fall, arts and humanities or sciences. In the 1999/2000 school year, 42 of 814 elementary schools implemented this reform, and by the school year 2003/2004 the process was completed. Fifteen students is the minimum necessary for an optional subject to be offered. If that minimum is achieved, the school must offer the course.

The proposals and teaching plans for the optional subject Religion and Ethics for Grade 7, 8 and 9 were presented in September 1998 by the committee for Religion and Ethics, the committee for primary school, and the National Curriculum Council. The plans were passed in late $1998 .{ }^{822}$ Beyond stipulating that the courses would be non-confessional, the teaching plans emphasised that children would learn a plurality of worldviews and religious belief systems. The nondenominational course entitled Religion and Ethics was made available to Grade 7, 8 and 9 students as an optional subject starting in the 1999/2000 school year. Religion and Ethics has the same status as all other elementary school optional subjects and must abide by the same laws as other school subjects.

The hours for Religion and Ethics were settled at 35 per school year in Grade 7 and 8, and 32 in Grade $9 .{ }^{823}$ The focus in Grade 7 is on world religions, patterns, and differences, with 5-7 hours each dedicated to Christianity, Islam, and Buddhism. The luminaries discussed include Primož Trubar, Anton Martin

\footnotetext{
${ }^{822}$ Kerševan, Ucni Načrt 2.

${ }^{823}$ Kerševan, Ucni Načrt 2.
} 
Slomšek, Mother Theresa, Albert Schweitzer, Martin Luther King, and

Gandhi ${ }^{824}$ Grade 9 curriculum includes an in-depth study of some Slovene luminaries, although only 3.4 hours are allotted to this. ${ }^{825}$ Although there is recognition that a significant portion of time will be dedicated to acquiring an understanding of "religious surroundings... which in our situation is indisputably Christianity," the emphasis is on equality in the treatment of the plurality of world religious traditions and philosophical ideals. ${ }^{826}$ The RCC in Slovenia has protested that this even-handedness distances students from their Roman Catholic heritage.

The teachers of the subject are discouraged from promoting their own beliefs and convictions. This has been particularly difficult for the RCC to accept. Teachers of the subject are drawn from a variety of undergraduate degree backgrounds, including theological, philosophical, pedagogic, or social sciences faculties. The main requirement is for teachers to have participated in some pedagogic training and taken courses from other faculties besides the one that had granted them their degree ${ }^{827}$ There is an expectation that all instructors have formal training in "sociology and humanistic higher education in pedagogy, philosophy

\footnotetext{
${ }^{824}$ Ibid. 5-7.

${ }^{825}$ This includes St. Modest (who was a figures in the wider Christian world) Primož Trubar (the Protestant clergyman who wrote the first books in Slovene) Juri Dalmatin (the Protestant clergyman who first translated the bible into Slovene) Anton Slomsek (Roman Catholic Bishop and avid promoter of Slovenian based elementary education) Janez E Krek (leader of the clerical Slovene Peoples Party) Friderik Irenej Baraga (Slovenian missionary among First Nations in the North American Great Lakes region) Ivan Cankar (writer and socialist) Jože Plecnik (architect) and Edvard Kocbek (writer and Christian Socialist politician) Kerševan, Ucni Načrt 25.

${ }^{826}$ Kerševan, Ucni Načrt 44.

${ }^{827}$ This was difficult before 1993 , because of the strictness of programs and few inter faculty or even course links).
} 
and didactic knowledge. ${ }^{, 828}$ However, only lay theologians, not clergy, are eligible to teach the course. This is so there are no overt confessional affiliations.

In 2001 Dr. Janez Juhant, Dean of the Theological Faculty of the University of Ljubljana, sent a letter to Prime Minister Drnovšek outlining the difficulties that graduates of the Theological Faculty, particularly lay theologians, have in finding suitable employment. He urged the prime minister to ensure that lay theologians have priority in becoming teachers of the subject Religion and Ethics. ${ }^{829}$ The RCC argues that priests and lay theologians of the Catholic Church should be the favoured if not exclusive candidates for teaching Religion and Ethics. The RCC in Slovenia has expressed its desire to control the content of teaching materials and has claimed the power to choose and veto potential teachers, even when classes include non-Catholics, as stipulated in Canon Laws 804 and 805. ${ }^{830}$ Canon Law 804 stipulates that any teaching of the Catholic religion must be "subject to the authority of the Church. It is for the Episcopal conference to issue general norms concerning this field of activity and for the diocesan Bishop to regulate and watch over it." ${ }^{\text {, }}$ Canon Law 805 notes that "in his own diocese, the local Ordinary has the right to appoint or to approve teachers of religion and, if religious or moral considerations require it, the right to remove them or to demand that they be

\footnotetext{
${ }^{828}$ Kerševan, Ucni Načrt 46.

${ }^{829}$ Resolution 388 of the latest Slovenian Synod puts forward the demand that theological graduates teach a confessional religion and ethics course in public schools. Ivan Štuhec, Julka Nežič, Peter Kvaternik, and Lojze Cvikl, eds., Izberi Življenje: Sklepni Dockument Plenarnega Zbora Cerkve na Slovenskem (Ljubljana: Družina, 2002) 149.

${ }^{830}$ Marko Kerševan, Cerkev, Politika, Slovenici: Po Letu 1990 (Ljubljana: CZP Enotnost, 1996) 16.

${ }^{831}$ Catholic Church 5.
} 
removed. ${ }^{9832}$ With the teaching plan and teacher requirements in place, the first course in Religion and Ethics was ready to be taught in the $1999 / 2000$ school year. The majority of Slovene schools have already by the school year 2002/2003 adopted the nine-year program along with optional subjects, but only one school in the country has as of the 2001/2002 school year offered the subject of Religion and Ethics.

Only nine Grade 7 students at elementary school Maksa Durjave taught by Rado Šumer have chosen the subject Religion and Ethics. ${ }^{833}$ This is below the required number of students that a school must have to be able to offer an optional course, but the Ministry of Education waived the requirement in this case and classified this class as a pilot project.

In Croatia, $80-90 \%$ of elementary school students take confessional Religious Instruction (RI), which is, nominally, optional in public schools. In Slovenia, RI remains a non-confessional and very unpopular subject. One of the reasons most often cited for this unpopularity is that Slovene society is heavily secularized and neither parents nor students are apt to be actively religiously observant, while the opposite holds true for Croatia. ${ }^{834}$ This ties into the argument,

832 Catholic Church 8.

${ }^{833}$ Andreja Zibret, “Zakaj ze Mulimani ne Jedo Svinjskega Mesa?" Delo 25 Feb. 2002: 11.

${ }^{834}$ In the well-respected statistical work, Toš et.al., is published a 1997 survey, which compared personal religiosity in 7 Central Eastern European countries, asking people to classify themselves as Type $\mathrm{A}=$ non-religious, Type $\mathrm{B}=$ autonomous religious, and Type $\mathrm{C}=$ church religious. Autonomous religious denoted people who believe in God and major tenets of a religion, but practice it on their own. They found that in Slovenia $60.1 \%$ of respondents were Type A (non-religious) $21.2 \%$ Type B (autonomous religious) and $18.7 \%$ Type $C$ (church religious). In Croatia 30.6 were Type A, 29.8\% Type B, and $39.6 \%$ Type C. Toš et. al. 72 . 
cited in the chapters on history, that the Slovene language is far more of an active identifier of their Slovene heritage than Catholic traditions or beliefs, while the opposite is true for Croatians. Accordingly, neither Slovene students nor their parents are very concerned with religious matters or with securing their Catholic identity ${ }^{835}$ At the same time, the RCC gained an immediate public space, even in schools in Croatia, so it already had a strong position and platform when its role in public schools was questioned.

Regardless of religious affiliation or strength of religious sentiment, parents and students choose elective subjects that they believe can forward their professional and career needs in the future. ${ }^{836}$ This could account for the fact that computer science and foreign languages are by far the most popular elective subjects in non-vocational Slovene schools ${ }^{837}$ To an extent that is difficult to measure, students are at times also influenced in their choice of elective subject by the reputation of the teacher. Students often choose courses known to have good teachers and not simply on the basis of the subject matter. Yet, there are few teachers in the school system trained for religious education, and as of December 2002 only one school implemented the teaching of the subject. Most students do not necessarily have a solid basis from which to evaluate potential teachers of RI.

\footnotetext{
${ }^{835}$ This is in some sense ironic, since Catholic priest/pedagogues are widely recognized as keeping the Slovene language alive. Catholic clergy kept Slovene alive by teaching it in their own parishes while pressuring Habsburg authorities to include Slovene language based education all levels of education available in Slovene lands.

${ }^{836}$ Zdenko Kodelja, personal interview, May 2002

${ }^{837} \mathrm{Ibid}$. For changing trends in vocational education see Pavel Zgaga, "Educational Policy and Quality in Education," South East European Educational Cooperation Network 17 Sept. 2002 $<$ http://www.see-educoonet/education_in/pdf/pbook-ways-006-zgaga-oth>.
} 
Among the most convincing reasons why RI has remained so unpopular is the strong exhortations of the RCC for religious parents not to enrol their children in the subject.

The Slovenian Bishops' Conference has written, distributed, and ensured the reading of two pastoral letters in every Slovene parish that instructed parents to boycott RI in public and/or concessionary schools. The first such letter was read on 13 September $1998 .^{838}$ This letter was issued as a celebration marking the beginning of the process of beatification of former school inspector and bishop Anton Martin Slomsek (1800-1862), who wrote extensively on the subject of pedagogy. ${ }^{839}$ That letter argued that the new laws on education entrench a "school system that remains anti-church and anti-religious," particularly because it creates a school system that denies the rights of parents to have their children reared as Christians. ${ }^{840}$ The only way to atone for this, it was argued, is to ensure that all teaching of religions or Christianity in the school system is under the jurisdiction of

\footnotetext{
${ }^{838}$ Slovenian Bishops' Conference, Pastisko Pismo ob Začetko Šolskega Leta, 1998/1999 (Ljubljana: Družina, 1998) 15.

${ }^{839}$ Šuštar 115. Slomsek was beatified by Pope John Paul II among a crowd of 250,000 in Maribor on 19 September 1999. After citing Slomsek's contribution to Slovenian education, Pope John Paul II addressed not only the religious education in public schools dispute, but a number of contested issues between the church and state in Slovenia, instructing clergymen to "not be afraid to ask for that freedom which is essential for performing the mission of the Church." He then added, "If Christians, as citizens, have a duty to contribute to the good of all society, as faithful they have the right not to be hampered in their legitimate activities. In this regard, given the fundamental role of Christianity and the Catholic Church in Slovenia's history and culture, it is only right to hope that the process towards effective Church-State collaboration can quickly move ahead by encouraging a resolution of the current difficulties, all to the advantage of that co-operation which is in the interests of society as a whole." Pope John Paul II, "Visit to the Cathedral: Maribor," Vatican I9 Sept. 1999, 20 Oct. $2002<$ http://www.vatican.va/holy_father/ john_paul_ii/travel/documents/hf_jpii_spe_1909199_slovenia-cathedral_en>. ${ }^{840}$ Slovenian Bishops' Conference, "Pastisko" 16.
} 
the RCC. Having failed to achieve this aim, Archbishop Rode in the education themed pastoral letter of 2001 urged parents not to send their children to RI in public or concessionary schools, simply because "it is not necessary." ${ }^{841}$ Even Dr.

Stanko Gerjolj, a church representative and theologian who was on the commission that wrote up and approved the subject Religion and Ethics, dissuades religious parents from enrolling their children in the subject. He called it a "scheme characteristic of communism." ${ }^{842}$ He said that the church has not accepted this scheme, and has disassociated itself from it.

\subsection{Conclusions}

It is ironic that the school subject, which has been the source of so much political and social debate and which has become a rallying point for criticism and comment on the whole process of school reform in Slovenia, is a course taken by only nine elementary school students in Slovenia as of June 2003. Despite the fact that few students have actually taken the course, it touched on politically sensitive subjects such as the status of church-state relations, the reform of the education system, and the interpretation of the constitution. The way in which the course was dealt with by the government exemplifies the process of reforms in Slovenia. In Slovenia, the liberal focus on separation of church and state was enhanced by incremental reforms that focused on the pragmatic goal of an enhanced, modern, and non-ideologically driven school system. The extensiveness of the debates and

\footnotetext{
${ }^{841}$ Snežič 5.

${ }^{842}$ Gerjolj 85-86.
} 
the inclusion of respected Catholics in the curricular reform process allowed for positive sum games and compromise that the RCC ultimately rejected. In Croatia, however, the implementation of RI was ad hoc and hurried, driven by an ideology that sought to bring the nation, the state, and the RCC into a closer embrace. The separation of church and state was not given as much consideration in Croatia as in Slovenia, because there was a lack of debate and consideration of these revolutionary changes. 


\section{Chapter 10: Church and State, Finance and Property Restitution}

\subsection{Introduction}

The post-communist relationship between church and state, including in the realm of finance was established in different ways in Croatia and Slovenia. In Slovenia the approach was reflective of swifter and more secure political liberalization in politics that was more disputatious, relied on incremental reforms, and made constant reference to the rule of law as established in the constitution. In Croatia the relative lack of dispute and open debate in the realm of financing of the RCC was indicative of the challenges to political liberalization. This included presenting the RCC as a central symbolic and national institution that patriotic Croats and the state must support. ${ }^{843}$

In Croatia direct state funding of the RCC and property restitution for property taken from the RCC during the era of communist rule in Yugoslavia were enshrined in the 1998 Agreement between the Holy See and the Republic of Croatia on Economic Questions. ${ }^{844}$ This agreement was reached through secretive, relatively expedient negotiations on the basis of social, cultural, educational, and humanitarian contributions of the RCC to the "common good." ${ }^{845}$ State funding of the RCC was justified by means of its contribution to Croatian national

\footnotetext{
${ }^{843}$ Ecumenical Christian theologian Peter Kuzmić spoke of the "uncritical equation of Catholicism, national identity and patriotism." "Letters," Feral Tribune 2 Sept. 2000: 19 .

${ }^{844}$ Ibid.

${ }^{845}$ Ibid.
} 
development. ${ }^{846}$ Rushing into this financial obligation without recourse to the public or the courts, the Republic of Croatia set a precedent that would further erode the separation of church and state. Once it was clear that the privileged position of the RCC cast doubts on religious equality required in order to enter the European Union, the Croatian government was required to further erode separation of church and state through agreements with other religious communities. The Croatian government was tied by the treaty obligations to the RCC, and although agreements with other religious communities included financial obligations, none were as extensive as the obligations to the RCC. ${ }^{847}$ The RCC was the only religious community with a financial agreement with the state until December 2002. As such, even Vice Prime Minister Goran Granić recognized its privileged status. ${ }^{848}$ In Slovenia, state financial support for the RCC, or the issue of a financial agreement analogous to the one between the RCC and Republic of Croatia, was not even on the agenda. The debate on church-state relations focused on the legal agreement with the RCC, as discussed in Chapter eight. However, the issue of property restitution did arise but the RCC was not a privileged actor in the debate on property restitution. ${ }^{849}$ The RCC was politically weaker in Slovenia than in

\footnotetext{
${ }^{846}$ Ivo Jakovljević, "Četvrti Ugovor- Hrvatski Dar Papi?" Novi List 22 Sept. 1998: 7.

${ }^{847}$ Republic of Croatia, "Ugovor Izmedju Svete Stolice i Republike Hrvatske o Gospodarskim Pitanjima Sveta Stolica i Republika Hrvatska," Narodne Novine 196/03 <http://www.nn.hr>. ${ }^{848}$ Slavica Lukić, "Crkve vs. Država," Globus 25 Feb. 2002: 30 . Goran Granić also headed the Commission for Religious Affairs. However the Commission focused on ensuring agreements with the RCC above all, so that the "commission appeared regularly as a joint Church-State, or more precisely as a Catholic-State Commision." Siniša Zrinščak, "Church and State in New Social Circumstances, the Croatian Story," Sociologija Religije: Hrvatsko Iskustvo 14.8 (1999): 126. ${ }^{849}$ Aloz Pluško, “Od Konkordata do Sporazuma," TV Slovenia 126 Jan. 2002.
} 
Croatia, because the RCC was not portrayed as an undisputed symbol of the Slovenian nation. There was thus greater political disagreement regarding the RCC's demands. In Slovenia, the RCC was unable to pressure the government into guaranteeing state funding of the Church. However, the center-right one bloc coalition that governed from May 1990 until May 1992 pushed through a denationalization law that was seen as a concession to the $\mathrm{RCC}{ }^{850} \mathrm{As}$ it became clear that the RCC in Slovenia would not receive a financial agreement analogous to the one in Croatia, the RCC focused on the requirements of property denationalization in order to supplement its finances. The Slovenian RCC desired a greater amount of direct state financing, but it may have recognized that it had a better chance of realizing property restitution as a source of funding for RCC activities. ${ }^{851}$ This is particularly true since European Union (EU) accession required that all property restitution claims be resolved prior to accession. ${ }^{852}$

It is important to note that in both countries the demands of the RCC were shaped by what state actors enabled, which in turn was shaped by historical memory of the relations between the RCC and the nation as well as enduring patterns of politics. In both countries, the RCC contemplated other methods through which it could ensure its financial well-being, but settled on what ensured

\footnotetext{
${ }^{850}$ Ali Žerdin \& Jure Trampuš, "Wealth and Power," Mladina 26 Aug. 2002, 20 Nov. 2002 $<$ http://www.mladina.si>.

${ }^{851}$ Aloz Pluško, "Od Konkordata do Sporazuma," TV Slovenia 126 Jan. 2002.

852 "Prompt Denationalization is in the Public Interest," Republic of Slovenia Apr. 2001, 9 Sept. $2003<$ http://www.gov.si >. "Constitution Watch," East European Constitutional Review Fall 2000, 28 Aug. $2003<$ http://www.law.nyu/eecr>.
} 
the greatest financial success. ${ }^{853}$ Some of the options for RCC demands on the state included the taxation of all declared believers, optional contributions of a set amount from personal income taxes, funds direct from the state budget, property restitution, profits from restitution of properties, or compensation for properties that could not be returned. ${ }^{854}$

In Croatia the 1998 Agreement on Economic Questions between the Republic of Croatia and the Holy See enshrined in an international treaty the obligations of the state to one religious community, the Roman Catholic Church. In Slovenia, the RCC focused on property restitution, which was enshrined in a law equal for all potential claimants.

This chapter focuses on the financial obligations of the Republic of Croatia to the RCC, because unlike in Slovenia the RH and Holy See in Croatia have an

\footnotetext{
${ }^{853}$ Kerševan "Sporozum" 15.

${ }^{854}$ The church tax option is not necessarily favoured by the RCC in Slovenia and Croatia. In the Slovenian RCC there is concern about secularization and the decline of potential contributors if such a system were enacted. In Croatia the concern is different, since the percentage of the population declaring themselves Catholic has increased from $76 \%$ to $88 \%$ of the population from the 1991 to the 2001 census. Government of Croatia, "The 2001 Census: Smaller Population, More Croats," Bulletin June/July 2002, 6 Sept. 2002 <http://www.vlada.hr/bulletin/2002/june-july/focus-full> Rather, the concern when it comes to a possible church tax is the expectation that this method would not generate much revenue form the church due to low wages and high unemployment rate $(22.3 \%$ on average for the year 2002 in Croatia). In that year there were approximately I million employed people in a population of 4.7 million. "Employment and Unemployment in Croatia," Hrvatski Zavod za Zapošljavanje 3 Aug. 2003, 28 Nov. 2003 <ttp://www.hzz.hr>. Some in the RCC also considered that believers might be less willing to donate to the church on their own volition if an automatic portion of their taxes went to the RCC. The RCC, however, is often dismissive of the revenue generated by parishioner or believer donations, indicating that these funds are not substantial enough to finance the spiritual and temporal work of the RCC. Davor Buktovic, "Dio Crkve u Hrvatskoj Razočaran je Četvrtim Ugovorom s Vatikanom,” Jutarnji List 5 Feb. 1999
} 
international agreement that delineates their responsibilities. ${ }^{855}$ On the other hand, the debate concerning state funding of the church is discussed in greater detail in the Slovenian case, as the debate was more widespread there.

\subsection{Republic of Croatia - Holy See Accord, Financial Support}

This section of the chapter focuses on the Holy See agreement, because it set the precedent for other agreements and went further in terms of property restitution obligations. The $\mathrm{RCC}$ remains the most prominent and privileged church in Croatia. ${ }^{856}$ The government, in recognition of the social, cultural, educational, and humanitarian contributions of the RCC to the common good, committed itself to funding the RCC through the budget in several ways. ${ }^{857}$ First, Article 6 stipulates that RH will give to the RCC through the Central Establishment of the Croatian Bishops' Conference (HBK) for Maintenance of Clerics and Other Church Workers "from [the] yearly state budget funding that amounts to two average labourers pay multiplied by number of parishes which exist in the Republic of Croatia on the day

\footnotetext{
${ }^{855}$ Republic of Croatia, "Ugovor Izmedju Svete Stolice i Republike Hrvatske o Gospodarskim Pitanjima Sveta Stolica i Republika Hrvatska," Narodne Novine 18/98<http://www.nn.hr>. The agreement does not apply to profitable activities of the RCC in Croatia.

${ }^{856}$ Mirko Djordjević, "How Strong are the Catholic Church in Croatia and the Orthodox Church in Serbia: Part II," Radio Free Europe/Radio Liberty 31 Jan. 2002, 8 Nov. 2002 $<$ http://www.rferl.org>.

${ }^{857}$ Article 1 notes that the "legal character [the] Catholic Church, in accordance with provisions of Canon Law, may freely get charity and gifts [from] believers and accept other general forms produced by believers for maintenance [of] church establishments," tax free. Republic of Croatia, "Ugovor lzmedju Svete Stolice i Republike Hrvatske o Gospodarskim Pitanjima Sveta Stolica i Republika Hrvatska," Narodne Novine 18/98<http://www.nn.hr>.
} 
that this agreement comes into effect. ${ }^{, 858}$ The same article further states that the HBK will by 1 February of every year give competent state authorities a list of any new or eliminated parishes. A parish eligible for state funds, as outlined in Article 6 of the agreement, includes a parish with 3,000 or more believers in a town or a parish with 1,000 or more believers in a village. ${ }^{859}$

Article 8 notes that the monthly income and insurance for clerics and other church workers on the basis of "equality and church unity" will be provided through the Central Establishment of the HBK dedicated to distributing those funds in harmony with state and church regulations. ${ }^{860}$ Pensions, as stipulated in Article 9 , will be provided to clerics, nuns, and monks once they reach the age of 65 . In line with the IV Agreement, the Croatian state was to earmark approximately 360 million kunas (50.7 million U.S. dollars as of June 2002) tax free for the Church. ${ }^{861}$ This amount includes funds for providing Catholic education in public schools and renovation of RCC buildings that are considered cultural monuments; they were funds that remain out of reach of other religious communities. ${ }^{862}$

\footnotetext{
${ }^{858}$ Republic of Croatia, "Ugovor Izmedju Svete Stolice i Republike Hrvatske o Gospodarskim Pitanjima Sveta Stolica i Republika Hrvatska," Narodne Novine 18/98<http://www.nn.hr>. ${ }^{859}$ Narodne Novine $18 / 98<\mathrm{http}: / / \mathrm{www} . n n . h r>$.

${ }^{860}$ Narodne Novine $18 / 98<\mathrm{http}: / /$ www.nn.hr $>$.

${ }^{861}$ Mladen Pleše, "The State Firmly Committed Itself to Unconditionally Fulfilling All the Controversial Issues in the Controversial Contracts between Croatia and the Vatican," Nacional 12 Dec. 2001,19 Sept. $2002<$ http://www.nacional.hr $>$.

${ }^{862}$ The basis for this funding, outlined in the preamble of the IV Agreement, is that RH recognizes in Croatia the "role of the Catholic Church in social, educational, cultural and charity work... [and on this basis] the Holy See and [the] Republic [of] Croatia [have] agreed to the following," after which all of the provisions of the agreement are laid out. Republic of Croatia, "Ugovor Izmedju Svete Stolice i Republike Hrvatske o Gospodarskim Pitanjima Sveta Stolica i Republika Hrvatska," Narodne Novine $18 / 98<\mathrm{http}: / / \mathrm{www} . n n . h r>$. Because of this the RH shall "ensure material conditions for pastoral work in harmony with the provisions of the Second Vatican Council and
} 
To clarify the implementation of the agreement, the government of $\mathrm{RH}$ and the HBK in February 1999 signed an Agreement on the Basis of Implementation (on) Defined Financial Obligations [of the] Republic of Croatia to the Catholic Church. This document reiterates the agreement, with RH recognizing the "general social worth [of the] work [of the] Catholic Church [on the] cultural, pedagogical, social and ethical fields" and committing itself to funding the RCC for the "continuation" of this RCC advancement of the "general [common] good." ${ }^{863}$ This includes state payment to given funds of the HBK, which will distribute them among similar institutions at the bishopric level. In this way both the HBK and bishopric levels allocate funds as they see fit. Article 3 of this agreement notes that the "state budget [of the] Republic of Croatia for the year 1999" in February began issuing the required instalments of payments to the Central Establishment of the HBK for maintenance of clerics and other church workers, contributing 190 million kuna (27 million U.S. dollars) in 1999. RH did this in order to fulfill its obligations as stipulated in Articles 6 and 9 of the IV Agreement between the HS and RH. ${ }^{864}$ However, it has been reported that the Republic of Croatia $(\mathrm{RH})$ has paid between

Canon Law," while the Constitution of RH is not mentioned by name." The agreement obliges the state to pay for activities that are deemed by the RCC and the state as contributing to "the common social good" in "cultural, educational, social, and ethical fields." These activities are eligible to receive additional state funding, the amount of which is not specified in the agreement or could lie outside of the parameters of this agreement.

${ }^{863}$ Josip Bozanić and Borislav Skegro, "Sporazum o Nacinu Izvrsavanja Odredjenih Financijskih Obveza Republike Hrvatske Prema Katoličkoj Crvki," Ugovori Izmedju Svete Stolice i Republike Hrvatska, ed. Nedjelko Pintarić (Zagreb: Glas Koncila, 2001) 118.

${ }^{864}$ Bozanić and Skegro 119. 
$75-80 \%$ of its obliged payment to the RCC, with many funds devoted to building churches given the previous regime's reluctance to do so. ${ }^{865}$

Alongside the remedies for property restitution and remuneration for church workers, the IV Agreement in Article 11 stipulates "on [the] recommendation [of] diocesan bishops [the] state shall... every year consider, approval and financial help [for] specific programs and projects [of the] legal person [or character of the] Catholic Church which are to the benefit of general good. ${ }^{9866}$ This stipulation provides the RCC with access to funds not only for remuneration of RCC employees or for property restitution, but also for possible access to further state funding for any other reason in the name of the common good (above and beyond the agreed-to direct payments).

\subsubsection{Financial Agreements between Croatia and the Holy See}

In the Croatian case, the agreement on finance with the Holy See, as was the case with the other agreements, was not the subject of extensive debate in national political bodies. ${ }^{867}$ Without this disputatious politics, it becomes important to understand what the agreement set in place and how the agreement constrained

\footnotetext{
${ }^{805}$ Padjen, "Church and State" 12 . Padjen also notes the difficulty in tracking payments form the RH to the RCC because annual reports on the State Budget are not published in the Official Gazette of RH and the State Budget lists all principal direct payments to the RCC under the title "Obligations under international Agreement between the Holy See and the Catholic Church."

${ }^{866}$ Nedjelko, Pintarić, ed. Ugovori Izmedju Svete Stolice i Republike Hrvatske. Zagreb: Glas Koncila, 2001, 286.

${ }^{867}$ Branko Madunić, "Zašto Još Nije Postignut Sporazum sa Svetom Stolicom o Financiranju Katoličke Crkve u Hrvatskoj?" Vjesnik 7 Mar. 1998: 18.
} 
the choices of policy-makers in dealing with other religious organizations and ensuring legal equality, while still violating the separation of church and state.

The Croatian Constitution in Article 41(1) does allow the state to assist religious communities. As legal expert Ivan Padjen notes, given Articles 14 and 41 (2), such assistance should be regulated under law so as to ensure equality. ${ }^{868}$ Until the Law on the Legal Position of Religious Communities was ratified in 2002 there was no law that regulated the equality for which the constitution called. ${ }^{869}$ In Croatia the RCC was able to avoid open public debate and to pressure the government into guaranteeing state funding of the Church codified in the Accord on Economic Questions between the Holy See and Republic of Croatia (RH) ${ }^{870}$ The accord, signed on 9 October 1998, is also known as the IV Agreement and is the last of the series of four agreements between the RH and the Holy See (HS). ${ }^{871}$ Those arguing against the agreement, particularly in the independent magazine Feral Tribune, argued that the accord between the Republic of Croatia and the Holy See contributed to the economic ills of an already economically stressed polity, diverting taxpayers' money to initiatives that are not in keeping with liberal tenets. ${ }^{872}$ The Feral Tribune noted that, "the main hospital in Split had

\footnotetext{
${ }^{868}$ Padjen, "Church and State" 12. Republic of Croatia, "Constitution of the Republic of Croatia," Official Gazette 56 (135/97, 113/2000, 124/2000, 28/2001).

${ }^{869}$ Republic of Croatia, "Zakon o Pravnom Polažaju Vjerskih Zajednica," Narodne Novine 83/02 $<$ http://www.nn.hr>. .

${ }^{870}$ Anna Maria Gruenfelder, personal interview, June 2002.

${ }^{871}$ Pintarić 184.

${ }^{872}$ Heni Erceg, "Mijeh Struktura," Feral Tribune 21 Dec. 1998: 7. At that time unemployment was the biggest concern in Croatia, along with increasing rates of poverty and lack of funds for pensions. Davorko Vidović, "Statement by Davorko Vidović: Ministry of Labour and Social Welfare,
} 
to cancel all operations because of a lack of [funds for] anaesthesia... and the Split dockyards were at a standstill waiting for 200 new workers that are needed. ${ }^{, 873}$ Money flowing from the state to the RCC has alienated some Croatians from the RCC, which became increasingly viewed as just another pillar of political power detached from the reality of everyday life. ${ }^{874}$ Opponents of the agreement noted that these agreements made religious communities dependent on state funds, opening a space for more demands and allowing for various religious organizations to influence policy and implementation in various state sectors, including public education. ${ }^{875}$ These communities claim independence from the state despite the fact that they receive funds from the state budget and now play an active role in policymaking.

Defenders of the agreements argued that the agreement facilitated the true independence and freedom of religious communities in Croatia, enabling them to undertake their pastoral activities. ${ }^{876}$ Don. Živko Kustić, editor in chief of the Catholic Information Agency and leading commentator in the Croatian Catholic weekly Glas Koncila, noted that the agreements between the RH and HS ensured "that it [the RCC in Croatia] will not end up as an organ of state administration, relying on the favour or disfavour of political leaders and to their momentary

Enhancing Social Protection and Reducing Vulnerability in a Globalizing World," Croatian Mission to the UN 14 Feb. 2001,18 Oct. $2002<$ http://www.un.org >.

${ }^{873}$ Heni Erceg, "Kaptolska Bozicnica" Feral Tribune 21 Dec. 1998: 12.

${ }^{874}$ Glas Koncila, “Jesu Li Vjerski Vodje Izgubili Autoritet?" 2 Feb. 2002: 4.

${ }^{875}$ Davor Gjenero, personal interview, June 2002.

${ }^{876}$ Nedjelko Pintarič, personal interview, June 2002. 
advantage. ${ }^{9877}$ This assertion ignores the fact that the RCC in Croatia received these agreements by being politically active and relying on the favour of President Tudjman and his party, the HDZ. ${ }^{878}$ It also ignores the fact that other communities received their agreements by virtue of the pressure to join the European Union. Furthermore, religious communities with agreements with the state are now tied to relations that, in the case of RCC, resemble pre-Vatican II type relations, where church and state share civic authority and obligations. ${ }^{879}$ For example, in educational institutions representatives of denominations with financial agreements are paid by the state as state employees. These agreements, whereby religious communities secure finance from the state, contravene the Croatian constitutional stipulation of the separation between church and state. ${ }^{880}$ Financing of the RCC by the state ties the RCC to the state even closer. There are some who support the agreement and believe it did not go far enough, even though the RCC received state funding through separate obligations for building and repair, property restitution, salaries/pensions, and even cultural objects. ${ }^{881}$ Spokesperson for the HBK, Dr. Ilia

\footnotetext{
${ }^{877}$ Živko Kustić, "Crkva Mora Biti Ekonomski Neovisna" Glas Koncila 1 Nov. (1998): 5.

${ }^{878}$ Mirko Vid Mlakar, "Izborni Grijeh Crkvenih Struktura," Jutarnji List 5 June 1999: 20. Boris Rašeta, "Krist u Pričuvi," Feral Tribune 7 Apr. 1997: 4. Gordan Pandža, "Političari Žele Iskoristiti Crkvu za Sovj Ciljeve, Vjesnik 16 May 1999: 2.

${ }^{879}$ Ivan Padjen, personal interview, June 2002.

${ }^{880}$ Republic of Croatia, "Constitution of the Republic of Croatia," Official Gazette 56 (135/97, $113 / 2000,124 / 2000,28 / 2001)$.

${ }^{881}$ Globus 17 Sept. 1999.
} 
Živković, argued "money which the Croatian state allocates for Catholic Church is not even close to enough for 2500 clergy and 3500 monks!" 882

The RCC sought a greater public role through this financing, and some argue that this introduced the peril of possible diminution of their spiritual mandate in favour of the financial gain, space in public institutions (namely public schools) and political involvement. ${ }^{883}$ There are some clerics and many commentators who argue that the RCC has damaged its reputation in Croatia through political involvement and the drive to secure ever greater financing from the state budget. ${ }^{84}$ The argument that the RCC needs these funds for its spiritual mission is contentious, as the RCC survived and thrived for many years without this stream of income. Even Živko Kustić notes that, in the communist era when the RCC was impoverished, had no property rights, and was left with only seminaries and theological faculties, it was "closer to the people. ${ }^{9885} \mathrm{He}$ also notes that Tito's attempts to influence the clergy through social security and health benefits provided to priests' associations beginning in 1950s and the donations from emigrants during

\footnotetext{
${ }^{882}$ Željko Preatović, "Crkva na Državnom Troškovniku," Globus 23 Oct. 1998: 19. ln 1995, HBK statistics show that there were 1,534 parishes in Croatia, and the total number of priests incardinated in all dioceses was 1,575 . There were 2,374 priests in the territory of all dioceses in 1995 . By the year 2000 there were 1,583 parishes, the total number of priests incardinated in all dioceses was 1,603 , there were 2,304 priests in the territory of all dioceses. "Church Statistics 1995: General Data From all Dioceses in Croatia 1995," Croatian Bishops' Conference 9 Apr. 2001 $<$ http://www.hbk.hr>.

${ }_{883}$ Among the prominent figures who have made such arguments are Anna Maria Gruenfelder (interview 30 May, 2002) Don Ivan Grubščić (interview 22 June, 2002) and Srdjan Vrcan, (interview 23 June 2002).

${ }^{884}$ Ivan Kalogjera-Brkić, "Zbog Povrata Imovine Iselit Će 33 Škole, Vrtića i Doma," Jurtarnji List 22 Jan. 2001: 6.

${ }^{885}$ Živko Kustić, “Treba li Crkvi Bogatstvo?” Glas Koncila 18 Oct. (1998): 185.
} 
the 1960s increased the gap between the RCC and its flock. ${ }^{886}$ There are a number of clergy members who take issue with the Croatian RCC's focus on securing ever-greater amounts of state funding, fearing that it has already detracted from the spiritual mission of the church. Legal scholar Ivan Padjen notes what some clergy have already pointed out, that Cardinal Stepinac exhorted the virtues of a poor church able to relate to parishioners. As Stepinac said, "I prefer to see that my priests remain poor, that they are Shepherds instead of farmers." 887

\subsubsection{State Justification of the Agreements}

The agreement between the Republic of Croatia and the Holy See and the subsequent agreements with the Serbian Orthodox Church and the Islamic community primarily justify state finance in recognition of the churches contribution to the common good, a nebulous concept. Since the agreement with the Holy See was the first to justify funding on this basis and since there are numerous instances where the funds provided by the state have been used for projects that might not be necessarily considered in the common good, the agreement will be the focus of this discussion.

\footnotetext{
${ }^{886}$ Stella Alexander, in her book Church and State in Yugoslavia Since 1945, discusses the establishment and role of priests' associations of the Catholic and Orthodox churches. Priests' associations were a type of "clerical trade union," sponsored by the state that provided welfare benefits for their members. Among the most prominent associations was Dobri Pastir (Good Shepard) and the Ciril Metodsko Društvo (Sts. Cyril and Methodius Society). The Vatican and Yugoslav Catholic bishops were particularly opposed to these associations, and in response set up diocesan insurance funds, which were not as well endowed as the state sponsored associations. Alexander, Church 124-127.

${ }^{887}$ Mirko Djordjević, "How Strong are the Catholic Church in Croatia and the Orthodox Church in Serbia: Part II," Radio Free Europe/Radio Liberty 31 Jan. 2002, 8 Nov. 2002

$<$ http://www.rferl.org >.
} 
The common good that is referred to in the financial accord is not specifically defined, other than in the preamble of the IV Agreement as the recognition of the "role of the Catholic Church in social, educational, cultural and charity work." ${ }^{888}$ Because of this the RH shall "ensure material conditions for pastoral work in harmony with the provisions of the Second Vatican Council and Canon Law. "The agreement obliges the state to pay for activities that are deemed by the RCC and the state as contributing to "the general social good" in "cultural, educational, social and ethical fields." ${ }^{889}$ However, the definition of general good has already been stretched beyond what the agreement suggests. The RCC has, with the funds provided by this agreement and for the general good, undertaken projects that are not, by most measures, required for spiritual care, charity, or cultural work. For example, the elaborate multi-million dollar offices for the Military Bishop and his 30 or so aids were included in this category. ${ }^{890}$ The Military Bishop also happens to be one of the most outspoken supporters of the opponents of the International Criminal Tribunal on the Former Yugoslavia. ${ }^{891}$ The $\mathrm{RCC}$ is one of Croatia's largest investors in building infrastructure. ${ }^{892}$ However, the money used for these projects flows from the state, which according to the

\footnotetext{
${ }^{888}$ Republic of Croatia, “Ugovor Izmedju Svete Stolice i Republike Hrvatske o Suradnji na Području Odgoja i Kulture," Narodne Novine $97<$ http://www.nn.hr>.

${ }^{889}$ Narodne Novine $97<$ http://www.nn.hr>.

${ }^{890}$ Estimated to cost the Croatian government 1 to 8.5 million U.S. dollars. Kristina Turcin, "Sveta Stolica Ostro ce Boriti Hrvatsku jer ne Vraca Nacionalizarnie Objekte,"Jutarnji List 29 Sept. 2001: 5. Mirjana Stošić, "Ministarstvo Obrane Gradi Vojni Ordinarijat Vrijedan Sedam Miljuna Kuna," Večernji List 18 Dec. 1997.

891 Mladen Pleše, "Vatikan Šokirao Hrvatski Biskupe," Nacional (2001).

${ }^{892}$ Globus 17 Sept. 1999.
} 
agreements with the HS must pay an unspecified amount for renovations or building of objects of cultural worth, thus facilitating RCC's contribution to the general good. ${ }^{893}$ This is at a time when the Croatian state is severely cash-strapped, having to pay for essential infrastructure such as roads, power facilities, and transmission lines, along with other structures damaged during the Homeland War. As of 2002 there were 80 churches being renovated or built. ${ }^{894}$ This includes a 3,700 square meter new building for the Croatian Bishop's Conference in Zagreb funded directly through the state budget. ${ }^{895}$ There are other objects being built as well, including 3,800 square meter Carmelite nunnery for 16 nuns in a remote town near Djakovo, built at an estimated cost of 5-30 million U.S. dollars. ${ }^{896}$ The estimate is so wide because the RCC does not publicly disclose such figures, and because there are many donations from different levels of government. Social commentator Drago Hedl cites the Carmelite nunnery near Djakovo, because the Osijek-Baranja district authorities donated the plot for the building, the construction site for the nunnery was prepared by the $37^{\text {th }}$ Engineer and Pontoon Brigade of the Croatian Army, and many undisclosed contributions were made by a number of other state owned firms, including the local water authorities, forestry authorities, and even a petroleum company ${ }^{897}$ While local authorities show

\footnotetext{
${ }^{893}$ Dragutin Hedl, "Dubious Business Deals of the Catholic Church," Aim Press 12 May 2001, 24 Sept. $2002<$ http://www.aimpress.org>.

${ }_{894}$ Boris Rašeta and Ivana Erceg, "Kapotolski New Deal," Feral Tribune 29 Sept. 2001: .

${ }^{895}$ Rašeta and Erceg, 4.

${ }^{896}$ Dragutin Hedl, "Dubious Business Deals of the Catholic Church," Aim Press 12 May 2001, 24 Sept. $2002<$ http://www.aimpress.org>.

${ }^{897}$ Dragutin Hedl, "Dubious Business Deals"
} 
deference to the RCC and even go as far as to supply it with costly goods and services, this is often done without disclosure to taxpayers or consideration of other religious or non-religious organizations. ${ }^{898}$

The RCC justifies the funding they were guaranteed because the majority of Croatian citizens classify themselves as Catholics. ${ }^{899}$ However, this classification does not mean that all Catholics equally support the actions of the RCC hierarchy in Croatia. Jure Radic noted when signing the IV Agreement on behalf of the Republic of Croatia: "With this agreement we desire to support the independent work of Catholic Church to the benefit of a large majority of our citizens who are Catholic." 900

10.2.3 Other Religious Communities and Agreements with the Republic of Croatia The agreements with the Holy See were signed in hopes of maintaining the support of the RCC and of re-affirming its place in the Croatian nation. In this spirit they were financially generous. However, the Holy See agreement set a precedent for agreements with other religious communities in Croatia, when the government

\footnotetext{
${ }^{898}$ As the previous example in Djakovo notes, local authorities even outside of the parameters of the agreements with the Holy See are apt to assist the RCC financially without public disclosure. The privileged economic standing of the RCC in Croatia and the favours that the RCC receives are not limited to property restitution or the financing of priest's salaries. The RCC is also privileged in matters where the service is beneficial but cannot be appraised monetarily. For example, "in 2000 the Catholic Church signed an agreement with the state-run Croatian State Radio and Television (HRT) to provide regular, extensive coverage of catholic events (as many as 10 hours per month). Other denominations receive approximately 10 minutes of broadcasting time per month or less." United States of America, "Report on Religious Freedom: Croatia," Department of State 2003, 12 Feb. $2003<$ http://www.state.gov>.

${ }^{899}$ Darko Pavičić, "Crkvi se Vraća Imovina i Financira Javno Koristan Rad," Večernji List 10 Oct.1998: 183.

${ }^{900}$ Erceg, "Kaptolska Bozicnica" 9.
} 
was interested in promoting a fairer treatment of religious communities. The financial requirements of the state to provide for various churches has grown, as has the direct link between church and state. These obligations and ties will continue to grow as the state signs more agreements. However, so will inequality, because there will be religious and non-religious communities that will not have the benefits of an agreement.

The agreements with the Serbian Orthodox Church (SPC) and the Islamic Community (IZ) signed on 20 December 2002 did provide for funding for parishes and mosques. Like the agreement with the RCC, each parish or mosque would receive monthly funds that amount to the average pay for two spiritual caregivers, at the time 4,232 kuna. ${ }^{901}$ These funds will be paid out to mosques that have 300 members in urban centres and 100 members in rural settings and to parishes that have 1,500 members in urban areas and 500 members in rural areas. Based on these calculations the state would give the Serbian Orthodox Church 7.5 million kuna annually and the Islamic Community 2.1 million annually. ${ }^{902}$ The state also became committed to helping with the financing of pensions and health insurance for priests and nuns.

The agreements between the Republic of Croatia and other religious communities did not detail the restitution of property, as did the agreement between the Republic of Croatia and the Holy See. However, the agreements did note that

${ }^{901}$ Department of State 2003, 12 Feb. 2003

902 "Račan Potpisao Ugovore sa SPC-om i Islamskom Zajednicom u Hrvatskoj," HINA 20 Dec. 2003, 7 Jan. $2003<$ http://www.hina.hr>. 
the state would give possession or ownership of all registration books and archival materials taken during the time of the Yugoslav communist regime and currently owned by the state to the religious communities. ${ }^{903}$ Restitution of property taken from religious communities other than the RCC during the communist regime in Yugoslavia is regulated under the same law as for others in Croatia, the 1996 Act on Restitution of Property Expropriated During Yugoslav Communist Rule. ${ }^{904}$ In contrast, the agreement between the Republic of Croatia and the Holy See does not only call for speedy return of property appropriated by the state during socialist Yugoslavia, but it also requires compensation for properties that are unable to be returned.

\subsubsection{Republic of Croatia - Holy See Accord, Property Restitution}

In Croatia the issue of property restitution is complicated. Not only must the Croatian state deal with property restitution claims stemming from WWII, it must also ensure repossession of property for owners who were dispossessed of it in the "Homeland War." The difference between these post-WWII nationalization restitution claims and post-Homeland War claims is that Homeland War property owners have the right to outright repossession, even if the property in question is occupied. As well, the majority of claimants are Serbs who fled Croatia in August 1995. If repossession is not possible by the end of 2002, restitution or government

\footnotetext{
${ }^{903}$ Republic of Croatia, Narodne Novine 196/03 <http://www.nn.hr>.

${ }^{904}$ Republic of Croatia, "Act on Restitution of Property Expropriated during Yugoslav Communist Rule," Narodne Novine 92/1996, 81/02 <http://www.nn.hr>.
} 
compensation is an option. ${ }^{905}$ Claims stemming from the Homeland War are treated differently than those stemming from post-1945 expropriation and nationalization. ${ }^{906}$ The type of property restitution discussed here deals with restitution claims stemming from the post 1945 expropriation and nationalization, because these types of returns involved most of the prominent religious denominations. These restitution claims have been the subject of much misunderstanding and the issues involved are comparable to those faced by Slovenia and other Central and Eastern European states.

After WWII, Tito's regime nationalized the majority of property held by all denominations. In Croatia, the RCC held most of its property before WWII in the form of forests, fields, and various buildings; like some other denominations, the RCC held on to some properties even after the nationalization, mostly places of

\footnotetext{
${ }^{905}$ As of April 2004 the return of Serb refugees and the restitution claims associated with their return remains a great concern. European Commission, Croatia: Opinion on the application of Croatia for membership of the European Union, Brussels, 20 April 2004, COM (2004) 257 final. ${ }_{906}$ Initially repossession was under the jurisdiction of local housing commissions, who consistently discriminated against Serbs desiring to return. For example, the recently repealed section of the Reconstruction Law, which prohibited funding for houses destroyed by "terrorist acts" including houses destroyed by looting after the Croatian military operations in 1995, is still cited by some county offices as reason for not reconstructing some Serbian houses. Beyond this, Croatian courts have "failed to rule favourably in repossession cases where the prewar housing had been socially owned and occupancy rights revoked because the residents were absent as refugees or internally displaced persons." "World Report: Croatia, 2002," Human Rights Watch 20 Dec. 2002 $<\mathrm{http}: / / \mathrm{www} . \mathrm{hrw} . \mathrm{org}>$. Even when court decisions were in their favour, a host of other officials did not implement these decisions. As of 31 August 2002 these local housing commissions ceased to exist, and the Ministry of Public Works, Reconstruction, and Construction took over this responsibility. According to 1 August 2002 amendments to the Law on Areas of Special State Concern, repossession decrees were to be issued by the Ministry of Public Works, Reconstruction, and Construction for already claimed properties by October 30, and for all other occupied properties by December 31, 2002. "Clock Starts Running on 1st of August for Croatian Governments Action on Property Repossession," OSCE 1 Aug. 2002, 20 Dec. 2002 <http://www.osece.org>.
} 
worship. ${ }^{907}$ Questions of what property should be returned to the RCC and how

this can be done are complicated, because the parameters are unclear. For example,

it is unclear what property is eligible for return to whom and with what

compensation. $^{908}$

The RCC stands to be the largest beneficiary of property restitution from

post-1945 nationalization. The RCC has pursued property restitution since the campaign for Croatia's first multiparty elections in the spring of 1990 and still in 2003 it remained a top priority. The RCC continued to support the HDZ, in part because of its promise to return property to the $\mathrm{RCC} .{ }^{909}$ By 1990 there was already a Property Restitution Law (amended in 1991 and 1993 and revised in July 2002) that focused on property seized during the era of communist rule. ${ }^{910}$ The 1996

${ }_{907}^{907 v i c a}$ H. Buljan, “Crkva je Vlastnik Četvrtine Zagreba," Feral Tribune 27 Feb. 1995: 14.

908 "The Government does not have detailed reports or statistics on the current value and amount of restituted property (houses or land)." "Stabilization and Association Report Croatia, 2002," Commission for the European Communities 4 Apr. 2002, 3 Nov. 2003 <http://www.europa.eu.int>. It doesn't have a comprehensive catalogue of properties claimed either.

${ }^{909}$ Darko Pavičić, "Je li Crkva prodala?" Vecernji List 20 Dec. 1998: 25.

${ }^{910}$ Republic of Croatia, "Zakon o Naknadi za Imovinu Oduzetu za Vrijeme Jugoslavenke Komunističke Vladavine," Narodne Novine 92/96 <http://www.nn.hr>. United States Embassy, Germany. "Summary of Property Restitution in Central and Eastern Europe," U.S. Embassy in Germany 16 July 2002, 15 Nov. $2002<$ http://www.usembassy.de/policy/holocaust $>$. However, the October 1996 Act on Restitution of Property Expropriated During Yugoslav Communist Rule (hereafter referred to as the Restitution Act) stipulated that only immediate family in the first generation after the property was taken by communist authorities, between 15 May 1945 and 25 June 1991, would be eligible for return or compensation. The law states that property deemed in the national or social interest will not necessarily be returned in kind. Instead, another property could be substituted for it, or claimants could receive monetary compensation.Article 54 of the Restitution Law clearly states that property used for such social goods or able to break the "economic or technological wholeness of a complex," including factories or schools, would not be eligible for return. The RCC has taken issue with that clause, as a number of properties the RCC requested for restitution are currently used by the government in their provision of social services or by private business concerns. Lawyer for the Zagreb Archbishopric, Zvjezdana Znidarčić-Begović, argued that this would then provide a loophole whereby no property would have to be returned. Dubravko Grakalić, "Hrvatski Politički vrh pravnim smicalicama prvo namiruje sebe!" Globus 28 June 1996: 
Restitution Law was revised in July 2002. Among other things, it allowed for compensation to those who did not have Croatian citizenship in 1996 and nonCroatian citizens. However, "foreigners also have rights to restitution under the condition that a bilateral agreement is signed with their governments. As of March 2003 no such agreements have been signed." ${ }^{.911}$

To add to the confusion and to legalize inequalities, the RCC had its own international agreement, the IV Accord between RH and HS, which took precedence over the 1996 Restitution Law. This is despite the fact that the restitution law covered the RCC, as it did other religious communities. The agreement provided the guidelines according to which RCC property would be returned, including the creation of a Mixed (RH, HBK) Committee that would identify property for restitution. ${ }^{912}$

The 1998 IV Agreement between RH and HS provided the RCC with an exclusive international treaty that calls for the return of property that once belonged to it. Many argued that this agreement and its provisions provided an advantage to the RCC, allowing it to accelerate the process of restitution, a privilidge denied to

51. Znidarčić-Begović went further to note that this was not the law they had anticipated, "especially after 5 years of legal insecurity." Mladen Pleše, "Vatikan je Odbio Potpisati Medjudržavni Sporazum s Hrvatskom Dok se ne Rijese 2464 Privjave Kaptola za Povrat Imovine," Nacional 18 Dec. (1996): 5.

911 "Stabilization and Association Report Croatia, 2002," Commission for the European Communities 4 Apr. 2002, 3 Nov. $2003<$ http://www.europa.eu.int>.

${ }^{912}$ To facilitate property restitution, Article 3 of the agreement clearly stipulates that a comprehensive list of the properties slated for restitution must be completed by a "Mixed Committee - established from an equal number of representatives from the Government [of the] Republic of Croatia and Croatian Bishops' Conference," within 60 days after the IV Agreement comes into effect. Republic of Croatia, "Ugovor Izmedju Svete Stolice i Republike Hrvatske o Gospodarskim Pitanjima Sveta Stolica i Republika Hrvatska," Narodne Novine Article 2 and 3. 
taken by the Yugoslav communist regime. ${ }^{918}$ Given that the list of properties in question was not completed, the monetary compensation that was to begin in 2000 for properties that could not be returned in kind has also been delayed. By March 2003 the government of Croatia has not even had a comprehensive list of or the current value of the properties to be returned, so that by April of that year the RCC submitted a list of their proposed restitution properties to the government. ${ }^{919} \mathrm{By}$ 2003 it was estimated that $35 \%$ of the properties claimed by religious communities had been returned, and that $20 \%$ of all other properties had been returned. ${ }^{920}$ The data on the percentage of returns for distinct religious communities is not available, but it is widely speculated that most returns were made to the RCC. ${ }^{921}$ In 2002 , after the first round of privatization of Croatia Osiguranje, the largest insurance company in the country, the RCC and government considered giving the RCC a stake in the denationalized companies. The discussions revolved around the Church receiving a stake in exchange for direct financial contributions for property restitution. ${ }^{922}$ In June 2003, in anticipation of the Pope's visit, the government offered the RCC $25 \%$ of Croatia Osiguranje, worth approximately 45 million U.S. dollars. ${ }^{923}$

\footnotetext{
${ }^{918}$ Turčin 11.

919 "Stabilization and Association Report Croatia, 2002," Commission for the European Communities 4 Apr. 2002, 3 Nov. $2003<$ http://www.europa.eu.int $>$.

${ }^{920}$ United States of America, "International Religious Freedom Report, 2003, Croatia," Department of State, Bureau of Democracy, Human Rights and Labour 18 Dec. 2003, 19 Dec. 2003 $<$ http://www.state.gov>.

921 Lukić 32.

${ }_{922}$ Snježana Mlinarević, "Croatia Osiguranje ide Crkvi za Dugove," Vecernji List 24 Feb. 2002: 6.

${ }^{923}$ Mlinarević 6.
} 
The state financial compensation package stipulated by the agreements between the RH and the HS were seen by the majority of the RCC in Croatia as "one of the best which the Holy See has ever concluded," a model for other postcommunist countries. ${ }^{924}$ Not all Croatians shared this enthusiasm, as a poll of 800 Croatians from 10 counties in Globus in 1998 found that $42 \%$ of respondents disagreed "with the decision of the Croatian government that 180 million kuna be given annually from the state budget for the needs of the Catholic Church," while $27.1 \%$ agreed with the decision and $30.9 \%$ did not offer an opinion. ${ }^{925}$

Some people who currently occupy properties, particularly apartments, that are slated for return, contest the Restitution Act. ${ }^{926}$ Some of these people have made improvements to these properties, but the law does not provide them with a guarantee of any compensation if the property is returned to previous owners. They may even have to pay the new owners rent, a cost many fear would be too high for people like pensioners. ${ }^{927}$ In February 1996 a group of citizens advocating on behalf of people who currently occupy living spaces set for restitution published an appeal to the government, arguing that they should be given the first option of purchasing their own living space back, regardless of the previous owners. ${ }^{928}$ One

\footnotetext{
${ }^{924}$ Kustić, "Dva" 5.

${ }^{925}$ Snježana Beroš, "Crkva na Državnom Troškovinku," Globus 23 Oct. 1998: 18.

${ }^{926}$ Gordana 1grec, "Stanovi Crkvi ili Stanarima?" Slobodna Dalmacija 7 Dec. 1998: 11.

${ }^{927}$ Buljan, "Crkva" 14.

${ }_{928}$ The signatories of the appeal are Udruženje prognanika Hrvatska [Association of exiles Croatia], Udruga veterana domovinskog rata [Association of Veterans of the Homeland War], Savez samostalnih sindikata [Alliance of Self-Governing Unions], Konfederacija nezavisnih sindikata [Confederation of Independent Unions], Hrvatska udruga sindikata [Croatian Association of
} 
of their first points was that since the constitution provides for equal treatment of all citizens in Croatia, the RCC should no longer be given the preferential treatment it has so far received in property restitution, which extends beyond the rights of the people who live in those spaces. ${ }^{929}$ The constitutional court addressed this issue, as well as the problems associated with the return of property used by the state in essential services, by stating:

\begin{abstract}
All laws...are based on the fundamental principle that the amending of old wrongs should not provoke new, weighty injustice. All principal provisions of the act derive from compromise and from the conflicting rights and interests of former owners, occupants holding the acquired rights over seized property and economic and other interests of the state and society. Because of that - and especially having continually in view the significant time lapse from the moment when property was expropriated - the absolute justice and equality among subjects who are successors in a property compensation process, that is restitution, is unfeasible. The compensation settlement for, or restitution of, seized property is therefore under exclusive competence and responsibility of the Croatian State Sabor. ${ }^{930}$
\end{abstract}

A host of other issues plagues restitution. For example, initially the state enforced limits on restitution to foreign nationals, but even when those were lifted after a constitutional court decision in 1999 , enforcement continues to vary by

Unions] Koordinacija Hrvatska sindikata, javnih službenika i namjestenika [Coordinated Croatian unions, public workers and employees]

Sindikat umirovljenika Hrvatske [Union of Pensioners Croatia], Savez organizacija invalida Hrvatske [Alliance Organization of Invalids Croatia] Matica hrvatskih umirovljenika [Registry of Croatian Pensioners], Gotovo sve politicke stranke [Completely all political parties] Udruženje stanara RH [United Tenants RH] Svjetsko udruženje stanara [World Union of Tenants], Above all many individual tenants. Group of Citizens, "Stanovi su se Morali Prodavati ili Nikome ili Svima," Novi List 5 Feb. 1996: 24

${ }_{929}$ Group of Citizens 24.

${ }^{930}$ Constitutional Court of Croatia, "Decision on Compensation for Property Seized during Yugoslav Communist Rule," Narodne Novine 39/99<http://www.nn.hr>. 
community. ${ }^{931}$ Incomplete records are another concern. Many properties were taken without documentation, or the documentation was destroyed during WWII and in the immediate post-WWII years. Even more contested was the fact that the Act only explicitly concerns property taken during the era of communist government, from 1945 until 1990, but leaves out the era of fascist rule, 1941-1945, when many (particularly Jewish people and the Jewish community) were deprived of their property by the fascist Independent State of Croatia (NDH). However, the 1999 constitutional court judgement addressed this concern and noted that, Chapters 3 and 4 of Article 2 of [the compensation act] specifies that compensation provisions shall also apply to property that owners had to abandon in the course of occupation... This means that this Act provides compensation for property that was expropriated prior to, and not only during Communist rule." 932

The compensation act's title refers to property seized druing the era of Communist rule. However, its content is wider and includes, in an indirect way, the property deprivation suffered earlier, that is, during fascist rule. ${ }^{933}$

Despite this ruling, since 1999 there has been little further government action on compensation of the hundreds of properties that could be potentially claimed, particularly by the Jewish community, if WWII era properties were consistently recognized as included in the Restitution Act. ${ }^{934}$ Even as of December

\footnotetext{
${ }^{931}$ Only people who were Croatian citizens when the Restitution Law was put into effect on 1 January 1997 were initially eligible to receive restitution or compensation. Vlado Rajić, "Katoličkoj Crkvi Posvlastice u Povratu Imovine-Ostaju," Jutarnji List 12 July 2000: 20.

${ }^{932}$ Constitutional Court of Croatia, "Decision on Compensation for Property Seized during Yugoslav Communist Rule," Narodne Novine 39/99 <http://www.nn.hr>.

${ }^{933}$ Constitutional Court of Croatia, "Decision on Compensation for Property Seized during Yugoslav Communist Rule," Narodne Novine 39/99 <http://www.nn.hr>. 934 Igrec 11.
} 
2003, the U.S. State Department noted, "the process of returning nationalized property to the Jewish community is at a near-standstill." $" 935$

The Jewish, Serbian Orthodox, Islamic, and Evangelical communities lacked the benefits of a specific agreement on property restitution and have argued that this disadvantage continues to delay restitution of properties they claim. The Serbian Orthodox Church (SPC) did have some success in the return of urban properties, but it has had less success in reclaiming certain buildings in central Zagreb as well as forests, arable lands, and monasteries. ${ }^{936}$ One of the problems associated with the return of SPC property is that during different times over the last century in Croatian lands the SPC was in local land registers labelled as the Greek-Eastern Church, a Greek-Rite Church, or the Serbian Orthodox Church. ${ }^{937}$ Complicating matters further, many clergy and SPC believers left Croatia after the Homeland War, so the of return of some local SPC buildings has not been vigorously pursued.

\footnotetext{
${ }^{935}$ United States of America, "International Religious Freedom Report, 2003, Croatia," Department of State, Bureau of Democracy. Human Rights and Labour 18 Dec. 2003, 19 Dec. 2003 $<$ http://www.state.gov>.

${ }^{936}$ The SPC desires 44-56 apartments in the centre of Zagreb, the Lepavina Monastery in the Zagreb Patriarchate, and approximately 7,000-8,000 square meters of commercial space in the city, including the building housing a movie theatre at Preradović Square \#5 along with the centrally located properties at Preradović Square \#4, Preobrazen \#2, Ilica\#7 and Bogović \#7. Helena Puljiz, "SPC trazi natrag 7000 kvadrata u strogom sredistu Zagreba" Novi List 31 July 1998: 8. The vast majority of the properties that the SPC would like returned is in Slavonia and includes 1,700 hectares of forests adjacent to the Orahovica Monastery. The other monasteries it would like returned in Dalmatia include the Krka, Krupa, and Dragović, and in the Kotar mountains the Gomirje Monastery. It also wants the land that falls under the jurisdiction of these monasteries. Mirjana Grce, "Prednost Naturalnom Povratu Oduzete Imovine," Novi List 20 Feb. 1999: 21-22. ${ }_{937}$ Puljiz, "SPC" 8.
} 
The Islamic community has not demanded the return of former properties, including the centrally located former mosque in Zagreb. Denuded of its minarets, the former mosque is now a centre for artists (Doma Hrvatskih Likovnih Umjetnika). Despite this, it is still commonly referred to as "the mosque" (džamija). The community has requested the return of objects that were taken from inside the mosque. ${ }^{938}$ Prior to the 2002 agreement with the state that promised the return of the important objects, authorities claimed that the Islamic community did not have the proper documents required to claim the objects. ${ }^{939}$ The Evangelical Church, once called the German Evangelical Church, had all of its property confiscated. It has had a handful of properties returned, but claims that they are only getting back the property that others do not want. ${ }^{940}$ For example, it continues to face strong resistance to its claims to the apartment block Jagicevoj in Zagreb. ${ }^{941}$ Though the RCC has had some difficulties in the area of property restitution, it has been the most consistently successful legal entity in resolving property restitution claims in its favour, in large part because of the special status conferred on it by the agreement with the Holy See. ${ }^{942}$

10.3 Financial Agreements and the Church in Slovenia

In the Slovenian case, the debate concerning the legal position of the RCC

\footnotetext{
${ }^{938}$ Lukić 30.

${ }^{939}$ Ivan Ugrin, “Tujce Nećemo, Svoje ne Damo," Slobodna Dalmacija 12 Jan. 2002: 4.

${ }^{940}$ Ibid.

${ }^{941}$ Lukić 31 .

942 "The HDZ government implemented property restitution in a discriminatory manner," in favour of the RCC. United States of America, "International Religious Freedom Report, 2003, Croatia," Department of State, Bureau of Democracy, Human Rights and Labour 18 Dec. 2003, 19 Dec. 2003 $<$ http://www.state.gov>.
} 
was so great that an agreement with the Holy See regarding financial obligations did not reach the drafting table. After years of bargaining, the Republic of Slovenia and the Holy See signed and passed an agreement on legal recognition, but not a financial one. In Slovenia, the RCC was unable to win the concessions it had won in Croatia, and so the RCC in Slovenia focused on issues of property restitution. ${ }^{943}$ Prior to discussing the specifics of property restitution, the following section offers some context on finance.

In terms of financial benefits for religious communities in Slovenia, as of 1991 religious communities were recognized as non-profit organizations and did not pay taxes on profits. This benefit extended to all religious communities in Slovenia registered for this special tax status. That same year, provisions for a subsidy of $40 \%$ for pensions and social insurance for religious workers (including clerics, nuns, and monks) was established. ${ }^{944}$ The provision of pensions and social insurance for clerics is a tradition. In most of Central and Eastern Europe, this tradition stems from the reforms of Joseph II, whereby the state sought greater power over the church. ${ }^{945}$ After confiscating church properties and engaging in agricultural reform, the state, in a bid to diminish the temporal power of religious communities, established the Religious Fund to pay for clerics and other church

\footnotetext{
${ }^{943}$ Katarina Fidermuc, “Za Zdaj Še Brez Cerkvenega Davka” Delo 6 Aug. 2001: 7. Stanislav Kovač, "Privilegiji," Delo 24 Oct. 1998: 5.

${ }^{944}$ Republic of Slovenia, "The State and Religious Communities in the Republic of Slovenia," Office for Religious Communities 2000, 9 Jan. $2001<\mathrm{http}$ ://www.sigov.si/uvs >. ${ }_{945}$ Bogdan Kolar, "Zgodovinski Temelji Premoženja Ljubljanske Nadškofije," Družina 12-22 Mar. 1998: 13.
} 
needs. ${ }^{946}$ This was extended through provisions for clergy during the political Christian socialist movement in Slovenia and through to the 1949 Cyril and Methodius Priests' Association (Ciril -Metodsko Društvo, CMD) in what was communist Slovenia. ${ }^{947}$ The benefits were further entrenched with the 1976 Socialist Republic of Slovenia Law of Religious Communities, which formally allowed the financing of religious communities. ${ }^{948}$

Following the 1976 Law on Financing Religious Communities, a 1991 executive council decision called for state contributions to health, social, and pension insurance for religious workers. As of 2002, the religious workers of the RCC and five other religious communities received these subsidies. ${ }^{949}$ That year there were approximately 1,200 religious workers who qualified for pensions and health and social insurance benefits from the state, with the majority being in the RCC, the largest religious community. In 1997 and 1998 respectively, 195 million Slovenian tolars and 210 million Slovenian tolars were paid out for pension, health, and social insurance to religious workers in Slovenia. ${ }^{950}$ The projections for payment of insurance subsidies were 255 million tolars in 2000, 296 million tolars in 2001 , and 319 million tolars in $2002 .{ }^{951}$ Registered religious communities also "compete for other funds from the state budget, i.e. for the performance of certain

\footnotetext{
${ }^{946}$ Ludvik Nemec, "The Pattern in the Historical Roots of Church-State Relationship in Central and Eastern Europe," East European Quarterly 20 (1986): 8.

${ }_{947}$ A lexander, Chruch 54.

${ }^{948}$ SRS, "Zakon o Pravnem Položaju Verski Skupnosti v Socialistični Republiki Sloveniji, UR. List SRS, $15 / 76$.

${ }^{949}$ A loz Pluško, "Od Konkordata do Sporazuma," TV Slovenia 126 Jan. 2002.

${ }_{950}^{950}$ Kovač 7.

${ }^{951}$ Aloz Pluško, "Od Konkordata do Sporazuma."
} 
programs, especially in the social area." 952 The vast majority of these funds are allocated to the RCC. ${ }^{953}$ However, there has been increasing controversy over the delay of registrations by the Government Office for Religious Communities. ${ }^{954}$

\subsubsection{Concerns of RCC Favouritism}

While neither the privileges of the RCC or the provisions that endangered the separation of church and state were legislated, there were instances of implementation that favoured the RCC and discriminated against other religious communities. However, these practices were exposed and debated by the actions of the Human Rights Ombudsman. They were also addressed in the Constitutional Court, particularly when it came to the registration of new religious communities and the failure to issue a permit for the building of a mosque. There remain concerns that the RCC is favoured, as was exemplified in the controversy over the registration of a number of religious communities. ${ }^{955}$ Recognition is important, because it is a gateway to state funding. On 1 September 2003 Slovenia's Human Rights Ombudsman, Matjaž Hanžek, issued a strong condemnation of the Government Office for Religious Communities of the Republic of Slovenia

\footnotetext{
${ }^{952}$ Republic of Slovenia, "The State and Religious Communities in the Republic of Slovenia, Office for Religious Communities 2002, 7 Oct. $2002<\mathrm{http}$ //www.gov.si/uvs/ang/aindex>.

${ }^{953}$ Aloz Pluško, "Od Konkordata do Sporazuma,"

${ }^{954}$ Matjaž Hanžek, "Annual Report 2003," Human Rights Ombudsman of Slovenia 26 Mar. 2004 $<$ http://www.varuh-rs.si $>$. In Slovenia the Ombudsman is an office with the mandate to protect human rights of citizens. Republic of Slovenia, "Constitution of the Republic of Slovenia," Uradini List 33/91-I (1991). The Ombudsman in Slovenia is elected by the National Assembly by a two thirds majority for a maximum of two six year mandates ${ }^{955}$ Matjaž Hanžek, “Annual Report 2003."
} 
(GORC). He criticized GORC for its "lack of work," concealed favouritism of the RCC, and unwillingness to solve the following problems:

- Lack of criteria for the allocation of budgetary means to religious communities;

- Refusals to handle applications submitted by new religious communities; and

- Non-concern for the slow management of affairs in the construction of the Muslim place of worship. ${ }^{956}$

The delay of or refusal to process applications for registration of new religious communities by the GORC was exposed between 2000 and 2003. Since the 2000 appointment of Drago Cepar as the Director of GORC, no community has yet been denied registration, but there has been a noticeable delay in processing applications for registration. Between 1999 and 2003, no new religious communities were registered, but none was officially denied. ${ }^{957}$ After this was pointed out and controversy arose in 2003 , four religious communities were registered. These communities are the Christian Cavalry Church, the Dharmaling Buddhist congregation, the Hindu community, and the Universal Religious Group Eastern Sun. ${ }^{958}$ Commenting on the delay in registration, the Slovenian Human Rights Ombudsman decried GORC's "failure to carry out duties defined by law ... and [lack of] willingness to solve any of the existing problems." 959

\footnotetext{
${ }_{956}^{956}$ Matjaž Hanžek, “Annual Report 2003."

${ }^{957}$ Republic of Slovenia, "The State and Religious Communities in the Republic of Slovenia," Office for Religious Communities 2002, 7 Oct. $2002<\mathrm{http}$ ://www.gov.si/uvs/ang/aindex>. ${ }_{958}$ Republic of Slovenia, "The State and Religious Communities in the Republic of Slovenia." 959 Matjaž Hanžek, "Annual Report 2003," Human Rights Ombudsman of Slovenia 26 Mar. 2004 $<$ http://www.varuh-rs.si>.
} 
The RCC, as the denomination with the largest percentage of adherents in Slovenia (according to the 2002 census, $57 \%$ of the population), has received the most funds for social, health, and retirement insurance subsidies and the most subsidies for maintenance and renovation of culturally significant monuments. ${ }^{960}$ The Ministry of Culture also subsidises the renovation of churches and other culturally significant monuments and relics. For example, in 1994 the RCC was the only religious group that received benefits from government ministries and offices other than the Office for Religious Communities for monuments and programs. ${ }^{961}$ That year the RCC received approximately 572 million tolars for its projects. ${ }^{962}$ In $2001,28 \%$ of state funds to maintain cultural heritage objects, approximately 316 million tolars, was used to maintain sacred cultural objects, the overwhelming majority of which were Roman Catholic. ${ }^{963}$ In addition to these funds, religious groups also qualify for municipal funds to restore their cultural objects. Municipal authorities are infamous for their favouritism of the RCC in terms of providing maintenance funds or issuing building permits. One of the starkest examples of this favouritism is the three decade long struggle of the second largest religious community in Slovenia, the Muslim community, to have just one mosque built. ${ }^{964}$

\footnotetext{
960 "Population Census Results," Statistical Office of the Republic of Slovenia 2002, 23 Dec. 2003 $<$ http://www.stat.si $>$.

${ }_{961}$ Republic of Slovenia, Poročevalec 21 Dec. 1995: 80-81.

962 Iztok Jurančič, "Potrebe se Srkvajo v Turnu Brez Kazalcev, Gospodarski Vestnik 17 Apr. 1999: 14.

${ }_{963}$ Aloz Pluško, "Od Konkordata do Sporazuma," TV Slovenia 126 Jan. 2002.

${ }^{964}$ The Muslim community in Slovenia was first registered with authorities in 1967. Drago Ocvirk, "Islam: A New Religion in a Traditionally Catholic Slovenia," Proceedings of the Dialogue of Christian-Muslim Collaboration Conference May 29-June 1, 1995
} 
The Islamic community of Slovenia, the second largest religious community in the republic, has grown from $1.5 \%$ of the population as reported in the 1991 census to $2.4 \%$ of the population as reported in the 2002 census. ${ }^{965}$ Despite this, its attempts to erect a mosque and cultural centre in Ljubljana, where most Muslims live, have met with constant delays. As the Slovenian Human Rights Ombudsman noted, municipal and other officials often cite "insurmountable obstacles," which clearly "illustrate their, although concealed, active opposition.",966 It was only in 2001 that a site for the mosque and cultural centre was approved by the city council of Ljubljana. However, in the years since, authorities have continued to delay and block construction. This systematic discrimination has slowly been addressed by the office responsible for ensuring religious equality, the Government Office for Religious Communities. However, it has been more forthrightly addressed by the ombudsman with reference to the constitutional rights guaranteed to all religious communities. ${ }^{967}$ The Mayor of Ljubljana has also strongly condemned those councillors who continue to block the building of the mosque and called for the recognition of the rights of all Muslims in Slovenia. ${ }^{968}$

$<\mathrm{http}: / / \mathrm{www}$.georgefox.edu $>$. These houses for prayer, meeting and administration primarily involve the Muslim communities who speak Serbian and Croatian and not Slovenian and Albanian.

965 "Population Census Results," Statistical Office of the Republic of Slovenia 2002, 23 Dec. 2003 $<$ http://www.stat.si $>$.

${ }^{966}$ Matjaž Hanžek, "Reply to Open Letter form the Justice and Peace Committee at the Slovene Bishop's Conference (SSK)," Human Rights Ombudsman of Slovenia 1 Sept. 2003

<http://www.varuh-rs.si>.

${ }_{967}$ Hanžek 5.

${ }^{968}$ Editorial, Delo 28 Feb. 2004:3. 
While the Islamic community has yet to build one mosque in Slovenia, the RCC has been able build and maintain its objects with much state support. It has the right to even more properties, as it has been able to gain back or be compensated for properties taken by communist authorities after WWII. A major victory for the RCC was the guarantee of return or compensation for properties taken after WWII. Although the RCC secured a guarantee of property restitution, it was not exclusive, since the first Slovenian centre-right government's commited to property restitution for all claimants.

The 1991 Act on Denationalization allowed for restitution for legal persons who held Yugoslav citizenship when lands were expropriated. ${ }^{969}$ Although the government did this in large part to secure the support of the RCC, the RCC was not the sole beneficiary. As of September 2003, 81 percent of all property claims had been adjudicated, either through return or financial compensation. ${ }^{970}$ The RCC has focused on property returns because other options such as taxation and direct state funding are seen as more complex, controversial, and difficult to achieve.

In the absence of generous agreements like in Croatia, and given the secularizing trend in Slovenia, the RCC in Slovenia stands to receive the most financial benefit from the properties that it claims. ${ }^{971}$ The financial gains to be had from these properties have made property restitution one of the most contentious

\footnotetext{
${ }^{969}$ Republic of Slovenia, Uradni List No. 27/91. Republic of Slovenia, Uradni List No. 31/93.

${ }^{970}$ United States of America, Commission on Security and Cooperation in Europe, "Summary of Property Resitution in Central and Easten Europe," State Department 10 Sept. 2003, 22 Mar. 2004 $<$ http://www.state.gov>.

${ }^{971}$ STA, "Z Zakonom o Dediščini Vsak po Svoje," Delo 19 Oct. 2000: 15.
} 
issue of church-state relations in Slovenia. Despite the debates and concern for greater RCC power at the expense of taxpayers, as well as possible favouritism in returning $\mathrm{RCC}$ properties, the $\mathrm{RCC}$ benefited from the fact that that restitution of all properties confiscated by the authorities after WWII is enshrined in a law. ${ }^{972}$

\subsubsection{Property Restitution}

The restitution in kind or financial compensation for properties claimed by pre-WWII owners in Slovenia proceeded swiftly. Restitution of property is not a general requirement for EU membership, but the fulfilment of laws regarding property restitution is. In the Slovenian case, parliamentary debate was focused on ensuring equality, non-favouritism of a given organization in restitution, awareness of the rights of current occupiers of properties, and the need to abide by the letter of the law. ${ }^{973}$

In Slovenia and Croatia the largest claimant and potential beneficiary of property restitution is the $\mathrm{RCC}$, but in many instances the property claimed by the RCC was in contention, namely because the properties have for almost half a century been used by other people. ${ }^{974}$ As of Spring 2002 , legal subjects and

\footnotetext{
972 Janez Šmidovnik, “Bo Cerkvi Uspelo Še Enkrat Prodati to, Kar Je Že Prodala?” Delo 24 Oct. 1998: 21 .

${ }^{973}$ Bogo Grafenenauer, "Polemika z Ustavnim Sodiščem," Mladina 23 Oct. 1997: 8.

${ }^{974}$ Lands and buildings were nationalized through the "Act on Agrarian Reform and Colonization in Slovenia," Uradni List 44/45 \& 62/45 and the "Act on the Nationalization of Buildings and Building Plots," Uradni List 52/58.
} 
organizations in the religious community (namely Catholic bishoprics and parishes) claimed 38,500 hectares of forests, 16,200 hectares of agricultural land, and 1.8 million square meters of building space. ${ }^{975}$

Both in Croatia and Slovenia, right-wing regimes when in power have attempted to use property restitution to win RCC's support. An excellent example of this in Slovenia was the 20 November 1991 Slovenian Law on Denationalization, drawn up by the Democratic Opposition of Slovenia (DEMOS) coalition, in which the Christian Democrats had the majority of seats. ${ }^{976}$ The law mandates the restitution of property that was nationalized from 1945 to 1963 for those who apply for its return. By 1998 there were over 37,000 claims for property restitution filed under that law. ${ }^{977}$ Some commentators criticized the law for being payback for the support the RCC had shown the Christian Democrats in the 1990 election. ${ }^{978}$ By 1992 , however, there was a new, centre-left governing coalition that put a standstill to property restitution. That year a law was passed that restricted restitution of properties less than 200 hectares in size. ${ }^{979}$ A year later, in 1993, the

\footnotetext{
${ }^{975}$ Aloz Pluško, "Od Konkordata do Sporazuma," TV Slovenia 126 Jan. 2002.

${ }^{976}$ Republic of Slovenia, Uradni List No. 27/91. Republic of Slovenia, Uradni List No. $31 / 93$.

977 Jernej Zupančič, “Mar Uradniki Res Nagajajo RKC?” Panorama 2 Dec. 1999: 16.

${ }^{978}$ The 1990 elections were held on Palm Sunday, and some parishes handed out leaflets and election documents to parishioners. It was reported that some leading prayers urged "the people to make a right choice." Igor Mekina, "Slovenia and Vatican: Alone against Everybody," Aim Press 4 Feb. 2000, 7 Jan. $2001<$ http://www.aimpress.org>. Mekina notes that in Škofja Loka, Parson Alfonz Grojzdek and Pastor Slavko Kalan concluded the mass with the following statement: "Elections are on Sunday! Decide so that the world and our own Slovenian history would not laugh at you!"

${ }_{979}$ Editorial, "Proti ustavi?" Delo 17 Oct. 1992: 5.
} 
constitutional court annulled the restriction. ${ }^{980}$ However, the constitutional court decision did not resolve a number of questions surrounding the issue of denationalization that resulted in a halt to restitution in the years immediately following its judgement. These issues included the possibility of legislative limits on the amount of property to be returned, the type of land that could be returned, the beneficiaries of restitution, and the type of investigation and proof mandatory to establish that claimants or their ancestors had not already been compensated. ${ }^{981}$ In 1995 the Slovenian parliament issued a moratorium (followed by others) suspending the Law on Denationalization that effectively lasted until 1998 , so as to resolve some of the many problems regarding property restitution. LDS and its defenders argued that if the 1991 Denationalization Law were more precise, restitution might have proceeded faster and more smoothly.

One of the most contentious issues was the possible return of feudal lands, which some argued would place the majority of Slovenian land under the ownership of the RCC and the descendants of Austro-Hungarian nobility, the majority of whom lived outside of Slovenia. ${ }^{982}$ Others argued that in order to proceed with democratic and liberal reforms, this once private property must be returned to claimants, even if their ancestors acquired it through feudal grants and

\footnotetext{
${ }^{980}$ Constitutional Court Decision, Uradni List 25/92, 1993.

${ }^{981}$ The ZSLD and SNS have been among the most vocal opponents of property restitution to the RCC. Drnovšek's governing coalition, however, had a large enough legislative majority to approve the text of the church-state agreement.

${ }_{982}$ Šmidovnik, "Go Cerkvi" 21.
} 
not a system that is compatible or comparable with liberal democracy. ${ }^{983}$ Some of these issues were resolved by the year 2000 , and some aspects of the original law were reinforced. For example, the law holds that property can only be restituted to those who held Yugoslav citizenship in 1947 and states that feudal lands are eligible for restitution. A 1997 constitutional court ruling allowed for feudal lands to be returned in kind or compensated. ${ }^{984}$ A 1998 ruling reiterated that the fact that the lands were feudal is of no consequence in terms of restitution when it came to Church lands. These lands must be treated as all other lands and claims. ${ }^{985}$ In 1997 the LDS began to use the Denationalization Law to its political advantage, as a bargaining chip to solidify a co-operative relationship with rightwing, pro-church, coalition partners. This became apparent in the 1997 agreement to continue property restitution between the government and the Ljubljana Archbishop. ${ }^{986}$ Even without the agreement with the $\mathrm{RCC}$, the state recognized that it needed to resolve all property restitution claims, in part to solidify a co-operative relationship with some coalition members and in part to convince international institutions that Slovenia is committed to the rule of law. The RCC had brought concerns about property restitution to the EU, other pan-European organizations,

\footnotetext{
${ }^{983}$ Anton Stres, “Katoliška Cerkev Je in Bo Ostala Zavezana Pravičnosti," Delo 7 Feb. 1998: 4.

${ }^{984}$ Republic of Slovenia, Constitutional Court, Uradni List 121/97.

${ }^{985}$ Republic of Slovenia, Constitutional Court, Uradni List 65/98, 3015 and 76/98, 3780. The Constitutional Court decision inspired an amendment to the Law on Denationalization, adding Article 27 A in 1998, which mandated that property of feudal origin could not be subject to denationalization except when the beneficiaries are religious communities Republic of Slovenia, Uradni List RS, 64/98.

986 "Slovenia to Return Church Property," Radio Free Europe/Radio Liberty 7 Apr. 1997, 3 Sept. $2002<$ http:// www.rferl.org/newsline/1997/07/4-SEE/see-250797>.
} 
and American government representatives, which began to question the RS government on the implementation of the 1991 law on denationalization. In August 2001, the U.S. ambassador to Slovenia, Johnny Young, stated that the settlement of property restitution claims was a prerequisite for Slovenian entry into NATO, even though these stipulations are not in the Membership Action Plan, which details requirements for consideration for NATO membership. ${ }^{987}$

There are clauses of the Denationalization Law that give the government an opportunity to legally distinguish what property and people are eligible to benefit. For example, the law sets the requirement that the beneficiary be able to prove Yugoslav citizenship during a specific time period. The RCC has particularly disputed Article 27 of the 1991 Denationalization Law, which stipulates that the state is justified in providing other compensation for lands that "are located in large plots of land and forests. ${ }^{" 988}$ The reasoning behind this is that remaining large tracts of land and forest should not be disturbed, with those rightfully claiming the land compensated by other means. The archbishopric has, without compromise, sought the direct return of lands and forests, regardless of their potential benefits to all citizens. ${ }^{989}$ As Archbishop Rode infamously stated,

The church sincerely wishes to establish relations with the state, no matter what governing coalition. If this does not come at an instant, the church will simply wait for an opportune moment. 990

\footnotetext{
987 "Constitution Watch," East European Constitutional Review Fall 2000, 23 Feb. 2002 $<$ http://www.law.nyu/eecr>.

${ }^{988}$ Republic of Slovenia, "Law on Denationalization," Uradni List 112 /91.

${ }^{989}$ Matija Grah, "Cerkev Se Bo Morala Pogajati," Mladina 21 Oct. 1997: 21.

${ }^{990}$ Grah, "Cerkev" 21.
} 
The problem is that this hastily prepared law did not provide a standard classification for property that is deemed in the public good. ${ }^{991}$ The general understanding of public good in terms of "oceans, rivers, air, and also possibly parks" is things which all have access to and which all can use. ${ }^{992}$ However, the definition according to the law has not been set, so it is even unclear whether the 1981 Natural and Cultural Heritage Act, which provides for environmental protection and the protection of places and objects of cultural heritage, limits what may be returned. ${ }^{993}$ For example, Betnava Castle, returned to the Maribor Archbishopric in 2000, was in the 1960s declared a cultural monument. ${ }^{994}$ The 1999 Nature Conservation Act, which pledges the protection of biodiversity and the natural environment, has also been questioned with regards to property restitution. ${ }^{95}$ In the case of forests in Triglav National Park and Bled Island, there have been a number of competing decisions at the national level, which included reference to the Nature Conservation Act and implementation problems at the local level.

\footnotetext{
${ }^{991}$ Articles 70 and 71 discuss the protection of national assets and natural resources as well as the protection of land. Article 71 notes that "special protection of agricultural land shall be provided by law." Republic of Slovenia. "Constitution of the Republic of Slovenia," Uradini List 33/91-I (1991). ${ }_{992}$ Mavtež Krivic, "Še Zadnjikrat o Gozdovih Pokljuških," Delo 22 Oct. $2001: 9$.

${ }^{993}$ SRS, "Zakon o Naravni in Kulturni Dediščini," Uradni List 1/81, 13 July 1981.

${ }^{994}$ Ali Žerdin \& Jure Trampuš, "Wealth and Power," Mladina 26 Aug. 2002, 20 Nov. 2002 $<$ http://www.mlad ina.si $>$.

${ }^{995}$ While forests cover $54 \%$ of Slovenia's land area, only $8 \%$ of Slovenia's land area is classified as a protected area. $4 \%$ of protected areas lie within TNP, which is the only protected area actively managed by state authorities. Slavica Crnica, "Cerkvi Je Mogoče Vrniti Le Bremen Prosto Premoženje," Delo 28 July 2000: 22.
} 
Mt. Triglav is an age-old symbol of Slovene identity, and surrounding forests are considered special to the Slovene nation. Bled Island is Slovenia's top tourist attraction. It is a small island on an alpine lake with a church on it dating to the $9^{\text {th }}$ century. Restitution to the RCC could and has put these special and/or revenue producing lands in the hands of one organization with headquarters outside of Slovenia, a proposition that many Slovenes are uneasy about. ${ }^{996}$ Polls conducted by a number of organizations in 1997 suggest that $80 \%$ of the population opposed the return of Church property. ${ }^{997}$ The fate of lands in these places has been tossed around in political battles over the last decade.

In April of 2001, Radovljica municipal authorities rejected the Archdiocese of Ljubljana claims to forests in their district of Triglav National Park (TNP). ${ }^{998}$ They based this action on the exemption of lands that are for the general good and on the fact that TNP forests are protected. The Minister of Culture of the left-wing ZLSD, Andrej Richter, soon followed with an affirmation that the RCC should seek financial compensation for the island on Lake Bled, because it was protected under Natural Conservation and Cultural Heritage Acts. ${ }^{999}$ In 2001, however, the

\footnotetext{
${ }^{996}$ Spomeka Hribar, "Cerkev Ni Pogledala v Strašnost Lastne Krivde,” Delo 24 Jan. 1998: 12. 997 "Slovenia to Return Church Property," Radio Free Europe/Radio Liberty 7 Apr. 1997, 3 Sept. $2002<$ http:// www.rferl.org/newsline/1997/07/4-SEE/see-250797>.

998 "Constitution Watch," East European Constitutional Review Fall 2001, 9 Sept.2001 $<$ http://www.law.nyu/eecr>.

${ }^{y(x)}$ Some of the more controversial claims are cases involving Bled Island claimed by the Ljubljana Archbishopric; buildings in the St. Joseph church complex in Ljubljana claimed by the Jesuits; Križanke claimed by the Križanke order; the Mansion of Goričane claimed by the Ljubljana Archbishopric; and the grounds of the Ljubljana Trade Fair claimed by the Lazarists. Janez Gril, "Speeding up the Denationalisation Process," Slovenia Weekly Aug. 2000, 8 Jan. 2001 <http://www.sloveniaweekly/vitrum.com>. The RCC in Slovenia also wants the Bezigrad Stadium,
} 
Ministry of Agriculture, Forestry, and Food decreed that 8,245 hectares of forests and other lands in TNP would be returned to the RCC, including Bled Island. ${ }^{1000}$ Agricultural Minster of the right-wing SLS+SKD, Franci But, defended his decision, stating that the Nature Conservation Act does "not apply to denationalization," and saying that since it was only passed in 1999, the act could not retroactively affect the denationalization rights of the RCC. ${ }^{1001}$ However, in May of 2002 the Ljubljana Administrative Court annulled that decree, stating that the state built roads on that land and thus the land could not be returned. ${ }^{1002}$

It was with the victory of the left-of-center LDS in October 2000 that the bulk of denationalization cases came to be resolved. As of May 2002, 35,090 claims were filed to administrative authorities. As of June $2002,70 \%$ of claims were resolved or settled (at the same time, however, there were 41,010 partial administrative decisions on property). ${ }^{1003}$ As of September 2002, 79\% of the approximately 37,988 property restitution claims were resolved through return or

which was built in 1935 for the RCC but now is used as a stadium for sporting events, particularly soccer.

${ }^{1000}$ Marjeta Šoštarič, "Sem Minister, Ki Se Ga Drži Smola, Interview z Franc But, Minister za Kmetijstvo, Gozdarstvo in Prehano," Delo 22 Sept. 2001: 21, and Vlado Miheljak, "Tolmačenje Sanj," Delo 7 July 2001: 11.

1001 "Constitution Watch," East European Constitutional Review Fall 2000, 28 Aug. 2003 $<$ http://www.law.nyu/eecr>.

${ }^{1002}$ Tomaž S. Natlačen, Mateja Babič, and Vlasta Felc, "Namesto Nadškofiji Vrnjeni v Nov Postopek," Delo 28 May 2002: 1. Archbishop Franc Rode and the Slovenian RCC had filed a lawsuit against the government for return of properties they claimed to be unresolved. This included a desire to reverse the May 2002 ruling annulling the return of forests in the Triglav National Park to the RCC. Summary of Property Restitution in Central and Eastern Europe," U.S. Embassy in Germany 16 July 2002, 15 Nov. $2002<\mathrm{http}: / /$ www.usembassy.de/policy/holocaust $>$.

1003 "Report on Slovenia's Progress towards Accession to the European Union," Republic of Slovenia June 2002, 24 Sept. $2002<$ http://www.gov.si/svex>. 
compensation. ${ }^{1004}$ This included more than $50 \%$ of the property slated for restitution to the RCC. The RS had a timetable for the adjudication for the remaining claims by the end of 2004 , the year of entry into the EU. ${ }^{1005}$

Although the initial Denationalization Law was hasty, it took a decade for the government to compensate the majority of claimants. The uncertainties surrounding the generous Denationalization Law have given way to compromise in order to strengthen the rule of law in Slovenia with regards to private property rights. In Slovenia the concern focused on the return of forests. In Croatia the focus was on the return of buildings used either by the state (state hospitals or schools) or private citizens (apartments). In Slovenia and Croatia denationalization has been a protracted process because of political sensitivities. In Croatia, the RCC, the biggest property restitution claimant, already procured funds through agreements with the Holy See, so the state felt free to lag on property restitution. In Slovenia, on the other hand, the RCC's focus on property restitution and the impending entry of Slovenia in to the EU provided the political will for the completion of property restitution, regardless of the institution or individual that sought it.

\subsection{Conclusions}

In Slovenia, the RCC has not received as many economic concessions as in Croatia. The separation of church and state in Slovenia has been maintained more

\footnotetext{
${ }^{1004}$ United States of America, "Country Reports on Human Rights Practices: Slovenia," Department of State 13 Mar. 2002, 20 Dec. $2002<$ http://www.state.gov>.

${ }^{1005}$ Brian J. Pozun, "Weekly News Bulletin," Ljubljana Life 18 Jan. 2003, 29 Jan. 2003

$<$ http://www.geocities.com/ljubljanalife/2003/24jan>.
} 
strongly than in Croatia due to more disputatious politics, debate, and incremental change that focused on what the formal rule of law permitted, the constitutional requirements of these relations, and the liberal democratic requirements. The RCC is not the powerful unifying symbol in Slovenia that it is in Croatia, so disputes regarding its role in the public sphere in Slovenia are more pronounced, to the benefit of liberalizing reforms. In Slovenia the RCC and political parties supporting it were seen as just another political interest vying for power in the public sphere. The RCC was not as universally remembered as an institution that traditionally supported Slovenians.

In the Slovenian modern political experience there has been a lack of sustained commitment to ideals such as state right. Rather than focusing on state right or redressing past wrongs, post-communist independence in Slovenia found more of a basis for an appeal to liberal democracy as well as financial and political benefits of joining the European Union. This focus was facilitated by memories of Slovenian political elite manoeuvring to gain the most benefits from larger political forces that surrounded them through positive sum games and incremental change. Therefore, the RCC had less appeal as a symbol of the past and of the nation, so it did not win as many concessions as desired through a concordat in the realms of funding. A common thread in all of the issues regarding church-state relations, from education to finance, is the concern with ensuring that individual rights and the rule of law are maintained in a liberal democratic polity. While the lines of 
debate often harken back to left-right divides of the past, compromise in favour of pragmatic liberal democratic reforms have predominated. 


\section{Chapter 11: Conclusions}

This work has aimed to demonstrate that long-term patterns of politics have influenced post-communist and post-Yugoslav political liberalization in Slovenia and Croatia. Drawing on historical institutionalism and scholarship on liberalism, this work has argued that long-term political legacies, even in parts of the world that have experienced drastic regime changes, can be traced through general patterns. In order to create a better understanding of political change, this study has challenged assumptions regarding political outcomes in the former Yugoslavia. There are numerous possible explanations of liberalization, but many focus on the years immediately preceding and following the demise of communism.

Throughout this work, it has been shown that political liberalization in Slovenia and Croatia did not begin and end with the fall of communism. While the events unfolding in the two states at the time of secession were seminal, and the presence or absence of minority populations was an important factor, how and why these factors played out as they did, as well as the political origins of these outcomes, have formed the focus of this work. This study challenges readers to reconsider history and contemporary politics by exploring key patterns to liberalization in political history, before considering why Slovenia embarked on swifter, more stable liberalization than Croatia. The conclusion reached is that the reconciliation of institutions, ideals, and memory in the past and present critically 
shaped the trajectory of liberalization in these post-communist polities, and will continue to have a role in their political future.

The first part of this thesis sets out the argument for applying historical institutionalism in the study of liberalization, even in states where liberal tradition has been weak or non-existent. This can be achieved by seeking out ideal types - in this case historically informed patterns of politics - that either support or detract from liberal movements, including types of authority and legitimation, reliance on pragmatism or ideology, zero or variable sum games, and incrementalism or revolutionary games. The historical tradition of the Croatian state could have provided a basis for cooperationist politics, but instead the state tradition was increasingly tied to exclusivist nationalism that threatened other ethnicities and nations. While there were instances of inclusionary movements and leaders who sought to engage in positive sum games in Croatia, the Croatian national ideal, based on state right, was used to justify zero sum games and revolutionary change, while denying, ignoring, or excluding others. In Slovenia, the emphasis was on cultural and linguistic development, where institutions of peasant politics and memories of a weak state have formed a political focus that provided a more solid basis for inclusion, variable sum games, and incrementalism in the years to come.

The second part of this thesis traced the general political patterns in modern Slovenian and Croatian history in order to understand why political liberalization has been so distinctive in these Yugoslav successor states. Modern politics in both 
states focused on the struggle for greater autonomy. While the goals were similar, significant differences existed in the approaches, conventions, demands, and narratives the Croats and Slovenes employed in their struggle for autonomy.

Political parties and their leaders were the main domestic arbiters of political power, and were the formal political institutions that denoted distinct Croat and Slovene politics, and were the focus of most modern political activity. This includes politics within the multinational Habsburg Empire, in the late $19^{\text {th }}$ century, the multinational Yugoslav Kingdom, the multinational Socialist Yugoslavia, and independent Croatia and Slovenia. In each of these political eras, the dominant political parties increasingly drove the agenda, and provided a focus for organized political activity in an otherwise unstable formal political institutional environment. From their inception, inclusion in a multinational state, domination by the center of that state, and fear of losing territorial, cultural and other rights were the main concerns for Slovenian and Croatian political parties. The strategies of parties in Slovenia and Croatia were distinct, even though some events and regimes were shared, and, although both nations experienced similar events, political parties and figures in Slovenia and Croatia called upon distinct legacies in shaping and justifying their policies and practices.

Chapters three, four and five, while recognizing memories and institutional legacies of previous eras, addressed politics in interwar and socialist Yugoslavia. In the late socialist era, decentralization by the Slovenian and Croatian communist 
parties, and the push for greater decentralization, led to very different results, due to long-term political developments and memories. In Croatia, decentralization demands reached a sudden apex with the Croatian Spring, which focused on national autonomy, and led to a crackdown, which itself fostered a lack of pluralism, compromise, pragmatism, and incrementalism within civil society. In contrast, the League of Communists of Slovenia (LCS) focused on incremental decentralizing gains, which averted the crackdown that occurred in Croatia, and allowed republican leaders to take advantage of gradual decentralization. The practical experiences in negotiation, conflict, and compromise engendered by civil society in the 1980 's, along with the experiences with disputatious politics in the early $20^{\text {th }}$ century and memories that emphasized Slovenian gains in variable sum rather than zero sum conflict with other political powers, transferred into postcommunist party politics.

Since the 1890 's, Slovenian politics has been, and continues to be, dominated by a sharp liberal-conservative divide. The issue of church-state relations exemplifies this divide, and the debate and resolution of these sensitive issues has helped strengthen liberal democratic practice. The RCC does not have a highly privileged or restricted status because of the competition and consensus that is part of the strong ideological divide in Slovenian politics. In Croatia, however, the RCC holds a privileged status because of the power it has accumulated through 
its connection with the $\mathrm{HDZ}$, its historical role, and the fear that any action perceived as anti-RCC can be construed as anti-Croat or anti-patriotic.

In order to provide a more in-depth understanding of political liberalization in post-communist and post-Yugoslav Croatia and Slovenia, Part III of this dissertation focused on one realm of policy-making undertaken in both states: church-state relations. The outcomes of interest intermediation in the realm of church-state relations reflected longstanding, distinctive patterns in the political legacies of both states. Divergence in national politics emerged, both in various institutional arrangements and in political memories throughout the modern era. An in-depth comparison of one area of policy-making demonstrated how these patterns of politics were expressed in the establishing of independent states. Institutional development and predominant memories in Slovenia proved to be more amenable to swifter and more secure political liberalization.

Agreements with the RCC were a foundational step in renegotiating churchstate relations in both Croatia and Slovenia. The manner in which these agreements were reached, as well as their content, demonstrated enduring patterns of politics that persisted in post-communist liberalization. In Croatia, the agreements were swiftly and secretly concluded. A zero-sum formula predominated; whoever questioned the agreements was portrayed as unpatriotic and precluded from influence. In Slovenia, debate was more open; policy reform was incremental, and requirements of liberalization were at the forefront. Religious inequality in Croatia 
was furthered amplified by the gap in provisions and the long delay in reaching agreements with other religious communities. The Croatian agreements with the $\mathrm{RCC}$ ensured that it became the de facto state church, without the conflict and compromise essential to liberalization. For the political elite, this was considered an essential part of reaffirming Croatia's state right, its role as the progeny of 1000 years of Croatian state history. Provisions of the agreements with the RCC were carried out so that constitutionally mandated separation of the church and state was endangered, as was particularly evident in Croatia's educational reforms.

The introduction of religious education into the public school curriculum formed a large component of church-state reforms. Following an already familiar pattern, the religious instruction issue in Slovenia was dealt with through successive rounds of incremental reform, focused on pragmatic concerns of what is necessary to ensure the liberal requirements of church-state separation. Many stakeholders, including teachers, parents, students, clergy and educational experts, were part of positive-sum negotiations. In Croatia, the focus on state right and historical memory of the RCC's role in creating and representing the state carried through in the overt, ad hoc introduction of religious instruction, which saw the RCC enter public schools immediately and without deliberation 10 years prior to the consideration of such rights for any other religious denomination. Catholic Croat European identity or "Croatianess" was privileged in independent Croatia 
and, as a part of that, the RCC enjoyed early, easy access into the public education system

Croatian economic reform, including property restitution, also demonstrated the powerful influence of religious traditions and memories of national-religious affiliation in negotiating post-communist transformations. The Croatian state made swift financial commitments to the RCC on the basis of social and cultural affiliation, without regard for the liberal requirements of the separation of church and state. Those opposed to the RCC's financial privileges were painted as unpatriotic and "anti-Croat," a strategy which fueled a lack of debate. Without careful, balanced consideration of state funding of churches, the agreement with the RCC set a precedent for less generous financial obligations to other religious affiliations years later, further eroding the liberal requirements for separation of church and state. Violation of this separation was not considered in Slovenia; rather, RCC financial claims became focused on property restitution. In these property restitution cases, the RCC, all other religious communities, and all other property claimants were treated equally, in a process that engendered open debate, deliberation of alternatives, and sustained regard for the requirements of liberal transformations.

The absence of disputatious politics and the reliance on zero-sum games used to advance the RCC's position in the renegotiation of church-state relations in Croatia was justified on the basis of reaffirming an autonomous Croatia for 
Croatians. The politics practiced to reach Croatian autonomy have differed greatly from those used to reach Slovenian autonomy, and both have been reproduced across different regimes. In both post-communist countries, the dominant parties created policies and shaped institutions which they felt would reconcile both the requirements of liberal democracy and the Croatian and Slovenian political traditions. In Slovenia, however, this process was more disputatious, pragmatic, and positive-sum than in Croatia. In the late 1980's and early 1990 's, these distinct memories were emphasized in the desire to justify the establishment of nation-states. This is not a re-emergence or rediscovery of history; rather, it is a re-emphasis on long-term memories, and a continuation of processes that have contributed to the unique political development of each country. The negotiation of church-state relations in post-communist Slovenia and Croatia serve as one example of how historical patterns continue to characterize political developments in states that have undergone dramatic regime changes.

Church-state relations are a prominent but under-explored aspect of postcommunist transformations, and can demonstrate how change in political institutions can coincide with a change in institutions beyond the state and government, resulting in a profound impact on politics. This thesis has furthered the study of church-state relations by systematically comparing approaches to concordat creation, education and finance as a means of evaluating political liberalization. The practice of zero-sum privileging of one religious institution over 
another is a danger to individual rights and freedoms. This is true both in states undergoing profound transformations and in those that are consolidated, as the privileging of a denomination can threaten liberalism. Because of the economic, personal, and political freedoms, rights, and opportunities it makes possible, liberalism is the foil to the political weaknesses of previous communist regimes. To again fall into the trap of non-transparency, inconsistency, and privileging based on belief systems would be to deny many hard won rights and freedoms.

This work stands alone in undertaking a comparison of Croatian and Slovenian political history. Although both countries declared independence on the same day and were widely recognized as being the most similar republics in the former Yugoslavia, there have been few attempts at an in-depth comparison of these polities. This study fills a gap in the literature comparing these states, and also in the comparative study of common contentious issues of church-state relations. The issue of church-state relations was chosen as the focus for comparison of these two "transition" countries because of the deeply contentious legislative efforts, which reveal unique institutional legacies, interpretations of collective history, and future approaches.

History and current politics are bridged in everyday political rhetoric in both countries, but few works have undertaken a systematic exploration of the influence of historical institutions and interpretations of history on present-day politics in this region. In this study, connections between political history and 
contemporary politics are established through recognition of the long-term patterns of politics that form the emergence of political institutions and persistent employment of collective memory. Despite the changes of regime, accompanied by massive institutional reforms, many peculiarities of institutional design had a lasting carryover, which characterized distinctive Croatian and Slovenian politics. These distinctions, as explored through patterns of political history, contribute not only to a better understanding of post-communist and post-Yugoslav regimes, but also to the historical institutionalist literature that explores the creation and consolidation of liberal democracies.

To gain insight into the emergence of liberal-democratic regimes, this work has traced political institutional developments through political patterns as ideals that informed transformations of states and parties in modern politics. These generalizations were then tested through an exploration of one realm of policymaking in the post-communist era: church-state relations. In doing so, this study presented four contrasting ideal types that characterize the distinctions between Croatian and Slovenian political history and political present.

The ideal types of rational legal and charismatic authority, pragmatism and ideology, zero sum and variable sum games, and incrementalism and revolutionary change account for distinctive political developments, and address processes that are key factors to political liberalization and the negotiation of politics in the states studied. The fact that patterns associated with political liberalism have historically 
been stronger in one state than the other is important, as is the fact that

liberalism has not developed evenly in the two states. Slovenia, without a history of a liberal regime, rapidly consolidated its liberal democracy, the origins of which lay in the patterns of politics addressed in this dissertation. Croatia, on the other hand, also without a liberal regime legacy, followed a different path, resulting in relatively slower liberalization.

In studying liberal-democratic transformations, it is widely recognized that states with a history of liberal democracy, however brief, will most likely fare better in later liberal-democratic transitions. Slovenia provides a powerful case of a state without a history of a liberal democratic regime that was able to initiate a successful, sustained liberal democracy. The patterns isolated here as contributing to the success of Slovenian transformations could be applied to the study of other transformations, providing insight beyond immediately recognizable, and perhaps obfuscating, factors. For example, the focus on the wars in the 1990's in Yugoslavia as the implicit explanation for Croatia's post-communist political development ignores the patterns in Croatian politics that contributed to the wars.

Difficulties in political liberalization in Croatia did not stem solely from the existence of a national minority. Rather, the focus should be, as it is in this work, on the manner in which political conflict in society is negotiated, be it in the face of ethnic, ideological, or other politically informed cleavages. 
The history of the former Yugoslavia and the individual states that have emerged from its break up is comprehensible, and does not involve "more history than can be consumed." 1006 An exploration of the complex palimpsest of histories in this region can be used to dispel the idea that enduring patterns of political interaction cannot be discerned in a region of the world that has known great amounts of violent conflict and frequent regime changes. Understanding political history is imperative to understanding transformations in Slovenia, Croatia, and other post-communist states. Even during periods of extraordinary political change, actors, institutions and interpretations of the past influence the policy choices of the present.

In an attempt to avoid a comparison of Slovenian and Croatian politics, it is common to cite the presence of the Serbian minority in Croatia and the long, destructive war Croatia endured in the 1990's. Slovenia also has distinctive minorities and endured a ten-day war in 1991. Yet, it is not the war in itself or the mere presence of a Serbian minority that established the necessary and sufficient condition for illiberal development in Croatia. The existence of minorities, wars, and physical geography alone does not explain political developments, although these factors should all be taken into consideration. An examination of political

\footnotetext{
${ }^{1006}$ During the 1990s some commentators argued that Yugoslavia and Yugoslavs had produced "more history than they could consume." This attitude was a simplistic way to explain to the Yugoslav wars but avoided any real exploration of history. Robert Kaplan's Balkan Ghosts: A Journey Through History lent credence to the "ancient ethnic hatreds" approach to Yugoslavian politics. This book dismissed the wars in Yugoslavia as far too complex and deeply rooted to understand or prevent.
} 
historical institutional norms, practices, rules, and conventions provides a key perspective that helps explain long-term social, political, and economic developments. Thus far, such an examination has been missing from the literature on the area.

Often alluded to, but rarely studied in depth, the institutions and ideals that have shaped distinctive patterns of modern political history in each country have influenced the scope and characteristics of post-communist liberalization. The ideologies, focus, and actions of political parties and the elite had a decisive influence on the establishment and operation of political institutions and distinctive political cultures in each polity. It is precisely in polities where specific state and party institutions may not have enjoyed a stable history, that patterns of politics, tracing the establishment and reproduction of institutions, can provide a powerful explanatory logic. Collective memories are also particularly prominent during periods of marked institutional change, invoked by competing actors to justify the actions they propose to take and the institutions they seek to (re)build. ${ }^{1007}$ As demonstrated in Slovenia and Croatia, lessons from these collective memories are capable of imparting similar understandings across different eras and regimes. This study provides an explanation for the divergent trajectories of political liberalization in Slovenia and Croatia, as well as a potential framework for explaining political developments in other post-communist or liberalizing polities.

\footnotetext{
${ }^{10 \times 17}$ Katzenstein demonstrates how collective norms "inform how political actors define what they want to accomplish" Peter Katzenstein, Corporatism and Change: Austria, Switzerland, and the Politics of Industry (Ithaca: Cornell University Press, 1984), 78.
} 
The focus on ideal typical political patterns offers an excellent and, thus far, seldom explored opportunity to examine the interplay of historical legacies, memories, and policy development in political liberalization. 


\section{Appendices}

\section{Appendix A: Croat Serb Relations}

Croats and Serbs within the Empire had struggled together for more autonomy from Vienna and Budapest and competed for leadership in uniting South Slavs in the mid-1800s, particularly during 1848-9 and after the Ausgleich. However, by the late 1800 s both Croats and Serbs were developing more exclusivist nationalist programs. These programs relied on mutually exclusive national identities based on distinguishing features. For example, Croats were Catholic and used the Latin script, while Serbs were Orthodox and used a Cyrillic script. For a while during the mid-1800s nationalist currents were confined to the intelligentsia who set out plans for national integration as well as political and territorial aggrandizement. ${ }^{1008}$

However, these nationalist ideas soon penetrated mass politics. Nationalism was an easy way to mobilize the increasingly politically aware and active masses and to explain disappointments of the late 1800s and early 1900s. Vienna and Budapest sought to foment tensions among their Serb and Croat subjects lest they join with Serbs in a South Slav state or become a part of Serbia. After a series of uprisings against the Ottomans (starting in 1804) Serbia became formally independent in 1878 .

By the mid to late 1800 s there were already many contradictions in the

\footnotetext{
${ }^{1008}$ As for example, in the case of Serbian Interior Minister Ilija Garašanin in his Načertanije of 1844 , which remained an "internal, un-circulated memorandum" until published by a Belgrade journal in 1906. Lampe, Yugoslavia 52.
} 
relationship between Serbia and Croatia, but it was nowhere near the hostility that would come to characterize some of the most infamous and violent Serbian and Croatian political and military exchanges in the 20 th century. For example, some members of Croatia's political elite respected and looked to the Serbian kingdom as a model and Piedmont for the South Slavs, while at the same time fearing the new kingdom and Serbian power. ${ }^{1009}$ And at the same time, not all Serbs within Croatia and Vojvodina sought unity with the pre-war Serbian Kingdom and some felt kinship with Slovenes and Croats as part of the Habsburg Empire. ${ }^{1010}$

While there was resentment among Croats about the status of the Military Frontier (Vojna Krajina) and the Serbs within it, Vienna was blamed for keeping them separate. The Military Frontier was a series of border garrisons established by the Habsburgs in the 1530s in southern Croatian and Slavonian lands to protect the Empire from Ottoman incursions. Mostly Serbian Orthodox refugees, along with some Germans and Croats, served as frontiersmen in the Vojna Krajina. By 1563 Hapsburg Emperor Ferdinand had made Croatia part of the hereditary Hapsburg lands and ruled the Krajina through military administration that answered to Vienna, the Hofskriegsrat. By 1630 frontiersmen were given land free from feudal obligations in exchange for defence against Ottoman incursions and advances.

Until 1881 the Krajina remained an entity separate from Croatia and outside

\footnotetext{
${ }^{1009}$ David McKenzie, "Serbia as Piedmont and the Yugoslav Idea, 1804-1914." East European Quarterly 28.4 (1994): 153-181.

${ }^{1010}$ The political behaviour of those Serbs that once lived in Austria Hungary would, in interwar Yugoslavia "oscillate" between "pan-Serb solidarity" and "ex-Habsburger" solidarity. Rothschild, East Central Europe 209.
} 
of the auspices of the Sabor. The relative autonomy granted to the frontiersmen, their distinct Orthodox faith, along with expansion of the Krajina at the expense of Croatia and Slavonia ensured that the Krajina would become a contentious issue. At the time, the Croat nobility and the RCC hierarchy resented the fact that the settlers were autonomous.

Authorities in civil Croatia resented that those in the Krajina did not pay tribute to them. Over time this resentment grew. However, the Habsburgs saw this arrangement as essential for the protection of their southern flank.

The 1886 full administrative integration of the Military Frontier with civil Croatia proved to be the key to setting off the sporadic and smouldering Serb-Croat conflicts that would emerge in the century to come. ${ }^{1011}$ By the time the Military Frontier was integrated into civil Croatia, Serbian nationalism was well established, as were Serbian public and private institutions, which people in the Krajina were loath to change. According to the 1840 census, 48.2 percent of the population of the Croatian Military Frontier was Serb, while in the Slavonian Military Frontier, 47.2 percent of the population was Serb. ${ }^{1012}$ The Croatian intention of fully integrating this region into civil Croatia threatened the Serbs, while the presence of this large minority of Serbs overwhelmed many Croats. ${ }^{1013}$

\footnotetext{
${ }^{1011}$ For more on the dissolution of the Ottoman Empire and Balkan politics see Barbara Jelavich and Charles Jelavich, The Establishment of the Balkan National States 1804-1920 (Seattle: University of Washington Press, 1986).

${ }^{1012}$ Tanner 38-39 and 555-56. Part of the change and expansion of the Krajina that fuelled this resentment was the incorporation of Eastern Slavonia, areas of Backa and Banat (what is largely present day Vojvodina) into the Krajina of Slavonia in the mid-1600s. Trifković 347

${ }^{1013}$ Horvat 21 1-212. Jelavich 59-63. Seton-Watson, The Southern Slav Question 194-208.
} 
Ban Károly Khuen-Héderváry (1883-1903) stoked these fears in order to promote Hungarian interests, which led to many demonstrations during his tenure, including the one in 1903 that led to his removal. Bosnia and Hercegovina $(\mathrm{BiH})$ was another territory to which both Serbs and Croats felt that they had a historic title. ${ }^{1014}$ The dying Ottoman Empire was losing control of $\mathrm{BiH}$, which fed the Eastern Crisis of 1875-1878. ${ }^{1015}$

Like with Russia and other European powers, Austria-Hungary's Emperor Franz Josef I (1830-1916, Emperor of Austria since 1848 and King of Hungary since 1867) sought to augment his possessions with $\mathrm{BiH}$ administered by Austria since 1878 and annexed in 1908 . BiH created great tension in the Western Balkans; politicians in Croatia, Serbia, and Austria all saw BiH as rightly belonging to them.

\footnotetext{
${ }^{1014}$ However, there was also Serb-Croat political cooperation, which would help facilitate the creation of the post-WWI South Slav state and foster some political cooperation in that state.

${ }^{1015}$ Banac, The National Question 50-51. Bilandžić, Hrvatska 28.
} 


\section{Appendix B: Monuments and the RCC}

The seat of the archdiocese of Zagreb, Kaptol, is more evocative of the politically powerful position of the RCC than any other, not only due to the style of the Cathedral of the Assumption of the Virgin Mary and St. Stephen and the Archiepiscopal Palace, but because of the history of that location. Situated on one of the two hills in the modern centre of Zagreb, Kaptol was a town established in 1094 and run by the RCC through the Bishopric. On the other hill there was Gradec, established in 1242 as a secular town of merchants. The two towns merged in 1850 , and by 1852 Zagreb was established as an archdiocese. In present day Zagreb, the Kaptol district remains the seat of the Roman Catholic Church in Croatia, while the Gradec district is the seat of government. The prominent St. Mark's Church is the namesake of the square where the Parliament is located. On the shingles of St. Mark's church, facing the parliament, is the coat of arms of Croatia. Inside the church, the altar has large candles decorated with the Croatian coat of arms and the colours of the Croatian flag. On the altar of the Zagreb Cathedral there is a life-size effigy of Archbishop Alojzije Stepinac in a glass case in addition to the relief of Stepinac in another part of the cathedral.

The locations of and national symbols within Slovenia's main churches are not as evocative of the church-state connection as in Croatia. The seat of the Slovenian Roman Catholic Church is below the Castle Hill in Pogarčarjev Square, where the bishop's palace, seminary, and the Cathedral of Saint Nicholas are 
located. This square is relatively far from the parliamentary buildings. The two most prominent buildings in the Square of the Republic, other than the parliament buildings, are the Maximarket Department Store and Cankarjev Dom, a concert hall and cultural centre named for novelist Ivan Cankar. In contrast to the Croatian diocese and archdiocese, the Ljubljana diocese was established late, in 1461, and was declared an archdiocese only in 1961.

While the Cathedral of Saint Nicholas has brass doors commemorating the 1996 visit of Pope John Paul II, the interior and exterior are bereft of Slovenian state symbols.

Even during the communist era church monuments and organizations maintained a strong public presence. The monumental influence of the RCC can be seen in the hundreds of roadside altars, churches, pilgrimage shrines, and cathedrals in both countries. 


\section{Appendix C: Territorial Settlements}

Post-war settlements confirmed by the Paris Peace Conference and subsequent acts brought most of Carniola into Yugoslavia as part of the province of Slovenia. The settlement also brought Croatia-Slavonia, most of Dalmatia, Medjumurje, Srijem, and southern Baranja into the Yugoslavian fold as part of the province of Croatia. However, this settlement and the Treaty of Rapallo (1920) between Italy and the kingdom of Serbs, Croats, and Slovenes left more than 370,000 Slovenes and Croats in Italy. According to the provisions of the Treaty of London (April 1915), one third of Slovene inhabited lands were ceded to Italy, namely parts of western Carniola, Gorizia, Trieste, and Istria.

Porabje was given to Hungary, and through a plebiscite in 1920 almost all of Carinthia was given to Austria.

The post-WWII settlement saw Slovene and mixed Slovene-Italian lands divided into two zones. Zone A was controlled by the Allies and included Trieste, Resia, and the Canale Valle; Zone B was controlled by the Yugoslavs and included Istria and Primorje.

By virtue of the 1954 London Agreement Zone A was awarded to Italy and Zone B to Yugoslavia. ${ }^{1016}$ However, the exact border was in dispute until the Osimo

\footnotetext{
${ }^{1016}$ For details on the dispute see Roberto G. Rabel, Between East and West: Trieste, the United States, and the Cold War, 1941-1954 (Durham: Duke University Press, 1988). Labeled the Free Territory of Trieste, Zone A had an Italian majority in Trieste, but a Slovenian majority in the Trieste hinterland. Zone B had a Slovenian and Croatian majority, with an Italian minority on the Istrian coast. Some blame this solution on Tito's hasty conclusion of a friendship agreement with 
Treaty was signed in November 1975. Although mandated by both agreements,

Slovene minority rights continued to be cast aside and implemented willy-nilly, with the most rights until 2001 enjoyed in Friuli-Venezia-Giulia. Despite this, the border between Italy and Yugoslavia remained relatively open during the Cold War, while economic and cultural co-operation and initiatives began to take hold in the late 1960s and 1970s. For example, Slovenia, Carinthia, and Friuli-VeneziaGiulia formed a regional co-operation group, Intart (1968), which became part of the Alpe-Adria group in 1978. However, Slovene minority rights were again threatened after the independence of Slovenia. Only in 2001 was the fiercely contested Minority Law passed in Italy. ${ }^{1017}$ Among other provisions the law allowed Slovenes the right to use Slovenian personal names and names of businesses with Slovenian spelling; in the provinces of Trieste, Gorizia, and Udine and encouraged the election of minority representatives and bilingual traffic signs in bilingual areas.

A similar story attests to the fate of Slovenes in Austria. The 1919 Treaty of Saint Germain called for a plebiscite to decide the fate of Carinthia, where approximately 70,000 to 80,000 Slovenes were concentrated south of

the Soviet Union on April 141945 and lack of Soviet support. Jelavich 317.

${ }^{1017}$ Before spring 1995 the Italian government vetoed the signing of an Association Agreement between Slovenia and the EU on the grounds of compensation for the approximately 21,000 Italians who fled Slovenian territory after WWII. The dispute was resolved in 1998, with Slovenia agreeing to pay $\$ 62$ million in compensation for the property seized from Italians. Ian Jeffries, The Former Yugoslavia at the Turn of the Twenty-First Century: A Guide to the Economies in Transition (New York: Routledge, 2002) 359 "Slovenian Minority Legally Protected," Slovenia Weekly June 200 I, 7 Oct. $2002<$ http://www.vitrum.si/2001/stari/sw2001-07-accession>. 
Klagenfurt. ${ }^{1018}$ At the end of the war the Slovene forces were too weak to advance into Slovene inhabited Carinthian lands. ${ }^{1019}$ By May the Yugoslav army had advanced to Klagenfurt, but it was too late. The peacemakers in Paris had decided on a plebiscite that took place in October 1920. A 59 percent majority, including approximately 12,000 Slovenes in Carinthia, voted to join Austria, leaving a small part of Carinthia in Slovenia. Similar to the situation in Italy, the Slovene language, associations, and identity were discriminated against and suppressed. There was also a sizable Croatian minority concentrated in Burgenland and Vienna that today numbers approximately 42,000 people.

The 1991 Austrian census counted 20,191 Slovenians. However, research cited by the Austrian government notes that 59,000 people over the age of 15 have a linguistic "command of Slovenian" in Carinthia, while Slovene organizations estimate there are approximately 50,000 Slovenes in Austria. ${ }^{1020}$ Unlike the Slovene population in Carinthia, the Burganland Croats do not live in a territory that bordered Croatia. Slovenes and Croats in Austria were treated with particular brutality after the 1938 Anschluss and subsequent Nazi rule. Again, many Slovenes

\footnotetext{
${ }^{1018}$ Thomas Barker notes that the Austrian census counted 85,051 Slovenes in 1880 and 66,463 in 1910. Ecclesiastical figures note 102,711 Slovenes in 1880 and 99,006 in 1910. Thomas M. Barker and Andreas Moritsch, The Slovene Minority of Carinthia (New York: East European Monographs, Columbia University Press, 1984) 88. The figure cited in most sources is approximately 70,000 to 80,000 .

${ }^{1019}$ General Rudolf Maister (1847-1934), the commander of the Maribor garrison, secured Maribor and a part of Styria for Slovenia during 1918-1919.

${ }^{1020}$ Council of Europe, "Report Submitted by the Republic of Austria, Pursuant to Article 25

Paragraph 1 of the Framework Convention for the Protection of National Minorities," Advisory

Committee on the Framework Convention for the Protection of National Minorities 15 Nov. 2000, 29 Oct. $2002<$ http://www.hri.ca/fortherecord2000/doucmentation/fcpnm-austria>. Melanie A. Sully,
} 
and Croats assimilated, while some emigrated and others joined underground organizations, particularly the communists and then the Partisans.

The British who occupied Carinthia at the end of WWII prevented the Partisans from taking it. The 1955 Austrian State Treaty established the borders of Austria and Yugoslavia. Although this treaty mandated the protection of Slovene and Croat minority rights, its provisions were systematically violated. The pressure for Slovenes and Croats to assimilate was and continues to be great. In the $1980 \mathrm{~s}$ some positive measures such as the some bilingual education and posting of some bilingual signs were implemented, although after protracted battles. Right-wing groups in Italy and Austria that sought to prevent Slovenia from joining the EU saw Slovenian independence as a threat. Croatian independence was not perceived as an equal threat because neither Italy nor Austria border Croatia. In the 1990s open anti-Slovene sentiment and intimidation resurfaced and gained strength through the political victories of Jörg Haider's (1950-2008) right-wing FPO (Freedom Party of Austria). ${ }^{1021}$

Haider is from Carinthia, the base of his support and the place where most Slovenes in Austria live. In both Italy and Austria this boycott was in part due to the fear that when Slovenia becomes part of the EU both counties would be forced to implement minority rights officially accorded to Slovenes half a century ago to their full extent.

${ }^{1021}$ The Haider Phenomenon (New York: East European Monographs, Columbia University Press, 1997) 39. 


\section{Appendix D: Post WWII Reprisal and Repression}

When the war ended, Tito's Partisans engaged in a wave of reprisals against alleged and actual Axis collaborators (mostly Slovenes and Croats) as well as mass deportations of German civilians. ${ }^{1022}$ The most infamous post-war retributions were the massacres of mainly Croatian, Slovenian, and a handful of Serbian Nazi collaborator POWs, their families, and other civilians who were forced back to Yugoslavia by the British after having escaped to Bleiburg Austria. It is estimated that upwards of 30,000 Slovenes and Croats were executed or died in death marches labelled "the Way of the Cross," which followed their expulsions from Blieburg. ${ }^{1023}$

There is no generally accepted figure of the number of people who died in reprisals both during the war and along the Austrian border in 1945. However, Jozo Tomašević notes that the figures of researcher Vladimir Žerjavić are among the most objective, citing that approximately " 65,000 were killed during the war and 60,000 on the border [Slovenia/Austria] in 1945., 1024 Many of the bodies of those killed at the border were dumped into the moss-covered deep caves that dot the forest-covered karst landscape of southwestern Slovenia. Annual commemoration

\footnotetext{
1022 Paul Shoup notes that an estimated " 320,000 [Germans from Yugoslavia] could be accounted for in Germany, that some 50,000 were known to be deported, and that 180,000 were unaccounted for" at the end of the war. Shoup 103.

${ }^{1023}$ Lampe, Yugoslavia 229. For an account of the retributions see Nikolai Tolstoy, The Minister and the Massacres (London: Century Hutchinson Ltd., 1986).

${ }^{1024}$ During the war as there was no accurate number of people who fled into northern Slovenia and southern Austria. Tomašević, War 765.
} 
masses presided over by the RCC and various political leaders have been taking place since 1991 to honour the dead. The Slovenian commemoration mass takes place in Kočevski Rog, Slovenia, while the Croatian mass takes place in Bleiburg, Austria. ${ }^{1025}$

Other groups of people who suffered severe repression and persecution were the members of the prewar Communist Party and by 1948 members of the Communist Party that supported or were accused of supporting Stalin after the Tito-Stalin split. ${ }^{1026}$

In Slovenia, WWII divisions are still a reference point for the current divisions of right and left, where the mistakes of both sides, fascist and communist, are often debated. In contrast, in Croatia, Tudjman's political domination, combined with his anti-communism and fear of open praise for the Ustaša, has fostered a type of automatic reconciliation.

It is based on Tudjman's own terms and ideals of an organic, unified Croatian nation and nationalism. ${ }^{1027}$

The problem is that this reconciliation precludes a thorough examination of and coming to terms with the past. Tudjman argued that what Ante Pavelić, Vladko Maček, and Tito held in common was that they were Croat leaders of the most

\footnotetext{
${ }^{1025}$ Often these ceremonies invite controversy, particularly with regards to the list of politicians who attend and the things they say. For example, at the 2000 Bleiburg commemorations Vice President of the Croatian Parliament, Baltazar Jalsoveć, praised the NDH as the foundation of current day Croatia. Heni Erceg, "Glede \& Unatoč: Budisa," Feral Tribune 20 May 2000, 9 Nov. 2002 $<$ http://www.feral.hr>. ${ }^{1026}$ See Banac, With Stalin 98.

${ }^{1027}$ Tudjman himself was a Partisan. He was the youngest general of the Yugoslav army and retired as a major general in 1961
} 
important movements in Croatian history. ${ }^{1028} \mathrm{He}$ sought to reconcile and unite Croats in their Catholicism, common desire for a strong independent Croatia, and a commonly accepted and celebrated past. The reconciled history that Tudjman made standard was not born out of reflection and reconsideration, but rather out of forgetting and a priori consensus. Subsequent Croatian political leaders have been beholden to Tudjman's history of Croatian solidarity, lest they appear unpatriotic.

In this vein, in 2002 Prime Minister Ivica Račan, the last leader of the League of Communists of Croatia, knelt at the Bleiburg Memorial and spoke of reconciliation. $^{1029}$

Post-WWII retribution, however, extended beyond Bleiburg and included expulsion of almost all Germans from and the persecution of the Roman Catholic Church in Yugoslavia.

After 1991 some on the right and in the RCC have attempted to revive the memory of the derided and forgotten collaborationist combatants. One of the largest annual gatherings of Slovenes is the RCC-officiated commemoration ceremony for collaborators killed by the Partisans at Kočevski Rog. The list of attending politicians and their speeches is sometimes controversial. The fate of these soldiers and the wounds that this right-left cleavage left on the Slovenian

\footnotetext{
${ }^{1028}$ Because of reports on this, Feral Tribune journalist Marinko Čulić and Editor-in-Chief Viktor Ivančić were indicted under the provisions of the Croatian Criminal Code (articles 71 and 72) that prohibited insulting and slandering of the President and government officials. "Awards 1997: Viktor Ivančić," Committee to Protect Journalists, 15 Nov. 2002 <http://www.cpj.org/awars97/Ivančić>. ${ }^{1029}$ Viktor Ivančić, "How Tudjman Spoke from Račan," trans. Marko Kocic, Feral Tribune 28 Sept. $2002<$ http://www.cdsp.neu.edu>.
} 
political landscape continue to be debated today, because there continues to be a pronounced right-left divide in Slovenian politics. ${ }^{1030}$ However, this divide has ensured parliamentary politics in which there is conflict and consensus. The divide has not hindered liberal democratic development, but rather has highlighted the need for continued compromise and incremental reform to achieve pragmatic political goals.

${ }^{1030}$ One of the factors that lead to the resounding defeat of the centre-right coalition was the participation of several leading members of the coalition in a ceremony in June of 2000 honouring those who had collaborated with the Nazis during WWII. Among those attending the sermon, during which the anthems for the collaborationist Home Guards were sung, were (reportedly) Prime Minister Andrej Bajuk, Assembly Speaker Janez Podobnik, Defence Minister Janez Janša, Foreign Minister Lojze Peterle, and Archbishop Franc Rode. The event sent shock waves thorough Slovenian society. Sabrina Petra Ramet, "Slovenia Since 1990," Wilson Centre Meeting Report 2002, 15 Jan. $2002<$ http://www.wwics.si.edu/index.cfm/ fuseaction+topics.publications\&topic>. 


\section{Appendix E: Post-Communist Croatia and Slovenia}

\section{Post-Communist Croatia}

The first 10 years of independent Croatia were dominated by President Franjo Tudjman and the HDZ. Tudjman, a historian by training, already in 1989 developed a clear memory strategy, one that he used to secure his position as the father of the Croatian nation who would realize "the 1,000 year dream of Croatian independence."

This was the platform that in 1990 , prior to the 1991 onset of war, won Tudjman his presidency.

By the time of Tudjman's death in December 1999 his popularity was waning, and it was clear that the voting public desired a government that responded to their everyday needs. Voters were searching for a government that would be transparent and accountable, able to deal with issues such as unemployment, and willing to weed out entrenched networks of state corruption. ${ }^{1031}$

Due to the nature and different interests of the coalitions, it remained difficult for the reform-minded parliamentary coalition elected in 2000 to back out of the obligations created by Tudjman such as the status and economic privileges conferred on the RCC or the historicist focus on Croatian independence. The 2003 parliamentary elections brought the HDZ back into power, but this time under reform-minded leadership that was not as enamoured of bald national chauvinism

\footnotetext{
${ }^{1031}$ Zoran Kusovać, "The Prospects for Change in Post-Tudjman Croatia: Autocracy's Aftermath,"
} East European Constitutional Review, Summer 2000, 9 Oct. 2002 <http://www.law.nyu/eecr>. 
as its predecessor. ${ }^{1032}$

Tudjman's selective approach to Croatian history was mirrored in his and HDZ's rule that challenged political liberalism. These challenges included lack of separation of powers, unfair elections, as well as arbitrary and erratic policymaking. The illiberal tendencies of the regime were all the more perilous given the lack of strong, diverse civil society networks. In this atmosphere it was easier for Tudjman to base his rule on national sentiment and charisma rather than on the promulgation of a policy platform for which he or the HDZ could be held accountable. ${ }^{1033}$ With Tudjman's death in 1999 and with successive governments political liberalization progressed in Croatia, but not as swiftly and securely as in Slovenia.

\section{Semi-Parliamentary to Parliamentary Democracy}

Even before the war, which strengthened the powers of the president, Tudjman set up a system whereby he held the ultimate power. ${ }^{1034}$ Tudjman maintained this regime through his power of appointment, oversight of state ministries, and manipulation of legal requirements. ${ }^{1035}$ Tudjman had a presidential

\footnotetext{
${ }^{1032}$ Anna McTaggart, "Reformed HDZ Set to Retake Power," Balkan Crisis Report, 20 Nov. 2003, $<$ http://www.iwpr.org $>$.

${ }^{1033}$ Cohen, "Embattled Democracy" 70.

${ }^{1034}$ Patrick Moore, "Croatia Votes on Monday," Radio Free Europe/Radio Liberty, 21 Jan. 2000, 4 Feb. $2000<$ http://www.rferl.org>.

${ }^{1035}$ Non-political appointments such as the dean of the public University of Zagreb which was determined by party loyalty as well as fealty to the RCC. Ivan Padjen "Cerkva i Sveučilište," Lecture (Zagreb: Hrvatskoga Pravnog Centra, 11 Nov. 1999).
} 
council for national security that by-passed the parliament. ${ }^{1036}$ Changes of legislation to Tudjman's favour were most apparent in his constant revision of electoral rules. ${ }^{1037}$

Through the constitutional amendments and reduction of power of the presidency the role of the Prime Minister was strengthened as was her/his accountability to parliament. ${ }^{1038}$ The Sabor is the primary legislative body in the country, it has the responsibility of amending and enacting the constitution, holds state budgetary powers, and has the power to declare war. With the constitutional revisions in 2000, the Prime Minister is the government leader and the government indisputably exercises executive functions. ${ }^{1039}$

The Prime Minister is held accountable through a vote of no confidence. While there was a vote of no confidence against Prime Minister Ivica Račan there was never one against Tudjman. During the Tudjman era society was completely politicized, and the HDZ controlled the media, the state bureaucracy, the judiciary,

${ }^{1036}$ The Council for Defence and National Security (VONS) was a body appointed and dismissed by the president that was entrusted with advising the President of the Republic on security matters. Dimitrios Koukourdinos, "Constitutional Law and the External Limits of the Legal Framing of DCAF: The Case of Croatia and the Federal Republic of Yugoslavia," Geneva Centre for the Democratic Control of Armed Forces, Aug. 2002, 15 Sept. $2003<$ http://www.dchaf.ch $>$. However, VONS operated as a sort of "central committee" as appointees were from Tudjman's party or high government officials who advised on many different matters, including tax policy and the basis for the state budget. Gojko Marinković, "Tudjman's New Suit," Aim Press 3 Sept. 1996, 6 Sept. 2002 $<\mathrm{http}: / /$ www.aimpress.org $>$.

${ }^{1037}$ Mirjana Kasapović, "Demokratska Konsolidacija i Izborna Politika u Hrvatskoj 1990-2000," Hrvatska Politika 1990-2000, ed. Mirjana Kasapović (Zagreb: Fakultet Političkih Znanosti) 15-36. ${ }^{1038}$ The constitutional amendments of November 2000 , ensured that the cabinet is accountable directly to the parliament. Republic of Croatia, "Promjena Ustava Republike Hrvatske," Narodne Novine $124 / 00<$ http://www.nn.hr $>$.

1039 "Stabilization and Association Report Croatia, 2002," Commission for the European Communities, 4 Apr. 2002, 3 Nov. 2003 <http://www.europa.eu.int>. 
the police, and the army ${ }^{1040}$ Most public sector jobs were politicized, with the party having a say in everything from the hiring of public school janitors, the state financing of the RCC, and the beneficiaries of industry privatization. ${ }^{1041}$ Lenard J. Cohen labels this "grand corruption," corruption that permeates most aspects of life in a given polity. ${ }^{1042}$ Some reports of HDZ corruption already surfaced in 1993, but truly poured out after Tudjman's death in December 1999. The legacy of corruption and focus on a grand history impaired the efforts of the centre-left coalition government elected in 2000 to implement incremental reforms. Rather than engaging in power sharing and jointly promoting the rule of law and pluralism, the post-Tudjman centre-left coalitions were consistently challenged by the HDZ and its right-wing allies. ${ }^{1043}$

Elections

The HDZ election victory in the 1990 elections was the first and fairest

\footnotetext{
${ }^{1040}$ A presidential decree promulgated in December 1991 allowed the President of the Republic to dism iss the President of the Supreme Court, violating separation of powers. Republic of Croatia, "Uredba o Organizaciji, Radu i Djelokrugu Sudbene Vlasti u Slučaju Ratnog Stanja," Narodne Novine 67/91, 25/92 <http://www.nn.hr>.

${ }^{1041}$ The magazine Nacional extensively reported on the economic misdeeds of the HDZ and Tudjman. This includes millions of dollars in "donations" to high-ranking HDZ officials from those who profited from denationalization of state enterprises. Dragutin Hedl, "Tapes Nail Tudjman Cronies," Institute for War and Peace Reporting 9 Apr. 2000, 7 July $2001<$ http://www.iwpr.nets. ${ }^{1042}$ Lenard Cohen, "Democratic Governance in the Yugoslav Successor States," Conference on Southeastern Europe Moving Forward, Canadian Forum on Southeastern Europe, 23-24 January 2003 (Ottawa: Canadian Forum on Southeastern Europe, 2003). These reports included charges of money laundering and profiteering for regime officials and others. "Nations in Transit 2001: Country Report of Croatia," United Nations Online Network in Public Administration and Finance 2001, 11 Nov. $2003<$ http://www.unpan.un.org>.

${ }^{1043}$ Damir Grubiša, "Political Corruption in Transitional Croatia: The Peculiarities of a Model" Political Thought: Croatian Political Science Review, May 2005, 55-74
} 
HDZ victory of the 1990s, during Tudjman's reign. After coming to power, Tudjman's HDZ constantly changed electoral rules and engaged in activities that compromised elections at every level including municipal, parliamentary, and presidential levels. ${ }^{1044}$

In municipal elections the most obvious case of foul play occurred in 1996, when the HDZ lost the Zagreb municipal elections by a large margin. Tudjman refused to confirm the municipal council nominees for Mayor three times, until the constitutional court upheld Tudjman's prerogative against the elected Zagreb council and Tudjman himself appointed mayor. This fuelled concern that the democratic transfer of power would face even greater challenges in the future. The OSCE denounced the 1997 presidential election that resulted in Tudjman's victory because of HDZ's control of the media and identification of ethnicity in voter registration. ${ }^{1045}$ This was compounded by the 1996 amendment to the criminal code that mandated criminal proceedings against anyone who "slanders" the President of the Republic or a handful of other elected officials. ${ }^{1046}$

Following Tudjman's death and subsequent reforms of 2000 and 2001,

\footnotetext{
${ }^{1044}$ The OSCE noted that of almost 400,000 members of the Croat Diaspora, comprising 10 percent of voters, were registered, while 200,000 ethnic Serbs who fled Croatia in 1995 were disenfranchised. "Statement Presidential Election in the Republic of Croatia" Observation Delegation to the Croatian Presidential Elections, 1997, OSCE 15 June 1997, 15 Feb. 2003 $<$ http://www.osce.org/odihr/documents/ reports/election>.

1045 "Statement Presidential Election in the Republic of Croatia" Observation Delegation to the Croatian Presidential Elections, 1997, OSCE 15 June 1997, 15 Feb. 2003

$<$ http://www.osce.org/odihr/documents/ reports/election>.

${ }^{1046}$ By 1998 the HDZ had more than 1,200 cases against independent media and dominated news dissemination through the state-owned Croatian Radio [and] Television (HRT).HRT was an outlet through which 88 percent of the population received their news. Pavlaković, "Minorities" 24.
} 
electoral rules became more regular and transparent. This resulted in the 2000 parliamentary and presidential elections and the 2003 parliamentary elections recognized as the freest and fairest in post-communist Croatia. With electoral reforms, the majoritarian system has steadily given way to a proportional system, and presidential powers have been reduced.

Party Politics, Post-Tudjman

After Tudjman's death in 1999, the January 2000 presidential and parliamentary elections were held, and former communists Stipe Mesić and Ivica Račan won the posts of president and prime minister, respectively. ${ }^{1047}$ Mesić and Račan ran on a "rule of law" and pro-European integration ticket. However, the HDZ won 41 seats, while Račan's Social Democratic Party (SDP) won 45 seats. The SDP did not win a strong mandate. The coalition government, even with its victory over the HDZ, did not prove unshakable. Firstly, the six-member coalition was two seats short of the two-thirds majority needed for constitutional changes; secondly, the coalition soon broke apart and the government was unable to meet the raised expectations of most Croats. ${ }^{1048}$

\footnotetext{
${ }^{1047}$ Mesic was the last president of the Presidency of SFRY and the first prime minister of Croatia from 1990-1991. He was also secretary of the HDZ from 1990 until his resignation from the HDZ in 1994 (over Croatia's involvement in Bosnia) and the speaker of the parliament from 1992-1994. In January 2000 he won the presidency under the banner of the Croatian People's Party. Racan was president of the League of Communists of Croatia 1989-1990, a member of parliament representing the Social Democratic Party from 1995 until 2000, and prime minister of Croatia in 2000. ${ }^{1048}$ This came as a response to the nine Social Liberal Party members of parliament who voted against the proposed agreement with Slovenia regarding the Krško nuclear power plant. "PM Announces End of Government," OSCE 5 July 2002, 4 Oct. $2002<$ http://www.osce.org>.
} 
Financially and politically Croatia remained unstable. The IDS withdrew from the coalition in 2001 and in July of 2002, faced by another challenge to the government, Račan resigned, forced a vote of confidence, and won it. Račan headed an unstable centre-left coalition that struggled to placate the rightwing forces that sought to frustrate reform. The weak coalition was unable to pursue a comprehensive package of reform, and many HDZ members remained in powerful positions, keeping the old networks of loyalty alive and harassing the government as "communists."

It was difficult for the regime to break from Tudjman-type nationalist rhetoric that focuses on an imagined past and a heroic future based on the sole goal of Croatian independence. ${ }^{1049}$ The reliance on this rhetoric was heightened by the inability to send inductees to the Hague and the RCC silence or support of the inductees. For example, after the publication of the indictment by the International Criminal Tribunal for the Former Yugoslavia (ICTY) of former general Janko Bobetko in October 2002, the Croatian Bishop's Conference (HBK) issued an official press release condemning the ICTY, ridiculing compliance, and reminding Croats that unity throughout their history lead Croats to surmount "internal troubles and external threats." 1050

\footnotetext{
${ }^{1049}$ Even the politicians who desire change find it difficult to negotiate the course of reform while retaining popularity through the continued promotion of victim-patriotism and exclusivist nationalism: "Various influential institutions, groups and individuals stick to their war-time convictions. Issues involving sovereignty are their meat and drink." Mark Thompson, "South Eastern Europe: New Means for Regional Analysis, Policy Brief No. 2., International Institute for Democracy and Electoral Assistance 2002, 4 Jan. $2003<\mathrm{http}: / /$ www.idea.int/balkans $>$. 1050 "Croatian Bishops Issue Statement," HRT 23 Oct. 2002, 28 Nov. 2002
} 
Račan responded by refocusing on communal identity and Croat unity as exemplified in the history emphasized by Tudjman and the Homeland war (1991-1995). Račan, on eve of Statehood Day in 2001, announced the erection of a monument to the Homeland War and urged Croats to overcome current political differences, to remember the communal sacrifices, to reinforce their unity as the "only way to resist the enemy," and to celebrate the "spiritual strength and power" of the Croatian nation. The unresolved pressures emanating from the right and the RCC resulted in a situation where Prime Minister Račan and his government sought to co-opt an uncompromising right-wing position and in the process diluted their reforms. The Račan government was unable to make the break from the institutions and the popular perceptions of history that dominated Tudjman's era. ${ }^{1051}$

Some reforms during the Račan/Mesić era that won the Croatian regime accolades from the Western liberal-democracies include the November 2000 constitutional revisions that reduced presidential authority and the March 2001 abolition of the upper house of the parliament, the House of Counties. ${ }^{1052}$ With these reforms in place, Croatia became a parliamentary system with a uni-cameral parliament, the Hrvatski Sabor (assembly of the republic of Croatia whose duties

\footnotetext{
$<$ http://www.hrt.hr/vijesti/archiv/2002/10/24>.

1051 Viktor Ivančić, "Slapping the Wind: Under the Firmament," trans. Marko Kocic, Feral Tribune 2 Dec. 2000 , 19 Nov. $2002<$ http://www.cdsp.neu.edu/info/students/marko/feralferal136>.

${ }^{1052}$ Mesić reduced some of his formal powers, particularly with regards to domestic policy. He still occupied an office that continues to hold significant authority. The president still holds the Tudjman-era prerogative of confirming mayors. The president also remains the commander-in-chief of the Armed Forces, controls the secret service, and has a leading role in foreign policy.
} 
are outlined in Chapter IV of the Croatian constitution). The coalition also delivered on some promises through partially successful anti-corruption campaigns in the military and intelligence services and its de-politicization of the bureaucracy, judiciary, police, and media.

A new constitutional law on national minorities was passed in order to provide greater recognition and representation to Croatia's minorities. ${ }^{1053}$ However, discrimination against minorities persisted, and the OSCE noted a lack of implementation of the right to return and the repossession of property. ${ }^{1054}$ Added to this was the fact that the government did not fully co-operate with the ICTY, and the chief prosecutor denounced the handling of key cases. ${ }^{1055}$

In November 2003 a more moderate $\mathrm{HDZ}$ won parliamentary elections, it is beyond the timeline of this study to evaluate the new HDZ government. However it should be noted that, this new HDZ seems cognizant of the importance of liberalizing reforms in order to truly enter Europe, campaigned to realize these reforms. This included a stated commitment to honour ICTY obligations, realize Serb refugee return. However, Croatia must still convincingly meet the Copenhagen Criteria and adopt the aquis communitaire.

One of the areas where Croatia has had difficulty in meeting the criteria is in the

\footnotetext{
${ }^{1053}$ Republic of Croatia, "Ustavni Zakon o Pravima Nacionalnih Manjina," Narodne Novine 155/02 $<$ http://www.nn.hr>.

1054 "Broken Promises: Impediments to Refugee Return to Croatia," Human Rights Watch Sept. 2003, 4 Mar. $2004<$ http://www.hrw.org>.

1055 "UN Chief Prosecutor Confident of Croatia's Cooperation with Court," EU Business 30 Jan. 2004, 5 Feb. $2004<$ http://www.eubusiness.com>.
} 
realm of human, specifically minority, rights. The European Commission has argued that Croatia must take further steps to ensure the rights of minorities. ${ }^{1056}$

One of the most glaring justice issues in Croatia was the transfer of indicted war criminals to the International Criminal Tribunal for the Former Yugoslavia (ICTY) in the Hague. The failure of Croatian officials to turn over a number of indicted individuals and the public debate over their status spoke directly to the weak application of the rule of law in Croatia. Another issue is the operation of the justice system. In 2003 the OSCE concluded that during the post-Tudman era, the independence of the courts remained jeopardized, while their decisions were often not enforced or routinely annulled by higher courts.

Many of the problems that continue to plague the justice system are exemplified in cases involving Serb refugee repatriation or restitution. These cases are often delayed, the rulings are discriminatory, and the implementation, if favourable to a Serbian defendant, ignored. ${ }^{1057}$ Another problem remains the practice of in absentia trials, where in most cases Serbs and non-Croats are regularly convicted and Croats are acquitted. ${ }^{1058}$

In January of 2003 the Association of Croatian Judges issued a report that denounced continuing, excessive executive influence and pressure on the

${ }^{1056}$ Commission for European Communities, "The Stabilisation \& Association Process (SAP): Second Annual Report, Report from the Commission," Brussels, Commission of the European Union 26 Mar. 2003, 14 Spet. 2003 $<$ http://www.europa.eu.int/comm/external_relations/see/sap/rep2/com03 341>.

1057 International Crisis Group 13 Dec. 2002, 22 Apr. 2003 <http://www.icg.org>. Brad K. Blitz, "Refugee Reutrns in Croatia: Contradictions and Reform," Politics 23.3 (2003)

${ }^{1058}$ Minorities in Croatia," Minority Rights Group International 2003, 5 Mar. 2004 <http://www.mrg.org $>$. 
judiciary. ${ }^{1059}$ Questions of judicial independence still linger and the legal status of the Serb returnees remains in question as of May 2004.

\section{The Economy}

Another area of concern and concentration of the government's efforts has been economic growth. ${ }^{1060}$ Prior to the break-up of Yugoslavia, the Croatian economy was the second strongest in SFRY after Slovenia. Croatia had a strong tourism industry, infrastructure that linked the country to Western Europe, and strong economic ties to other regions in Yugoslavia. ${ }^{1061}$ After the wars, the damage to Croatia's infrastructure and economy was substantial. Even after the war, Tudjman was preoccupied with enriching his loyal followers through numerous now exposed schemes. ${ }^{1062}$ This did nothing to help create the desperately needed new jobs, as work in many of the old standby industries has been increasingly less available. While the Račan government cracked down on grand corruption, bringing Croatia to place 47 out of 91 in the ranking by Transparency International, many people feel that corruption continues to contribute to the bleak employment

\footnotetext{
1059 “Croatia: Status Report No. 11," OSCE 18 Nov. 2002, 15 Feb. 2003 $<\mathrm{http}: / /$ www.osce.org/reports/ croatia/2002>.

${ }^{1060}$ Katarina Ott, "The Underground Economy in Croatia 1990-2000," Institute of Public Finance Mar. 2002, 16 Apr. $2003<$ http://www.csd.bg>.

${ }^{1061}$ For more on the post-war and post Tudjman Croatian Economy see: Ian Jeffries, The Former Yugoslavia at the Turn of the Twenty-First Century: A Guide to the Economies in Transition (New York: Routledge, 2002).

${ }^{1062}$ When Mesić assumed the presidential office his team found a treasure of tapes that documented the pillaging of the economy and exposed Tudjman sanctioned grand corruption. Tim Judah, "Croatia Reborn," New York Review of Books 67.13 (2000): 20-22.
} 
situation. $^{1063}$

The unemployment rate in 2001 in Croatia was 23.1 percent, as compared to 11.8 percent in Slovenia. However, Croatia still retained many of the economic advantages of the socialist era, including a well-educated labour force and proximity to Western markets. In ensuing years, telecommunications and transport infrastructure were rebuilt and improved. As of April 2004 the European Commission issued an opinion that

Croatia can be regarded as a functioning market economy. It should be able to cope with competitive pressures and market forces within the Union in the medium term, provided that it continues implement its reform programme to remove remaining weaknesses. ${ }^{1064}$

These weaknesses include the judicial sector, incomplete land registries, economic restructuring and privatization and reform of the fiscal and social security systems and public administration. ${ }^{1065}$ Croatia still has a long way to go, and the Croatian government must prove that it will carry through the promised reforms. This is in contrast to Slovenia, which has already been accepted into the EU as of 2004 .

Post-Communist Slovenia

Although there was a common focus on "entering into Europe" and being accepted by Western European states, Croatia and Slovenia did this in distinctive

\footnotetext{
${ }^{1063}$ Slovenia is ranked at 34th place. "The Corruption Perceptions Index 2001," Transparency International 27 June 2001, 24 Feb. $2003<$ http://www.transparenc.org/cpi/201>.

${ }^{1064}$ Stabilization and Association Report Croatia, 2002," Commission for the European Communities 4 Apr. 2002, 3 Nov. $2003<$ http://www.europa.eu.int $>$.

1065 "World Bank Country Brief," World Bank, 17 May 2004 <"http://www.worldbank.hr">
} 
ways. In Croatia the focus was on establishing an independent state, a Croat state right based exclusively on the Croat nation and Tudjman's right wing ideology, to the exclusion of Serbs and other political options. In Slovenia the political focus was on ensuring that the independent state is able to join other European states in an economic and political union, thus securing Slovene economic well-being and cultural preservation through acceptance into the European Economic Community. Even with this common focus deep liberal versus conservative, left-right cleavages have dominated Slovenian politics. The left-right cleavage today finds opposing camps referring to the liberal versus conservative stances delineated in the pre-WWII and WWII era. As defence studies scientist Anton Bebler notes, "The deepest political divide between the right and the left in Slovenia concerns attitudes towards the past, particularly the Second World War and the postwar communist regime, as well as toward the Roman Catholic Church. ${ }^{\text {1066 }}$

While Slovene politics continue to be characterized by strongly opposing ideological camps, these camps are themselves not immovable. There have been many political fractures, and one-block coalitions have proven untenable. However, shared commitment to individual rights and freedoms, economic prosperity, and swift entry into the EU has ensured the stability required to ensure an open forum

\footnotetext{
${ }^{1066}$ Anton Bebler, "Slovenia's Smooth Transition," Journal of Democracy 13.1 (2000): 134. Bebler was a candidate for the 2002 presidential elections with the Democratic Party of Slovenian Pensioners (DeSUS).
} 
for conflict and consensus. ${ }^{1067}$ Competing interests were able and empowered to voice their concerns and desires without the predominance of one standpoint that characterized most of post-communist Croatian politics.

By 1989 a number of political parties across the political spectrum had developed in Slovenia. While there was great consensus on economic affairs and a desire to join the EU, some of the most divisive issues were related to church-state relations and thus became a key point of differentiation. As political scientist Igor Lukšič notes "the arena of political parties is split on the dividing line between Catholic and non-Catholic."1068

The right-wing parties supported the RCC and found their base of support in rural communities, particularly in the centre of Slovenia. ${ }^{1069}$ The leading parties of the right, some of which have changed names, were as of 2003 the Social Democratic Party of Slovenia (Social demokratska Stranka Slovenije, SDS) led by Janez Janša, the Slovenian Peoples Party and Slovenian Christian Democrats (Slovenska Ljudska Stranka Slovenski krščanski Demokrati SLS+SKD) led by Franc But, and the New Slovenia Christian Peoples Party (Nova Slovenija

\footnotetext{
${ }^{1067}$ For more on Slovenian Politics during the 1990s see Danica Fink-Hafner and John R. Robbins, eds., Making a New Nation: the Formation of Slovenia (Brookfield: Dartmouth Publishing Company, 1997); Jill Benderly and Evan Kraft eds., Independent Slovenia: Origins, Movements, Prospects (New York: St. Martin's Press, 1994); I

Igor Lukšič, The Political System of the Republic of Slovenia: A Primer, trans. Erica Johnson Debeljak (Ljubljana: Znanstveno in Publicisticno Sredisce, 2001).

${ }_{1068}$ Lukšič, Political System 80.

${ }^{1069}$ For the platforms of the parties running in the 2000 elections see Danica Fink-Hafner, ed., Volitve 2000: Volilni Programi Politicnih Strank (Ljubljana: FDV-IDV Center za Politoloske Raziskave, 2000).
} 
Krščanska ljudska stranka, NSi) led by Andrej Bajuk. ${ }^{1070}$

On the left of the political spectrum are the following parties that support the separation of church and state and whose base of support remains in urban areas: the Liberal Democratic Party (Liberalna demokracija Slovenije, LDS) led by Janez Drnovšek and the United List of Social Democrats (Združena lista socialnih demokratov, ZLSD) led by Borut Pahor. Since 1992 and except for a six-month period in 2000 the LDS has been the leading party of six coalition governments. The LDS has had the highest returns of any party, but never enough to eschew the coalition government. In 1992 there was a vote of no confidence, and an LDS coalition replaced the DEMOS coalition. In April 2000 the LDS led coalition collapsed, and a right-wing coalition led by Prime Minister Andrej Bajuk of the SLS+SKD ruled for six months, after which a general election swept the LDS back into top position. ${ }^{1071}$

Parliamentary System

\footnotetext{
${ }^{1070}$ The following parties were part of the 2004 coalition government: Slovene National Party (Slovenska nacionalna stranka) led by Zmago Jelincic; Democratic Party of Retired People of Slovenia (Demokraticna Stranka Upokojencev Slovenije, DeSUS) led by Jože Globacnik; the Greens of Slovenia (Zeleni Slovenije, ZS); and Slovene Youth Party (SMS).

${ }^{1071}$ Ramet notes that one of the reasons that the right was defeated in the 2000 elections was because a number of their leaders, along with the Slovenian archbishop participated at the commemoration at Kočevski Rog. They "(honoured) those who had collaborated with the Nazis during WWII and rejecting as "absurd" the partisan resistance against axis occupation." Sabrina Petra Ramet, "Slovenia since 1990," Wilson Centre Meeting Report 2002, 15 Jan. 2002 $<$ http://www.wwics.si.edu/index.cfm/ fuseaction+topics.publications\&topic $>$.
} 
Slovenia was established as a parliamentary democracy. ${ }^{1072}$ In contrast to post-communist Croatia and the position of its president, the president of Slovenia holds a largely symbolic role, with limited powers. Milan Kučan, president of Slovenia from 1990 until 2002, was a popular president who did not overstep his limited powers. His successor and leader of the centre-left Liberal Democratic Party (LDS) Janez Drnovšek (1950-2008) was the Prime Minster of Slovenia from May 1992 until May 2000 and again in November 2000 until December 2002. Janez Drnovšek and Milan Kučan exhausted the number of terms for which they could be elected as prime minister and president, respectively. In 2002 Drnovšek was elected president of Slovenia, and his finance minister Anton Rop was elected prime minister. Although Drnovšek held the office of prime minister for most of the post- communist era in Slovenia, he did not dominate politics like Tudjman in Croatia. Drnovšek only led grand coalitions and accordingly headed governments that had very public internal conflicts.

The prime minister (PM) heads the government. The number of portfolios and cabinet members changes with each new mandate, and as of 2002 there were 15 cabinet members. The president proposes a PM, who is then confirmed by the parliament. The PM then proposes a cabinet, and each potential minister if confirmed by the National Assembly (Državni Zbor). The executive branch is separated from the legislative branch, because the PM and his cabinet are not

\footnotetext{
${ }^{1072}$ Much of the information for the "Parliamentary System" section has been derived from Lukšič, Political System.
} 
members of the National Assembly. However, the PM can be held accountable through a vote of no confidence, which has happened twice since 1991. The first time this happened was in 1992, resulting in the demise of the one block centreright DEMOS coalition and the replacement of PM Lojze Peterle with Janez Drnovšek and a grand coalition. The second time this occurred when Drnovšek tied a vote of confidence with a bill for replacing 10 ministers. The bill did not pass, and Drnovšek and his grand coalition were replaced by Andrej Bajuk and a sixmonth centre-right one block coalition.

The 1991 Slovenian constitution established a bi-cameral parliament consisting of a powerful lower chamber (National Assembly) and a weaker upper chamber (National Council, Državni Svet). The 90-member National Assembly is the representative and main legislative body in Slovenia. Its deputies are elected for four-year terms and possess control over budgetary measures, PM and ministerial appointments, and a host of other lesser positions. It is collectively responsible for the work of the government.

The National Council reflects the continued influence of corporatism in Slovenian society through representatives of economic, social, provisional, and local interests.

There was a corporatist element to the peasant communes of the late 19th century as well as to the system of Workers' Self-Management. ${ }^{1073}$ It continued with the

\footnotetext{
${ }^{1073}$ Igor Lukšič, "Changing Patterns of Social Partnership," Making a New Nation: The Formation of Slovenia, eds. Danica Fink-Hafner and John R. Robbins (Brookfield: Dartmouth Publishing
} 
National Council and the tripartite Economic and Social Council in the Ministry of Labour. The National Council is composed of 40 non-directly elected members, who serve in five-year terms. The members are composed of the following: 4 groups representing employers, employees, farmers, craftsmen, and other professionals; 6 representatives in the public sector fields of health, education, research, culture, sports, and social welfare; and 22 local representatives. This body is a means for representing civil society as well as economic and other collective interests that might not be clearly articulated in the National Assembly. ${ }^{1074}$ While the council can initiate, amend, advise on, investigate, and veto legislation, its role is mainly supervisory.

Elections

Since amendments to the Slovenian constitution in 1989 , elections in Slovenia have been free, open, and contested, based on universal equal franchise and secret ballots. The spring 1990 elections to the still tri-cameral assembly included a different electoral system for each: proportional for the socio-political chamber, majority for the chamber of communes, and plurality for the chamber of associated labour. This changed with the 1992 elections, and the president is now

\footnotetext{
Company, 1997) 106-113. Lukšič propounds that Slovenian political culture rests on corporatism, the strongest variants being Catholic and socialist corporatism of bygone eras and in the era of democratization pluralist corporatism. Igor Lukšič, "Political Culture in Slovenia," Political Culture in East Central Europe, eds., Fritz Plasser and Andreas Pribersky (Amersham: Avebury, 1996) 94. ${ }^{1074}$ Party interests are only able to enter the council through the representatives of localities. Lukšič, Political System 40.
} 
directly elected by a majority popular vote.

National Assembly members were elected through an open list proportional system in multi-member constituencies, with the seats distributed nationally using the d'Hondt system. Both political parties and voters were able to nominate candidates. The National Assembly among its 90 members includes two seats that are automatically reserved for representatives of the autochthonous Italian and Hungarian minorities.

Through this system, a number of fragile grand coalitions under the leadership of LDS leader and PM Janez Drnovšek were created. While these coalitions were lead by the LDS, they did involve the inclusion of some right-wing parties. The National Assembly is elected through a proportional representation, individual voters choose candidates in party lists and there is a 4 percent threshold. Although this does not change much, it does exemplify how controversies in Slovenia are often dealt with through incremental reform, parliamentary debate, and adherence to the constitution.

The Justice System

By the 1980s Slovenian courts were no longer used as venues to pursue political persecutions. The WSM courts that existed in SFRY were abolished and were replaced with district, regional, courts of appeal, administrative courts, the Supreme Court, and constitutional courts. The 11-member Judicial Council that 
appoints and supervises judges has 5 members, who are elected by the National Assembly. The constitutional court in Slovenia, as in many other post-communist Eastern European countries, is responsible for protecting "constitutionality, legality, human rights and fundamental freedoms. ${ }^{.1075}$ Although the courts are subject to the separation of power, the judiciary has been considered as politically activist until approximately $1998 .^{1076}$

The Constitutional Court in Slovenia has been very active in part because so many politically important issues have been referred to it. For example, issues that have provoked fierce debate, including electoral laws, the agreement with the Holy See, numerous referendum questions, and others have been referred to the court. In Croatia, similar issues were not referred to the Constitutional Court because they were not as openly disputed. In Slovenia, the Constitutional Court has been extensively used in order to ensure that constitutionally guaranteed rights and freedoms are respected. The Constitutional Court is an autonomous institution, where nine judges are proposed by the president and elected by the National Assembly to a single nine-year term.

The Economy

Exports and manufacturing have been key in maintaining Slovenia's status

1075 "Constitutional Court Act," Official Gazette of the Republic of Slovenia no. 15/94, $11 \mathrm{Dec}$. $2002<$ http://www.us-rs.si>.

${ }^{1076}$ Elected in 1990, six of the nine members of the Constitutional Court had reached the end of their term by 1998 (since prior to the 1991 constitution which stipulates nine year terms justices were elected for eight year terms). 
as one of the most successful "transition countries." ${ }^{\text {"1077 }}$ The stable economic picture after the mid-1990s has left Slovenia with an unemployment rate of 6.5 percent, inflation of 7.5 percent, GNP growth of 4 percent, and GDP per-capita growth of 14,293 in 2001 and 18,400 in $2003 .{ }^{1078}$

Slovenia's economic restructuring was incremental, and this slow approach to liberalization is credited with the country's current economic success. Slovenia did not hastily privatize many of its key industrial and utility assets, it did not allow for much foreign ownership, and neither has it courted large amounts of foreign direct investment. ${ }^{1079}$ The incremental privatization process has favoured former managers and employees, who in Slovenian case were already familiar with operating within freer markets. ${ }^{1080}$ Slovenia's economic planners focused on creating new enterprises instead of restructuring and selling off old ones. In this way economic restructuring did not result in overwhelming unemployment and loss of productivity.

Slovenia built on the advantages of a highly skilled labour force and international trade ties of the Yugoslav communist system. Slovenia continues to

1077"National Report: Slovenia 2003," Eurochambers (The Association of European Chambers of Commerce and Industry), 5 Apr. $2003<\mathrm{http}: / /$ www.eurochambers.be/whatwedo/

EESNationalReports2003/Slovenia>.

1078 "Freedom in the World 2000-2001: Combined Average Freedom Rating and GDP Per Capita," Freedom House 2001, 18 Feb. 2003 <http://www.freedomhouse.org/research/ freeworld/2001/gdp.pdf >.

${ }^{1079}$ Evan Kraft, Milan Vodopivec, and Milan Cvik1, "On Its Own: The Economy of Independent Slovenia," Independent Slovenia: Origins, Movements, Prospects, eds. Jill Benderly and Evan Kraft (New York: St. Martin's Press, 1994) 201-223.

1080 "Pragmatism and gradualism proved successful in coping with the consequence of the federal economic policy by establishing sovereignty in the fiscal and foreign exchange systems and preparing institutional settings for a "new" country long before the proclamation of independence." Mencinger, "Costs and Benefits" 209. 
use its geography, infrastructure, diversified manufacturing base, and skilled labour force to its economic advantage. Even prior to independence and the 1991 Ten Day War, Slovenia sent delegations to various Western trading partners seeking support for independence and assuring them that trade would continue, customs would run smoothly, and Slovenia would assume a certain amount of debts. ${ }^{1081}$ As in other policy areas, reform in the country was incremental.

${ }^{1081}$ In February 1996 Slovenia assumed eighteen percent of the former Yugoslavia's total debt to the commercial banks. "The total debt was valued at $\$ 5.58$ billion (of which $\$ 4.4$ billion represented principal)." Jeffries 67-68. 


\title{
Appendix F: War in Croatia and War in Slovenia
}

\author{
The War in Croatia
}

The war in Croatia, which varied in intensity and from region to region lasted from 1991 until 1995. In Serbia, the political will to establish a "Greater Serbia" that included parts of Croatia was fuelled by claims that this would protect Serbs in Croatia and Bosnia from the fate of their forbearers in WWII. The international community lacked political will or ability to bring a swift end to the war, which many portrayed as a manifestation of ancient ethnic hatreds that could not be stopped until the warring parties were exhausted.

The war lasted so long in Croatia in part because of Tudjman's and Milošević's use of almost complete authority to engage in nationalist fearmongering and propaganda. ${ }^{1082}$ Weapons and tactical support for Serb uprisings in Croatia during the summer of 1990 as well as Tudjman's refusal to deal with the situation facilitated the start of war in the summer of $1991 .^{1083}$ Croatia had not prepared for war as well as Slovenia. Even in late 1990, when weapons and tactical support for Serb uprisings were flowing in from Serbia, Tudjman did not believe that Croatia would face a significant challenge from Serb irregulars or the JNA. ${ }^{1084}$

\footnotetext{
${ }^{1082}$ Just like not all Croats supported Tudjman, not all Serbs supported Milošević. However, opponents of both, from extremists to moderates, were silenced by the two leaders' authoritarian hold on power. As Sabrina Petra Ramet notes, in June 1990 "some 30,000 Serbs marched through Belgrade...bearing pictures of Milošević, with a black ' $X$ ' across his face and the slogan written above, "We don't want another dictator!" Ramet, Nationalism and Federalism 234.

${ }^{1083}$ Bennett 125. Gow, Triumph 34.

${ }^{1084}$ This was demonstrated with the November 1990 Croat capture and release of one of the most infamous Serb paramilitary leaders, Želko Ražnatović aka Arkan. Arkan was arrested with "a car 
A year later full-scale war exploded and eventually engulfed one third of

Croatian territory.

Tudjman had relied on Milošević's promise that he was only interested in BiH. $^{1085}$

Tudjman eschewed pragmatic policy-making and planning exemplified by the disarmament of the Croatian territorial defence forces. ${ }^{1086}$ In response to this move and to the Serb uprisings of the spring and summer of 1990, Tudjman created a 1,500 member special police unit that would form the backbone of the Croatian Army (Hrvatska Vojska, HV). He also began to train some 20,000 men in light arms and established the Croatian National Guard Corps after JNA tanks were deployed in Plitvice national Park in April 1991. It was only at the start of 1991 that Tudjman allowed General Martin Špegelj to engage in large purchases of arms. 1087 Špegelj was replaced in July 1991 with a trio headed by the inexperienced but politically prominent former Ottawa pizza parlour owner Gojko Šušak, who slowed down the purchase of weapons.

It was only in February 1991 that the primacy of the Croatian Constitution

full of arms and ammunition [and ] he was tried, convicted and released pending an appeal." Judah, Serbs 184.

$\frac{1085}{105}$ This promise was made at their infamous 1991 Karadjordjevo meeting, where Tudjman and Milošević agreed to divide $\mathrm{BiH}$. Following that meeting, "the Community of Herceg-Bosna" (which included areas claimed by Bosnian-Croats) and an independent Bosnian Serb Republic (which included the areas claimed by Bosnian-Serbs) were established. By April 1992 the independent Bosnian Serb Republic was proclaimed and later renamed Republika Srpska. In June 1992 HercegBosna declared itself an independent state. Silber and Little 157. Thomas 86.

${ }_{1086}$ Meier 154.

${ }^{1087}$ However, Špegelj was caught negotiating an arms deal on a video that was later broadcast throughout Serbia.Tanner 234-236. 
and Croatian law was established. A referendum on independence was only undertaken in May 1991. After the fighting escalated in the summer of 1991 Tudjman officially prepared for war. Without the legislative, civil society, or military preparations undertaken by Slovenia, Croatia still set the same date for independence as the Slovenia, 25 June $1991 .^{1088}$

Two days after proclaiming independence and one day after independence celebrations, Slovene forces set out to secure the borders and airports sought after by the JNA. Tudjman did not mobilize his forces to secure the borders, nor did he offer help to the Slovenes. ${ }^{1089}$ After the ten-day war and the peace agreement negotiated by the European community, Slovenes were not obligated to provide help to the Croats, whose war already began and would last much longer.

Already in early 1991 Serbs in Croatia joined paramilitary groups, while the Serbian Autonomous District of Krajina (Srpska autonomna oblast, SAO, Krajina, re-designated Republika Srpska Krajina) was declared and supported by Milošević in an effort to protect "Serb ethnic territory." ${ }^{1090}$ In Plitvice National Park, the Krajina army with the help of JNA tanks and troops ambushed Croatian police and began a series of skirmishes that drew the JNA and Serbian paramilitaries deeper into conflict with Croat forces throughout Croatia. When the JNA began pulling out of Slovenia on 6 July 1991, it sent its troops to Croatia and Bosnia and

\footnotetext{
${ }^{1088}$ On 25 June 1991 Croatia officially declared itself a "Sovereign and Independent State," while Slovenia declared "Disassociation from Yugoslavia."

${ }^{1089}$ Janša 152-156

${ }^{1090}$ Meier 176.
} 
Hercegovina (BiH). In July and August of 1991 it was clear that war started in Croatia with fierce fighting in Vukovar and surrounding towns. By 1992 one third of Croatia was in Serb/JNA(VJ) hands, and during the spring of 1992 war broke out in $\mathrm{BiH}$ between Serb and the allied Bosniak and Croat forces, which later saw fighting between all camps, Croat, Bosniak, and Serb. In Hercegovina the local HDZ (Croatian Democratic Union) had its own militia, the Croat Defence Council (Hrvatsko Vijeće Obrane, HVO).

On 3 July 1992 Croat forces in Hercegovina declared the autonomous region of Herceg-Bosna. Lead by Mate Boban, Herceg-Bosna was supported by Tudjman. In the spring of 1993 Croat and Bosniak forces began fighting each other. These battles included the November 1993 Croat shelling and destruction of the medieval bridge in the Town of Mostar. ${ }^{1091}$ In the spring of 1994 both sides agreed to a Croat-Bosniak federation, and in July 1995 a common defence plan against Bosnian Serbs was created. Already in May 1995 the Croats started to gain the upper hand in Croatia with Operation Flash (bljesak). But it was Operation Storm (oluja), initiated on 4 August that secured the Croat victory. By 8 August Operation Storm was complete, with an estimated 200,000 Serbs fleeing from Croatia, with a total of approximately 300,000 Serbs who had fled from all regions of Croatia. ${ }^{1092}$

\footnotetext{
${ }^{1091}$ In secret transcripts of a secret staff meeting in late summer 1995, president Tudjman noted that "we didn't accidentally create the Croatian Republic of Herceg-Bosna and the Croatian Defense Council." Feral Tribune was the first to publish these secret transcripts in 2003. "Historical Transcript: Tudjman on Ethnic Cleansing," trans. Mirna Skrbic; Transitions On-Line 17 July 2003, 18 Aug. $2004<$ http://www.tol.org>.

1092 "Croatia: Impunity for Killings after Storm," Amnesty International 1 Aug. 1998, $<$ http://web.amnesty.org/library/Index/ENGEUR640041998?open\&of=ENG-HRV>.
} 
The SAO Krajina was dismantled, and Croatia's pre-war borders were restored.

Milošević was forced to sign and adhere to peace in Croatia and $\mathrm{BiH}$, which

came with the 14 December 1995 Dayton Accords. ${ }^{1093}$ By the end of the war, an estimated 20,000 people died in Croatia, and over 200,000 died in Bosnia, with 1.2 million displaced. ${ }^{1094}$ Many more were left injured and homeless. The demographics of Croatia had changed drastically, with the total population dropping from 4.91 million in 1991 to 4.44 million in $2001 .^{1095}$ Speaking in a secret staff meeting shortly after operations Storm and Flash, Tudjman noted that,

It is necessary for military command precisely to be come one of the most efficient components of our state policies in solving the demographic situation of Croatia. We have to consolidate Croatianhood in Istria and populate certain parts. ${ }^{1096}$

The last census before the war was conducted in 1991 and confirmed a 12 percent Serbian minority in Croatia. The next census in 2001 revealed a 4 percent Serb minority. ${ }^{1097}$ This drop cannot be simply explained by the number of Serbs who fled Croatia, but it must take into account the number of Serbs in Croatia who chose to hide their identities fearing Croat chauvinism. ${ }^{1098}$ It is expected that most

\footnotetext{
1093 "Dayton Peace Accords," 21 Nov. 1995, 5 Oct. 2002 <http://wwwl .umn.edu/humanrts/ peace/docs/daytonaccord>.

${ }^{094}$ United Nations Mission in Bosnia and Herzegovina, "Background," United Nations Dec. 1998, 3 Nov. 2002 <http:/www.un.org/Depts/dpko/missions/unmibh/background>.

1095،Croatia: Official Census Results Made Public," OSCE May 2002, 3 Nov. 2002

$<$ http://www.osce.org/croatia $>$.

${ }^{1096}$ Feral Tribune was the first to publish these secret transcripts in 2003. "Historical Transcript: Tudjman on Ethnic Cleansing," trans. Mirna Skrbic, Transitions On-Line 17 July 2003, 18 Aug. 2004 <http://www.tol.org>

${ }^{1097}$ Census of the Population, Households and Dwellings, Republic of Croatia: Central Bureau of Statistics 31 Mar. 2001, 17 Sept. 2003 <http://www.dzs.hr/Eng/Census/census2001>.

1098 Jean-Pierre Altier, "Croatian Serbs Say They are Still Victims of Discrimination," Agence France-Presse 23 June 2002, <http://www.afp.org $>$.
} 
Croatian Serbs will not return because of the arbitrary enforcement of repatriation laws, physical confrontations, and lack of a secure future. ${ }^{1099}$ In late August 1995, Tudjman took the "train of freedom," touring areas won in operations Storm and Flash. In his speech at Karlovac, while noting that Serbs will be guaranteed human rights, he stated that

never again will they be able to rule in Croatia, or work under those who wanted to rule Croatia and had in that respect made it their slave [adding that Croatia would be rebuilt for citizens and so that] Croats from all corners of the world to return to it. ${ }^{1100}$

\section{War in Slovenia}

Slovenia's war lasted only ten days, June 27 until June 7th 1991, for a number of reasons. Primarily, because of the way that Slovenia negotiated political change. Secondly, the political will in Serbia to sustain war in Slovenia was weak to non-existent, in large part because the Serbian minority in Slovenia only consisted of approximately 50,000 people or 2.4 percent of the Slovenian population. ${ }^{1101}$ Thirdly, the JNA (Yugoslav People's Army) contingents that were sent to Slovenia were primarily non-Serbs; their morale was low, and many surrendered. ${ }^{102}$ Fourthly, the international community was swift in seeking an end to the war, which saw fighting on the EU borders of Austria and Italy. Finally,

${ }^{1099}$ Of the Serbs that have returned as of Spring 2002, the vast majority are elderly. "Broken Promises: Impediments to Refugee Return to Croatia," Human Rights Watch Sept. 2003, 4 Mar. $2004<$ http://www.hrw.org>.

1100 "The Train of Freedom," Croatia Radio Television 26 Aug. 1995, 6 Dec. 2003 $<$ http://www.hrt.hr>.

1101 Petra Roter, "Slovenia: Statistics," European Centre for Minority Issues 2002, 3 Mar. 2003

$<$ htttp://www.ecmi.de/emap/slo_stat>.

${ }^{1102}$ Goldstein 227. 
there existed the less publicized fact that Slovenia was better prepared for war than Croatia.

Through incremental reforms, Slovenian Territorial Defence Force (Slovensko Teritorialna Obramba, TO) was empowered and the Slovenian contribution to the national army was weakened. The TO was a Yugoslav peculiarity, a force was initiated in each republic after the Prague Spring (in 1968) as a compliment to the JNA so as to provide additional defence against a possible Soviet invasion. The TO configuration played to Partisan ideals of local defence and demonstrated the extent of decentralization in Yugoslavia. Each republic funded its own TO force and each TO was composed of a small group of professionals and of a much larger number of reservists. Subordinate to the JNA, the commanders of the TO were drawn from the retirees from the highest ranks in the JNA. With the trial of the Ljubljana Four, Slovenia's political reforms and the opposition to centralization caused the JNA to increasingly side with Milosevic and to increasingly seek TO's disarmament. ${ }^{1103}$

Milošević came to convince the JNA that it was Slovenia's (and by 1989/1990 Croatia's) liberalizing and decentralizing aspirations and growing nationalism and not his own nationalist call to arms that were serious threats to communist Yugoslavia. ${ }^{104}$ Although Milošević initially fought the Kosovars as a

\footnotetext{
1103 Janša, Making of a New 41-62.

${ }^{1104}$ Bennett 179-192.The irony is that the JNA chose Milošević because they saw him as fighting for what had been the mandate of the JNA, a unified (if not centralized) socialist Yugoslavia. However, once Milošević gained power he dismantled the JNA and used its remnants to fight for his
} 
collective threat to the Serbian nation and then focused on fighting against Slovene efforts at liberalization and decentralization, he settled on fighting the Croats and Bosniaks in wars that lasted from 1991 until 1995. After Milošević engineered purges in the late 1980s and early 1990s, the remnants of the JNA (Yugoslav People's Army) and its spring 1992 successor, Serbia's Army of Yugoslavia (VJ), were motivated to fight for Serbs in Croatia and later in BiH. ${ }^{1105}$ Just after non-communist parties won the multiparty elections in Slovenia and Croatia in April and May of 1990, the JNA began to confiscate the weapons of the TO in both republics. When Slovenian political leaders were unofficially alerted to this, unlike the leadership in Croatia they put a stop to the confiscations. ${ }^{106}$ This is why Slovenia retained approximately 30 percent of its weapons, whereas Croatia's TO lost almost all of its weapons. ${ }^{1107}$

In the fall of 1989 revisions to the Slovenian constitution had already ensured that republican authorities could veto the imposition of a state of emergency in Slovenia.

However, by September 1990 further amendments to the Slovenian constitution resolved that the Slovenian constitution had precedence over the federal constitution and the command of the Territorial Defence (TO) was transfered to the

own portrayal of Serbian interests. Bennett 119.

${ }^{1105}$ For more on the JNA/Serb Alliance see Bennett 131-155.

${ }^{1106}$ Janša 45. Božo Repe, Slovenci v Osemdesetih Letih (Ljubljana: Zveza Zgodovinskih Društev Slovenije, 2001) 54-57.

${ }^{1107}$ Kadijević 74. Magaš 269. Gow, Legitimacy 40-64. 
Presidency of the Republic of Slovenia. ${ }^{1108}$ In this way the Slovenian government had assumed sole command of the TO which was reinforced by the establishment of the Contingency Operational Coordination Staff, headed by Janez Jansa and Igor Bavčar, which enabled the republic's leaders to control the TO.

1108 "Državna Ureditev Republike Slovenija," Uradne List 28 Sept. 1990, 11 Mar. 2002 <http://www.zakonodaja.gov.si>. Gow and Carmichael 176-177. 


\section{Appendix G: Croatia, the RCC and The International Criminal Tribunal for the Former Yugoslavia (ICTY)}

The ICTY became a lighting rod for government criticism in 2001, when indictments were issued for Croatian officers Mirko Norac, Rahim Ademi, Ante Gotovina, and in 2002 Janko Bobetko, men celebrated as heroes of the Homeland war. An important issue here is that not only did those against the ICTY try to deny the proper operation of the rule of law, but the government did not openly and with conviction pursue the implementation of the rule of law. They did not openly confront criticism and seek to change the perceptions that fuelled this opposition either. As historian Vjeran Pavlaković notes, the government "pursued a policy of denial and secrecy." ${ }^{1109}$ However, as Pavlaković goes on to note, after the 2003 sentencing of Croatians accused of war crimes during the 1990s, the Croatian judicial system demonstrated that it can handle war crimes trials. ${ }^{1110}$ However, even in those sentences the judge argued that since it was a defensive war, the defendants should receive lighter sentences.

Mirko Norac was indicted in February 2001 for the killing of Serbian civilians in Gospić in October 1991. Immediately widespread protests began. Because of the protests and the promise of a fair trial by Croat authorities, the ICTY chief prosecutor Carla Del Ponte allowed the trial to be held in Croatia. As a

\footnotetext{
${ }^{1109}$ Vjeran Pavlaković, "Minorities in Croatia Since Independence." Nationalism, Culture and Religion in Croatia Since 1990. Ed. Verjan Pavlaković. Seattle: The Donald W. Treadgold Papers, the Henry M. Jackson School of International Studies, University of Washington, 2001, 35. ${ }^{1110}$ Pavlaković 31-33.
} 
result, in March 2003 Norac was found guilty and sentenced to 12 years in prison. By July 2001 the ICTY had indicted and requested the extradition of General Rahim Ademi and General Ante Gotovina. This led to a political crisis in which Prime Minister Ivica Račan's coalition government requested a vote of no confidence over the extradition. The request was undertaken so the government could have a clear mandate to go through with the extraditions, which it had delayed to the chagrin of the ICTY. ${ }^{111}$ Former general Rahim Ademi, an ethnic Albanian, surrendered and was handed over to the ICTY by Croatian officials in July 2001. Rather, it was former generals Mirko Norac and Ante Gotovina who were at the centre of the $\mathrm{RCC}$ and political right-wing campaigns denouncing the current government as anti-Croatian.

The protest against the decision to hand over Gotovina and the mass demonstrations that accompanied the decision to try Norac were staged by rightwing factions and attended by a number of high ranking church leaders. ${ }^{1112}$ The

\footnotetext{
1111 Five coalition partner deputies of the Croatian Social Liberal Party (HSLS) resigned over the matter, including former presidential candidate and leader of the HSLS Drazen Budisa. This is despite the fact that Budisa requested all of his deputies to resign (Budisa won $44 \%$ of the votes in the 2000 presidential elections). However, a number of deputies, including Budisa, returned to parliament. When Budisa returned, he demanded the resignation of a number of members of his party who he saw as supporting the government too much. He also did not support the ratification of an agreement with Slovenia over the Krško nuclear power plant. By July 2002, Prime Minister Račan formed a new government without the HSLS.

1112 Norac was born near Sinj on the Dalmatian mainland, 40 kilometres from Split, where the Alka (knights game or tilting at the ring) festival is held annually to commemorate the 1715 victory of the Croats over Ottoman soldiers in the Battle of Sinj. Held on the first weekend of August, the festival's centrepiece is a lancing competition. Mirko Norac was the Duke of Alka, who during the festival is reserved a place of honour and who acts as a sort of master of ceremonies. Because of his incarceration, there was an acting duke. The 286th festival in 2001 was dedicated to Norac and the Alka Knights Society declared that the winner for the first time should refuse the reward given by the President of Croatia. Norac refused the reward, and the City Council of Sinj declared Norac an
} 
Norac demonstrations were organized by the HDZ and Homeland War Veterans' groups, and included a series of road blocs on the main Zagreb/Split highway, in effect splitting Croatia in two for five days. Split proved to be a stronghold of Norac supporters, with 100,000 gathering for a protest in his name, while only approximately 10,000-20,000 gathered in Zagreb. ${ }^{1113}$

In an interview with the right-wing daily, Slobodna Dalmacija, following his indictment Norac specifically thanked auxiliary bishops Marin Barišić of SplitMakarska and Mile Bogović of Rijeka-Senj for their strong support. He also noted that "before and after every [military] action I went to church."1114 Archbishop of Split-Makarska, Ante Jruić, also publicly advocated on behalf of Norac. The HBK, as a group headed by Arcbhishop Josip Bozanić, in all of its public pronouncements did not state any clear position on the controversy of extradition of those indicted by the Hague because the bishops were not able to reach consensus on the matter. The influential bishops of Zagreb, Rijeka, and Istria did not provide any judgement on the issue. Their silence has been amplified by the denunciations of the indictments, most notably by auxiliary bishops Bogović and Barišić, the Military Bishop Juraj Jezerinac, as well as a number of lower clergy. ${ }^{1115}$ For

honorary citizen. Snježana Šetka, Zoran Šagolj, and Mirjana Ljubić, "150 Tisuća Puta Svi Smo Mi Mirko Norac," Slobodna Dalmacia 12 Feb. 2001,

1113 "Miting u Splitu: Od Potpore Norcu do Zahtjeva za Raspisivanjem Izbora," Vjesnik 12 Feb. 2001, 14 Feb. $2001<$ http://www.vjesnik.hr>. The most prominent placard carried at the demonstration was the one that proclaimed "We are all Mirko Norac."

1114 Josip Jovic, "Interview, General Norac: This Rally has Filled Me with Pride, I am Ready for one More Sacrifice," Slobodna Dalmacija 14 Feb. 2001, 4 Dec. $2002<\mathrm{http}: / / w w w . c d s n e u . e d u>$.

1115 Some Croatian RCC bishops agreed "to serve a mass for the fatherland in all Croatian churches on August 5th," the anniversary of when the Croatian army, in 1995 during Operation Storm 
example, on the Day of the Croatian Armed Forces ( alternatively labelled the Day of Gratitude to the Homeland), 6 August 2001 Bishop Jezerinac stated that Croatians should not "be covered by the shroud of grief because of attempts to behead us with indictments issues against our defenders."1116

The Dominican Order in Croatia sent a letter to President Stipe Mesić, stating that they had lost trust in the president because of his commitment to arrest war veterans indicted by the ICTY. Even the elite RCC Justitia et Pax (Justice and Peace) Commission publicly proclaimed their support of Norac and Gotovina, along with an indictment of the current government in the realm of social services, stating that "in addition to the crisis in relations with international factors, the most serious crisis is in relations existing in the country." $" 1117$

There were countless anti-government sermons delivered from pulpits throughout the country. Beyond this, a large group of RCC leaders openly criticized the government for handing over indicted war criminals, while the moderates kept silent. ${ }^{118}$ The political and social distance that the RCC placed between itself and the leftist government was a sharp political pronouncement in

liberated Knin. Jelena Lovrić, "Church against Tribunal," Aim Press 26 July 2001, 4 Jan. 2001 $<$ http://www.aimpress.org $>$.

${ }^{1116}$ S. Dukić, D. Sarać, G. Jelavić, Z. Juras, M. Ljubić, A. Dragicević, J. Celar, D. Mezic, and T. Kolumbić. Msgr. Juraj Jezerinac "They are Trying to Behead Us with Indictments." Slobodna

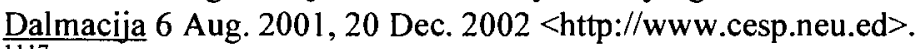

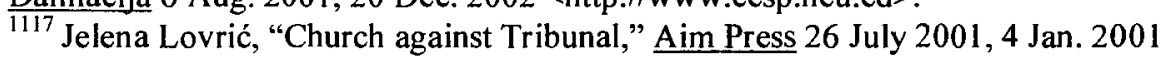
$<$ http://www.aimpress.org>.

${ }^{1118}$ Dr. Ivan Padjen notes that it is not that the new government is anti-Catholic. There were Catholics in their ranks, including Deputy Prime Minister Granić, a "declared Catholic," who was most likely the person who drafted the response to the Bishops' letter. Mirko Djordjević, "How Strong are the Catholic Church in Croatia and the Orthodox Church in Serbia: Part II," Radio Free Europe/Radio Liberty 31 Jan. 2002, 8 Nov. $2002<$ http://www.rferl.org $>$. 
itself. Despite debates and demonstrations regarding indictments and the ICTY, the Bishops' letter of November 2001 was not the most extreme example of antigovernment sentiment in the RCC, but it was certainly the most unified expression of it. Immediately after the publication of the Bishop's letter, the Račan government sent a rebuttal admonishing the Catholic Bishops for "politically and ideologically" clashing with the government under the guise of having social concerns. $^{1119}$

The government issued a press release that expressed its concern regarding "the closeness of the Church's opinions with the standpoints of certain opposition parties and Radical political groups." ${ }^{.120}$ This closeness included the HDZ and various other right-wing groups, the same parties that were vehemently against the Hague extradition. A December 2001 meeting between the Croatian government and Catholic Bishops led to a tacit agreement whereby the two parties would cease to voice their differences in public and seek to work things out.

The government representatives argued that they were spending more on social services than the HDZ government had and that the aforementioned government left the state in financial ruin. The church criticized the slow progress of property restitution, inadequate social services (particularly for the destitute), and the need for a role of the RCC in education. Their criticisms were assuaged by renewed government commitment to carry out the requirements of the Republic of

\footnotetext{
${ }^{1119}$ Mladen Plese, "Drama in the Government" Nacional 28 June $2001<\mathrm{http}: / /$ www.nacional.hr>. ${ }^{1120}$ Goran Vezić, "Priests Flex Their Muscles," Balkan Crisis Report 2 Aug. 2002, 16 Dec. 2002 <http://www.iwpr.net>.
} 
Croatia and Holy See agreements, particularly in the realm of Catholic

education, tax exemptions, guaranteed income, and public holidays. This signaled

tacit co-operation between the government and the RCC that would serve the

RCC's immediate financial concerns at the expense of taxpayers and churchgoers.

As a Zagreb parish priest noted,

It looks as though our bishops toned their social decree only harsh enough to frighten the government and to force them to give in. After the government promised to fulfill the majority of their requests with respect to protecting the material and financial interests of the clergy, they are no longer insisting on the missed policies of the government. Such conduct is already considered by the congregation as a betrayal, since they feel isolated, deprived and tricked. ${ }^{12}$

The government feared further anti-government backlash, and the RCC won concessions that furthered their privileged status. The government increasingly focused on legitimacy on a patriotic rather than a legal-rational platform.

Žarko Puhovski, then president of the Croatian Helsinki Committee, noted that "their efforts to present themselves as good Croats, [the government seeks] to ingratiate themselves with the church to an even larger extent than Tudjman and the HDZ." "122

He further comments that there is no party in Croatia that dares to "sand up to" the RCC hierarchy, because "priests and the Catholic press are all to ready to mount

${ }^{1121}$ Mladen Plese, "The State Firmly Committed Itself to Unconditionally Fulfilling All the Controversial Issues in the Controversial Contracts between Croatia and the Vatican," Nacional 12 Dec. 2001, 19 Sept. $2002<$ http://www.nacional.hr>.

${ }^{1122}$ Goran Vezić, "Priests Flex Their Muscles," Balkan Crisis Report 2 Aug. 2002, 16 Dec. 2002 $<$ http://www.iwpr.net>. 
orchestrated campaigns capable of wrecking political careers." ${ }^{1123}$ The new understanding between the RCC and the government set an ominous precedent, with the government delaying and subverting justice on the behest of the RCC and others. This strategy extended to the next ICTY indictment crisis, the Bobetko Affair.

On 23 August 2002 the former Croatian chief of staff, General Janko Bobetko, was indicted by the ICTY for crimes against humanity. As the highest raking Croatian army official and homeland hero to be indicted as of May 2004, he became an instant rallying point for anti-government forces. ${ }^{1124}$ Instead of confronting those who challenged the rule of law, however, the government joined them. The government refused to carry out the indictment and employed a host of delaying tactics, challenging the indictment and not serving it due to medical reasons until April 2003, the same month in which Bobetko died. Through almost a year of attempting to avoid the application of the rule of law, the government demonstrated its inability and unwillingness to respect the rule of international law and it's own Constitutional Law on Co-operation with the ICTY. This stance was agreeable to the RCC. The Croatian Bishops, including Bozanić, in a joint

\footnotetext{
1123 Vezić, "Priests Flex"

${ }^{1124}$ Because of his position as the most senior military commander of the Croatian army, Bobetko was charged as having responsibility for the actions of the Croatian army, particularly in the Medak Pocket in September 1993, Graham Blewitt, "Prosecutor of the Tribunal against Janko Bobetko: Indictment, Case No. IT-02-62," International Criminal Tribunal for the Former Yugoslavia 23 Aug. 2002, 11 Nov. 2002 <http://www.un.org/icty/indictment/english/bob-ii020826>. Bobetko was a Partisan in WWII, chief of staff and deputy commander of the Yugoslav Peoplesi Army, 5th Military District (Slovenia and Croatia) from 1966-1971, and chief of staff of the Croatian army in November 1992 until his retirement July 1995.
} 
statement reiterated that they were "glad that the Croatian people once again stood united." 1125

As opposed to the 2001 indictments, which exposed a cleavage in Croatian society, the Bobetko Affair solidified a dangerous new consensus in Croatia, namely the fact that the rule of law did not apply equally to all. Protests against the ICTY indictments often hinged on arguments that Croatian forces were merely protecting their homeland and therefore could not be culpable of war crimes. Furthermore, indictments of Croats for crimes in the Homeland War were indictments of Croats and their effort to establish an independent state. Any patriotic Croatian would defend those who had defended the nation during the wars. This reiterated a sentiment popular during the Tudjman years, that Croats were victims defending their homeland and that international pressure to criminalize heroes, in fact threatens Croatian sovereignty. The fact that the RCC did not seek to counter such ideas and indeed had many members who supported the undermining of the establishment of the rule of law had a great influence on and reflected the influence of such ideologies.

The RCC often reiterates that it is committed to the sanctity of life, particularly in the fight against abortion, for example. However, in this case many clerics were able to vociferously justify and defend generals and other members of the military who forsook the sanctity of life. Instead, the RCC backed a bid by

1125 "Zagreb Archbishop Glad Croatian People Stand United," HRT 22 Aug. 2002, 9 Sept. 2002 <http://www.hrt.hr/vijesti>. 
indicted war criminals to evade justice. At the same time, the government, which took little action of its own to bring war criminals to justice and which blocked ICTY attempts to do so, has done a great disservice to the realization of the rule of law in Croatia. The fact that the RCC sided with anti-Hague activists and that the government refused to co-operate with the ICTY signal that the sanctity of human life was not taken seriously by the former and that the rule of law was not valued by the latter. 


\section{Appendix H: Interviews}

1. Interviews in Croatia May-June 2002

Baričević, Josip, Theological Faculty, University of Zagreb.

Čular, Goran, University of Zagreb, Faculty of Political Science, Zagreb.

Dubrović, Franjo, Secretary of the Committee for Relations with Religious

Communities, Zagreb.

Duvnjak, Neven, Ivo Pilar Institute for Social Sciences, Split.

Flego, Gvozden, Minister of Science and Technology, Republic of Croatia, Zagreb.

Gjenero, Davor, Journalist and Political Analyst, Zagreb.

Gruenfelder, Ana Maria, Theologian and Historian, Zagreb.

Malović, Stjepan, Vice Dean, University of Zagreb, Department of Political

Science, Zagreb.

Marinović-Bobinac, Ankica, Research Fellow, Institute for Social Research of Zagreb, Zagreb.

Padjen, Ivan, University of Zagreb, Faculty of Political Science, Zagreb.

Pleše, Mladen, Journalist, Nacional, Zagreb.

Radić, Jure, Deputy Prime Minister of Croatia, Zagreb.

Sanjek, Franjo, University of Zagreb, Catholic Faculty of Theology, Zagreb.

Simac, Nevan, Legal Expert, Split.

Tanjić, Željko, University of Zagreb, Catholic Faculty of Theology, Zagreb.

Tomčić, Zlatko, President of the Croatian Peasant's Party, Zagreb. 
Vrcan, Srđan, University of Split Law School, Dean Emeritus, Split.

Zorenić, Mišo, Member of the Presidency of the Croatian Peasants' Party, Zagreb.

Zrinščak, Siniša University of Zagreb, Faculty of Law, Zagreb.

2 Interviews Slovenia May-June 2002

Bizjak, Ivan, Minister of Justice, Republic of Slovenia, Ljubljana.

Cepar, Drago, Director, Office for Religious Communities, Government of Slovenia, Ljubljana.

Aleš, Črnič Research Fellow, University of Ljubljana, Faculty of Social Sciences, Ljubljana.

Dragoš, Srečo, University of Ljubljana, School of Social Work, Ljubljana

Fink-Hafner, Danica, Head of the Center for Politological Research, University of Ljubljana, Faculty of Social Sciences, Ljubljana.

Flere, Sergej, University of Maribor, Faculty of Education, Maribor.

Gaber, Slavko, Minister of Education, Republic of Slovenia, Ljubljana.

Gabrič, Aleš, Historian, Institute for Contemporary History, Ljubljana.

Gril, Janez, Director, Družina, Ljubljana

Ivelja, Ranka, Journalist, Dnevnik, Ljubljana

Jelinčič-Plemeniti, Zmago, President of the Slovenian National Party, Ljubljana.

Kerševan, Marko, University of Ljubljana, Faculty of Arts, Department of Sociology, Ljubljana. 
Kodelja, Zdenko, Head of the Center for the Philosophy of Education,

Educational Research Institute, Ljubljana.

Krivic, Matevž, lawyer and former Slovenian Constitutional Court judge, Ljubljana.

Mencinger, Jože, Rector, University of Ljubljana, Ljubljana.

Mlakar, Jože, Principal, Diocesan Classical Secondary School, Ljubljana-Sentvid.

Podobnik, Janez, Chariman of the parliamentary group of the Slovene People's

Party, Ljubljana.

Pogorelec, Janez, The Government Office for Legislation, Republic of Slovenia, Ljubljana.

Potrč, Miran, Head of the United List of Social Democrats, Ljubljana.

Repe, Božo, University of Ljubljana, Faculty of Arts, Department of History, Ljubljana.

Rizman, Rudolf M., University of Ljubljana, Faculty of Arts, Department of Sociology, Ljubljana.

Rode, Franc, Archbishop of Ljubljana and Metropolitan of Slovenia, Ljubljana.

Smrke, Marjan, University of Ljubljana, Faculty of Social Sciences, Center for Cultural and Religious Studies, Ljubljana.

Stres, Anton, Bishop of Maribor and President of the Committee for Justice and Peace, Slovenia, Maribor.

Štuhec, Ivan, University of Maribor, Department of Theology, Maribor. 
Tomc, Gregor, University of Ljubljana, Faculty of Social Sicences, Department of Sociology, Ljubljana.

Uhan, Samo, University of Ljubljana, Insitute for Public Opinian Resarch and Mass Communication, Ljubljana.

Vodopivec, Peter, Historian, Institute for Contemporary History, Ljubljana.

Zerdin, Ali, H., Journalist, Mladina, Ljubljana.

Zgaga, Pavel, Director, Center for Educational Policy Studies, University of Ljubljana, Faculty of Education, Ljubljana. 


\section{Works Consulted}

"Activity Rates and Employment and Unemployment Rates: Statistical Yearbook, 2001." Croatian Bureau of Statistics 6 Nov. 2002

$<$ http://www.dzs.hr/ljetopis2002>.

Alexander, Stella. Church and State in Yugoslavia since 1945. New York:

Cambridge University Press, 1979.

---. The Triple Myth: The Life of Archbishop Alojzije Stepinac. New York:

Columbia University Press, 1987.

Anderson, Benidict. Imagined Communities. London: Verso, 1983.

Anic, Alen. “Interview-Ivan Padjen.” Aim Press 1 Dec. 1995. 14 Jan. 2001 $<$ http://www.aimpress.org $>$.

---. "Polemics on the Role of the Catholic Church in Croatia." Aim Press 8 Apr. 1995. 14 Jan. $2001<\mathrm{http}: / /$ www.aimpress.org>.

---. "Social and Political Neo-Conservativism in Croatia." Aim Press 5 Mar. 1995. 14 Jan. $2001<\mathrm{http} / /$ www.aimpress.org $>$.

"The Archdiocese of Ljubljana," Slovenian Bishops' Conference 4 November 2003 $<$ http://www.rkc.si $>$.

Arato, Andrew, and Jean L. Cohen. Civil Society and Political Theory. Cambridge: MIT Press, 1992.

"Awards 1997: Viktor Ivančić." Committee to Protect Journalists. 15 Nov. 2002 $<$ http://www.cpj.org/awars97/Ivančić>

Bajruši, Robert. "Skandal oko Gradnje Islamskog Centra u Rijeci." Nacional 16 Oct. 2001. 19 Sept. $2002<$ http://www.nacional.hr>.

Balkovec, Bojan. Prva Slovenska Vlada 1918-1921. Ljubljana: Znanstveno in Publicistično Središče, 1992.

Ballinger, Pamela. History in Exile: Memory and Identity at the Borders of the Balkans. Princeton: Princeton University Press, 2003. 
Banac, Ivo. The National Question in Yugoslavia: Origins, History, Politics. Ithaca: Cornell University Press, 1984.

---. With Stalin against Tito: Cominformist Spoils in Yugoslav Communism. Ithaca: Cornell University Press, 1988.

Barker, Thomas M., and Andreas Moritsch. The Slovene Minority of Carinthia. New York: East European Monographs, Columbia University Press, 1984.

Barton, Allen H., Bogdan Denitch, and Charles Kadushin, eds. Opinion-Making Elites in Yugoslavia. New York: Praeger, 1973.

Baruch Wachtel, Andrew. Making a Nation, Breaking a Nation: Literature and Cultural Politics in Yugoslavia. Stanford: Stanford University Press, 1998.

Bašić Hrvatin, Sandra. "The Role of the Media in the Transition." Making a New Nation: The Formation of Slovenia. Eds. Danica Fink-Hafner and John R. Robbins. Brookfield: Dartmouth Publishing Company, 1997. 270-279.

Bavčar, Igor, and Janez Janša. Dnevnik in Spomini, 1972-1987. Ed. Stane Kavčič. Ljubljana: Časopis za Kritiko Znanosti, 1988.

---. Osem Let Potem. Klagenfurt: Celovac Založba, 1999.

---, eds. Punk Pod Slovenci. Ljubljana: Knjižnica Revolucionarne Teorije (KRT), 1985.

Bax, Mart. Medjugorje: Religion, Politics, and Violence in Rural Bosnia. Amsterdam: VU University Press, 1995.

"Beatification and Papal Visit, 10 September 1999." Roman Catholic Church Slovenia 5 Nov. $2002<$ http://www.rck.si/slomsek>.

Bebler, Anton. "Slovenia's Smooth Transition." Journal of Democracy 13.1 (2000): 127-140.

Belak-Krilc, Anita, Karmen Ban, Tanja Šimundić - Benčić, Andelka Kelava, and Božena Sviličić. "Shakespeare in Cyrillic." Slobodana Dalmacia 1999. 14 Oct. 1999 <http://www.cdsp.neu.edu/info/students/marko/slodal/slodal 12.html $>$. 
Bell, Daniel. The End of Ideology: On the Exhaustion of Political Ideas in the Fifties. Glencoe: Free Press, 1960.

Beloff, Nora. Tito's Flawed Legacy: Yugoslavia and the West, 1939-1984. London: V. Gollancz, 1985.

Benderly, Jill, and Evan Kraft, eds. Independent Slovenia: Origins, Movements, Prospects. New York: St. Martin's Press, 1994.

Benedik, Metod. Zgodovina Cerkve na Slovenskem. Celje: Mohorjeva Družba, 1991.

Benigar, Aleksa. Alojzije Stepinac, Hrvatski Kardinal. Rome: Ziral, 1974.

Bennett, Christopher. Yugoslavia's Bloody Collapse: Causes, Course and Consequences. New York: New York University Press, 1995.

Berend, Ivan T. Economic Development in East-Central Europe in the 19th and 20th Centuries. New York: Columbia University Press, 1974.

Bernik, Ivan, Brina Malnar, and Niko Toš. "Slovenian Political Culture: Paradoxes of Democratization." Fink-Hafner, Danica, and John R. Robbins, eds. Making a New Nation: The Formation of Slovenia. Brookfield: Dartmouth Publishing Company, 1997.

Beroš, Snježana. "Crkva na Državnom Troškovinku." Globus 23 Oct. 1998: 18.

Betz, Hans-Georg, and Stefan Immerfall. The New Politics of the Right: NeoPopulist Parties and Movements in Established Democracies. New York: St. Martin's Press, 1998.

Bibič, Adolf. "Politics: Power Struggle or Quest for the Common Good? Slovenian Public Opinion on Politics." Political Culture in East Central Europe. Eds. Fritz Plasser and Andreas Pribersky. Brookfield: Ashgate, 1996. 214-226.

Bieber, Florian. "Nationalist Mobilization and Stories of Serb Suffering. The Kosovo Myth from the 600th Anniversary to the Present." Rethinking History 6.1 (2002): 95-110.

"BiH Media Round-Up." Office of the High Representative 15 May 2002. 2 Nov. $2002<$ http://www.ohr.int/ohr-dept/presso/bh-media-rep>. 
Bilandžić, Dušan. Povijest Socijalističke Federativni Republike Jugoslavije. Zagreb: Školska Knjiga, 1979.

---. Hrvatska Moderna Povijest. Zagreb: Golden Marketing, 1999.

Biondich, Mark. Stjepan Radić, the Croat Peasant Party, and the Politics of Mass Mobilization, 1094-1928. Toronto: University of Toronto Press, 2000.

Blewitt, Graham. "Prosecutor of the Tribunal against Rahim Ademi: Second Amended Incitement, Case no IT-01-46-PT." International Criminal Tribunal for the Former-Yugoslavia in the Hague 1 Feb. 2002. 14 Sept. $2002<$ http://www.un.org/icty/incictment>.

Bognar, Ladislav. "Problems and Perspectives in the Development of Schooling in Croatia." Education and Media in South East Europe: Country Reports. Eds. Ulf Brunnbauer, Hannes Grandits, Siegfried Gruber, Karl Kaser, Robert Pichler, and Chistian Promitzer. Graz: Centre for the Study of Balkan Societies and Cultures at the Department for Southeast European History, University of Graz, 2000. 1-43.

Bokovoy, Mellisa K. Peasants and Communists: Politics and Ideology in the Yugoslav Countryside, 1941-1953. Pittsburgh: University of Pittsburgh Press, 1998.

Bokovoy, Melissa, K., Jill Irvine, and Carol Lilly, eds. State Society Relations in Yugoslavia 1945-1992. New York: St. Martin's Press, 1997.

Bonutti, Karl. "The Unratified Concordat between the Kingdom of Yugoslavia and the Holy See of 1935." State and Church: Selected Historical and Legal Issues, International Conference June 21-22. 2001. Eds. Alenka Šelih and Janko Pleterski. Ljubljana: Slovenska Akademija Znanosti in Umetnosti, 2002. 461-477.

Boyle, Kevin, and Juliet Sheen, eds. Freedom of Religion and Belief: A World Report. New York: Routledge, 1997.

Bozanić, Josip, and Nikola Eterović. Ugovori Izmedju Svete Stolice i Rpublike Hrvatske.

Zagreb: Glas Koncila, 2001.

Bozanić, Josip, and Borislav Skegro. "Sporazum o Nacinu Izvrsavanja Odredjenih Financijskih Obveza Republike Hrvatske Prema Katoličkoj Crvki." Ugovori 
Izmedju Svete Stolice i Republike Hrvatska. Ed. Nedjelko Pintarić.

Zagreb: Glas Koncila, 2001. 294-314.

Branko, Bjelajac. "Free Churches Unhappy over Government Agreements." Forum

18 News Service 1 May 2003. 22 Jul. $2003<$ http://www.hrwf.net>.

Bras-Car, Misela. "Education for All: The Year 2000 Assessment, National EFA Report: The Republic of Croatia." UNESCO 2000.

$<\mathrm{http}: / /$ www.2unesco.org $>$.

Broderik, Robert C., ed. Catholic Encyclopaedia: Revised and Updated Edition. Nashville: Thomas Nelson Publishers, 1986.

"Broken Promises: Impediments to Refugee Return to Croatia." Human Rights Watch Sept. 2003. 4 Mar. $2004<$ http://www.hrw.org>.

Brown, Louise. "German Recession Hits Catholic Church." Deutsche Welle 11 Nov. 2002. 12 Nov. $2002<$ http://www.dw-world.de>.

Buljan, Ivica H. "Crkva je Vlastnik Četvrtine Zagreba." Feral Tribune 27 Feb. 1995: 14.

---. "A Human and Women's Rights Lawyer from Zagreb." Interview with Dafinka Vecerina. Feral Tribune 1 Aug. 1996. 20 Nov. 2002 <http:/www.cdsp.neu.edu/ info/students/marko/feral/feral17>.

Bunce, Valerie. Do New Leaders Make a Difference? Executive Succession and Public Policy under Capitalism and Socialism. Princeton: Princeton University Press, 1981.

---. “Should Transitologists be Grounded?" Slavic Review. 54.1 (1995): 965-987.

---. Subversive Institutions: The Design and the Destruction of Socialism and the State. New York: Cambridge University Press, 1999.

---. "The Yugoslav Experience in Comparative Perspective." State Society Relations in Yugoslavia 1945-1992. Eds. Jill Irvine, Mellisa Bokovoy and Carol Lilly. New York: St. Martin's Press, 1997. 345-366.

Bundy, Frank. Administration of the Illyrian Provinces of the French Empire 18091813. London: Taylor and Francis Inc., 1987. 
Burdick, Michael A. For God and Fatherland: Religion and Politics in Argentina. Albany: State University of New York Press, 1995.

Burg, Steven L. Conflict and Cohesion in Socialist Yugoslavia. Princeton: Princeton University Press, 1983.

Butković, Davor. "Dio Crkve u Hrvatskoj Razočaran je Četvrtim Ugovorom Vatikanom." Jutarnji List 5 Feb. 1999: 6.

---. "Predsjednik Franjo Tuđman Tajnim je Pismom Naredio Zastupnicima HDZ-a da Izglasaju Zakon o Denacionalizaciji Kojim su Tesko Osteceni Crkva i 250 Thousand Gradjana!" Globus 18 Oct. 1996: 10.

Butterfield, Jim and Weigle, Marcia. "Civil Society in Reforming Communist Regimes: The Logic of Emergence." Comparative Politics 25.1 (1992): 123.

Carlton, Eric. The Few and the Many: a Typology of Elites. Brookfield: Ashgate Publishing Co., 1996.

Carter, April. Democratic Reform in Yugoslavia: The Changing Role of the Party. Princeton: Princeton University Press, 1982.

The Catholic Church. Code of Canon Law: A Text and Commentary. New York: Paulist Press, 1985.

"Census 2001." Republic of Croatia, Central Bureau of Statistics. 17 September 2003

$<$ http://www.dzs.hr/Eng/Census/ census2001>, 2001.

Cerjan-Letica, Gordana. "Jesu li Hrvatski Biskupi Politički Ucijenili HDZ?" $\underline{\text { Jutarnji List }}$

10 Feb. 1999: 11.

Chirot, Daniel, ed. The Origins of Backwardness in Eastern Europe. Berkley: University of California Press, 1989.

Cholij, Roman. "Priestly Celibacy in Patristics and in the History of the Church." Vatican 1993. 28 Mar. $2003<$ http://www.vatican.va>. 
Chrostowski, Waldemar. "Poland: Pluralism after the Experience of the Desert: A Roman Catholic Perspective." 1999. 15 Feb. 2001

$<$ http://www.cis.articles/ chrostow.bud $>$.

"Church Statistics 1995: General Data From all Dioceses in Croatia." Croatian Bishops' Conference 1995. 9 Apr. $2001<$ http://www.hbk.hr/stat/1995>.

"Church Statistics 2000: General Data From all Dioceses in Croatia." Croatian Bishops' Conference 2000. 9 Apr. $2001<$ http://www.hbk.hr/stat/2000>.

Ćimić, Esad. "Graniće Pravne Regulative-Graniće (Ne) Slobode." Crkva i Država u Društvima u Tranziciji. Ed. Ivan Grubšić. Split: Nkjižnica Dijalog, 1997. 223-226.

"Clock Starts Running on 1st of August for Croatian Governments Action on Property Repossession." Organization for Security and Cooperation in Europe 1 Aug. 2002. 20 Dec. $2002<$ http://www.osece.org>.

Cohen, Leonard J. Broken Bonds: Yugoslavia's Disintegration and Balkan Politics in Transition. Boulder: Westview Press, 1995.

-.-. "Democratic Governance in the Yugoslav Successor States." Southeastern Europe Moving Forward: Canadian Forum on Southeastern Europe (CFSEE), Ottawa, Carleton University, 23-24 January 2003 1-25.

---. "Embattled Democracy: Postcommunist Croatia in Transition." The Consolidation of Democracy in East-Central Europe. New York: Cambridge University Press, 1997. 69-129.

---. "Embracing Democracy: Weak States and Institution-Building in "Balkan Europe." Southeastern Europe Moving Forward: Canadian Forum on Southeastern Europe (CFSEE), Ottawa, Carleton University, 23-24 January 2003. 1-12.

--. Serpent in the Bosom: The Rise and Fall of Slobodan Milosevic. Bourlder: Westview Press, 2000.

--- The Socialist Pyramid: Elites and Power in Yugoslavia. Oakville: Mosaic Press, 1989.

Cohen, Shari. Politics Without a Past: The Absence of History in Post-Communist Nationalism. Durham: Duke University Press, 1999. 
Čokl, Vanessa. "Ucitelj Ne More Pridobivati Vernikov, Duhovnik Pac." Vecer 20 Feb.

1999: 15.

Coleman, John, and Miklos Tomka, eds. Religion and Nationalism. London: Concilium 1995/1996.

"Commentary." Dnevnik 18 Mar. 2000. 20 Jan. $2001<$ http://www.dnevnik.si>.

Commission of the European Communities. Croatia: Opinion on the Application of Croatia for Membership of the European Union. Brussels: European Commission, 2004.

"Committee on Economic, Social and Cultural Rights Concludes Review of Initial Report of Croatia." United Nations: Committee on Economic, Social and Cultural Rights 20 Nov. 2001. 6 Nov. 2002 $<$ http://www.unhchr.ch/hurricane/huricane.nsf/0/ 96415CF30899493DC1256B0S005C8B1>.

"Constitution Watch." East European Constitutional Review Autumn 2001. 9 Sept. $2001<$ http://www.eecr.org>.

"Constitutional Watch: Croatia." East European Constitutional Review Winter/Spring 2000. 6 Sept. 2002 $<$ http://www.law.nyu.edu/eecr/vol9num_onehalf/ consitutionwatch/croatia>.

Cooper, Henry R. France Prešeren. Boston: Twayne Publishers, 1981.

Cornwell, John. Hitler's Pope: The Secret History of Pius XII. New York: Viking, 1999.

"The Corruption Perceptions Index 2001." Transparency International 27 June 2001. 24 Feb. $2003<\mathrm{http}: / /$ www.transparenc.org/cpi/201>.

Cotta, Jean, and Maurizio Blondel, eds. Party and Government: An Inquiry into the Relationship between Governments and Supporting Parties in Liberal Democracies. Oxford: Oxford University Press, 1996. 
Council of Europe. "Croatia: Demographic and Ethnic Structure of Population, 1999." Human Rights. 10 Jan. 2001

$<$ http://www.humanrights.coe.int/minorities/1999/ croatia>.

---. "European Convention on Human Rights and Fundamental Freedoms." Treaty Office 3 Sept. 1950, 17 Apr. $2000<$ http://www.conventions.coe.int $>$.

---. "Religion and Democracy: Council of Europe Parliamentary Assembly." Official Gazette of the Council of Europe 27 Jan. 1999. 21 June 2001 $<$ http://www.assembly.coe.int/documents/adoptedtext/ta99/erec1396>.

---. "Report Submitted by Croatia," Human Rights 1999. 10 Jan. 2001 $<$ http:/www.humanrights.coe.int/Minorities/statereports/1999/croatia>.

Council of Europe, Advisory Committee on the Framework Convention for the Protection of National Minorities. "Report Submitted by the Republic of Austria, Pursuant to Article 25, Paragraph 1 of the Framework Convention for the Protection of National Minorities." Human Rights Internet 15 Nov. 2000. 29 Oct. 2002 $<$ http:/www.hri.ca/fortherecord2000/doucmentation/fcpnm-austria $>$.

"Country Reports on Human Rights Practices: Croatia." U.S. Department of State, Bureau of Democracy, Human Rights and Labour 2 Mar. 2002. 4 Jan. 2003 $<$ http://www.state.gov>.

“Croatia: Background Report, 1999.” Human Rights Watch 11 Dec. 2002 $<$ http://www.hrw.org/reports/ 1999/croatia>.

"Croatia: Constitution, Government and Legislation." Jurist 2003. 20 Feb. 2003 $<$ http://www.jurist.law.pitt.edu>.

"Croatia Drops Plan for Yoga in Schools after Church Objects." Agence FrancePresse 17 Jul. 2003. 20 Jul. $2003<$ http://www.clarinet.com>.

“Croatia: Human Rights Developments." Human Rights Watch 1997. 11 Dec. 2002 <http://www.hrw.org/reports/1997/WR97>.

"Croatia: Impunity for Killings after Storm." Amnesty International 1 Aug. 1998. <web.amnesty.org/library/Index/ENGEUR640041998?open\&of=ENGHRV $>$. 
"Croatia: Official Census Results Made Public." OSCE May 2002. 3 Nov. 2002 $<$ http://www.osce.org/croatia $>$.

"Croatia: Recent Political Developments." Australian Department of Foreign Affairs and Trade May 2003. 20 May $2003<\mathrm{http}: / /$ www.adfat.geo/croatia $>$.

"Croatia Returns Update." Human Rights Watch 13 May 2004. 22 June 2004 $<$ http://www.hrw.org $>$.

"Croatia Statistics, 2002." International Monetary Fund 20 Dec. 2002 $<$ http://www.imf.org/country/hrvcats $>$.

"Croatia: Status Report No. 11." OSCE 18 Nov. 2002. 15 Feb. 2003 $<$ http://www.osce.org/reports/croatia/2002>.

"Croatia's Democracy Deficit: A Pre-Electoral Assessment." Human Rights Watch 1999. 22 Mar. $2003<$ http://www.hrw.org>.

"Croatian Archbishop Slams Increasing Split between Rich, Poor." Catholic World News 17 Dec. 1997. 19 Dec. 2002 $<$ http://www.cwnews.com/1997/126538>.

“Croatian Bishops Issue Statement." HRT 23 Oct. 2002. 28 Nov. 2002 $<$ http://www.hrt.hr/vijesti/archiv/2002/10/24>.

"Croatian Economic Outlook Quarterly." Institute of Economics Zagreb (EIZ) Oct. 2003. 29 Feb. $2004<$ http://www.eizg.hr>.

"Croatian Education Ministry Cancels Yoga." The Times of India 17 Jul. 2003. 20 Jul. $2003<$ http://www.timesofindia.indiatimes.com>.

"Croats Vote for Change." BBC News 25 Jan. 2000. 17 Sept. 2002 $<$ http://www.bbc.co.uk/1/hi/world $>$.

Crnica, Slavica. "Cerkvi Je Mogoče Vrniti Le Bremen Prosto Premoženje." Delo 28 July 2000: 22 .

Crnjaković, Aleksa. "Crkvi Se Vraca posjed u Djakovu, a Za Zagrebački Stambeni Block 'Vatikan' ce Biti Obeštećena." Vjesnik 18 July 1998: 183.

Crnobrnja, Mihailo. The Yugoslav Drama. Montréal McGill-Queen's University Press, 1994. 
Cruz, Consuelo. "Identity and Persuasion How Nations Remember Their Pasts and Make Their Futures." World Politics 52 (2000): 275-312.

Čular, Goran, and Nebojša Blanduša. "Prilozi.” Hrvatska Politika 1990-2000. Ed. Mirjana Kaapović. Zagreb: Biblioteka Politička Misao, 2001. 254-366.

Čulić, Marinko. “Bishops Marching.” Feral Tribune 30 Sept. 2000. $<$ http://www.feral.hr>.

--.. "Bones in the Mixer." Feral Tribune 29 Apr. 1996. 5 Feb. 2002 $<$ http://www.feral.hr>.

---. "By Intimidation and Bribery to Constitutional Amendments." Aim Press 14 Dec. 1997. date accessed <http://www.aimpress.org >.

---. "The Pope for the Second Time among the Croats." Aim Zagreb 4 Oct. 1998. $<\mathrm{http}: / /$ www.aimpress.org $>$.

Cvirn, Janez. "Evropska Razsežnost Celjskega Gimnazijskega Vprašanja." Slovenci v Evropi (O Nekaterih Vidikih Slovenske Povezanosti s Sosedi in Evropo). Ed. Peter Vodopivec. Ljubljana: Historia 5 Znanstvena Zbirka Oddelka za Zgodovino Filozofske Fakultete Univerze v Ljubljani, 2002. 3543.

Dahl, Robert. Modern Political Analysis. Englewood Cliffs: Prentice Hall, 1970.

---. Polyarchy: Participation and Opposition. New Haven: Yale University Press, 1971.

Daskalović, Zoran. "Vatikanski Zavjera." Feral Tribune 10 Feb. 1997: 3.

Davies, Norman. Europe: A History. New York: Oxford University Press, 1996.

Dawisha, Karen, and Bruce Parrot, eds. The Consolidation of Democracy in EastCentral Europe. New York: Cambridge University Press, 1997.

"Dayton Peace Accords." University of Minnesota Human Rights Library 21 Nov. 1995. 5 Oct. $2002<$ http://www1.umn.edu/humanrts/ peace/docs/daytonaccord $>$. 
Deakin, Fredrick William. The Embattled Mountain. New York: Oxford University Press, 1971.

Dedijer, Vladimir. Tito Speaks: His Self Portrait and Struggles with Stalin. London: Weidenfeld and Nicholson, 1953.

Dejan, Djokić, ed. Yugoslavism: Histories of a Failed 1918-1992. London: Hurst and Company, 2003.

DelPonte, Carla. "The Prosecutor of the Tribunal against Ante Gotovina: Indictment, Case No IT-01-45-I. ICTY." International Criminal Tribunal for the Former Yugoslavia in the Hague 21 May 2001. 15 Sept. 2002 $<$ http://www.un.org./icty/ indictment/english/got-ii01608>.

---. "The Prosecutor of the Tribunal against Janko Bobetko: Indictment, Case No. IT-02-62." International Criminal Tribunal for the Former-Yugoslavia in the Hague 23 Aug. 2002. 11 Nov. 2002 $<\mathrm{http}: / /$ www.un.org/icty/indictment/english/bob-ii020826>.

---. "Prosecutor of the Tribunal against Rahim Ademi: Second Amended Incitement, Case No. IT-01-46-PT." International Criminal Tribunal for the Former Yugoslavia in the Hague 1 Feb. 2002. 14 Sept. 2002 $<$ http://www.un.org/icty/ indictment $>$.

"Demographic Year Book: Social Cohesion and Quality of Life, Croatia." Council of Europe 20 December 2001.<http://www.coe.int/t/e/social_cohesion/population/ democraphic_year_book/2001_edition/Cro>.

Denitch, Bogdan. The Legitimation of a Revolution: The Yugoslav Case. New Haven: Yale University Press, 1976.

DeTocqueville, Alexis. Democracy in America, Volume I. New York: A. A. Knopf, 1949.

Diamond, Larry J., and Marc F. Plattner. Developing Democracy: Towards Consolidation. Baltimore: Johns Hopkins University Press, 1999.

---, eds. The Global Resurgence of Democracy. Baltimore: Johns Hopkins University Press, 1993. 
Dikić, Ivica. "Croatian Fascism: Victims of Our-ism." Feral Tribune 17 May 1999. 17 Feb. $2001<$ http://www.feral.hr >.

DiMaggio, Paul, and Walter W. Powell. Introduction. The New Institutionalism in Organizational Analysis. By DiMaggio and Powell, eds. Chicago: University of Chicago Press, 1991. 1-38.

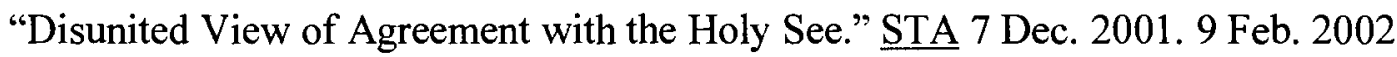
$<$ http://www.sta.si>.

Divjak, Milan. Šola-Morala-Cerkev na Slovenskem. Ljubljana: Enotnost, 1995.

Djilas, Aleksa. The Contested Country: Yugoslav Unity and Communist Revolution 1919-1953. Cambridge: Harvard University Press, 1991.

Djilas, Milivoj. The Air Only for HDZ. Zagreb: Aim Press, 1997.

Djilas, Milovan. Tito the Story from Inside. Trans. Vasilije Kojić and Richard Hayes. New York: Harcourt Brace, 1980.

---. Wartime. New York: Harcourt Brace, 1977.

Djokić, Dejan, ed. Yugoslavism Histories of a Failed Idea 1918-1992. London: Hurst \& Co, 2003.

Djordjević, Dimitrije, ed. The Creation of Yugoslavia, 1914-1918. Santa Barbara: Clio Books, 1980.

---. "The Yugoslav Phenomena." The Columbia History of Eastern Europe in the Twentieth Century. Ed. Joseph Held. New York: Columbia University Press, 1992. 254-268.

Djordjević, Mirko. "How Strong are the Catholic Church in Croatia and the Orthodox Church in Serbia: Part II." Radio Free Europe/Radio Liberty 31 Jan. 2002. 8 Nov. $2002<$ http://www.rferl.org>.

Dogan, Mattei, and John Higley, eds. Elites, Crises, and the Origins of Regimes. Lanham: Rowman and Littlefield Publishers, 1998.

Dolčič, Tone. "Pravno Mnenje G. Krivica v Zvezi s Sporazumom med Republiko Slovenijo in Svetim Sedežem o Pravnih Vprašanjih." Vlada Republike Slovenije, Služba za Zakonodajo 21.9 (1999). 
Dolenc, Ervin. “"The Generation at a Closed Door': Slovenian Intellectual Issues between the Two World Wars." Slovene Studies 23.1 (2001): 15-16.

Dolinar, Franc, Joza Mahnic, and Peter Vovopivec, eds. Cerkev, Kultura in Politica. Ljbulana: Slovenska Matica, 1993.

Dolinar, France M. "Jožefinizem in Janzenizem." Zgodovina Cerkve na

Slovenskem. Ed.

Metod Benedik. Celje: Mohorjeva Duzba, 1991. 152-162.

---. "Katoliška Cerkev v Sloveniji po Drugi Svetoini Vojni." Temna Stran Meseca : Kratka Zgodovina Totalitarizma v Sloveniji, 1945-1990. Ed. Drago Jančar. Ljubljana: Nova Revija, 1998. 75-87.

Douglass, Bruce R., and David Hollenbach. Catholicism and Liberalism. New York: Cambridge University Press, 1994.

"Dr. Franjo Tudjman—Historian and Statesman." HRT 13 Dec. 1999 $<$ http://www.hrt.org $>$.

Dragojević, Rade. "Croats Can Forget about their Sovereignty." Interview with Boris

Buden. Novi List 4 June 2002. 7 Oct. 2002

$<$ http://www.cdsp.neu/du/info/stuents/ marko/novi/novilist $4>$.

Dragoš, Srečo. Katoličizem na Slovenskem: Socialni Koncepti do Druge Svetovne Vojne. Ljubljana: Morherjeva Družba, 1998.

“Državna Ureditev Republike Slovenija." Uradne List 28 Sept. 1990. 11 Mar. 2002 $<$ http://www.zakonodaja.gov.si $>$.

Dujmović, Kresimir. "Izgon Boga is školskog Imenik." Vjestnik 15 (2000): 17-19.

Dukic, S, D. Sarac, G. Jelavić, Z. Juras, M. Ljubić, A. Dragicević, J. Celar, D. Mezić, and

T. Kolumbić. "Msgr. Juraj Jezerinac-They are Trying to Behead Us with Indictments." Slobodna Dalmacija 6 Aug. 2001. 20 Dec. 2002 $<$ http://www.cesp.neu.ed $>$.

Duricic, Vuk. Interview with Don Anto Baković. Nedjeljna Dalmacija 8 Oct. 1999. 
Jan. $2001<$ http://www.cdsp.neu.edu/info/students/marko/slodal/slodal11>.

Duvnjak, Neven. "Muslim Community in the Republic of Croatia." Religion in Eastern Europe 19.3 (1999): 1-17.

Dye, Thomas R., and Harmon Zeigler. The Irony of Democracy. Belmont:

Duxbury Press, 1972.

"EC Justice and Home Affairs Team Visits Croatia." OSCE July 2002. 15 Feb. $2003<\mathrm{http}: / /$ www.osce.org/news $>$.

"Editorial Comment." Slobodna Dalmacija 3 Mar. 2000. 8 Apr. 2003 $<$ http://www.slobodnadalmacija.hr>.

"Elections for Deputies to the National Assembly." Republic of Slovenia 15 Oct. 2000. 27 Mar. $2002<$ http://www.gov.si $>$.

"Employment and Unemployment in Croatia." Hrvatski Zavod za Zapošljavanje 3 Aug. 2003. 28 Nov. $2003<$ http://www.hzz.hr>.

Enyedi, Zsolt. "Conclusion: Emerging Issues in the Study of Church-State Relations." Church and State in Contemporary Europe: The Chimera of Neutrality. Eds. John T. S. Madeley and Zsolt Enyedi. London: Frank Cass, 2003. 218-232.

Erceg, Heni. "Glede \& Unatoč: Budisa." Feral Tribune 20 May 2000. 9 Nov. 2002 $<$ http://www.feral.hr>.

Erceg, Heni. "Kaptolska Bozicnica" Feral Tribune 21 Dec. 1998, 12.

---. "Mijeh Struktura," Feral Tribune 21 Dec. 1998: 7.

Erceg, Ivana. "Minorities in Post-HDZ Croatia." Aim Press 5 Mar. 2001. 22 Feb. $2002<\mathrm{http}: / /$ www.aimpress.org $>$.

Eterović, Nikola. "Komentar Ugovora Izmedju Svete Stolice i Republike Hrvatske." Ugovori Izmedju Svete Stolice i Republike Hrvatske, ed. Nedjelko Pintarić. Zagreb: Glas Koncila, 2001. 129-354.

---, ed. Ugovori Izmedju Svete Stolice i Republike Hrvatske, ed. Nedjelko Pintarić. Zagreb: Glas Koncila, 2001. 
Etzioni-Halevy, Eva. The Elite Connection: Problems and Potential of Western Democracy. Cambridge: Polity Press, 1993.

"European Convention on Human Rights and Fundamental Freedoms, 1950." Council of Europe <http:///www.conventions.coe.int/treaty/ en/cadrelisttraites.html $>$.

Evans, Peter B., Dietrich Rueschemeyer, and Theda Skocpol. Bringing the State Back In. New York: Cambridge University Press, 1985.

Felak, James R., and Herbert J. Ellison, eds. Nations and Nationalisms in EastCentral Europe, 1806-1948: A Fetschrift for Peter F. Sugar. Bloomington: Slavica, 2002.

Feral Tribune, editorial, 2 Sept. 2000: 781.

Fidermuc, Katarina. "Za Zdaj Še Brez Cerkvenega Davka." Delo 6 Aug. 2001: 7.

Fink-Hafner, Danica. Nova Družbena Gibanja: Subjeckti Politične Inovacije. Ljubljana: Znanstvena Knjižnica, Faculteta za Družbene Vede, 1992.

---, ed. Volitve 2000: Volilni Programi Političnih Strank. Ljubljana: FDV-IDV Center za Politoloske Raziskave, 2000.

Fink-Hafner, Danica, and Terry Cox, eds. Into Europe? Perspectives from Britain and Slovenia. Ljubljana: Scientific Library of the Faculty of Social Sciences, 1996.

Fink-Hafner, Danica, and John R. Robbins, eds. Making a New Nation: The Formation of Slovenia. Brookfield: Dartmouth Publishing Company, 1997.

Flere, Sergej. "The Impact of Religiosity upon Political Stands: Survey Findings From

Seven Central European Countries." East European Quarterly 35.2 (2001): 183-200.

Flere, Sergej, and Marko Kerševan. Religija in (Sodobna) Družba: Znanstveno in Publicistčno Središće. Ljubljana: Faculteta za Družbene Vede, 1995. 
Fowler, Robert Booth. Religion and Politics in America: Faith. Culture, and Strategic Choices. Boulder: Westview, 1995.

"Freedom in the World 2000-2001: Combined Average Freedom Rating and GDP per Capita." Freedom House 18 Feb. 2003 $<$ http://www.freedomhouse.org/research/ freeworld/2001/gdp.pdf $>$.

"Freedom in the World, Croatia." Freedom House 31 Oct. 2003. 28 Nov. 2004 $<$ http://www.freedomhouse.org $>$.

Fukuyama, Francis. The End of History and the Last Man. New York: Free Press, 1992.

Gabrič, Aleš. "Cultural Activities as Political Action." The Repluralization of Slovenia in the 1980s: New Revelations from Archival Records. Eds. Leopoldina Plut-Pregelj, Aleš Gabrič and Božo Repe. Seattle: The Donald W. Treadgold Papers, the Henry M. Jackson School of International Studies, University of Washington, 2001. 25-59.

---. Slovenska Agitpropovska Kulturna Politika 1945-1952. Ljubljana: Borec, 1991.

Gabrić, Toni. "Bog i Hrvati D. D." Feral Tribune 2 Dec. 1998: 20-23.

Gabrscek, Sergij, and Neli Dimc, eds. Strategies of Educational Reform in South East Europe Countries: Proceedings of the Seminar Beld Slovenia June 810,2000. Ljubljana: Open Society Institute, 2000.

Gall, Zlatko. "Pitt-Bull in Court." Vijenac 5 June1997. 11 Sept. 2002. $<$ http://www.cdsp.neu.edu/info/students/marko/vijenac/vijenac6.html $>$.

Gams, Ivan. "The Republic of Slovenia-Geographical Constants of the New Central-European State." Nationalities Papers 21.1 (1993): 15-30.

Garton-Ash, Timothy. "Eastern Europe: The Year of Truth." The New York Review of Books, 37, 2 (1990): 22-23.

Gavrovic, Milan. "Bribe and Rule." Feral Tribune 29 Nov. 1999. 12 Nov. 2002 $<$ http://www.cdsp.neu.edu/info/students/marko/feral/feral94>.

Gazi, Stephen. A History of Croatia. New York: Philosophical Library, 1973.

Gellner, Ernest. Nations and Nationalism. Ithaca: Cornell University Press, 1983. 
Gerjolj, Stanko. "Modes of Religious Education in Slovenia." Religion and Nationalism. Eds. Miklos Tomka and John Coleman. London: Concilium, 1995/1996.82-89.

Gill, Graeme J. The Dynamics of Democratization: Elites, Civil Society and the Transition Process. New York: St. Martin's Press, 2000.

Girard, Michel. "Two Dilemmas of Liberalism: Historical Exhaustion and Internal Division in a World of Globalization." The Meaning of Liberalism - East and West. Eds. Zdenek Suda and Jiri Musil. New York: Central European University Press, 2000. 195-229.

Giugni, Marco, Doug McAdam, and Charles Tilly, eds. From Contention to Democracy. Lanham: Rowman and Littlefield Publishers, 1998.

Gjenero, Davor. "Jos Jedan Oblik Ideje Izolacionizma." Novi List 10 Feb. 1997: 5.

Glas Koncila. “Jesu Li Vjerski Vodje Izgubili Autoritet?” 2 Feb. 2002: 4.

Glen, Charles Leslie. The Ambiguous Embrace: Government and Faith-Based

Schools and Social Agencies. Princeton: Princeton University Press, 2000.

Glenny, Misa. The Fall of Yugoslavia: The Third Balkan War. Toronto: Penguin Books, 1992.

Gligorov, Vladimir. "The Discovery of Liberalism in Yugoslavia." East European Politics and Societies 5.1 (1991): 5-25.

Godeč, Željka "Monument in Slunj: Provocation or Manipulation?" Nacional 15 June 2000. 15 Apr. $2003<$ http://www.nacional.hr>.

Goldstein, Ivo. Croatia: A History. Montreal: McGill-Queen's University Press, 1999.

Govorchin, Gerald Gilbert. "Pravastvo and the Croatian National Issue." East European Quarterly 12.1 (1978): 57-67.

Gow, James. Legitimacy and the Military: The Yugoslav Crisis. New York: St. Martin's Press, 1997. 
---. Triumph of the Lack of Will: International Diplomacy and the Yugoslav War. New York: Columbia University Press, 1997.

Gow, James, and Cathie Carmichael. Slovenia and the Slovenes. Bloomington: Indiana State Press, 2000.

Grafenauer, Niko, ed. The Case of Slovenia. Ljubljana: Nova Revija, 1991.

Grafenenauer, Bogo. "Polemika z Ustavnim Sodiščem." Mladina 23 Oct. 1997: 8.

Grah, Matija. “Cerkev Se Bo Morala Pogajat.” Mladina 21 Oct. 1997: 21.

--.. "Marko Kerševan, v Strahu je Tudi Džava." Delo 27 Nov. 1999: 15.

Grakalić, Dubravko. "Hrvatski Politički Vrh Pravnim Smicalicama Prvo Namiruje Sebe!" Globus 28 June 1996: 51-52.

Grce, Mirjana. "Hrvatska Lake Ruke, Slovenija Rezervirana." Novi List 8 Jan. 2002: 9-10.

---. “Hrvatska Izmedju Europskih Modela,” Novi List 20 Sept. 1998: 18.

---. "Prednost Naturalnom Povratu Oduzete Imovine." Novi List 20 Feb. 1999: 2122.

Grce, Mirjana, Igor Vukić, and Suad Ahmetovic. "Povrat Nadoknadaja I Zamjenen Imovine." Novi List 21 Oct. 1998: 18-19.

Greenberg, Robert D. "The Politics of Dialects among Serbs, Croats, and Muslims in the Former Yugoslavia." East European Politics and Societies 10.3 (1996): 393-415.

Griesser-Pečar, Tamara. "Procesi Proti Duhovnikom in Redovništvu po Maju 1945." Temna Stan Meseca: Kratka Zgodovina Totalitarizma v Sloveniji 1945-1990. Ed. Drago Jančar. Ljubljana: Nova Revija, 1991. 113-126.

Gril, Janez. “Za Šolo po Evropskih Merah.” Družina 5.10 (1997): 3.

Janez Gril, "Speeding up the Denationalisation Process," Slovenia Weekly 8 Jan. $2001<\mathrm{http}: / / \mathrm{www}$. sloveniaweekly/vitrum.com> 
Grizold, Aanton. "The Defence of Slovenia." Making a New Nation: The Formation of Slovenia. Eds. Danica Fink-Hafner and John R. Robbins. Dartmouth: Dartmouth Publishing Co., 1997. 46-56.

Gross, Mirjana. Počeci Moderne Hrvatske: Neoapsolutizam u Civilnoj Hrvatskoj i Slavoniji, 1850-1860. Zagreb: Globus, 1985.

---. Povijest Pravaške Ideologije. Zagreb: Institut za Hrvatsku Povijest, 1973.

Group of Citizens. "Stanovi su se Morali Prodavati ili Nikome ili Svima." Novi List 7 April, 1996: 24.

Grubišić, Ivan. "Katoličizam i Postkomunizam u Hrvatskoj." Crkva i Država u Društvima u Tranziciji. Ed. Ivan Grubišič. Split: Knjižnica Dijalog, 1997. 158-195.

---. Religija i Sloboda: Religijska Situacija u Hrvatskoj 1945-1990. Split: Knjižnica Dijalog1993.

---. "Vjeronauk Smo Kompromitirali-Pretvorili u Predmet." Čovjek Nadasve. Split: Knjižnica Dijalog, 2001. 257-265.

-.-. "Zagubljeno Kršćanstvo." Čovjek Nadasve. Split: Knjižnica Dijalog, 2001. 9193.

Gruenfelder, Anna Maria. "The Catholic Church among Croats: A Change of Paradigm?" Central Europe Review 15 May 2000. 2 Oct. 2002 $<$ http://www.ce-review.org/ 00/19/gruenfelder19>.

--.. "Isprazne Muske Tlapnje o Zastiti Nerodne Djece." Slobodna Dalmacija 26 Sept. 1997: 11.

Guldescu, Stanko. The Croatian-Slavonian Kingdom, 1526-1792. The Hague: Mouton, 1970.

---. A History of Medieval Croatia. The Hague: Mouton \& Co, 1964.

Habermas, Jurgen. Legitimation Crisis. Trans. Thomas McCarthy. Boston: Beacon Press, 1975.

Hafner, Fink Mitja. "Social Structure and Cleavages Changing Patterns." Making a New Nation: The Formation of Slovenia. Eds. Danica Fink-Hafner and John R. Robbins. Dartmouth: Dartmouth Publishing Co., 1997. 254-267. 
"A Half-Hearted Welcome: Refugee Returns to Croatia." International Crisis Group 13 Dec. 2002. 22 Apr. $2003<$ http://www.icg.org>.

Hall, Peter A., and Rosemary C. R. Taylor. "Political Science and the Three New Institutionalisms." Political Studies 6 (1996): 936-957.

---. "The Potential of Historical Institutionalism: A Response to Hay and Wincott." Political Studies 46 (1998): 958-962.

Hanson, Eric O. The Catholic Church in World Politics. Princeton: Princeton University Press, 1987.

Hanžek, Matjaž. "Reply to Open Letter form the Justice and Peace Committee at the Slovene Bishop's Conference (SSK)." Human Rights Ombudsman of Slovenia 1 September $2003<\mathrm{http} / / /$ www.varuh-rs.si>.

Harriman, Helga H. "Slovenia as an Outpost of the Third Reich." East European Quarterly 5.2 (1971): 222-231.

Harris, Erica. Nationalism and Democratization: Politics of Slovakia and Slovenia. Burlington: Ashgate, 2002.

Hastings, Adrian. The Construction of Nationhood: Ethnicity, Religion, and Nationalism. New York: Cambridge University Press, 1997.

Hay, Colin, and Daniel Wincott. "Structure, Agency and Historical Institutionalism." Political Studies 46 (1998): 951-957.

Haynes, Jeffrey. Religion in Global Politics. London: Longman, 1998.

Hedl, Dragutin. "Clerics Attack Government." Balkan Crisis Report, Institute for War and Peace Reporting 2 Nov. 2001. 2 Feb. 2002 $<$ http://www.balkanpeace.org/rs/ archivenov01>.

---. "Dubious Business Deals of the Catholic Church." Aim Press 12 May 2001. 24 Sept. $2002<\mathrm{http}: / /$ www.aimpress.org $>$.

---. "Fokus Pocus." Trans. Marko Kocic. Feral Tribune 19 May 2001. 2 Oct. 2001 $<$ http://www.www.feral.hr>.

---. Models of Democracy. Cambridge: Polity Press, 1987. 
---. "Tapes Nail Tudjman Cronies." Institute for War and Peace Reporting 9 Apr. 2000. 7 July $2001<$ http://www.iwpr.net>.

---. "Zagreb Pushes Through Media Reforms." Institute for War and Peace Reporting 7 Mar. $2001<\mathrm{http} / /$ www.iwpr.net>.

Held, Joseph, ed. The Columbia History of Eastern Europe in the Twentieth Century. New York: Columbia University Press, 1992.

HINA (Croatian Press Agency). "Biography of Cardinal Alojzije Stepinac." Papa 30 Sept. 1998. 18 Nov. $2002<$ http://www.papa.hr/mvijesti/10>.

--.. "Mesić Receives Einaudi Ten Years after Croatia's Recognition." Embassy of the Republic of Croatia in the U.S. 14 Jan. 2001. 8 Aug. 2002 $<$ http://www.croatiaemb.org>.

---. "President Tudjman's Welcome Address to Pope John Paul II." Papa 2 Oct. 1998. 2 Feb. $2003<$ http://www.papa.hr/mvijesti/49>.

"Historical Transcript: Tudjman on Ethnic Cleansing." Trans. Mirna Skrbic. Transitions On-Line 17 July 2003. 18 Aug. $2004<$ http://www.tol.org>.

Hobsbawm, Eric. Nations and Nationalism since 1780: Programme, Myth, Reality. New York: Cambridge University Press, 1990.

Hočevar, Ksenja. "Dediščina Komunizma Všolstvu.” Družina 14 November 1999: 22-30.

Hočevar, Toussaint. The Structure of the Slovene Economy 1848-1963. New York: Studia Slovenica, 1965.

Hockenos, Paul. Free to Hate - The Rise of the Right in Post-Communist Eastern Europe. New York: Routlege, 1993.

Hofferbert, Richard I., and Hans-Dieter Klingemann. "Remembering the Bad Old Days: Human Rights, Economic Conditions, and Democratic Performance in Transitional Regimes." European Journal of Political Research 36 (1999): 155-174.

Holmes, Stephen. The Anatomy of Antiliberalism. Cambridge: Harvard University Press, 1996. 
---. "Gag Rules or the Politics of Omission." Constitutionalism and Democracy. Eds. Jon Elster and Rune Slagstad. Cambridge: Cambridge University Press, 1988. 19-58.

---. Passions and Constraint: On the Theory of Liberal Democracy. Chicago: University of Chicago Press, 1995.

Hopken, Wolfgang, ed. Oil on Fire? Textbooks, Ethnic Stereotypes and Violence in South-Eastern Europe. Hanover: Hahnsche Buchhandlung, 1996.

Horvat, Branko, Mihailo Marković, and Rudi Supek, eds. Self-Governing Socialism. White Plains: International Arts and Sciences Press, 1975.

Horvat, Josip. Politička Povijest Hrvatske. Zagreb: August Cesarec, 1990.

Howard, Mark Morje. The Weakness of Civil Society in Post-Communist Europe. Cambridge: Cambridge University Press, 2003.

Hribar, Spomeka. “Cerkev Ni Pogledala v Strašnost Lastne Krivde.” Delo 24 Jan. 1998: 12.

Hribar, Tine. "Odločitev za Samostojnost." Mladina 29 Dec. 1989: 6.

Hrvatske Biskupske Konferencije. "Nacionalni Katehetski Ured.” Katehetski Glasnik 4.1 (2002): 165-229.

"Hrvatski Biskupi Izražavanju Zbrinutost za Obstanak Države." Slobodna Dalmacija 23 Sept. 2000.9 Jan. $2001<$ http://www.slobodnadalmacija.hr>.

Hrvatsko Katoličko Bratstvo "Branimir." "Povratak u Podjele Proslosti." Novi List 19 Nov. 1998: 27.

Hummel, Ralph P. The Bureaucratic Experience: A Critique of Life in the Modern Organization. New York: St. Martin's Press, 1994.

Huntington, Samuel. The Clash of Civilizations and the Remaking of the World Order. New York: Simon \& Schuster, 1996.

Huttenbach, Henry R., and Peter Vodopivec. "Voices from the Slovene Nation, 1990-1992." Nationalities Papers 21.1 (1993): 51-59. 
Ignatieff, Michael. The Rights Revolution. Toronto: Anansi Press, 2000.

Igrec, Gordana. "Stanovi Crkvi ili Stanarima?" Slobodna Dalmacija 7 Dec. 1998: 11.

Immergut, Ellen M. "The Normative Roots of the New Institutionalisms: Historical Institutionalism." Beitrage zur Theorieentwicklung in der Politik - Und Verwaltungswissenschaft. Eds. Arthur Benz and Wolfgang Seibel. BadenBaden: Nomos, 1996. 325-355.

"Implementation of the International Covenant on Economic, Social and Cultural Rights." United Nations Economic and Social Council 4 July 2000. $<$ http://www.unhchr.ch/tbs/doc.nsf $>$.

Ingaro, Charles. The Habsburg Monarchy, 1618-1815. New York: Cambridge University Press, 1994.

International Helsinki Federation for Human Rights. "Human Rights in the OSCE Region: The Balkans, the Caucasus, Europe, Central Asia and North America, Report 2001: Croatia." IHF Research Foundation 2 Oct. 2002 $<$ http://www.ihf-hr.org/documents/doc summary.php?sec_id$3 \&$ d_id_=791>.

---. "Human Rights in the OSCE Region: The Balkans, the Caucasus, Europe, Central Asia and North America, Report 2002: Croatia." IHF Research Foundation 6 Dec. $2002<\mathrm{http} / /$ www.ihf-hr.org/reports/ar2002>.

Internet Editorial Staff of the Croatian Parliament. "Statistics about Members of Parliament." Sabor 24 Sept. 2004. 21 Jan. $2004<$ http://www.sabor.hr/ default.asp?ru=184\&sid=\&akcija $>$.

"Interview with Archbishop Dr. Franc Rode: Agreement Needed on Legal Status of Roman Catholic Church." Slovenia Weekly 12 Feb. 2000. $<$ http://www.sloveniaweekly/vitrum.com>.

"Interview with Dr. Janez Gril: Speeding up the Denationalisation Process." Slovenia Weekly Aug. 2000. 8 Jan. 2001 $<$ http://www.sloveniaweekly/vitrum.com>.

"Interview with Foreign Minister Dimitrij Rupel." Transcript Radio Television Slovenia 7 Jan. 2004, 1-22. 
Irvine, Jill. The Croat Question: Partisan Politics in the Formation of the Yugoslav Socialist State. Boulder: Westview Press, 1993.

Issac, Jeffery C. "The Meanings of 1989." Social Research 63 (1996): 2-58.

Ivančić, Viktor. "How Tudjman Spoke From Racan.” Trans. Marko Kocic. Feral Tribune date created. 28 Sept. $2002<\mathrm{http} / / /$ www.cdsp.neu.edu>

---. "Slapping the Wind: Under the Firmament." Trans. Marko Kocic. Feral Tribune 2 Dec. 2000. 19 Nov. 2002 $<$ http://www.cdsp.neu.edu/info/students/marko/feral/ feral136>.

Ivanović, Renata. "Don Ivan Grubišić: Vjeronauku Nije Mjesto u Školi i Vrticu." Arena 12 Nov. 1998: 31.

Ivelja, Ranka. "Cerkev in Šola." Dnevnik 6 Nov. 2000: 3.

---. "DZ Danes o Ratificakciji Vatikansega Sporozum." Dnevnik 28 Jan. 2004. 18 Mar. $2004<$ http://www.dnevnik.si>.

--.. "Koalicija se je Lotila Vatikanskega Oreha." Denvnik 18 Jan. 2001. 7 Feb 2001 $<$ http://www.dnevnik.si $>$.

---. “Nova Popuščanju Svetemu Sedežu?” Dnevnik 13 Apr. 2001. 19 Aug. 2001 $<$ http://www.dnevnik.si>.

--.. "Pa Če Koza Crkne?" Dnevnik 14 Dec. 1999. 30 Jan. 2001 $<$ http://www.dnevnik.ca $>$.

---. "Šolstvo in Novi Nadškof: Poraz Klera, ne Demokracije." Dnevnik 12 Apr. 1997: 15.

---. "Sporazum Je Lahko za Zagled.” Dnevnik 16 Nov. 1999. 20 Dec. 2000 $<$ http://www.dnevnik.si $>$.

Jakovljević, Ivo. “Četvrti Ugovor--Hrvatski Dar Papi?” Novi List 22 September 1998: 7.

Jancar, Drago, and Peter Vodopivec, eds. Slovenci v XX Stoletju. Ljubljana: Slovenska Matica v Ljublnani, 2001. 
Janos, Andrew C. East Central Europe in the Modern World: The Politics of the Borderlands from Pre to Post-Communism. Stanford: Stanford University Press, 2000.

Janša, Janez. The Making of the Slovenian State 1988-1992: The Collapse of Yugoslavia.

Ljubljana: Mladinska Knjiga Publishing House, 1994.

Jefferson, Thomas. "Letter to Danbury Baptist Association: To Messers Nehmiah Dodge and Others, a Committee of Danbury Baptist Association, in the State of Connecticut, January 1 1802." The CIRCA Grove Computer at the University of Florida 27 Nov. $2002<\mathrm{http}$ //www.grove.ufl.edu>.

Jeffries, Ian. The Former Yugoslavia at the Turn of the Twenty-First Century: A Guide to the Economies in Transition. New York: Routledge, 2002.

Jelavich, Barbara. History of the Balkans: Twentieth Century. New York: Cambridge University Press, 1983.

Jelavich, Barbara, and Charles Jelavich. The Establishment of the Balkan National States, 1804-1920. Seattle: University of Washington Press, 1987.

Jelić, Ivica. “Crkvi oko 180 Miljuna Kuna Godišnje.” Novi List 7 Oct. 1998: 3.

Jelinić, Borislav. "Catholic Social Policy and the "Sins of Structure." Nacional 15 Nov. 2001. 2 Oct. $2002<$ http://www.nacional.hr>.

Jerovšek, Tone, Franci Grad, and Lovro Šturm. "Vatikanski Sporazum." Dnevnik 10 Mar. 2000. 8 Jan. $2001<$ http://www.dnevnik.si>.

Jezernik, Božidar. Italijanska Koncentracijska Taborišča za Slovence Med 2 $\underline{\text { Svetovno }}$ Vojno. Ljubljana: Borec, 1997.

Johnson, Juliet. "Path Contingency in Postcommunist Transformations." Comparative Politics 3 (2001): 253-273.

Jovic, Josip. "Interview, General Norac: This Rally Has Filled Me with Pride, I am Ready for One More Sacrifice." Slobodna Dalmacija 14 Feb. 2001. 4 Dec. $2002<$ http://www.cdsp.neu.edu>. 
Jowitt, Ken. "The Leninist Legacy." The Revolutions of 1989: Rewriting Histories. Ed. Vladimir Tismaneanu. New York: Routlege, 1999, 213-230.

Judah, Tim. "Croatia Reborn." New York Review of Books 67.13 (2000): 20-22.

---. The Serbs: History, Myth \& the Destruction of Yugoslavia. New Haven: Yale University Press, 2000.

Jurančič, Iztok. "Potrebe se Srkvajo v Turnu Brez Kazalcev." Gospodarski Vestnik 17 Apr. 1999: 14.

Jurko, Gregor. "The Church is in the Majority." Mladina Sept. 2000. $<\mathrm{http}: / /$ www.mladina.si $>$.

Kadijević, Veljko. Moje Vidjenje Raspada: Vojska bez Države. Beograd: Politika, 1993.

“Kaj Vsebuje Vatikanski Sporazum?" STA 10 Dec. 2001. 9 Feb. 2002 $<$ http://www.sta.si>.

Kalogjera-Brkić, Ivana. "S Molitvenikom u Školu." Vecernji List 8 Jun. 1991: 8.

---. “Zbog Povrata Imovine Iselit Će 33 Škole, Vrtića I Doma," Jurtarnji List 22 Jan. 2001: 6.

Kann, Robert A. A History of the Habsburg Empire, 1526-1918. Berkeley: University of California Press, 1974.

Kaplan, Robert D. Balkan Ghosts: A Journey through History. New York: Vintage, 1994.

Karabeg, Omar. Interview with Ivan Padjen and Mirko Djordjević. "How Strong Are the

Catholic Church in Croatia and the Orthodox Church in Serbia?" Radio Free Europe/Radio Liberty 31 Jan. 2002. 2 Feb. $2002<\mathrm{http}$ ://www.rferl.org/ southslavic/2002/01/4-310102>.

"Karšna bo Šola Takšna bo Prihodnja Podoba Slovenskega Naroda: Pastoral Letter at the

Beginning of the 1998/1999 School Year." Družina 20 Sept. 1998: 1. 
Kasapović, Mirjana. "Demokratska Konsolidacija i Izborna Politika u Hrvatskoj 1990-2000." Hrvatska Politika 1990-2000. Ed. Mirjana

Kasapović. Zagreb: Fakultet Političkih Znanosti, 2001. 15-36.

Katzenstein, Peter. Corporatism and Change: Austria, Switzerland, and the Politics of Industry. Ithaca: Cornell University Press, 1984.

--. Cultural Norms and National Security: Police and Military in Postwar Japan. Ithaca: Cornell University Press, 1996.

Kavčič, Stane. Dnevnik in Spomini, 1972-1987. Ljubljana: Casopis za Kritiko Znanosti, 1988.

Keane, John. Civil Society and the State. London: Verso, 1988.

Kerševan, Marko. Cerkev, Politika, Slovenici: Po Letu 1990. Ljubljana: CZP Enotnost, 1996.

---. "Predmet Verstva in Etika v Osnovni Šoli." Lecture on a Seminar for Teachers of the Subject, Religion and Ethics. Ljubljana, 19 Feb. 1999.

---. "Sporazumi s Svetim Sedežem in Družbeni Položaj Rimskokatoliške Cerkve (RCK) v Republiki Sloveniji." Čarnijev Zbornik (1931-1996): Zbornik Mednarodnih Družboslovnih in Humanističnih Razprav. Ed. Alojz Cindrič. Ljubljana: Filozofska Fakulteta v Ljubljani Oddelek za Sociologijo, 1999. 14-23.

Kerševan, Marko, Andreja Barle, Stanko Gerjol, Martina Jeriha Gregoric, Tine Hribar, Ludvik Josar, Zdenko Kodelja, Drago Ocvrk, Jozica Pohar, Marjan Smrke, and Alenka Šverc. Ucni Načrt za Izbirni Predmet: Verstva in Etika. Ljubljana: Ministry of Education Republic of Slovenia, 1998.

Kitschelt, Herbert, Zdenka Mansfeldova, Radoslaw Markowski, and Gabor Toka. Post-Communist Party Systems: Competition, Representation, and InterParty Cooperation. New York: Cambridge University Press, 1999.

Kliphuis, James. "Nationalist Protests in Croatia." Radio Netherlands: Wereldomroep 14 Feb. 2001. 14 Dec. 2002 <http://www.rnw.nl/hotspots/croatia>.

Kloppenberg, James T. The Virtues of Liberalism. New York: Oxford University Press, 1998. 
Knevic, D. Interview with Goran Granić. "Katoliče Cervka Privligenieara Ugovorm $\mathbf{s}$

Vatikonom." Jutarnji List 7 Oct. 2000: 6.

Kocbek, Edvard. Dnevnik 1945. Ljubljana: Cankarjeva Založba, 1991.

Kočović, Bogoljub. Žrtve drugog svetskog rata u Jugoslaviji. Veritas Foundation Press,

London, 1985.

Kodelja, Zdenko. Laicna Šola: Pro et Contra. Ljubljana: Mladinska Knjiga, 1993.

Kojić, Branko, and Radojica Barbalić. Ilustrirana Povijest Jadranskog Pomorstva.

Zagreb: Stvarnost, 1975.

Kolak, Mato. Vjeronauk je Izborni Predmet. Vjestnik 29 Oct. 1998: 9.

Kolar, Bogdan. "Zgodovinski Temelji Premoženja Ljubljanske Nadškofije." Družina 22 Mar. 1998: 13.

Korošec, Anton. Enciklopedija Slovenija. Ljubljana: Mladinska Knjiga, 1991.

Košir, Borut. "Legal Concept of the Church Property." State and Church: Selected Historical and Legal Issues, International Conference June 21-22, 2001. Eds. Alenka Šelih and Janko Pleterski. Ljubljana: Slovenska Akademija Znanosti in Umetnosti, 2002. 575-591.

Koukourdinos, Dimitrios. "Constitutional Law and the External Limits of the Legal Framing of DCAF: The Case of Croatia and the Federal Republic of Yugoslavia." Centre for the Democratic Control of Armed Forces Aug. 2002. 15 Sept. $2003<$ http://www.dchaf.ch>.

Kovač, Stanislav. "Privilegiji." Delo 24 Oct. 1998: 5.

Kraft, Evan, Milan Vodopivec, and Milan Cvikl. "On Its Own: The Economy of Independent Slovenia." Independent Slovenia: Origins, Movements, Prospects. Eds. Jill Benderly and Evan Kraft. New York: St. Martin's Press, 1994.201-223.

Krasner, Stephen D. "Approaches to the State: Alternative Conceptions and Historical Dynamics." Comparative Politics 16.2 (1984): 223-46. 
Krek, Janez. "Private Schools and Preschool Institutions: The Conceptual Background and the Legislation." Private Education, Structure, Comparison of Different Educational Systems and Legislative Solutions in the Republic of Slovenia. Ed. Janez Krek. Ljubljana: The Ministry of Education and Sport, 1996.235-254.

---, ed. White Paper on Education in the Republic of Slovenia. Ljubljana: Ministry of Education, Republic of Slovenia, 1995.

Kristan, Ivan. "Readers Letter." Dnevnik 9 Mar. 2000. 30 Jan. 2001 $<$ http://www.dnevnik.si>.

Krišto, Jure. Prešućena Povijest: Katolička Crkva u Hrvatskoj Politici, 1850-1918. Zagreb: Hrvatska Sveučilištna Naklada, 1994.

Krivic, Mavtež. "Miloš Notranje Vernosti.” Delo 2 Feb. 2002: 6.

--.. "Pravno Mnenje o Besedilu Sporazuma med RS in Svetim Sedežem o Pravnih Vprašanjih Odobrenem na Seji Vlade Dne 11, 11, 1999." Dnevnik 13 Nov. 1999: 1-7.

--.. "Razlike Med Novemberskim in Januarskim Tekstom." Paper from Personal Collection, 2000. 1-21.

---. "Še Zadnjikrat o Gozdovih Pokljuških.” Delo 22 Oct. 2001: 9.

--.. "Spodnje Pirnice." Dnevnik 15 Nov. 1999: 16.

Krzić-Roban, Sandra. "Ciji je Kaptol: Unatoč Crkvenoj Jurisdikciji Urbani Prostori Pripadaju Svima Nama." Vjesnik 10 Jan. 2001: 15.

Kučan, Milan. "Govor na Zborovanju Izgnacev na Gradu v Brestanici, 9 June 1991." Izganci. Ed. Franc Setinc. Ljubljana: Društvo Izgancev Slovenije, 1993. 1-12.

Kuhar, Aloysius L. Conversion of the Slovenes and the German-Slav Ethnic Boundary in the Eastern Alps. New York: Studia Slovenica, 1959.

--- Slovene Medieval History. New York: Studia Slovenica, 1962. 
Kurian, George Thomas, ed. Nelson's New Christian Dictionary. Nashville: Thomas Nelson Publishers, 2001.

Kusovac, Zoran. "Autocracy's Aftermath: The Prospects for Change in Post Tuđman Croatia." East European Constitutional Review 9.3 (2000): 57-62.

--. "The Prospects for Change in Post-Tudjman Croatia: Autocracy's Aftermath." East European Constitutional Review Summer 2000. 9 Oct. 2002 $<$ http://www.law.nyu/eecr>.

Kustić, Živko. "Crkva Mora Biti Ekonomski Neovisna." Glas Koncila 1 Nov. 1998: 5 .

---. "Dva Ugovora u Jednome." Glas Koncila 25 Oct. 1998: 5.

---. “Ne Mijenjamo Ustav Nego Zakon.” Jutarnji List 11 Feb. 1999: 8.

---. "Treba li Crkvi Bogatstvo?" Glas Koncila 18 Oct. 1998: 185.

--.. "U Razumnome Roku." Glas Koncila 8 Nov. 1998: 5.

Kymlicka, Will. Liberalism, Community, and Culture. New York: Oxford University Press, 1989.

Lampe, John R. "Imperial Borderlands or Capitalist Periphery? Redefining Balkan Backwardness, 1520-1914." The Origins of Backwardness in Eastern Europe: Economics \& Politics from the Middle Ages until the Early Twentieth Century. Ed. Daniel Chirot. Berkeley: University of California Press, 1991.177-210.

---. Yugoslavia as History: Twice There was a Country. New York: Cambridge University Press, 2000.

Langlois, Claude. "Catholics and Seculars." Realms of Memory, Volume I: Conflicts and Divisions. Ed. Pierre Nora. New York: Columbia University Press, 1996. 113-143.

Lazarević, Žarko. "Razvoja Slovenskega Bančništva do Prve Svetovne Vojne.” Prispevki Inštitut za Novejšo Zgodovino. Ljubljana: Inštitut za Novejšo Zgodovino, 1999. 1-23

"Le President Mesić a Fonde le Groupe d'Experts Charge de l'Elaboration des 
Changements de la Constitution." Ambassade de France en Croatie 1

Mar. 2000. 9 Nov. $2002<$ http://www.ambafrance.hr/fr/medias/rp280200>.

Lenchek, Rado L. The Structure and History of the Slovene Language. Columbus: Slavica, 1982.

Lesjak, Miran, and Meta Roglic. Interview with Janez Janša. "Vsak je Kdaj Naredil Kakšno Napako, Tudi Jaz." Dnevnik 28 Apr. 2001. 4 Aug. 2001.

$<$ http://www.dnevnik.ca>.

Lešnik, Doroteja. "Slovensko Partizanstvo." Rdeče in Črno: Slovensko

Partizanstvo in Domobranstvo. Eds. Doroteja Lešnik and Gregor Tomc. Ljubljana: Znanstveno in Publicistično Središče, 1995.23-49.

"Letters." Feral Tribune 2 Sept. 2000: 19.

Levak, Nevanka. "Cyrillic Alphabet as a Condition" Glas Slavonije 7 May 1997. 28 Oct. 2002

<http://www.cdsp.neu.edu/info/students/marko/glasslav/glasslav1 >.

Lijphart, Arend. Democracy in Plural Societies. New Haven: Yale University Press, 1977.

---. The Politics of Accommodation. Berkeley: University of California Press, 1975.

---. "Religious vs. Linguistic vs. Class Voting: The Crucial Experiment of Comparing Belgium, Canada, South Africa, and Switzerland." American Political Science Review 73.2 (1979): 442-456.

Lindblom Charles E. "The Science of "Muddling Through." Public Administration: Concepts and Cases. Ed. Richard J. Stillman. Boston: Houghton Mifflin Company, 1996.77-88.

Linz, Juan J. "Church and State in Spain from the Civil War to the Return of Democracy." Daedalus 120 (1991): 159-179.

Linz, Juan J., and Alfred Stepan, eds. The Breakdown of Democratic Regimes. Baltimore: Johns Hopkins Press, 1978. 
---. Problems of Democratic Transition and Consolidation: Southern Europe, South America, and post-communist Europe. Baltimore: Jons Hopkins University Press, 1996.

Llobera, Josep R. "Herder and Cultural Nationalism." The God of Modernity: The Development of Nationalism in Western Europe. Ed. Josep R. Llobera. Providence: Oxford University Press, 1994. 164-170.

Locke, John E. The Correspondence of John Locke. Ed. E.S. DeBeer. Oxford: Clarendon Press, 1976.

---. Two Treatises of Government. Ed. Peter Laslett. New York: Cambridge University Press, 1960.

Lomax, Bill. "Impediments to Democratization in Post-communist East-Central Europe." Party Formation in East-Central Europe: Post-communist Politics in Czechoslovakia, Hungary, Poland and Bulgaria. Ed. Gordon Wightman. Brookfield: Edward Elgar, 1995. 179-201.

Lovrić, Jelena. "Church against Tribunal.” Aim Press 26 July 2001. 4 Jan. 2001 $<$ http://www.aimpress.org $>$.

Loza, Tihomir, and Dragan Stojković. "Religious Education Sparks Controversy." Institute for War and Peace Reporting 8 July 2001. <http://www.iwpr.org>.

Lukes, Steven. Power a Radical View. New York: Macmillan, 1974.

Lukić, Slavica. "Crkve vs. Država." Globus 25 Feb. 2002: 30-33.

Lukšić, Branimir. "Kršćanstvo Kao Dekoracija." Slobodna Dalmacija 14 Apr. 1995: 3.

Lukšič, Igor. "Changing Patterns of Social Partnership." Making a New Nation: The Formation of Slovenia. Eds. Danica Fink-Hafner and John R. Robbins. Brookfield: Dartmouth Publishing Company, 1997. 106-113.

---. The Political System of the Republic of Slovenia: A Primer. Trans. Erica Johnson Debeljak. Ljubljana: Znanstveno in Publicistično Središče, 2001.

Luther Kurt Richard, and Peter Pulzer. Austria 1945-1995: Fifty Years of the Second Republic. Brookfield: Ashgate, 1998. 
Lydall, Harold. Yugoslav Socialism: Theory and Practice. Oxford: Clarendon Press, 1984.

---. Yugoslavia in Crisis. Oxford: Clarendon Press, 1989.

Macan, Trpimir. Povjest Hrvatskoga Naroda. Zagreb: Skolska Knjiga, 1999.

Maček, Davor. "Zabrana-Nudenje Mrkve Crkvi i Konzervativnim Glasacima." Novi List 12 Feb. 1997: 5.

Macesich, Susana S. "The French Revolution, Napoleon and the Balkan Enlightenment." East European Quarterly 9.4 (1975): 455-470.

MacIntyre, Alasdair C. After Virtue. Notre Dame: University of Notre Dame Press, 1984.

MacLean, Fitzroy. Eastern Approaches. London: J Cape, 1950.

Maddox, Graham. Religion and the Rise of Democracy. New York: Routledge, 1996.

Madunić, Branko. "Zašto Još Nije Postignut Sporazum sa Svetom Stolicom o Financiranju Katoličke Crkve u Hrvatskoj?" Vjesnik 7 Mar. 1998: 18.

Magaš, Branka. The Destruction of Yugoslavia: Tracking the Break-Up, 1980-92. New York: Verso, 1993.

Magocsi, Paul Robert. Historical Atlas of Central Europe, Revised and Expanded Edition. Toronto: University of Toronto Press, 2002.

March, James G., and Johan P. Olsen. "The New Institutionalism: Organizational Factors in Political Life." American Political Science Review 78.3 (1984): 734-749.

Marinković, Gojko. "Assembly Votes Contrary to the Constitution.” Aim Press 28 Feb.

$1997<$ http://www.aimpress.org $>$.

---. “Tudjman's New Suit.” Aim Press 3 Sept. 1996. 6 Sept. 2002

$<$ http://www.aimpress.org $>$. 
Marinković, Skomrlj E. "Vjeronauku Nije Mjesto u Školama." Novi List 31 Oct. 1998: 3.

Marković, Marko. "Slvoenske Zamke za Zamak Mokrice." Slobodna Dalmacija 11 Nov. 1993: 10.

Marković, Mihailo. From Affluence to Praxis: Philosophy and Social Criticism. Ann Arbour: University of Michigan Press, 1974.

Markovich, Stephen C. "Democracy in Croatia: Views from the Opposition." East European Quarterly 32.1 (1998): 88-97.

Mart, Bax. "Medjugorje: Religion, Politics, and Violence in Rural Bosnia." Amsterdam: Free University Press, 1995.

Martinović, Bratonja. "Okrecemo Leda Europskim Dosezima. Novi List 27 Oct. 1998: 9.

Mastnak, Tomaž. "Crusader in Education Ministry?" Dnevnik 17 June 2000: 7

---. "From the New Social Movements to Political Parties." Yugoslavia in Turmoil: After Self-Management. Eds. James Simmie and Jože Dekleva. New York: Pinter Publishers, 1991. 47-52.

---. "Ni nas Šola." Dnevnik 29 Mar. 2000. 29 Jan. 2001<http://www.dnevnik.si>.

---. "On the Orders of the Devil." Dnevnik 25 Mar. 2000. <http://www.dnevnik.si>.

Matic, Andrej. "Electoral Reform as a Constitutional Dilemma." New York School of Law Summer 2000. 3Aug. $2002<\mathrm{http} / /$ www.law.nyu.edu>.

Matscher, Franz, Hanna Suchocka, and Pieter Van Dijk. "Revision of the Croatian Constitutional Law of 1991 on Human Rights and Rights of National Minorities: Preliminary Report on the Draft Proposal of Amendments to the Constitutional Law of 1991, Strasbourg: European Commission for Democracy Through Law (Venice Commission)." Council of Europe 10 May 2000: 31 .

McKenzie, David. "Serbia as Piedmont and the Yugoslav Idea, 1804-1914." East European Quarterly 28.4 (1994): 153-181. 
McTaggart, Anna. "Reformed HDZ Set to Retake Power." Balkan Crisis Report. 20 Nov. 2003, <http://www.iwpr.org>.

Meier, Viktor. Yugoslavia: A History of Its Demise. Trans. Sabrina Petra Ramet. London: Routledge, 1999.

Mekina, Igor. "Disrespect with Hosts." Mladina 48 (2000): 8-10.

---. "Slovenia and Vatican: Alone Against Everybody." Aim Press 4 Feb. 2000. 7 Jan. $2001<$ http://www.aimpress.org $>$.

---. "Support to Former Collaborationists of Hitler: Changing History." Aim Press 12 July 2000.8 Sept. $2002<$ http://www.aimpress.org $>$.

Mencinger, Jože. "The Costs and Benefits of Secession." Making a New Nation: The Formation of Slovenia. Eds. Danica Fink-Hafner and John R. Robbins. Brookfield: Dartmouth Publishing Company, 1997. 204- 215.

---. "From a Capitalist to a Capitalist Economy?" Yugoslavia in Turmoil: After Self-Management? Eds. James Simmie and Jože Dekleva. New York: Pinter Publishers, 1991. 71-86.

"Message from the Croatian Bishops on the Current Social Situation in Croatia." Croatian Bishop's Conference 7 Nov. 2001, 18 Sept. 2002 $<$ http://www.hbk.hr>.

Meštrović, Stjepan, Slaven Letica, and Miroslav Goreta. Habits of the Balkan Heart: Social Character and the Fall of Communism. Texas: A \& M University Press, 1993.

Meta, Roglic, and Sonja H. Vogric. "Vatikanski Sporazum, Njega Krizi in Tezave." Dnevnik 15 Dec. 2001.14 Jan. $2002<\mathrm{http}: / /$ www.dnevnik.si>.

Michel, Patrick. Politics and Religion in Eastern Europe; Catholicism in Hungary, Poland and Czechoslovakia. Oxford: Oxford University Press, 1991.

Michels, Robert. Political Parties. Glencoe: Free Press of Glencoe, 1949.

Miheljak, Vlado. "Religija z Etikami." Mladina 24 Nov. 1995: 8-9.

---. "Ten Years Later." Dnevnik 12 Dec. 2000. <www.dnevnik.si>. 
---. "Tolmačenje Sanj." Delo 7 July 2001: 11.

Milisa, Zlatko, ed. Croatian Education System Interim Report. Zagreb: Republic of Croatia Ministry of Education and Sports Institute for Educational Development, 2000.

"Milošević Clashes with Croat President." BBC News 2 Oct. 2002. $<$ http://www.news.bbc.co.uk>.

Ministry of Education, Science and Sport Republic of Slovenia. Organization, Administration and Financing of the Slovenian Education. Ljubljana: Republic of Slovenia, 2000.

"Ministry of Finance Monthly Statistical Review, July 2002." Croatia Ministry of Finance July $2002<$ http://www.mfin.hr/stat>.

Ministry of Foreign Affairs, Slovenia. "Sporazum med Republiko Slovenijo in Svetim Sedežem o pravnih vprašanjih." 23 Jan. 2002.

Minnich, Robert Gary. "Civil Society and the Legacy of Ethnic Cleansing in the Southeastern Alps." Some Implications for Conflict Prevention. Bergen: University of Bergen, 1997, 15-22.

"Minorities in Croatia." Minority Rights Group International 2003. 5 Mar. 2004 $<$ http://www.mrg.org $>$.

Mlakar, Boris. O Položaju Slovenskega Domobranstva 1943-1945. Ljubljana: IZDG, 1980.

Mlakar, Jože. "Kaj pa Pravice Kristjanov: Šolsko Vprašanje Znotraj Razmerja med Državo in Cerkvijo." Družina 16 Jan. 2000: 9.

Mlheljak, Vlado. "Religija z Etikami." Mladina 24 Nov. 1995: 8-9.

Mlinarević, Snježana. "Croatia Osiguranje ide Crkvi za Dugove." Vecernji List 24 Feb. 2002: 6 .

Mlinarič, Jože. "Cerkev na Slovenskem v Srednjem Veku." Zgodovina Cerkve na Slovenskem. Ed. Metod Benedik. Celje: Mohorjeva Duzba, 1991.61-91. 
Mlivonicić, Ivica. "Površan i Nekritičan Pristup." Nedleljna Dalmacija 31 Mar. 1995: 12.

Moder, Janko. "Slovenski Jezikoslovci." Cerkev, Kultura in Politika, 1890-1941. Eds. France M. Dolinar, Joža Mahnič, and Peter Vodopivec. Ljubljana: Slovenska Matica, 1993.35-49.

Mojzes, Paul. "The Camouflaged Role of Religion in the War in B\&H." Religion and the War in Bosnia. Ed. Paul Mojzes. Atlanta: Scholars Press, 1998. 7778 .

---. "The Role of the Religious Communities in the War in Former Yugoslavia." Religion in Eastern Europe 13.3 (1999): 13-32.

Mommsen, Wolfgang J. The Age of Bureaucracy: Perspectives on the Political Sociology of Max Weber. Cambridge: Polity Press, 1989. 20-23.

---. The Political and Social Theory of Max Weber: Collected Essays. Oxford: Polity Press, 1989.

Moore, Patrick. "Croatia Votes on Monday." Radio Free Europe/Radio Liberty 21 Jan. 2000. 4 Feb. $2000<$ http://www.rferl.org>.

Moritsch, Andreas. "German Nationalism and the Slovenes in Austria between the Two World Wars." Slovene Studies: Journal of the Society for Slovene Studies 8.1 (1986): 15-21.

Mosca, Gaetano. The Ruling Class. Trans. A. Livingston. Toronto: McGraw-Hill, 1939.

Mosma, Stephen V., and Christopher J. Soper. The Challenge of Pluralism: Church and State in Five Democracies. New York: Rowman and Littlefield Publishers, 1997.

"Nations in Transit 2001: Country Report of Croatia." United Nations Online Network in Public Administration and Finance. 2001. 11 Nov. 2003 $<$ http://www.unpan.un.org $>$.

Natlačen, Tomaž S., Mateja Babič, and Vlasta Felc. "Namesto Nadškofiji Vrnjeni v Nov Postopek." Delo 28 May 2002: 1. 
Nedovic, Slobodanka. "The New Patterns of State Control: The State and Civic Education in Yugoslavia." Religion in Eastern Europe XVII (1997): 1-32.

Nedjelko, Pintarić, ed. Ugovori Izmedju Svete Stolice i Republike Hrvatske. Zagreb: Glas Koncila, 2001.

Nemec, Ludvik. "The Pattern in the Historical Roots of Church-State Relationship in Central and Eastern Europe." East European Quarterly 20 (1986): 8-17.

"News Review for Croatia." Central Europe Review 18 Oct. 1999. $<$ http://www.cereview.org/99/17/croatianews17>.

Nezmah, Bernard. "Anticerkveni Refleks." Dnevnik 8 Jan. 2001. $<$ http://www.dnevnik.si>.

Nichols, Peter. The Politics of the Vatican and The Pope's Divisions. London: Faber \& Faber, 1981.

Nora, Pierre, ed. Rethinking the French Past, Realms of Memory: Volume I: Conflicts and Divisions. New York: Columbia University Press, 1996.

North, Douglass C. Institutions, Institutional Change and Economic Performance. New York: Cambridge University Press, 1990.

Novi Kolektivizem. Neue Slowenische Kunst. Hong Kong: Paramount Printing, 1991.

"Number of Marriages in 1999 in Croatia." Croatian Bishops' Conference (HBK) 1999. 4 Sept. $2001<$ http://www.hbk.hr/stat/1999/englezi/ecerkvena.99>.

Ocvirk, Drago. "Islam: A New Religion in a Traditionally Catholic Slovenia." Proceedings of the Dialogue of Christian-Muslim Collaboration Conference May 29-June 1, 1995, 3 September $2001<$ www.georgefox.edu>

---. "Uniformirana ali Pluralna Šola: Šola za Svobodo, Resnico in Človečnost." Družina 2 Oct. 1994: 11.

Odić, Zoran. "Conflict over School Reform." Aim Press 23 Dec. 1997. 4 Nov. 2001 $<$ http://www.aimpress.org $>$.

---. "School Reform in Slovenia: Struggle for Souls." Aim Press 23 Dec. 1997. $<\mathrm{http}: / /$ www.aimpress.org $>$. 
O'Donnell, Guillermo, Philippe C. Schmitter, and Laurence Whitehead, eds. Transitions from Authoritarian Rule: Tentative Conclusions About Uncertain Democracies. Baltimore: Johns Hopkins University, 1986.

Offe, Claus. "New Social Movements." Social Research 52 (1985): 817-868.

"On the Occasion of the 7th Anniversary of the Constitution, President Tudjman Addresses the Parliament on the new Amendments to the Constitution." Croatian Information Center 19 Dec. $1997<\mathrm{http} / / / \mathrm{www} . h i c . h r /$ news $>$.

Opacic, Milanka. "Ante Gotovina Honorary Citizen of Zadar." Slobodna Dalmacija 23 Nov. 2001. 4 Dec. $2001<\mathrm{http}: / /$ www.cdsp.neu.edu>

Orčolić, Nikola. "Razgovor s Ivanom Pađenom." Kana 31 July 1999: 5.

"Organization, Administration and Financing of the Slovenian Education." Ministry of Education, Science and Sport Republic of Slovenia. 2000. $<$ http://www.mszs.si/eng/edcuation/system/admninistration.asp $>$.

Orren, Karen and Stephen Skowronek, "Beyond the Iconography for Order: Notes for a New Institutionalism." The Dynamics of American Politics, eds. Lawrence Dodd \& Calvin Jillson. Boulder: Westview Press, 1994. 311332.

Ostrom, Elinor. "New Horizons in Institutional Analysis." The American Political Science Review 89.1 (1995): 174-178.

Ostrom, Elinor, and Sue Crawford. "A Grammar of Institutions." The American Political Science Review 89. 3 (1995): 582-600.

Ott, Katarina. "The Underground Economy in Croatia 1990-2000." Institute of Public Finance Mar. 2002. 16 Apr. $2003<$ http://www.csd.bg>.

Ott, Katarina, and Anto Bajo. "Local Government Budgeting in Croatia." Institute of Public Finance 2001. <http://www.csd.bg>.

Padjen, Ivan. "Aristokracija i Ustavna Država: Od Plemstva i Klera Do Provodudja i Profesija." Croatian Political Science Review. 35, 1998. 92-111.

-.-. "Cerkva i Sveučilište." Lecture. Zagreb: Hrvatskoga Pravnog Centra, 11 Nov. 1999. 
---. "Church and State in Croatia." Law and Religion in Post Communist Europe. Eds. Silvio Ferrari \& Elizabeth Sewell. Trier: European Consortium of Church and State Research, 2003. 1-16.

---. "The State's Authority in Religious Rights." Croatian Political Science Review 38 (2002): 5-31.

Pandža, Gordan. "Političari Žele Iskoristiti Crkvu za Sovj Ciljeve. Vjesnik 16 May 1999: 2.

Pantic, Miroslav, ed. "Memorandum of the Serbian Academy of Arts and Sciences, Answers to Criticisms." Presidency of the Serbian Academy of Sciences and Arts. 23 Apr. 1993. 7 Aug. 2001 $<$ http://www.beograd.com/sanu/images/memo.pdf $>$.

Pareto, Vilfredo, and E. Finer, eds. Sociological Writings. Oxford: Blackwell, 1976.

"Parliamentary Elections 2003." OSCE Mission to Croatia 12 Jan. 2004 $<$ http://www.osce.org/croatia/political_affairs/elections_parliamentary_200 $3>$.

Pateman, Carole. Participation and Democratic Theory. New York: Cambridge University Press, 1970.

Pavičić, Darko. “Crkva kao Država.” Obzor 15 Feb. 1997: 14-15.

---. “Crkva se Odmče Državne Politike!” Arkzin 10 Apr. 1990: 5.

---. "Crkvi se Vraća Imovina i Financira Javno Koristan Rad." Večernji List 10 Oct. 1998: 9.

--.. “Je li Crkva prodala?” Vecernji List 20 Dec. 1998: 25.

---. "Ključni Dogovori Hrvatski i Vatikana." Panorama 24 May 1995: 21.

---. “Knjige za Osobnu Duhovnost.” Vjesnik 21 Jan. 1993: 26.

--.. "Rezultat Vjeronaučne Utakmice." Vecernji List 21 Mar. 2000: 3.

---. "Što je Oteto Treba Vratiti." Vjesnik 11 June 1994: 13. 
---. "Vecernjakova Anketa: O Religijskom Odgoju u Škoki." Vecer 14 Nov. 1998: 25.

Pavlaković, Verjan. "Minorities in Croatia Since Independence." Nationalism, Culture and Religion in Croatia Since 1990. Ed. Verjan Pavlaković. Seattle: The Donald W. Treadgold Papers, the Henry M. Jackson School of International Studies, University of Washington, 2001. 13-30.

---. Introduction. Nationalism, Culture and Religion in Croatia Since 1990. Ed. Verjan Pavlaković. Seattle: The Donald W. Treadgold Papers, the Henry M. Jackson School of International Studies, University of Washington, 2001. 912.

Pavlowitch, Stevan K. Yugoslavia. New York: Prager Publishers, 1971.

Pelikan, Egon. Akomodacija Ideologije Politic`Nega Katoličizma na Slovenskem. Maribor: Založba Obzorja, 1997.

---. Duhovščine Pod Fašizmom. Ljubljana: Nova Revija, 2002.

---. "Slovenski Politični Katoličizem v Tridesetih Letih v Luci Evropskih Izkusenj."

Slovenci v Evropi (O Nekaterih Vidikih Slovenske Povezanosti s Sosedi in Evropo). Ed. Peter Vodopivec. Ljubljana: Historia Znanstvena Zbirka Oddelka za Zgodovino Filozofske Fakultete Univerze v Ljubljani, 2002. 115-122.

---. Tajno Delovanje Primorske Duhovščine pod Fašizmom. Ljubljana: Korenine, Nova Revija, 2002.

Pelinka, Anton. Austria: Out of the Shadow of the Past. Boulder: Westview Press, 1998.

Peratovic, Zeljko. "Crkva na Državnom Troškovniku." Globus 23 Oct. 1998: 1820.

Perica, Vjekoslav. Balkan Idols: Religion and Nationalism in Yugoslav States. Toronto: Oxford University Press, 2002.

---. "The Catholic Church and Croatian Statehood." Nationalism, Culture and Religion in Croatia since 1990. Ed. Verjan Pavlaković. Seattle: The Donald 
W. Treadgold Papers, the Henry M. Jackson School of International Studies, University of Washington, 2001. 55-71.

Perovšek, Jurij. Liberalizem in Vprašanje Slovenstva: Nacionalna Politička Liberalnega Tabora v Letih. 1918-1929. Ljubljana: Modrijan, 1996.

Perry, Michael J. Religion in Politics: Constitutional and Moral Perspectives. New York, Oxford University Press, 1997.

Petranović, Branko, and Momčilo Zečević, eds. Jugoslavija 1918/1988: Tematska Zbirka Dokumenata. Beograd: Izdavačkat Radna Organizacija, 1988.

Pibernik, France, and Franc Drolc, eds. Poems: Pesmi. Ljubljana: Mohoreva Zolozba, 1999.

Pierson, Paul, and Theda Skocpol. "Historical Institutionalism in Contemporary Political Science." The State of the Discipline. Eds. Ira Katznelsonm and Helen Milner. New York: W.W. Norton, 2002. 1-46.

Pikalo, Jernej. "Vrnitev (Ali Samo Vztrajanje) Levice na Slovenskem." Demoktratični Prehod I. Eds. Danica Fink Hafner and Miro Haček. Ljubljana: Fakulteta za Družbene Vede, Knjižna Zbirka Profesija, 2000. 204-209.

Pilić, Damir. "Intervu, Don Ivan Grubišić, Svećenik i Sociolog." Feral Tribune 9 June 2001: 6-7.

Pilsel, Drago. "Bishops Do Not Want to Recognize Some Fears." Novi List 27 Oct. 2002. 13 Nov. $2002<$ cdsp.neu.edu>

Pintarić, Nedjelko, ed. Ugovori Izmedju Svete Stolice i Republike Hrvatske. Zagreb: Glas Koncila, 2001.

Pirjevec, Jože. Jugoslavija: Nastanek, Razvoj ter Razpad Karadjordjevićeve in Titove Jugoslavije. Koper: Založba Lipa, 1995.

---. "Slovenes and Yugoslavia, 1918-1991." Nationalities Papers 21.1 (1993): 112128.

---. "Slovenci in Zahodna Meja." Slovenci v XX Stoletju: Simpozij Slovenske Matice, December 2001. Eds. Drago Jančar and Peter Vodopivec. Ljubljana: Slovenska Matica, 2001. 34-40. 
Plasser, Friz, and Andreas Pribersky. Political Culture in East Central Europe. Brookfield: Ashgate, 1996.

Plattner, Marc F. "From Liberalism to Liberal Democracy." Journal of Democracy 10.3 (1999): 121-134.

Plattner, Marc F., Andreas Schedler, and Larry Jay Diamond. The Self-Restraining State: Power and Accountability in New Democracies. Boulder: Lynne Rienner Publishers, 1999.

Pleše, Mladen. "Archbishop Bozanić Strengthens His Position.” Nacional 20 Apr. 2000. <www.nacional.hr>.

---. "Drama in the Government-Croatia on the Brink of Financial Ruin." Nacional 28 June $2001<$ www.nacional.hr>.

---. "Historical Visit to Israel." Nacional 8 Nov. 2001 <www.nacional.hr>.

-.-. Interview with Wolfgang Petritsch. Nacional 19 Apr. 2001.29 Nov. 2002 $<$ http://www.nacional.hr $>$.

--.. "Open War: Bozanić and Racan." Nacional" 15 Nov. 2001. 19 Dec. 2002 $<$ http://www.nacional.hr>.

-... "The State Firmly Committed Itself to Unconditionally Fulfilling all the Controversial Issues in the Controversial Contracts between Croatia and the Vatican." Nacional 12 Dec. 2001. 19 Sept. $2002<\mathrm{http}: / /$ www.nacional.hr>.

--.. "Vatikan je Odbio Potpisati Medjudržavni Sporazum s Hrvatskom Dok se ne Rijese

2464 Privjave Kaptola za Povrat Imovine." Nacional 18 Dec. 1996 $<$ www.nacional.hr>.

-... "Vatikan Šokirao Hrvatski Biskupe." Nacional 23 Oct. 2001

$<$ www.nacional.hr>.

Pleterski Janko. "Katoliška ali Socialna, Narodna ali Ljudska Stranka? (Koncepcije Katoliške Ljudske Demokracije 1980-1918)." Cerkev, Kultura in Politika, 1890-1941. Eds. France M. Dolinar, Joža Mahnič, and Peter Vodopivec. Ljubljana: Slovenska Matica, 1993. 21-22. 
--- Prva Odločitev Slovencev za Jugoslavijo. Ljubljana: 1971.

Pluško, Aloz. "Od Konkordata do Sporazuma." Transcript TV Slovenia 126 Jan. 2002.

Plut-Pregelj, Leopoldina. "Slovenia's Concerns about the Proposed Yugoslav Core Curriculum in the 1980s." The Repluralizaiton of Slovenia in the 1980s: New Revelations from Archival Records. Seattle: University of Washington Press, 2000. 58-78.

Plut-Pregelj, Leopoldina, Aleš Gabrič, and Božo Repe. The Repluralizaiton of Slovenia in the 1980s: New Revelations from Archival Records. Seattle: The Donald W. Treadgold Papers, the Jackson School of International Studies, University of Washington, 2000.

Plut-Pregelj, Leopoldina, and Carole Rogel. Historical Dictionary of Slovenia. Lanham: The Scarecrow Press, 1996.

Poglajen, Jože. "Dnevnikov Parlament." Dnevnik 7 May 2001. 8 Apr. 2001 $<$ http://www.dnevnik.si $>$.

--.. "O Religijah Vesrtvih in Etici." Dnevnik 14 Feb. 1996: 17.

"Political Affairs: Croatian Parliament." OSCE 2003. 20 Feb. 2003 $<$ http://www.osce.org/croatia/political_affairs $>$.

"Pope Beatifies Controversial Croatian Cardinal." CNN 3 Oct. 1998. 8 Nov. 2002 $<$ http://www.cnn.com/world/europe/9810/03/pope.croatia $>$.

Pope John Paul II. "Encyclical Letter: Centesimus Annus." Vatican 1 May 1991. 6 Nov. 2002 $<$ http://www.vatican.va/holy_father/john_paul_ii/encyclicals/documents/ hf_jp-ii_enc_01051991>.

-... "Visit to the Cathedral: Maribor, 19 September 1999." Vatican $<$ http://www.vatican.va/holy_father/john_paul_ii/travel/documents/hf_jpii_spe_19091999_slovenia-cathedral_en>.

Pope Paul VI. "Dignitatis Humanae." Vatican 7 Dec. 1965. 24 Mar. 2002 $<$ http://www.vatican.va/archive/hist_councils/ii_vatican_council/documents $>$.

Pope Pius IX. "Encyclicals." Vatican23 Nov. $2002<$ http://www.vatican.va>. 
---. "Quadragesimo Anno: On Reconstruction of the Social Order." Vatican 15 May 1931. 25 Nov. $2002<$ http://www.vatican.va>.

---. "Quant Cura." Papal Encyclicals Online 8 Dec. 1864. 24 Mar. 2002 $<$ http://www.papalencyclicals.net/Pius09/p9quanta $>$.

"The Pope's Address to the Pilgrims Concerning His Visit to Croatia in 1994." Pope 14 Sept. 1994. <http://www.pope.hr/English>.

Potočnik, Vinko. "Krek in Socialna Misel pri Slovenskih Katoličanih." Cerkev, Kultura in Politika, 1890-1941. Eds. France M. Dolinar, Joža Mahnič, and Peter Vodopivec. Ljubljana: Slovenska Matica, 1993. 224-249.

Potrč, Miran. "Zahteva za Razpis Referenuma." Poslanska Skupina Ždružene Liste 15 Feb. 1996: 14.

"Pozdrav, Nadskov Rode." Slovenian Bishops's Conference 18 May 2002. 29 Sept. $2002<$ ww.rck.si/plenary-zbor.rode>

Preatović, Željko. “Crkva na Državnom Troškovniku.” Globus 23 Oct. 1998: 19.

"Presidential Election in the Republic of Croatia: Observation Delegation to the Croatian Presidential Elections." OSCE 15 June 1997. 19 Feb. 2003 $<\mathrm{http}$ //www.osce.org/odihr/documents/reports/election>.

Prijevec, Jože. Jugoslavija: Nastanek, Razvoj ter Razpad Karadjordjevićeve in Titove Jugoslavije. Koper: Založba Lipa, 1995.

“Prime Minster Zlatko Mateša Speaks to Foreign Journalists." Vlada Sept.-Oct. 1999. 8 Oct. $2002<$ http://www.vlada.hr/bulletin/1999/sept-oct>.

Prlenda, Sandra. "Odnos Izmedju Nacije i Religije u Hrvatskim Nacionalnim Ideologijama." Religija, Društvo i Politika. Kontroverzna Tumačenja i Približavanja. Ed. Thomas Brember. Bonn: Wissenschaftliche Arbeitsgruppe fur Weltkirchliche Aufgaben der Deutschen Bischofskonferenz, 2002. 131-141.

"Profile: Controversy and Joerg Haider." BBC News 29 Feb. 2000. 5 Dec. 2001 $<$ http://www.news.bbc.co.uk./hi/english/world/europe/464260>. 
"The Program of the Government of the Republic of Croatia for the 2003-2007

Mandate." The Republic of Croatia 23 Dec. 2003. 2 Feb. 2004

<http://www.vlada.hr/Download/2004/02/04/VRHProgramVRHeng_ft $>$.

"Prompt Denationalization is in the Public Interest." Republic of Slovenia. Apr. 2001. 9 Sept. $2003<$ http://www.gov.si>.

Prunk, Janko. A Brief History of Slovenia. Ljubljana: Založba Grad, 2000.

--. "The Origins of an Independent Slovenia." Making a New Nation: The Formation of Slovenia. Eds. Danica Fink-Hafner and John R. Robbins. Brookfield: Dartmouth Publishing Company, 1997. 21-30.

---. Slovenski Narodni Vzpon: Narodna Politika (1768-1992). Ljubljana: Državna Založba Slovenije, 1992.

Przeworski, Adam. Democracy and the Market. Cambridge: Cambridge University Press, 1991.

Przeworski, Adam, and Henry Teune. Logic of Comparative Social Inquiry. New York: John Wiley \& Sons Inc., 1970.

Puc, Ivan. Interview with Bishop Anton Stres. Mag 1 Mar. 2002: 45-47.

Pucić, Sinaša. "Ugovor Hrvatske Vlade s Predstavnicima Islamske Zajednice i Srpske Pravoslavne Crkve." Novi List 21 Dec. 2002.

Pukanić, Ivo. "Wiretapping Fever Has Shaken the New Government." Nacional 21 June 2001. <http://www.nacional.hr>.

Puljiz, Helena. "SPC Traži Natrag 7,000 Kvadrata u Strogom Sredistu Zagreba." $\underline{\text { Novi }}$ List 31 July 1998: 8.

Presern, Janja. "Political Idol." Mladina 29 Nov. 2000: 3.

Purvis, Andrew. "Father of the Nation, Franjo Tudjman: 1922-1999." Time Europe 20 Dec. 1999: 22.

Pušenak, Dejan. "Dva Pogleda na Vatikanski Sporazum, A: Še Več Nejasnosti, B: Nič Novega." Delo 7 Dec. 2001: 9. 
---. "Hvala Bogu za Krivica." Delo 18 Nov. 1999: 18

-.-. "Šola Naj ne Vzgaja v Veri ali Neveri." Delo 20Aug. 1994: 19-20.

-.-. "V Sensi Vatikanskega Sporazuma." Delo 12 Dec. 2001: 19.

Putnam, Robert D. Making Democracy Work: Civic Traditions in Modern Italy. Princeton: Princeton University Press, 1993.

"Račan Potpisao Ugovore sa SPC-om i Islamskom Zajednicom u Hrvatskoj." HINA (Croatian Press Agency) 20 Dec. 2003. 7 Jan. 2003 $<$ http://www.hina.hr>.

Radić, Stjepan. “Tri Skupštine HSS u Zagrebu.” Dom 22 Dec. 1926: 6.

Radnić, Ante. "Tourism and the Croatian Development." Institute for Tourism 20 Apr. 2001. 3 Mar. $2002<$ http://www.hrvatska21.hr>.

Radulović, Mirjana. “Ocenas u Razredu.” Oko 18 Sept. 1990: 30-31.

Rahten, Andrej. Slovenska Ljudska Stranka v Beograjski Skupscini. Ljubljana: Založba ZRC, 2002.

-.-. "Trialisticni Koncepti Veliko Avstriskih Krogov in Slovensko Vprašanje." Slovenci v Evropi (o Nekaterih Vidikih Slovenske Povezanosti s Sosedi in Evropo). Ed. Peter Vodopivec. Ljubljana: Historia 5 Znanstvena Zbirka Oddelka za Zgodovino Filozofske Fakultete Univerze v Ljubljani, 2002. 4353.

Rajic, Vlado. "Katoličkoj Crkvi Posvlastice u Povratu Imovine-Ostaju." Jutarnji List 12 July 2000: 20.

Rajšp, Vinenc. "Prispevek Katoliške Duhovščine k Promociji Slovenskega Jezika in

Slovenske Narodnosti," Slovenija 1848-1998: Iskanje Lastne Poti. Eds. Stane Granda and Barbara Šatej.Ljbuljana: Zveza Zgotovinskih Društev Slovenije, 1998. 
Ramet, Pedro. "The Catholic Church in Yugoslavia 1945-1989." Catholicism and Politics in Communist Societies. Ed. Pedro Ramet. Durham: Duke University Press, 1990. 183-206.

---, ed. Catholicism and Politics in Communist Societies. Durham: Duke University Press, 1990.

--.. "Catholicism and Politics in Socialist Yugoslavia." Religion in Communist Lands 10 (1982): 256-272.

--- Nationalism and Federalism in Yugoslavia 1963-1983. Bloomington University of Indiana Press, 1984.

---, ed. Religion and Nationalism in Soviet and East European Politics. Durham: Duke University Press, 1989.

---, ed. Yugoslavia in the 1980s. Boulder Westview, 1985.

Ramet, Sabrina Petra, ed. Adaptation and Transformation in Communist and Post Communist Systems. Boulder: Westview, 1992.

--. Balkan Babel: The Disintegration of Yugoslavia from the Death of Tito to Ethnic War. Boulder: Westview Press, 1996.

--- Cross and Commissar: The Politics of Religion in Eastern Europe and the USSR. Bloomington: Indiana University Press, 1987.

--.. "Democratization in Slovenia-the Second Stage." The Consolidation of Democracy in East-Central Europe. Eds. Karen Dawisha and Bruce Parrot. New York: Cambridge University Press, 1997. 189-225.

--. Eastern Europe and the Natural Law Tradition. Seattle: The Donald W. Treadgold Papers, the Henry M. Jackson School of International Studies, University of Washington, 2000.

---. Eastern Europe: Politics. Culture, and Society Since 1939. Bloomington: Indiana University Press, 1998.

-.-. Nationalism and Federalism in Yugoslavia, 1962-1991. Bloomington: Indiana University Press, 1992. 
--.. Nihil Obstat: Religion, Politics, and Social Change in East-Central Europe and Russia. Durham: Duke University Press, 1998.

---, ed. The Radical Right in Central and Eastern Europe Since 1989. University Park: Pennsylvania State University Press, 1999.

-.-. "Sacred Values and the Tapestry of Power: An Introduction." Render Unto Caesar: The Religious Sphere in World Politics. Eds. Sabrina-Petra Ramet and Donald W. Treadgold. Washington: The American University Press, 1995. 3-21.

---. "The Serbian Church and the Serbian Nation." Render Unto Caesar: The religious Sphere in World Politics. Eds. Sabrina-Petra Ramet and Donald W. Treadgold. Washington: The American University Press, 1995. 301-325.

--.. "Slovenia Since 1990." East European Studies Meeting Report 22722 Feb. 2001. <http://www.wwics.si.edu/ees/report>.

---. Whose Democracy? Nationalism, Religion, and the Doctrine of Collective Rights in Post-1989 Eastern Europe. New York: Rowman and Littlefield Publishers, Inc., 1997.

Ramet, Sabrina Petra, and Ljubisa S. Adamovic, eds. Beyond Yugoslavia: Politics, Economics, and Culture in a Shattered Community. Boulder: Westview Press, 1995.

Rašeta, Boris. "Government and Church at War." Aim Press 14 Nov. 2001. 3 Sept. $2002<\mathrm{http}: / /$ www.aimpress.org $>$.

-.-. "Krist u Pričuvi." Feral Tribune 7 Apr. 1997: 4.

Rašeta, Boris, and Ivana Erceg. "Kapotolski New Deal." Feral Tribune 29 Sept. 2001: 4.

Rawls, John. Political Liberalism. New York: Columbia University Press, 1993.

---. A Theory of Justice. Cambridge: Harvard University Press, 1971.

Rehar, Marija Čipić. "Priprava, Sprejem in Pomen Protokola Med SFRJ in Svetim Sedežem." Ljubljana: Inštitut za Novejšo Zgodovino, 2002. 1-24. 
Rekhviashvili, Irakli. "Decentralization Experience and Reforms: Case Study on Croatia." World Bank 1999.

$<$ http://www.worldbank.org/wbiep/decentralization/module1/croatiacasestu dy.html $>$.

Rendon, Jim. "When Nations Need a Little Marketing." New York Times 23 Nov. 2003: 5 .

Renić-Miločević, Ivo. "Retracing the Past to the Cradle of Croatian History." East European Quarterly 36 (2002): 1-23.

Renne, Tanya, ed. Ana's Land: Sisterhood in Eastern Europe. Boulder: Westview Press, 1997.

Repe, Božo. "The Introduction of Political Parties and Their Role in Achieving Independence." The Repluralization of Slovenia in the 1980s: New Revelations from Archival Records. Eds. Leopoldina Plut-Pregelj, Aleš Gabrič, and Božo Repe. Seattle: The Donald W. Treadgold Papers, the Henry M. Jackson School of International Studies, University of Washington, 2001. 36-58.

---. Jutri je Nov Dan: Slovenci in Razpad Jugoslavije. Ljubljana: Modrijan, 2002.

--.. "Liberalizem" v Sloveniji. Ljubljana: Borec, 1992.

---. Slovenci v Odsemdesetih Letih. Ljubjana: Zveza Zgodovinkih Društev Slovenije, 2001.

"Report on Slovenia's Progress towards Accession to the European Union." Republic of Slovenia June 2002. 24 Sept. $2002<$ http://www.gov.si/svex>.

Republic of Croatia. "The 2001 Census: Smaller Population, More Croats." Vlada June/July 2002. 6 Sept. $2002<$ http://www.vlada.hr/bulletin/2002/junejuly/focus-full>.

---. "The Constitution of the Republic of Croatia." Official Gazette 1998. 17 Jan. $2001<\mathrm{http}: / /$ www.usud.hr/html/the_consitution_of_the_republic $>$.

---. "Constitutional Law on the Rights of National Minorities." Narodne Novine 23 Dec. 2002. 18 Jul. $2003<$ http://www.nn.hr>. 
--.. "Croatia and Vatican Sign Economic Agreement." Vlada Oct 1988. 4 Jan. $2001<$ http://www.vlada.hr/bulletin/1998/October/focus-full>.

--.. "Decision on Compensation for Property Seized During Yugoslav Communist Rule." Official Gazette 39 (1999): 1118-1126.

---. "Education and Training Laws." Narodne Novine Mar. 1996. 11 Jan 2004 $<$ http://www.nn.hr>.

---. "Law on the Coat-of-Arms, the Flag, and the National Anthem of the Republic of Croatia, and on the Flag and Sash of the President of the Republic of Croatia." Official Gazette 34 (1990): 1-34.

---. "Ugovor Između Vlade Republicke Hrvatske i Srpsku Pravoslavnu Crkvu u Hrvatskoj o Pitanjima od Zajedničkog Interesa." Narodne Novine 23 Dec. $2002<$ http://www.nn.hr>.

---. "Ugovor Između Svete Stolice i Republike Hrvatske o Gospodarskim Pitanjima Sveta Stolica I republika Hrvatska." Official Gazette 18 (1998): 1-25

---. White Paper on Croatian Education Strategy for the Development of the Republic of Croatia. Zagreb: Office for the Strategy of the Development of the Republic of Croatia, 2001.

---. "Zakon o Naknadi za Imovinu Oduzetu za Vrijeme Jugoslavenke Komunističke Vladavine." Official Gazette 92 (1996): 324-346.

---. Zakon o Osnovnom Školstvu. Narodne Novine 31 Dec.

1990.<http://www.nn.hr>.

---. "Zakon o Porodnom Dopustu Majki koje Obavljaju Samostalnu Djelatnost I Nezaposlenih Majki." Official Gazette 24 (1996): 165-178.

---. "Zakon o Pravnom Polažaju Vjerskih Zajednica." Narodne Novine 2002. $<$ http://www.nn.hr>.

---. "Zakon o Radu." Official Gazette 38 (1995): 582-601.

--.. "Zakon o Srednjem Školstvu." Narodne Novine 2 Apr. 1992. $<$ http://www.nn.hr>. 
Republic of Slovenia. "The Constitution of the Republic of Slovenia." Official Gazette 1991. 3 Jan. $2001<$ http://www.us-rs.si>.

---. "Constitutional Court Act." Official Gazette 1994. 11 Dec. 2002 $<$ http://www.us-rs.si>.

--.. "Independence Day and 10thAnniversary of the Plebiscite." Public Relations and Media Office June 2001. 4 Nov. $2002<$ http://www.uvi.si/eng/ slovenia/backround-information/plebiscite $>$.

-.-. "Law on the Coat-of-Arms, Flag and the National Anthem of Republic of Slovenia." Official Gazette RS 67 (1990):1-10.

---. Local Self-Government to Slovenia. Ljubljana: Center Vlade RS za Informatiko, 2002.

---, Poročevalec 21 Dec. 1995: 80-81.

---. "Religious Communities in Slovenia 1997-2002." Government Office for Religious Communities 9 Feb. $2001<\mathrm{http} / /$ www.gov.si/uvs/ang/aindex>.

-.-. "Second Report of the Republic of Slovenia on the Implementation of the Provisions of the Convention to the Committee on the Elimination of Discrimination against Women." Office for Equal Opportunities Jan. 1999. 27 Apr. $2001<$ http://www.uem-rs.si>.

---. Soglasje: Komisije Vlade Republike Slovenije za Rešitev Odprtih Vprasanj Rimskokatoliske Cerkve in Komisije Slovenske Škofovske Konference za Ureditev Odnosov z Drzavo. Ljubljana: Republic of Slovenia, 1999.

---. Sporazum o Pravnem Polozaju Evangelicanske Cerkve v Republiki Sloveniji. Ljubljana: Republic of Slovenia, 2000.

---. Sporazuma med RS in Svetim Sedežem o Pravnih Vprašanjih. Ljubljana: Republic of Slovenia, 1999.

---. "The State and Religious Communities in the Republic of Slovenia. Office for Religious Communities. 7 Oct. $2002<$ http://www.gov.si/uvs/ang/aindex>.

-.-. "Zakon o Organizaciji in Financiranju Vzgoje in Izobraževanje." Uradni List Jan. $2003<$ http://www.zakonodaja.gov.si>. 
---. "Zakon o Ratifikaciji Sporazuma med Republiko Slovenijo in Svetim Sedežem o Pravnih Vprašanjih." Uradni List 12 Feb. 2004. 17 Oct. 2004 $<$ http://www.uradnilist.si >.

Republic of Slovenia, Ministarstvo za Zunanje Zadeve. "Sporazum med Republiko Slovenijo in Svetim Sedežem o Pravnih Vprašanjih." EVA 3.21 (2002): 1811-2004.

Republic of Slovenia, Ministry of Labour, Family and Social Affairs. "Statement of the Republic of Slovenia to the Hague Forum 8-12 February 1999." United Nations 26 Jan. 2001 $<$ http://www.un.org/popin/icpd/icpd5/hague/slovenia.pdf $>$.

Reuschemeyer, Dietrich, and Theda Skocpol. States, Social Knowledge, and the Origins of Modern Social Policies. Princeton: Princeton University Press, 1996.

Ridley, Jasper. Tito: A Biography. London: Constable, 1994.

Rizman, Rudolf M. "Radical Right Politics in Slovenia." The Radical Right in Central and Eastern Europe since 1989. Ed. Sabrina-Petra Ramet. University Park: Pennsylvania State University Press, 1999. 155-177.

--.. "Radikalna Desnica na Slovenskem.” Teorija in Praksa 2 (1998): 249-270.

Rogel, Carole. "In the Beginning: The Slovenes From the Seventh Century to 1945." Independent Slovenia: Origins, Movements, Prospects. Eds. Jill Benderly and Evan Kraft. New York: St. Martin's Press, 1994. 3-21.

-.-. "The Slovenes and Cultural Yugoslavism on the Eve of World War I." Canadian Slavonic Studies 2.1 (1968): 221-276.

---. The Slovenes and Yugoslavism, 1890-1914. New York: Columbia University Press, 1977.

Roglič, Meta. "Od Dosežka do Skrpucala.” Dnevnik 7 Dec. 2001. 26 Feb. 2002 $<$ http://www.dnevnik.si>.

--.. "Vlada je Storila." Dnevnik 26 Jan. 2002. 26 Feb 2002 $<$ http://www.dnevnik.si>. 
Roglič, Meta, and Sonja H. Vogrič. "Vatikanski Sporazum, Njega Križi in Težave." Dnevnik 6, 11, 2001: 14.

Rogošić, Željko. "Sveti Duje u Stredištu Financijskog Skandala." Nacional 9 Dec. 1999. <www.nacional.hr>.

Rohrbacher, Robert J., and Bishop J. "Strossmayer's Yugoslavism in the Light of the Eastern Crisis of 1875-1878." East European Quarterly 15.3 (2001): 343-371.

Roksandic, Drago. "Shifting References: Celebrations of Uprisings in Croatia, 1945-1991." East European Politics and Societies 9.2 (1995): 256-271.

Rotar, Bračko. "Milenrizem in Šolsvo." Delo 11 Feb. 1995: 16.

---. "Slovenia: Statistics." European Centre for Minority Issues 2002. 3 Mar. 2003 $<$ http://www.ecmi.de/emap/slo_stat $>$.

Roter, Zdenko. Katoliška Cerkev v Jugoslaviji 1945-1973. Ljubljana: Cankarjeva Založba, 1976.

--.. "Premišljevanje o (Katoliški) Sloveniji." Teorija in Praksa 7/8 (1992): 627-636.

-.-. "Revitalizacija Religije v Sloveniji Konec Osemdesetih Let." Nova Revija 83/84 (1989): 439-446.

Roth, Guenther, and Wolfgang Schluchter, eds. Max Weber's Vision of History: Ethics and Methods. Berkeley: University of California Press, 1979.

Rothenberg, Gunther . The Austrian Military Border in Croatia 1740-1881. Chicago: University of Chicago Press, 1966.

Rothschild, Joseph. East Central Europe between the Two World Wars. Seattle: University of Washington Press, 1977.

Rothschild, Joseph, and Nancy M. Wingfield. Return to Diversity: A Political History of East Central Europe Since World War II. New York: Oxford University Press, 2000.

Rueschemeyer, Dietrich A., Evelyne Huber Stephens, and John D. Stephens. Capitalist Development and Democracy. Chicago: University of Chicago Press, 1992. 
Rusinow, Dennison. Introduction. The Repluralizaiton of Slovenia in the 1980s: New Revelations from Archival Records. Ed. Leopoldina Plut-Pregelj Seattle: The Donald W. Treadgold Papers, the Henry M. Jackson School of International Studies, University of Washington, 2000. 11-16.

---. The Yugoslav Experiment 1948-1974. London: C. Hurst \& Company, 1977.

Sadkovich, James J. "Terrorism in Croatia, 1929-1934." East European Quarterly 22.1 (1988): 55-76.

Safer, Morley. "Mostar: Nation Building." 60 Minutes 20 Oct. 2003. 23 Jun. 2004 $<$ http://www.cbsnews.com>.

Šagi, Bono Zvonimir. “Crkva u Postkomunizmu.”Vijenac 86 (1997): 151-179.

Sahlberg, Pasi. "Changing Croatian Education System as a part of Stabilization and Association Processes: Final Conclusions." International Conference on Education, May 24-25, 2002. Zagreb, 2002. 1-45.

Sajo, Andras, Shlomo Avineri, and Lorri Rutt Bentch. The Law of Religious Identity: Models for Post-Communism. The Hague: Kluwer Law International, 1999.

Sakwa, Richard. Postcommunism. Philadelphia: Open University Press, 1999.

Sandel, Michael J. Liberalism and the Limits of Justice. Cambridge: Cambridge University Press, 1981.

Šanjek, Franjo. Kršćanstvo na Hrvatskom Prostoru. Zagreb: Kršćanska Sadašnjost, 1996.

Santić, Neven. "S Slučaj Šešelj.” Novi List 9 Apr. 2003. 16 Sept. 2003 $<$ http://www.novilist.hr>.

Schmitter, Philippe C., and Terry Lynn Karl. "The Conceptual Travels of Transitologists and Consolidologists: How Far to the East Should They Go?" Slavic Review 53.1 (1994): 173-185.

Schopflin, George. "Konservativna Politika in Konservativni Dejavniki v Postkomunisticnih Družbah." Nova Revija 133 (1993): 515-524. 
-.-. Politics in Eastern Europe. Cambridge: Blackwell, 1993.

Schrapf, Fritz W. "Institutions in Comparative Policy Research." Comparative Political Studies 33.6/7 (2000): 762-790.

Schumpeter, Joseph A. Capitalism, Socialism and Democracy. New York: Harper and Brothers, 1976.

Scott, Hamish M., ed. Enlightened Absolutism: Reform and Reformers in Later Eighteenth-Century Europe. Hampshire: Macmillan, 1990.

Šega-Čeh, Barbara. "Religia s Temelji Etike." Mladina 12 Dec. 1995: 26-27.

Segers, Mary C., and Ted G. Jelen, eds. A Wall of Separation?: Debating the Public Role of Religion. Lanham: Roman \& Littlefield Publishers, 1998.

Seselj, Zlatko. Interview. "Implementing Catechism in Pre-Schools is Not a Good Idea." Nacional 22 Nov. 2001. <www.nacional.hr>.

Setinc, Franc, ed. Izganci. Ljubljana: Društvo Izgancev Slovenije, 1993.

Seton-Watson, Hugh. Eastern Europe Between the Wars, 1918-1941. Cambridge: Cambridge University Press, 1946.

Seton-Watson, Robert W. The Southern Slav Question and the Habsburg Monarchy. London: Constable, 1911.

Sever, Jani. "Defeat of Liberalism." Mladina 20 June 2001. 4 Nov. 2002 $<\mathrm{http}: / /$ www.mladina.si $>$.

Shafir, Michael. "Deflective Negationism of the Holocaust in Postcommunist EastCentral Europe (Part 4): Deflecting the Guilt to the Jews." Radio Free Europe/Radio Liberty, East European Perspectives 30 Oct. 2002. 11 Nov. $2002<\mathrm{http}: / /$ www.rferl.org/eepreport/2002/10/22-301002>.

Shanks, Andrew. Civil Society, Civil Religion. Oxford: Blackwell, 1995.

Shenk, Gerald. God with US?: The Roles of Religion in Conflicts in the Former Yugoslavia. Upsala: Life and Peace Institute, 1993.

Shoup, Paul. Communism and the Yugoslav National Question. New York: Columbia University Press, 1968. 
Shumpeter, Joseph Alois. Capitalism, Socialism and Democracy. London: Allen \& Unwin, 1976.

Šidak, Jaroslav. Kroz Pet Stolieća Hrvatske Povijesti. Zagreb: Školska Knjiga, 1981.

Šidak, Jaroslav, Mirjana Gross, Igor Karaman, and Dragovan Šepić. Povijest Hrvatskog Naroda, 1860-1914. Zagreb: Školska Knjiga, 1968.

Silber Laura, and Alan Little. "The Death of Yugoslavia. London: Penguin Books and BBC Books, 1997.

Singleton, Fred. Twentieth Century Yugoslavia. New York: Columbia University Press, 1976.

Singleton, Fred, and Bernard Carter. The Economy of Yugoslavia. New York: St. Martin's Press, 1982.

Skocpol, Theda. Protecting Soldiers and Mothers: The Political Origins of Social Policy in the United States. Cambridge: Belknap Press of Harvard University Press, 1992.

---. States and Social Revolutions. Cambridge: Cambridge University Press, 1979.

---. "Why I am an Historical Institutionalist." Polity 28.1 (1995): 103-106 .

Slana-Miros, Miroslav. Oživitev Dr. Antona Korošca: Oče Domovine na Tehtnici. Maribor: Založba za Alternativno Teorijo, 1991.

“Slovene Parliament Ratifies Vatican Agreement." Delo 28 Jan. 2004: 6.

Slovene Writers Association. The Case of Slovenia Ljubljana. Ljubljana: Nova Revija July 1991.

"Slovenia: Protection of Conscience Laws." Protection of Conscience Project. 12 Oct. $2002<$ http://www.consciencelaws.org/Slovenia>.

"Slovenia to Return Church Property." Radio Free Europe/Radio Liberty 7 Apr. 1997. 3 Sept. $2002<$ http://www.rferl.org/newsline/1997/07/4-SEE/see250797>. 
Slovenian Bishops' Conference. Izberi Zivljenje: Sklepni Document Plenarnega Zbor Cerkve na Slovenskem. Ljubljana: Družina, 2002.

--. Pastisko Pismo ob Začetko Šolskega Leta, 1998/1999. Ljubljana: Družina, 1998.

"Slovenian Minority Legally Protected." Slovenia Weekly June 2001. 7 Oct. 2002 $<$ http://www.vitrum.si/2001/stari/sw2001-07-accession>.

Slovenian School Museum. Pedagoski Pogledi na Antona Martina Slomska: Zbornik ob Raztavi. Ljubljana: Slovenski Solski Muzej, 1999.

Šmidovnik, Janez. "Bo Cerkvi Uspelo še Enkrat Prodati to, Kar je že Prodala?" Delo 24 Oct. 1998: 21.

---. "Dysfunctions of the System of Self-Management in the Economy, in Local Territorial Communities and in Public Administration." Yugoslavia in Turmoil: After Self-Management? Eds. James Simmie and Jože Dekleva. New York: Pinter Publishers, 1991. 17-32.

Smith, Anthony D. The Ethnic Origins of Nations. New York: Blackwell. 1986.

Smith, Christopher. "Written Testimony of Vladislav Bevc, American Owners of Property in Slovenia, and Slovenian Association of Former Owners of Expropriated Property: The Long Road Home: Struggling for Property Rights in Post-Communist Europe." Commission on Security and Cooperation in Europe 25 Mar. 1999. 19 Nov. 2002 $<$ http://www.house.gov/csce/032599>.

Smrke, Marjan. "Naj se Držaljani Zaradi Cerkve Razdržavimo." Delo 7 Aug. 1999: 16.

---. Religija in Politika: Spremembe v Deželah Prehoda. Ljubljana: Znanstveno in Publicistično Središče, 1996.

Snježana, Šetka, Zoran Šagolj, and Mirjana Ljubić. "150 Tisuća Puta Svi Smo Mi Mirko Norac." Slobodna Dalmacia 12 Feb. 2001. 14 Feb. 2001 $<$ http://www.slobodnadalmacia.hr $>$.

Snežič, Jasna. "Verouka ali Confeionalnega Verskega Pouk v Javni Šoli (se) Ni." Vecer 10 Dec. 2001: 11. 
Snoj, Slavko. "Cerkveni Dokumenti o Vlogi Verskega Pouk v Sodobnem Šolstvu." Bogoslovski Vestnik 61.3 (2001): 273-287.

Socialist Federal Republic of Yugoslavia. The Constitution of the Socialist Federal Republic of Yugoslavia. Trans. Marko Vavicic. Belgrade: Socialist Federal Republic of Yugoslavia, 1974.

Šošić, Mirjana. "Ministarstvo Obrane Gradi Vojni Ordinarijat." Novi List 18 Oct. 1997:

2.

Šoštarič, Marjeta. "Sem Minister, Ki Se Ga Drži Smola, Interview z Franc But, Minister

za Kmetijstvo, Gozdarstvo in Prehano." Delo 22 Sept. 2001: 21.

Spajic-Vrkas, Vedrana. "Education Policy in Education for Democratic Citizenship and the Management of Diversity in South East Europe: Stocktaking Research Project, Country Report: Croatia." Stability Pact for South Eastern Europe Sept. 2001. 7 Nov. $2002<\mathrm{http}$ ://www.see-educoop.net>.

"Sporazum med Republica Slovenijo in Sveta Sedežem o Pravnih Vprašanjih." Dnevnik 11 Nov. 1999.<http://www.dnevnik.si>.

"The Stabilisation and Association Process (SAP): Second Annual Report, Report from the Commission." Brussels Commission of the European Union 26 Mar. 2003. 14 Sept. 2003 $<$ europa.eu.int/comm/external_relations/see/sap/rep2/com03_341>.

"Stabilization and Association Report Croatia, 2002." Commission for the European Communities 4 Apr. 2002. 3 Nov. 2003 $<$ http:/www.europa.eu.int>.

Starčević, Ante. Misli i Pogledi. Ed Blaž Jurišić. Zagreb: Matica Hrvatska, 1971.

"State and Religious Communities: The Culture of Dialogue." Slovenia Weekly 7 Dec. 2000. 27 Jan. $2001<$ http://www.sloweekly.vitrum.si>.

"The State and Religious Communities in the Republic of Slovenia." Republic of Slovenia, Office for Religious Communities 2000. 9 Jan. 2001 $<$ http://www.sigov.si/uvs $>$. 
Štefanič, Bogoir. Interview with Bishop of Maribor Anton Stres. "Šole Kot Simboli Države: Ob Rob Razpravi o Konfesionalnosti v šolskem Prostoru." Družina $1062002: 23$.

Stepan, Alfred." Religion, Democracy, and the "Twin Tolerations." Journal of Democracy 37 (2001): 37-55.

--.. State and Society. Princeton: Princeton University Press, 1978.

Stojanović, Traian. Balkan Worlds: The First and Last Europe. Armonk: M. E. Sharpe, 1994.

Stokes, Gale. Three Eras of Political Change in Eastern Europe. Toronto: Oxford University Press, 1997.

Strecha, Mario. Katoličko Hrvatstvo: Počeci Politickog Katoličizma u Banskoj Hratskoj 1897-1904. Zagreb: Barbat, 1997.

Stres, Anton. Cerkev in Država. Lubljana: Družina, 1998.

---. "The Church in a Democratic State after the Model of Slovenia." Religion State and Society 28.3 (2000): 291-299.

---. "Katoliška Cerkev Je in Bo Ostala Zavezana Pravičnosti." Delo 7 Feb. 1998: 4.

---. "Naš Komentar, Sporazum: Da Ali Ne." Družina 12 Dec. 1999: 3.

Strjan, Darko, ed. Meje Demokracije. Ljubljana: Liberalna Akademija, 1996.

Štuhec, Ivan. "Svoboda Veroizpovedi in Šolska Zakonodaja." Zvon 1 (1998): 6271.

Štuhec, Ivan, Julka Nežič, Peter Kvaternik, and Lojze Cvikl, eds. Izberi Življenje: Sklepni Dockument Plenarnega Zbora Cerkve na Slovenskem. Ljubljana: Družina, 2002.

Šturm, Lovro. “Brez Fig v Žepu.” Dnevnik 15 Dec. 2001. 6 Jan. 2002 $<$ http://www.dnevnik.si>.

Šunji, Marijan. "Higher Education in Croatia: Unfinished Reform." International Higher Education 26.4 (2002): 1-26. 
Sugar, Peter F. "East European Nationalism, Politics and Religion." Variorum Collected Studies Series, Studies in East-Central Europe. Brookfield: Ashgate, 1999.

---, ed. Native Fascism in the Successor States, 1918-1945. Santa Barbara: AbcClio, 1971.

---. Southeastern Europe under Ottoman Rule. Seattle: University of Washington Press, 1977.

Sully, Melanie A. The Haider Phenomenon. New York: East European Monographs, Columbia University Press, 1997.

Šuštar, Branko, ed. Pedagoski Pogledi na Antona Martina Slomska. Ljubljana: Slovenski Šolski Muzej, 1999.

Šverc, Alenka. "Šola Med Laičnostjo in Laicizmom." Družina 29 Nov. 1998: 9.

Svetlik, Ivan. Social Policy in Slovenia. Brookfield: Avebury, 1992.

Svetlik, Ivan, and Andreja Brle-Lakota. "Plenary Session Paper Curricular Reform the Case of Slovenia: Strategies of Educational Reform in South East Europe Countries, Beld, Slovenia, 8-10 June 2000." South East European Educational Cooperation Network 8 Jan. $2001<\mathrm{http}: / / \mathrm{www}$. seeeducoop.net>.

Swatos, William H., ed. Politics and Religion in Central and Eastern Europe: Traditions and Transitions. Westport: Praeger, 1994.

Szacki, Jerzy. Liberalism after Communism. New York: Central European University Press, 1995.

Tamhane, Mark. "Nationalist Democratic Union Party wins Croatian Elections." The World Today 25 Nov. 2003: 1

Tanackovic, Tatjana. "Hrvati Kaznovali Jorasa." Dnevnik 7 Dec. 2000. 20 Oct. $2002<$ http://www.dnevnik.si>.

Tanner, Marcus. Croatia: A Nation Forged in War. New Haven: Yale University Press, 1997. 
Taškar, Jana. "V Javnih Izobraževanih Programih Verouka Ne Bo." Delo 11 Dec. 2001: 24.

Taylor, Charles. Philosophy and the Human Sciences, Philosophical Papers. Cambridge: Cambridge University Press, 1985.

Testen, Franc. "Case Number: U-I-68/98, E-66/01." Ustavno Sodisce Republike Slovenije" 19 July 2002.

Thelen, Kathleen. "Historical Institutionalism in Comparative Politics." Annual Review of Political Science 2 (1999): 369-371.

Thelen, Kathleen, and Sven Steinmo. Structuring Politics: Historical Institutionalism in Comparative Analysis. Cambridge: Cambridge University Press, 1992.

Therborn, Goran. European Modernity and Beyond: The Trajectory of European Societies 1945-2000. London: Sage Publications, 1995.

Thiemann, Ronald F. Religion in Public Life: A Dilemma for Democracy. Washington, D.C.: Georgetown University Press, 1996.

Thompson, Mark. "South Eastern Europe: New Means for Regional Analysis, Policy Brief No. 2." International IDEA, Institute for Democracy and Electoral Assistance 2002. 3 Jan. $2003<$ http://www.idea.int/balkans>.

Tilly, Charles. Big Structures, Large Processes, Huge Comparisons. New York: Russell Sage, 1981.

Tismaneanu, Vladimir. Fantasies of Salvation: Democracy, Nationalism, and Myth in Post-Communist Europe. Princeton: Princeton University Press, 1998.

Tolstoy, Nikolai. The Minister and the Massacres. London: Century Hutchinson Ltd., 1986.

Toma, Ivanka, and Darko Pavičić. "Sukob Bozanić-Zunec: Je Li Ugovor Vatikana i Hratske Neustavan?" Jutarnji List 5 Jan. 2002: 27.

Tomašević, Jožo. The Chetniks: War and Revolution in Yugoslavia, 1941-1945. Stanford: Stanford University Press, 1975. 
--. Peasant Politics and Economic Change in Yugoslavia. Stanford: Stanford University Press, 1955.

--. War and Revolution in Yugoslavia, 1941-1945, Occupation and Collaboration. Stanford: Stanford University Press, 2001.

Tomažic, Dore. “Revija 2000.” Nedelski Dnevnik 31 Dec. 2000. 7 Jan. 2001 $<$ http://www.dnevnik.si>.

Tomc, Gregor. Profano Kultura v Modernem Svetu. Ljubljana: Knjižna Zbirka KRT, 1994.

-... "Slovensko Domobranstvo: Od Kontrarevolucije do Kolaboracije." Rdeče in Crno: Slovensko Partizanstvo in Domobranstvo. Eds. Doroteja Lešnik and Gregor Tomc. Ljubljana: Znanstveno in Publicistično Središče, 1995. 150265 .

---. "Spori in Spopadi Druge Slovenije." Punk Pod Slovenci. Eds. Igor Bavčar and Tomaž Mastnak. Ljubljana: Knjižnica Revolucionarne Teorije, 1984. 10-39.

Tomc, Gregor, Radmila Pavlovic, Andreja Potokar, Peter Barbaric, Rastko Mocnik, Peter Mlakar, and Marjan Ogrinc. Punk Pod Slovenci. Ljubljana: Borec, 1985.

Tomka, Miklos, and John Coleman, eds. Religion and Nationalism. London: SCM Press Concilium, 1995.

Tomka, Miklos, and Paul M. Zulehner. Religion during and after Communism. London: SCM Press Concilium, 2000.

Torov, Ivan. "DOS vs. DOS." Trans. Dragan Stojkovic. Transitions On-Line 2001. 29 July $2001<\mathrm{http}: / /$ www.tol.cz>.

Toš, Niko. "Non-Religiousness in Slovenia." George Fox University Jan. 2002 $<$ http://www.georgefox.edu/ree/html_articles/TOS.REL.html $>$.

---. Slovenski Izziv II. Ljubljana: CRJM, 1994.

Toš, Niko, Vinko Potocnik, Sergej Flere, Marjan Smrke, Samo Uhan, and Srečo Dragoš.

Podobe o Cerkvi in Religiji (na Slovenskem v 90-ih). Ljubljana: Fakulteta za Duzbene Vede, Center za Raziskovanje Javnega Mnenja in 
Množičnih Komunikacija, 1999.

Toš, Niko et. al. "Slovensko Javno Mnenje." Center za Raziskovanje Javnega Mnenja in

Množičnih Komunikacija. Ljubljana: FDV: CJMMK, 1994.

"The Train of Freedom." Croatia Radio Television On-Line 26 Aug. 1995. 6 Dec. $2003<$ http://www.hrt.hr>.

Trifković, Srdjan. "The First Yugoslavia ad Origins of Croatian Separatism." East European Quarterly 26.3 (1992): 175-191.

Truman, David. The Governmental Process. New York: Knopf, 1971.

Tudjman, Franjo. Bespuća Povijesne Zbiljnosti: Rasprava o Povijesti i Filozofiji

Zlosilja.

Zagreb: Nakladni Zavod Matice Hrvatske, 1989.

---. "Declaration of the New Constitution." Croatian Radio and Television On-Line

22

Dec. 1990.<http://www.hrt.hr/ tudjman/ustav90-eng.html> .

---. The Horrors of War: Historical Reality and Philosophy. New York: M. Evans and Company, 1996.

Turčin, Kristina. "Sveta Stolica Oštro će Ukoriti Hrvatsku jer ne Vraća Nacionalizirane Objekte." Jutarnji List 29 Sept. 2001: 11.

Udovički, Jasmina, and James Ridgeway, eds. Burn This House: The Making and Unmaking of Yugoslavia. Durham: Duke University Press, 1997.

Ugrin, Ivan. "I Veliki Petak-Neradni Dan!?" Slobodna Dalmacija 7 Dec. 1996: 3.

---. "Tujce Nećemo, Svoje ne Damo." Slobodna Dalmacija 12 Jan. 2002: 4-5.

Ule, Mirjana, and Tanja Rener, eds. Youth in Slovenia: New Perspectives from the Nineties. Ljubljana: Republic of Slovenia Youth Department, 1997.

"United Nations Chief Prosecutor Confident of Croatia's Cooperation with Court." EU Business 30 Jan. 2004. 5 Feb. $2004<$ http://www.eubusiness.com>. 
United Nations High Commissioner for Human Rights. "Summary Record of the 281 Meeting: Croatia, CRC/C/SR.281." UN Secretariat 23 Jan. 1996. 17 Nov. $2002<$ http://www.unhcr.org>.

United States of America. "Country Report: Croatia, 2000." Committee for Refugees 19 Sept. $2001<\mathrm{http}$ ://www.refugees.org>.

-.-. "Country Report on Human Rights Practices: Slovenia." Department of State 13 Mar. $2002<$ http://www.state.gov>.

---. "Country Report: Slovenia, 2000." Committee for Refugees 3 May 2001 $<$ http://www.refugees.org $>$.

-.-. "International Religious Freedom Report, Croatia 2003." Department of State, Bureau of Democracy, Human Rights and Labour 18 Dec. 2003. 19 Dec. $2003<$ http://www.state.gov>.

---. "Report on Religious Freedom, Croatia 1999." Department of State 9 Sept. 1999. 18 Dec. $2002<$ http://www.state.gov>.

--.. "Report on Religious Freedom, Croatia 2001." Department of State 26 Oct. 2001. January $232003<\mathrm{http}: / /$ www.state.gov>.

---. "Report on Religious Freedom, Croatia 2002." Department of State 7 Oct. 2002. 18 Dec. $2002<$ http://www.state.gov>.

---. "Report on Religious Freedom, Croatia 2003." Department of State 12 Feb. $2003<$ http://www.state.gov>.

--.. "Summary of Property Restitution in Central and Eastern Europe." United States of America Embassy in Germany 16 July 2002. 29 Nov. 2002 $<$ http://www.usembassy.de/policy/holocaust/property $>$.

-.-. "Testimony by Under Secretary of State Stuart E. Eizenstat before the Commission on Security and Cooperation in Europe on Property Restitution in Central and Eastern Europe." Association for Denationalization in Macedonia 25 Mar. 1999. 9 Oct. $2001<$ http://www.restitution.org/uscongress>.

“Ustav Savezne Republike Jugoslavije.” Službeni List 1974.

Uzelać, Alan. "Od Liberalizma do Katoličizma: Neki Aspekti Pravnih Odnosa 
Izmedju

Crkve i Države u Republici Hrvatskoj-Novo Pravno Uredjenje Braka." Zbornik PFZ 49.3/4 (1999) 341-374.

Uzelak, Gordana. "Franjo Tuđman's Nationalist Ideology." East European Quarterly 31.4 (1998) 449-472.

Valković, Marijan. "Vera I Moral U Hrvatskoj, Djelomično Izvješće, Opći Uvod." Bogoslovska Smotra 22.4 (1998) 461-473.

Velikonja, Mitja. "Slovenia's Yugoslav Century." Yugoslavism: Histories of a Failed 1918-1992. Ed. Dejan Djokić. London: Hurst \& Company, 2003. 85100.

---. "Slovenian Sociology of Religion." Religion. State. and Society 27.1 (1999): $147-151$.

Velimirović, Nikolaj. "Konkordatska Borba 1937 Godine." Vladika Nikolaj: Izabrana Dela, Knjiga XII. Eds. Ljubomir Ranković, Radovan Bigović, and Mitar Milovanović. Valjevo: Glas Crkve, 1997. 310-324.

Vezić, Goran. "Priests Flex Their Muscles." Balkan Crisis Report 2 Aug. 2002. 16 Dec. $2002<\mathrm{http} / /$ www.iwpr.net>.

Vid, Mlakar. "Izborni Grijeh Crkvenih Struktura." Jutarnji List 5 Jun. 1999: 20.

Vidovac, Davorko. "Ministry of Labour and Social Welfare: Enhancing Social Protection and Reducing Vulnerability in a Globalizing World." Croatian Mission to the UN 14 Feb. 2001. 18 Oct. $2002<$ http://www.un.org >.

Vlahović, Edita. "Katolički Vjeronauk Postaje Ravan Obveznim Predmetima." Jutarni

List 23 Oct. 1998: 9-10.

---. “Krsi li Vlada Ugogorom o Djece u Vrticima Ustavnu?” Jurtani List 25 Oct. 1998: 3 .

Vodopivec, Peter. "The Historical Background to "the Slovene Question." The Case of Slovenia. Ed. Niko Grafenauer. Ljubljana: Nova Revija, 1991. 2530 . 
-.-. "Seven Decades of Unconfronted Incongruities: The Slovenes and Yugoslavia." Independent Slovenia: Origins, Movements, Prospects. Eds. Jill Benderly and Evan Kraft. New York: St. Martin's Press, 1994. 23-46.

-... "Slovene Intellectuals' Response to Political and Social Modernization in the Nineteenth and at the Beginning of the Twentieth Centuries." Slovene Studies 23.1 (2001): 5-12.

---. "The Slovenes and Yugoslavia." East European Politics and Society 6.3 (1992): 220-242.

Vončina, Marjana. "Boj za Otroške Duse.” Nedelski Dnevnik 4 Oct. 1998: 8.

Vrcan, Srdjan. "Elections in Croatia: A Symptomatic Case or an Anomaly?" Center for Democratic Transition 2000.<http://www.cedet.org.yu $>$.

--.. "Religion and Churches and the Post-Yugoslav War." Religion and Nationalism. London: Concilium, 1995. 59-67.

---. "Religious Factor in the War in B\&H." Religion and the War in Bosnia. Ed. Paul Mojzes. Atlanta: Scholars Press, 1998. 108-131.

Vucinich, Wayne S. "Interwar Yugoslavia." Contemporary Yugoslavia. Ed. Wayne S. Vucinich. Berkeley: University of California Press, 1969. 18-58.

Vuckovic, Gojko. "Failure of Socialist Self-Management to Create a Viable Nation-State, and Disintegration of the Yugoslav Administrative State and State Institutions." East European Quarterly 32.2 (1998): 353-377.

Vukovic, Vesna. "Vatikanski Sporazum." Dnevnik 10 Mar. 2000. 8 Jan. 2001 $<$ http://www.dnevnik.si>.

Weber, Max. The Methodology of Social Sciences. Glencoe: Free Press, 1949.

--. Politics as a Vocation. Minneapolis: Fortress Press, 1965.

Weber, Max, Roth Gunther, and Claus Wittich, eds. Economy and Society. Vol. 1. Trans. Ephraim Fischoff. Berkley: University of California Press, 1978.

Wellen, Richad. Dilemmas in Liberal Democratic Thought since Max Weber. Peter Lang: Baltimore, 1996. 
West, Richard. Tito and the Rise and Fall of Yugoslavia. London: SinclairStevenson, 1994.

Wilson, Duncan. Tito's Yugoslavia. London: Cambridge University Press, 1979.

Wolff, Larry. Inventing Eastern Europe: The Map of Civilisation on the Mind of the

Enlightenment. Sandford: Stanford University Press, 1994.

Wolf, Stuart Joseph. Fascism in Europe. New York: Methuen, 1968.

Woodward, Susan. Balkan Tragedy: Chaos and Dissolution after the Cold War. Washington: The Brookings Institution, 1995.

---. Socialist Unemployment: The Political Economy of Yugoslavia 1945-1990. Princeton: Princeton University Press, 1995.

"World Bank Country Brief." World Bank 17 May 2004 $<$ http://www.worldbank.hr>.

"World Report: Croatia, 2002." Human Rights Watch 2 Jan. 2003 $<$ http://www.hrw.org $>$.

"World Report: Croatia, 2003." Human Rights Watch 9 Mar. 2004 $<$ http://www.hrw.org $>$.

Wranka, Miroslav. "Vjeronauku je Mjesto u Vjerskim Zajednicama." Glas Slavonije 12 Dec. 1998: 20.

Zagar, Mitja. "The Constitution of the Republic of Slovenia." Into Europe? Perspectives from Britain and Slovenia. Eds. Danica Fink-Hafner and Terry Cox. Ljubljana: Scientific Library of the Faculty of Social Sciences, 1996. 86-101.

"Zagreb Archbishop Glad Croatian People Stand United." HRT 22 Aug. 2002. 9 Sept. $2002<$ http://www.hrt.hr/vijesti>.

Zajc, Drago. "The Changing Political System." Eds. Danica Fink-Hafner and John R. Robbins. Making a New Nation: The Formation of Slovenia. Brookfield: Dartmouth Publishing Company, 1997. 68-83. 
Zakaria, Fareed. The Future of Freedom: Illiberal Democracy at Home and Abroad. New York: W. W. Norton, 2003.

Zanić, Ivo. "The Curse of King Zvonimir and Political Discourse in Embattled Croatia." Trans. William B. Tomljanovic. East European Politics and Societies 9.1 (1995): 90-123.

Zečević, Momičilo. Na Istorijskoj Prkretnici: Slovenci u Politici Jugoslovenski Države, 1918-1929. Belgrade: Narodna Knjiga, 1979.

Žerdin, Ali H. "Denationalization, Feudalism in the 21st Century." Mladina 13 June $2001 .<\mathrm{http}: / /$ www.mladina.si $>$.

---. "Proposal to Recall Dr. Rode." Mladina 3 Nov. 2001. <http://www.mladina.si>.

Žerdin Ali H., and Jure Trampuš. "Wealth and Power." Mladina 26 Aug. 2002. 20 Nov. $2002<$ http://www.mladina.si $>$.

Zgaga, Pavel. "Educational Policy and Quality in Education." South East European Educational Cooperation Network 2000. 17 Sept. $2002<\mathrm{http} / / / \mathrm{www}$. seeeducoop.net/education_in/pdf/pbook-ways-006-zgaga-oth>.

Zibret, Andreja. "Zakaj se Mulimani ne Jedo Svinjskega Mesa?" Delo 25 Feb. 2002: 11 .

Zimmerman, Warren. Origins of a Catastrophe: Yugoslavia and its DestroyersAmerica's Last Ambassador Tells What Happened and Why. New York: Random House, 1996.

Živkovic, Mario. Points for Discussion: Tribune on Religious Education. Zagreb: Europa House, 2002.

Zrinščak, Siniša. "Church and State in New Social Circumstances: The Croatian Story." Sociologija Religije: Hrvatsko Iskustvo 14.8 (1999): 126-134.

Zupančič, Jernej. "Mar Uradniki Res Nagajajo RKC?” Panorama 2 Dec. 1999: 16.

Zwitter, Fran. O Slovenskem Narodnem Vprašanju. Ljubljana: Slovenska Matica, 1969. 